\title{
EXPERIMENT DATA REPORT FOR SEMISCALE MOD-1 \\ TEST S-28-5 \\ (STEAM GENERATOR TUBE RUPTURE TEST)
}

\author{
BRENT L. COLLINS KENNETH E. SACKETT \\ CHERYL E. COPPIN
}

November 1977
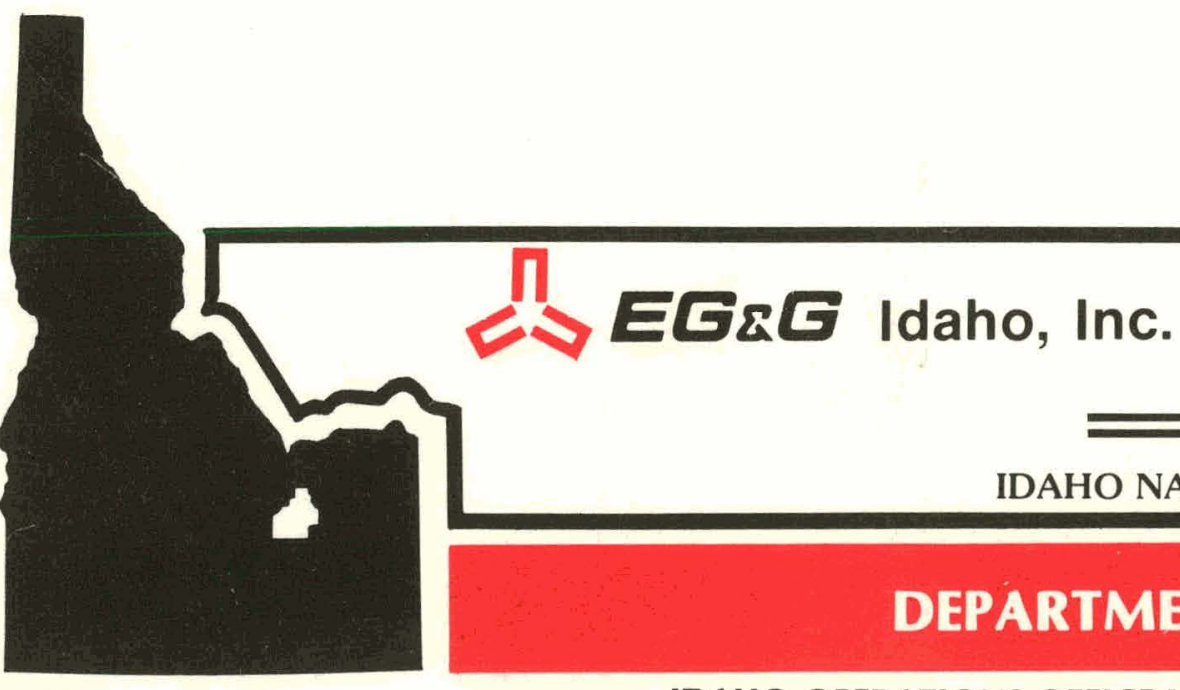

\section{DEPARTMENT OF ENERGY}




\section{DISCLAIMER}

This report was prepared as an account of work sponsored by an agency of the United States Government. Neither the United States Government nor any agency Thereof, nor any of their employees, makes any warranty, express or implied, or assumes any legal liability or responsibility for the accuracy, completeness, or usefulness of any information, apparatus, product, or process disclosed, or represents that its use would not infringe privately owned rights. Reference herein to any specific commercial product, process, or service by trade name, trademark, manufacturer, or otherwise does not necessarily constitute or imply its endorsement, recommendation, or favoring by the United States Government or any agency thereof. The views and opinions of authors expressed herein do not necessarily state or reflect those of the United States Government or any agency thereof. 


\section{DISCLAIMER}

Portions of this document may be illegible in electronic image products. Images are produced from the best available original document. 
Printed in the United States of America

Available from

National Technical Information Service

U.S. Department of Commerce

5285 Port Royal Road

Springfield, Virginia 22161

Price: Printed Copy $\$ 10.75$; Microfiche $\$ 3.00$

\section{NOTICE}

This report was prepared as an account of work sponsored by the United States Government. Neither the United States nor the Department of Energy, nor any of their employees, nor any of their contractors, subcontractors, or their employees, makes any warranty, express or implied, or assumes any legal liability or responsibility for the accuracy, completeness or usefulness of any information, apparatus, product or process disclosed, or represents that its use would not infring privately owned rights.

"The NRC will make available data tapes and operational computer codes on research programs dealing with postulated loss-of-coolant accidents in light water reactors. Persons requesting this information must reimburse the NRC contractors for their expenses in preparing copies of the data tapes and the operational computer codes. Requests should be submitted to the Research Applications Branch, Office of Nuclear Regulatory Research, Nuclear Regulatory Commission, Washington, D.C. 20555." 
TREE-NUREG-1152

\section{EXPERIMENT DATA REPORT FOR SEMISCALE MOD-1}

TEST S-28-5

\section{(STEAM GENERATOR TUBE RUPTURE TEST)}
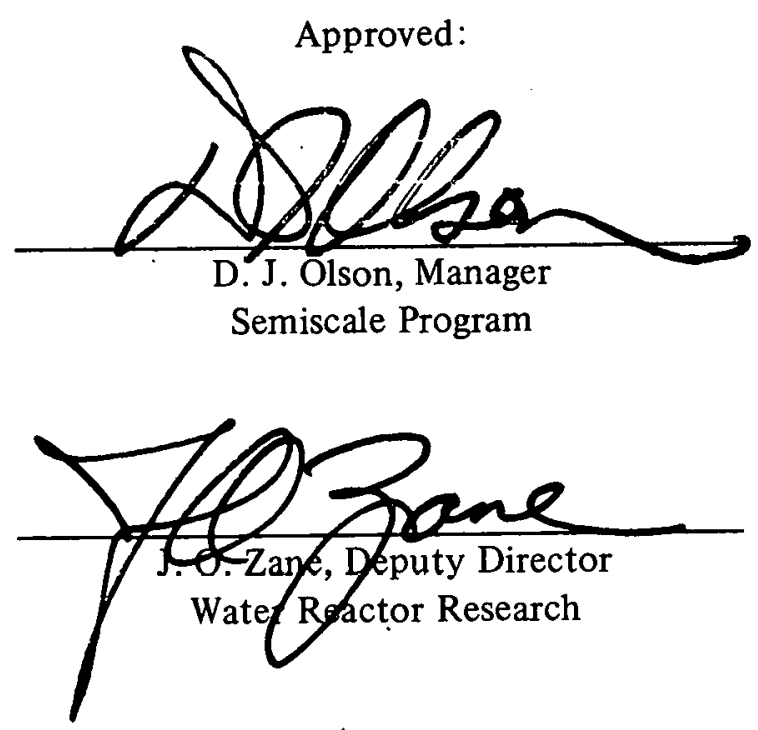

NOTHET -

This report was prepared as an account of work sponsored by the United States Govemment. Neither the United States nor the United States Department of Energy, nor any of their employees, nor any of their contractors, subcontraction, or their employees, makes any warranty, express or implied, or assumes any legal or usefosponsibitity for the accuracy, completeness or tsefulness of any information, apparatus, product or process disclosed, or represents that it use would not infringe privately owned rights. 


\section{EXPERIMENT DATA REPORT FOR SEMISCALE MOD-1}

\section{TEST S-28-5}

(STEAM GENERATOR TUBE RUPTURE TEST)

by

Brent L. Collins

Kenneth E. Sackett

Chcryl E. Coppin

EG\&G IDAHO, INC.

November 1977

PREPARED FOR THE

U.S. NUCLEAR REGULATORY COMMISSION

AND THE

DEPARTMENT OF ENERGY

IDAHO OPERATIONS OFFICE

UNDER CONTRACT NO. EY-76-C-07-1570 


\begin{abstract}
Recorded tcst data are presented for Test S-28-5 of the Stmiscale Mud-1 steam generator tube rupture test series. These tests are among several Semiscale Mod-1 experiments conducted to investigate the thermal and hydraulic phenomena accompanying a hypothesized loss-of-coolant accident in a pressurized water reactor (PWR) system.

Test S-28-5 was conducted from initial conditions of $15768 \mathrm{kPa}$ and $556 \mathrm{~K}$ to investigate the response of the Semiscale Mod-1 system to a depressurization and reflood transient following a simulated double-ended offset shear of the broken loop cold leg piping. During the test, cooling water was injected into the cold leg of the intact and broken loops to simulate emergency core coolant injection in a PWR. For Test S-28-5, accumulator injection into the intact loop hot leg was provided to simulate the rupture of 20 steam generator tubes.
\end{abstract}

The purpose of this report is to make available the uninlerpreled data from Test S-28-5 for future data analysis and test reporting activities. The data, presented in the form of graphs in engineering units, have been analyzed only to the extent necessary to ensure that they are reasonable and consistent: 


\section{SUMMARY}

Test S-28-5 was performed as part of the Semiscale Mod-1 portion of the Semiscale Program conducted by EG\&G Idaho, Inc. for the United States Government. This test is part of the steam generator tube rupture test series (Test Series 28) performed to investigate the response of the Mod-1 system to steam generator tube ruptures during a hypothesized loss-of-coolant accident (LOCA). The test objective specific to Test S-28-5 was to refine the definition of the upper limit set by Test S-28-1 and to investigate the range of steam generator tube ruptures over which high peak cladding temperatures can occur. Hardware configuration and test parameters were selected to yield a system response that simulates the response of a pressurized water reactor during a hypothesized LOCA with subsequent refill and reflood.

Test S-28-5 utilized the Semiscale Mod-1 system equipped with a pressure vessel with a 40-rod electrically heated core; an intact loop with pump, steam generator, and pressurizer; a broken loop with simulated pump, simulated steam generator, and rupture assemblies; and a pressure suppression system with header, pressure suppression tank, and heated steam supply system. High and low pressure coolant injection pumps and a coolant injection accumulator were provided for each system loop. An additional injection accumulator was provided for the intact loop hot leg. The intact loop hot leg injection flow rate was set to simulate the rupture of 20 steam generator tubes. For Test S-28-5, four heater rods were intentionally unpowered to simulate the effects of control rod guide tubes and the power in three heater rods was increased to produce a slightly peaked power profile.

The test was conducted from initial conditions of $15768 \mathrm{kPa}$ and $556 \mathrm{~K}$ (at the intact loop cold leg vessel inlet) with a simulated full size (200\%) double-ended offset shear of the broken loop cold leg piping at an initial core power level of $1.39 \mathrm{MW}$, and an initial core inlet flow rate of $9.06 \mathrm{l} / \mathrm{s}$. The instantaneous offset shear of the broken loop cold leg piping was simulated by simultaneous (within $10 \mathrm{~ms}$ ) actuation of the rupture assemblies. After initiation of blowdown, power to the heated core was reduced to simulate the predicted heat flux response of nuclear fuel rods during a LOCA. Blowdown was accompanied by simulated emergency core coolant injection into the cold leg piping of the intact and broken loops. This injection was followed by a controlled injection from a heated accumulator into the intact loop hot leg to simulate steam generator tube ruptures.

Test S-28-5 was generally conducted as specified. Conditions which did not conform to the specified test configuration were considered acceptable for analysis purposes within the test objectives. The instrumentation used generally functioned as intended. All 221 measurements taken produced usable data. 


\section{CONTENTS}

ABSTRACT $\ldots \ldots \ldots \ldots \ldots \ldots \ldots \ldots \ldots \ldots \ldots \ldots \ldots \ldots \ldots \ldots \ldots$

SUMMARY $\ldots \ldots \ldots \ldots \ldots \ldots \ldots \ldots \ldots \ldots$ iii

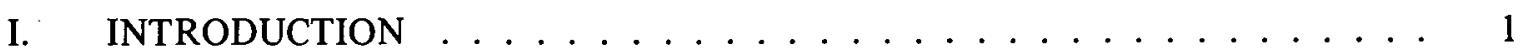

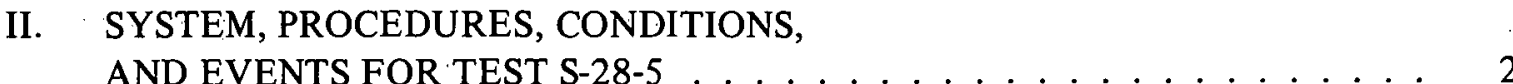

1. SYSTEM CONFIGURATION AND TEST PROCEDURES . . . . . 2

2. INITIAL TEST CONDITIONS AND SEQUENCE OF EVENTS $\ldots \ldots \ldots$

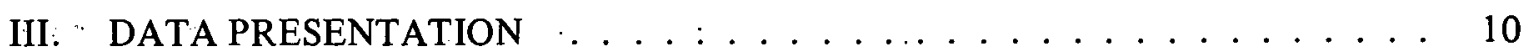

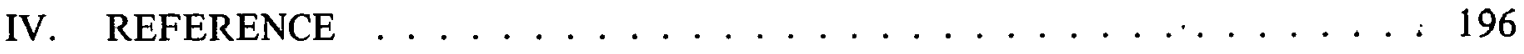

APPENDIX A - DATA ACQUISITION SYSTEM CAPABILITIES $\ldots \ldots \ldots$

APPENDIX B - POSTTEST ADJUSTMENTS TO DATA FROM

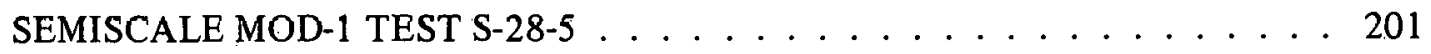

APPENDIX C - SELECTED DATA WITH ESTIMATED TOTAL ERROR

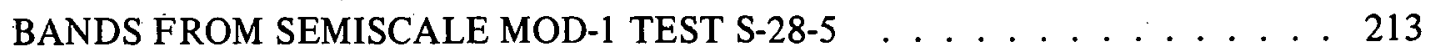

\section{FIGURES}

1. Semiscale Mod-1 system for cold leg break

configuration - isometric $\ldots \ldots \ldots \ldots \ldots \ldots \ldots \ldots \ldots$

2. Semiscale Mod-1 system for cold leg break

configuration - schematic $: \ldots \ldots \ldots \ldots \ldots \ldots$

3. Semiscale Mod-1 system and instrumentation for cold leg break

configuration - isometric $\ldots \ldots \ldots \ldots \ldots \ldots \ldots \ldots \ldots \ldots$

4. Semiscale Mod-1 system and instrumentation for cold leg break

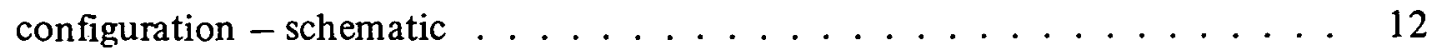

5. Semiscale Mod-1 pressure vessel - cross section showing instrumentation $\ldots \ldots \ldots \ldots \ldots \ldots \ldots$ 
6. Semiscale Mod-1 pressure vessel - isometric

showing instrumentation . . . . . . . . . . . . . . . . . 14

7. Semiscale Mod-1 pressure vessel - penetrations

and instrumentation . . . . . . . . . . . . . . . 15

8. Semiscale Mod-1 heated core - plan view ............... 16

9. Fluid temperature in intact loop hot leg (TFU-1 and

RBU-2), from -20 to $736 \mathrm{~s} \ldots \ldots \ldots \ldots$. . . . . . . . . . 28

10. Fluid temperature in intact loop hot leg (TFU-1 and

RBU-2), from -6 to $42 \mathrm{~s} \ldots \ldots \ldots \ldots . \ldots \ldots$

11. Fluid temperature in intact loop hot leg (TFU-6),

from -20 to $736 \mathrm{~s} \ldots \ldots \ldots \ldots \ldots \ldots$

12. Fluid temperature in intact loop hot leg (TFU-6),

from -6 to $42 \mathrm{~s} \ldots \ldots \ldots \ldots . \ldots . \ldots . \ldots 29$

13. Fluid temperature in intact loop cold leg (TFU-7

and TFU-10), from -20 to $736 \mathrm{~s} \ldots \ldots \ldots$. . . . . . . . . . . . . .

14. Fluid temperature in intact loop cold leg (TFU-7

and TFU-10), from -6 to $42 \mathrm{~s} \ldots \ldots \ldots$. . . . . . . . . . . . . .

15. Fluid temperature in intact loop cold leg (RBU-14A and

TFU-14B), from -20 to $736 \mathrm{~s} \ldots \ldots \ldots . \ldots \ldots$

16. Fluid temperature in intact loop cold leg (RBU-14A and

TFU-14B), from -6 to $42 \mathrm{~s} \ldots \ldots \ldots 31$

17. Fluid temperature in intact loop cold leg (TFU-15),

from -20 to $736 \mathrm{~s} \ldots \ldots \ldots \ldots \ldots$

18. Fluid temperature in intact loop cold leg (TFU-15),

from -6 to $42 \mathrm{~s} \ldots \ldots \ldots \ldots . \ldots \ldots \ldots$

19. Fluid temperature in broken loop, vessel side (TFB-20 and

TFB-23), from -20 to $736 \mathrm{~s} \ldots \ldots \ldots 33$

20. Fluid temperature in broken loop, vessel side (TFB-20 and

TFB-23), from -6 to $42 \mathrm{~s} \ldots \ldots \ldots \ldots$

21. Fluid temperature in broken loop, pump side (TFB-30,

TFB-37, and TFB-42), from -20 to $736 \mathrm{~s}$ 
22. Fluid temperature in broken loop, pump side (TFB-30,

TFB-37, and TFB-42), from -6 to $42 \mathrm{~s} \ldots \ldots \ldots . \ldots . \ldots 34$

23. Fluid temperature in inlet annulus (TFV-ANN-4A and

TFV-ANN-4M), from -20 to $736 \mathrm{~s} \ldots \ldots . \ldots 35$

24. Fluid temperature in inlet annulus (TFV-ANN-4A and

THV-ANN-4M), trom -6 to $42 \mathrm{~s} \ldots \ldots \ldots 35$

25. Fluid temperature in downcomer annulus (TFV-ANN-35A,

TFV-ANN-70A, TFV-ANN-115A, and TFV-ANN-156A),

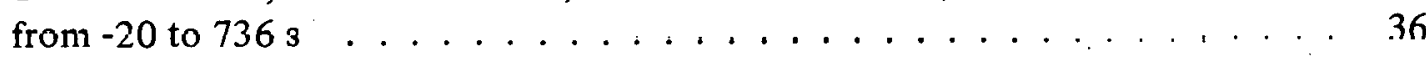

26. Fluid temperature in downcomer annulus (TFV-ANN-35A,

TFV-ANN-70A; TFV-ANN-115A, and TFV-ANN-156A),

liruin $=6$ lu $42 \mathrm{~s} \ldots \ldots \ldots \ldots$

27. Fluid temperature in upper plenum (TFV-UP+13),

from -20 to $736 \mathrm{~s} \ldots \ldots \ldots \ldots \ldots \ldots$

28. Fluid temperature in upper plenum (TFV-UP+13),

from -6 to $42 \mathrm{~s} \ldots \ldots \ldots \ldots \ldots \ldots$

29. Fluid temperature in lower plenum (TFV-LP-2, TFV-LP-4,

and TГV-LP-7), from 20 to $736 \mathrm{~s} \ldots \ldots \ldots \ldots$

30. Fluid temperature in lower plenum (TFV-LP-2, TFV-LP-4, and TFV-LP-7), from -6 to $42 \mathrm{~s} \ldots \ldots \ldots \ldots . \ldots . \ldots . \ldots 38$

31. Fluid temperature in core inlet (TFV-CORE-IN),

from -20 to $736 \mathrm{~s}$

32. Fluid temperature in core inlet (TFV-CORE-IN),

from -6 to $42 \mathrm{~s} \ldots \ldots \ldots \ldots \ldots \ldots$

33. Fluid temperature in core, Grid Spacer 5 ('TFG-5C'U-45),

from -20 to $736 \mathrm{~s}$

34. Fluid temperature in core, Grid Spacer 5 (TFG-5CD-45),

from -6 to $42 \mathrm{~s} \ldots \ldots \ldots \ldots \ldots$

35. Fluid temperature in core, Grid Spacer 6 (TFG-6CD-45),

from -20 to $736 \mathrm{~s}$

36. Fluid temperature in core, Grid Spacer 6 (TFG-6CD-45),

from -6 to $42 \mathrm{~s} \ldots \ldots \ldots \ldots \ldots \ldots$ 
37. Fluid temperature in core, Grid Spacer 10 (TFG-10AB-45), from -20 to $736 \mathrm{~s}$

38. Fluid temperature in core, Grid Spacer 10 (TFG-10AB-45), from -6 to $42 \mathrm{~s} \ldots \ldots \ldots \ldots \ldots$

39. Fluid temperature in intact loop coolant injection line (TFU-ECC-14), from -20 to $736 \mathrm{~s} \ldots \ldots \ldots$

40. Fluid temperature in intact loop coolant injection line

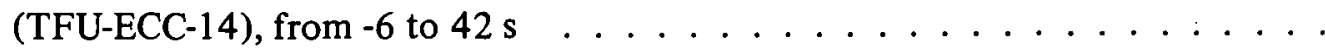

41. Fluid temperature in broken loop coolant injection line (TFB-ECC-42), from -20 to $736 \mathrm{~s}$

42. Fluid temperature in broken loop coolant injection line (TFB-ECC-42), from -6 to $42 \mathrm{~s}$

43. Fluid temperature in steam generator, feedwater line (TFU-SGFW), from -20 to $736 \mathrm{~s}$.

44. Fluid temperature in steam generator, feedwater line (TFU-SGFW), from -6 to $42 \mathrm{~s}$

45. Fluid temperature in steam generator, steam dome (TFU-SGSD), from -20 to $736 \mathrm{~s}$

46. Fluid temperature in steam generator, steam dome (TFU-SGSD), from -6 to $42 \mathrm{~s} \ldots \ldots \ldots \ldots$

47. Fluid temperature in steam generator; secondary side (TFU-SG1, TFU-SG2, and TFU-SG3), from -20 to $736 \mathrm{~s}$

48. Fluid temperature in steam generator, secondary side (TFU-SG1, TFU-SG2, and TFU-SG3), from -6 to $42 \mathrm{~s}$

49. Fluid temperature in steam generator rupture system accumulator (TFU-SGS3), from -20 to $736 \mathrm{~s}$

50. Fluid temperature in steam generator rupture system accumulator (TFU-SGS3), from -6 to $42 \mathrm{~s} \ldots \ldots \ldots$. . . . . . . .

51. Fluid temperature in steam generator rupture system injection line (TFU-SGS), from -20 to $736 \mathrm{~s}$ 
52. Fluid temperature in steam generator rupture system

injection line (TFU-SGS), from -6 to $42 \mathrm{~s} \ldots \ldots \ldots$

53. Fluid temperature in steam generator rupture system

(TFU-SGS-D), from -20 to $736 \mathrm{~s} \ldots \ldots \ldots \ldots$

54. Fluid temperature in steam generator rupture system

(TFU-SGS-D), from -6 to $42 \mathrm{~s} \ldots \ldots \ldots \ldots$. . . . . . . . . . 50

55. Fluid temperature in pressurizer surge line (TFU-PRIZE),

from -20 to $736 \mathrm{~s}$

56. Fluid temperature in pressurizer surge line (TFU-PRIZE),

from 6 to $423 \ldots \ldots \ldots \ldots \ldots \ldots$

57. Fluid temperature in pressure suppression tank (TF-PSS-33

and TF-PSS-130), from -20 to $736 \mathrm{~s}$

58. Fluid temperature in pressure suppression tank (TF-PSS-33

and TF-PSS-130), from -6 to 42 s . . . . . . . . . . . . 52

59. Material temperature in intact loop (TMU-1T16), from -20

to $736 \mathrm{~s}$

60. Material temperature in intact loop (TMU-1T16), from -6

to $42 \mathrm{~s}$

61. Material temperature in broken loop (TMB-20B16), frum -20

to $736 \mathrm{~s} \ldots \ldots \ldots \ldots$

62. Material temperature in broken loop (TMB-20B16), from -6

to $42 \mathrm{~s}$

63. Material temperature in vessel filler (TMV-FI-115A and

TMV-FI-156A), from -20 to $736 \mathrm{~s}$

64. Material temperature in vessel filler (TMV-FI-115A and TMV-FI-156A), from -6 to $42 \mathrm{~s} \ldots \ldots \ldots 55$

65. Material temperature in vessel filler insulator (TMV-FO-156A),

from -20 to $736 \mathrm{~s}$

66. Material temperature in vessel filler insulator (TMV-FO-156A), from -6 to $42 \mathrm{~s}$ 
67. Material temperature in vessel filler insulator (TIV-FO-35A and TIV-FO-115A), from -20 to $736 \mathrm{~s} \ldots \ldots \ldots 57$

68. Material temperature in vessel filler insulator (TIV-FO-35A and TIV-FO-1 15A), from -6 to $42 \mathrm{~s} \ldots \ldots \ldots$

69. Material temperature in core barrel inner diameter (TMV-CI-70A), from -20 to $736 \mathrm{~s} \ldots \ldots \ldots \ldots$. . . . . . . . . . . . . 58

70. Material temperature in core barrel inner diameter (TMV-CI-70A), from -6 to $42 \mathrm{~s} \ldots \ldots \ldots \ldots \ldots$

71. Material temperature in core barrel outer diameter (TMV-CO-70A and TMV-CO-115A), from -20 to $736 \mathrm{~s} \ldots \ldots \ldots$

72. Material temperature in core barrel outer diameter (TMV-CO-70A and TMV-CO-115A), from -6 to $42 \mathrm{~s} \ldots \ldots . \ldots 59$

73. Material temperature in core housing filler (TMV-HF-115W, TMV-HF-127W, and TMV-HF-138W), from -20 to $736 \mathrm{~s}$ 60

74. Material temperature in core housing filler (TMV-HF-115W, TMV-HF-127W, and TMV-HF-138W), from -6 to $42 \mathrm{~s}$

75. Material temperature in steam generator (TMU-SG1, TMU-SG2, and TMU-SG3), from -20 to $736 \mathrm{~s}$.

76. Material temperature in steam generator (TMU-SG1, TMU-SG2, and TMU-SG3), from -6 to $42 \mathrm{~s}$

77. Core heater temperature, Rod D-4 (TH-D4-14 and TH-D4-29), from -20 to $736 \mathrm{~s}$

78. Core heater temperature, Rod D-4 (TH-D4-14 and TH-D4-29), from -6 to $42 \mathrm{~s} \ldots \ldots \ldots \ldots$. . . . . . . . . . . . . . . 62

79. Core heater temperature, Rod D-5 (TH-D5-29) from -20 to $736 \mathrm{~s} \ldots \ldots 3$

80. Core heater temperature, Rod D-5 (TH-D5-29) from -6 to $42 . \mathrm{s} \ldots \ldots 3$

81. Core heater temperature, Rod E-4 (TH-E4-09, TH-E4-27, and TH-E4-55), from -20 to $736 \mathrm{~s}$

82. Core heater temperature, Rod E-4 (TH-E4-09, TH-E4-27, and TH-E4-55), from -6 to $42 \mathrm{~s}$ 
83. Core heater temperature, Rod E-5 (TH-E5-20 and TH-E5-25),

from -20 to $736 \mathrm{~s} \ldots \ldots \ldots \ldots \ldots$

84. Core heater temperature, Rod E-5 (TH-E5-20 and TH-E5-25),

from -6 to $42 \mathrm{~s} \ldots \ldots \ldots \ldots \ldots \ldots \ldots$

85. Core heater temperature, Rod A-4 (TH-A4-09, TH-A4-29, and

TH-A4-39), from -20 to $736 \mathrm{~s} \ldots \ldots \ldots \ldots$

86. Core heater temperature; Rod A-4 (TH-A4-09, TH-A4-29, and

TH-A4-39), from -6 to $42 \mathrm{~s} \ldots \ldots \ldots 66$

87. Core heater temperature, Rod A-5 (TH-A5-29 and TH-A5-45),

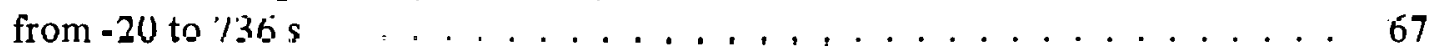

88. Core heater temperature, Rod A-5 (TH-A5-29 and TH-A 5-45),

from -6 to $42 \mathrm{~s} \ldots \ldots \ldots \ldots \ldots$. . . . . . . . . . . . . 67

89. Core heater temperature, Rod B-3 (TH-B3-32), from -20 to $736 \mathrm{~s} \ldots \ldots 8$

90. Core heater temperature, Rod B-3 (TH-B3-32), from -6 to $42 \mathrm{~s} \ldots \ldots 6$

91. Core heater temperature, Rod B-5 (TH-B5-29 and TH-B5-33),

from -20 to $736 \mathrm{~s} \ldots \ldots \ldots \ldots$

92. Core heater temperature, Rod B-5 (TH-B5-29 and TH-B5-33),

from -6 to $42 \mathrm{~s} \ldots \ldots \ldots \ldots$

93. Core heater temperature, Rod B-6 (TH-B6-29), from -20 to $736 \mathrm{~s} \ldots \ldots . . .70$

94. Core heater temperature, Rod B-6 (TH-B6-29), from -6 to $42 \mathrm{~s} \ldots \ldots . . . .70$

95. Core heater temperature, Rod C-2 (TH-C2-38), from -20 to $736 \mathrm{~s} \ldots \ldots 71$

96. Core heater temperature, Rod C-2 (TH-C2-38), from -6 to $42 \mathrm{~s} \ldots \ldots . \ldots 71$

97. Core heater temperature, Rod C-4 (TH-C4-20, TH-C4-26, and

TH-C4-53), from -20 to $736 \mathrm{~s} \ldots \ldots \ldots 72$

98. Core heater temperature, Rod C-4 (TH-C4-20, TH-C4-26, and

TH-C4-53), from -6 to $42 \mathrm{~s} \ldots \ldots \ldots \ldots \ldots \ldots$. . . . . . . . . . . .

99. Core heater temperature, Rod C-5 (TH-C5-28), from -20 to $736 \mathrm{~s} \ldots \ldots . . . .73$

100. Core heater temperature, Rod C-5 (TH-C5-28), from -6 to $42 \mathrm{~s} \ldots \ldots 73$ 
101. Core heater temperature, Rod C-6 (TH-C6-53), from -20 to $736 \mathrm{~s} \ldots \ldots 74$

102. Core heater temperature, Rod C-6 (TH-C6-53), from -6 to $42 \mathrm{~s} \ldots \ldots 74$

103. Core heater temperature, Rod C-7 (TH-C7-07 and TH-C7-15), from -20 to $736 \mathrm{~s} \ldots \ldots \ldots \ldots$

104. Core heater temperature, Rod C-7 (TH-C7-07 and TH-C7-15), from -6 to $42 \mathrm{~s} \ldots \ldots \ldots \ldots \ldots$. . . . . . . . . . . . . . . . . . . . .

105. Core heater temperature, Rod D-1 (TH-D1-21), from -20 to $736 \mathrm{~s} \ldots \ldots$

106. Core heater temperature, Rod D-1 (TH-D1-21), from -6 to $42 \mathrm{~s} \ldots \ldots 76$

107. Core heater temperature, Rod D-2 (TH-D2-14 and TH-D2-61), from -20 to $736 \mathrm{~s} \ldots \ldots \ldots \ldots 77$

108. Core heater temperature, Rod D-2 (TH-D2-14 and TH-D2-61), from -6 to $42 \mathrm{~s} \ldots \ldots \ldots \ldots$. . . . . . . . . . . 77

109. Core heater temperature, Rod D-3 (TH-D3-29 and TH-D3-39), from -20 to $736 \mathrm{~s} \ldots \ldots \ldots \ldots$. . . . . . . . . . . . . . . . . .

110. Core heater temperature, Rod D-3 (TH-D3-29 and TH-D3-39), from -6 to $42 \mathrm{~s} \ldots \ldots \ldots \ldots 78$

111. Core heater temperature, Rod D-6 (TH-D6-25), from -20 to $736 \mathrm{~s} \ldots \ldots 79$

112. Core heater temperature, Rod D-6 (TH-D6-25), from -6 to $42 \mathrm{~s} \ldots \ldots 79$

113. Core heater temperature, Rod D-7 (TH-D7-20), from -20 to $736 \mathrm{~s} \ldots \ldots 0$

114. Core heater temperature, Rod D-7 (TH-D7-20), from -6 to $42 \mathrm{~s} \ldots \ldots$

115. Core heater temperature, Rod D-8 (TH-D8-26), from -20 to $736 \mathrm{~s} \ldots \ldots 1$

116. Core heater temperature, Rod D-8 (TH-D8-26), from -6 to $42 \mathrm{~s} \ldots \ldots$. . . . 81

117. Core heater temperature, Rod E-1 (TH-E1-33), from -20 to $736 \mathrm{~s} \ldots \ldots 2$

118. Core heater temperature, Rod E-1 (TH-E1-33), from -6 to $42 \mathrm{~s} \ldots \ldots 2$

119. Core heater temperature, Rod E-2 (TH-E2-33), from -20 to $736 \mathrm{~s} \ldots \ldots$

120. Core heater temperature, Rod E-2 (TH-E2-33), from -6 to $42 \mathrm{~s} \ldots \ldots$ 
121. Core heater temperature, Rod E-3 (TH-E3-05, TH-E3-20, and

TH-E3-24), from -20 to $736 \mathrm{~s} \ldots \ldots \ldots \ldots$

122. Core heater temperature, Rod E-3 (TH-E3-05, TH-E3-20, and TH-E3-24); from -6 to $42 \mathrm{~s}$

123. Core heater temperature, Rod E-6 (TH-E6-08, TH-E6-28, and TH-E6-37), from -20 to $736 \mathrm{~s}$

124. Core heater temperature, Rod E-6 (TH-E6-08, TH-E6-28, and TH-E6-37), from -6 to $42 \mathrm{~s}$

125. Core heater temperature, Rod E-7 (TH-E7-44), from -20 to $736 \mathrm{~s} \ldots \ldots 6$

126. Core heater temperature, Rod E-7 (TH-E7-44), from -6 to $42 \mathrm{~s} \ldots \ldots$

127. Core heater temperature, Rod E-8 (TH-E8-14 and TH-E8-29), from -20 to $736 \mathrm{~s}$

128. Core heater temperature, Rod E-8 (TH-E8-14 and TH-E8-29), from -6 to $42 \mathrm{~s} \ldots \ldots \ldots \ldots \ldots$

129. Core heater temperature, Rod F-2 (TH-F2-07, TH-F2-22, and TH-F2-25), from -20 to $736 \mathrm{~s} \ldots \ldots . \ldots 8$

130. Core heater temperature, Rod F-2 (TH-F2-07, TH-F2-22, and TH-F 2-25), from -6 to $42 \mathrm{~s}$

131. Core heater temperature, Rod F-4 (TH-F4-14, TH-F4-29, and TH-F4-44), from -20 to 736

132. Core heater temperature, Rod F-4 (TH-F4-14, IH-F4-29, and TiT-F4-44), from 6 to $42 \mathrm{~s}$

133. Core heater temperature, Rod F-5 (TH-F5-20, TH F5-26, TH-F5-33, and TH-F5-53), from -20 to $736 \mathrm{~s}$

134. Core heater temperature, Rod F-5 (TH-F5-20, TH-F5-26, TH-F5-33, and TH-F5-53), from -6 to $42 \mathrm{~s}$

13.5. Core heater temperature, Rod G-3 (TH-G3-13); from -20 to $736 \mathrm{~s}$

136. Core heater temperature, Rod G-3 (TH-G3-13), from -6 to $42 \mathrm{~s} \ldots \ldots$

137. Core heater temperature, Rod G-4 (TH-G4-29, TH-G4-33, and TH-G4-38), from -20 to $736 \mathrm{~s}$ 
138. Core heater temperature, Rod G-4 (TH-G4-29, TH-G4-33, and TH-G4-38), from -6 to $42 \mathrm{~s} \ldots \ldots . \ldots . \ldots 92$

139. Core heater temperature, Rod G-5 (TH-G5-14 and TH-G5-24), from -20 to $736 \mathrm{~s}$

140. Core heater temperature, Rod G-5 (TH-G5-14 and TH-G5-24), from -6 to $42 \mathrm{~s}$

141. Core heater temperature, Rod H-5 (TH-H5-32), from -20 to $736 \mathrm{~s} \ldots \ldots 4$

142. Core heater temperature, Rod H-5 (TH-H5-32), from -6 to $42 \mathrm{~s} \ldots \ldots$

143. Pressure in intact loop (PU-13 and PU-15L), from -20 to $736 \mathrm{~s} \ldots \ldots 5$

144. Pressurc in intact loop (PU-13 and PU-15L), from -6 to $42 \mathrm{~s} \ldots \ldots 5$

145. Pressure in broken loop, vessel side (PB-21 and PB-23), from -20 to $736 \mathrm{~s}$ 96

146. Pressure in broken loop, vessel side (PB-21 and PB-23), from -6 to $42 \mathrm{~s}$

147. Pressure in broken loop, vessel side (PB-CN1), from -20 to $736 \mathrm{~s}$

148. Pressure in broken loop, vessel side (PB-CN1), from -6 to $42 \mathrm{~s}$. 97

149. Pressure in broken loop, pump side (PB-37 and PB-42), from -20 to $736 \mathrm{~s}$

150. Pressure in broken loop, pump side (PB-37 and PB-42), from -6 to $42 \mathrm{~s}$

151. Pressure in broken loop, pump side nozzle (PB-HN1), from -20 to $736 \mathrm{~s} \ldots \ldots \ldots \ldots \ldots \ldots$

152. Pressure in broken loop, pump side nozzle (PB-HN1), from -6 to $42 \mathrm{~s}$

153. Pressure in vessel (PV-UP+10 and PV-LP-166), from -20 to $736 \mathrm{~s}$ 100

154. Pressure in vessel (PV-UP+10 and PV-LP-166), from -6 to $42 \mathrm{~s}$ 
155. Pressure in intact loop accumulator (PU-ACC1);

from -20 to $736 \mathrm{~s} \ldots \ldots \ldots \ldots 1$

156. Pressure in intact loop accumulator (PU-ACC1), from -6 to $42 \mathrm{~s} \ldots \ldots \ldots \ldots 10 \ldots \ldots 1$

157. Pressure in broken loop accumulator (PB:ACC2), from -20 to $736 \mathrm{~s} \ldots \ldots \ldots \ldots 10 \ldots 2$

158. Pressure in broken loop accumulator (PB-ACC2), from -6 to $42 \mathrm{~s} \ldots \ldots \ldots \ldots \ldots 2 \ldots \ldots \ldots$

159. Pressure in steam generator, secondary side (PU-SGSD), from 20 to 7360

160. Pressure in steam generator, secondary side (PU-SGSD), from -6 to $42 \mathrm{~s} \ldots \ldots \ldots \ldots$. . . . . . . . . . . . . 103

161. Pressure in steam generator, secondary side (PU-SGS3), from -20 to $736 \mathrm{~s}$

162. Pressure in steam generator, secondary side (PU-SGS3), from -6 to $42 \mathrm{~s} \ldots \ldots \ldots \ldots$. . . . . . . . . . . . 104

163. Pressure in pressurizer (PU-PRIZE), from -20 to $736 \mathrm{~s} \ldots \ldots \ldots$

1.64. Pressure in pressurizer (PU-PRIZE), from -6 to $42 \mathrm{~s} \ldots \ldots \ldots$

165. Pressure in pressure suppression tank (P-PSS), from -20 to $736 \mathrm{~s} \ldots \ldots \ldots$. . . . . . . . . . . . 106

166. Pressure in pressure suppression tank (P-PSS), from -6 to $42 \mathrm{~s} \ldots \ldots \ldots \ldots$. . . . . . . . . . . . . . . . .

167. Differential pressure in intact loop (DPU-3-7), from -20 to $736 \mathrm{~s}$ 107

168. Differential pressure in in tact loop (DPU-3-7), from -6 to $42 \mathrm{~s} \ldots \ldots \ldots \ldots \ldots$. . . . . . . . . . . 107

169. Differential pressure in intact loop (DPU-6-SGIP), from -20 to $736 \mathrm{~s} \ldots \ldots \ldots \ldots$. . . . . . . . . . . 108

170. Differential pressure in intact loop (DPU-6-SGIP), from -6 to $42 \mathrm{~s} \ldots \ldots \ldots \ldots$. . . . . . . . . . . . . . . . . . . . . 
171. Differential pressure in intact loop (DPU-SGOP-7),

from -20 to $736 \mathrm{~s}$

172. Differential pressure in in tact loop (DPU-SGOP-7),

from -6 to $42 \mathrm{~s} \ldots \ldots \ldots \ldots$. . . . . . . . . . . . . . . . . . . . . . .

173. Differential pressure in intact loop (DPU-7-10),

from -20 to $736 \mathrm{~s}$

174. Differential pressure in intact loop (DPU-7-10),

from -6 to $42 \mathrm{~s} \ldots \ldots \ldots \ldots$. . . . . . . . . . . . 110

175. Differential pressure in intact loop (DPU-12-10),

from -20 to $736 \mathrm{~s}$

176. Differential pressure in intact loop (DPU-12-10),

from -6 to $42 \mathrm{~s}$.

177. Differential pressure in in tact loop, low range (DPU-12-10L),

from -20 to $736 \mathrm{~s}$

178. Differential pressure in intact loop, low range (DPU-12-10L),

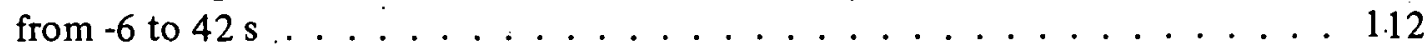

179. Differential pressure in intact loop (DPU-12-15),

from -20 to $736 \mathrm{~s}$ s. . . . . . . . . . . . . . . . 113

180. Differential pressure in intact loop (DPU-12-15), from -6 to $42 \mathrm{~s} \ldots \ldots \ldots \ldots \ldots 113$

181. Differential pressure in intact loop (DPU-15-3),

from -20 to $736 \mathrm{~s}$

182. Differential pressure in intact loop (DPU-15-3),

from -6 to $42 \mathrm{~s}$

183. Differential pressure in intact loop, low range (DPU-15-3L),

from -20 to $736 \mathrm{~s}$

184. Differential pressure in intact loop, low range (DPU-15-3L),

from -6 to $42 \mathrm{~s}$

185. Differential pressure in intact loop (DPU-PRESLL),

from -20 to $736 \mathrm{~s}$ 
186. Differential pressure in intact loop (DPU-PRESLL),

from -6 to $42 \mathrm{~s} \ldots \ldots \ldots \ldots \ldots 16$

187. Differential pressure in intact loop (DPU-PR-4),

from -20 to $736 \mathrm{~s} \ldots \ldots \ldots \ldots \ldots 117$

188. Differential pressure in intact loop (DPU-PR-4),

from -6 to $42 \mathrm{~s} \ldots \ldots \ldots \ldots \ldots 117 \ldots \ldots \ldots$

189. Differential pressure in broken loop (DPB-21-IANN),

from -20 to $736 \mathrm{~s} \ldots \ldots \ldots \ldots \ldots$

190. Differential pressure in broken loop (DPB-21-IANN),

from -6 to $42 \mathrm{~s}$

191. Differential pressure in broken loop (DPB-23-CN1),

from -20 to $736 \mathrm{~s} \ldots \ldots \ldots \ldots \ldots 119 \ldots \ldots \ldots$

192. Differential pressure in broken loop (DPB-23-CN1),

from -6 to $42 \mathrm{~s} \ldots \ldots \ldots \ldots \ldots 119$

193. Differential pressure in broken loop (DPB-CN1-24),

from -20 to $736 \mathrm{~s} \ldots \ldots \ldots \ldots$. . . . . . . . . . . . 120

194. Differential pressure in broken loop (DPB-CN1-24),

from -6 to $42 \mathrm{~s} \ldots \ldots \ldots \ldots 120 \ldots \ldots$

195. Differential pressure in broken loop (D̈̄B-30-43),

from -20 to $736 \mathrm{~s} \ldots \ldots \ldots \ldots 121$

196. Differential pressure in broken loop (DPB-30-43),

frnm -6 to $42 \mathrm{~s} \ldots \ldots \ldots \ldots \ldots . \ldots \ldots \ldots$

197. Differential pressure in broken loop (DPB-32U-36L),

from -20 to $736 \mathrm{~s}$

198. Differential pressure in broken loop (DPB-32U-36L),

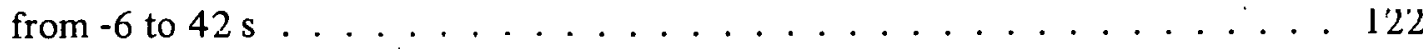

199. Differential pressure in broken loop (DPB-36L-37), from -20 to $736 \mathrm{~s}$

200. Differential pressure in broken loop (DPB-36L-37), from -6 to $42 \mathrm{~s}$ 
201. Differential pressure in broken loop (DPB-38-40),

from -20 to $736 \mathrm{~s} \ldots \ldots \ldots \ldots \ldots \ldots$

202. Differential pressure in broken loop (DPB-38-40),

from -6 to $42 \mathrm{~s} \ldots \ldots \ldots \ldots \ldots$. . . . . . . . . . . . . . . 124

203. Differential pressure in broken loop (DPB-40-42),

from -20 to $736 \mathrm{~s} \ldots \ldots \ldots \ldots 125$

204. Differential pressure in broken loop (DPB-40-42),

from -6 to $42 \mathrm{~s} \ldots \ldots \ldots \ldots \ldots \ldots$

205. Differential pressure in broken loop (DPB-42-HN1),

from -20 to $736 \mathrm{~s}$

206. Differential pressure in broken loop (DPB-42-HN1),

126

207. Differential pressure in broken loop (DPB-HN1-43),

from -20 to $736 \mathrm{~s}$

208. Differential pressure in broken loop (DPB-HN1-43),

from -6 to $42 \mathrm{~s} \ldots \ldots \ldots \ldots \ldots$. . . . . . . . . . . . 127

209. Differential pressure in vessel (DPV-UP-IANN),

from -20 to $736 \mathrm{~s} \ldots \ldots \ldots \ldots \ldots$. . . . . . . . . . . . . . . . . . .

210. Differential pressure in vessel (DPV-UP-IANN),

from -6 to $42 \mathrm{~s} \ldots \ldots \ldots \ldots \ldots \ldots$. . . . . . . . . . . . . . . . . . . . . .

211. Differential pressure in vessel (DPV-O-9GQ),

from -20 to $736 \mathrm{~s}$

212. Differential pressure in vessel (DPV-O-9GQ),

from -6 to $42 \mathrm{~s} \ldots \ldots \ldots \ldots \ldots$. . . . . . . . . . . . . . . . . . . . . . . .

213. Differential pressure in vessel (DPV-9-26QQ),

from -20 to $736 \mathrm{~s} \ldots \ldots \ldots \ldots \ldots$

214. Differential pressure in vessel (DPV-9-26QQ),

from -6 to $42 \mathrm{~s} \ldots \ldots \ldots \ldots \ldots$. . . . . . . . . . . . . . . . . . . . .

215. Differential pressure in vessel (DPV-9-166QQ),

from -20 to $736 \mathrm{~s}$ 
216. Differential pressure in vessel (DPV-9-166QQ),

from -6 to $42 \mathrm{~s} \ldots \ldots \ldots \ldots \ldots 131$

217. Differential pressure in vessel (DPV-26-55QM),

from -20 to $736 \mathrm{~s}$

218. Differential pressure in vessel (DPV-26-55QM),

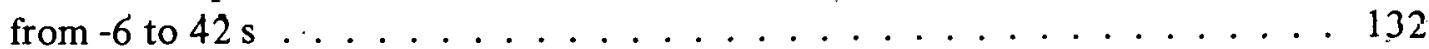

219. Differential pressure in vessel (DPV-55-1 10MM),

from -20 to $736 \mathrm{~s} \ldots \ldots \ldots \ldots \ldots \ldots$

220. Differential pressure in vessel (DPV-55-110MM),

from -6 tn $42, \mathrm{~s} \ldots \ldots \ldots \ldots \ldots$

221. Differential pressure in vessel (DPV-1 1U-156MQ),

from -20 to $736 \mathrm{~s} \ldots \ldots \ldots \ldots . \ldots \ldots 134$

222. Differential pressure in vessel (DPV-110-156MQ),

from -6 to $42 \mathrm{~s} \ldots \ldots \ldots \ldots \ldots$. . . . . . . . . . . . . . . . . . .

223. Differential pressure in vessel (DPV-156-173QQ),

from -20 to $736 \mathrm{~s} \ldots \ldots \ldots \ldots \ldots \ldots$

224. Differential pressure in vessel (DPV-156-173QQ),

from -6 to $42 \mathrm{~s} \ldots \ldots \ldots \ldots \ldots \ldots$

225. Differential pressure in vessel (DPV-166Q +10$)$,

from -20 to $736 \mathrm{~s} \ldots \ldots \ldots \ldots \ldots \ldots$

226. Differential pressure in vessel (DPV-166Q+10),

from -6 to $42 \mathrm{~s} \ldots \ldots \ldots \ldots \ldots \ldots$

227. Differential pressure in intact loop accumulator (DPU-ACC1-TB),

from -20 to $736 \mathrm{~s}$

228. Differential pressure in intact loop accumulator (DPU-ACC1-TB),

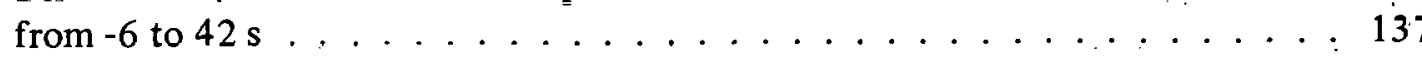

229. Differential pressure in broken loop accumulator (DPB-ACC2-TB),

from -20 to $736 \mathrm{~s} \ldots \ldots \ldots \ldots \ldots \ldots$

230. Differential pressure in broken loop accumulator (DPB-ACC2-TB),

from -6 to $42 \mathrm{~s}$ 
231. Differential pressure in steam generator secondary (DPU-SG-SEC), from -20 to $736 \mathrm{~s} \ldots \ldots \ldots \ldots \ldots$

232. Differential pressure in steam generator secondary (DPU-SG-SEC), from -6 to $42 \mathrm{~s} \ldots \ldots \ldots \ldots \ldots \ldots \ldots \ldots \ldots$

233. Differential pressure across steam generator outlet orifice (DPU-SG-DISC), from -20 to $736 \mathrm{~s} \ldots \ldots \ldots$. . . . . . . . . 140

234. Differential pressure across steam generator outlet orifice (DPU-SG-DISC), from -6 to $42 \mathrm{~s} \ldots \ldots \ldots \ldots \ldots$

235. Differential pressure between simulated rupture injection line and Spool 6 (DPU-SGS-6), from -20 to $736 \mathrm{~s}$

236. Differential pressure between simulated rupture injection line and Spool 6 (DPU-SGS-6), from -6 to $42 \mathrm{~s} \ldots \ldots \ldots \ldots 141$

237. Differential pressure in intact loop accumulator (DPU-SGS3-TB),

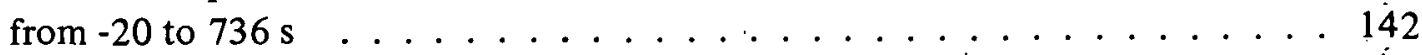

238. Differential pressure in intact loop accumulator (DPU-SGS3-TB),

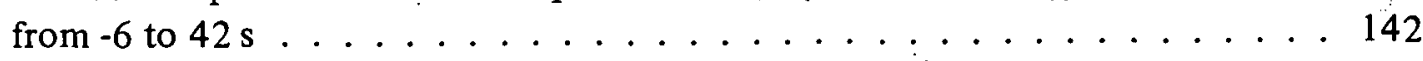

239. Differential pressure in pressure suppression tank (DP-PSS-TB), from -20 to $736 \mathrm{~s} \ldots \ldots \ldots \ldots \ldots \ldots \ldots \ldots$

240. Differential pressure in pressure suppression tank (DP-PSS-TB), from -6 to $42 \mathrm{~s} \ldots \ldots \ldots \ldots \ldots \ldots \ldots \ldots \ldots \ldots$

241. Volumetric flow in intact loop (FTU-1 and FTU-9), from -20 to $736 \mathrm{~s} \ldots \ldots \ldots \ldots \ldots \ldots . \ldots \ldots$

242. Volumetric flow in intact loop (FTU-1 and FTU-9), from -6 to $42 \mathrm{~s} \ldots \ldots \ldots \ldots \ldots \ldots \ldots . \ldots \ldots$

243. Volumetric flow in intact loop (FTU-15), from -20 to $736 \mathrm{~s} \ldots \ldots . \ldots 145$

244. Volumetric flow in intact loop (FTU-15), from -6 to $42 \mathrm{~s} \ldots \ldots \ldots \ldots$

245. Volumetric flow in broken loop (FTB-21), from -20 to $736 \mathrm{~s} \ldots \ldots . . .146$

246. Volumetric low in broken loop (FTB-21), from -6 to 42 s . . . . . . . 146

247. Volumetric flow in broken loop (FTB-30 and FTB-37), from -20 to $736 \mathrm{~s}$ 
248. Volumetric flow in broken loop (FTB-30 and FTB-37),

from -6 to $42 \mathrm{~s} \ldots \ldots \ldots \ldots \ldots$. . . . . . . . . . . . . . . . .

249. Volumetric flow in core entrance (FTV-CORE-IN),

from -20 to $736 \mathrm{~s} \ldots \ldots \ldots \ldots \ldots$. . . . . . . . . . . . . . . . . . . . . . . .

250. Volumetric flow in core entrance (FTV-CORE-IN),

from -6 to $42 \mathrm{~s} \ldots \ldots \ldots \ldots \ldots$. . . . . . . . . . . . . 148

251. Volumetric flow in intact loop high pressure injection line

(FTU-HPIS), from -20 to $736 \mathrm{~s} \ldots \ldots \ldots$. . . . . . . . . . . . . . . . .

252. Volumetric flow in intact loop high pressure injection line

(FTU-HPIS), from -6 to $42 \mathrm{~s} \ldots \ldots \ldots \ldots$. . . . . . . . . . . . . . . . . . .

253. Volumetric flow in broken loop high pressure injection line

(FTB-HPIS), from -20 to $736 \mathrm{~s} \ldots \ldots \ldots 150$

254. Volumetric flow in broken loop high pressure.injection line

(FTB-IIPIS), from -6 to $42 \mathrm{~s} \ldots \ldots \ldots \ldots$. . . . . . . . . . . . . . .

255. Volumetric flow in intact loop low pressure injection line

(FTU-LPIS), from -20 to $736 \mathrm{~s}$

256. Volumetric flow in intact loop low pressure injection line

(FTU-LPIS), from -6 to $42 \mathrm{~s} \ldots \ldots \ldots \ldots 151$

257 Vnlumetric flow in hroken loop low pressure iniection line

(FTB-LPIS), from -20 to $736 \mathrm{~s} \ldots \ldots \ldots \ldots . \ldots \ldots 2$

258. Volumetric flow in broken loop low pressure injection line

(FTB-LPIS), from -6 to $42 \mathrm{~s} \ldots \ldots \ldots \ldots 152$

259. Volumetric flow in intact loop accumulator discharge line

(FTU-ACC1), from -20 to $736 \mathrm{~s} \ldots \ldots \ldots \ldots$. . . . . . . . . . . . . .

260. Volumetric flow in intact loop accumulator discharge line

(FTU-ACC1), from -6 to $42 \mathrm{~s} \ldots \ldots \ldots \ldots \ldots . \ldots \ldots$. . . . . . . 153 .

261. Volumetric flow in broken loop accumulator discharge line

(FTB- $\Lambda$ CC2), from -20 to $736 \mathrm{~s} \ldots \ldots \ldots \ldots$

262. Volumetric flow in broken loop accumulator discharge line

(FTB-ACC2), from -6 to $42 \mathrm{~s} \ldots \ldots \ldots \ldots . \ldots \ldots$ 
263. Volumetric flow in intact loop steam generator (FTU-SGS), from -20 to $736 \mathrm{~s}$

264. Volumetric flow in intact loop steam generator

(FTU-SGS), from -6 to $42 \mathrm{~s}$

265. Volumetric flow from pressurizer (FTU-PRIZE), from -20 to $736 \mathrm{~s} \ldots \ldots$

266. Volumetric flow from pressurizer (FTU-PRIZE), from -6 to $42 \mathrm{~s} \ldots \ldots$

267. Fluid velocity in vessel (FTV-40A and FTV-40M),

from -20 to $736 \mathrm{~s}$

268. Fluid velocity in vessel (FTV-40A and FTV-40M),

from -6 to $42 \mathrm{~s}$

269. Momenturn flux in intact loop (FDU-1), from -6 to $42 \mathrm{~s}$ 158

270. Momentum flux in intact loop (FDU-5), from -6 to $42 \mathrm{~s} \ldots \ldots$. . . . . 158

271. Momentum flux in intact loop (FDU-10), from -6 to $42 \mathrm{~s} \ldots \ldots . . . . . .59$

272. Momentum flux in intact loop (FDU-13), from -6 to $42 \mathrm{~s} \ldots \ldots \ldots$

273. Momentum flux in broken loop (FDB-21), from -6 to $42 \mathrm{~s} \ldots \ldots$. . . . . . 160

274. Momentum flux in broken loop (FDB-23), from -6 to $42 \mathrm{~s} \ldots \ldots$. . . . . 160

275. Momentum flux in broken loop (FDB-30), from -6 to $42 \mathrm{~s} \ldots \ldots 161$

276. Momentum flux in broken loop (FDB-37), from -6 to $42 \mathrm{~s} \ldots \ldots$. . . . . . 161

277. Moninéntun flux in broken loop (FDB-42), from -6 to $42 \mathrm{~s} \ldots \ldots . . . . .162$

278. Momentum flux in core entrance (FDV-CORE-IN), from -20 to $736 \mathrm{~s} \ldots \ldots 163$

279. Momentum flux in core cntrance (FDV-CORE-IN), from -6 to $42 \mathrm{~s} \ldots \ldots 3$

280. Density in intact loop (GU-1T and GU-1B), from -20 to $736 \mathrm{~s}$

281. Density in intact loop (GU-1 T and GU-1B),

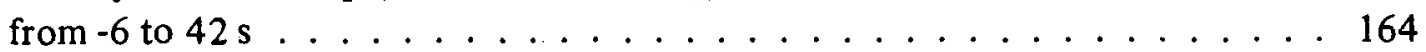

282. Density in intact loop (GU-1C), from -20 to $736 \mathrm{~s} \ldots \ldots 165$

283. Density in intact loop (GU-1C), from -6 to $42 \mathrm{~s} \ldots \ldots \ldots$ 
284. Density in intact loop (GU-5VR and GÜ-10VR), from -20 to $736 \mathrm{~s} \ldots \ldots \ldots \ldots 6 . \ldots \ldots$

285. Density in intact loop (GU-5VR and GU-10VR), from -6 to $42 \mathrm{~s} \ldots \ldots \ldots \ldots \ldots$. . . . . . . . . . . . . . . . . . 66

286. Density in intact loop (GU-13VR), from -20 to $736 \mathrm{~s} \ldots \ldots . \ldots 167$

287. Density in intact loop (GU-13VR), from -6 to $42 \mathrm{~s} \ldots \ldots \ldots$

288. Density in intact loop (GU-15T and GU-15B), from -20 to $736 \mathrm{~s} \ldots \ldots \ldots \ldots \ldots$. . . . . . . . . . . . . . . . . . .

289. Density in intact loop (GU-15T and GU-15B), from -6 to $42 \mathrm{~s} \ldots \ldots \ldots \ldots \ldots$. . . . . . . . . . . . . . . . . 68

290. Density in intact loop (GU-15C), from -20 to $736 \mathrm{~s} \ldots \ldots \ldots 9$

291. Density in intact loop (GU-15C), from -6 to $42 \mathrm{~s} \ldots \ldots \ldots$. . . . . . 169

292. Density in broken loop (GB-21T and GB-21B), from -20 to $736 \mathrm{~s} \ldots \ldots \ldots \ldots \ldots$. . . . . . . . . . . . . . . . . . . .

293. Density in broken loop (GB-21T and GB-21B), from -6 to $42 \mathrm{~s} \ldots \ldots \ldots \ldots$. . . . . . . . . . . . 170

294. Density in broken loop (GB-21C), from -20 to $736 \mathrm{~s} \ldots \ldots \ldots 171$

295. Density in broken loop (GB-21C), from -6 to $42 \mathrm{~s} \ldots \ldots \ldots 171$

296. Density in broken loop (GB-23VR), from -20 to $736 \mathrm{~s} \ldots \ldots \ldots$

297. Density in broken loop (GB-23VR), from -6 to $42 \mathrm{~s} \ldots \ldots \ldots \ldots$

298. Density in broken loop (GB-30T and GB-30B), from -20 to $736 \mathrm{~s}$

299. Density in broken loop (GB-30T and GB-30B), from -6 to $42 \mathrm{~s} \ldots \ldots \ldots \ldots \ldots$. . . . . . . . . . . . . . . .

300. Density in broken loop (GB-30C), from -20 to $736 \mathrm{~s} \ldots \ldots \ldots \ldots$

301. Density in broken loop (GB-30C), from -6 to $42 \mathrm{~s} \ldots \ldots \ldots$. . . . . . . 174

302. Density in broken loop (GB-37HZ), from -20 to $736 \mathrm{~s} \ldots \ldots \ldots$

303. Density in broken loop (GB-37HZ), from -6 to $42 \mathrm{~s} \ldots \ldots . \ldots 175$ 
304. Density in broken loop (GB-42VR), from -20 to $736 \mathrm{~s} \ldots \ldots \ldots$

305. Density in broken loop (GB-42VR), from -6 to $42 \mathrm{~s} \ldots \ldots \ldots$

306. Density in vessel (GV-COR-150HZ), from -20 to $736 \mathrm{~s} \ldots \ldots \ldots$. . . . . 177

307. Density in vessel (GV-COR-150HZ), from -6 to $42 \mathrm{~s} \ldots \ldots \ldots \ldots$

308. Density in vessel (GVLP-165HZ and GVLP-172HZ), from -20 to $736 \mathrm{~s} \ldots \ldots \ldots \ldots . \ldots \ldots$

309. Density in vessel (GVLP-165HZ and GVLP-172HZ), from -6 to $42 \mathrm{~s} \ldots \ldots \ldots \ldots \ldots$. . . . . . . . . . . . . . . . . . . . .

310. Density in pressurizer (GU-PRIZE), from -20 to $736 \mathrm{~s} \ldots \ldots \ldots$

311. Density in pressurizer (GU-PRIZE), from -6 to $42 \mathrm{~s} \ldots \ldots \ldots$

312. Mass flow in intact loop (FDU-1, GU-1C), from -6 to $42 \mathrm{~s} \ldots \ldots \ldots \ldots \ldots$

313. Mass flow in intact loop (FTU-1, GU-1C), from -6 to $42 \mathrm{~s} \ldots \ldots \ldots \ldots \ldots$

314. Mass flow in intact loop (FDU-5, GU-5VR), from -6 to $42 \mathrm{~s} \ldots \ldots \ldots \ldots 1 . \ldots \ldots 1$

315. Mass flow in intact loop (FTU-9, GU-10VR), from -6 to $42 \mathrm{~s} \ldots \ldots \ldots \ldots \ldots 1 . \ldots \ldots \ldots$

316. Mass flow in intact loop (FDU-10, GU-10VR), from -6 to $42 \mathrm{~s} \ldots \ldots \ldots \ldots \ldots 2 \ldots \ldots \ldots$

317. Mass flow in intact loop (FDU-13, GU-13VR), from -6 to $42 \mathrm{~s} \ldots \ldots \ldots \ldots 2 \ldots \ldots \ldots$

318. Mass flow in intact loop (FTU-15, GU-15C), from -6 to $42 \mathrm{~s} \ldots \ldots \ldots \ldots \ldots \ldots$

319. Mass flow in broken loop (FDB-21, GB-21C), from -6 to $42 \mathrm{~s} \ldots \ldots \ldots \ldots$. . . . . . . . . . . . . . . . 83

320. Mass flow in broken loop (FTB-21, GB-21C), from -6 to $42 \mathrm{~s} \ldots \ldots \ldots \ldots$. . . . . . . . . . . . 184

321. Mass flow in broken loop (FDB-23, GB-23VR), from -6 to $42 \mathrm{~s} \ldots \ldots \ldots \ldots \ldots$ 
322. Mass flow in broken loop (FDB-30, GB-30C), from -6 to $42 \mathrm{~s} \ldots \ldots \ldots \ldots \ldots$

323. Mass flow in broken loop (FTB-30, GB-30C), from -6 to $42 \mathrm{~s} \ldots \ldots \ldots \ldots \ldots$. . . . . . . . . . . . . . . . . . . .

324. Mass flow in broken loop (FDB-37, GB-37HZ), from -6 to $42 \mathrm{~s} \ldots \ldots \ldots \ldots \ldots$. . . . . . . . . . . . . . . . . 186

325. Mass flow in broken loop (FTB-37, GB-37HZ), from -6 to $42 \mathrm{~s} \ldots \ldots \ldots \ldots \ldots \ldots$

326. Mass flow in broken loop (FDB-42, GB-42VR), from -6 to $42 \mathrm{~s} \ldots \ldots \ldots \ldots \ldots 7$

327. Mass flow in vessel (FDV-CORE-IN, GV-COR-150HZ), from -20 to $736 \mathrm{~s}$

328. Mass flow in vessel (FDV-CORE-IN, GV-COR-150HZ), from -6 to $42 \mathrm{~s} \ldots \ldots \ldots \ldots \ldots$. . . . . . . . . . . . . . . . . . . . .

329. Mass flow in vessel (FTV-CORE-IN, GV-COR-150HZ), from -20 to $736 \mathrm{~s}$ 189

330. Mass flow in vessel (FTV-CORE-IN, GV-COR-150HZ), from -6 to $42 \mathrm{~s} \ldots \ldots \ldots \ldots$. . . . . . . . . . . . 189

331. Mass flow in pressurizer (FTU-PRIZE, GU-PRIZE), from -6 to $42 \mathrm{~s} \ldots \ldots \ldots \ldots$. . . . . . . . . . . . . . . . . . . . .

332. Core heater rod total power (PWRCOR T-1 and PWRCOR T-2), from -20 to $736 \mathrm{~s}$

333. Core hcater rod total power (PWRCOR T-1 and PWRCOR T-2), from -6 to $42 \mathrm{~s} \ldots \ldots \ldots \ldots 1 . \ldots \ldots 1$

334. Cure heatel voltage (VOLTCOR T), frum -20 to $736.8 \ldots \ldots$. . . . . . . 192 335. Core heater voltage (VOLTCOR-T), from -6 to $42 \mathrm{~s} \ldots \ldots \ldots 2$ 336. Core heater total current (AMPCOR-T), from -20 to $736 \mathrm{~s} \ldots \ldots$. . . . . 193 337. Core heater total current (AMPCOR-T), from -6 to $42 \mathrm{~s} \ldots \ldots \ldots 3$ 338. Primary pump current (PUMPU-CUR), from -20 to $736 \mathrm{~s} \ldots \ldots$. . . . . . . 194 
339. Primary pump current (PUMPU-CUR), from -6 to 42 s . . . . . . . . . . . . 194

340. Primary pump speed (PUMPU-RPM), from -20 to $736 \mathrm{~s} \ldots \ldots$. . . . . . 195

341. Primary pump speed (PUMPU-RPM), from -6 to 42 s . . . . . . . . . . 195

B-1. Geometry used for processing of density data obtained from two-beam gamma densitometers . . . . . . . . . . . . 210

C-1. Fluid temperature in broken loop (TFB-23) . . . . . . . . . . 220

C-2. Fluid temperature in downcomer annulus (TFV-ANN-35A) . . . . . . . 220

C-3. Fluid temperature in lower plenum (TFV-LP-2) . . . . . . . . . . 221

C-4. Fluid temperature in lower plenum (TFV-LP-4) . . . . . . . . . 221

C-5. Fluid temperature in lower plenum (TFV-LP-7) . . . . . . . . . . 222

C-6. Fluid temperature in core, Grid Spacer 5 (TFG-5CD-45) . . . . . . . . . 222

C-7. Fluid temperature in steam generator, secondary side

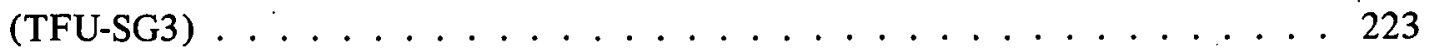

C-8. Fluid temperature in pressurizer surge line (TFU-PRIZE) . . . . . . . . 223

C-9. Material temperature in intact loop (TMU-1T16) . . . . . . . . . . . . 224

C-10. Material temperature in vessel filler (TMV-CI-70A) . . . . . . . . . . . 224

C-1 1. Core heater temperature, $\operatorname{Rod}$ E-4 (TH-E4-09) . . . . . . . . . . . 225

C-12. Core heater temperature, Rod E-4 (TH-E4-27) . . . . . . . . . 225

C-13. Core heater temperature, Rod E-4 (TH-E4-55) . . . . . . . . . 226

C-14. Pressure in intact loop, Spool 13 (PU-13) . . . . . . . . . . 226

C-15. Pressure in broken loop, Spool $23(\mathrm{~PB}-23) \ldots \ldots . \ldots 227$

C-16. Differential pressure in intact loop (DPU-6-SGIP) . . . . . . . . . . . 227

C-17. Differential pressure in intact loop (DPU-SGOP-7) $\ldots \ldots \ldots$

C-1 8. Differential pressure in intact loop (DPU-7-10) . . . . . . . . . . . 228 
C-19. Differential pressure in in tact loop (DPU-12-10) . . . . . . . . . . . . 229

C-20. Differential pressure in intact loop (DPU-12-15) . . . . . . . . . . . 229

C-21. Volumetric flow in intact loop (FTU-1) . . . . . . . . . . . . 230

C-22. Volumetric flow in intact loop $($ FTU-15) $\ldots \ldots \ldots . \ldots . \ldots 230$

$\mathrm{C}-23$. Volumetric flow in in tact loop high pressure injection line

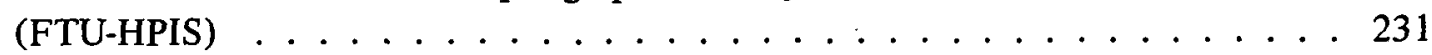

$\mathrm{C}-24$. Volumetric flow in intact loop low pressure injection line

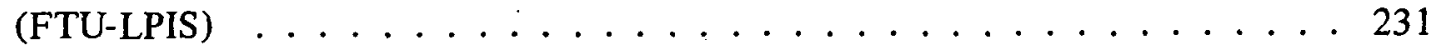

C-25. Volumetric flow in intact loop accumulator discharge line (FTU-ACC1) ........................ 232

C-26. Fluid velocity in vessel (FTV-4UA) . . . . . . . . . . 232

C-27. Fluid velocity in vessel (FTV-40M) . . . . . . . . . . . . 233

C-28. Density in intact loop $(G U-1 T) \ldots \ldots \ldots \ldots \ldots$

C-29. Density in intact loop (GU-1B) . . . . . . . . . . . . . . . 234

C-30. Density in intact loop $(\mathrm{GU}-1 \mathrm{C}) \ldots \ldots \ldots \ldots \ldots$

$(-31$. Density in iñ táct loop (GU-10VR) . . . . . . . . . 23b

C-32. Density in intact loop (GU-15T) . . . . . . . . . . . 235

C-33. Density in intact loop (GU-15B) . . . . . . . . . . . 236

C-34. Density in intact loop $(\mathrm{GU}-15 \mathrm{C}) \ldots \ldots \ldots \ldots$

r-35. Density in broken loop (GB-23VR) . . . . . . . . . . 237

C-36. Density in vessel (GV-COR-150HZ) . . . . . . . . . 23'

C-37. Density in vessel (GVLP-165HZ) . . . . . . . . . . . 238

C-38. Density in vessel (GVLP-172HZ) . . . . . . . . . . . 238

C-39. Mass flow in intact loop (FTU-1, GU-1C) . . . . . . . . . . . . 239

C-40. Mass flow in intact loop (FDU-5, GU-5VR) . . . . . . . . . 239 
C-41. Mass flow in intact loop (FTU-15, GU-15C) . . . . . . . . . . . . 240

C-42. Mass flow in broken loop (FDB-21, GB-21C) . . . . . . . . . . . . 240

C-43. Mass flow in broken loop (FTB-21, GB-21C) . . . . . . . . . . . 241

C-44. Mass flow in vessel (FTV-CORE-IN, GV-COR-150HZ) . . . . . . . . . . 241

\section{TABLES}

I. Conditions at Blowdown Initiation $\ldots \ldots \ldots$

II. Primary Coolant Temperature Distribution Prior to Rupture . . . . . . . 7

III. Water Chemistry Prior to Blowdown . . . . . . . . . . . . . 8

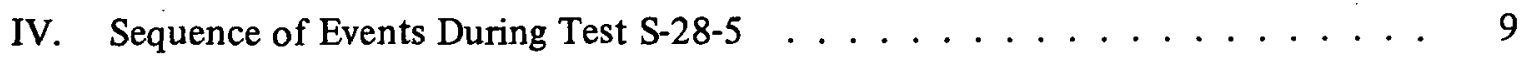

V. Data Presentation for Semiscale Mod-1 Test S-28-5 . . . . . . . . 17

B-I. Constants for Pressure Measurement Corrections

(Test s-28-5) . . . . . . . . . . . . . . . . . 204

B-II. Constants for Differential Pressure Measurement

Corrections (Test S-28-5) . . . . . . . . . . . . . 205

B-III. Constants for Momentum Flux Measurement Corrections

(Test S-28-5) . . . . . . . . . . . . . . . 207

B-IV. Constants for Density Measurement Conversion tn

Engineering Units (Test S-28-5) . . . . . . . . . . . . . . . 209

C-I. Random Error Variance . . . . . . . . . . . . . . . 215

C-II. General Measurement Engineering Error Sources and Error Values (Test S-28-5) . . . . . . . . . . . . . . . . . 243

C-III. Time Perinds When Flow Regime Errors Werc Applied

(Test S-28-5) . . . . . . . . . . . . . . . . . . . . 248 


\section{EXPERIMENT DATA REPORT FOR SEMISCALE MOD-1}

TEST S-28-5

\section{(STEAM GENERATOR TUBE RUPTURE TEST)}

\section{INTRODUCTION}

The Semiscale Mod-1 experiments represent the current phase of the Semiscale Program conducted by EG\&G Idaho, Inc. for the United States Government. The program, which is sponsored by the Nuclear Regulatory Commission through the Department of Energy ${ }^{[a]}$, is part of the overall program designed to investigate the response of a pressurized water reactor system to a hypothesized loss-of-coolant accident (LOCA). The underlying objectives of the Semiscale Program are to quantify the physical processes controlling system behavior during a LOCA and to provide an experimental data base for assessing reactor safety evaluation models. The Semiscale Mod-1 Program has the further objective of providing support to other experimental programs in the form of instrumentation assessment, optimization of test series, selection of test parameters, and evaluation of test results.

Test S-28-5. was conducted July 19, 1977 in the Semiscale Mod-1 system as part of the steam generator tube rupture test series (Test Series 28). This series was designed to obtain thermal-hydraulic response data from blowdown, refill, and reflood transients in a simulated nuclear reactor with a heated core to study system response during a LOCA with steam generator tube ruptures. The test objective specific to Test S-28-5 was to refine the definition of the upper limit set by Test S-28-1 and to investigate the range of steam generator tube ruptures over which high peak cladding temperatures can occur.

The purpose of this report is to present the test data in an uninterpreted but readily usable form for use by the nuclear community in advance of detailed analysis and interpretation. Section II briefly describes the system configuration, procedures, initial test conditions, and events that are applicable to Test S-28-5; Section III presents the data graphs and provides comments and supporting information necessary for interpretation of the data. A description of the overall Semiscale Program and test series, a more detailed description of the Semiscale Mod-1 system, and a description of the measurement and data processing techniques and uncertainties can be found in Reference 1. Appendix A also provides additional information on the data acquisition system capabilities.

[a] Test conducted under the Energy Research and Development Administration. 


\section{SYSTEM, PROCEDURES, CONDITIONS, AND EVENTS FOR TEST,S-28-5}

The following system configuration, procedures, initial test conditions, and events are specific to Test S-28-5 as indicated.

\section{SYSIIEM CUNFIGURATIUN AND TEST PROCEDURES}

The Semiscale Mod-1 system used for this test consisted of a pressure vessel with internals, including a 40-rod core with 36 electrically heated rods; an intact loop with steam generator, pump, and pressurizer; a broken loop with simulated steam generator, simulated pump, and two rupture assemblies; coolant injection accumulators for the cold legs of the intact and broken loops, and a heated accumulator for the intact loop hot leg; high and low pressure injection pumps for each of the system loops; and a pressure suppression system with a suppression tank, header, and heated steam supply system. For Test S-28-5, the volume of the lower plenumm was reduced to $0.014980 \mathrm{~m}^{3}$ by the addition of a metal filler piece. Semiscale Mod-1 experimental system configuration information is described further in Reference 1. Figures 1 and 2 show the system configuration for Test S-28-5.

For Test S-28-5, 33 rods of the 40-rod electrically heated core were operated at a peak power density of approximately $37.7 \mathrm{~kW} / \mathrm{m}$, three rods (Rods D-4, E-4, and E-5) were operated at a peak power density of approximately $39.7 \mathrm{~kW} / \mathrm{m}$ to yield a slightly peaked power profile, and four rods (Rods C-3, D-5, F-3, and F-6) were unpowered to simulate the effect of control rod guide tubes. The resulting total core power was approximately $1.39 \mathrm{MW}$.

In preparation for the test, the accumulators for the intact and broken loop cold legs were filled with treated demineralized water, drained to the specified initial levels, and pressurized with nitrogen to $4223 \mathrm{kPa}$. The accumulator for the intact loop hot leg was filled with treated demineralized water, drained to the specified initial level, heated to $541 \mathrm{~K}$, and pressurized to $7584 \mathrm{kPa}$. The system was filled with treated demineralized water and vented at strategic points to ensure a liquid-full system. Prior to warmup the system was pressurized to check for leakage, system instrumentation was checked, and transducer readings were initialized. Warmup to initial test conditions was accomplished with the heaters in the vessel core. Heatup of the broken loop piping was accomplished with bypass lines which served to allow circulation through the broken loop. During warmup, the purification and sampling systems were valved into the primary system to maintain water chemistry requirements and to provide a water sample at system conditions for subsequent analysis. At 56-K-temperature intervals during warmup, detector readings were sampled to allow the integrity of the measurement instrumentation and the operability of the data acquisition system to be checked.

Prior to the initial core power level being established, the pressure suppression system was pressurized to $241 \mathrm{kPa}$ with saturated steam from the steam supply system. After the 


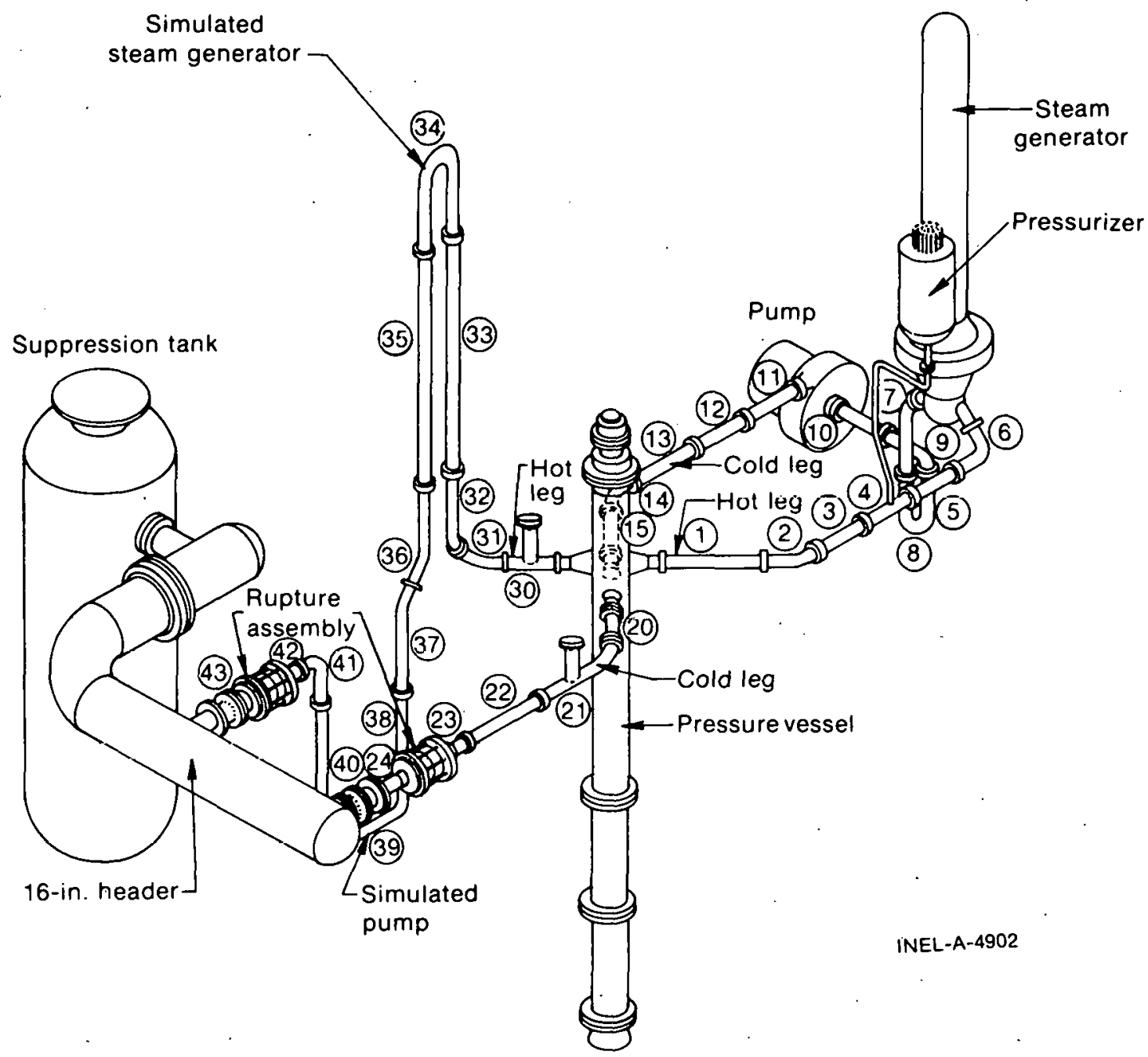

Fig. 1 Semiscale Mod-1 system for cold leg break configuration -isometric.

core power was increased to $1.39 \mathrm{MW}$, initial test conditions were held for $1183 \mathrm{~s}$ to establish equilibrium in the system. At the end of this period all auxiliary systems including the bypass lines were isolated to prevent blowdown through those systems.

The system was successfully subjected to a simulated double-ended cold leg break through two rupture assemblies and two blowdown nozzles, each having a break area of $0.000243 \mathrm{~m}^{2}$. Pressure to operate the rupture assemblies and initiate blowdown was taken from an accumulator system filled with water and pressurized to $15513 \mathrm{kPa}$ with gaseous nitrogen. Immediately (within $0.02 \mathrm{~s}$ ) after initiation of blowdown, the lines to the accumulator were again isolated. The effluent was ejected from the primary system into the pressure suppression system which was vented to maintain a constant pressure of $241 \mathrm{kPa}$. At blowdown, power to the primary coolant circulation pump was reduced and the pump was allowed to coast down to a speed of $1480 \mathrm{rpm}$ which was maintained for the duration of the test. During the blowdown transient, power to the electrically heated core was automatically controlled to simulate the thermal response of nuclear heated fuel rods. 


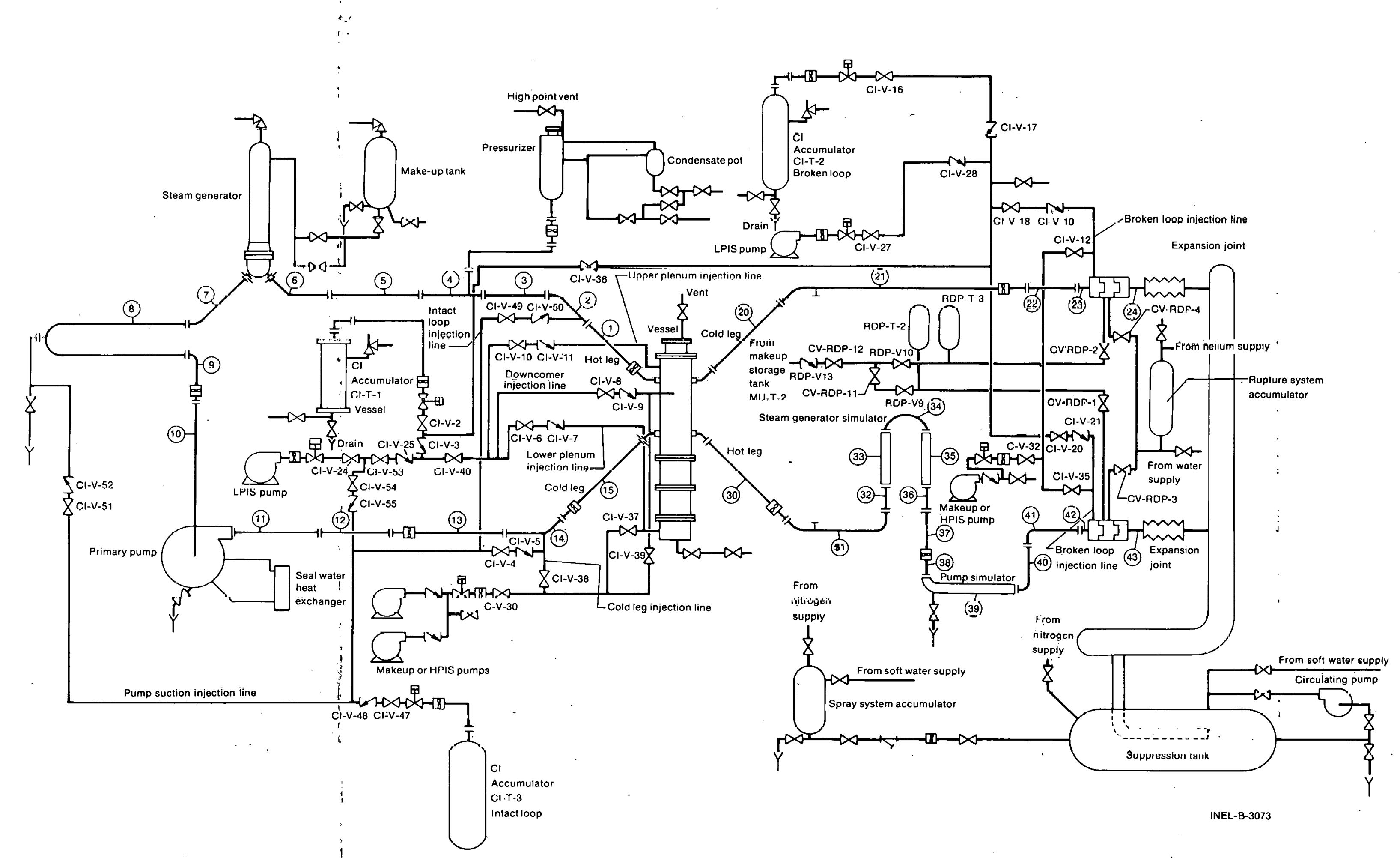

Fig. 2 Semiscale Mod-1 system for cold leg break configuration -schematic. 
For Test S-28-5, the coolant injection systems were arranged to discharge into both system loops at the cold leg injection points (Spool 14 and Spool 42). The high pressure coolant injection pumps were started immediately after initiation of blowdown $(0 \mathrm{~s})$ and continued to the end of the test (736 s). Low pressure coolant injection was initiated $25 \mathrm{~s}$ after blowdown at a system pressure of $1034 \mathrm{kPa}$ and continued until test termination (736 s). Coolant injection from the intact loop accumulator (CI-T-1) started $17 \mathrm{~s}$ after blowdown, and nitrogen discharge began $64 \mathrm{~s}$ after rupture and was terminated $88 \mathrm{~s}$ after blowdown. The broken loop accumulator (CI-T-2) began injection $4 \mathrm{~s}$ after blowdown, nitrogen discharge began $28 \mathrm{~s}$ after rupture and contined to test termination ( $736 \mathrm{~s}$ ). The steam generator rupture system accumulator (CI-T-3) began injection at $40 \mathrm{~s}$ after blowdown and continued until $464 \mathrm{~s}$ after blowdown.

\section{INITIAL TEST CONDITIONS AND SEQUENCE OF EVENTS}

Conditions in the Semiscale Mod-1 system at initiation of blowdown are given in Tables I and II; the primary system water chemistry prior to blowdown is given in Table III; and the sequence of events relative to rupture is given in Table IV. 
TABLE I

CONDITIONS AT BLOWDOWN INITIATION

\begin{tabular}{|c|c|c|c|}
\hline & & \multicolumn{2}{|c|}{ Test S-28-5 } \\
\hline & & Measured $^{[a]}$ & Specified \\
\hline \multicolumn{2}{|c|}{ Core power (MW) } & 1.399 & $1.43 \pm 0.01$ \\
\hline \multicolumn{2}{|c|}{$\begin{array}{l}\text { Intact loop cold leg fluid } \\
\text { temperature }(K)\end{array}$} & 556 & $558 \pm 1$ \\
\hline \multicolumn{2}{|c|}{$\begin{array}{l}\text { Hot leg to cold leg temperature } \\
\text { differential }(\mathrm{K})\end{array}$} & 37.5 & $37 \pm 0.5$ \\
\hline \multicolumn{2}{|c|}{ Pressurizer pressure (k.Pa) } & 15768 & $156 n n \pm 34$ \\
\hline \multicolumn{2}{|c|}{ Pressurizer liquid mass $(\mathrm{kg})^{[\mathrm{b}]}$} & 8.94 & 9.07 \\
\hline \multicolumn{2}{|c|}{$\begin{array}{l}\text { Steam generator feedwater } \\
\text { temperature }(K)\end{array}$} & 502 & $\begin{array}{ll} & +6 \\
497 & -17\end{array}$ \\
\hline \multicolumn{2}{|c|}{$\begin{array}{l}\text { Steam generator liquid level (fror } \\
\text { bottom of tube sheet) }(\mathrm{cm})\end{array}$} & 278 & $295 \pm 5$ \\
\hline \multicolumn{2}{|c|}{$\begin{array}{l}\text { Broken loop fluid temperature } \\
\quad \text { (pump side) }(\mathrm{K})\end{array}$} & 588 & 589 to 594 \\
\hline \multicolumn{2}{|c|}{$\begin{array}{l}\text { Broken loop fluid temperature } \\
\text { (vessel side) }(K)\end{array}$} & 554 & Not Specified \\
\hline \multicolumn{2}{|c|}{ Intact loop cold leg flow $(\ell / s)$} & 9.06 & [c] \\
\hline \multicolumn{2}{|c|}{$\begin{array}{l}\text { Pressure suppression tank } \\
\text { water level }(\mathrm{cm})\end{array}$} & 121 & $121 \pm 1$ \\
\hline \multicolumn{2}{|c|}{$\begin{array}{l}\text { Pressure suppression tank } \\
\text { pressure }(k \Gamma n)\end{array}$} & 240 & $211 \pm 6$ \\
\hline \multicolumn{2}{|c|}{$\begin{array}{l}\text { Pressure suppression tank water } \\
\text { temperature }(K)\end{array}$} & 291 & $<297$ \\
\hline \multicolumn{4}{|c|}{$\begin{array}{l}\text { [a] Measured initial conditions are taken from digital scan read just } \\
\text { prior to blowdown. Those measured conditions which did not meet } \\
\text { the specified initial conditions were considered acceptable for } \\
\text { analysis purposes within the test objectives. }\end{array}$} \\
\hline \multicolumn{4}{|c|}{ [b] Pressurizer liquid mass including surge line. } \\
\hline \multicolumn{4}{|c|}{$\begin{array}{l}\text { [c] Flow is not specified, since it must be adjusted to achieve the } \\
\text { required differential temperature across the core. }\end{array}$} \\
\hline
\end{tabular}


TABLE II

PRIMARY COOLANT TEMPERATURE DISTRIBUTION PRIOR TO RUPTURE[a]

\begin{tabular}{llc}
\hline & \multicolumn{2}{c}{ Test S-28-5 } \\
\cline { 2 - 2 } $\begin{array}{l}\text { Vessel lower plenum (upper portion } \\
\text { above filler block) }\end{array}$ & Detector & Temperature (K) \\
Intact loop hot leg (near vessel) & TFV-LP-7 & 555 \\
Intact loop cold leg (near pump inlet) & RBU-2 & 594 \\
Intact loop cold leg (near vessel) & RBU-14A & 556 \\
Broken loop cold leg (near nozzle) & TFB-23 & 554 \\
Broken loop hot leg (near vessel) & TFB-30 & 595 \\
Broken loop cold leg (near nozzle) & TFB-42 & \\
\hline [a] Data taken from final digital scan 0.5 s before blowdown. & \\
\hline
\end{tabular}


TABLE III

WATER CHEMISTRY PRIOR TO BLOWDOWN [a]

\section{Test S-28-5}

$\begin{array}{lc}\mathrm{pH} & 10.50 \\ \text { Conductivity }(\mu \mathrm{S} / \mathrm{cm}) & 93 \\ \text { Lithium }(\mu \mathrm{g} / \mathrm{ml}) & 3.1 \\ \text { Chlorides }(\mathrm{ppm}) & 0.30 \\ \text { Fluorides }(\mu \mathrm{g} / \mathrm{ml})(\mathrm{b}\rfloor & 0.48 \\ \text { Oxygen }(\mathrm{cc} / \ell) & 0.06 \\ \text { Total gas }(\mathrm{cc} / \ell) & 149.3 \\ \text { Suspended sol } 1 \mathrm{ds}(\mu \mathrm{g} / \mathrm{mll}) & 0.33\end{array}$

[a] Water sample taken at a system pressure of approximately $15603 \mathrm{kPa}$ and a system temperature of approximately $555 \mathrm{~K}$ (cold leg).

[b] Present analytical methods prevent accurate determination of fluorides at concentrations of less than $0.4 \mu \mathrm{g} / \mathrm{m} \ell$. 
TABLE IV

SEQUENCE OF EVENTS DURING TEST $\cdot S-28-5^{[a]}$

Event

Core power level established

Bypass lines valved out of system

Blowdown initiated

Pump power reduced

High pressure injection system

$$
\text { pumps started }[\mathrm{b}]
$$

ECC accumulators valved in

Steam generator feedwater and discharge valves closed

Core power decay transient started

Low pressure injection system pumps started $[b]$

Core power tripped off ${ }^{[c]}$
Time Relative

to Rupture (s)

$-1143$

$-2.5$

0

. 0

0

0

0

2.7

30

736

[a] A time-controlled sequencer was used to control critical events during the test.

[b] Injection from ECC accumulators and high and low pressure injection system pumps does not start until system pressure drops below accumulator or pump pressure, respectively.

[c] Core power tripped manually at termination of test. 


\section{DATA PRESENTATION}

The data from Semiscale Mod-1 Test S-28-5 are presented with brief comment. Processing analysis has been performed only to the extent necessary to obtain appropriate engineering units and to ensure that the data are reasonable and consistent. In all cases, in converting transducer output to engineering units, a homogeneous fluid was assumed. Further interpretation and analysis should consider that sudden decompression processes such as those occurring during blowdown may have subjected the measurement devices to nonhomogeneous fluid conditions.

The performance of the system during Test S-28-5 was monitored by 221 detectors. The data obtained were recorded on both digital and analog data acquisition systems. The digital system was used to process the data presented in this report. The analog system was used to provide redundant data. The long term data and plots $(-32$ to $736 \mathrm{~s})$ presented in this report were recorded at an effective sample rate of 1.369 points per second. Short term data and plots ( -6 to $42 \mathrm{~s}$ ) were recorded at an effective sample rate of 19.17 points per second.

The data are presented, in some instances, in the form.of composite graphs to facilitate comparison of the values of given variables at several locations. The scales selected for the graphs do not reflect the obtainable resolution of the data. (The data processing techniques are described further in Reference 1 and Appendix A.)

Figures 3 through 8 and Table $\mathrm{V}$ provide supporting information for interpretation of the data graphs shown in Figures 9 through 341 and provide relative locations of all detectors used during 'Test $S-28-5$. 'l'able $V$ groups the measurements according to measurement type; identifies the specific measurement location and the range of the detector and actual recording range of the data acquisition system; provides brief comments regarding the data; and references the measurements and comments to the corresponding figure. Figures 9 through 341 present all the blowdown and reflood data obtained. Time zero on the graphs is the time of rupture initiation. Appendix A provides information explaining the data acquisition system capabilities. Appendix B provides information explaining posttest data processing for data conversion into engineering units and data adjustments. Presented in Appendix $\mathrm{C}$ is an analysis of selected data which provide a guide to the uncertainty associated with data measurements in the Seiniscale Mod-1 system. 


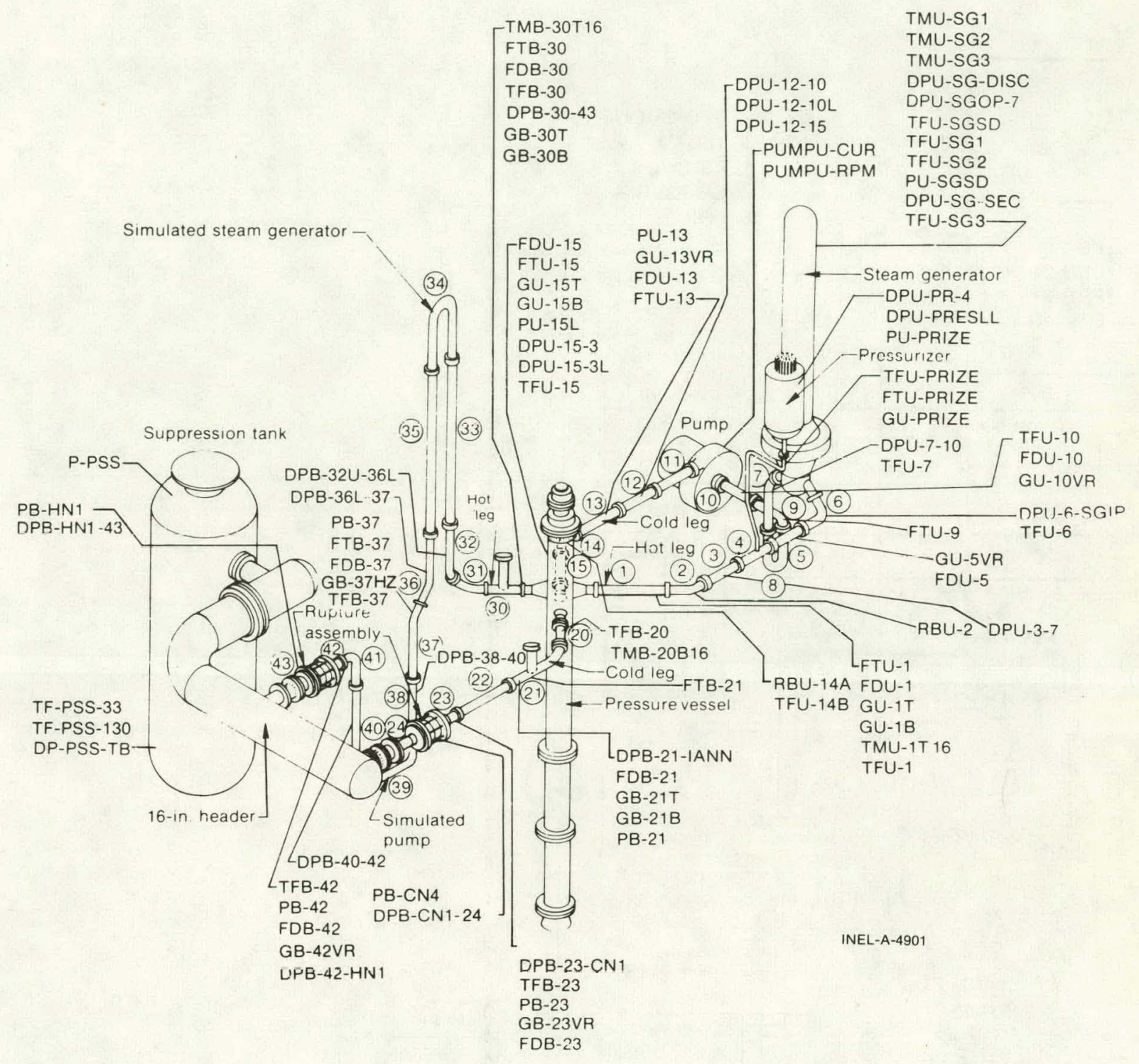

Fig. 3 Semiscale Mod-1 system and instrumentation for cold leg break configuration -- isometric. 


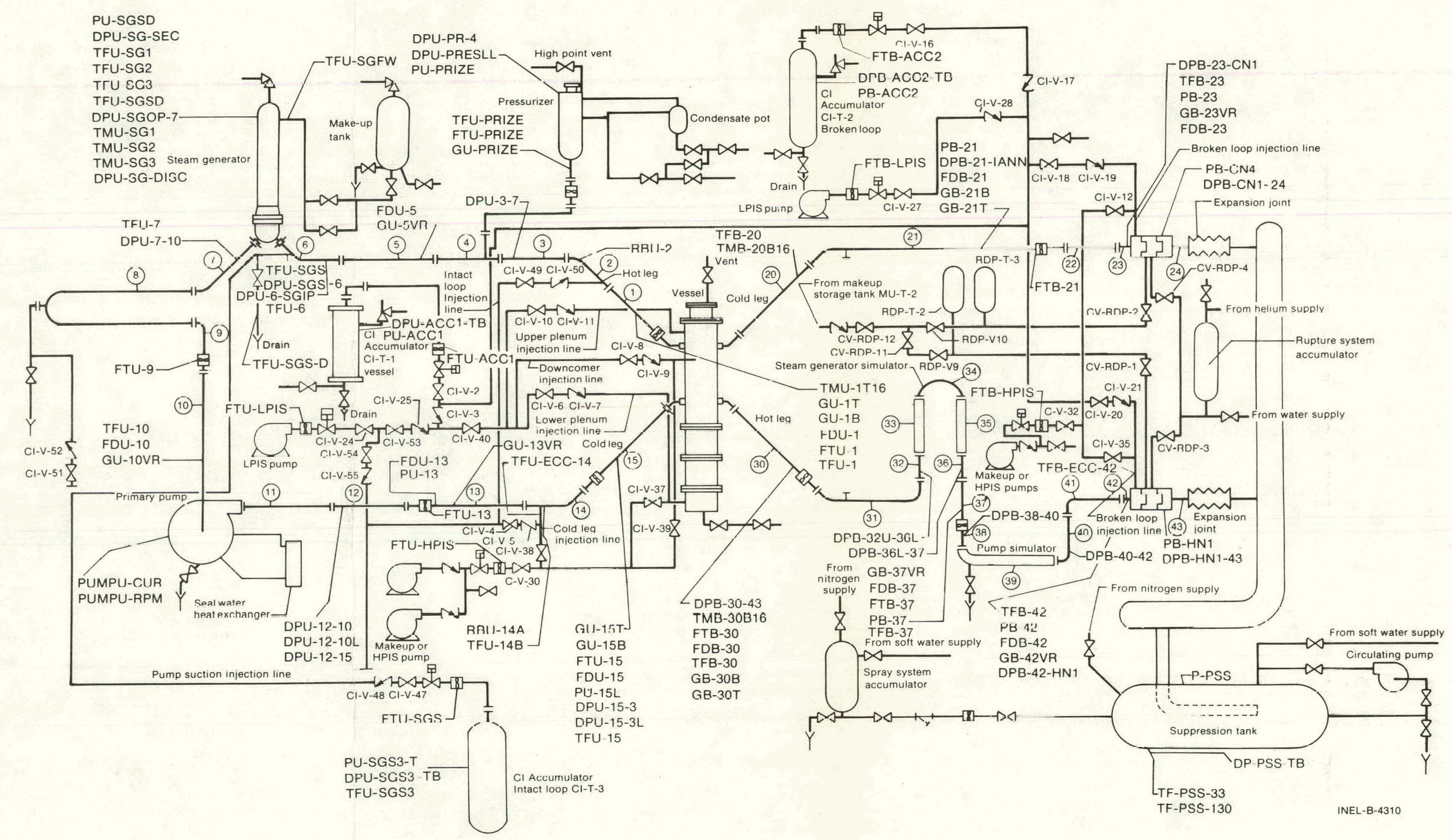

Fig. 4 Semiscale Mod-1 system and instrumentation for cold leg break configuration -- schematic. 


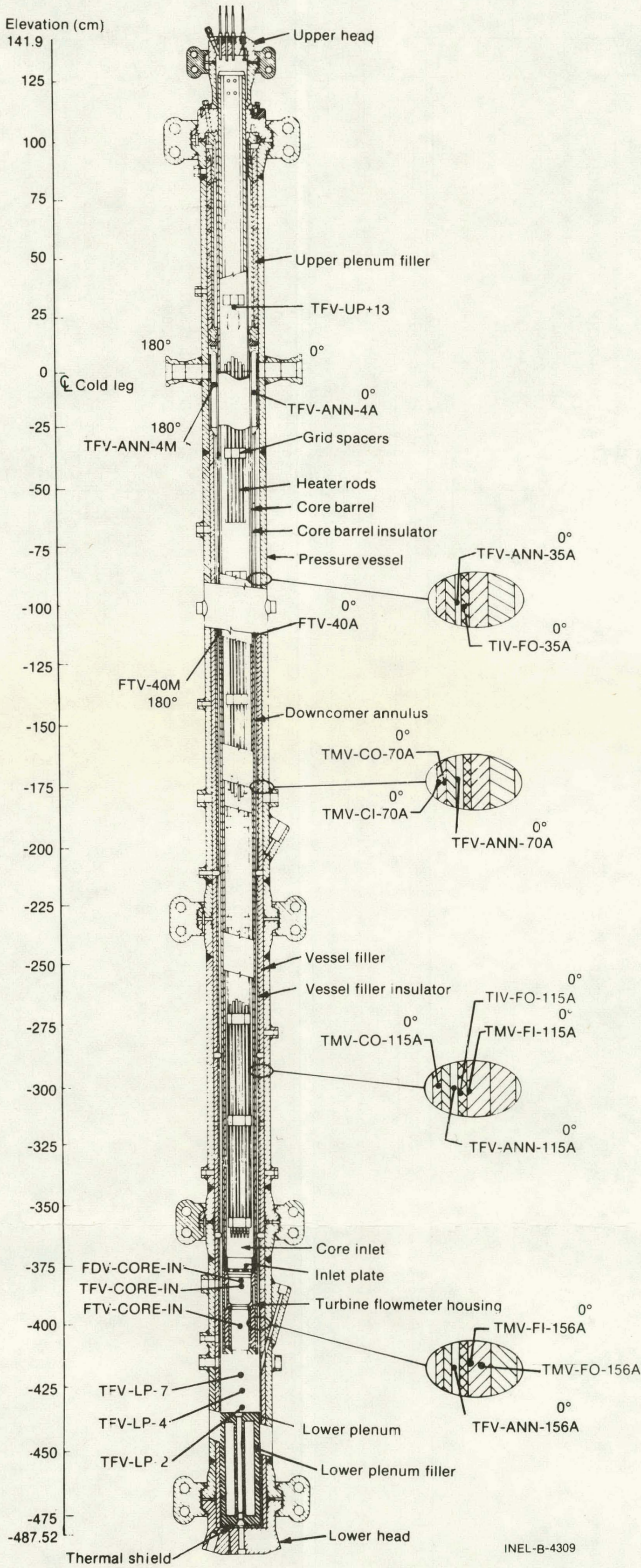

Fig. 5 Seniscale Mod-1 pressure vessel -- cross section showing instrumentation. 
Distance from

cold leg \& $(\mathrm{cm})$

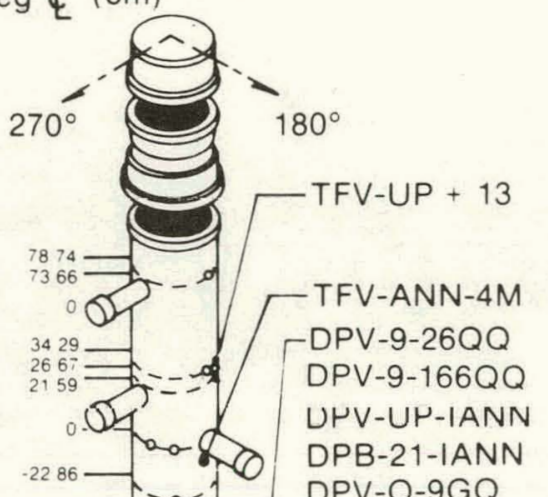

DPV-O-9GQ
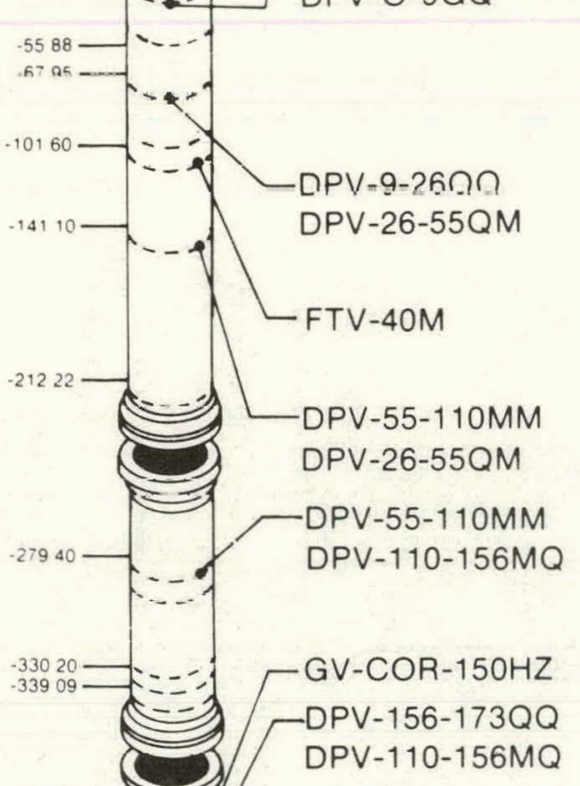

230

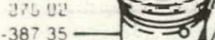

$.38735 \longrightarrow-10$

$-41910$

$64 \div=-$

13600

$\Rightarrow$ GVLP-172HZ

$-4521270=-1720-156-173 Q$

48: 52

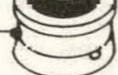

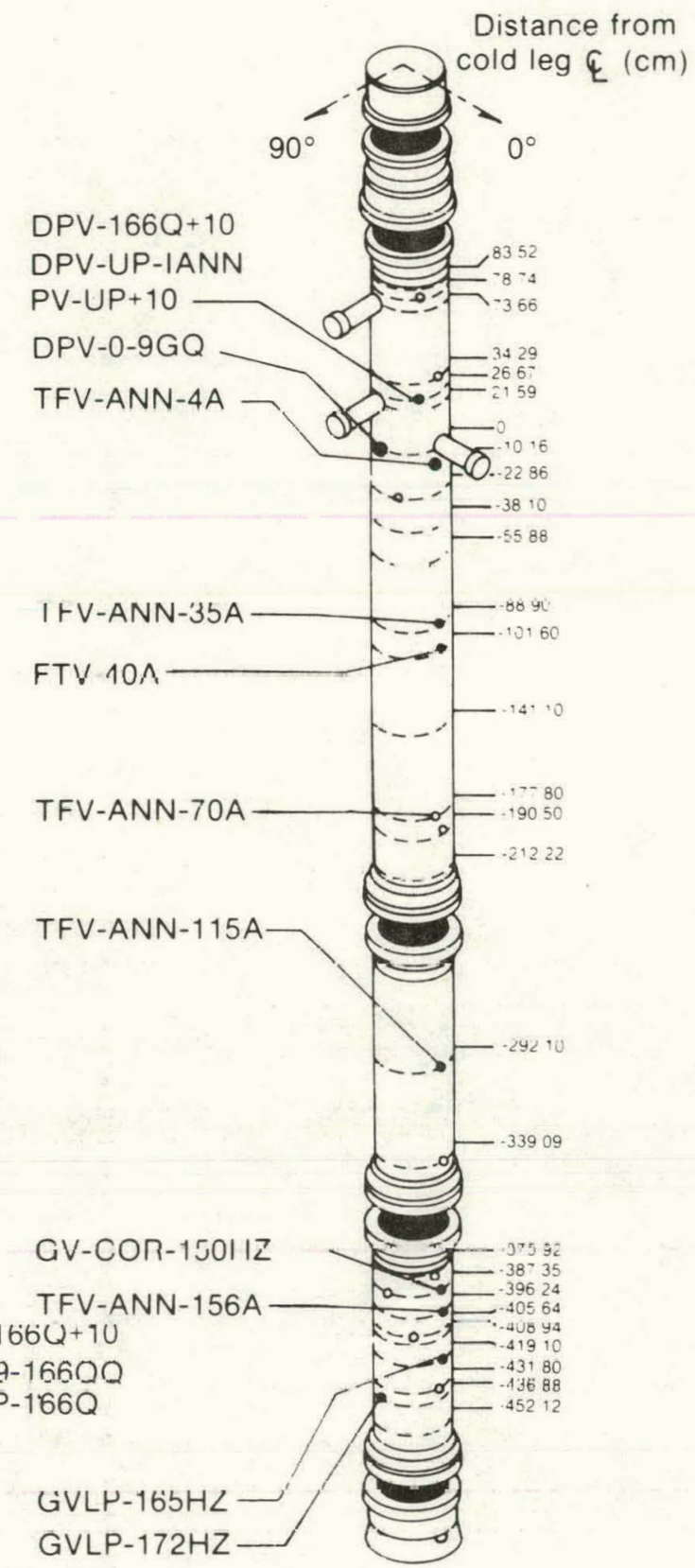

INEL-A-4307

Fig. 6 Semiscale Mod-1 pressure vessel -- isometric showing instrumentation. 


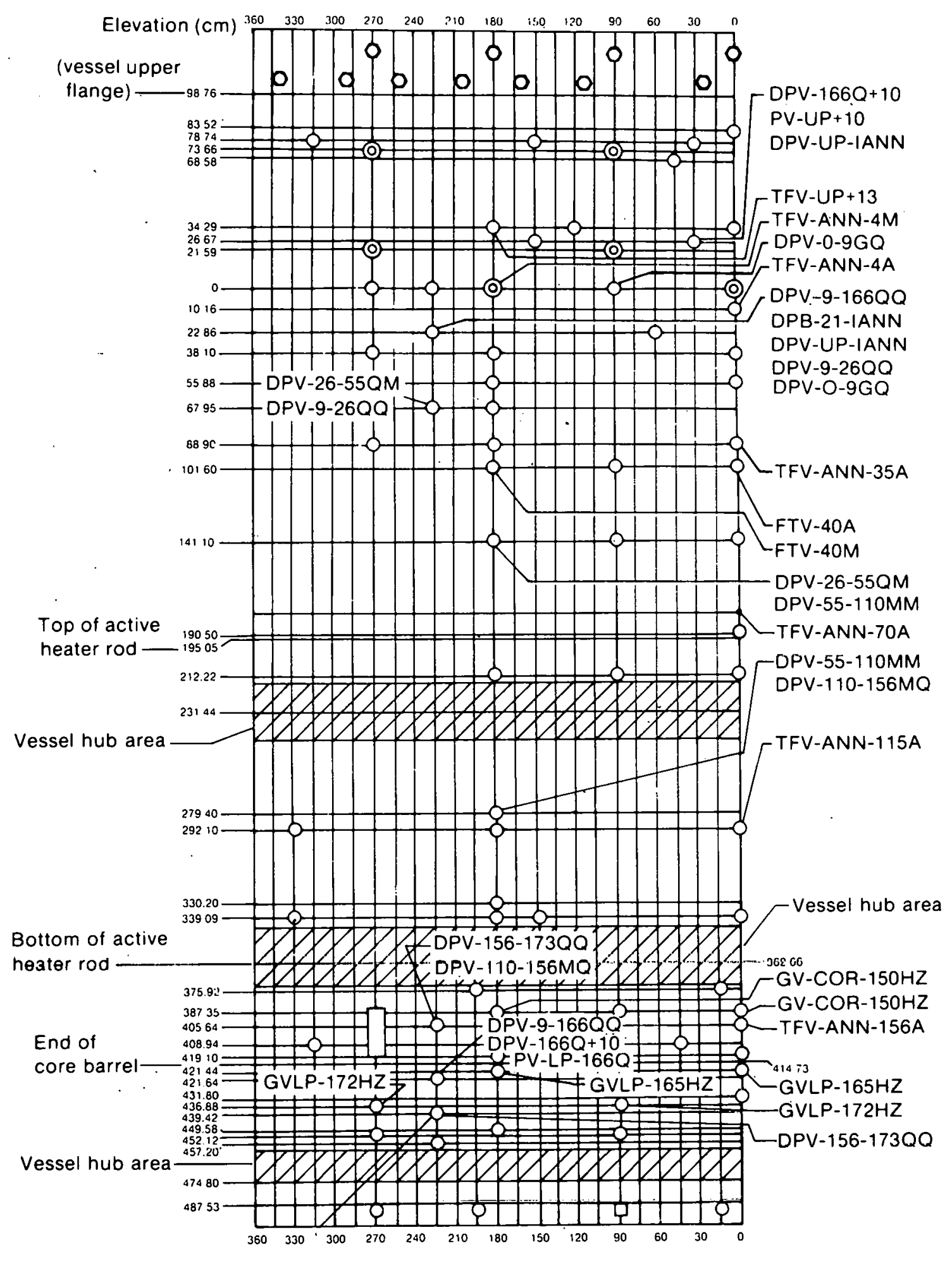

INEL-A-4306

Fig. 7 Semiscale Mod-1 pressure vessel -- penetrations and instrumentation. 
$\begin{array}{lllllllll}A & B & C & D & \text { D } & E & F & G & H\end{array}$

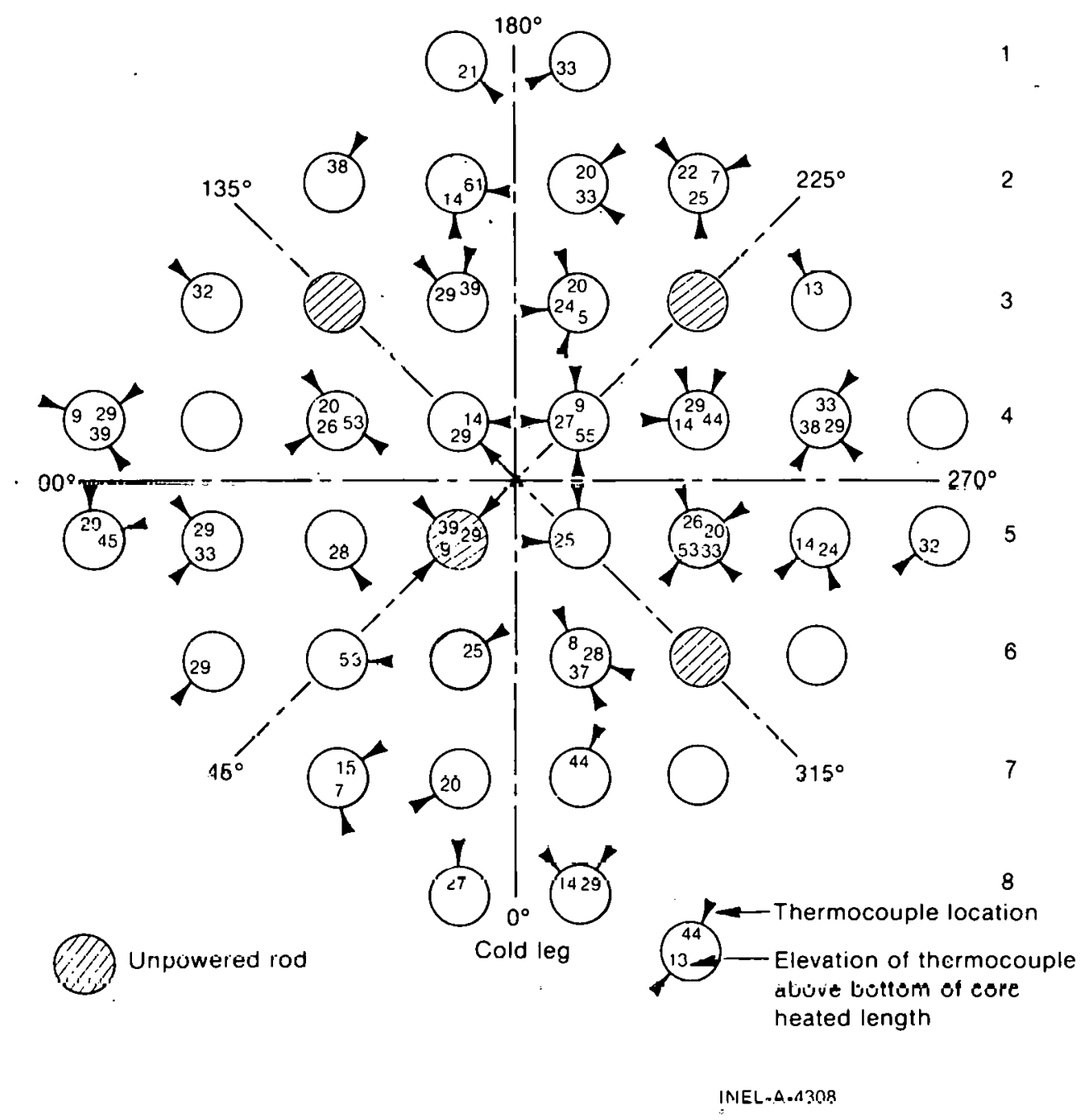

Fig. 8 Semiscale Mod-1 heated core -- plan view. 
TABLE V

DATA PRESENTATION FOR SEMISCALE MOD-1 TEST S-28-5

\begin{tabular}{|c|c|c|c|c|c|}
\hline \multirow[b]{2}{*}{ Measurement } & \multirow[b]{2}{*}{ Location and comments ${ }^{[a]}$} & \multicolumn{2}{|c|}{ Range $^{[a]}$} & \multirow{3}{*}{ Fígure ${ }^{[\mathrm{a}]}$} & \multirow[b]{2}{*}{ Measurement Comments ${ }^{[b]}$} \\
\hline & & Detector & $\begin{array}{l}\text { Data Acquisition } \\
\text { System } \\
\end{array}$ & & \\
\hline FLUID TEMPERATURE & $\begin{array}{l}\text { Chromel-Al unel thermocouples uniess } \\
\text { specified otherwise. }\end{array}$ & & & & \\
\hline$\underline{\text { Intact Loop }}$ & & 0 to $1533 \mathrm{~K}$ & $n$ to $584 \mathrm{~K}$ & & \\
\hline TFU-1 & $\begin{array}{l}\text { Hot leg, Spool 1, } 54 \mathrm{~cm} \text { from vessel } \\
\text { center. }\end{array}$ & & 0 to $820 \mathrm{~K}$ & 9,10 & \\
\hline RBU-2 & $\begin{array}{l}\text { Hot leg, Spool 2. } 117 \mathrm{~cm} \text { from vessel } \\
\text { center (platinum resistance bulb). }\end{array}$ & 0 to $811 x$ & 0 to $811 \mathrm{~K}$ & 9,10 & \\
\hline TFU-6 & $\begin{array}{l}\text { Hot leg, Spool 6, } 290 \mathrm{~cm} \text { from vessel } \\
\text { center. }\end{array}$ & & . & 11,12 & - \\
\hline TFU-7 & $\begin{array}{l}\text { Cold leg, Spool } 7,624 \mathrm{~cm} \text { from vessel } \\
\text { center. }\end{array}$ & & & 13,14 & \\
\hline TFU-10 & $\begin{array}{l}\text { Cold leg, Spool } 10,367 \mathrm{cml} \text { from } \\
\text { vesscl center. }\end{array}$ & & . & 13,14 & \\
\hline RBU-14A & $\begin{array}{l}\text { Cold leg, Spool } 14,109 \mathrm{~cm} \text { from } \\
\text { vesse) center, upstream of cold leg } \\
\text { injection port (platinum resistance } \\
\text { buib). }\end{array}$ & 0 to $811 \mathrm{~K}$ & 0 to $811 \mathrm{~K}$ & 15.16 & \\
\hline TFU-14B & $\begin{array}{l}\text { Cold leg, Spool } 14,99 \mathrm{~cm} \text { from } \\
\text { vessel center, downstream of cold } \\
\text { leg injection port. }\end{array}$ & & & 15,16 & \\
\hline TFU-15 & $\begin{array}{l}\text { Cold leg, Spool 15, } 54 \mathrm{~cm} \text { from } \\
\text { vessel center. }\end{array}$ & & & 17,18 & \\
\hline Broken Loop & & 0 to $1533 \mathrm{~K}$ & 0 to $820 \mathrm{~K}$ & & \\
\hline TFQ-20 & $\begin{array}{l}\text { Culd ley, } 5 \text { pool } 20,52 \mathrm{~cm} \text { from } \\
\text { vessel center. }\end{array}$ & & . & 19.20 & · \\
\hline T.FB-23 & $\begin{array}{l}\text { Cold leg, Spool } 23,232 \mathrm{~cm} \text { from } \\
\text { vessel center, upstream of vessel- } \\
\text { side nozzie. }\end{array}$ & & & 19,20 & \\
\hline TFB-30 & $\begin{array}{l}\text { Hot leg, Spool } 30,40 \mathrm{~cm} \text { from } \\
\text { vessel center. }\end{array}$ & & & 21,22 & \\
\hline TFB-37 & $\begin{array}{l}\text { Cold leg, Spool } 37,703 \mathrm{~cm} \text { from } \\
\text { vessel center along hot leg, dis. } \\
\text { charge of simulated steam generator. }\end{array}$ & & & 21,22 & \\
\hline TFB- 42 & $\begin{array}{l}\text { Cold ley, } 5 p 00142,1054 \mathrm{~cm} \text { from } \\
\text { vessel center along hot leg, upstream } \\
\text { of pump-side nozzle. }\end{array}$ & & & 21,22 & \\
\hline Inlet Annulus & $\begin{array}{l}10 \mathrm{~cm} \text { be iow cold leg centerline, } \\
0.5 \mathrm{~cm} \text { from vessel wall, Type } \\
\text { iron-constantan thermocouples. }\end{array}$ & 0 to $1033 \mathrm{~K}$ & 0 to $701 \mathrm{~K}$ & & \\
\hline TFV-ANN-AA & $0^{\circ}$. & & & 23,24 & \\
\hline TFV-ANN-4M & $180^{n}$. & & & 23,24 & \\
\hline Downcomer Annulus & $\begin{array}{l}\text { Centered in annulus, Type } \mathrm{J} \text { iron- } \\
\text { constantan thermocouples. }\end{array}$ & 0 to $1033 \mathrm{~K}$ & 0 to $701 \mathrm{~K}$ & & \\
\hline TFV-ARN-35A & $\begin{array}{l}89 \mathrm{~cm} \text { below cold leg centerline, } \\
0^{\circ},\end{array}$ & & & 25.26 & \\
\hline TFV-ANH-7OA & $\begin{array}{l}178 \mathrm{~cm} \text { below cold leg centerline, } \\
0^{4} .\end{array}$ & & . & 25,26 & . \\
\hline TFV-ANN-115A & $\begin{array}{l}292 \mathrm{~cm} \text { below cold leg centerline, } \\
0^{\circ} \text {. }\end{array}$ & & & 25,26 & \\
\hline TFV-ANH-156A & $\begin{array}{l}396 \mathrm{~cm} \text { below cold leg centerline, } \\
0^{\circ} \text {. }\end{array}$ & & & 25,26 & $\begin{array}{l}\text { Questionable data, appears to be } \\
\text { reading vessel filicr tcmperature. }\end{array}$ \\
\hline Upper Plenum & & 0 to $1533 \mathrm{~K}$ & 0 to $820 \mathrm{~K}$ & & \\
\hline TFV-UP+13 & $\begin{array}{l}\text { in upper plenum, } 34 \mathrm{~cm} \text { above } \\
\text { cold leg centeri ine at } 180^{\circ} .\end{array}$ & & & 27,28 & - \\
\hline Lower Plenum & $\begin{array}{l}\text { On fluid thermocouple rack, } 2.54 \mathrm{~cm} \\
\text { from vessel center, } 45^{\circ} \text {. }\end{array}$ & 0 to $1533 k$ & 0 to $820 \mathrm{~K}$ & & . \\
\hline$T F V=t P=?$ & $\begin{array}{l}5 \mathrm{~cm} \text { abovo top of laver plenum filler } \\
\text { block. }\end{array}$ & & & $2 y, 30$ & \\
\hline TFV-LP-4 & $\begin{array}{l}10 \mathrm{~cm} \text { above top of lower plenum filler } \\
\text { block. }\end{array}$ & & & 29,30 & . \\
\hline TFB-LP-7 & $\begin{array}{l}18 \mathrm{~cm} \text { above top of lower plenum filler } \\
\text { block. }\end{array}$ & & & 29,30 & \\
\hline \multicolumn{6}{|l|}{ Core } \\
\hline TFV-CORE-IN & $\begin{array}{l}\text { In core flow mixer box, } 381 \mathrm{cal} \\
\text { below cold leg centerl ine (a } \\
\text { part of FoV cone- }-\mathrm{I}) \text {. }\end{array}$ & o to $1533 \mathrm{~K}$ & o to $820 \mathrm{~K}$ & 31,32 & \\
\hline
\end{tabular}




\section{TABLE V (continued)}

\begin{tabular}{|c|c|c|c|c|c|c|}
\hline \multirow[b]{2}{*}{ Measurement } & \multirow[b]{2}{*}{ Location and Comments ${ }^{\text {aj }}$} & \multicolumn{2}{|c|}{ Range $_{[a]}$} & \multirow{3}{*}{\multicolumn{2}{|c|}{$\underline{\text { Figure }}$}} & \multirow[b]{2}{*}{ Measurement Commenus ${ }^{[\mathrm{b}]}$} \\
\hline & & Detector & $\begin{array}{l}\text { Data Acquisition } \\
\text { System }\end{array}$ & & & \\
\hline \multicolumn{6}{|l|}{ Core Grid Spacers } & \\
\hline Grid Spacer 5 & $\begin{array}{l}140 \mathrm{~cm} \text { below cold leg centerline, } \\
54.6 \mathrm{~cm} \text { above top of heated length. }\end{array}$ & 0 to $1533 \mathrm{~K}$ & 0 to $1579 \mathrm{x}$ & & & \\
\hline TFG-5CD-45 & $\begin{array}{l}\text { Thermocouple in space defined by } \\
\text { Columns } C \text { and } D \text {, Rows } 4 \text { and } 5 \text {. }\end{array}$ & & & 33,34 & & \\
\hline Grid Spacer 5 & $\begin{array}{l}193 \mathrm{~cm} \text { below cold leg centerline, } \\
1.3 \mathrm{~cm} \text { above top of heated length. }\end{array}$ & & & & & \\
\hline TFG- 6 CD -45 & $\begin{array}{l}\text { Thermocouple in space defined by } \\
\text { columins } C \text { and } 0 \text {, Rows } 4 \text { and } 5 \text {. }\end{array}$ & & & 35,36 & & . \\
\hline Grió Spacer 10 & $\begin{array}{l}363 \mathrm{~cm} \text { below cold leg centerline } \\
\text { at bottom of heated length. }\end{array}$ & & & & & \\
\hline TFG-10AB-45 & $\begin{array}{l}\text { Thermocouple in space defined by } \\
\text { columns } A \text { and } B \text {, Rows } 4 \text { and } 5 \text {. }\end{array}$ & & & 37,38 & & \\
\hline ECC System & & 0 to $1533 \mathrm{~K}$ & 0 to $584 \mathrm{~K}$ & & & \\
\hline TFU-ECC-14 & $\begin{array}{l}\text { In ECC line leading to intact } \\
\text { loop Spool } 14 .\end{array}$ & & & 39,40 & & \\
\hline$T F B-E C C-\dot{4} \dot{2}$ & 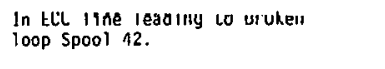 & & & $A 1 \quad \Delta P$ & & \\
\hline Steam Generator & & 0 to $1533 \mathrm{~K}$ & 0 to $584 \mathrm{~K}$ & & & \\
\hline IFU-SGFW & $\begin{array}{l}\text { In feedwater line leading to steam } \\
\text { generator. }\end{array}$ & & & 43,44 & & \\
\hline IFU-SGSD & $\begin{array}{l}\text { In steam dome, } 329 \mathrm{~cm} \text { above } \\
\text { bottom of tube sheet. }\end{array}$ & 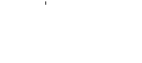 & & 45,40 & & \\
\hline TFU-SGI & $\begin{array}{l}\text { Secondary side, } 30 \mathrm{~cm} \text { above bottori } \\
\text { of tube sheet. }\end{array}$ & & & $47, .48$ & & \\
\hline IFU-SG2 & $\begin{array}{l}\text { Secondary side, } 61 \mathrm{~cm} \text { above bottom } \\
\text { of tube sheet. }\end{array}$ & & - & 47,48 & & \\
\hline TFU-SG3 & $\begin{array}{l}\text { Secondary side, I'Z } \mathrm{cm} \text { above bottum } \\
\text { of tube sheel. }\end{array}$ & & & 47,48 & & \\
\hline$\frac{\text { Steam Generator }}{\text { Rupture Systẹm }}$ & & 0 to $1533 \mathrm{~K}$ & 0 to $584 \mathrm{~K}$ & & & \\
\hline TFU-SGS3 & In bottom of Accunulator Tank T-3. & & & 49,30 & & \\
\hline TFU-SGS & $\begin{array}{l}\text { In injection line leadoling from } \\
\text { Arcunullator Tank T-3 just upstream } \\
\text { of junction with Spoois } 6 \text {. }\end{array}$ & & & $51,5 ?$ & & \\
\hline TFU-SGS-D & $\begin{array}{l}\text { In drain of injection line leading } \\
\text { from Accullum latur faind } T=3 \text {. }\end{array}$ & & & 53,54 & & \\
\hline \multicolumn{7}{|l|}{ Pressurizer } \\
\hline TFU-PRIZL & 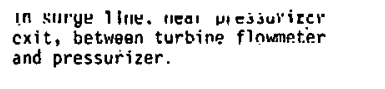 & 0 to $1533 \mathrm{r}$ & $n+n \operatorname{Ron} x$ & 55,56 & & \\
\hline$\frac{\text { Pressure Suppression }}{\text { Systerif }}$ & & $U$ to $1633 \mathrm{~K}$ & U $20584 \wedge$ & & . & · \\
\hline Tr-rss-33 & $84 \mathrm{~cm}$ from hot.tnm of tank. & & & 57,58 & & \\
\hline TF-PSS- 130 & $330 \mathrm{~cm}$ from bottom of tank. & & - & 57,58 & & \\
\hline MATERIAL TEMPERATÜRE & $\begin{array}{l}\text { Chromel-Alumel thermocouples } \\
\text { unless specified otherwise. }\end{array}$ & & & & & \\
\hline Intact loop & & $801537 \mathrm{~V}$ & $n: n \operatorname{son} x$ & & & \\
\hline TMU-1T16 & $\begin{array}{l}\text { Hot } 1 \text { leg, Spaol } 1, \text { top, } 1.6 \mathrm{~cm} \\
\text { from pipe } 10,54 \mathrm{~cm} \text { from vessel } \\
\text { center. }\end{array}$ & - & & 59,60 & & \\
\hline Rrnken Innn & & 0 to $1533 \mathrm{~K}$ & 0 to $584 \mathrm{~K}$ & & & $\cdot$ \\
\hline TMR-20B16 & $\begin{array}{l}\text { Cold leg, spool } 20, \text { bottom, } 1.6 \mathrm{~mm} \\
\text { from pipe } 10,52 \mathrm{~cm} \text { trom vessel } \\
\text { conter. }\end{array}$ & & & 61,62 & & \\
\hline - & & & & 61,62 & & \\
\hline Vessel filler & Type $J$ iron-constantan & 0 to $1033 \mathrm{~K}$ & 0 to $701 \mathrm{~K}$ & & & \\
\hline IHW of I IOS! & $\begin{array}{l}999 \text {, in lirelinn iold leq oentorlino, } \\
1.6 \mathrm{~mm} \text { from filler } 10,0^{8} \text {. }\end{array}$ & & & 63,64 & & \\
\hline TMV-F1-156A & $\begin{array}{l}396 \mathrm{~cm} \text { below culd ley centerline, } \\
1.6 \mathrm{rm} \text { from filler } \mathrm{ID}, 0^{\circ} \text {. }\end{array}$ & & & 63.64 & & \\
\hline TMV-F0-156A & $\begin{array}{l}396 \mathrm{~cm} \text { below cold leg centerline, } \\
1.65 \mathrm{~cm} \text { from filler } \mathrm{ld}, 0^{\circ} .\end{array}$ & & & 65,66 & & \\
\hline
\end{tabular}




\section{TABLE V (continued)}

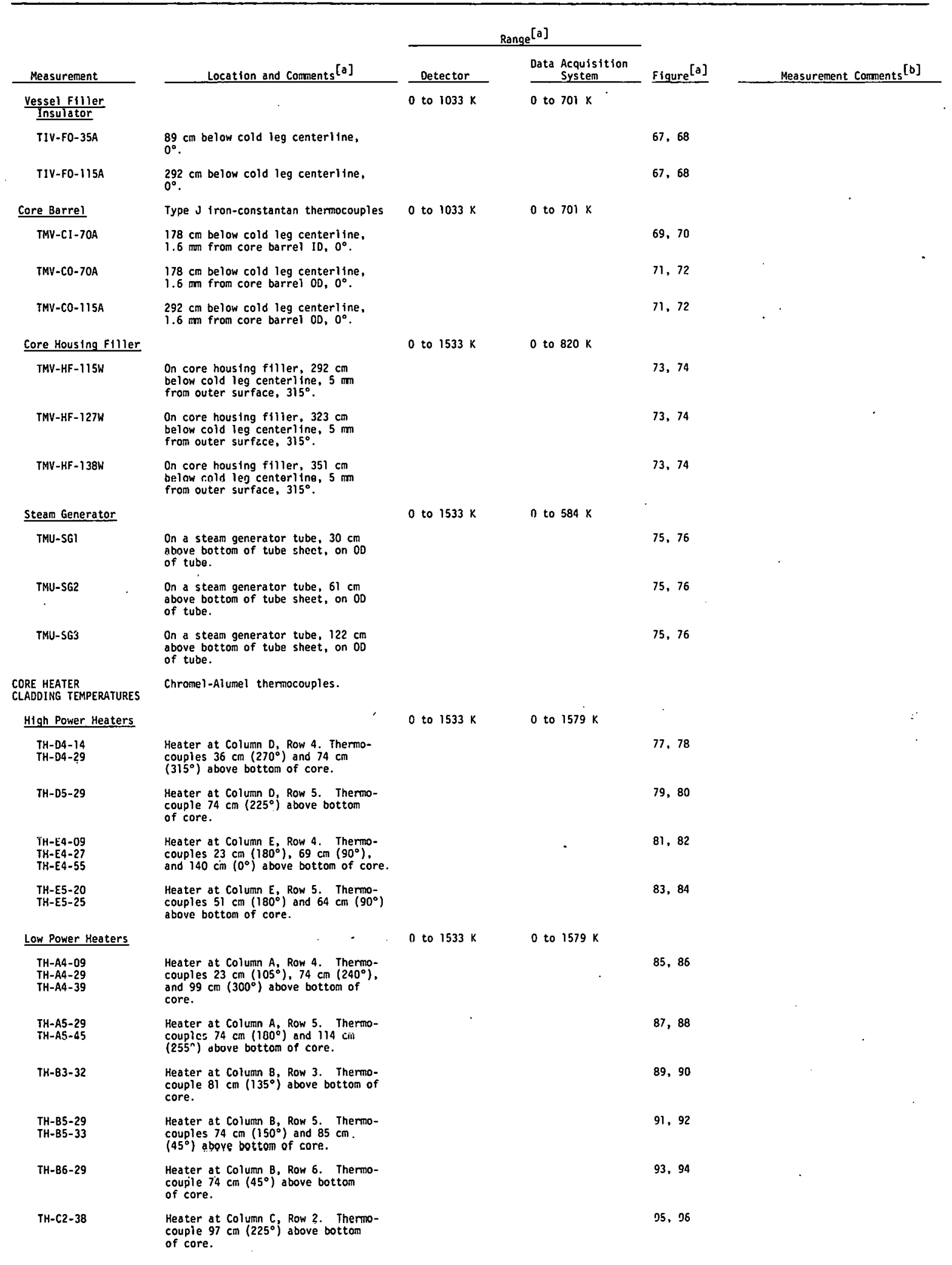




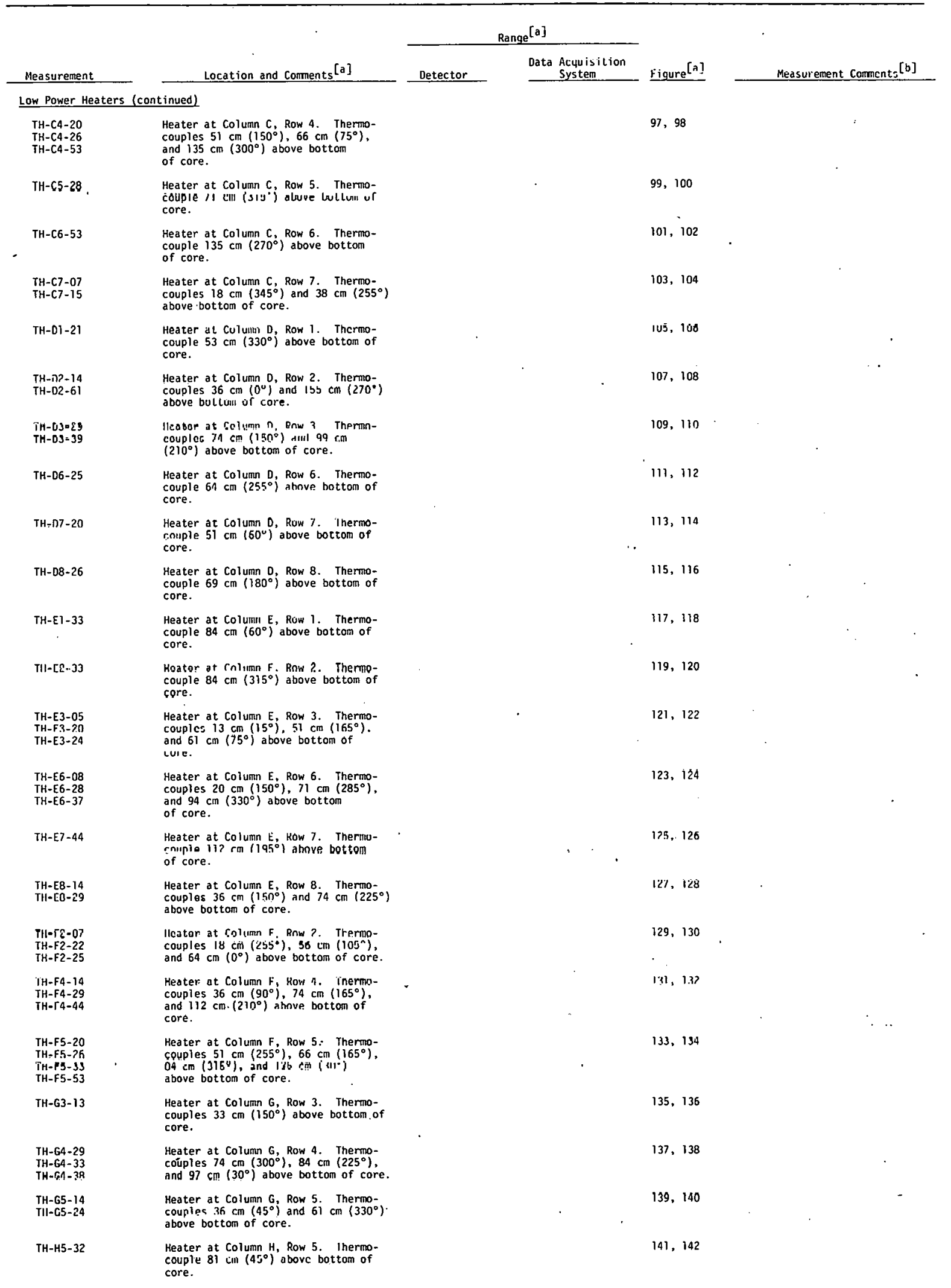




\section{TABLE V (continued)}

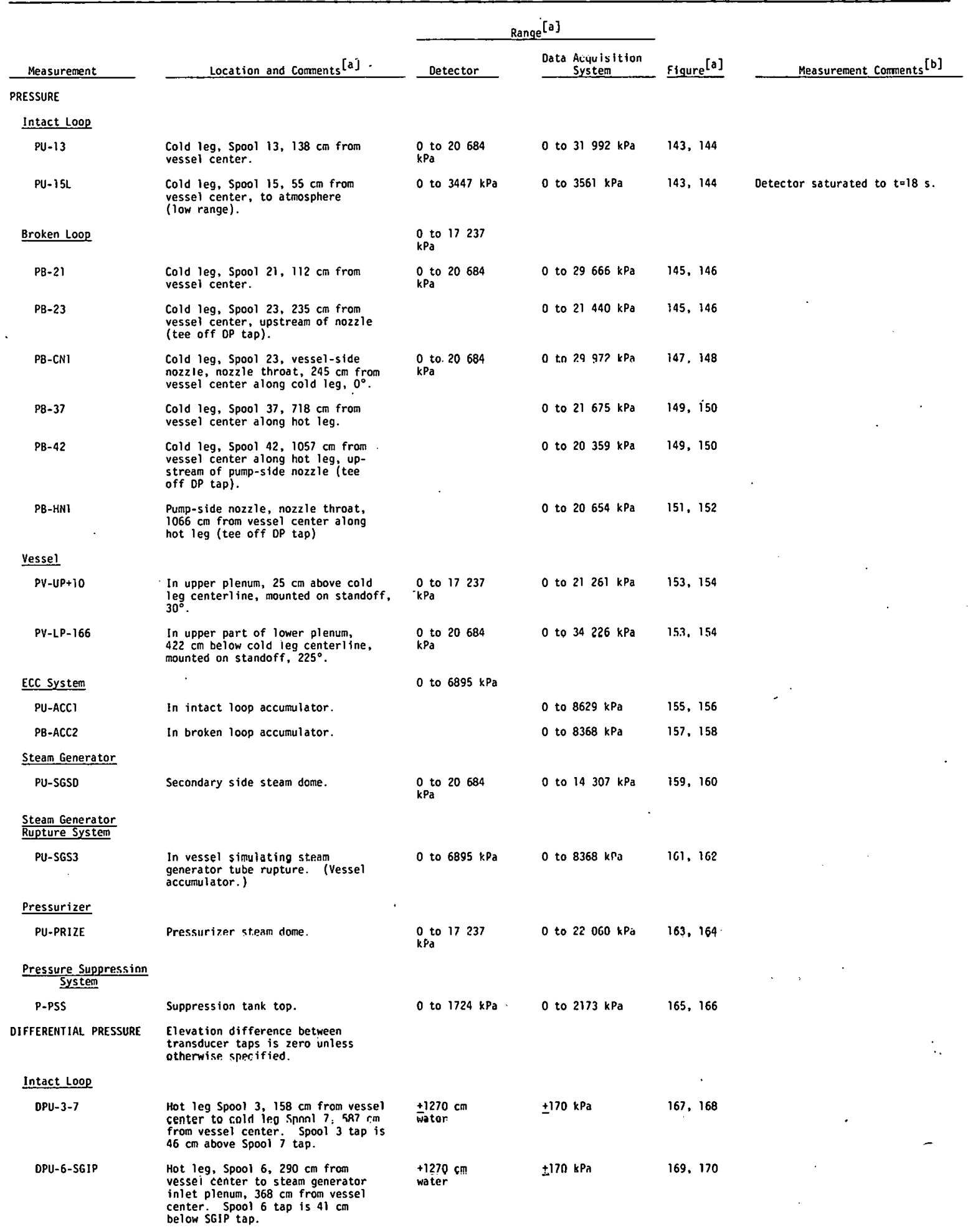




\section{TABLE V (continued)}

\begin{tabular}{|c|c|c|c|c|c|}
\hline \multirow[b]{2}{*}{ Measurement } & \multirow[b]{2}{*}{ Location and Comments ${ }^{[a]}$} & \multicolumn{2}{|c|}{ Range $^{[a]}$} & \multirow[b]{2}{*}{ Figure $^{[a]}$} & \multirow[b]{2}{*}{ Measurement Comments ${ }^{[\mathrm{b}]}$} \\
\hline & & Detector & $\begin{array}{l}\text { Data Acquisition } \\
\text { System } \\
\end{array}$ & & \\
\hline \multicolumn{6}{|c|}{ Intact Loop (continued) } \\
\hline DPU-560P-7 & $\begin{array}{l}\text { From steam generator outlet plenum } \\
683 \mathrm{~cm} \text { from vessel center along } \\
\text { cold leg to cold leg Spool } 7,587 \mathrm{~cm} \\
\text { from vessel center, including orifice. } \\
\text { Spool } 7 \text { tap is } 89 \mathrm{~cm} \text { below SGOP tap. }\end{array}$ & $\underset{\text { water }}{ \pm 1270 \mathrm{~cm}}$ & $\pm 169 \mathrm{kPa}$ & 171,172 & v \\
\hline DPU-7-10 & $\begin{array}{l}\text { Stean generator outlet to pump } \\
\text { inlet, cold leg Spool } 7,587 \mathrm{~cm} \\
\text { from vessel center, to cold leg } \\
\text { Spool } 10,359 \mathrm{~cm} \text { from vessel } \\
\text { center. }\end{array}$ & $\begin{array}{l}+127 \mathrm{~cm} \\
\text { water }\end{array}$ & $\pm 17.2 \mathrm{kPa}$ & 173,174 & \\
\hline DPU-12-10 & $\begin{array}{l}\text { Pump outiet to pump inlet, cold } \\
\text { leg Spool i2, } 192 \mathrm{~cm} \text { from vessel } \\
\text { center, to cold leg Spool } 10,359 \mathrm{~cm} \\
\text { from vessel center. Spool } 10 \text { tap is } \\
23 \mathrm{~cm} \text { below spool is tap. }\end{array}$ & $\pm 345 \mathrm{kPa}$ & $\pm 343 \mathrm{kPa}$ & 175,176 & \\
\hline DPU-12-10L & $\begin{array}{l}\text { Pump outlet to pump inlet, cold } \\
\text { leg spool } 12 \text {. } 192 \mathrm{~cm} \text { from vessel } \\
\text { center, to cold leg spool } 10,359 \mathrm{~cm} \\
\text { frnm vessel renter. Snnol } 10 \text { tap is } \\
2 b \mathrm{~cm} \text { below Spool i2 tap (luw range). }\end{array}$ & $\stackrel{+254 \mathrm{~cm}}{\text { water }}$ & $\pm 33.2 \mathrm{kPa}$ & 111,178 & Detector saturated to $t=7 \mathrm{~s}$. \\
\hline DPU-12-15 & $\begin{array}{l}\text { Cold leg Spool 12, } 192 \mathrm{~cm} \text { from } \\
\text { vessel center, to coid leg Spool } \\
15,55 \mathrm{~cm} \text { from vessel center. }\end{array}$ & $\underset{\text { water }}{+254 \mathrm{~cm}}$ & $\pm 33.9 \mathrm{kPa}$ & 179,180 & \\
\hline DPU-15-3 & $\begin{array}{l}\text { Cold leg to hot leg; cold leg Spool } \\
15,55 \mathrm{~cm} \text { from vessel center, to } \\
\text { hot leg Spoul } 3,158 \text { cul from vessel } \\
\text { center. Spool i5 tap is } 22 \mathrm{~cm} \\
\text { helow Spool } 3 \text { tap. }\end{array}$ & $\begin{array}{l}+1270 \mathrm{~cm} \\
\text { water }\end{array}$ & $\pm 169 \mathrm{kPa}$ & 181,182 & \\
\hline DPU-15-3L & $\begin{array}{l}\text { Cold leg to hot lcg, cold leg Spool } \\
15,55 \mathrm{~cm} \text { from vessel center, to } \\
\text { hot leg Spool } 3,158 \mathrm{~cm} \text { from vessel } \\
\text { center. Spool is tap is } 22 \mathrm{~cm} \text { beluw } \\
\text { Spool } 3 \text { tap (low range). }\end{array}$ & $\frac{+254 \mathrm{rm}}{\text { water }}$ & $\pm 33.5 \mathrm{kPa}$ & $183,184^{\circ}$ & Uetector saturated $t \mathrm{tu}^{\circ} \mathrm{t}=0 \mathrm{~s}$. \\
\hline OPU-PRESIII. & $\begin{array}{l}\text { Pressurizer water level. Eleva- } \\
\text { tion difference between taps is } \\
135 \mathrm{~cm} \text {. Lower tap is } 9 \mathrm{~cm} \text { above } \\
\text { pressurizer exit. }\end{array}$ & $\begin{array}{l}+127 \mathrm{~cm} \\
\text { water }\end{array}$ & $\pm 17.1 \mathrm{kPa}$ & 185,186 & . \\
\hline UPU-PR-4 & $\begin{array}{l}\text { Pressurizer bottom to spool } 4 \text {. Elcva- } \\
\text { tion difference between taps is } \\
167 \text { rm. Sponl } n \text { tap is lan r.m helnw } \\
\text { pressurizer exit. }\end{array}$ & $\pm 3117 \mathrm{kPa}$ & $\pm 3456 \mathrm{kPa}$ & 187.188 & $\begin{array}{l}\text { Detector saturated from } t=0 \\
\text { to } t=10 \mathrm{~s} \text {. }\end{array}$ \\
\hline \multicolumn{6}{|l|}{ Broken Loop } \\
\hline DPB-21-IANN & $\begin{array}{l}\text { cold leg Spnol } 21.112 \mathrm{~cm} \text { from } \\
\text { vessel center, to vessel inlet } \\
\text { annulus, } 23 \mathrm{~cm} \text { below cold leg } \\
\text { centerline at } 225^{\circ} \text {. Inlet annulus } \\
\text { tap is } 23 \mathrm{~cm} \text { below spool } 21 \text { tap. }\end{array}$ & $\begin{array}{l}+254 \mathrm{~cm} \\
\text { water }\end{array}$ & $\pm 33.6 \mathrm{kPa}$ & 189,190 & \\
\hline$O P B-23 \cdot C N 1$ & 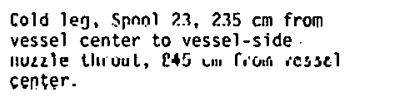 & $\pm 30342 \mathrm{kPa}$ & $\pm 13843 \mathrm{kPa}$ & 191,192 & \\
\hline DPB-CHI-24 & $\begin{array}{l}\text { Yessel-side nozzle throat, } 245 \mathrm{~cm} \\
\text { from vessel celler lo } 5 \text { pool } 24, \\
264 \mathrm{~cm} \text { from vcsscl center. }\end{array}$ & $\pm 3447 \mathrm{kPa}$ & $\pm 6961 \mathrm{kPa}$ & 193,194 & · \\
\hline DPD- $30-43$ & $\begin{array}{l}\text { Across entire broken lnnp hnt. ley } \\
\text { including rupture assembly; hot leg } \\
\text { Spool } 30,45 \mathrm{~cm} \text { from vessel to cold } \\
\text { leg Spool } 43,1086 \mathrm{~cm} \text { from vessel } \\
\text { center along hot leg. }\end{array}$ & $\pm 3447 \mathrm{kPa}$ & $.6973 \mathrm{ksa}$ & 195,196 & $\begin{array}{l}\text { Detector overranged from } t=0 \text { to. } \\
t=14 \mathrm{~s} \text {. }\end{array}$ \\
\hline DPB-32U-36L & 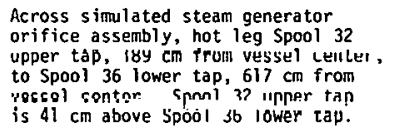 & $\pm 1379 \mathrm{kPa}$ & $\pm 1388 \mathrm{kPa}$ & 197. 198 & . \\
\hline DPB-36L-37 & $\begin{array}{l}\text { Across nozzle assembly. Spool } 36 \\
\text { lower tap, } 617 \mathrm{~cm} \text { from vessel } \\
\text { center along hot leg to Spool } 37 \text {, } \\
718 \mathrm{~cm} \text { \&rnm vess } 4 \text { litulter along } \\
\text { hot leg. Spool } 37 \text { tap is } 102 \mathrm{~cm} \\
\text { below Spool } 36 \text { lower tap. }\end{array}$ & $\pm 345 \mathrm{kPa}$ & $\pm 346 \mathrm{kPa}$ & 199,200 & \\
\hline UI'B $.36=10$ & $\begin{array}{l}\text { Atroms. gimulatod pump, sold leg } \\
\text { Spool } 38,776 \mathrm{~cm} \text { from vessel center } \\
\text { along hot leg, to cold leg Spool } 40 \text {, } \\
929 \text { cill frum vessel center along hot } \\
\text { leg. }\end{array}$ & $+6895<P_{n}$ & $\pm 9227 \mathrm{kPa}$ & 201,202 & \\
\hline
\end{tabular}


TABLE V (continued)

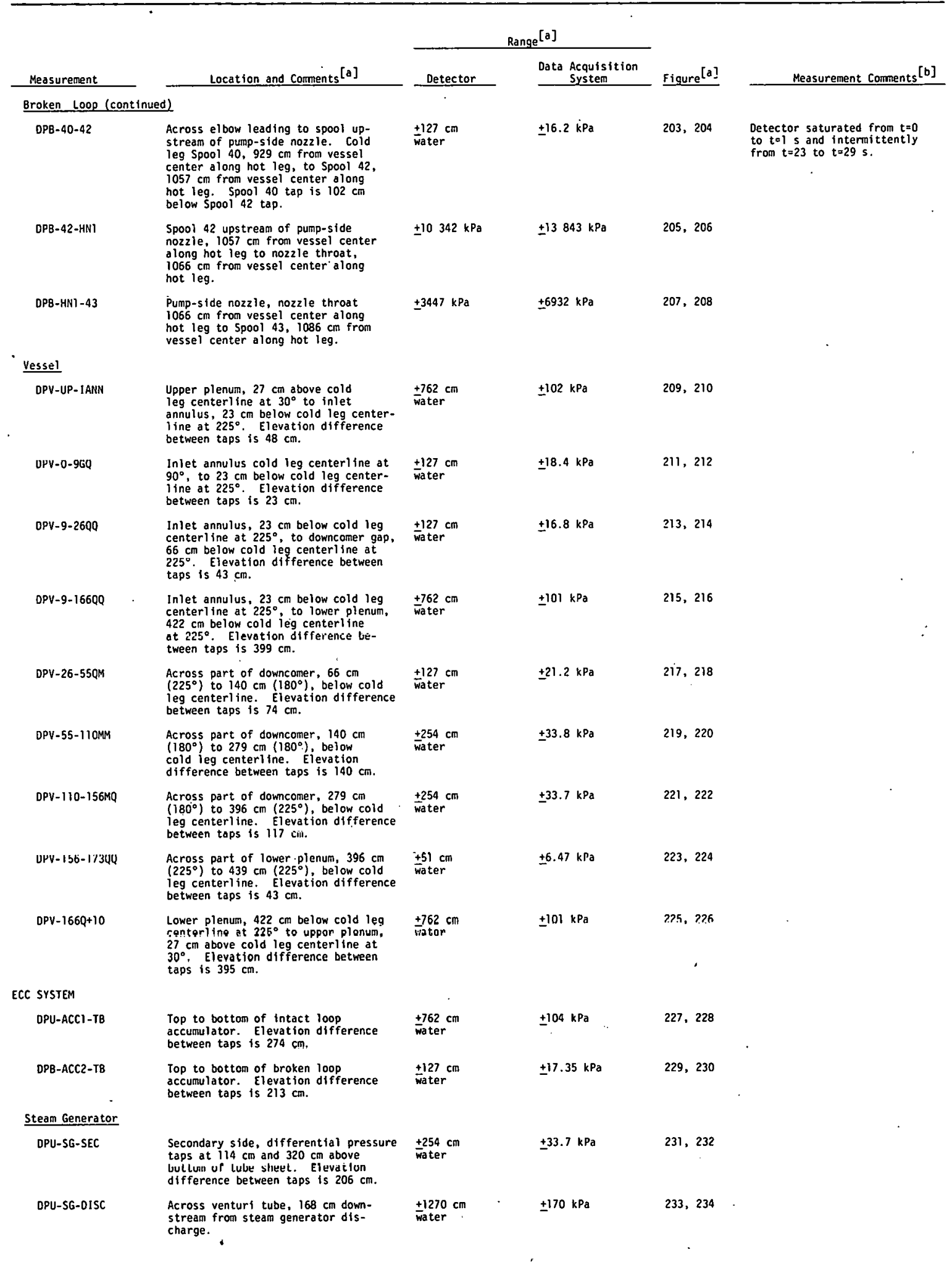




\section{TABLE V (continued)}

\begin{tabular}{|c|c|c|c|c|c|c|}
\hline \multirow[b]{2}{*}{ Measurement } & \multirow[b]{2}{*}{ Location and Comments $[\mathrm{a}]$} & \multicolumn{3}{|c|}{ Range $^{[\mathrm{a}]}$} & \multirow{3}{*}{ Figure $\lfloor a\rfloor$} & \multirow[b]{2}{*}{ Measurement Comments ${ }^{[0]}$} \\
\hline & & Detector & Doto $\hat{s}$ & $\begin{array}{l}\text { Acquisition } \\
\text { System }\end{array}$ & & \\
\hline \multicolumn{6}{|l|}{$\begin{array}{l}\text { Steam Generator } \\
\text { Rupture System }\end{array}$} & \\
\hline DPU-SGS-6 & $\begin{array}{l}\text { From instrumented spool piece } \\
\text { in simulated tube rupture injection } \\
\text { line to hot leg Spool } 6,318 \mathrm{~cm} \text { from } \\
\text { vessel center. }\end{array}$ & $\pm 6895 \mathrm{kPa}$ & \pm 9230 & $\mathrm{kPa}$ & 235,236 & $\begin{array}{l}\text { Data acquisition system } \\
\text { saturated to } t=0 \mathrm{~s} \text {. }\end{array}$ \\
\hline DPU-SGS3-TB & $\begin{array}{l}\text { Top to bottom of steam generator } \\
\text { rupture system accumulator tank. }\end{array}$ & $\underset{\text { water }}{ \pm 1270 \mathrm{~cm}}$ & $\pm 108 \mathrm{k}$ & $\mathrm{kPa}$ & 237,238 & \\
\hline \multicolumn{7}{|l|}{$\frac{\text { Pressure Suppression }}{\text { System }}$} \\
\hline DP-PSS-TB & $\begin{array}{l}\text { Top to bottom of pressure } \\
\text { suppression tank. Elevation } \\
\text { difference between taps } \\
\text { is } 338 \mathrm{~cm} \text {. }\end{array}$ & $\begin{array}{l}+762 \mathrm{~cm} \\
\text { water }\end{array}$ & $\pm 103 k$ & $\mathrm{kPa}$ & 239,240 & \\
\hline VOLUMETRIC FLOW RATE & Turbine flowmeter, bidirectional. & & & & · & 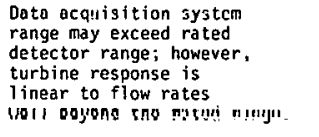 \\
\hline Intact Loop & 3-in. Schedule 160 pipe. & & & & & \\
\hline FTU-1 & $\begin{array}{l}\text { Hot leg, Spool } 1,42 \mathrm{~cm} \text { from } \\
\text { vessel center. }\end{array}$ & $\begin{array}{l} \pm 1.26 \text { to } \\
\pm 25.2 \mathrm{\ell} / \mathrm{s}\end{array}$ & \pm 75.7 & $2 / 5$ & 241,242 & $\begin{array}{l}\text { Data acquisition system } \\
\text { saturated at } t=40 \mathrm{~s}\end{array}$ \\
\hline \multirow[t]{2}{*}{ FTU-9 } & $\begin{array}{l}\text { Cold leg, Spool 9, } 393 \mathrm{~cm} \text { from } \\
\text { vessel Lenier. }\end{array}$ & $\begin{array}{l}+5.05 \text { to } \\
1.50: 5 \mathrm{l} / \mathrm{s}\end{array}$ & \pm 75.7 & $\ell / \mathrm{s}$ & 241,242 & \\
\hline & & & & & 243,244 & \\
\hline FTU-15 & $\begin{array}{l}\text { Cold leg, Spool } 15,42 \mathrm{~cm} \text { from } \\
\text { vessel center. }\end{array}$ & $\begin{array}{l} \pm 1.26 \mathrm{th} \\
\pm 50.5 \mathrm{l} / \mathrm{s}\end{array}$ & \pm 63.1 & $\ell / \mathrm{s}$ & 243,244 & \\
\hline Broken Loop & Schedule 160 pipe. & & & & & \\
\hline FTB-? & $\begin{array}{l}\text { Cold leg. Spool } 21.146 \mathrm{~cm} \text { from } \\
\text { vessel center; } 3-\mathrm{in} \text {. pipe. }\end{array}$ & $\begin{array}{l} \pm 1.26 \text { to } \\
\pm 25.2 \mathrm{l} / \mathrm{s}\end{array}$ & \pm 75.7 & $\ell / \mathrm{s}$ & 245,246 & $\begin{array}{l}\text { Signal prior to blowdown is } \\
\text { noise. }\end{array}$ \\
\hline FTB-30 & $\begin{array}{l}\text { Hot leg, Spool } 30,63 \mathrm{~cm} \text { from } \\
\text { vessel center; 3-in. pipe. }\end{array}$ & $\begin{array}{l}+1.26 \text { to } \\
+25.2 \mathrm{k} / \mathrm{s}\end{array}$ & \pm 50.5 & $2 / 5$ & 247,248 & $\begin{array}{l}\text { Signal prior to blowdown is } \\
\text { noise. }\end{array}$ \\
\hline rTD-37 & $\begin{array}{l}\text { Cold leg, 5pool } 37,739 \text { om from } \\
\text { vessel center along hot leg; } 2-i n . \\
\text { ninfe }\end{array}$ & \pm 1.26 to & $\pm 5 n$ & $8 / 8$ & 207,208 & $\begin{array}{l}\text { Signal priar to hlowertown is. } \\
\text { noise. }\end{array}$ \\
\hline \multicolumn{7}{|l|}{ Core } \\
\hline FTV-CORE-IN & $\begin{array}{l}\text { Entrance to core, } 401 \mathrm{~cm} \text { below } \\
\text { cold iey cemlerifile: }\end{array}$ & $\begin{array}{l} \pm 1.26 \text { to } \\
\pm 12.0 \mathrm{tis}\end{array}$ & \pm 69.4 & $2 / 5$ & 249,250 & $\begin{array}{l}\text { Data acquisition system } \\
\text { osturatod botwoen } t=10 \\
\text { alid } t=80 \mathrm{~s} \text {. }\end{array}$ \\
\hline \multicolumn{7}{|l|}{ ECC System } \\
\hline FTU-HPIS & $\begin{array}{l}\text { In line immediately apter HPls } \\
\text { pump for intact loop, } 1 / 2-\text { in. } \\
\text { ine. }\end{array}$ & $\begin{array}{l} \pm 0.007 \text { to } \\
\pm 0.47 \mathrm{e} / \mathrm{s}\end{array}$ & \pm 11.315 & 5 pis & 291,292 & $\begin{array}{l}31 \text { [ounal rartar to blowitume is } \\
\text { noise. }\end{array}$ \\
\hline FTB-HPIS & $\begin{array}{l}\text { In line imrediately after HPIS } \\
\text { pump for broken loop, } 1 / 2-\text { in. line. }\end{array}$ & \pm 0.0126 to & \pm 0.315 & $5 \mathrm{l} / \mathrm{s}$ & 253,254 & . \\
\hline FTU-LPIS & $\begin{array}{l}\text { in line leading from LrIs pump } \\
\text { fnr intart. innp, } 1 / \text { p }^{-} \text {in. line. }\end{array}$ & $\begin{array}{l}+0.017 \text { to } \\
+0.47 \mathrm{~s} / \mathrm{s}\end{array}$ & \pm 0.315 & $52 / 8$ & 255,256 & $\begin{array}{l}\text { Data acquistinn syct.em } \\
\text { saturated at } t=26 \mathrm{~s} \text {. }\end{array}$ \\
\hline FTB-I.PIS & $\begin{array}{l}\text { In line leading from LPIS pump } \\
\text { for broken loop, } 3 / 4-\text { in. line. }\end{array}$ & $\begin{array}{l}+0.097 \text { to } \\
\pm 0.47 \mathrm{e} / \mathrm{s}\end{array}$ & \pm 0.126 & $6 \mathrm{2} / \mathrm{s}$ & 257. 258 & \\
\hline FTU-ACCI & $\begin{array}{l}\text { In line leading from: intact loop } \\
\text { accumulator, } 1-\text { in. line. }\end{array}$ & $\begin{array}{l}+0.315 \text { to } \\
\pm 3.15 \% / 5\end{array}$ & +4.42 & $2 / 5$ & 259,260 & $\begin{array}{l}\text { Data àcquisition system } \\
\text { socuraled rear l-ốs. }\end{array}$ \\
\hline FTB-ACC2 & $\begin{array}{l}\text { In line leading from broken loop } \\
\text { accumulator, } 1 \text {-in. line. }\end{array}$ & $\begin{array}{l}+0.126 \text { to } \\
+1.26 \mathrm{l} / \mathrm{s}\end{array}$ & \pm 1.39 & $\ell / s$ & 261,262 & $\begin{array}{l}\text { Data acquicition syst.em } \\
\text { saturated from } t=30 \text { to } \\
t=50 \mathrm{~s}\end{array}$ \\
\hline$\frac{\text { Stopm pongrarnr }}{\text { Rupture System }}$ & & & & $\cdot$ & & \\
\hline FTU-SGS & $\begin{array}{l}\text { In simulated tube rupture injection } \\
\text { line. }\end{array}$ & $\begin{array}{l}+0.315 \text { to } \\
\pm+\$ 3.15 \mathrm{Q} / \mathrm{s}\end{array}$ & \pm 0.631 & $t / 5$ & 263,264 & \\
\hline Pressurizer & 1-1/2-ill. Lut birte & & & & ' & - \\
\hline FTU-PRIZE & Surge line. & $\begin{array}{l} \pm 0.315 \text { to } \\
\pm 3.15 \mathrm{R} / \mathrm{s}\end{array}$ & \pm 6.31 & $\ell / s$ & 265,266 & · \\
\hline
\end{tabular}


TABLE V (continued)

\begin{tabular}{|c|c|c|c|c|c|}
\hline \multirow[b]{2}{*}{ Measurement } & \multirow[b]{2}{*}{ Location and Comments ${ }^{[a]}$} & \multicolumn{2}{|c|}{ Range $^{[\mathrm{a}]}$} & \multirow{3}{*}{ Figure $^{[\mathrm{a}]}$} & \multirow[b]{2}{*}{ Measurement Comments $[\mathrm{b}]$} \\
\hline & & Detector & $\begin{array}{l}\text { Data Acquisition } \\
\text { System } \\
\end{array}$ & & \\
\hline FLUIO VELOCITY & Turbine flowneter, bidirectional. & & & & \\
\hline \multicolumn{6}{|l|}{ Downcomer } \\
\hline FTV $-40 A$ & $\begin{array}{l}102 \mathrm{~cm} \text { below cold leg centerline, } \\
0^{\circ} .\end{array}$ & $\begin{array}{l}+0.762 \text { to } \\
\pm 15.24 \mathrm{~m} / \mathrm{s}\end{array}$ & $\pm 15.24 \mathrm{~m} / \mathrm{s}$ & 267,268 & $\begin{array}{l}\text { Data acquisition system saturated } \\
\text { intermittentiy from } t=20 \text { to. } \\
t=60 \mathrm{~s} \text {. }\end{array}$ \\
\hline FTV-40M & $\begin{array}{l}102 \mathrm{~cm} \text { below cold leg centerline, } \\
180^{\circ} \text {. }\end{array}$ & $\begin{array}{l} \pm 0.762 \mathrm{to} \\
\pm 15.24 \mathrm{~m} / \mathrm{s}\end{array}$ & $\pm 15.24 \mathrm{~m} / \mathrm{s}$ & 267,268 & $\begin{array}{l}\text { Data acquisition system saturated } \\
\text { intermittently from } t=20 \text { to } \\
t=60 \mathrm{~s} \text {. }\end{array}$ \\
\hline MOMENTUM FLUX & Orag disc, bidirectional. & & & & $\begin{array}{l}\text { Mamentum flux reported only for } \\
-6 \text { to } 42 \mathrm{~s} \text {, except as noted. } \\
\text { Orag disc data may exhibit } \\
\text { significant temperature } \\
\text { dependence. Drag disc data } \\
\text { should be used only for short- } \\
\text { tem transient response. }\end{array}$ \\
\hline Intact Loop & 3-in. pipe. & & & & \\
\hline FOU-1 & $\begin{array}{l}\text { Hot leg. Spool } 1,60 \mathrm{~cm} \text { from } \\
\text { vessei center; Larigel size } \\
2.22 \mathrm{~cm} \text {. }\end{array}$ & $\begin{array}{l} \pm 298 \text { to } \pm 17 \quad 113 \\
\mathrm{~kg} / \mathrm{m}-\mathrm{s}^{2}\end{array}$ & $\begin{array}{l} \pm 76090 \\
\mathrm{~kg} / \mathrm{m}-\mathrm{s}^{2}\end{array}$ & 269 & . \\
\hline FOU -5 & $\begin{array}{l}\text { Hot leg, Spool } 5,256 \mathrm{~cm} \text { from } \\
\text { vessel center; target size } \\
2.54 \mathrm{~cm} \text {. }\end{array}$ & $\begin{array}{l} \pm 1.49 \text { to } \pm 2976 \\
\mathrm{~kg} / \mathrm{m}-\mathrm{s}^{2}\end{array}$ & $\frac{ \pm 6994}{\mathrm{~kg} / \mathrm{m}-\mathrm{s}^{2}}$ & 270 & $\begin{array}{c}\text { Detector saturated to } \mathrm{t}=2 \mathrm{~s} \text {. } \\
\text {. }\end{array}$ \\
\hline FDU-10 & $\begin{array}{l}\text { Cold leg, Spool } 10,349 \mathrm{~cm} \text { from } \\
\text { vessel center; target size } 2.22 \mathrm{~cm} \text {. }\end{array}$ & $\begin{array}{l} \pm 298 \text { to } \pm 154769 \\
\mathrm{~kg} / \mathrm{ki}-\mathrm{s}^{2}\end{array}$ & $\begin{array}{l} \pm 35344 \\
\mathrm{~kg} / \mathrm{m}-\mathrm{s}^{2}\end{array}$ & 271 & \\
\hline FDU-13. & $\begin{array}{l}\text { Cold leg, Spool 13, } 138 \mathrm{~cm} \text { from } \\
\text { vessel center; target size } 2.22 \mathrm{~cm} \text {. }\end{array}$ & $\begin{array}{l} \pm 298 \text { to } \\
\mathrm{kg} / \mathrm{m}-\mathrm{s}^{2}\end{array}$ & $\begin{array}{l} \pm 28528 \\
\mathrm{~kg} / \mathrm{m}-\mathrm{s}^{2}\end{array}$ & 272 & \\
\hline \multicolumn{6}{|l|}{ Broken Loop } \\
\hline FDB-21 & $\begin{array}{l}\text { Cold leg, Spool } 21,134 \mathrm{~cm} \text { from } \\
\text { vessel center, } 3-\text { in. pipe; target } \\
\text { size } 1.67 \mathrm{~cm} \text {. }\end{array}$ & $\underset{\mathrm{kg} / \mathrm{m}-\mathrm{s}^{2}}{ \pm 298 \text { to }} \pm 104915$ & $\begin{array}{l} \pm 66774 \\
\mathrm{~kg} / \mathrm{m}-\mathrm{s}^{2}\end{array}$ & 273 & \\
\hline FOB -23 & $\begin{array}{l}\text { Cold leg, Spool 23, } 238 \mathrm{~cm} \text { from } \\
\text { vessel center, upstream of vessel } \\
\text { side nozzle, } 2-\text { in. pipe; target } \\
\text { size } 1.03 \mathrm{~cm} \text {. }\end{array}$ & $\underset{\mathrm{kg} / \mathrm{m}-\mathrm{s}^{2}}{ \pm 298 \text { to }} \pm 180067$ & $\begin{array}{l} \pm 155319 \\
\mathrm{~kg} / \mathrm{m}-\mathrm{s}^{2}\end{array}$ & 274 & $\begin{array}{l}\text { Detector saturated from } t=0 \\
t=2 \mathrm{~s} \text {. }\end{array}$ \\
\hline FDB -30 & $\begin{array}{l}\text { Hot leg, spool } 30,52 \mathrm{~cm} \text { from } \\
\text { vessel center, 3-in. pipe; target. } \\
\text { size } 1.67 \mathrm{~cm} \text {. }\end{array}$ & $\begin{array}{l} \pm 298 \text { to } \\
\mathrm{kg} / \mathrm{m}-\mathrm{s}^{2}\end{array}$ & $\begin{array}{l} \pm 67280 \\
\mathrm{~kg} / \mathrm{m}-\mathrm{s}^{2}\end{array}$ & 275 & $\begin{array}{l}\text { Questionable data, transducer was } \\
\text { mounted horizontally and possibly } \\
\text { filled with cold water. }\end{array}$ \\
\hline FDB-37 & $\begin{array}{l}\text { Cold leg, Spool } 37,725 \mathrm{~cm} \text { from } \\
\text { vessel center along hot leg, steam } \\
\text { generator outlet, vertical pipe, } \\
\text { 2-in. pipe; target size } 1.03 \mathrm{~cm} \text {. }\end{array}$ & $\begin{array}{l} \pm 298 \text { to } \pm 180067 \\
\mathrm{~kg} / \mathrm{m}-\mathrm{s}^{2}\end{array}$ & $\begin{array}{l} \pm 374272 \\
\mathrm{~kg} / \mathrm{m}-\mathrm{s}^{2}\end{array}$ & 276 & $\begin{array}{l}\text { Questionable data, transducer was } \\
\text { mounted horizontaily and filled } \\
\text { with cold water. }\end{array}$ \\
\hline F08-42 & $\begin{array}{l}\text { Cold leg, spool } 42,1057 \mathrm{~cm} \text { from } \\
\text { vessel center alnng hnt leg, up- } \\
\text { stream of pump-side nozzle, down- } \\
\text { stream of injection point, } 2-1 \mathrm{n} \text {. } \\
\text { pipe; target size } 1.03 \mathrm{~cm} \text {. }\end{array}$ & $\begin{array}{l} \pm 298 \text { to } \pm 172627 \\
\mathrm{~kg} / \mathrm{m}-\mathrm{s}^{2}\end{array}$ & $\begin{array}{l} \pm 165320 \\
\mathrm{~kg} / \mathrm{m}-\mathrm{s}^{?}\end{array}$ & 277 & . \\
\hline \multicolumn{6}{|l|}{ Yessel } \\
\hline FDV-CORE-IN & $\begin{array}{l}\text { In core flow mixer box, } 381 \mathrm{~cm} \\
\text { below cold leg centerline; target } \\
\text { size } 2.54 \mathrm{~cm} \text {. }\end{array}$ & $\frac{ \pm 1.44 \text { to } \pm 2977}{\mathrm{~kg} / \mathrm{m} \cdot \mathrm{s}^{2}}$ & $\frac{ \pm 1725}{\mathrm{Hg} / \mathrm{ms}^{2}}$ & 278,279 & $\begin{array}{l}\text { Figure } 278 \text { is long-term plot } \\
(-20 \text { to } 736 \mathrm{~s}) .\end{array}$ \\
\hline \multicolumn{6}{|l|}{ UENSSITY } \\
\hline Intact Loop & & $\begin{array}{l}1.6 \text { to } 1600 \\
\mathrm{~kg} / \mathrm{m}^{3}\end{array}$ & $\begin{array}{l}0 \text { to } 1600 \\
\mathrm{~kg} / \mathrm{m}^{3}\end{array}$ & & 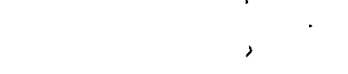 \\
\hline $\begin{array}{l}\text { GU-1T } \\
\text { GU-IB } \\
\text { GU-IC }\end{array}$ & $\begin{array}{l}\text { Hot leg, Spool } 1,77 \mathrm{~cm} \text { from } \\
\text { vessel center. T' (top) ranges } \\
270 \text { to } 360^{\circ} \text {. B (botton) ranges } \\
30 \text { to } 330^{\circ} \text {. C, mathematical } \\
\text { composite of } Y \text { and } B \text {. }\end{array}$ & & & $\begin{array}{l}280,281 \\
282,283\end{array}$ & \\
\hline QU-TVR & $\begin{array}{l}\text { Hüt ley, 3pivul 5, } 246 \text { LiI früul } \\
\text { vessel center, vertical. }\end{array}$ & & & 804,205 & \\
\hline GU-1OVR & $\begin{array}{l}\text { Cold leg, Spool } 10,359 \mathrm{~cm} \text { from } \\
\text { versel conter, vertical. }\end{array}$ & . & & 284,285 & \\
\hline GU-13VR & $\begin{array}{l}\text { Cold leg, Spool } 13,142 \mathrm{~cm} \text { from } \\
\text { vessel center, vertical. }\end{array}$ & & & 286,287 & \\
\hline $\begin{array}{l}\text { GU-15T } \\
\text { fill-15R } \\
\text { GU-15C }\end{array}$ & $\begin{array}{l}\text { Cold leg, Spool } 15,77 \mathrm{~cm} \text { from vessel } \\
\text { center. T (tnp) ranges } 270 \text { th } 36 n^{\circ} \text {. } \\
B \text { (bottom) ranges } 30 \text { to } 330^{\circ} \text {. } C \text {, } \\
\text { mathematical composite of } T \text { and } B \text {. }\end{array}$ & & . & $\begin{array}{l}288,289 \\
290,291\end{array}$ & \\
\hline
\end{tabular}




\section{TABLE V (continued)}

\begin{tabular}{|c|c|c|c|c|c|}
\hline \multirow[b]{2}{*}{ Measurement } & \multirow[b]{2}{*}{ Location and Comments ${ }^{[a]}$} & \multicolumn{2}{|c|}{ Range $^{[a]}$} & \multirow{3}{*}{ Figure ${ }^{[a]}$} & \multirow[b]{2}{*}{ Measurement Comments ${ }^{[b]}$} \\
\hline & & \multirow{2}{*}{$\begin{array}{l}\text { Detector } \\
1.6 \text { to } 1600 \\
\mathrm{~kg} / \mathrm{m}^{3}\end{array}$} & $\begin{array}{l}\text { Data Acquisition } \\
\text { System }\end{array}$ & & \\
\hline Broken Loop & & & $\begin{array}{l}0 \text { to } 1600 \\
\mathrm{~kg} / \mathrm{m}^{3}\end{array}$ & & \\
\hline $\begin{array}{l}\mathrm{GB}-21 \mathrm{~T} \\
\mathrm{~GB}-21 \mathrm{~B} \\
\mathrm{~GB}-21 \mathrm{C}\end{array}$ & $\begin{array}{l}\text { Cold leg, Spool } 21,123 \mathrm{~cm} \text { from } \\
\text { vessel center. T(top) ranges } \\
270 \text { to } 360^{\circ} . \text { B (bottom) ranges } \\
30 \text { to } 330^{\circ} \text {. C C, mathematical } \\
\text { composite of T' and B. }\end{array}$ & & & $\begin{array}{r}292,293 \\
294,295\end{array}$ & - \\
\hline GB-23VR & $\begin{array}{l}\text { Cold leg, spool } 23,235 \mathrm{~cm} \text { from } \\
\text { vessel center, vertical. }\end{array}$ & & . & 296,297 & \\
\hline $\begin{array}{l}\text { GB-30T } \\
\text { GB-30B } \\
\text { GB-30C }\end{array}$ & $\begin{array}{l}\text { Hot leg, Spool } .30,49 \mathrm{~cm} \text { from } \\
\text { vessel center. T(top) ranges } \\
270 \text { to } 360^{\circ} \text {. B (Dottom) ranges } \\
30 \text { to } 30^{\circ} \text {. C, mathematical } \\
\text { composite of T' and B. }\end{array}$ & & & $\begin{array}{l}298, \quad 299 \\
300,301\end{array}$ & \\
\hline CB $37 \mathrm{~Hz}$ & $\begin{array}{l}\text { Cold leg. } 5 \mathrm{pmol}, 37,711 \mathrm{rm} \text { from } \\
\text { vessel center along hot leg, across } \\
\text { vertical pipe, simulated steam } \\
\text { generator discharge. }\end{array}$ & & & 302,303 & . \\
\hline$G B-42 V R$ & $\begin{array}{l}\text { Cold leg, Spool } 42, \text { lub/ cin from } \\
\text { vessel center along hot leg, } \\
\text { vertical. }\end{array}$ & & & jöt, 989 & \\
\hline Vesse1 & · & $\begin{array}{l}1.0 \mathrm{tu} 1000 \\
\mathrm{~kg} / \mathrm{m}^{3}\end{array}$ & $\begin{array}{l}0 l u 1600 \\
\mathrm{~kg} / \mathrm{m}^{3}\end{array}$ & & - \\
\hline GV-COR-15OHZ & $\begin{array}{l}\text { Core flow mixer box, } 386 \mathrm{~cm} \\
\text { below cold leg centerl ine, } \\
\text { harizontal. o to } 180^{\circ} \text {. }\end{array}$ & & & 306,307 & \\
\hline GVLP-165HZ & $\begin{array}{l}\text { Upper part of lower plenum, } 419 \mathrm{~cm} \\
\text { below cold leg centerline, } 4.379 \mathrm{~cm} \\
\text { below downcomer exit. horizontal. } \\
\text { o to } 180^{\circ} \text {. }\end{array}$ & & & 308,309 & \\
\hline GVLr-172HZ & $\begin{array}{l}\text { Lower planum, } 437 \mathrm{~cm} \text { be } 10 \mathrm{w} \text { cold leg } \\
\text { centerline. } 22 \mathrm{~cm} \text { below donmcomer } \\
\text { exit, horizontal, g0 to } 270^{\circ} \text {. }\end{array}$ & & & 308,309 & \\
\hline \multicolumn{6}{|l|}{ Pressurizer } \\
\hline GU-PKILL. & surge 1 the. & $\begin{array}{l}1.6 \text { lo } 1600 \\
\mathrm{~kg} / \mathrm{m}^{3}\end{array}$ & $\begin{array}{l}0 \text { to } 1600 \\
\mathrm{~kg} / \mathrm{m}^{3}\end{array}$ & 310,311 & \\
\hline MASS FLOW RATE & $\begin{array}{l}\text { Mass flow rate obtained by com- } \\
\text { bining density (ganna attenua- } \\
\text { tion technique) with volumetric } \\
\text { flnw rate (tirhine flometeter) or } \\
\text { momentum flux (orag disc). }\end{array}$ & \multicolumn{2}{|c|}{ 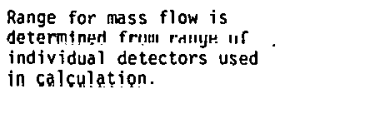 } & & $\begin{array}{l}\text { Mass flow rate reported only for } \\
-6 \text { to } 42, \text { s, cxcept as noted; soe } \\
\text { comnents on individual detectors. }\end{array}$ \\
\hline \multicolumn{6}{|l|}{ Intact Loop } \\
\hline $\begin{array}{l}\text { FOU-1, GU-1C } \\
\text { FTU-1, CU-1C }\end{array}$ & Hot leg, Spool 1. & & & $\begin{array}{l}312 \\
313\end{array}$ & \\
\hline$F U U-b$, GU-5VK & nUL rey, jpuvi o. & & & 219 & 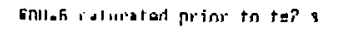 \\
\hline FTU-9, GU-10VR & Cold leg, spool 9. & & & 315 & \\
\hline FUU-1U, GU-IUVK & Lo10 leg, spool iu. & & & 316 & \\
\hline FDU-13, GU-13VR & Cold leg, Spool 13. & & & 317 & \\
\hline FTU-15, GU-15C & Cold leg, Spaol 15. & & & 318 & \\
\hline \multicolumn{6}{|l|}{ Brüleil Loup } \\
\hline $\begin{array}{l}\text { FDB-21, GB-21C } \\
\text { FTB-21; } 6 B-21 C\end{array}$ & Cold Icg, Spool 21. & & & $\begin{array}{l}319 \\
320\end{array}$ & \\
\hline FDB-23, GB-23VR & cold leg, Spool 23. & & - & $321^{*}$ & {$[00-2]$ soturated ncar $t-1$ S. } \\
\hline $\begin{array}{l}\text { TDM-20, } G C D-30 C \\
F T B-30, G B-30 C\end{array}$ & lleq 1eq, Epool 30. & & & 322 & $\begin{array}{l}\text { FOB-30 contatains questionable } \\
\text { dala: }\end{array}$ \\
\hline $\begin{array}{l}\text { FDB-37, GB-37HZ } \\
\text { FTB-37; GB-37HZ }\end{array}$ & Cold leg, Spool 37. & & & $\begin{array}{l}324 \\
325\end{array}$ & $\begin{array}{l}\text { FDB-37 contains questionable } \\
\text { soté. }\end{array}$ \\
\hline$F D B-4 \varepsilon, G B-42 V R$ & Cold $1 \mathrm{cg}$, Spao1 12. & & & 320 & \\
\hline \multicolumn{6}{|l|}{ Vessel } \\
\hline $\begin{array}{l}\text { ruY LUUHe-ing } \\
\text { GV-COR-15OHZ }\end{array}$ & Enliatice (a s...n. & & & $377 \cdot 328$ & \\
\hline $\begin{array}{l}\text { FTV-CORE-IN } \\
\text { GV-COR-150HZ }\end{array}$ & Entrance to core. & & & 329,330 & $\begin{array}{l}\text { FTV-CORE- IN saturated between } \\
\mathrm{t}=40 \text { and } t=80 \mathrm{~s} \text {. }\end{array}$ \\
\hline \multicolumn{6}{|l|}{ Pressurizer } \\
\hline $\begin{array}{l}\text { FTU-PRIZE } \\
\text { GU-PRIZE }\end{array}$ & Pressurizer surge line. & & & 331 & \\
\hline
\end{tabular}




\section{TABLE V (continued)}

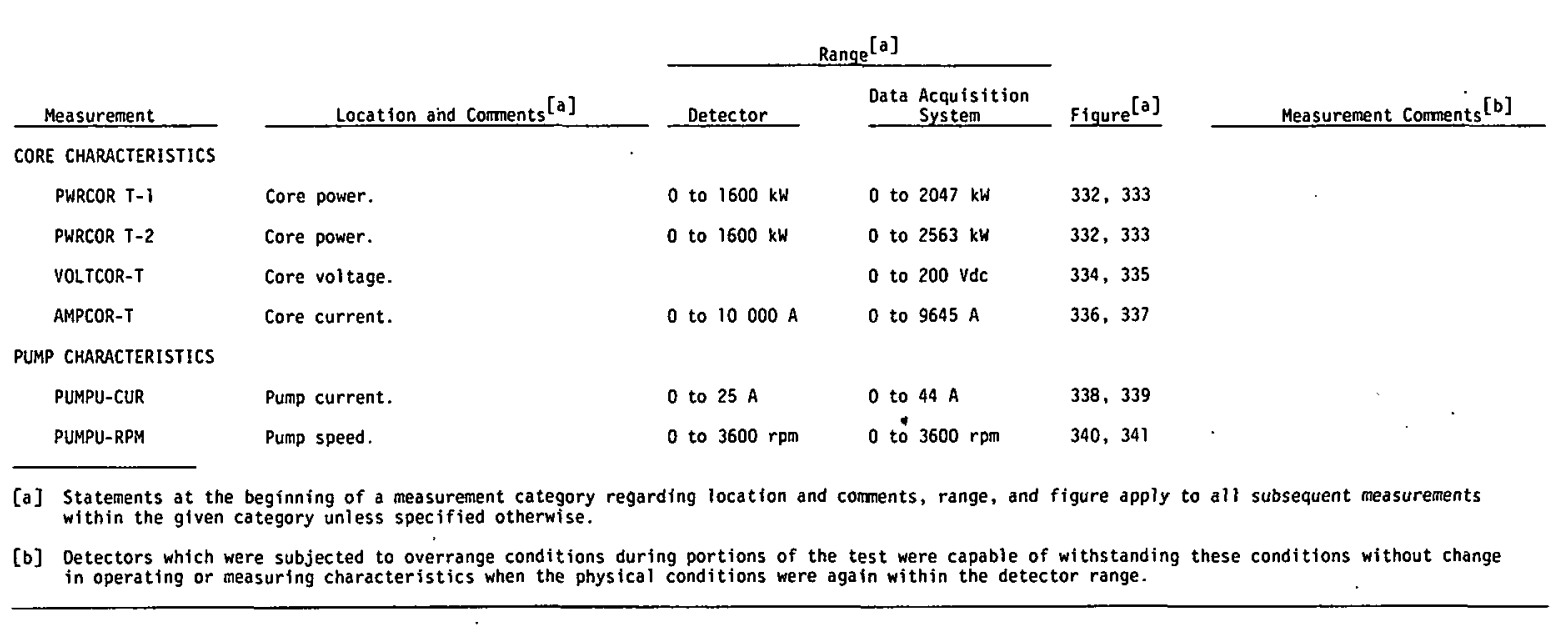




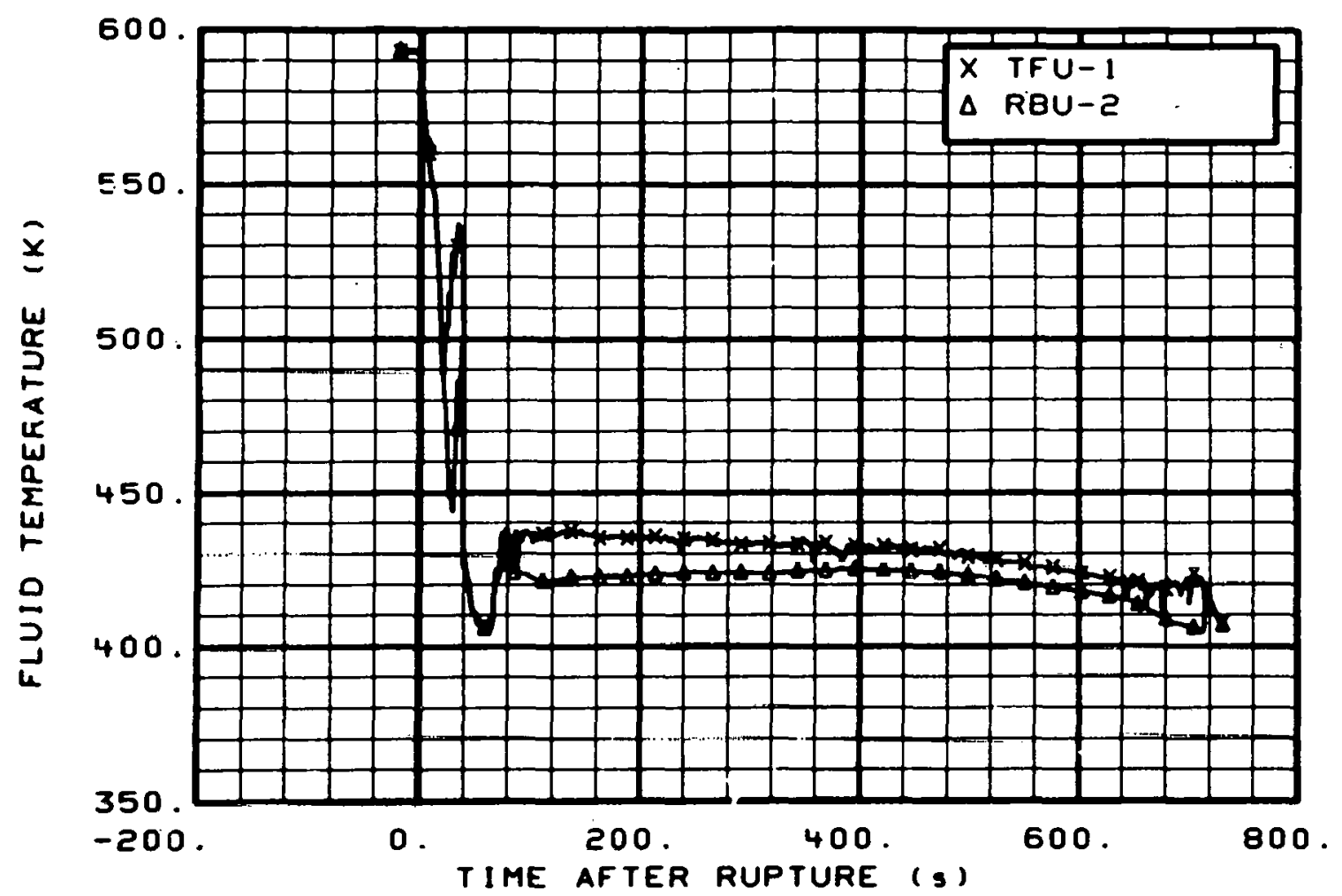

Fig. 9 Fluid temperature in intact loop hot leg (TFU-1 and RBU-2), from -20 to $736 \mathrm{~s}$.

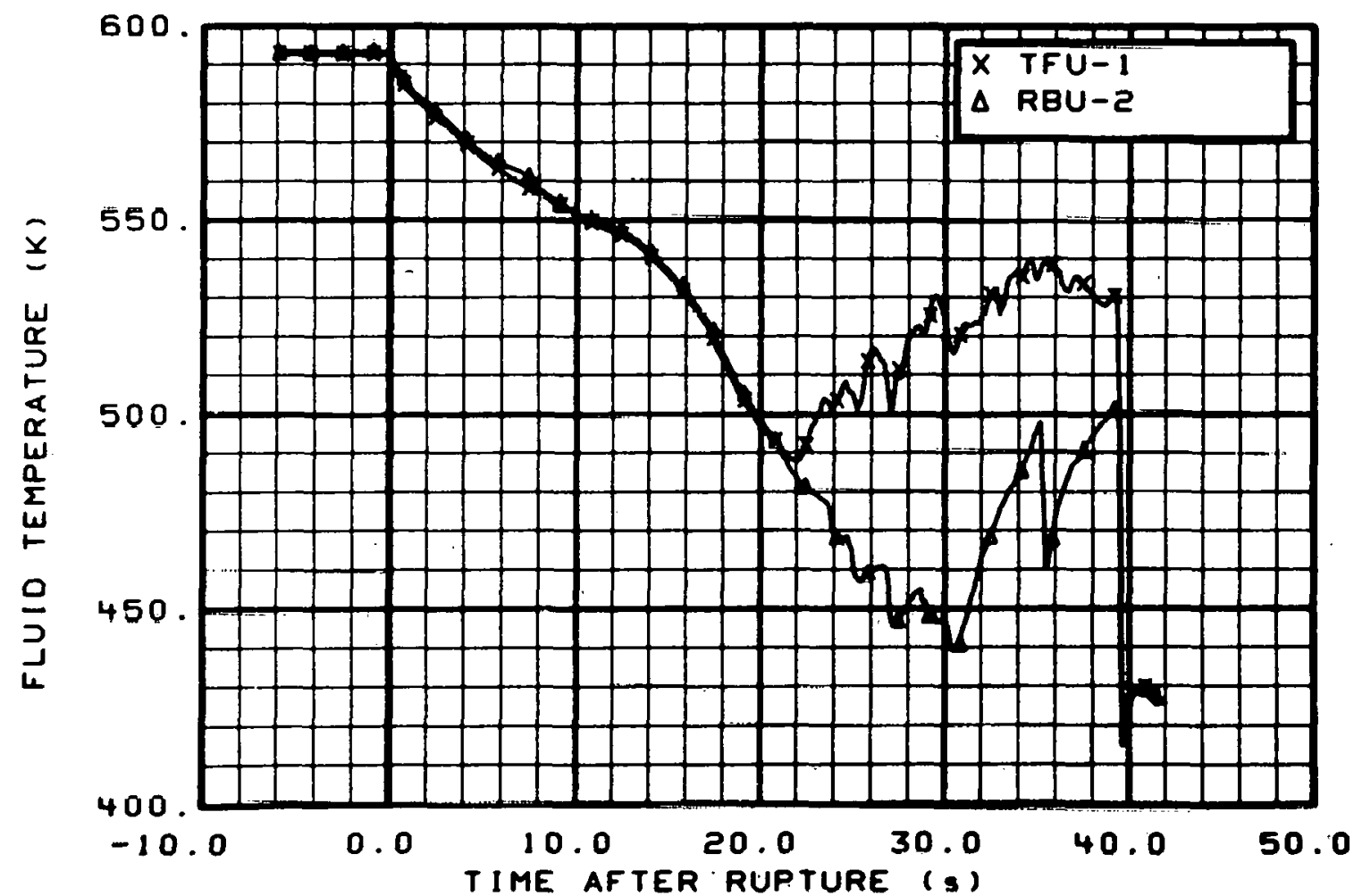

Fig. 10 Fluid temperature in intact loop hot leg (TFU-1 and RBU-2), from -6 to $42 \mathrm{~s}$. 


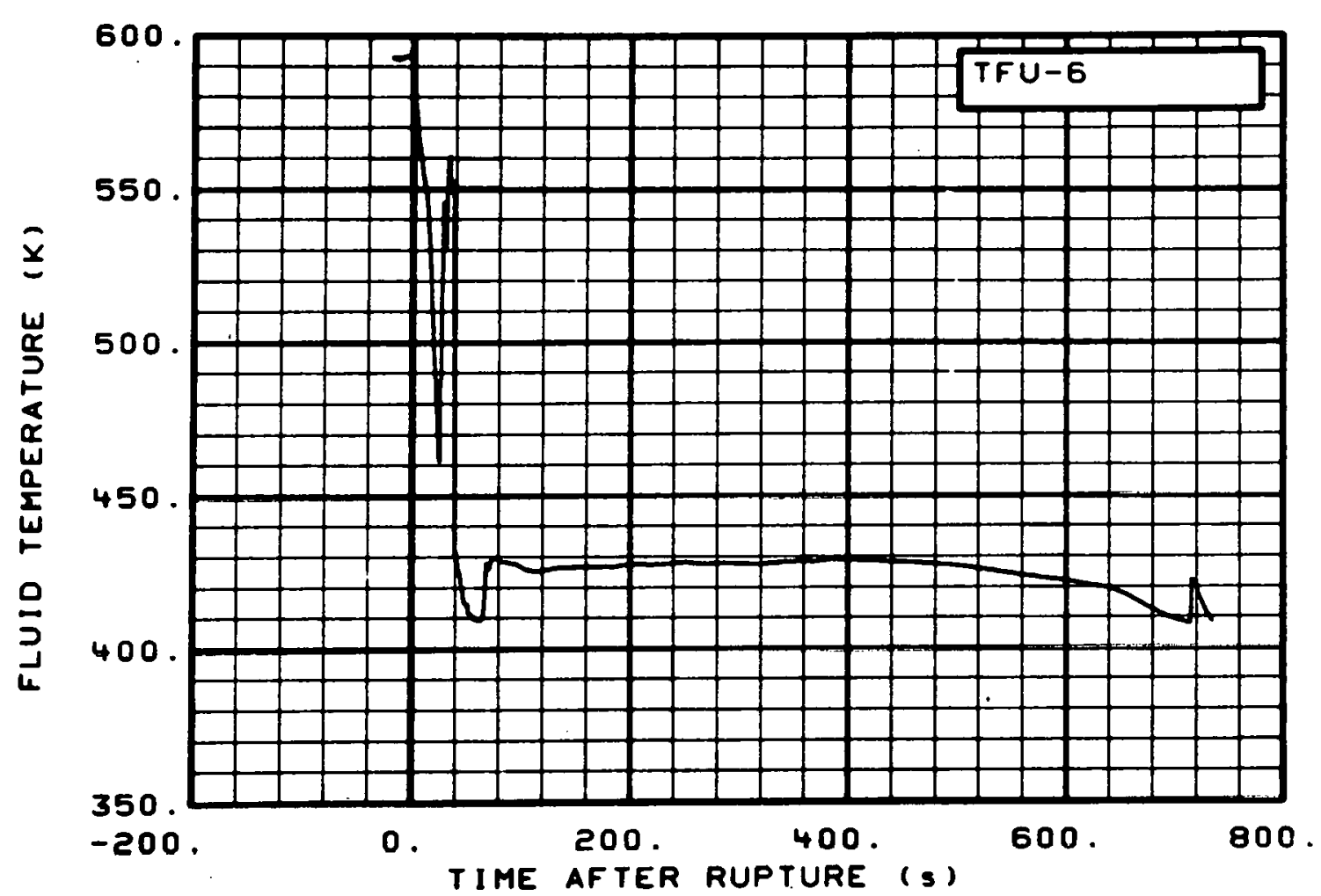

Fig. 11 Fluid temperature in intact loop hot leg (TFU-6), from -20 to $736 \mathrm{~s}$.

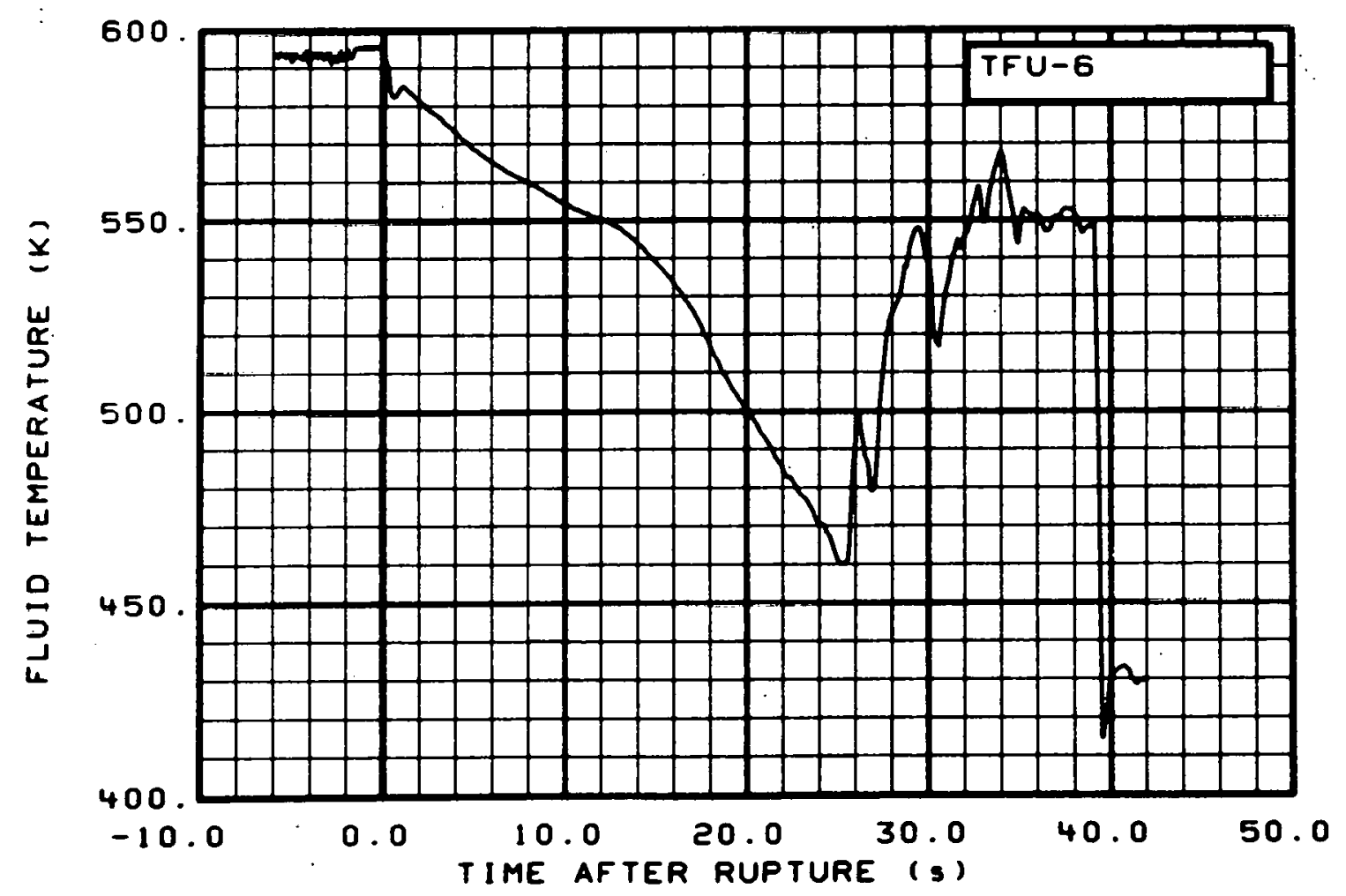

Fig. 12 Fluid temperature in intact loop hot leg (TFU-6), from -6 to $42 \mathrm{~s}$. 


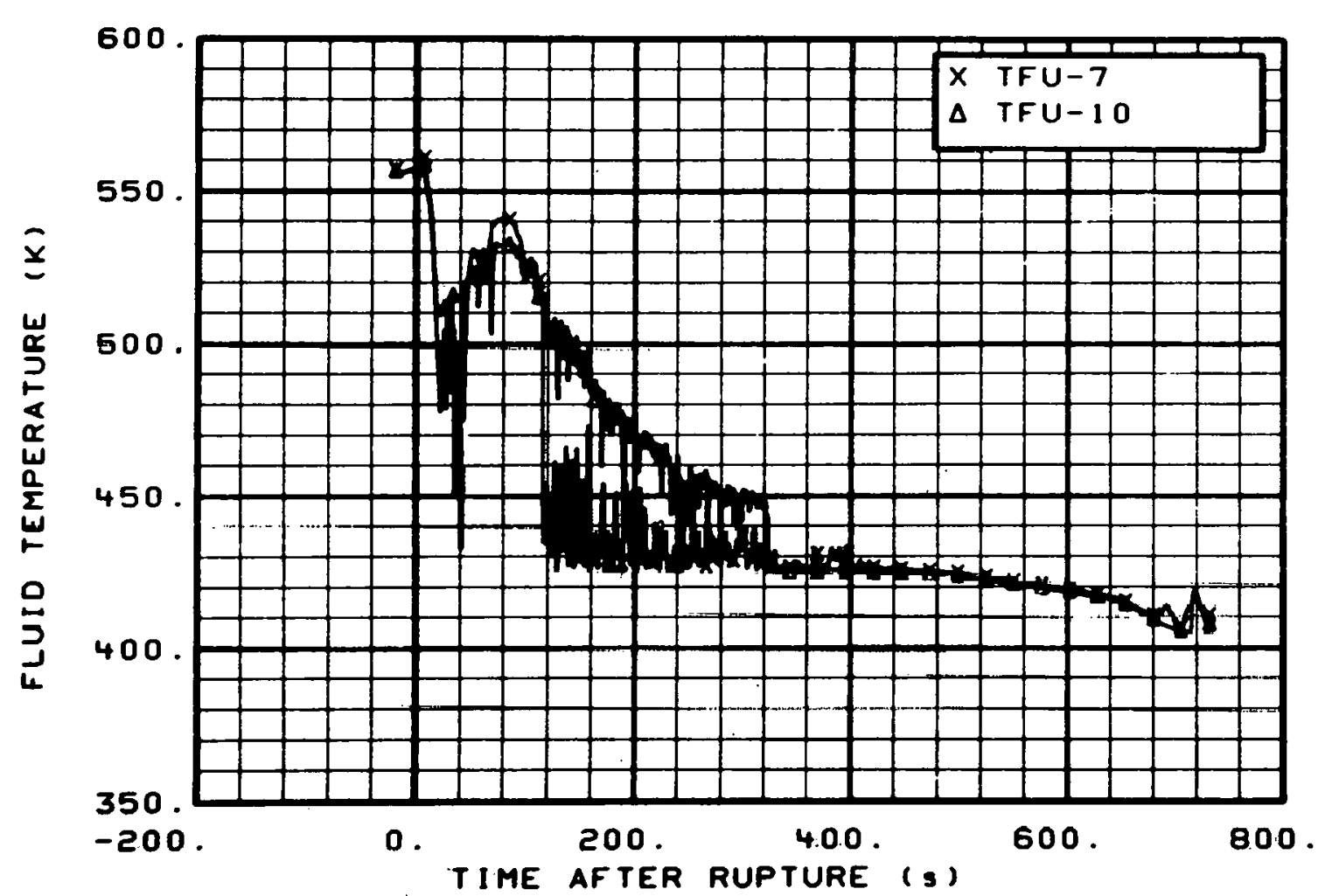

Fig. 13 Fluid temperature in intact loop cold leg (TFU-7 and TFU-10), from -20 to $736 \mathrm{~s}$.

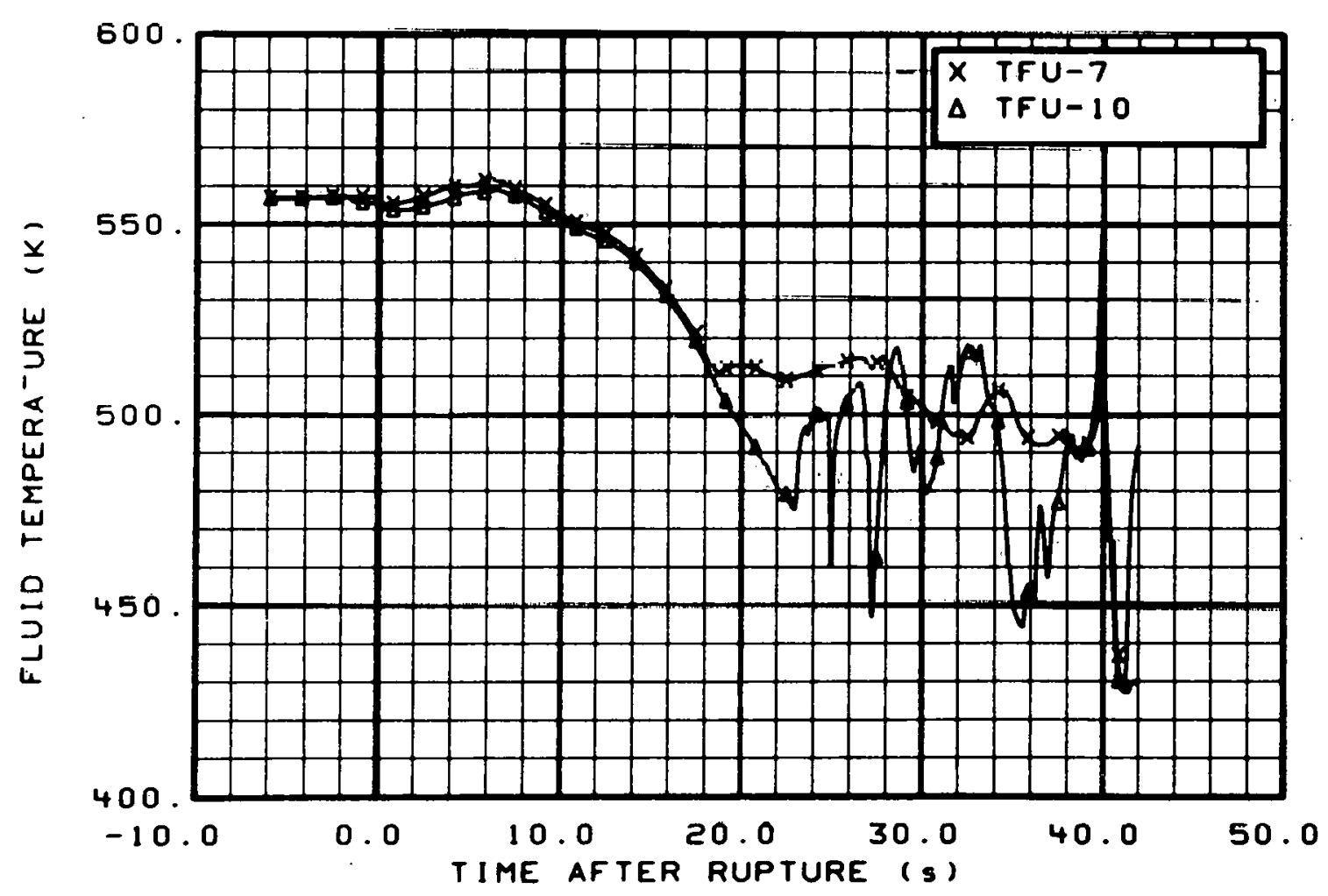

Fig. 14 Fluid temperature in intact loop cold leg (TFU-7 and TFU-10), from -6 to $42 \mathrm{~s}$. 


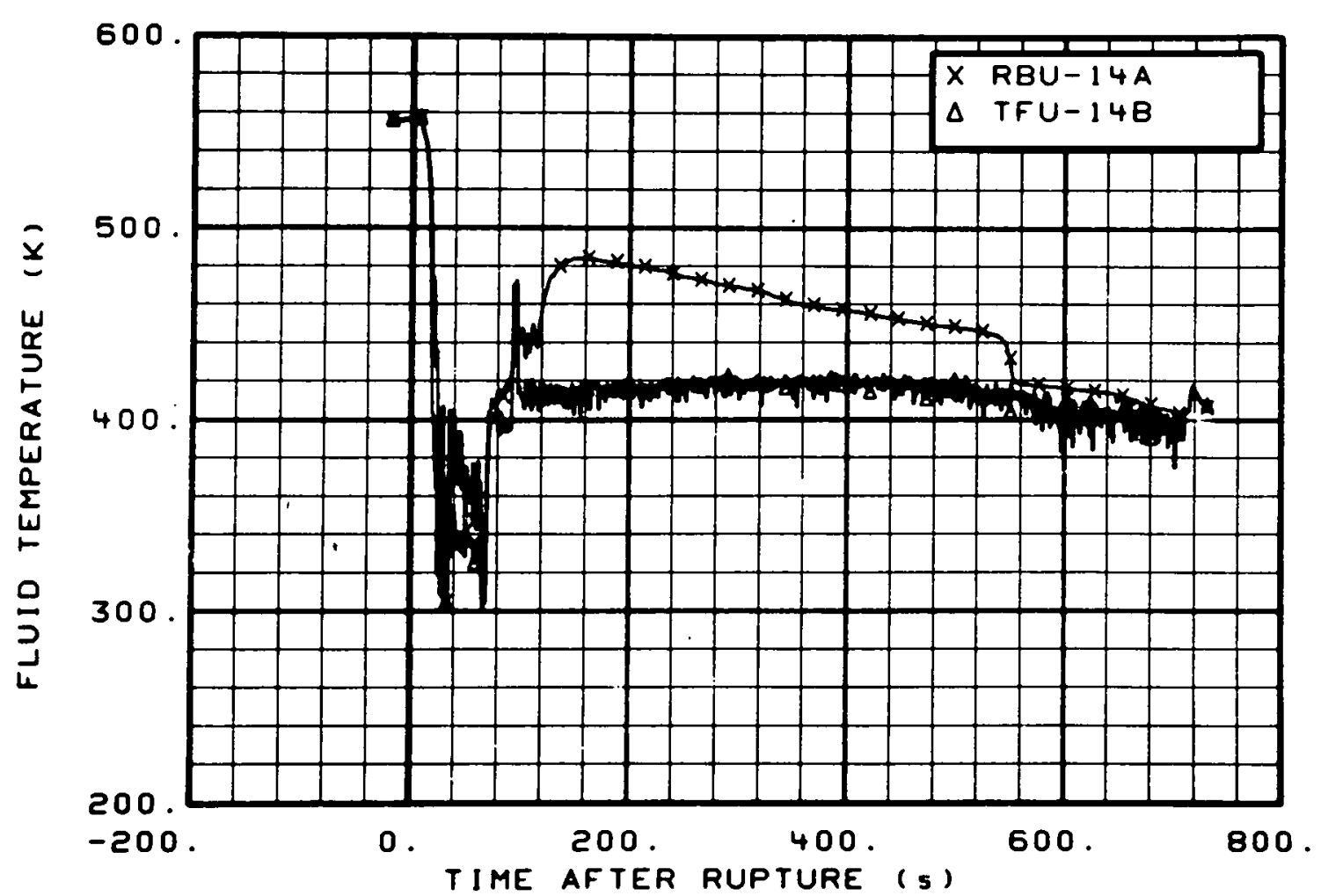

Fig. 15 Fluid temperature in intact loop cold leg (RBU-14A and TFU-14B), from -20 to $736 \mathrm{~s}$.

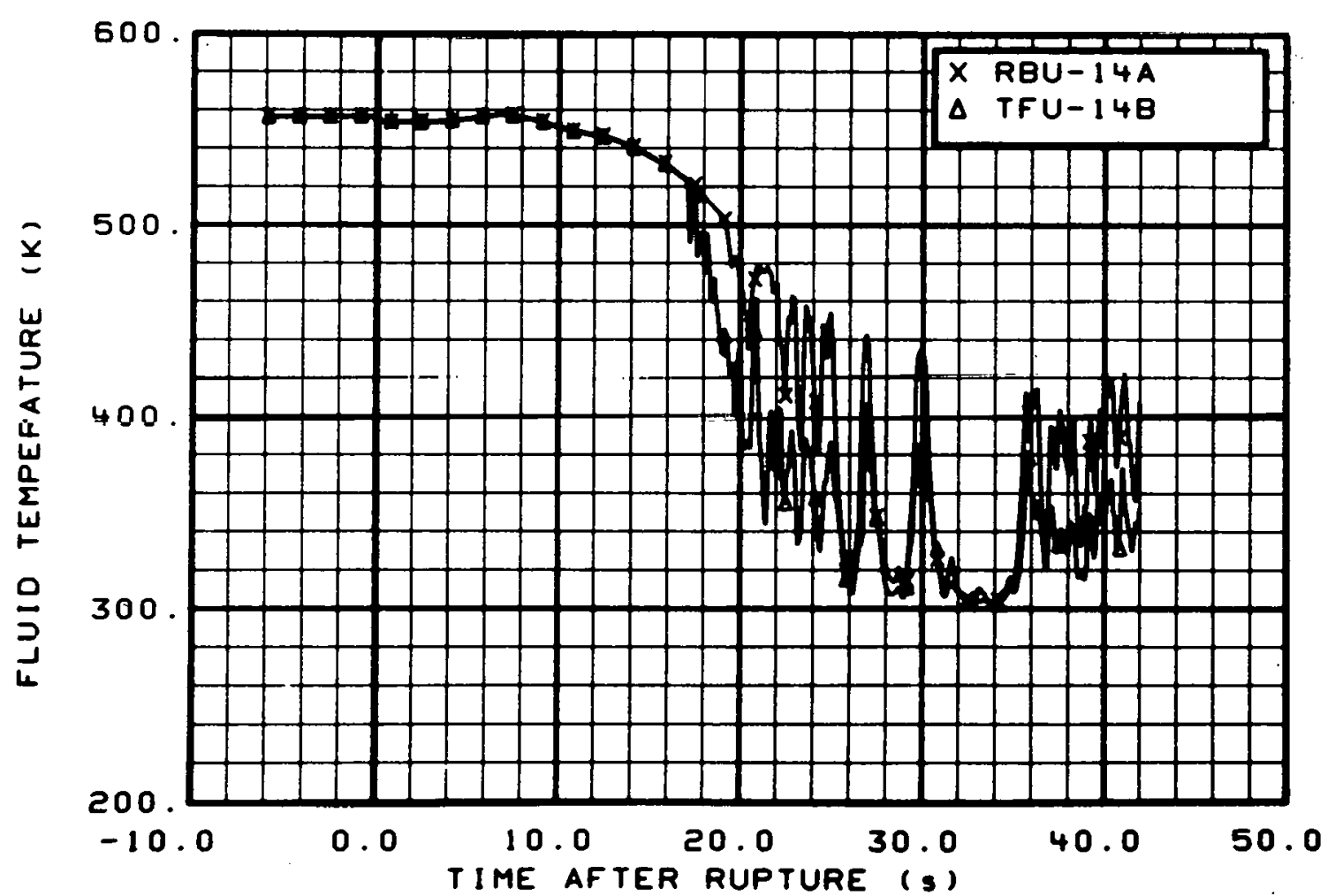

Fig. 16 Fluid temperature in intact loop cold leg (RBU-14A and TFU-14B), from -6 to $42 \mathrm{~s}$. 


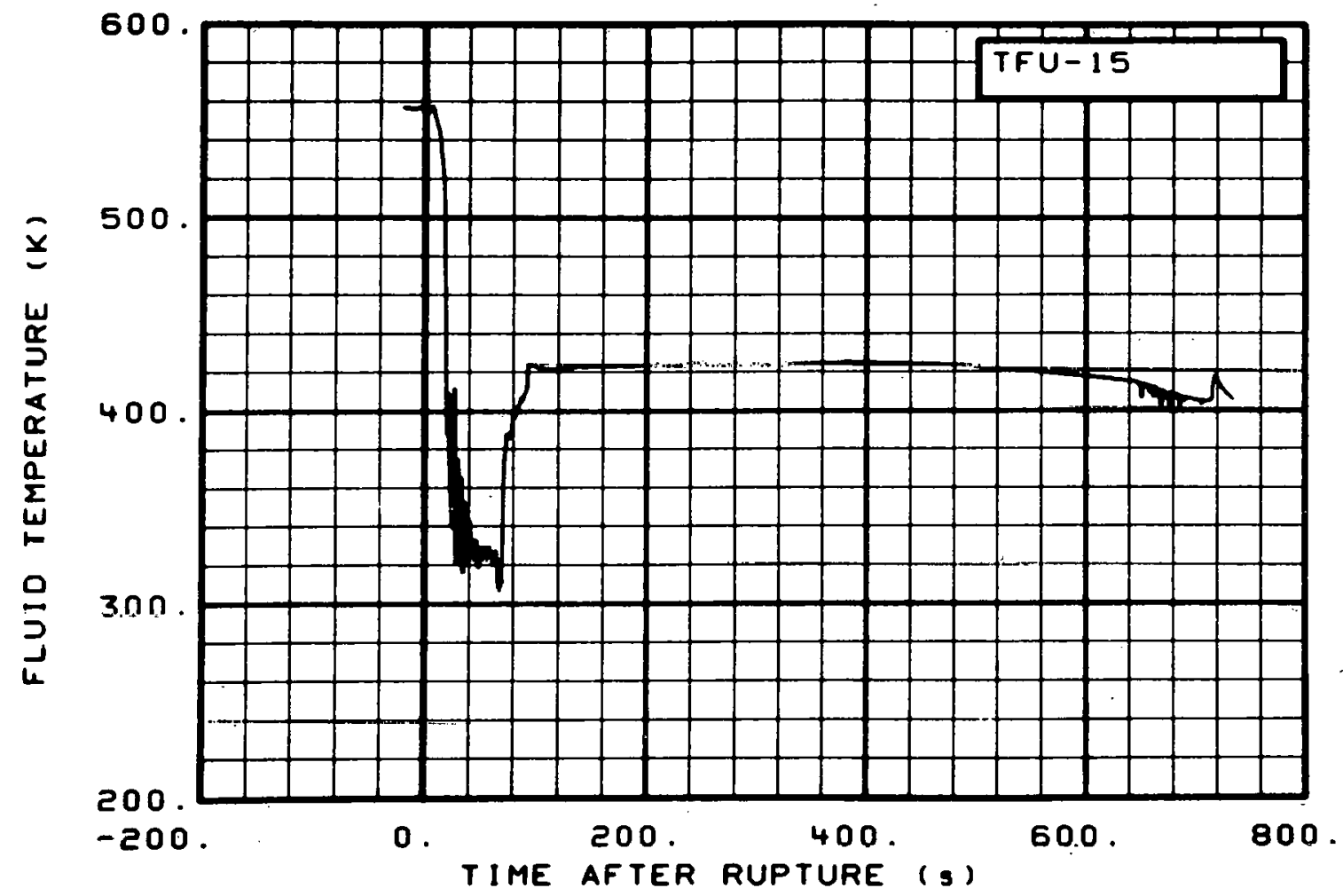

Fig. 17 Fluid temperature in intact loop cold leg (TFU-15), from -20 to $736 \mathrm{~s}$.

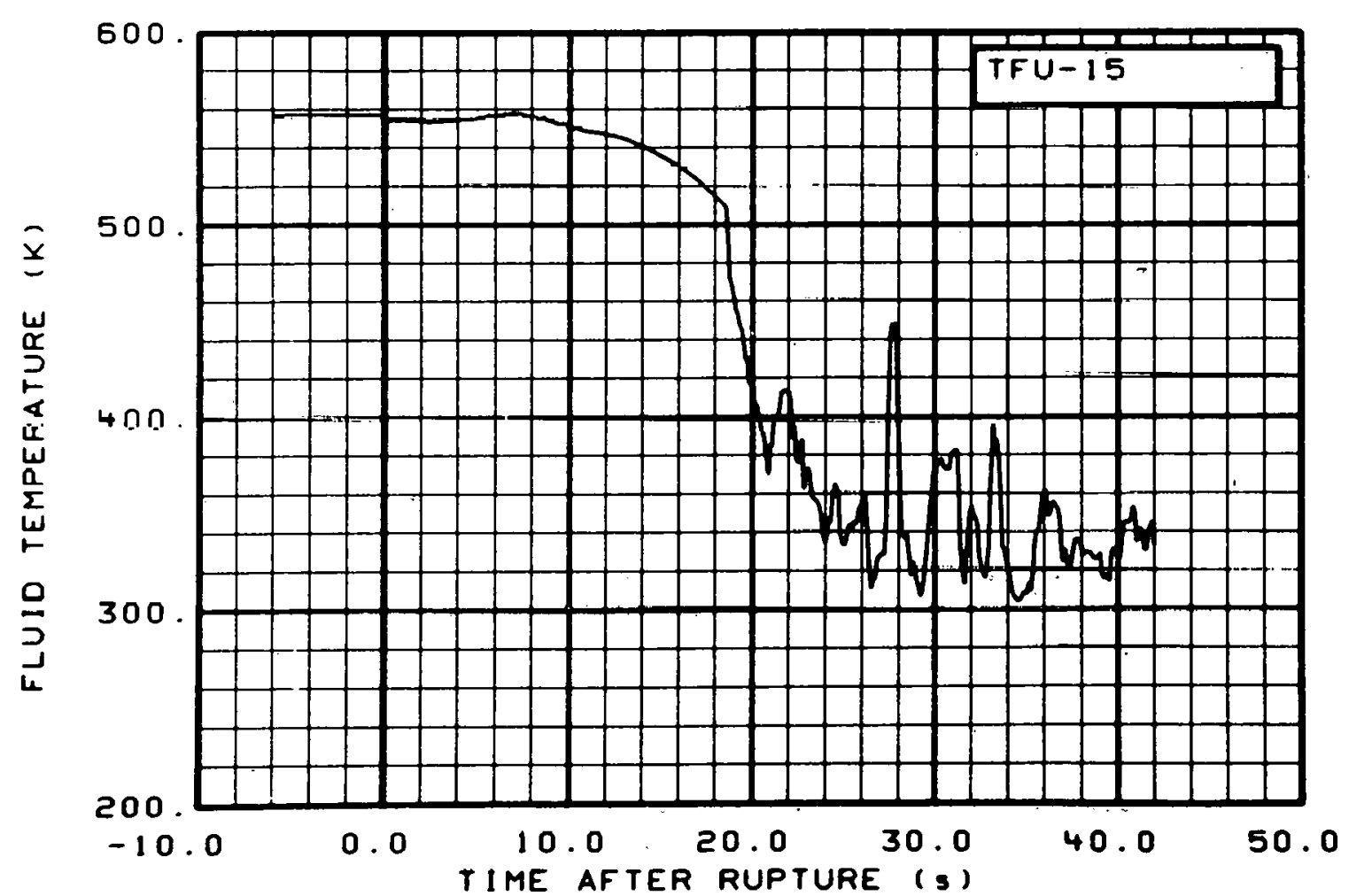

Fig. 18 Fluid temperature in intact loop cold leg (TFU-15), from -6 to $42 \mathrm{~s}$. 


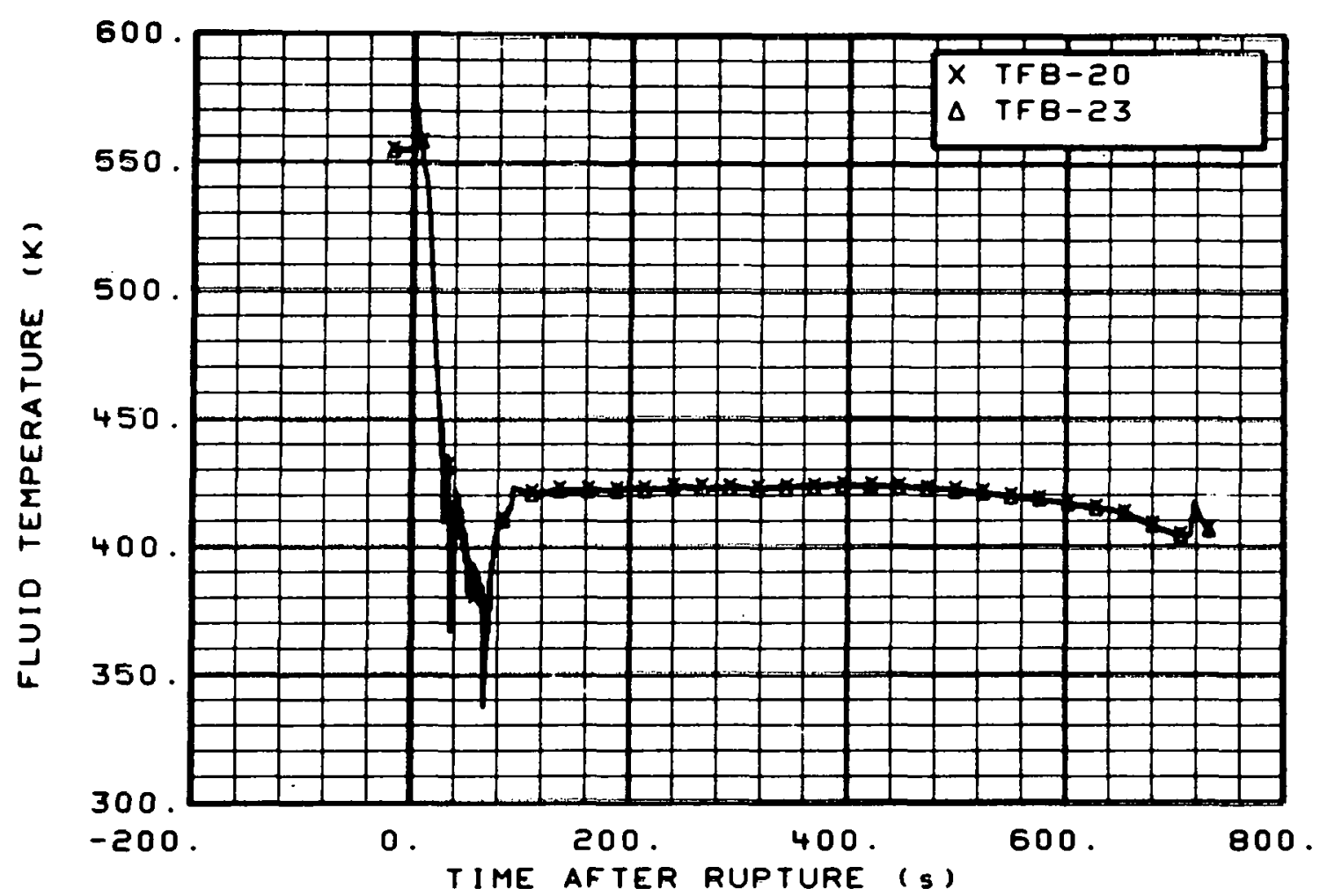

Fig. 19 Fluid temperature in broken loop, vessel side (TFB-20 and TFB-23), from -20 to $736 \mathrm{~s}$.

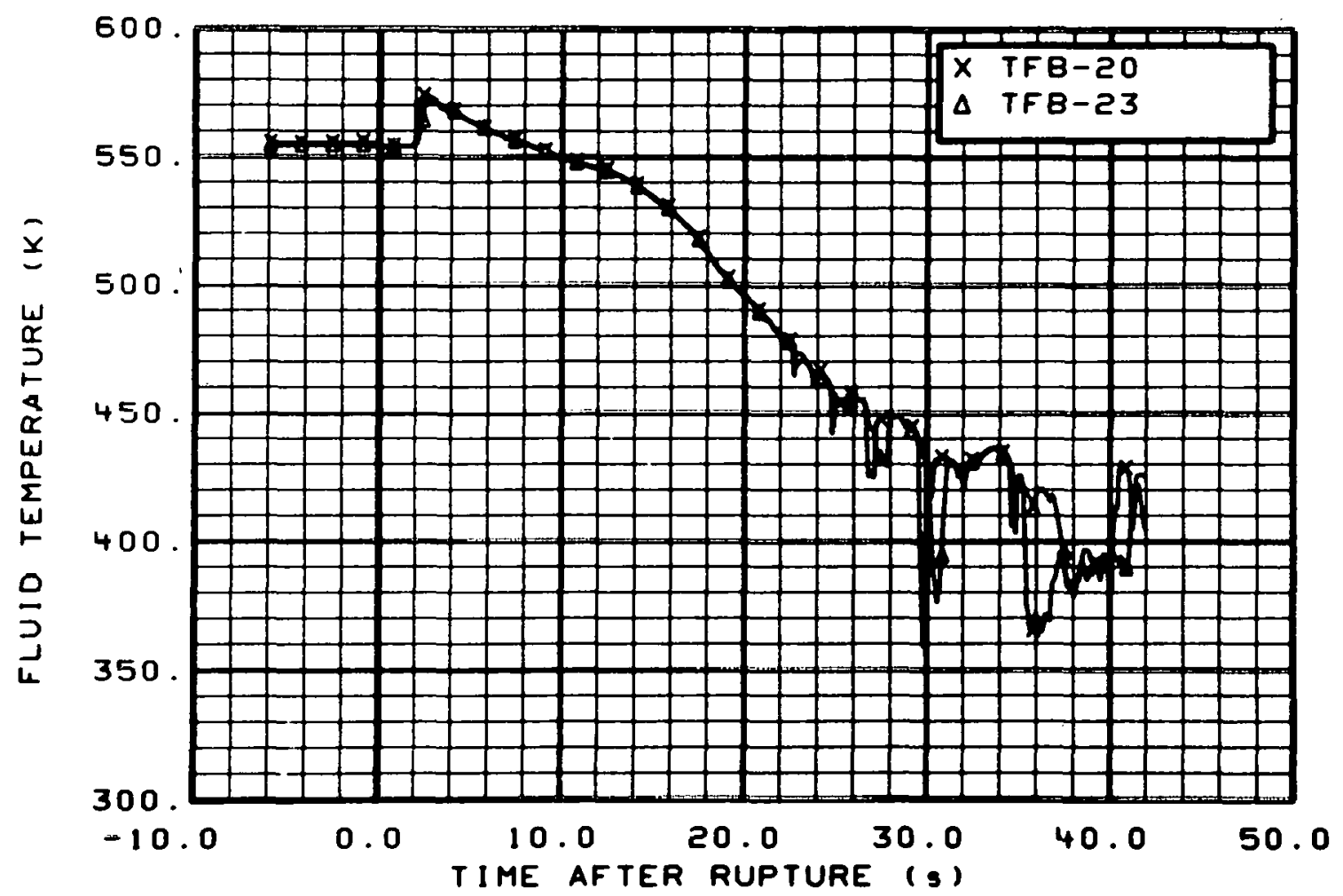

Fig. 20 Fluid temperature in broken loop, vessel side (TFB-20 and TFB-23), from -6 to $42 \mathrm{~s}$. 


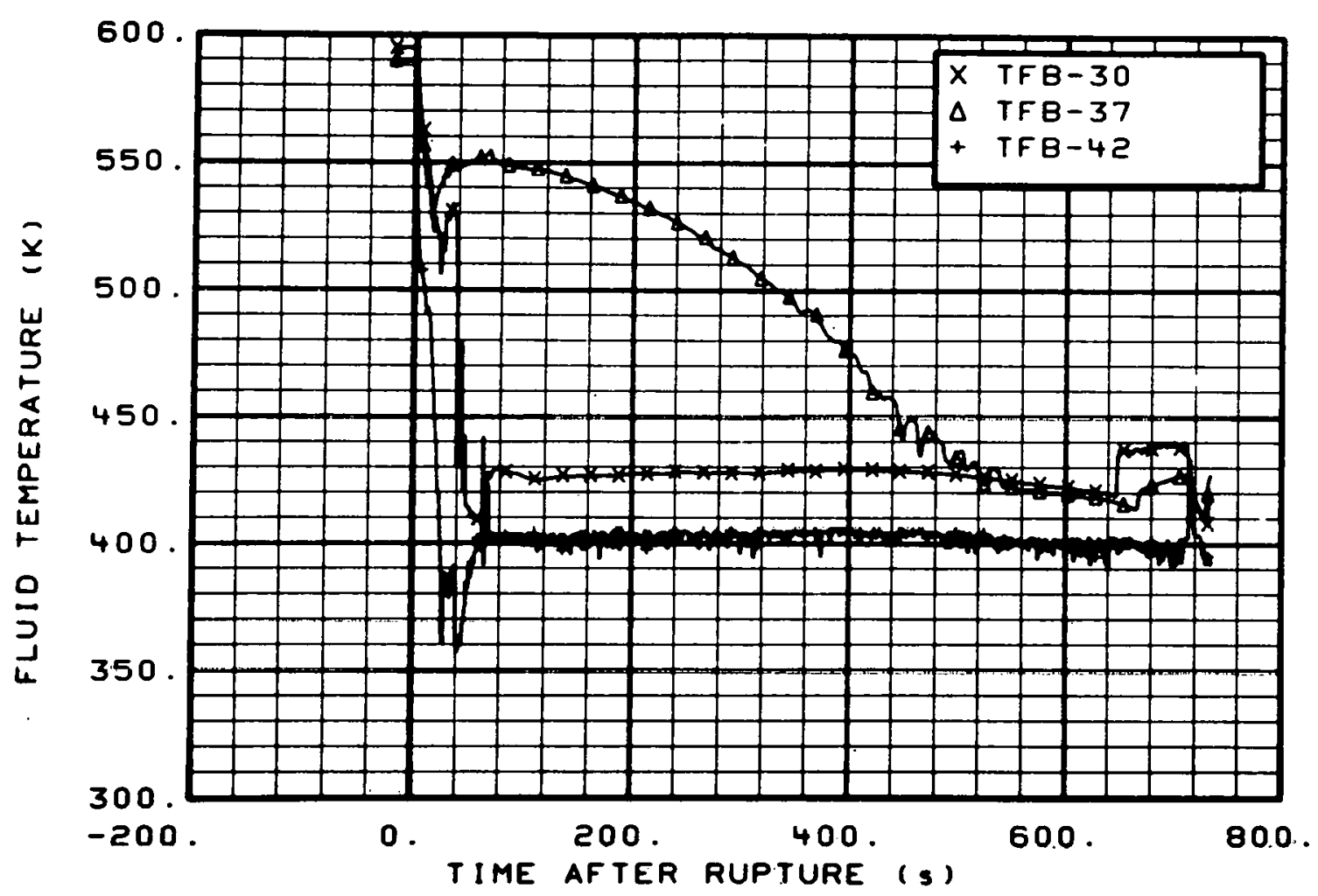

Fig. 21 Fluid temperature in broken loop, pump side (TFB-30, TFB-37, and TFB-42), from -20 to $736 \mathrm{~s}$.

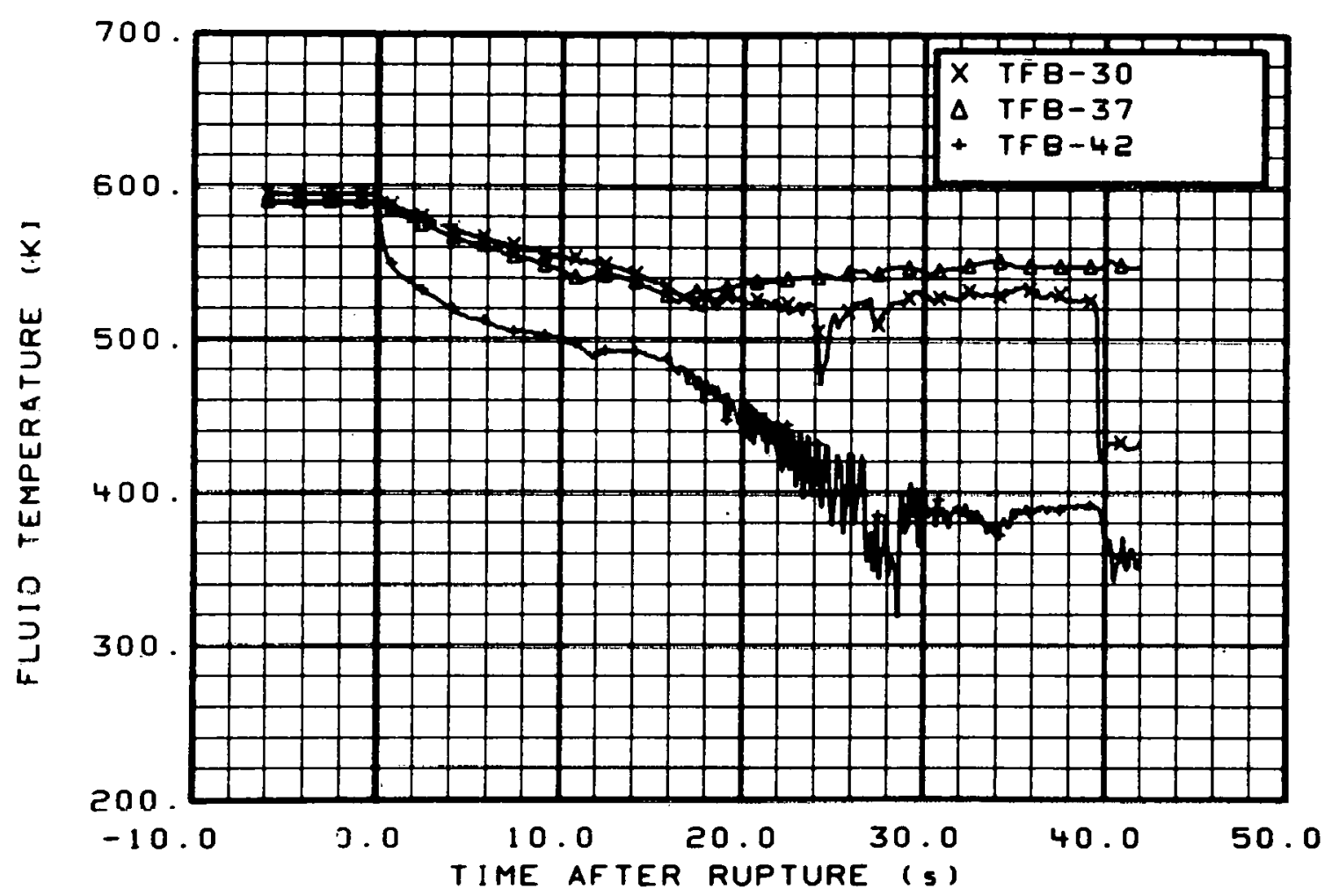

Fig. 22 Fluid temperature in broken loop, pump side (TFB-30, TFB-37, and TFB-42), from -6 to $42 \mathrm{~s}$. 


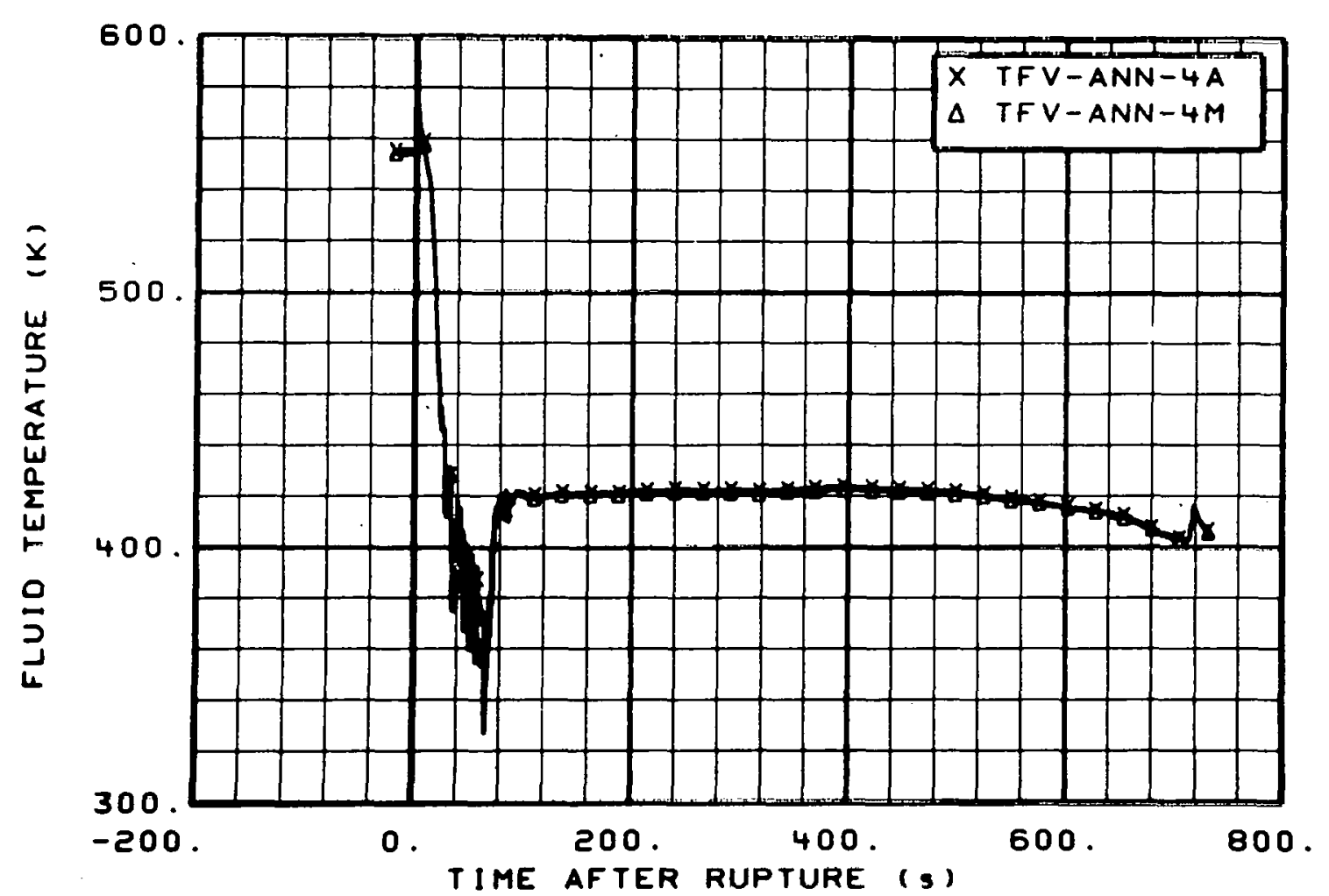

Fig. 23 Fluid temperature in inlet annulus (TFV-ANN-4A and TFV-ANN-4M), from -20 to $736 \mathrm{~s}$.

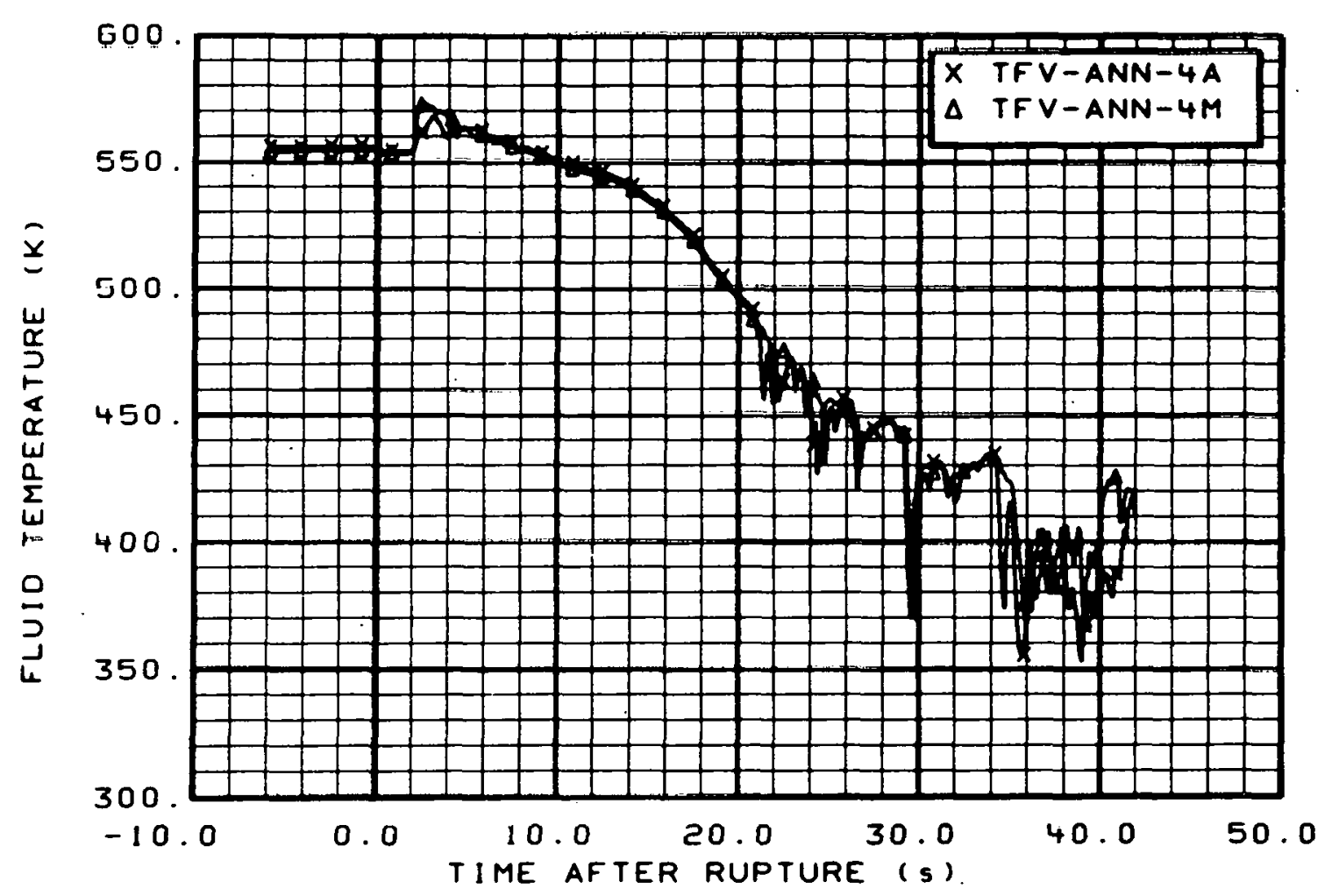

Fig. 24 Fluid temperature in inlet annulus (TFV-ANN-4A and TFV-ANN-4M), from -6 to $42 \mathrm{~s}$. 


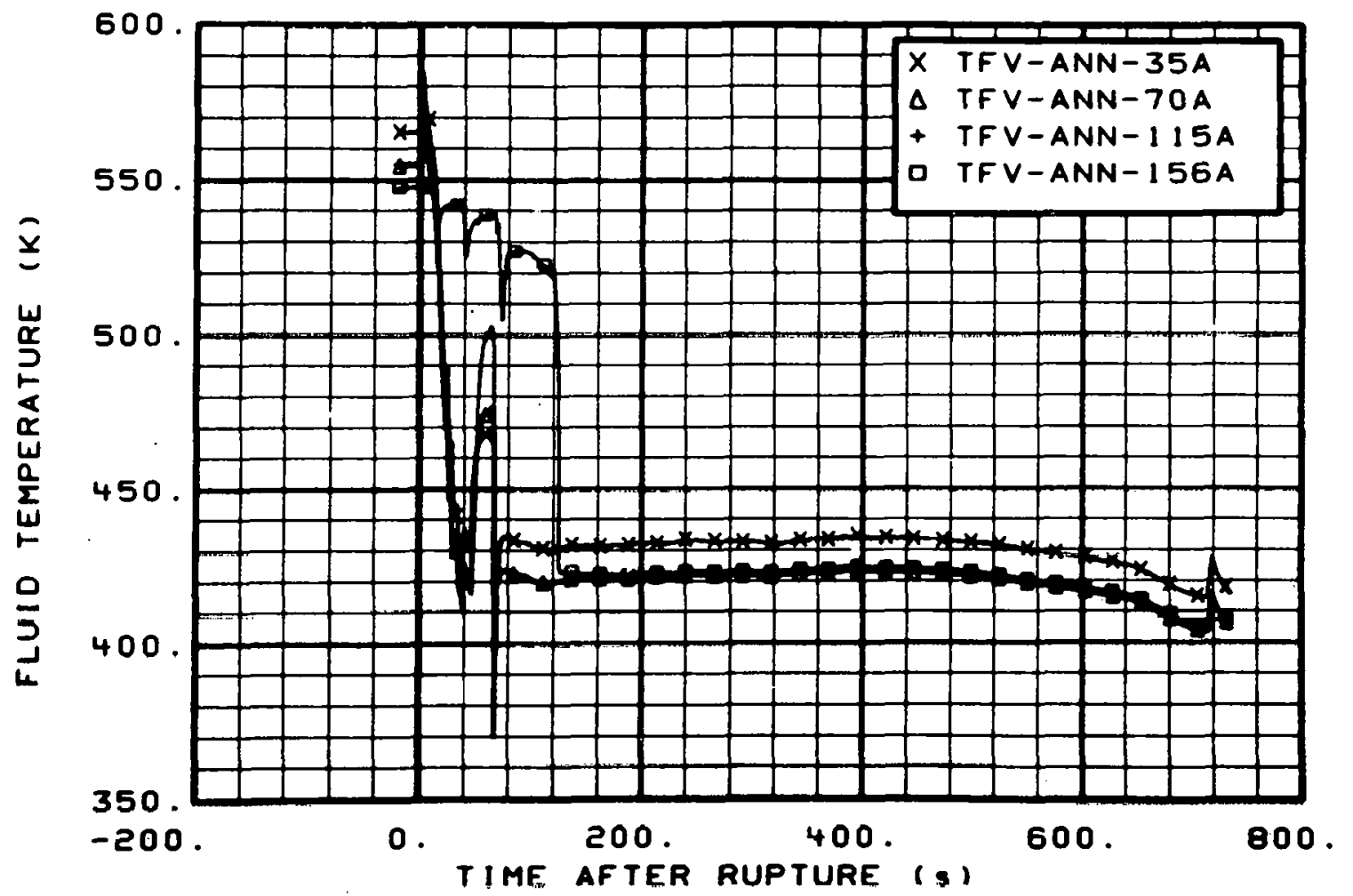

Fig. 25 Fluid temperature in downcomer annulus (TFV-ANN-35A, TFV-ANN-70A, TFV-ANN-115A, and TFV-ANN-156A), from -20 to $736 \mathrm{~s}$.

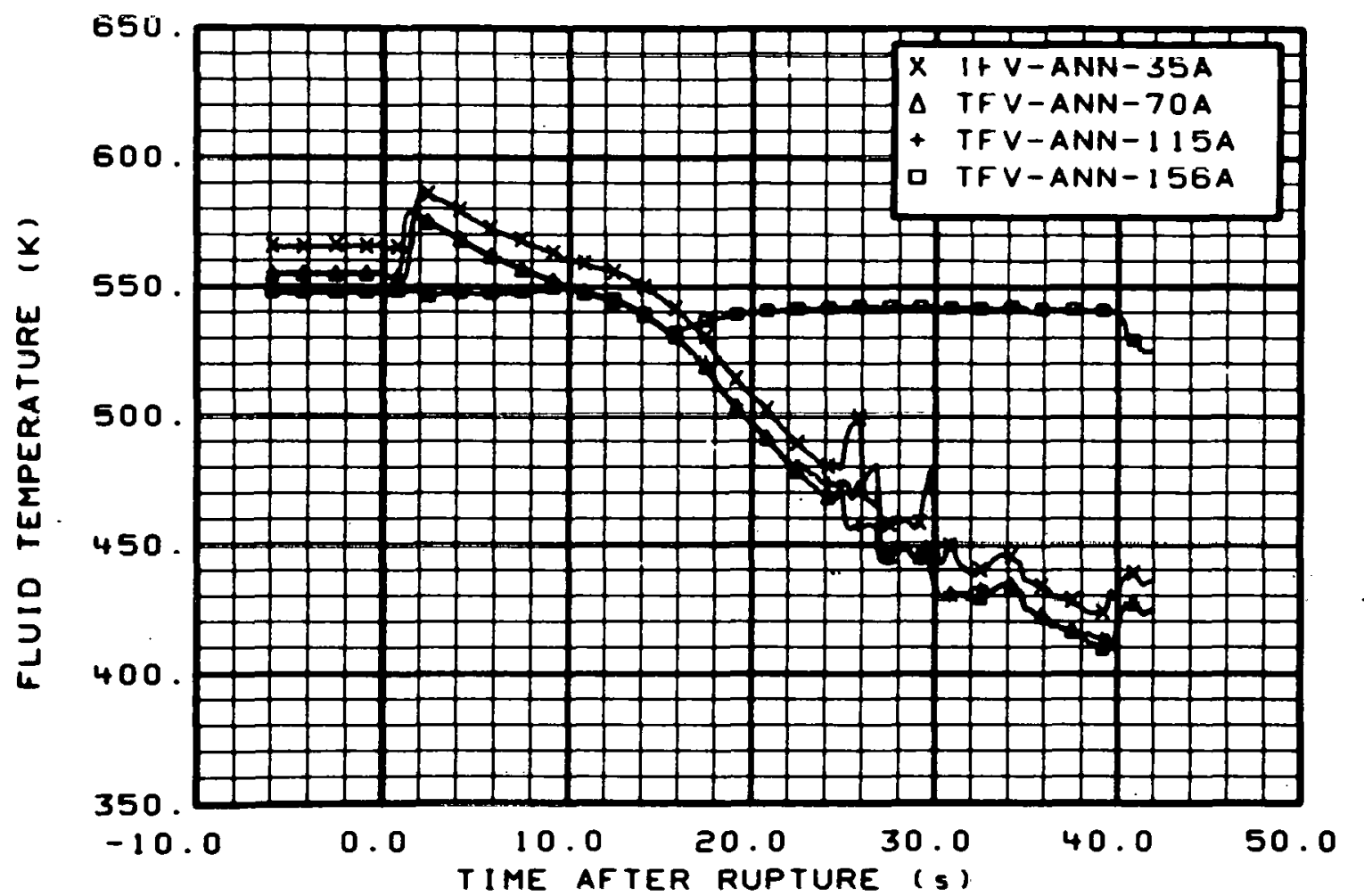

Fig. 26 Fluid temperature in downcomer annulus (TFV-ANN-35A, TFV-ANN-70A, TFV-ANN-115A, and TFV-ANN-156A), from -6 to $42 \mathrm{~s}$. 


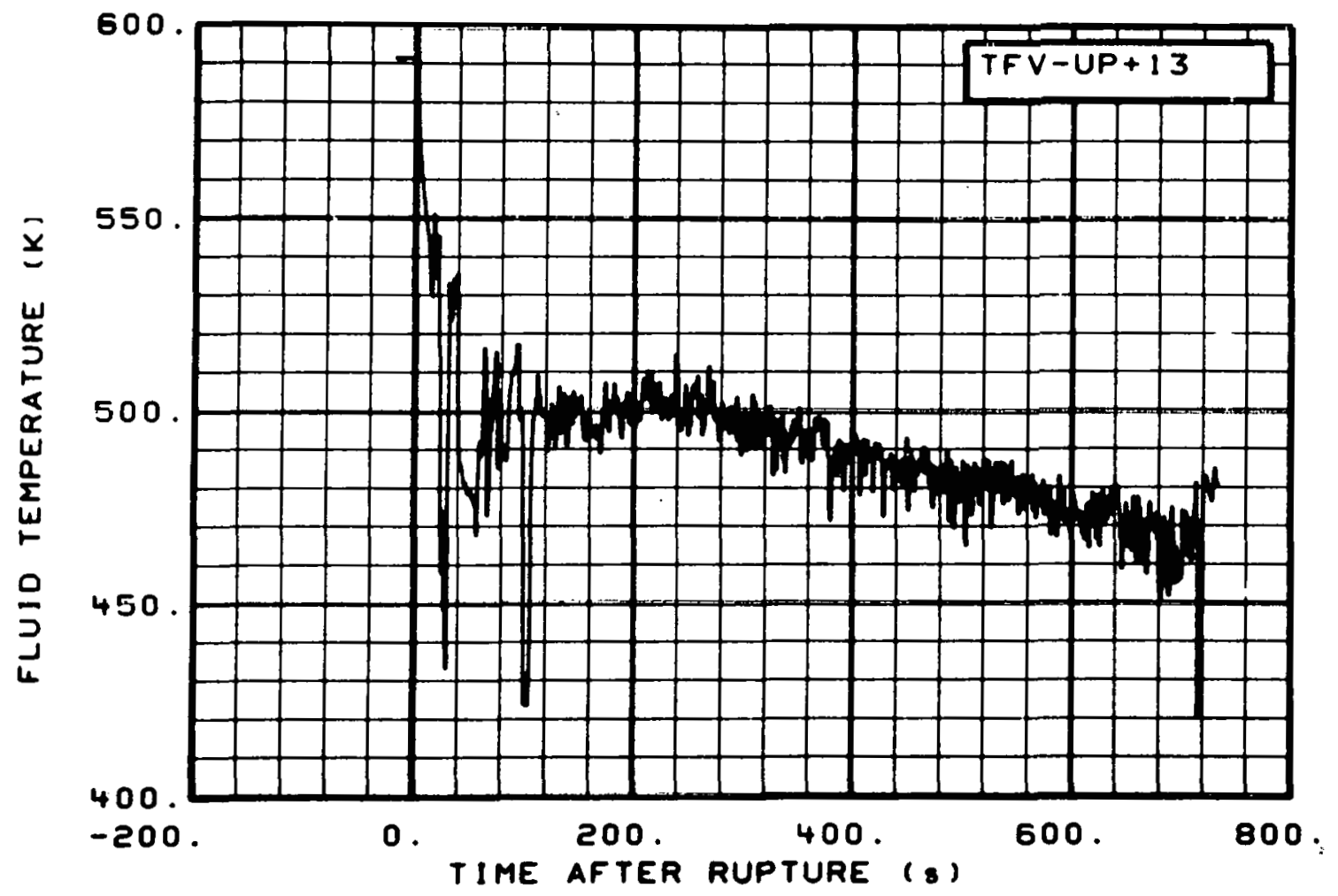

Fig. 27 Fluid temperature in upper plenum (TFV-UP+13), from -20 to $736 \mathrm{~s}$.

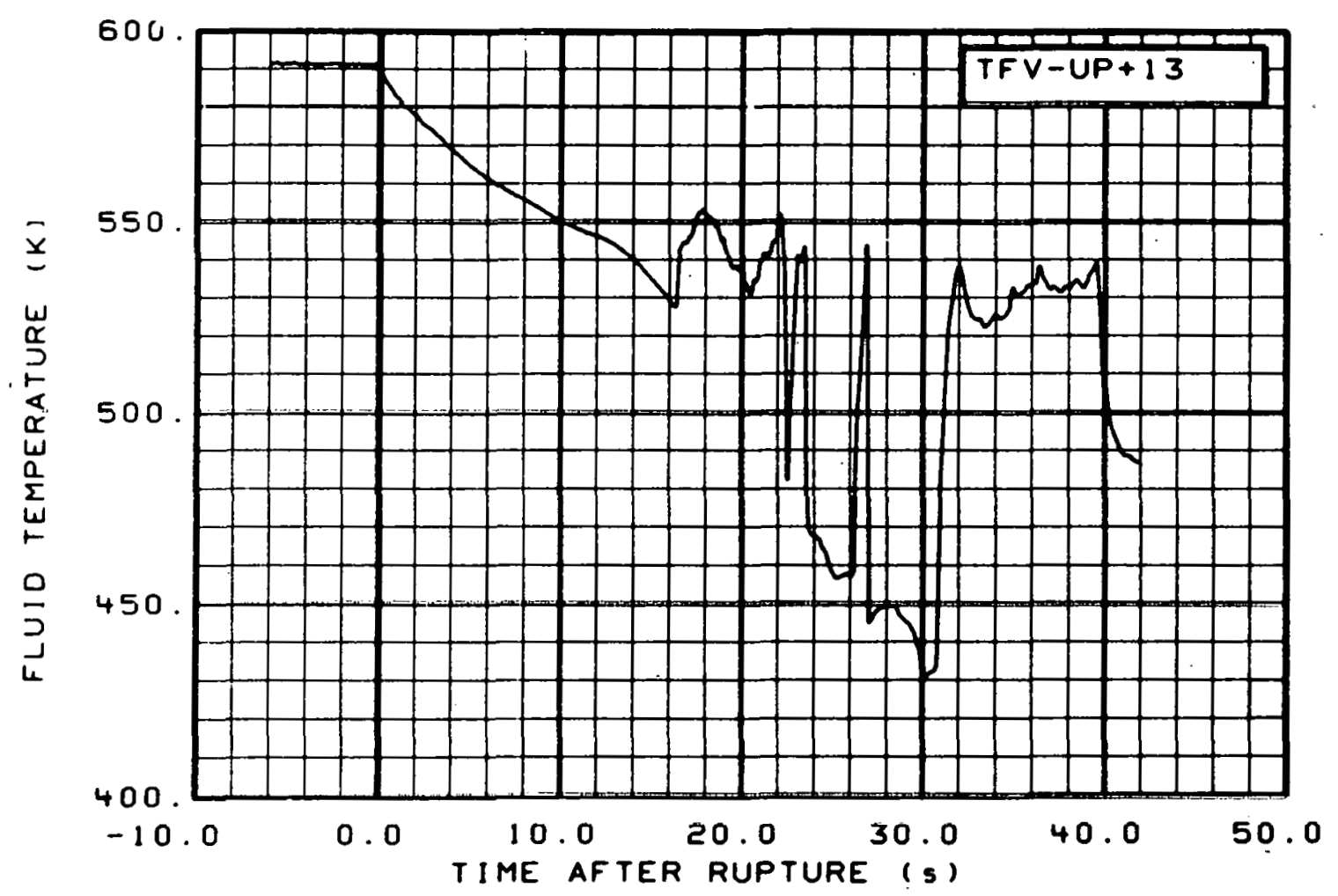

Fig. 28 Fluid temperature in upper plenum (TFV-UP+13), from -6 to $42 \mathrm{~s}$. 


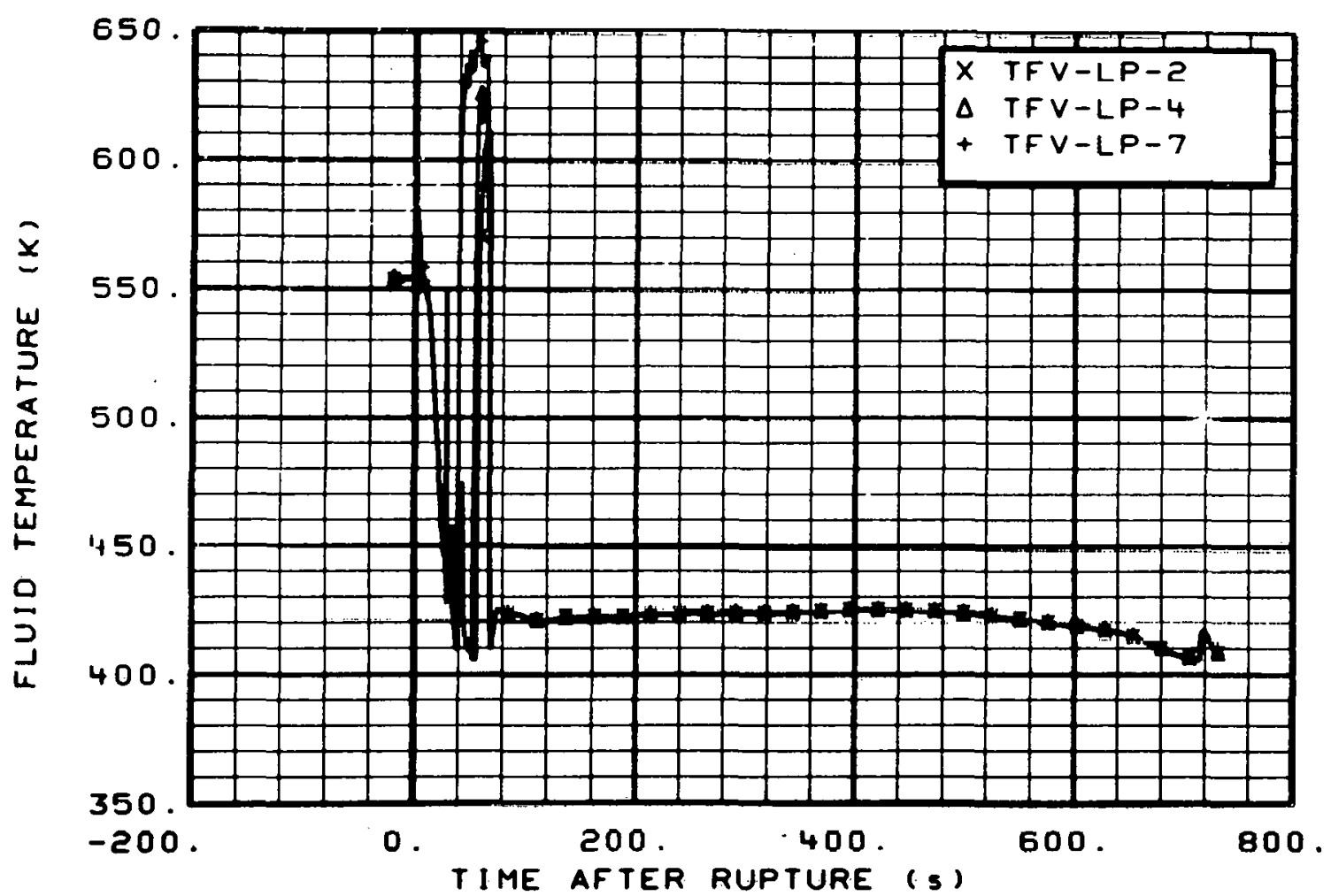

Fig. 29 Fluid temperature in lower plenum (TFV-LP-2, TFV-LP-4, and TFV-LP-7), from -20 to $736 \mathrm{~s}$.

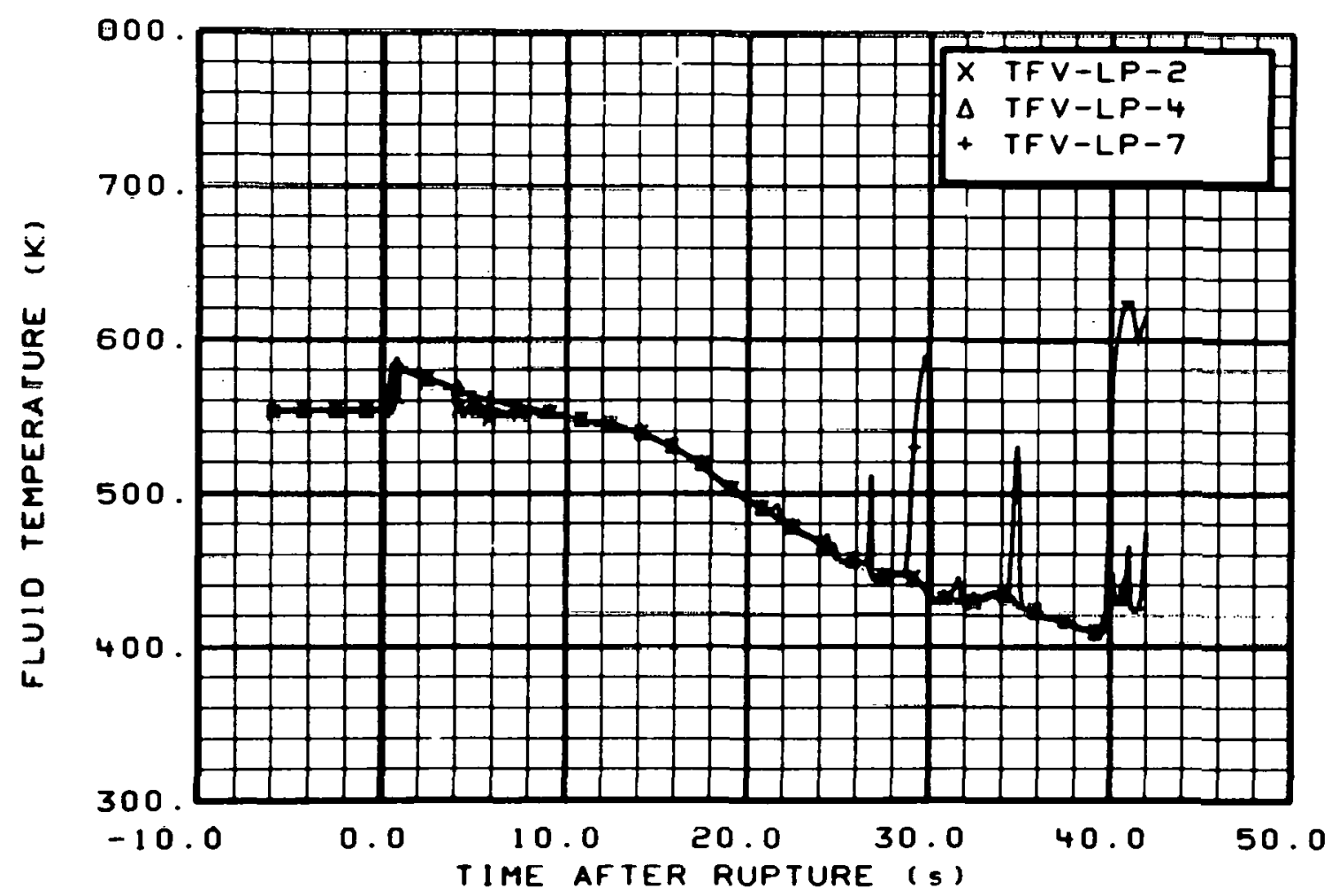

Fig. 30 Fluid temperature in lower plenum (TFV-LP-2, TFV-LP-4, and TFV-LP-7), from -6 to $42 \mathrm{~s}$. 


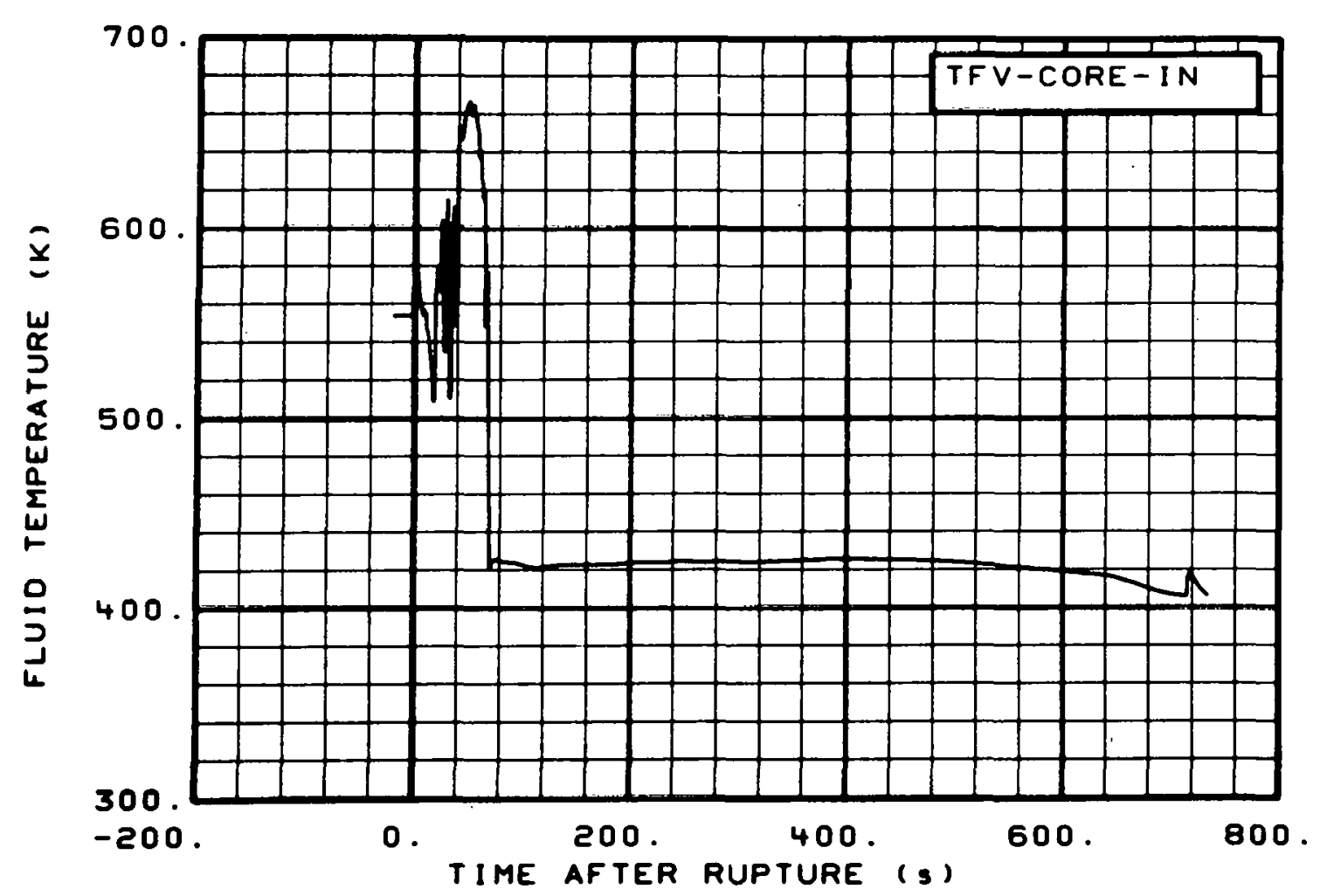

Fig. 31 Fluid temperature in core inlet (TFV-CORE-IN), from -20 to $736 \mathrm{~s}$.

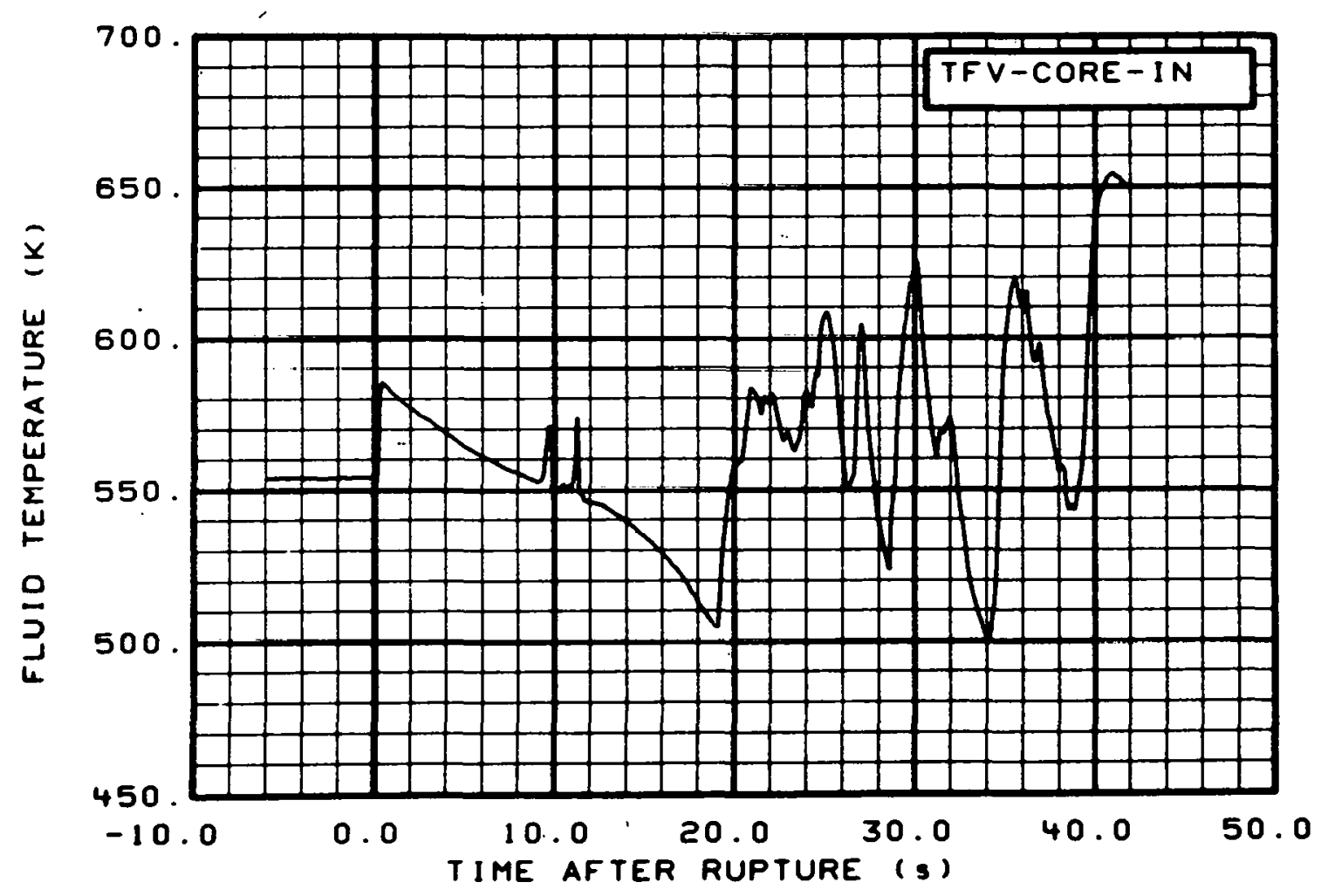

Fig. 32 Fluid temperature in core inlet (TFV-CORE-IN), from -6 to $42 \mathrm{~s}$. 


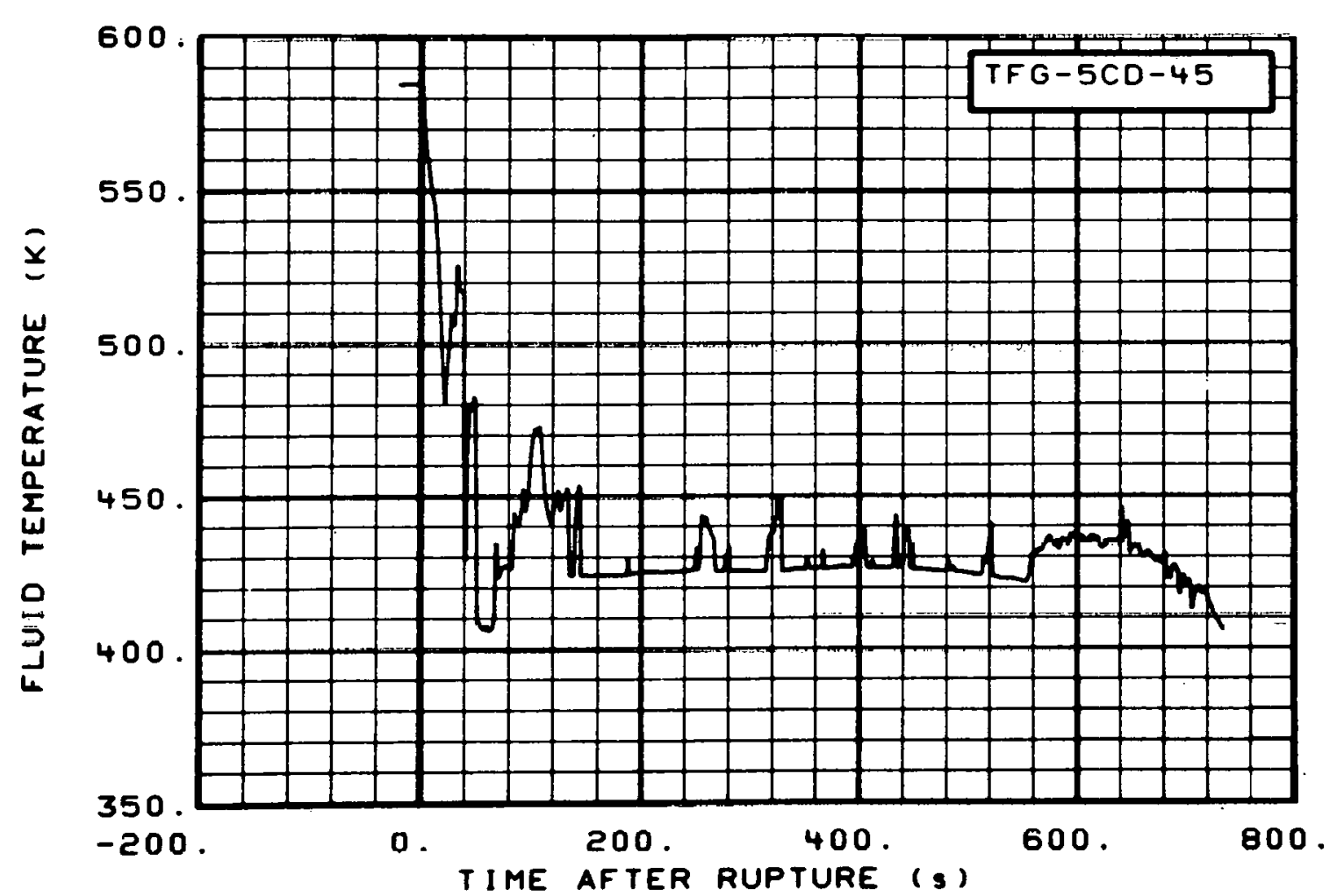

Fig. 33 Fluid temperature in core, Grid Spacer 5 (TFG-5CD-45), from -20 to $736 \mathrm{~s}$.

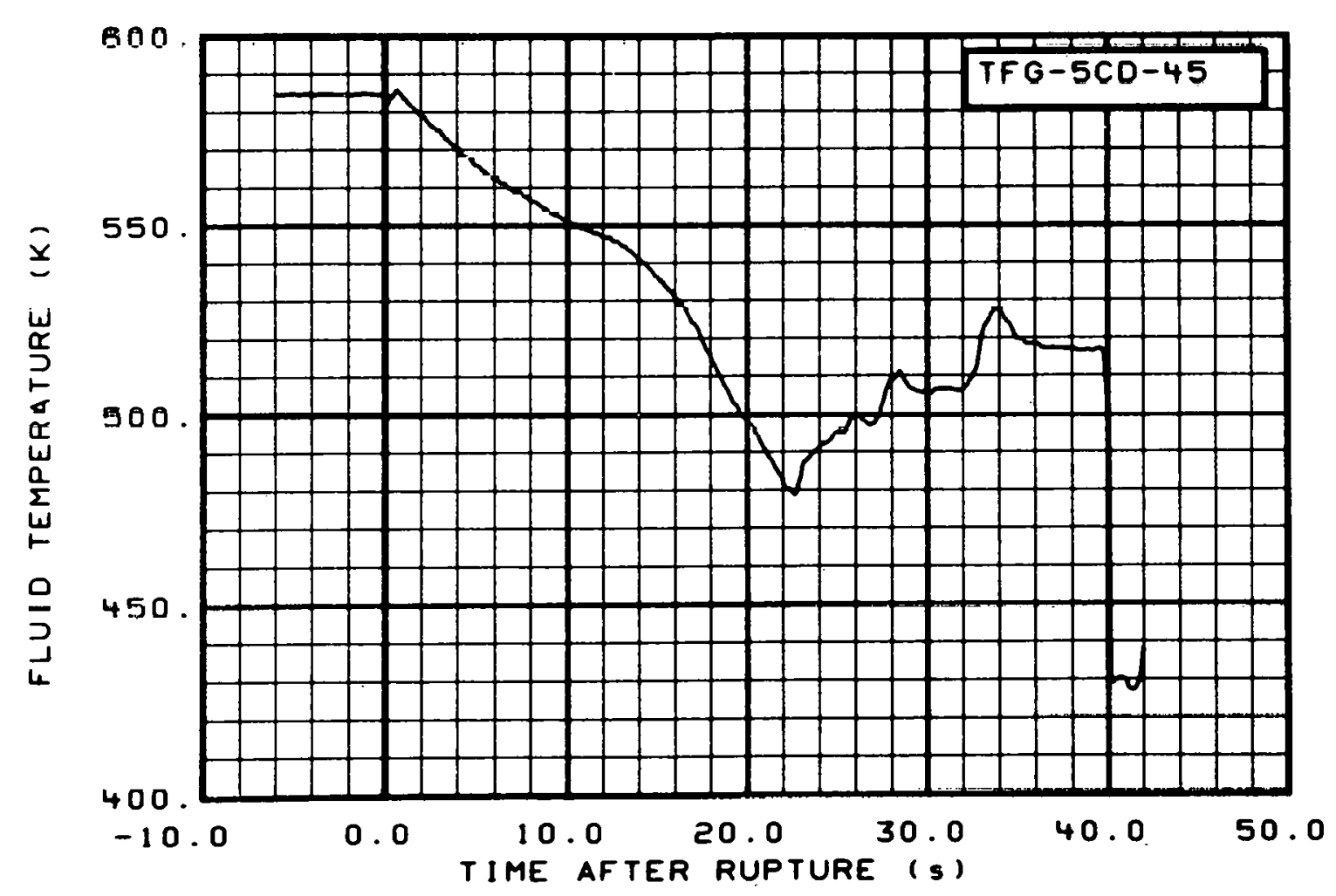

Fig. 34 Fluid temperature in core, Grid Spacer 5 (TFG-5CD-45), from -6 to $42 \mathrm{~s}$. 


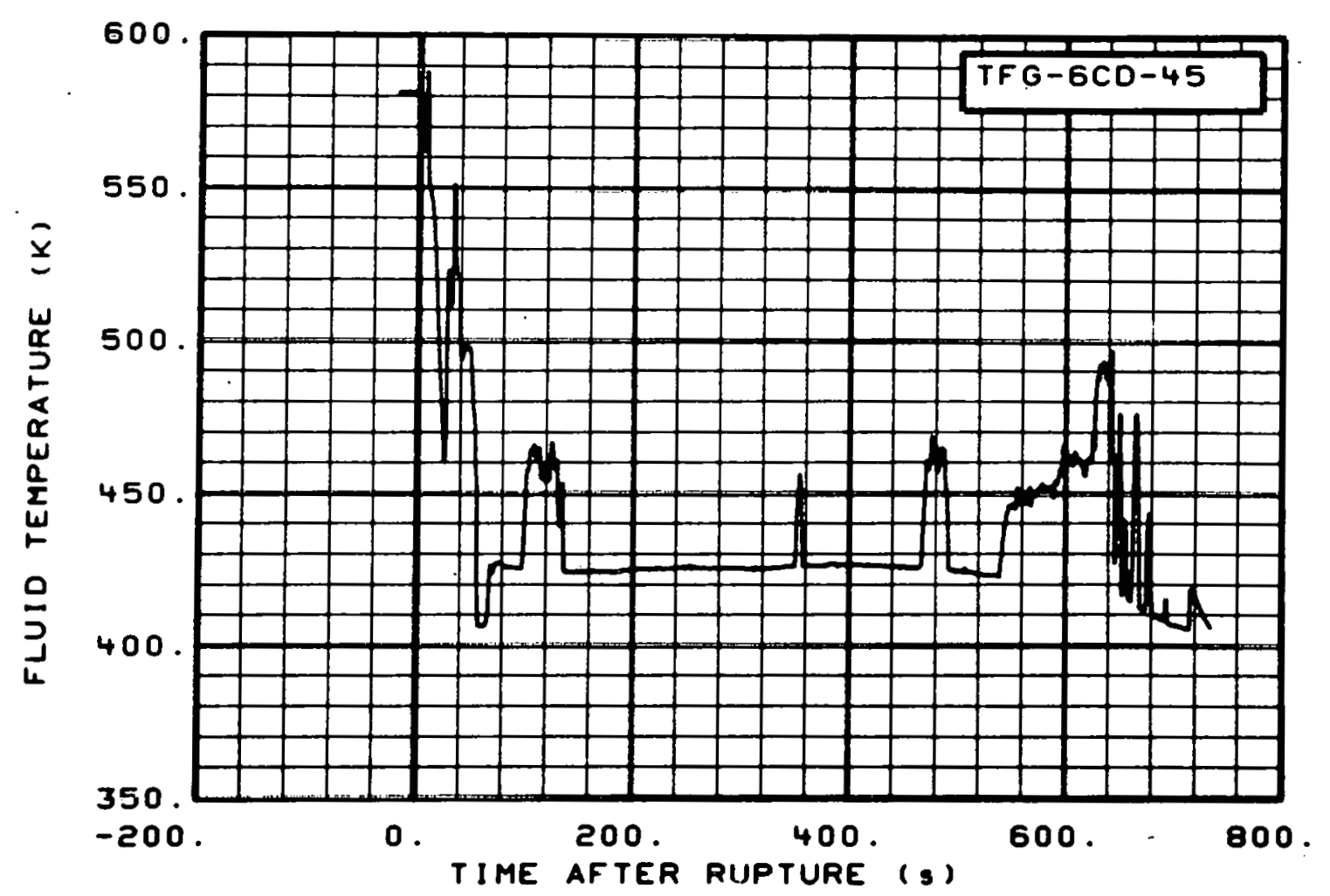

Fig. 35 Fluid temperature in core, Grid Spacer 6 (TFG-6CD-45), from -20 to $736 \mathrm{~s}$.

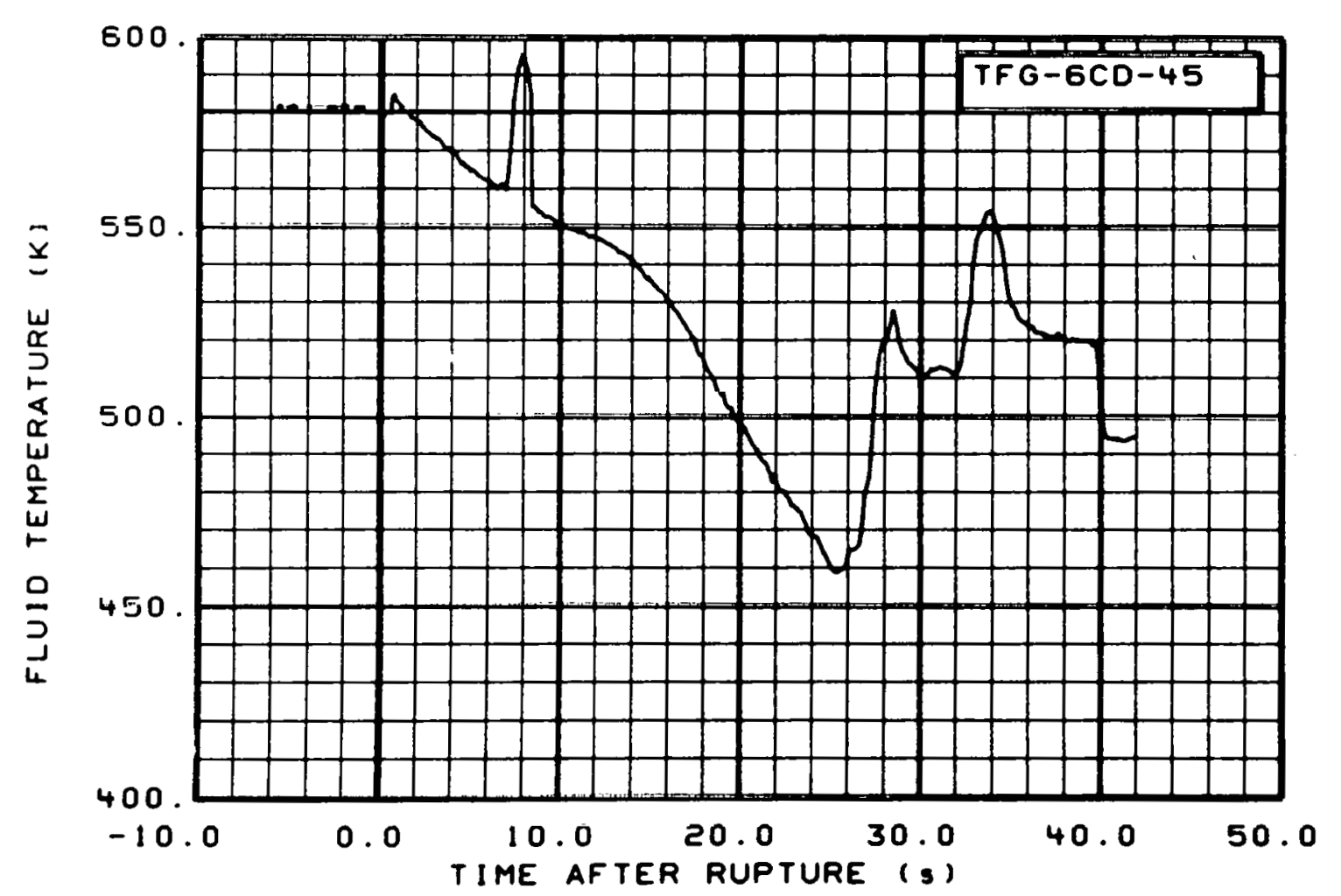

Fig. 36 Fluid temperature in core, Grid Spacer 6 (TFG-6CD-45), from -6 to $42 \mathrm{~s}$. 


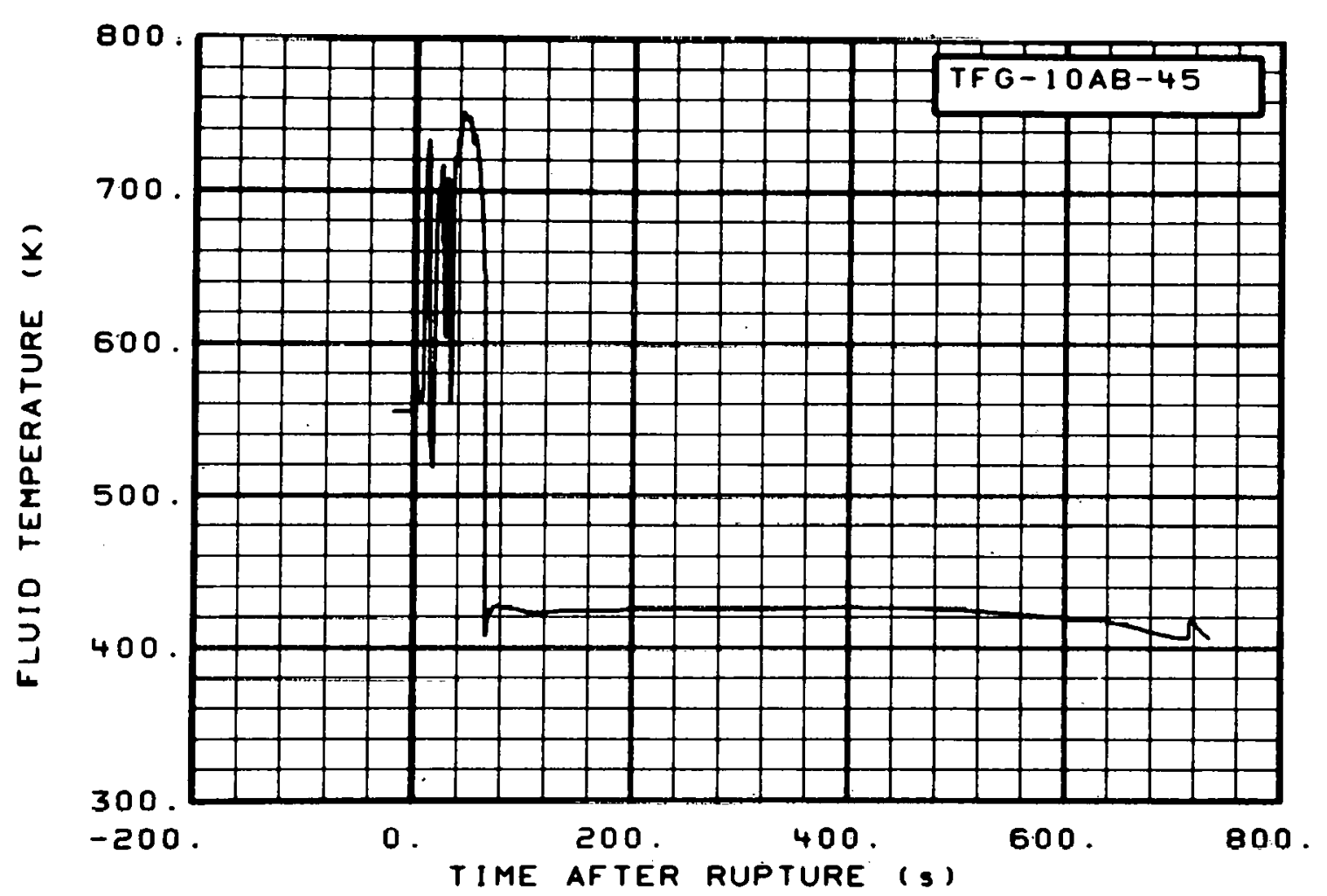

Fig. 37 Fluid temperature in core, Grid Spacer 10 (TFG-10AB-45), from -20 to $736 \mathrm{~s}$.

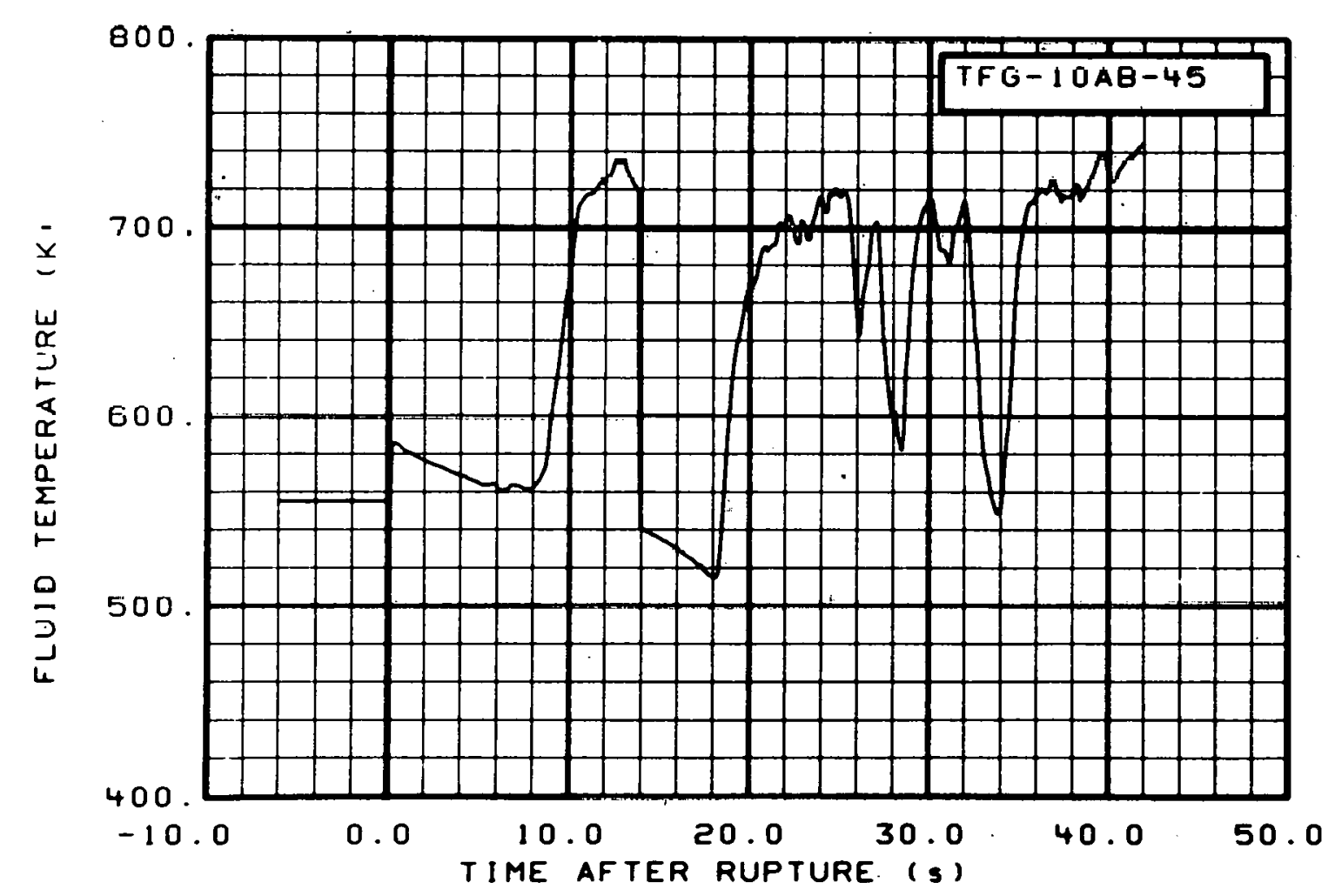

Fig. 38 Fluid temperature in core, Grid Spacer 10 (TFG-10AB-45), from -6 to $42 \mathrm{~s}$. 


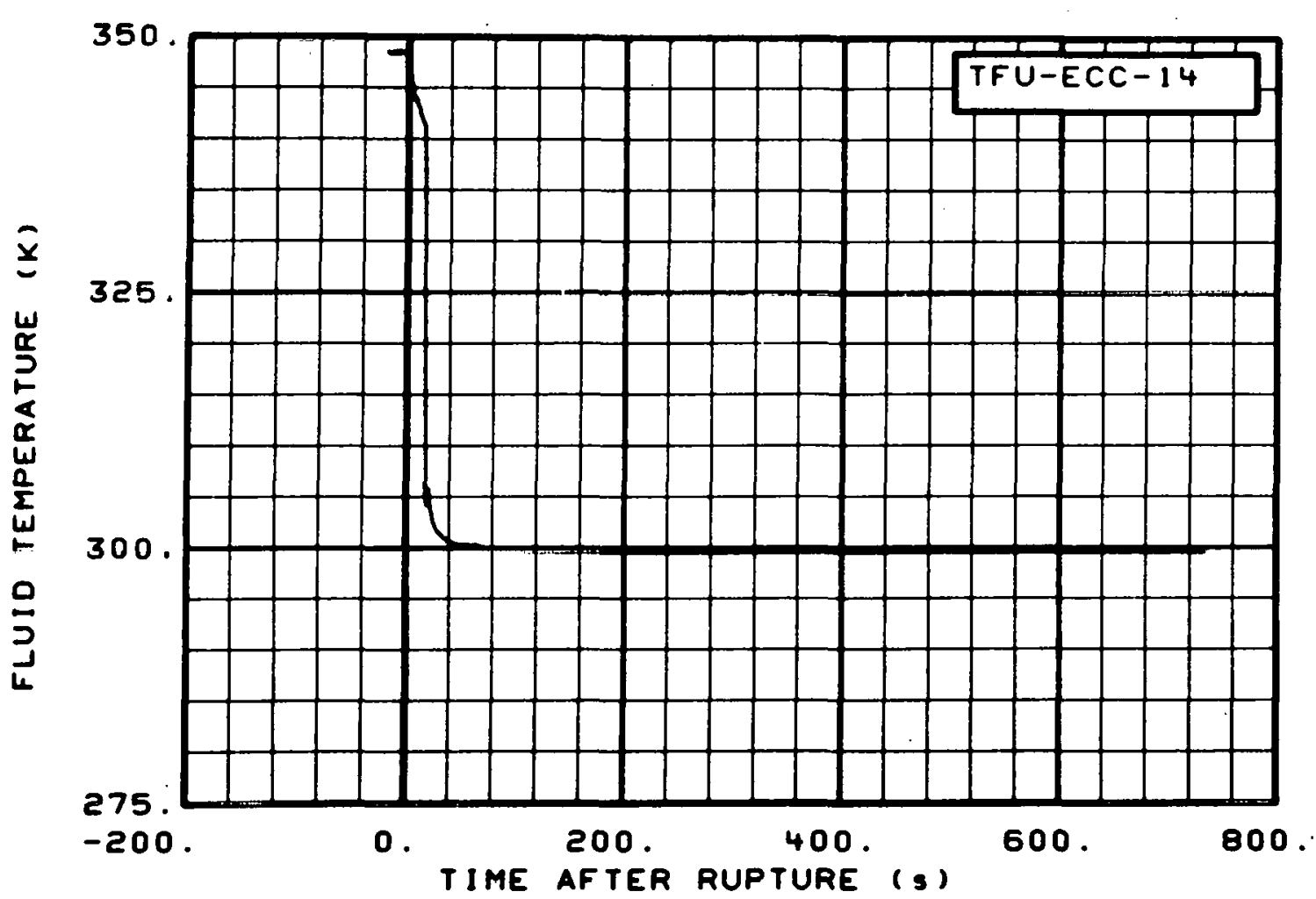

Fig. 39 Fluid temperature in intact loop coolant injection line (TFU-ECC14), from -20 to $736 \mathrm{~s}$.

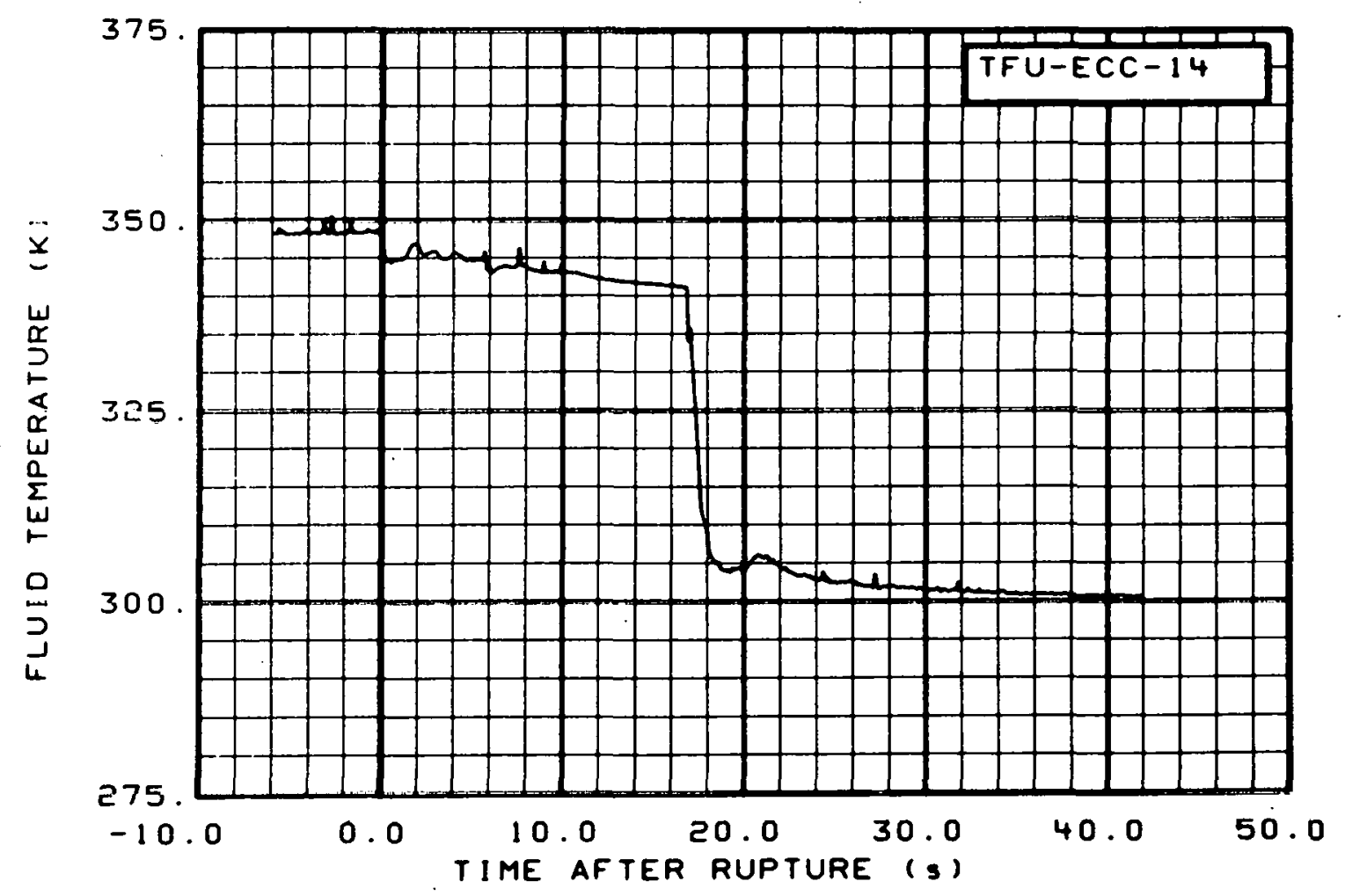

Fig. 40 Fluid temperature in intact loop coolant injection line (TFU-ECC14), from -6 to $42 \mathrm{~s}$. 


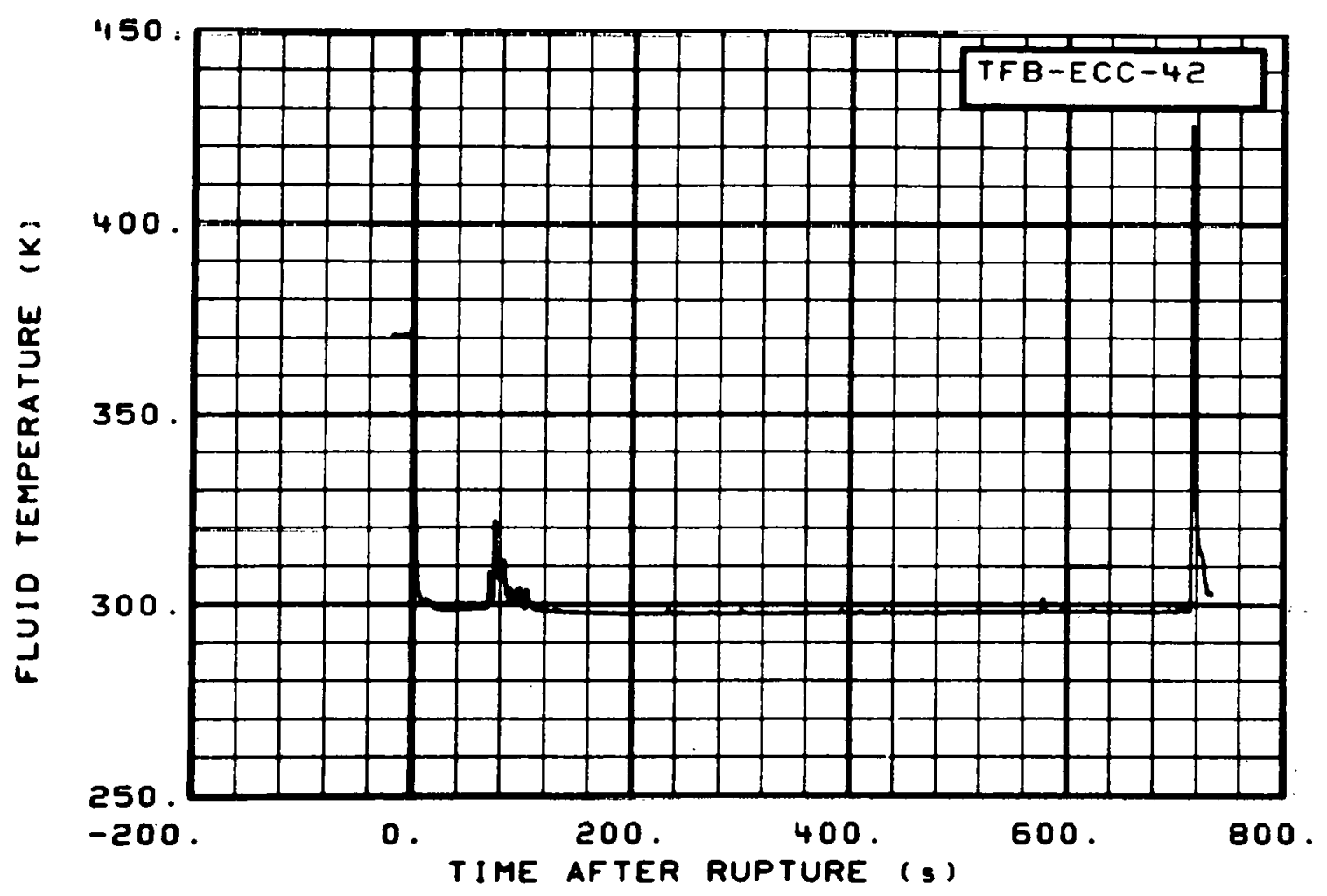

Fig. 41 Fluid temperature in broken loop coolant injection line (TFB-ECC42), from -20 to $736 \mathrm{~s}$.

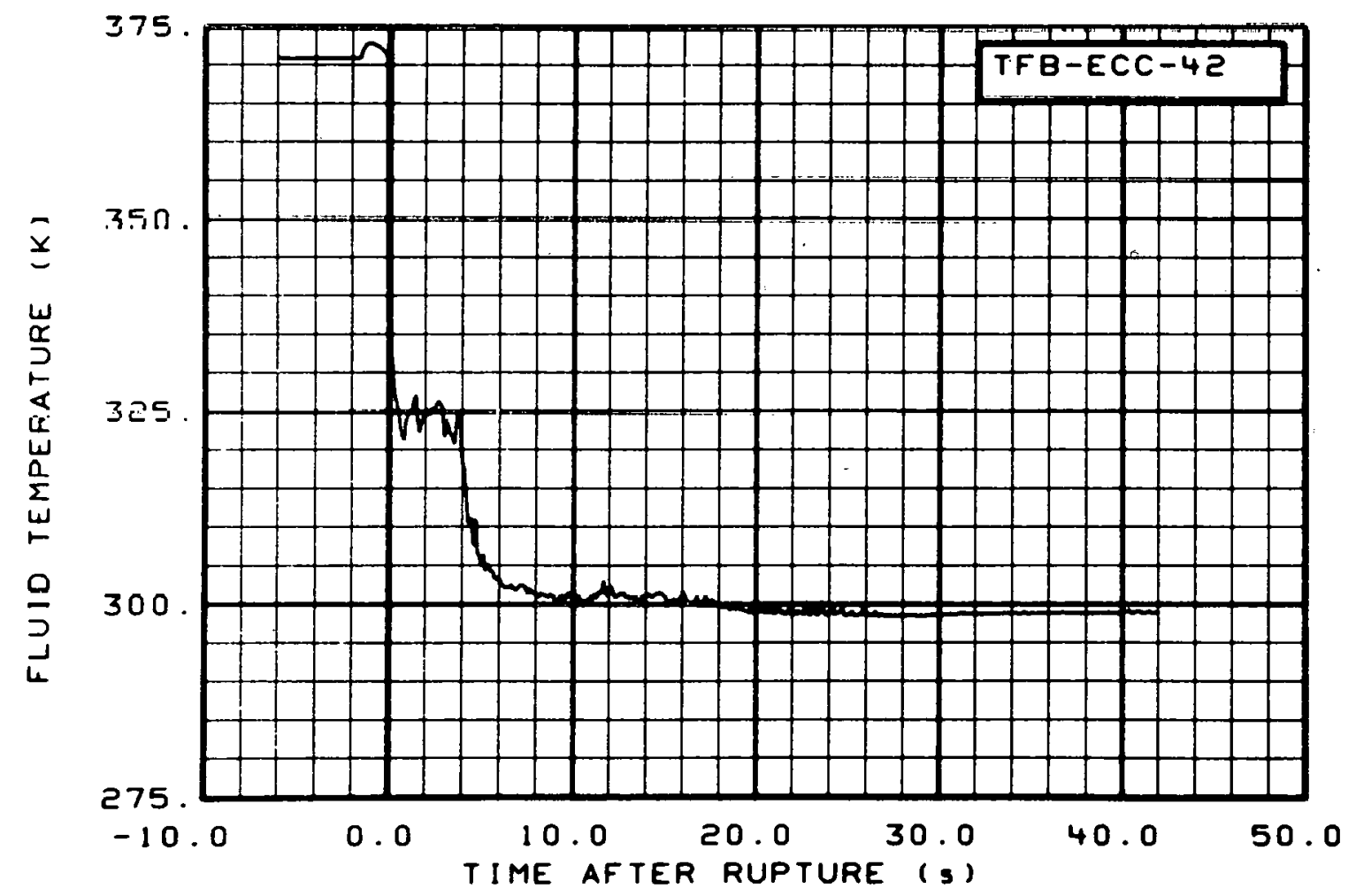

Fig. 42 Fluid temperature in broken loop coolant injection line (TFB-ECC42), from -6 to $42 \mathrm{~s}$. 


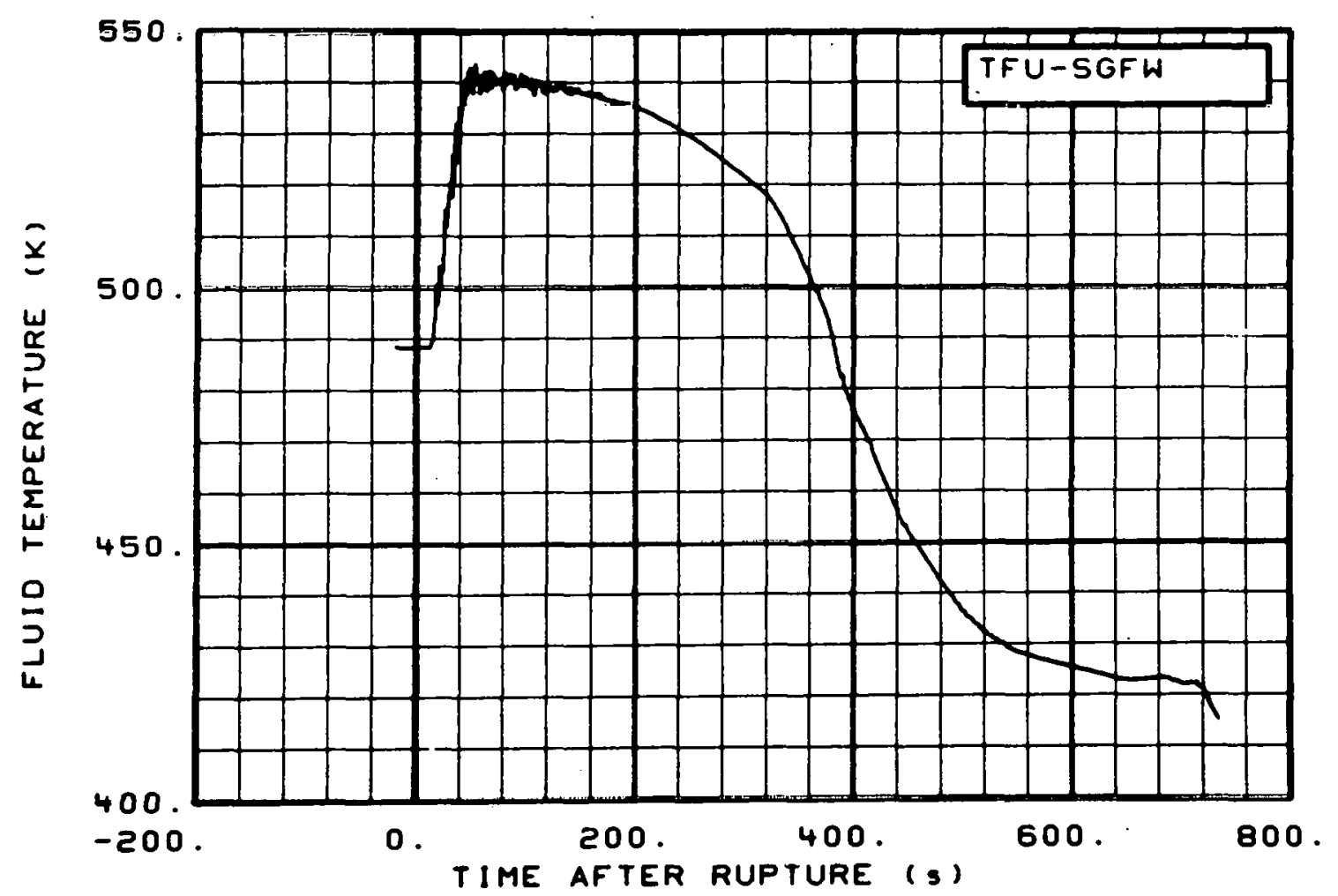

Fig. 43 Fluid temperature in steam generator, feedwater line (TFU-SGFW), from -20 to $736 \mathrm{~s}$.

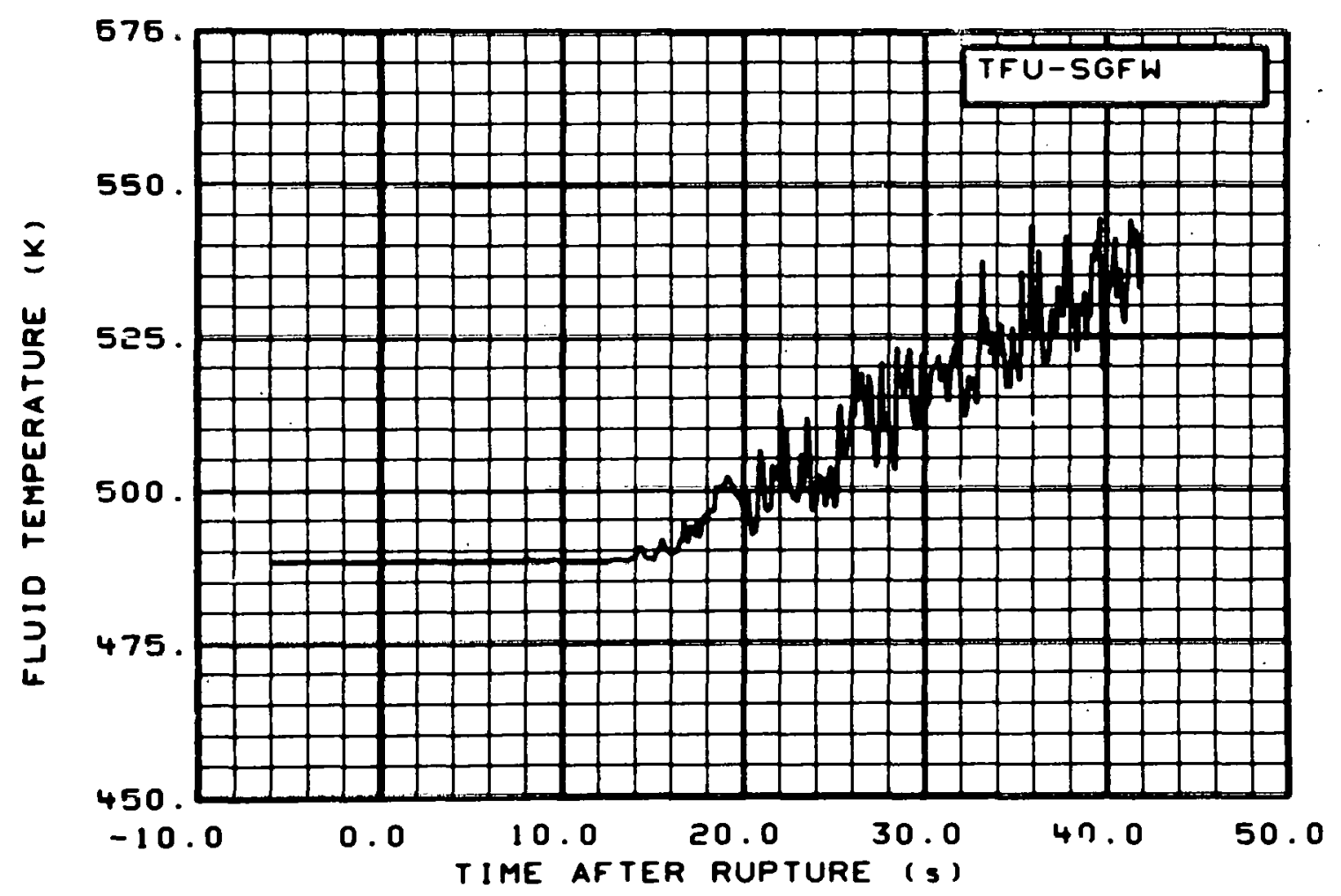

Fig. 44 Fluid temperature in steam generator, feedwater line (TFU-SGFW), from -6 to $42 \mathrm{~s}$. 


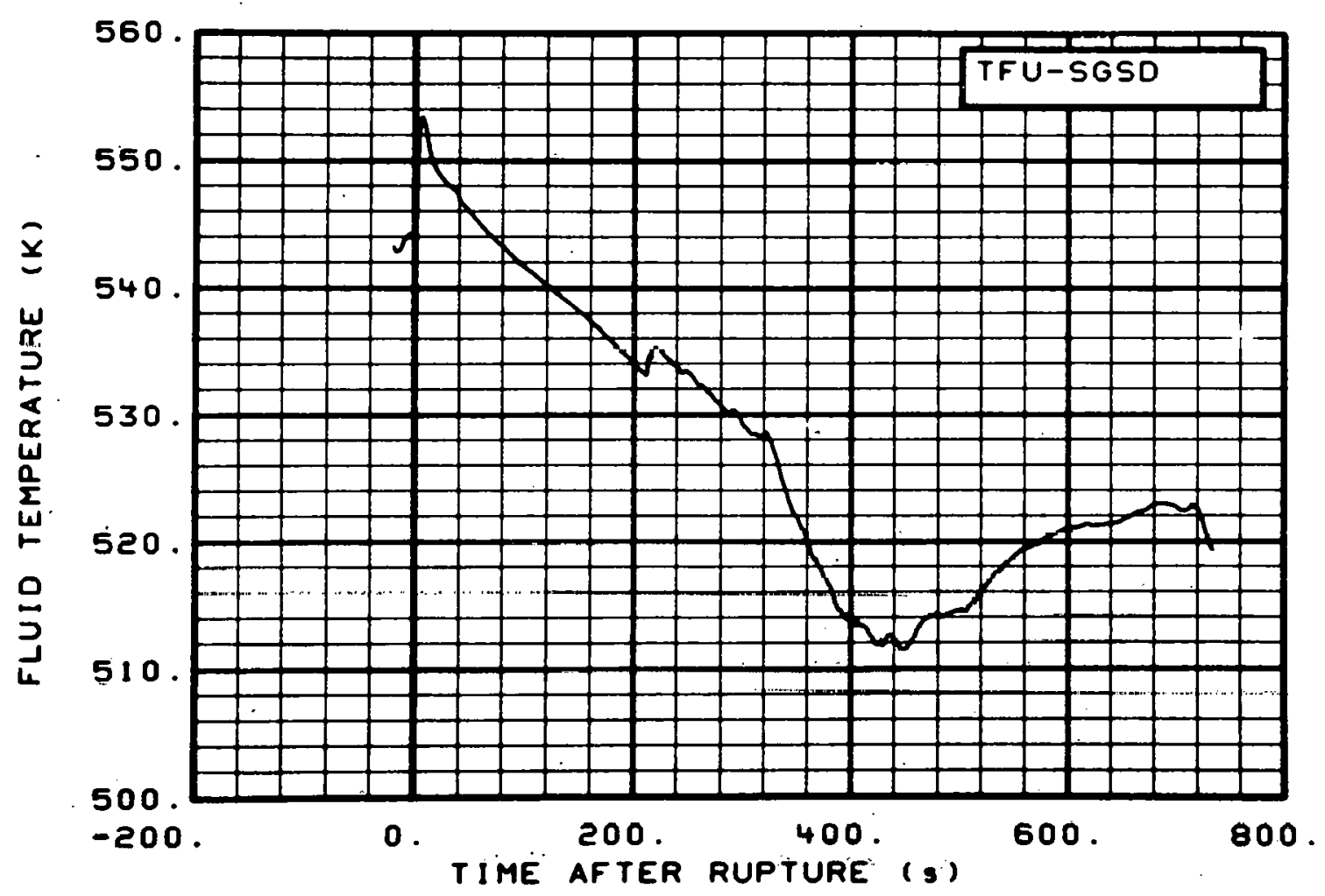

Fig. 45.Fluid temperature in steam generator, steam dome (TFU-SGSD), from -20 to $736 \mathrm{~s}$.

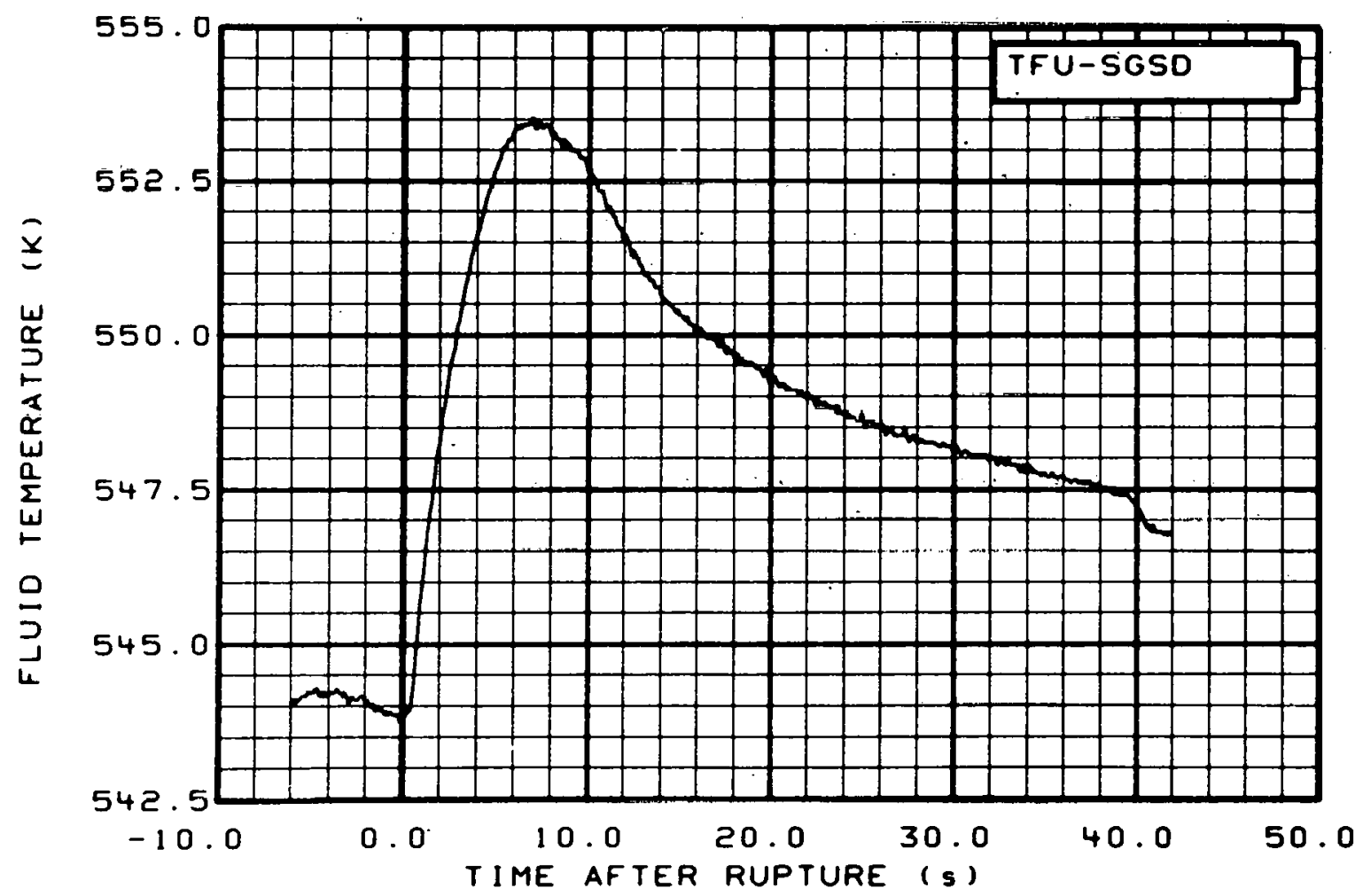

Fig. 46 Fluid temperature in steam generator, steam dome (TFU-SGSD), from -6 to $42 \mathrm{~s}$. 


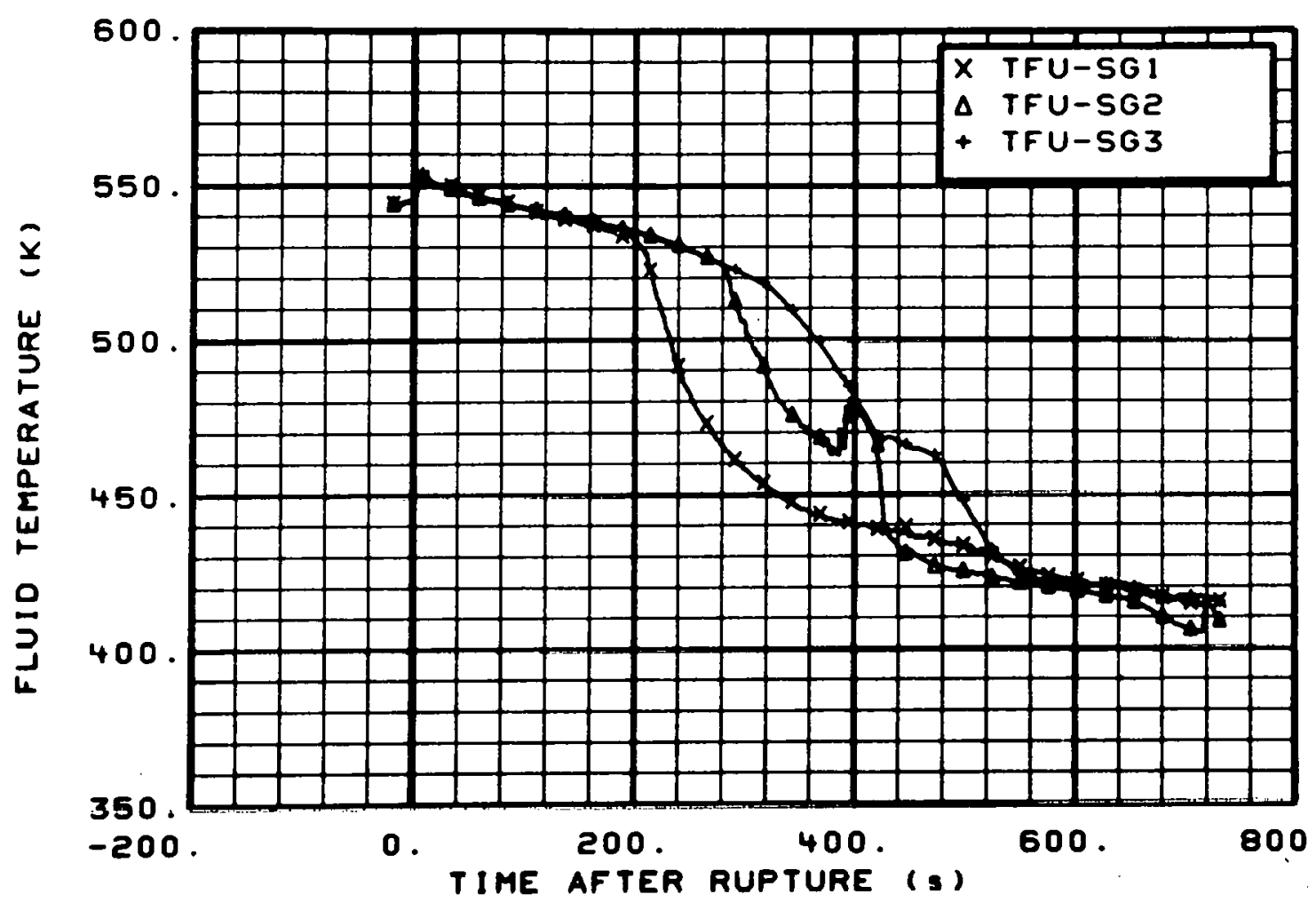

Fig. 47 Fluid temperature in steam generator, secondary side (TFU-SG1, TFU-SG2, and TFU-SG3), from -20 to $736 \mathrm{~s}$.

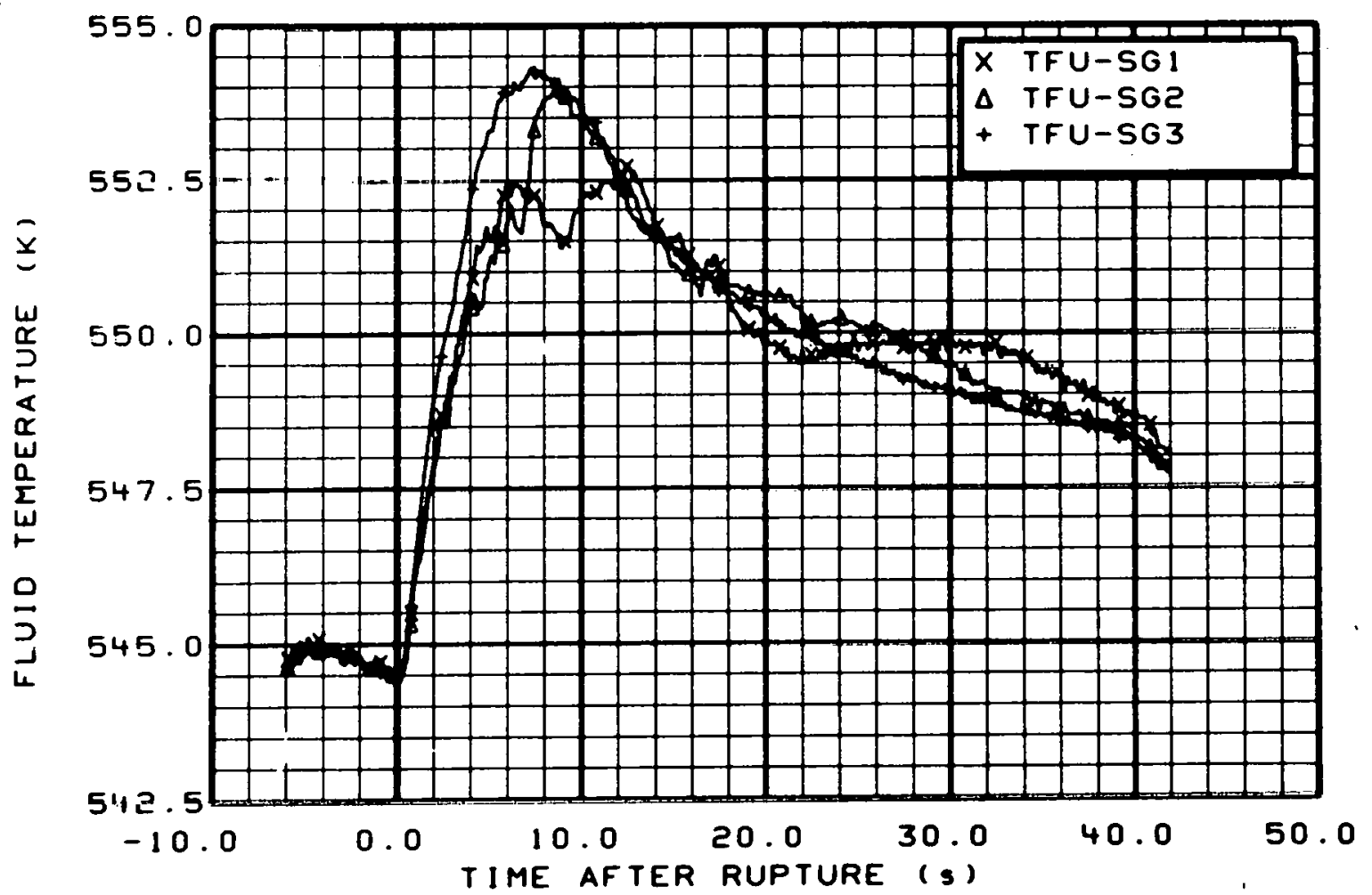

Fig. 48 Fluid temperature in steam generator, secondary side (TFU-SGI, TFU-SG2, and TFU-SG3), from -6 to $42 \mathrm{~s}$. 


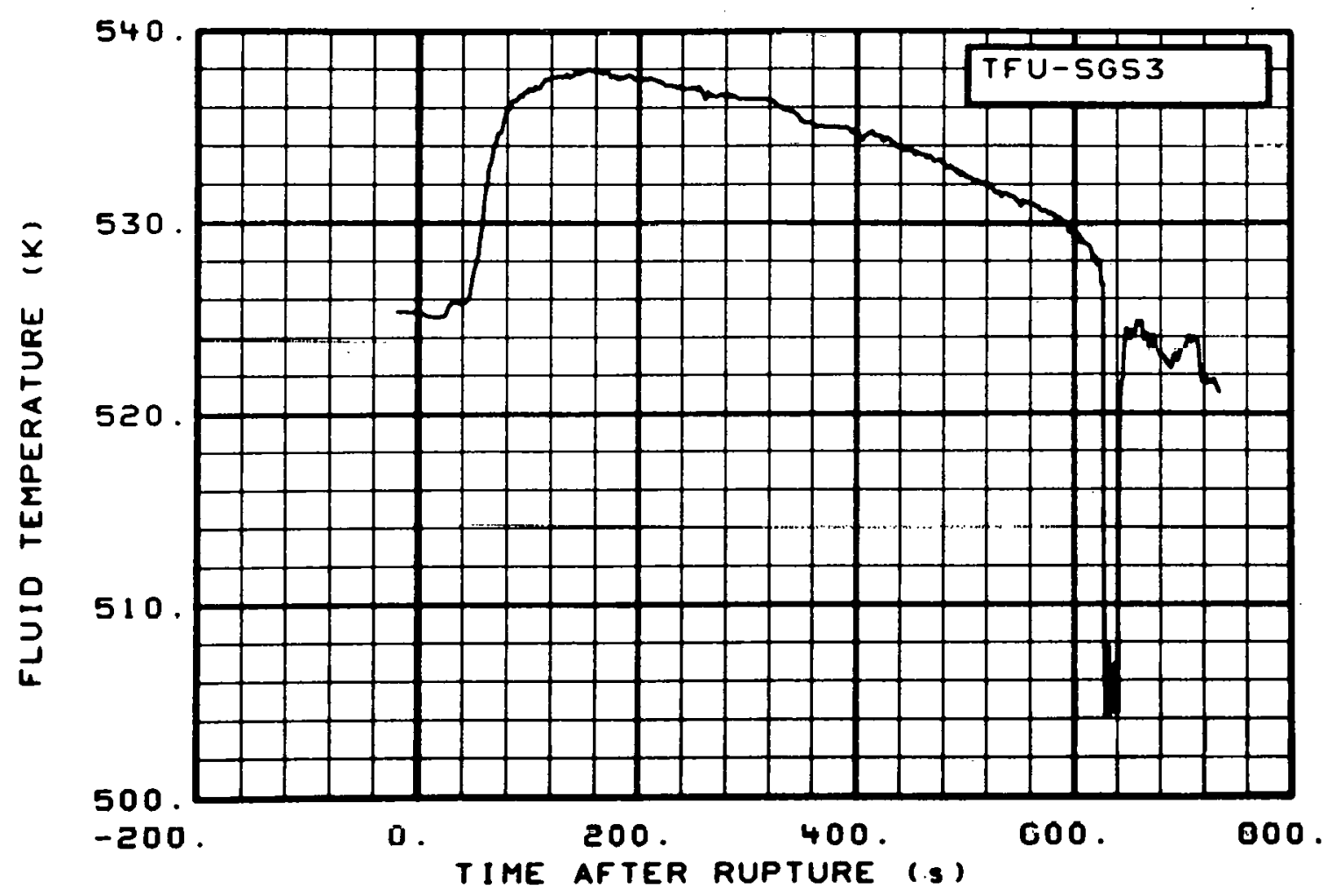

Fig. 49 Fluid temperature in steam generator rupture system accumulator (TFU-SGS3), from -20 to $736 \mathrm{~s}$.

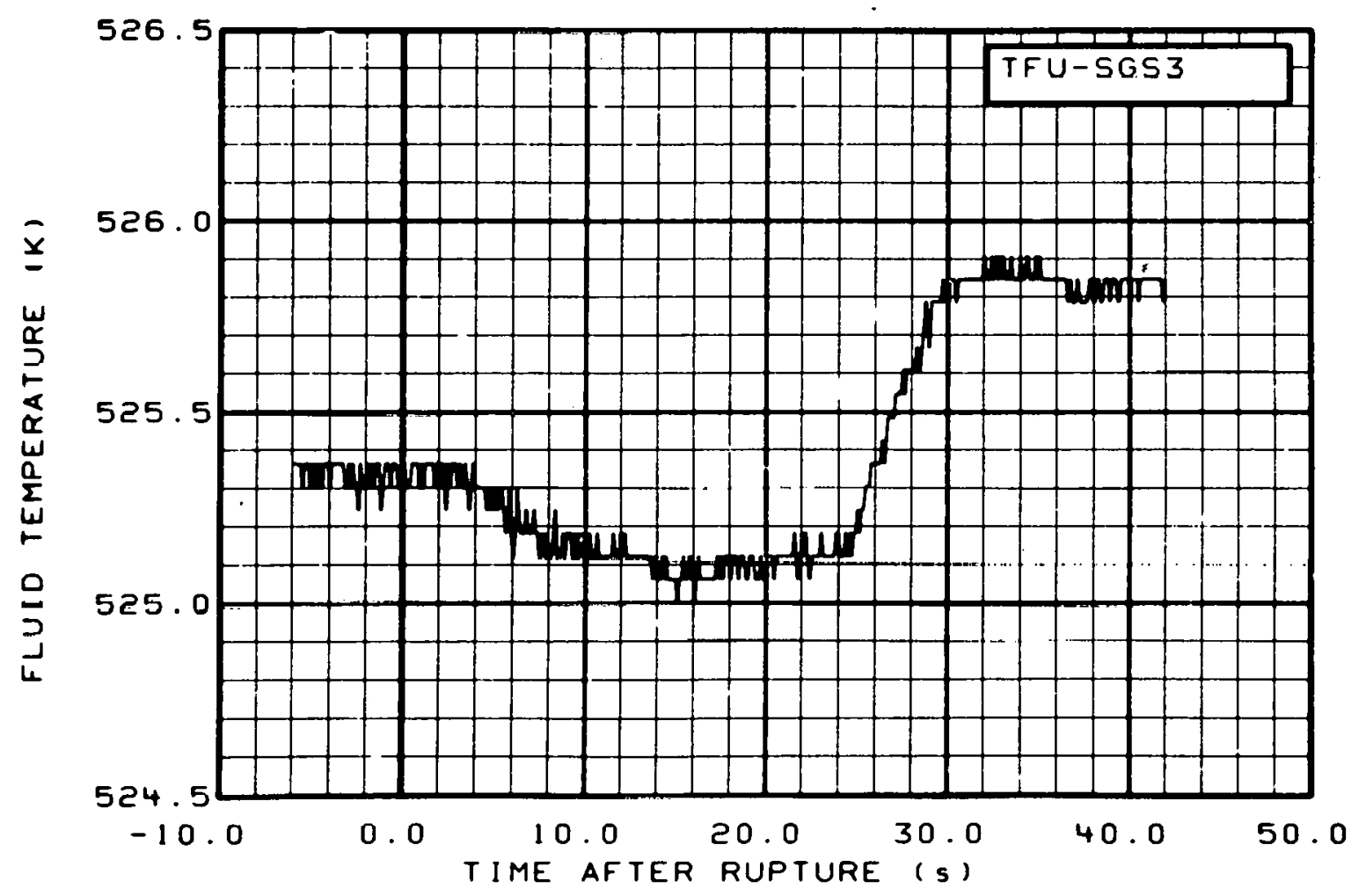

Fig. $50 \mathrm{Fluid}$ temperature in steam generator rupture system accumulator (TFU-SGS3), from -6 to $42 \mathrm{~s}$. 


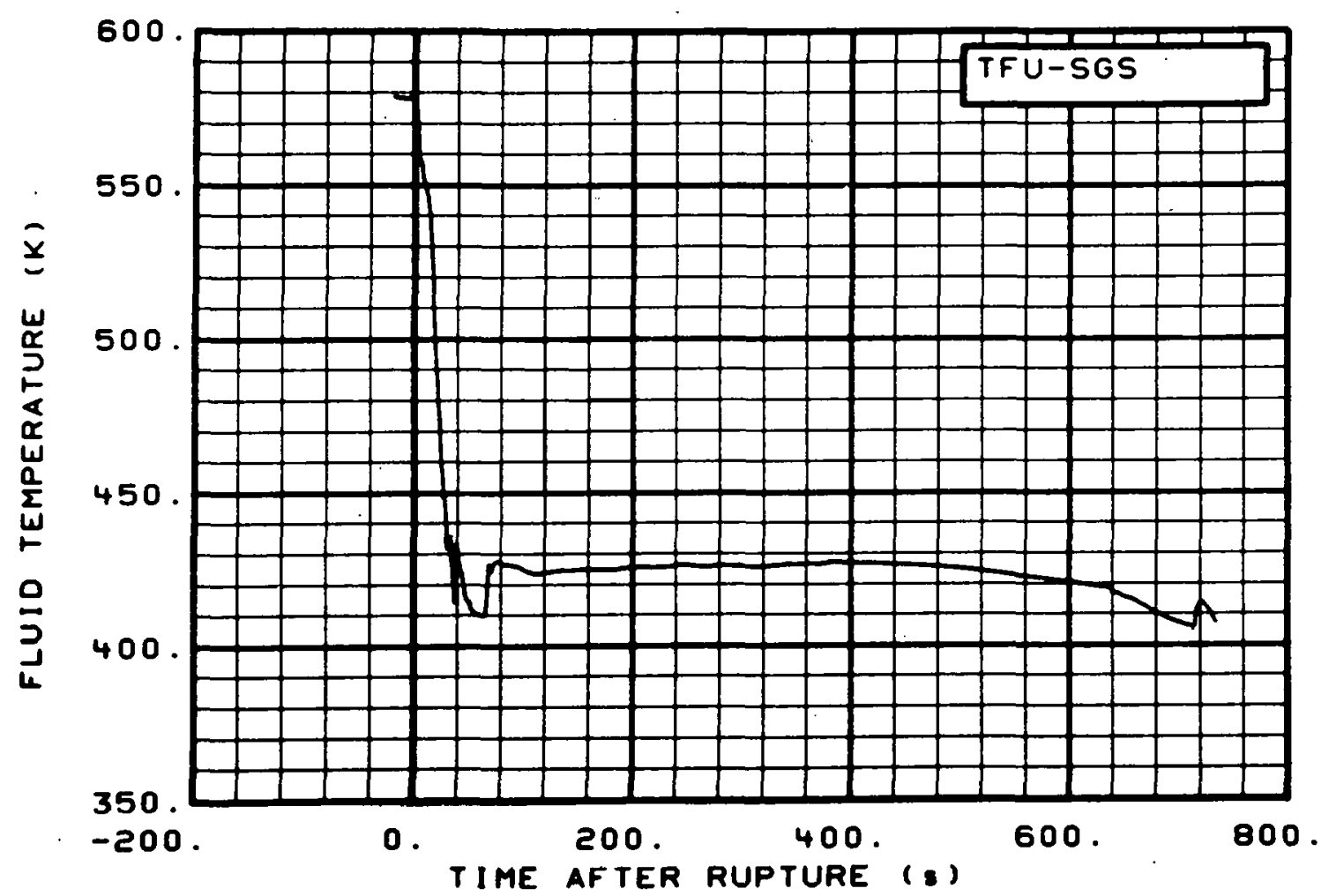

Fig. 51 Fluid temperature in steam generator rupture system injection line (TFU-SGS), from -20 to $736 \mathrm{~s}$.

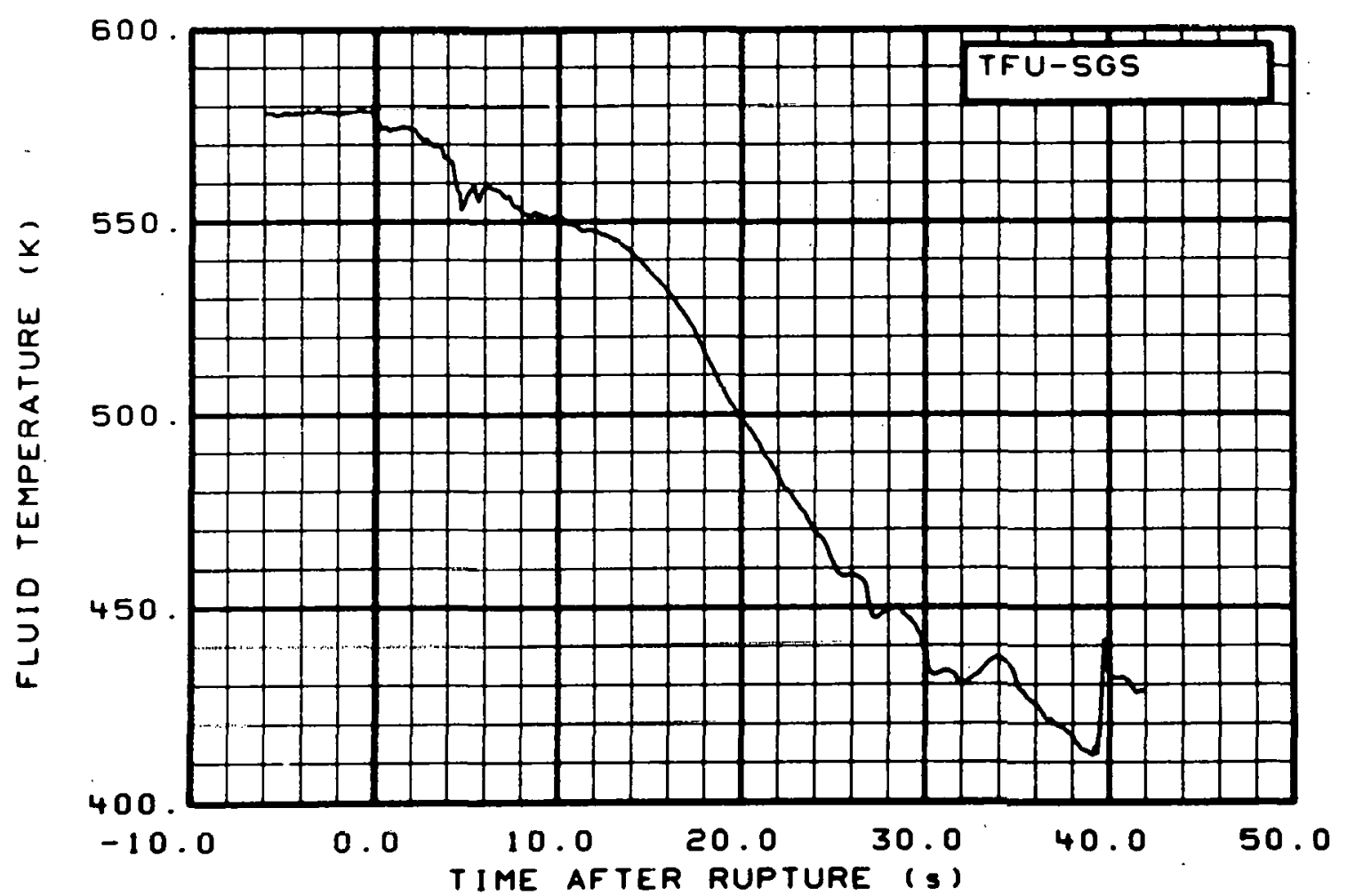

Fig. 52 Fluid temperature in steam generator rupture system injection 1 ine (TFU-SGS), from -6 to $42 \mathrm{~s}$. 


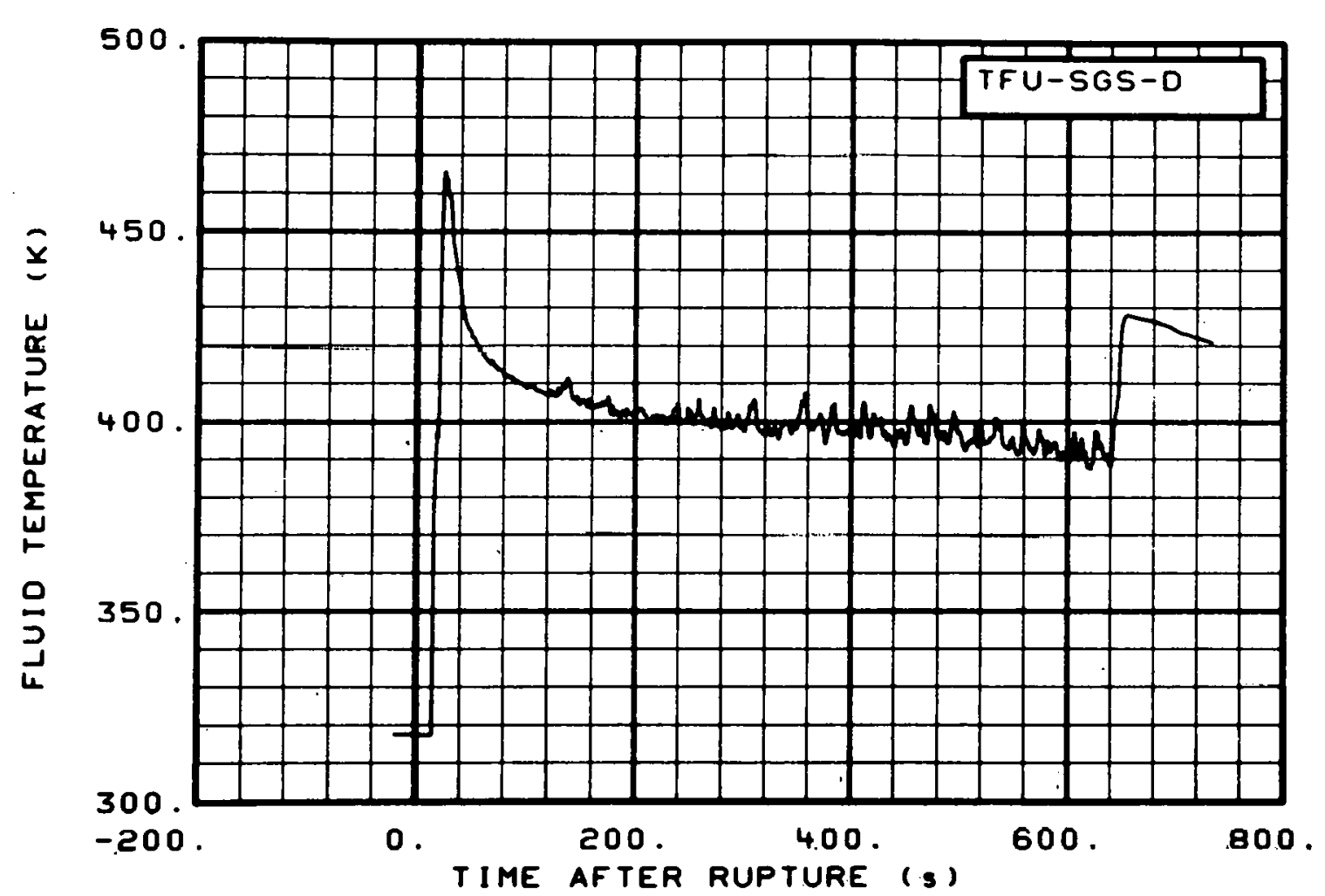

Fig. 53 Fluid temperature in steam generator rupture system (TFU-SGS-D), from -20 to $736 \mathrm{~s}$.

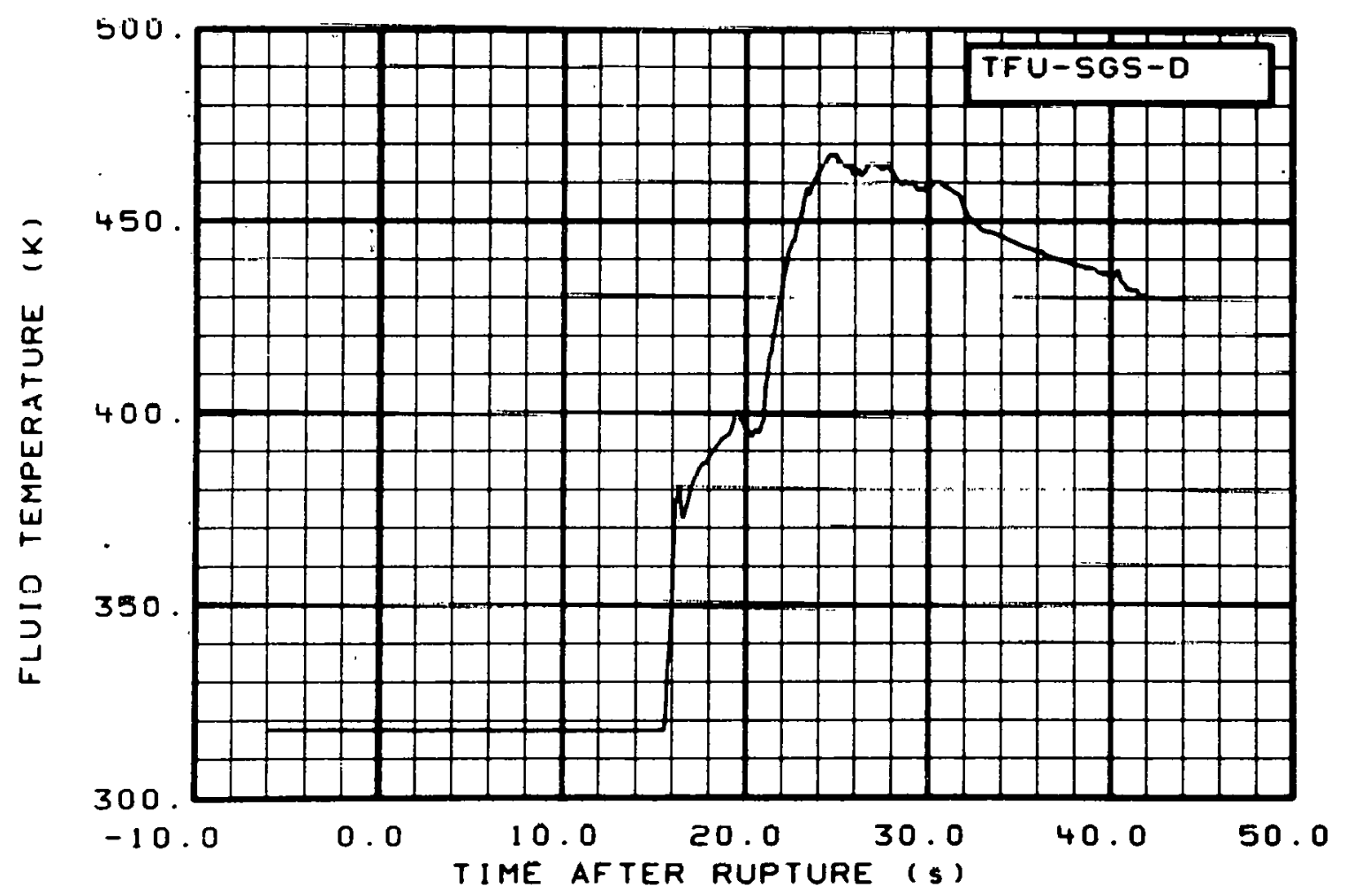

Fig. 54 Fluid temperature in steam generator rupture system (TFU-SGS-D), from -6 to $42 \mathrm{~s}$. 


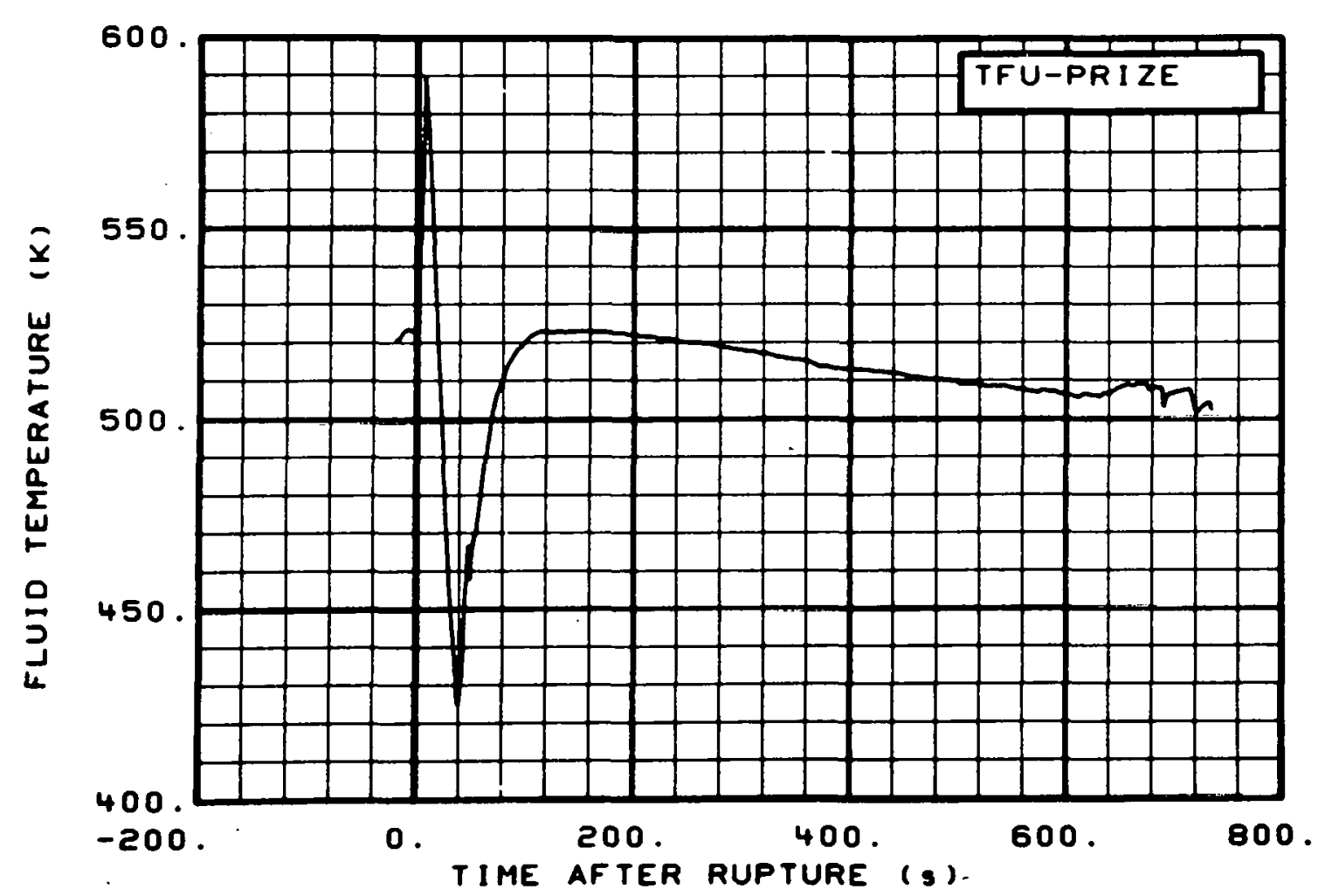

Fig. 55 Fluid temperature in pressurizer surge line (TFU-PRIZE), from -20 to $736 \mathrm{~s}$.

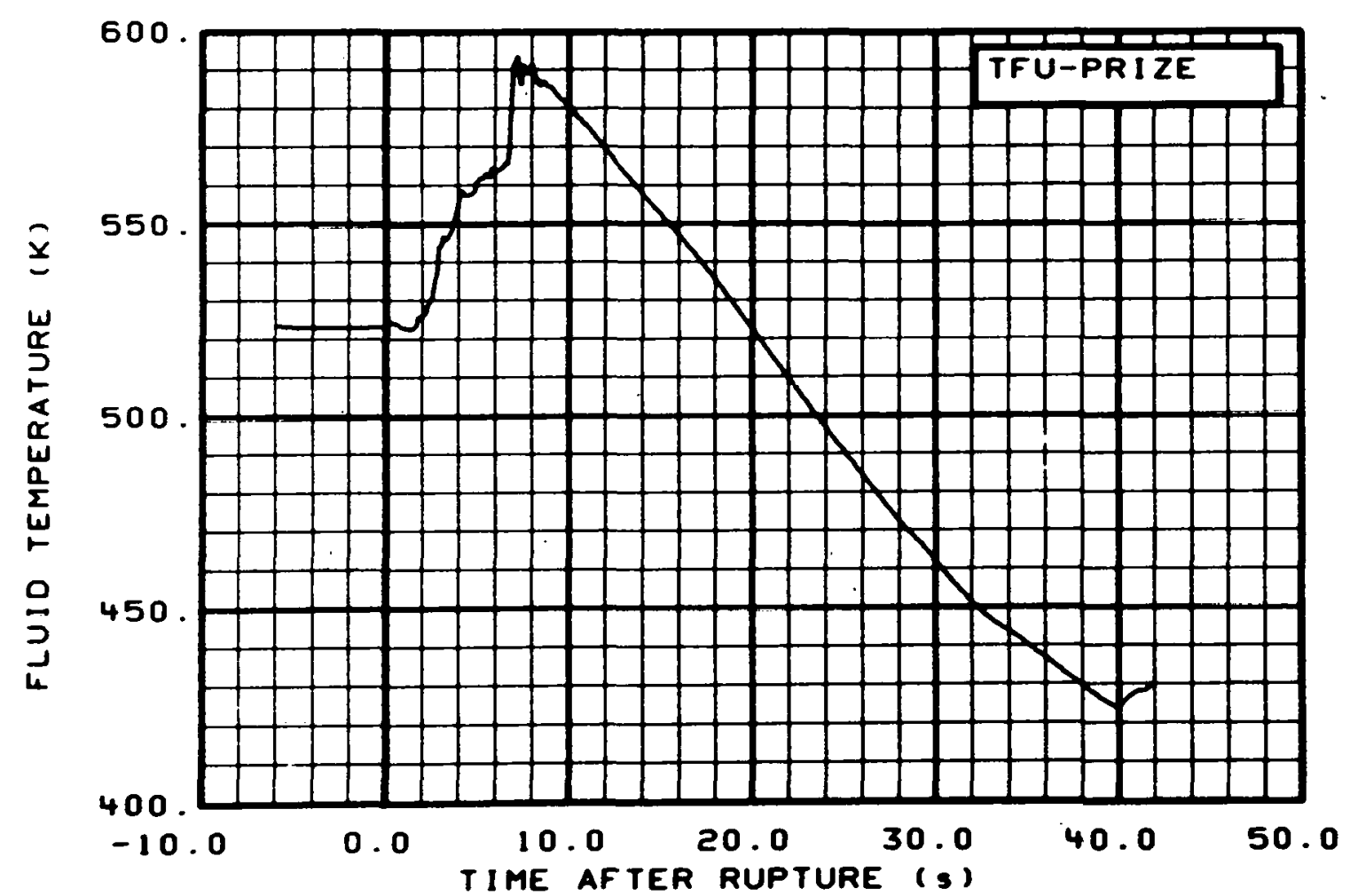

Fig. 56 Fluid temperature in pressurizer surge line (TFU-PRIZE), from -6 to $42 \mathrm{~s}$. 


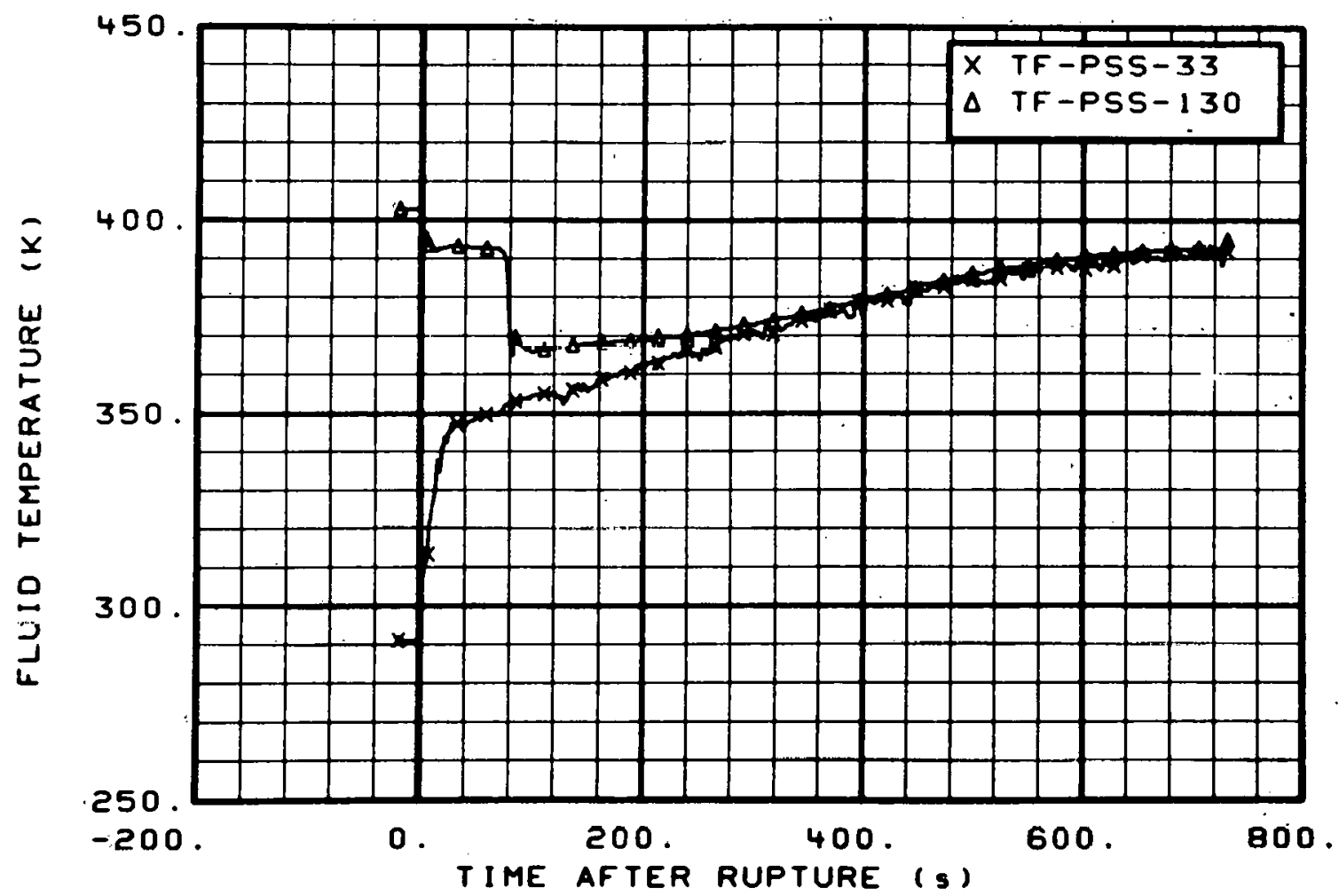

Fig. 57 Fluid temperature in pressure suppression tank (TF-PSS-33 and TF-PSS-130), from -20 to $736 \mathrm{~s}$.

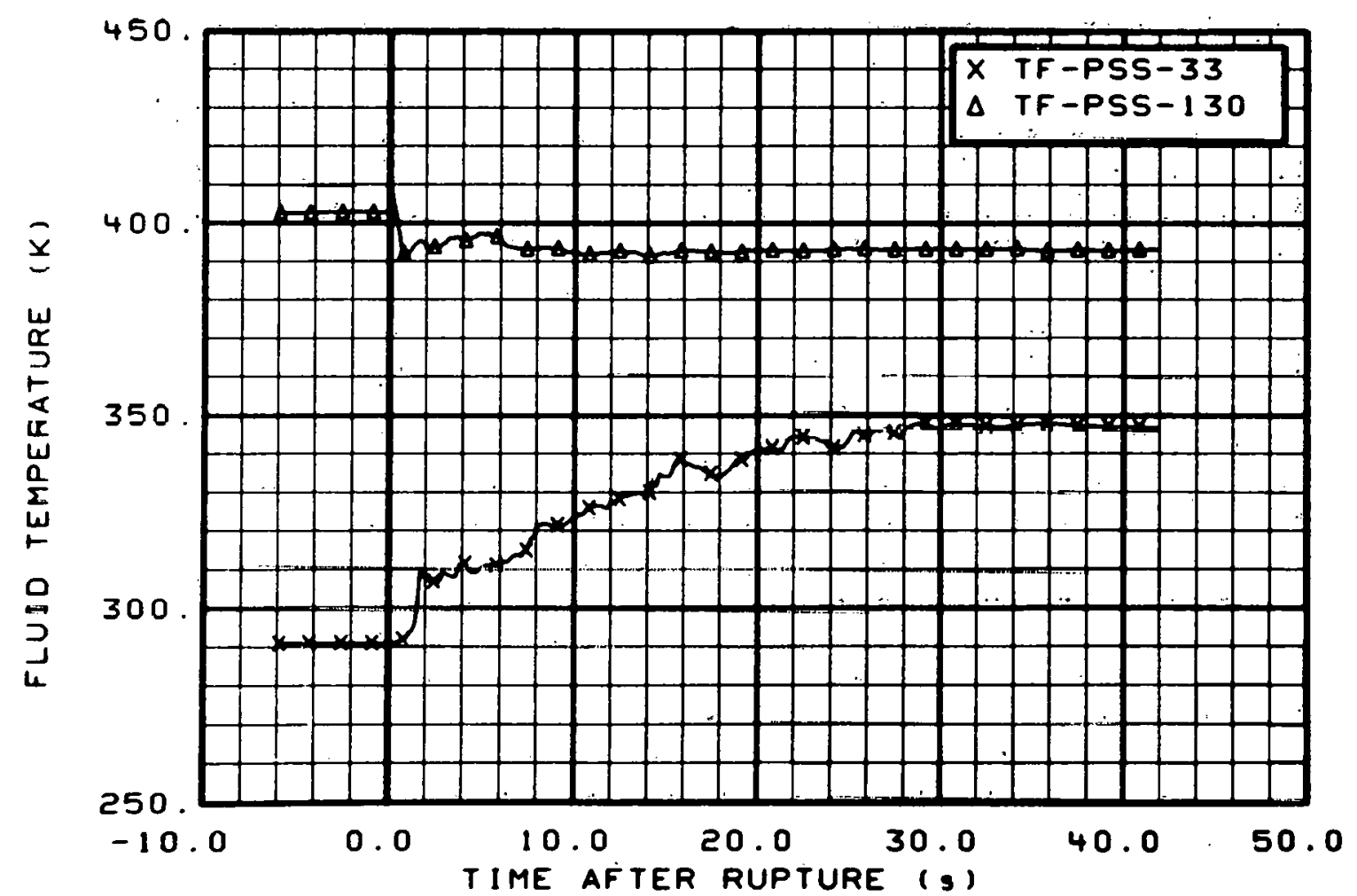

Fig. 58 Fluid temperature in pressure suppression tank (TF-PSS-33 and TF-PSS-130), from -6 to $42 \mathrm{~s}$. 


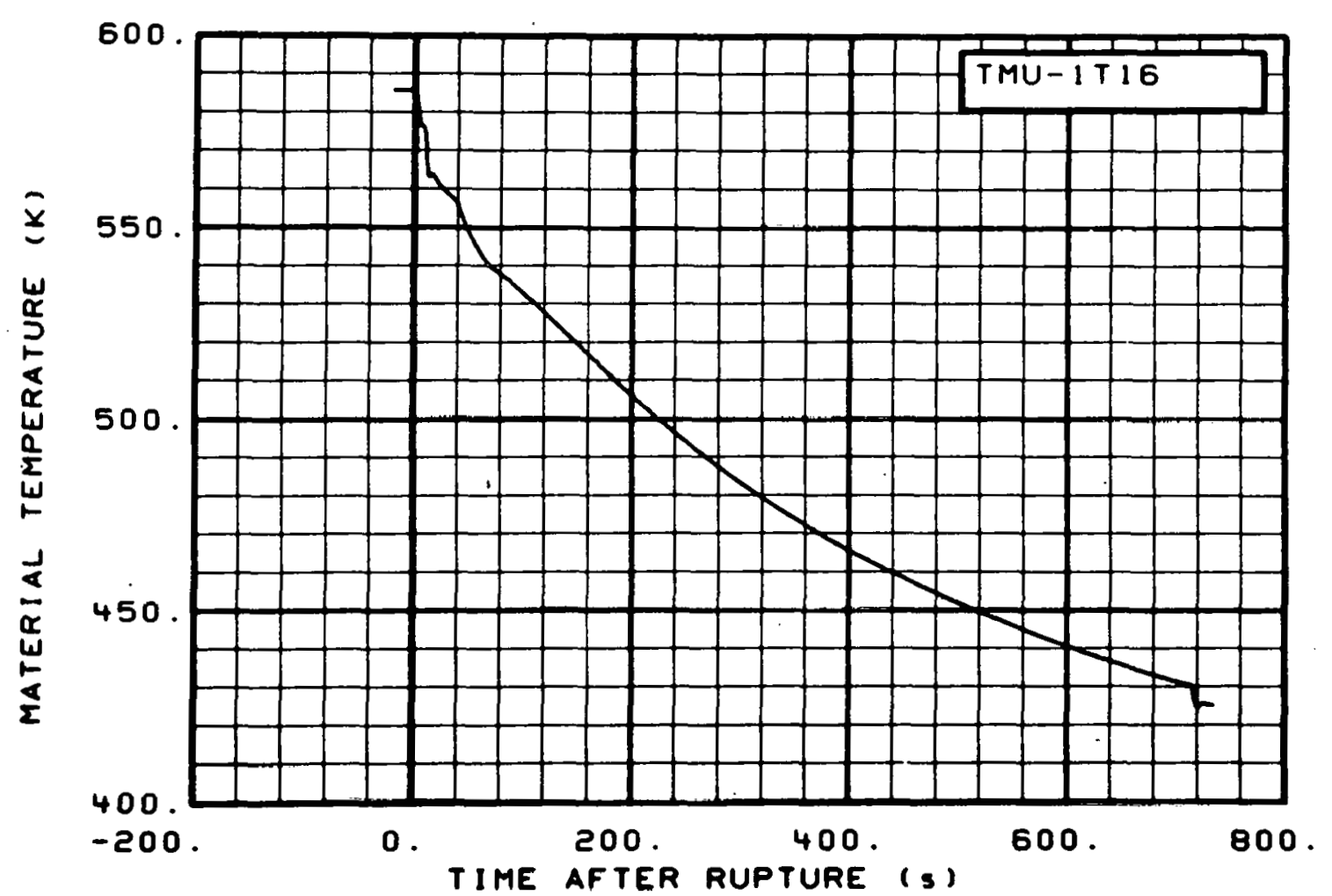

Fig. 59 Material temperature in intact loop (TMU-1T16), from -20 to $736 \mathrm{~s}$.

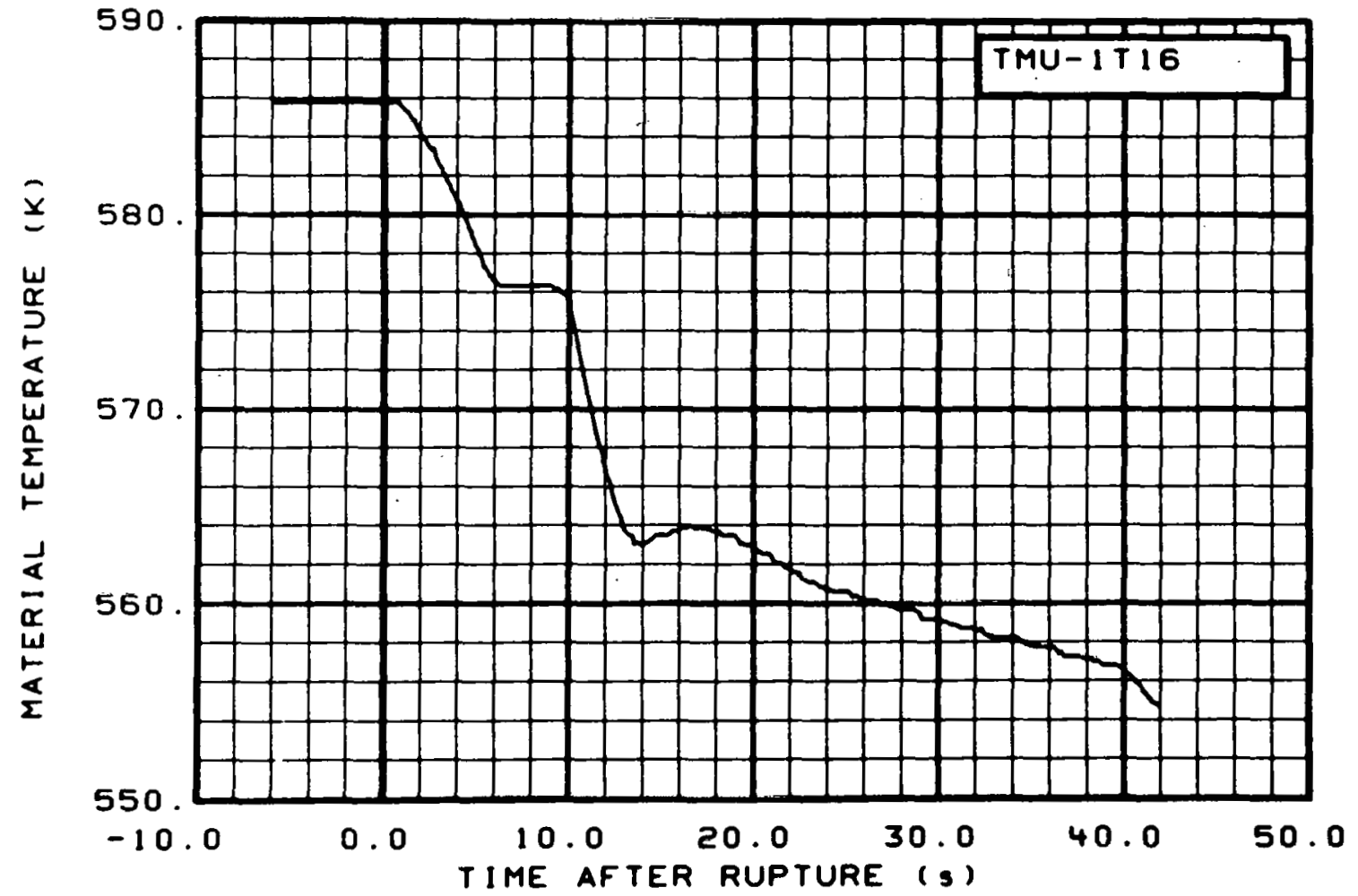

Fig. 60 Material temperature in intact loop (TMU-1T16), from -6 to $42 \mathrm{~s}$. 


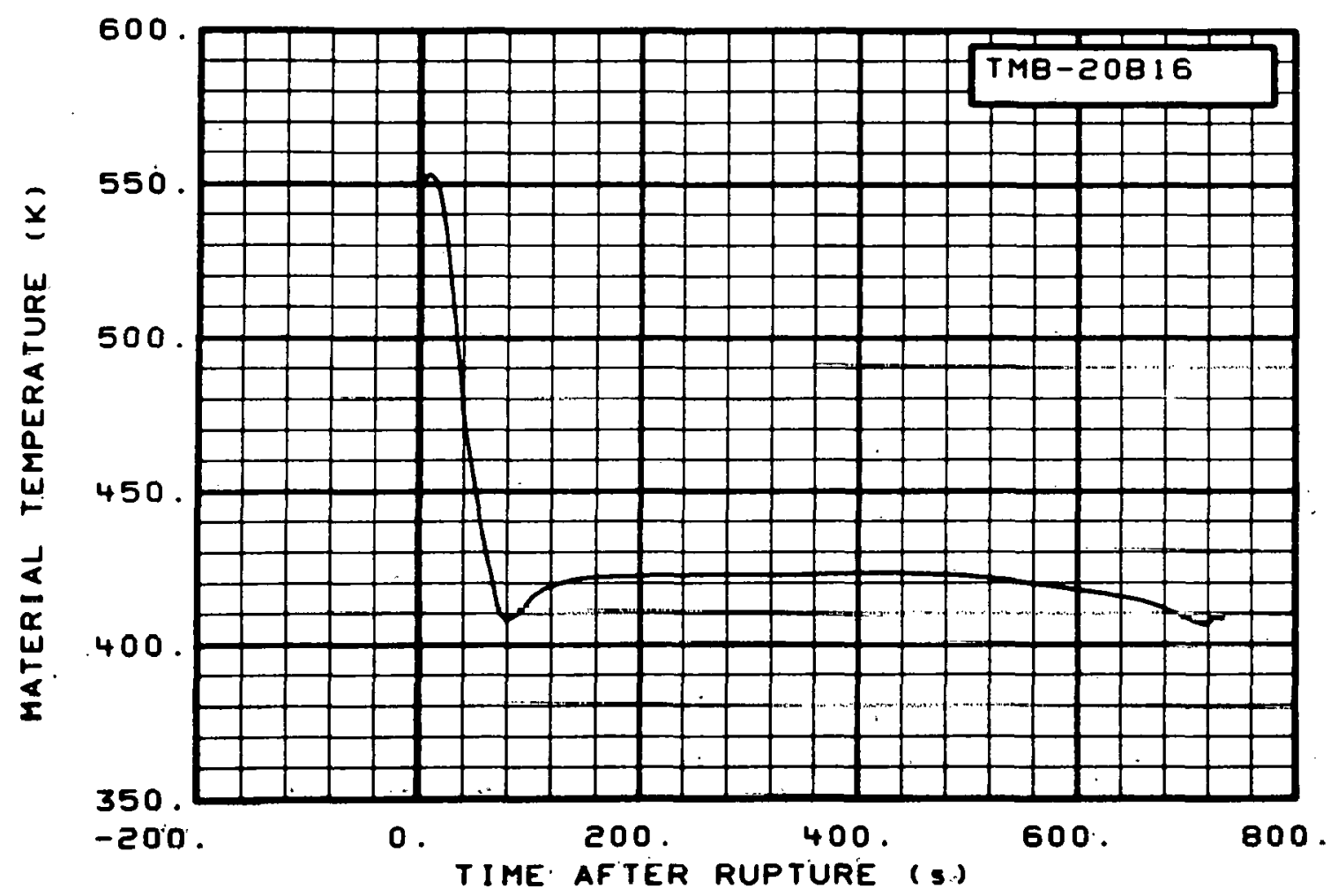

Fig. 61 Material temperature in broken loop (TMB-20B 16), from -20 to $736 \mathrm{~s}$.

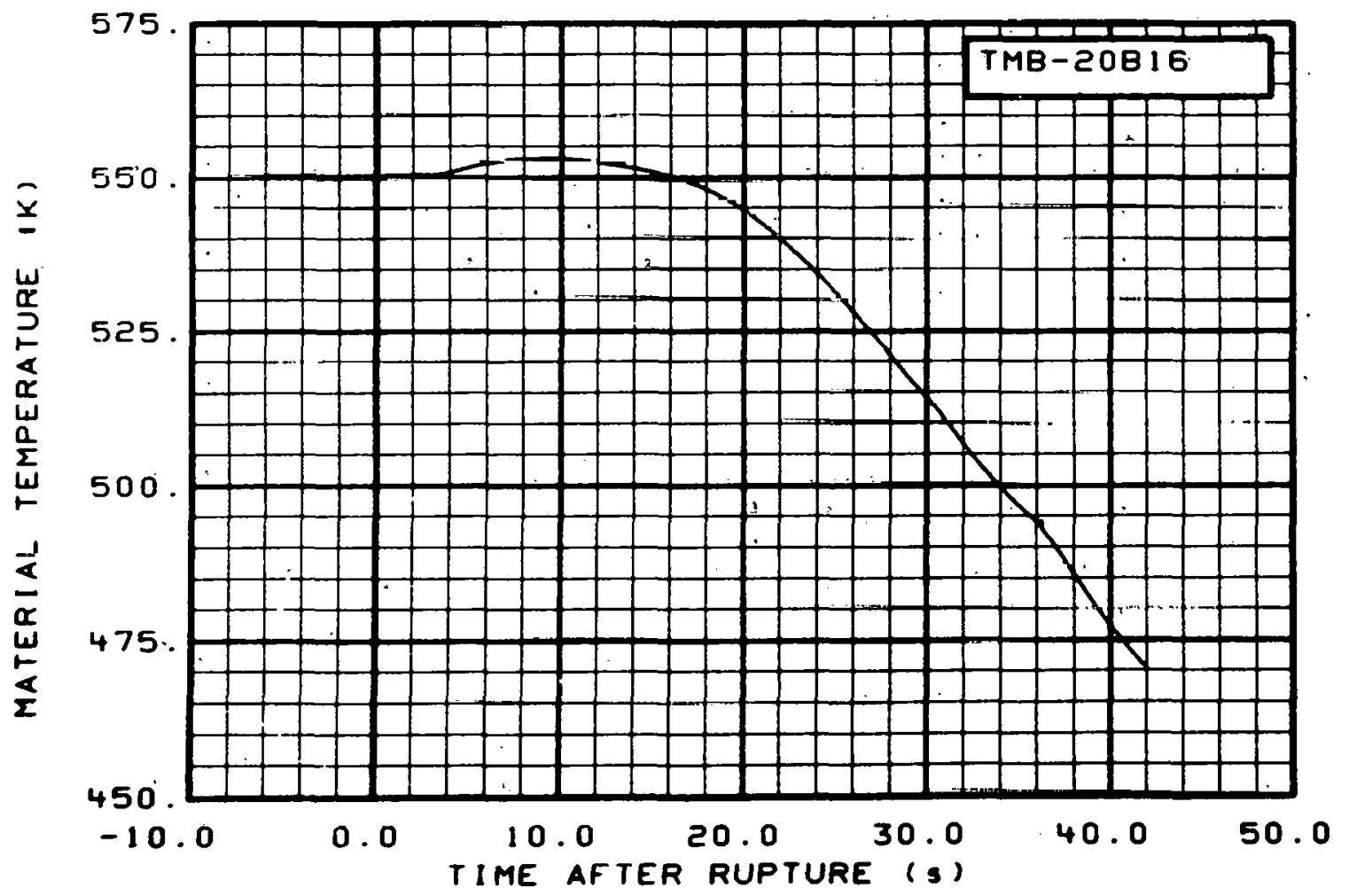

Fig. 62 Material temperature in broken loop (TMB-20B16), from -6 to $42 \mathrm{~s}$. 


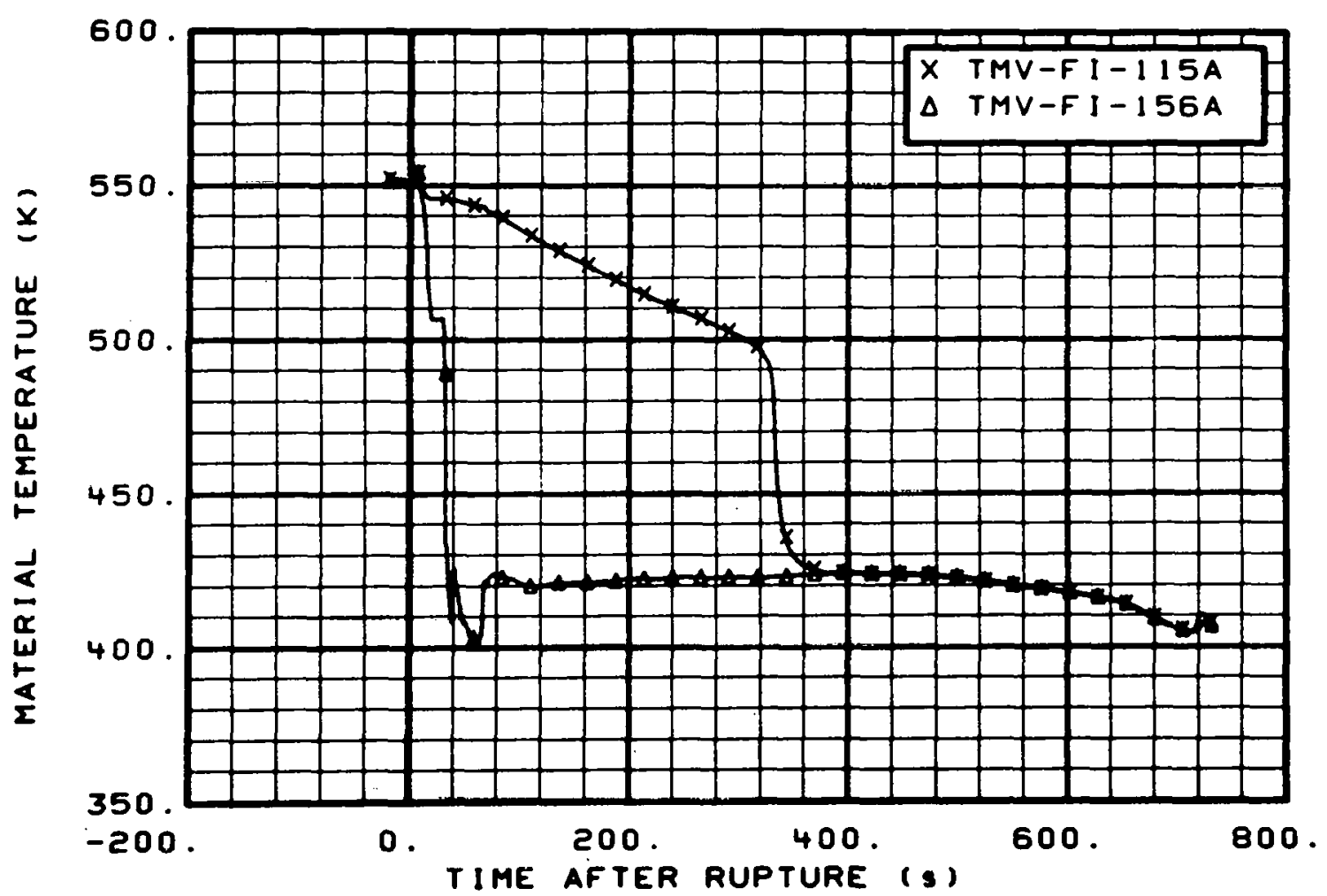

Fig. 63 Material temperature in vessel filler (TMV-FI-115A and TMV-FI$156 \mathrm{~A})$, from $-20^{\circ}$ to $736 \mathrm{~s}$.

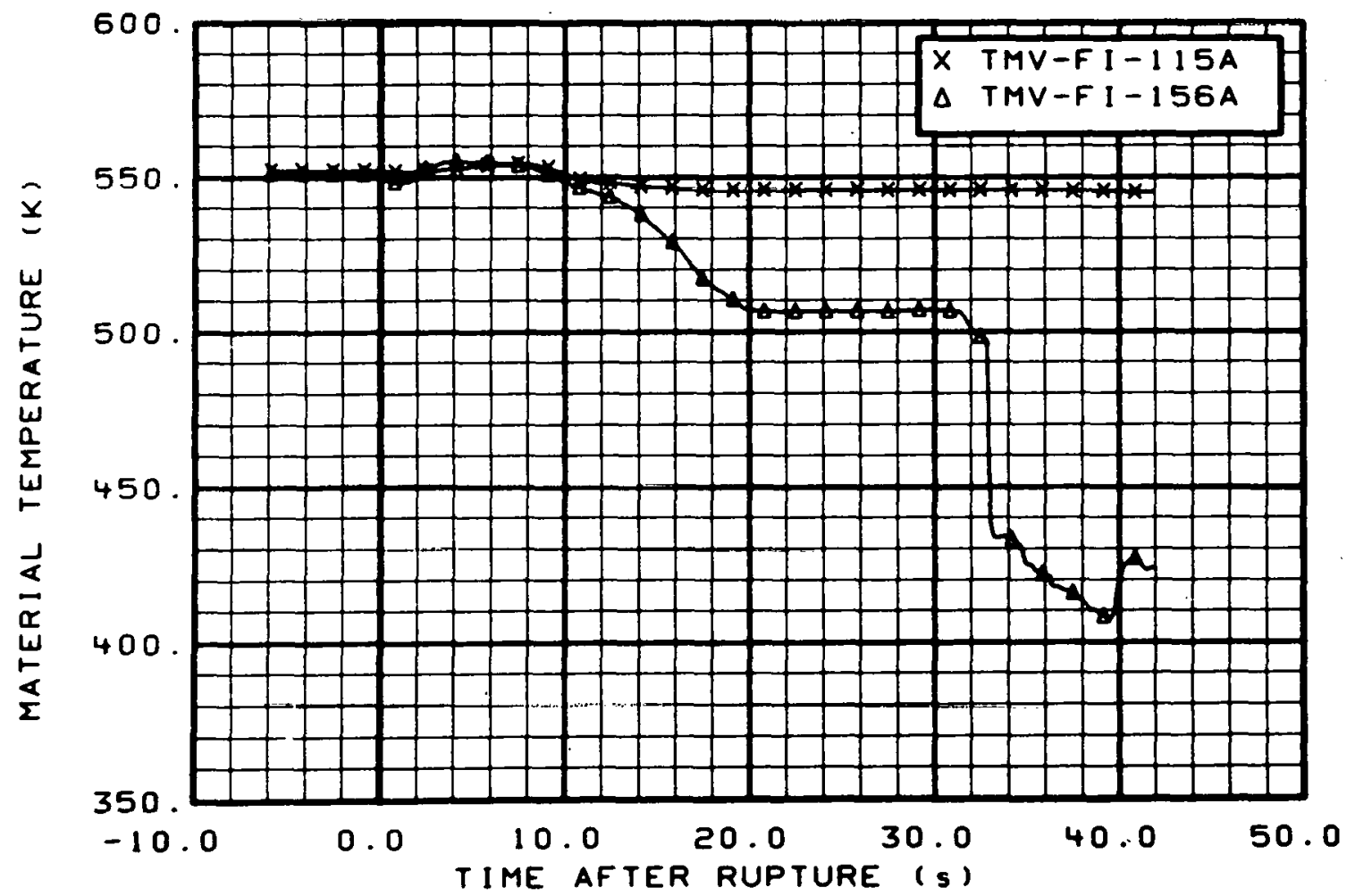

Fig. 64 Material temperature in vessel filler (TMV-FI-115A and TMV-FI156A), from -6 to $42 \mathrm{~s}$. 


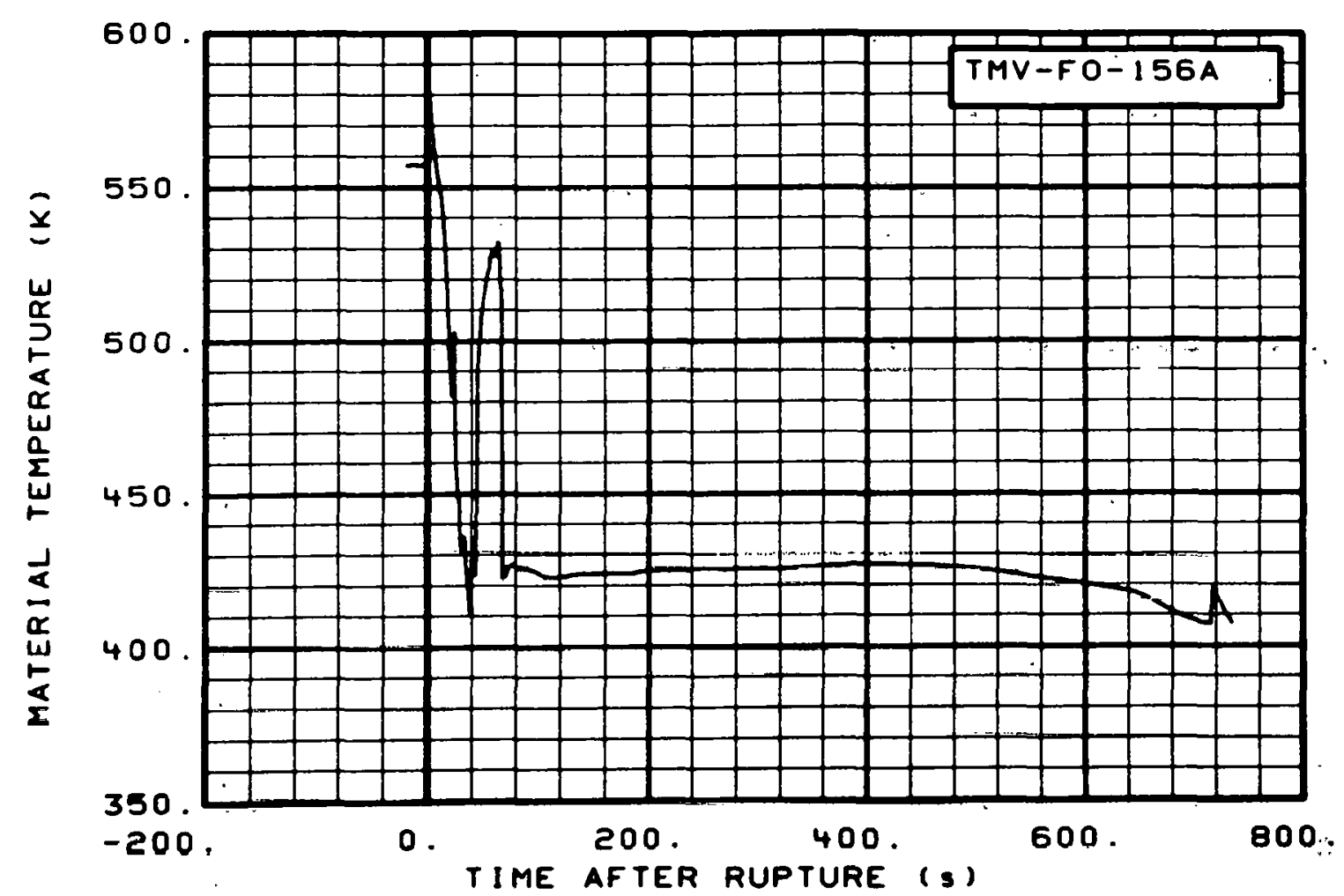

Fig. 65 Material temperature in vessel filler insulator (TMV-F0-156A), from -20 to $736 \mathrm{~s}$.

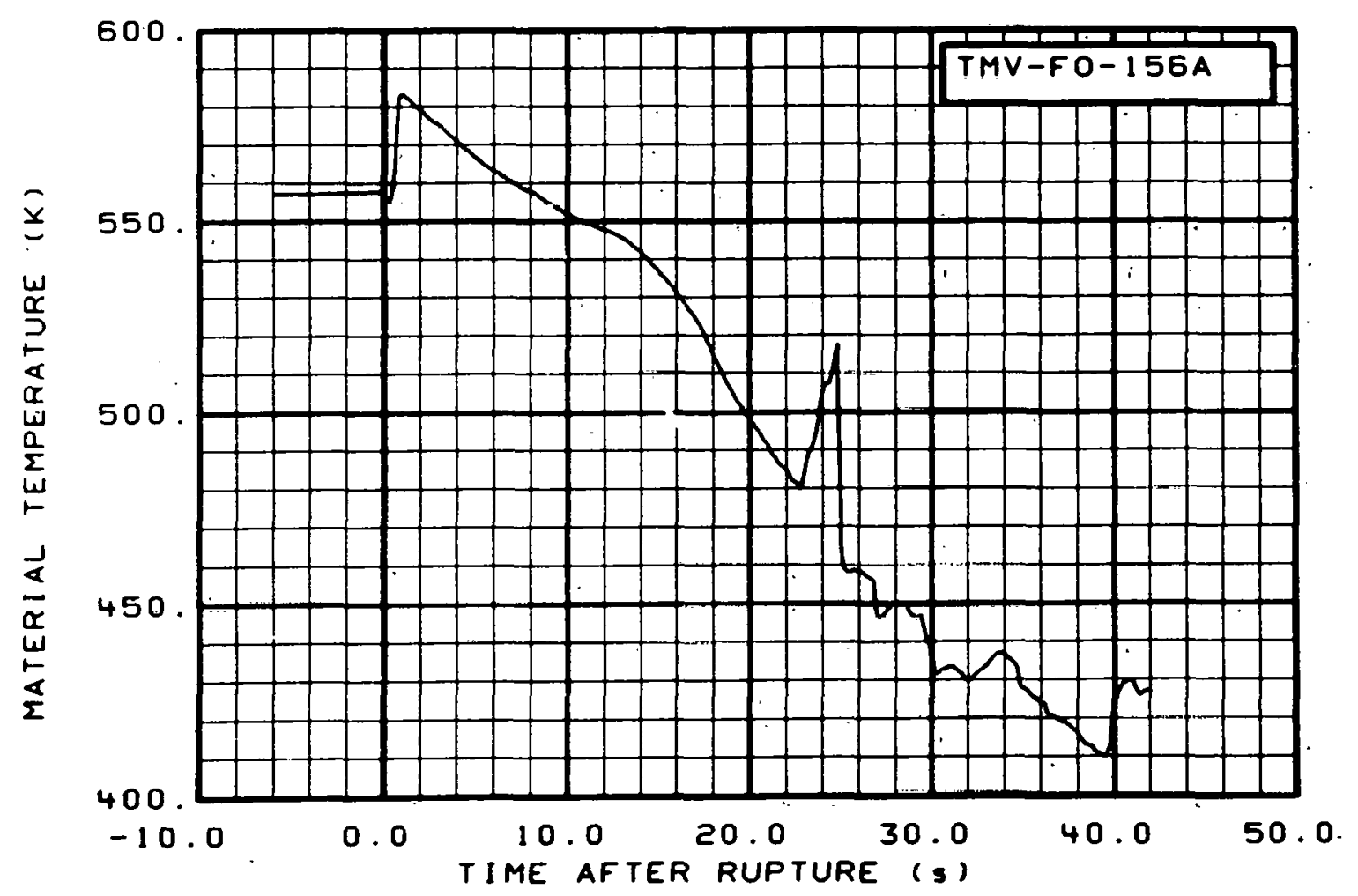

Fig. 66 Material temperature in vessel filler insulator (TMV-F0-156A), from -6 to $42 \mathrm{~s}$. 


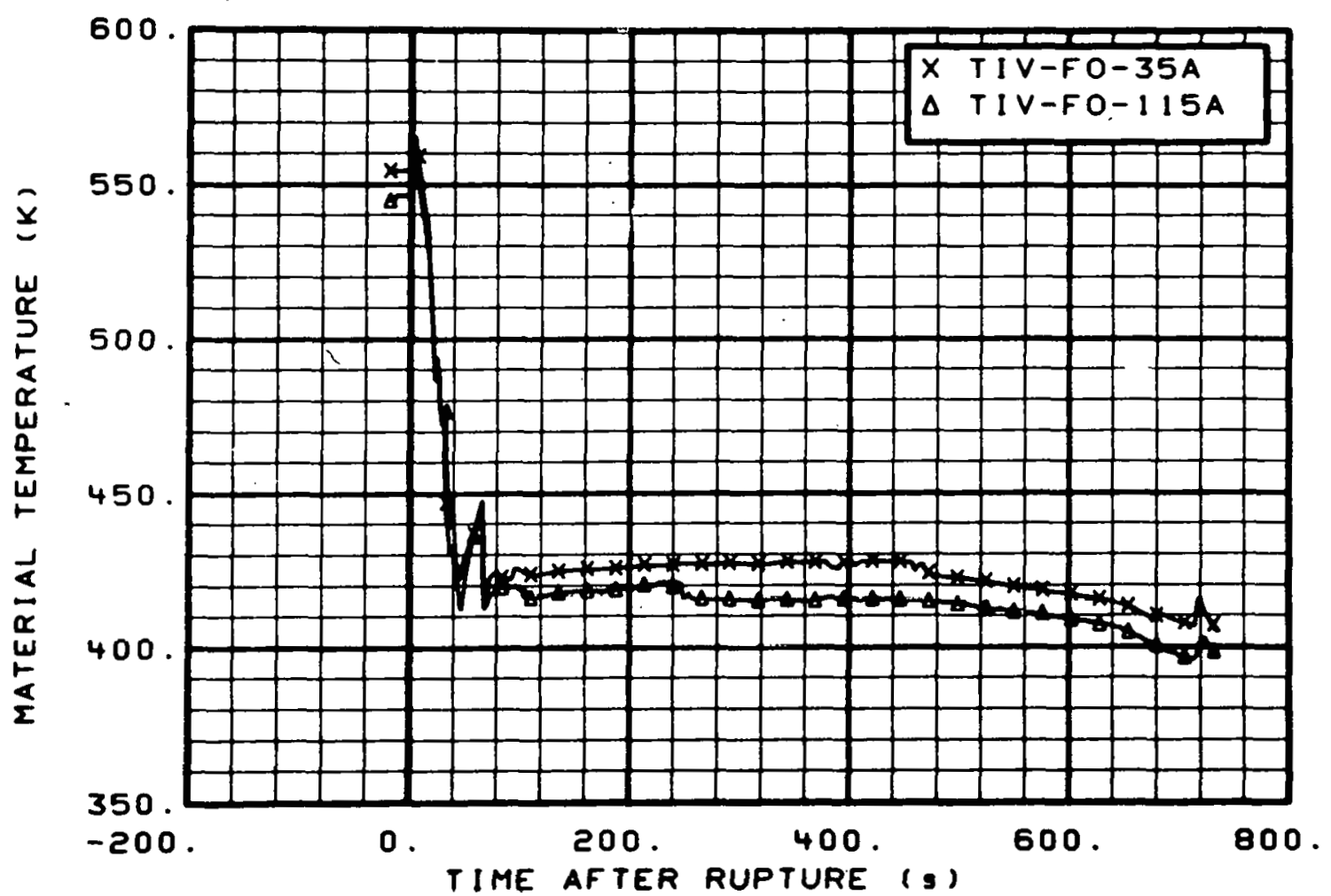

Fig. 67 Material temperature in vessel filler insulator (TIV-F0-35A and TIV-FO-115A), from -20 to $736 \mathrm{~s}$.

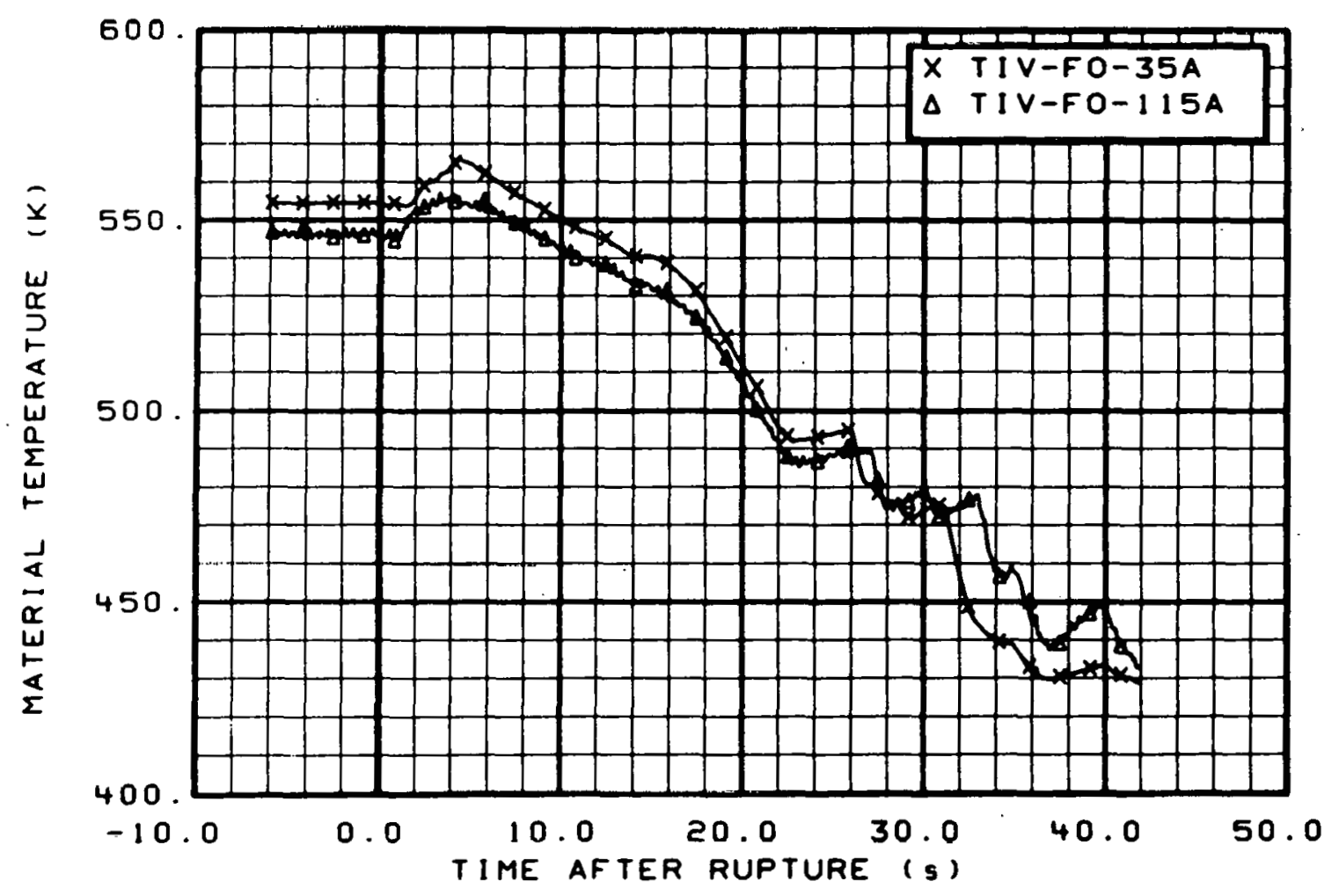

Fig. 68 Material temperature in vessel filler insulator (TIV-F0-35A and TIV-F0-115A), from -6 to $42 \mathrm{~s}$. 


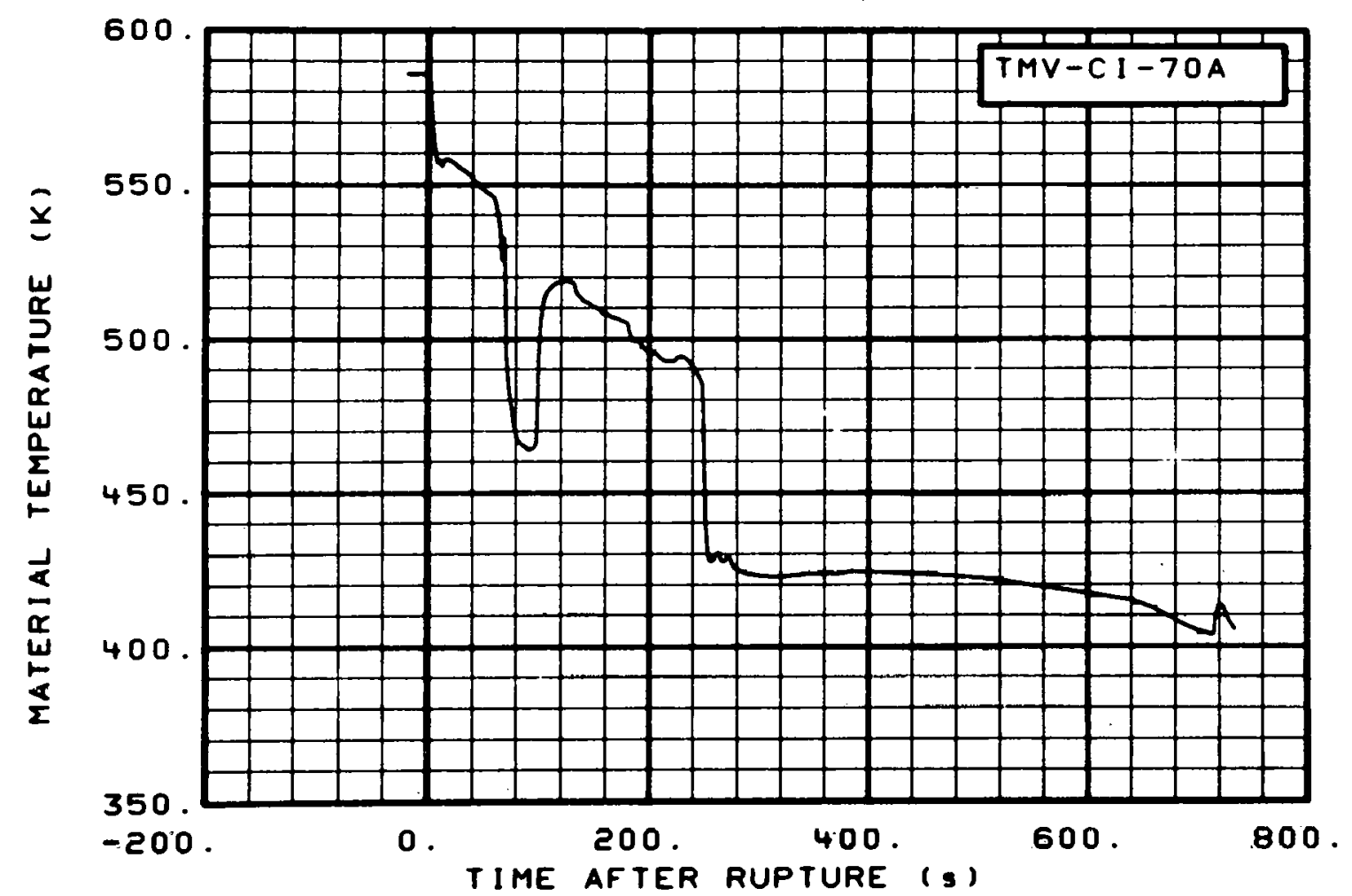

Fig. 69 Material temperature in core barrel inner diameter (TMV-CI-70A), from -20 to $736 \mathrm{~s}$.

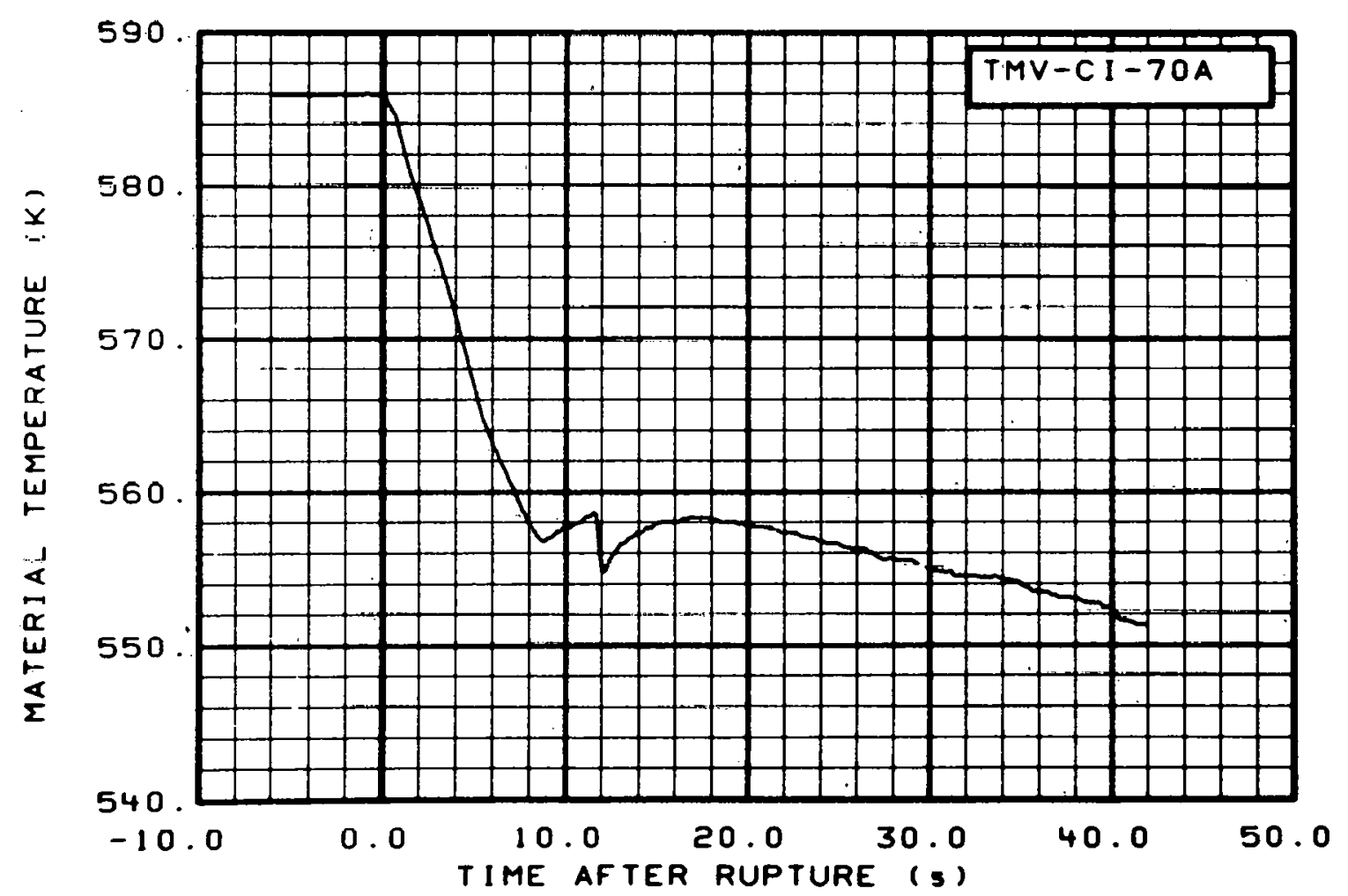

Fig. 70 Material temperature in core barrel inner diameter (TMV-CI-70A), ifrom -6 to $42 \mathrm{~s}$. 


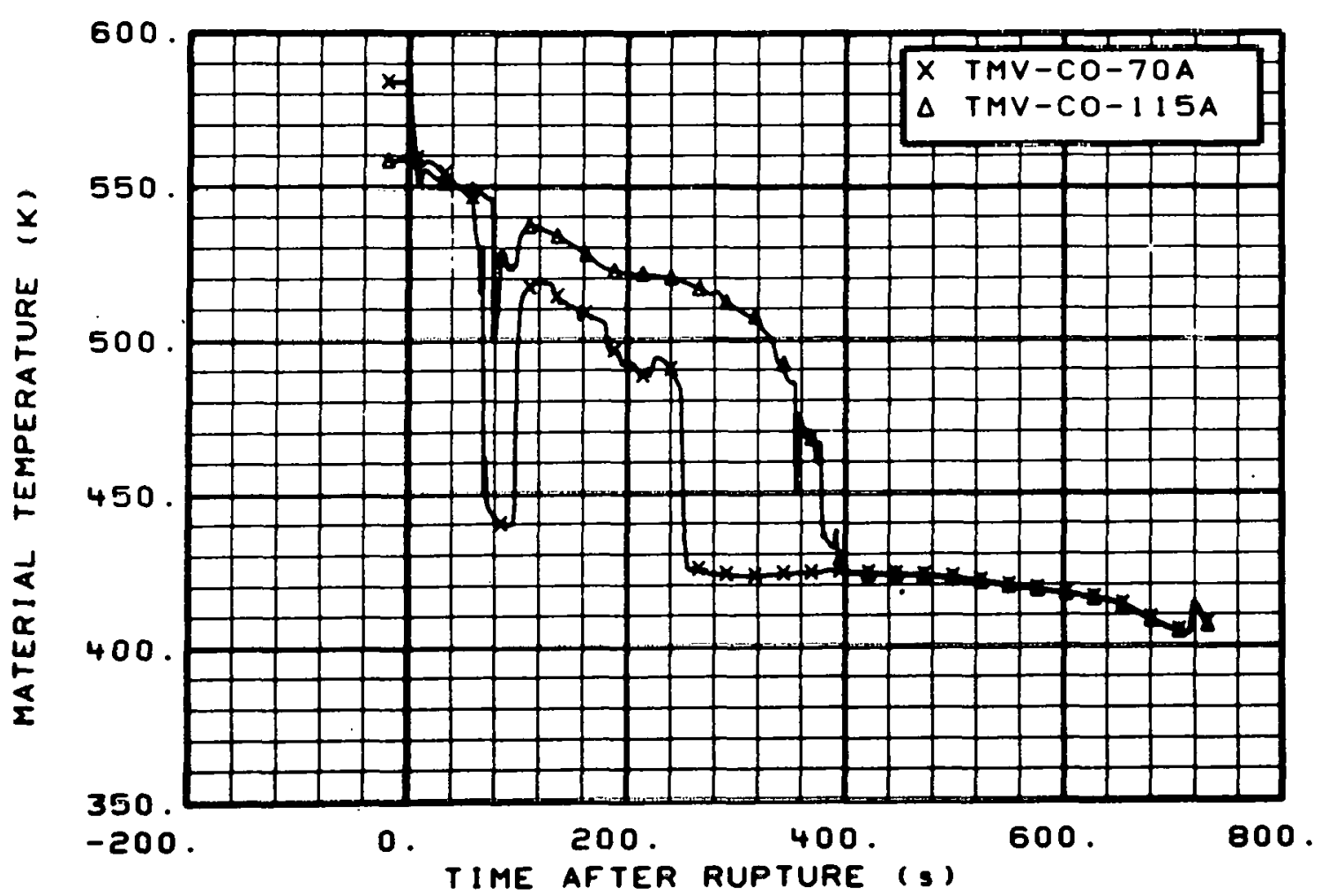

Fig. 71 Material temperature in core barrel outer diameter (TMV-CO-70A and $T M V-C 0-115 \mathrm{~A})$, from -20 to $736 \mathrm{~s}$.

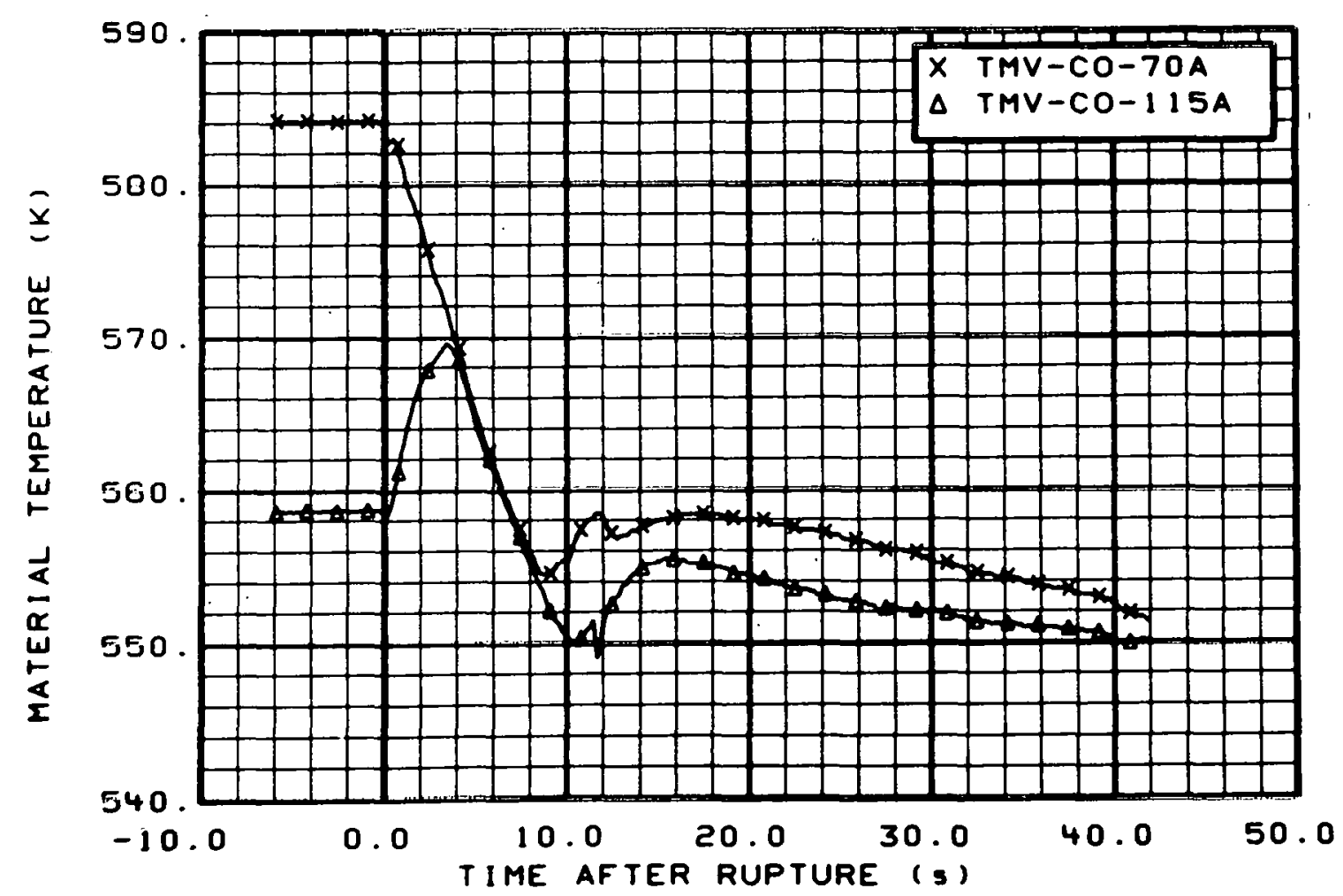

Fig. 72 Material temperature in core barrel outer diameter (TMV-CO-70A and TMV-C0-115A), from -6 to $42 \mathrm{~s}$. 


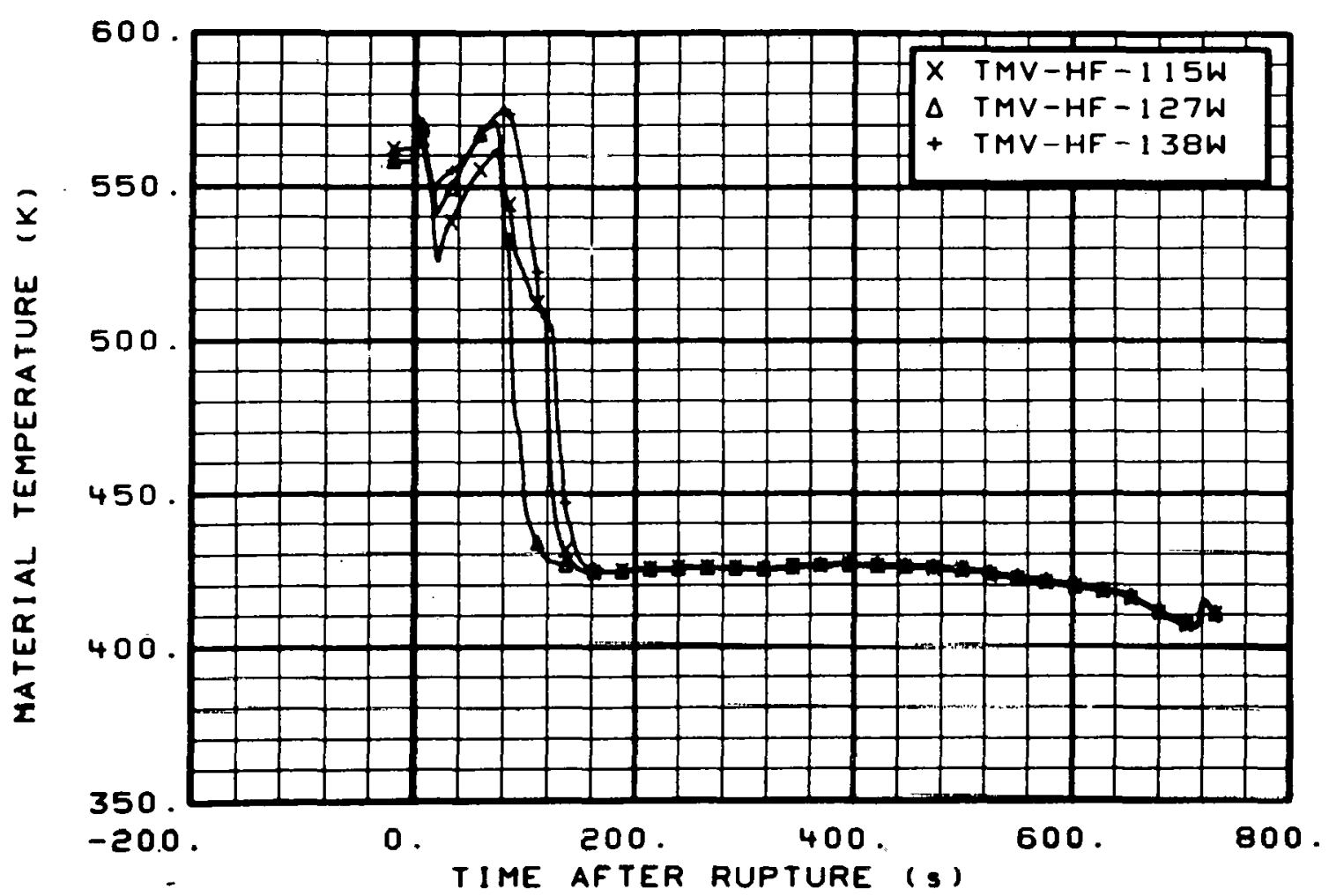

Fig. 73 Material temperature in core housing filler (TMV-HF-115W, TMV-HF$127 \mathrm{~W}$, and TMV-HF-138W), from -20 to $736 \mathrm{~s}$.

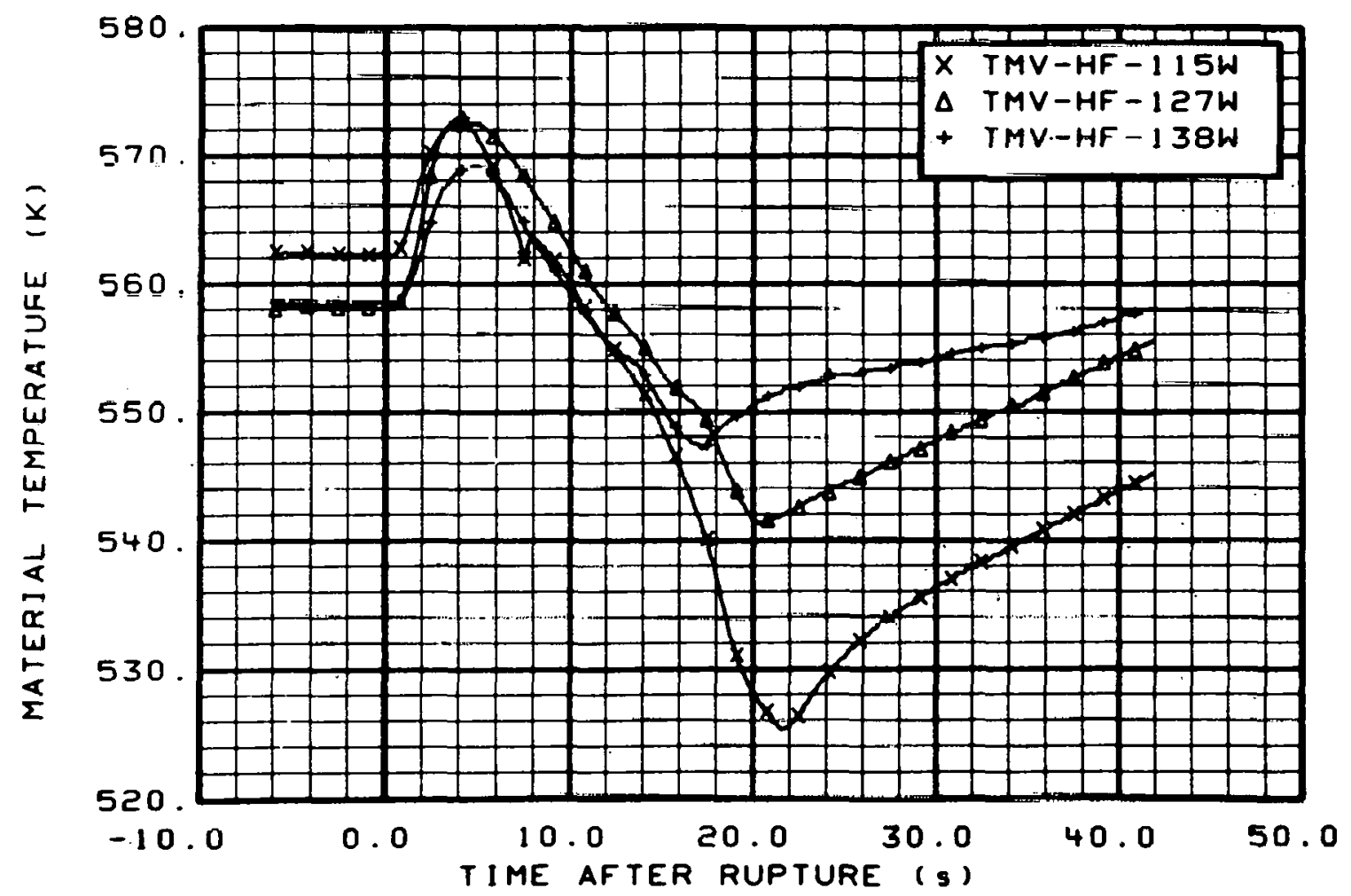

Fig. 74 Material temperature in core housing filler (TMV-HF-115W, TMV-HF$127 \mathrm{~W}$, and TMV-HF-138W), from -6 to $42 \mathrm{~s}$. 


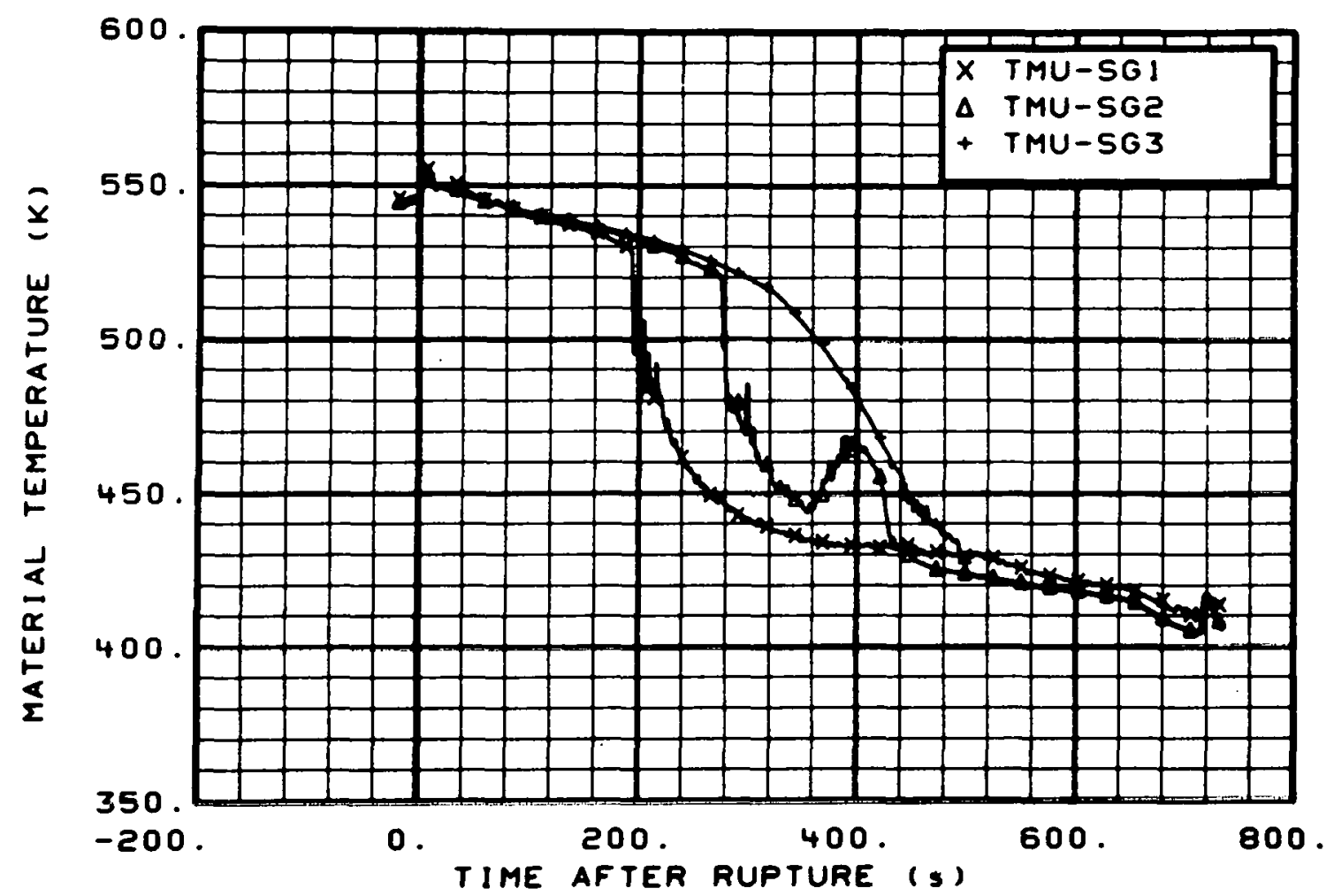

Fig. 75 Material temperature in steam generator (TMU-SG), TMU-SG2, and TMU-SG3), from -20 to $736 \mathrm{~s}$.

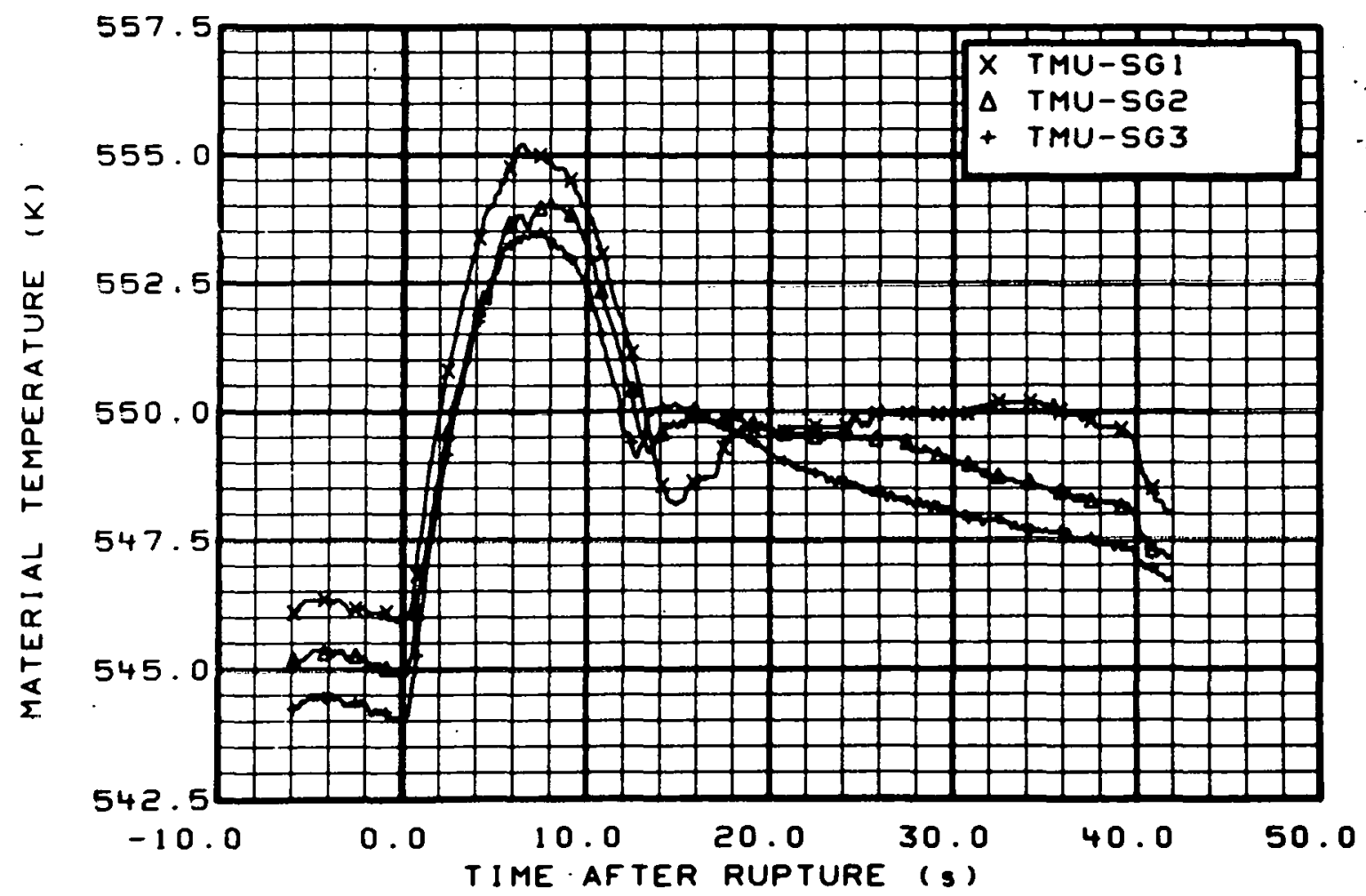

Fig. 76 Material temperature in steam generator (TMU-SG1, TMU-SG2, and TMU-SG3), from -6 to $42 \mathrm{~s}$. 


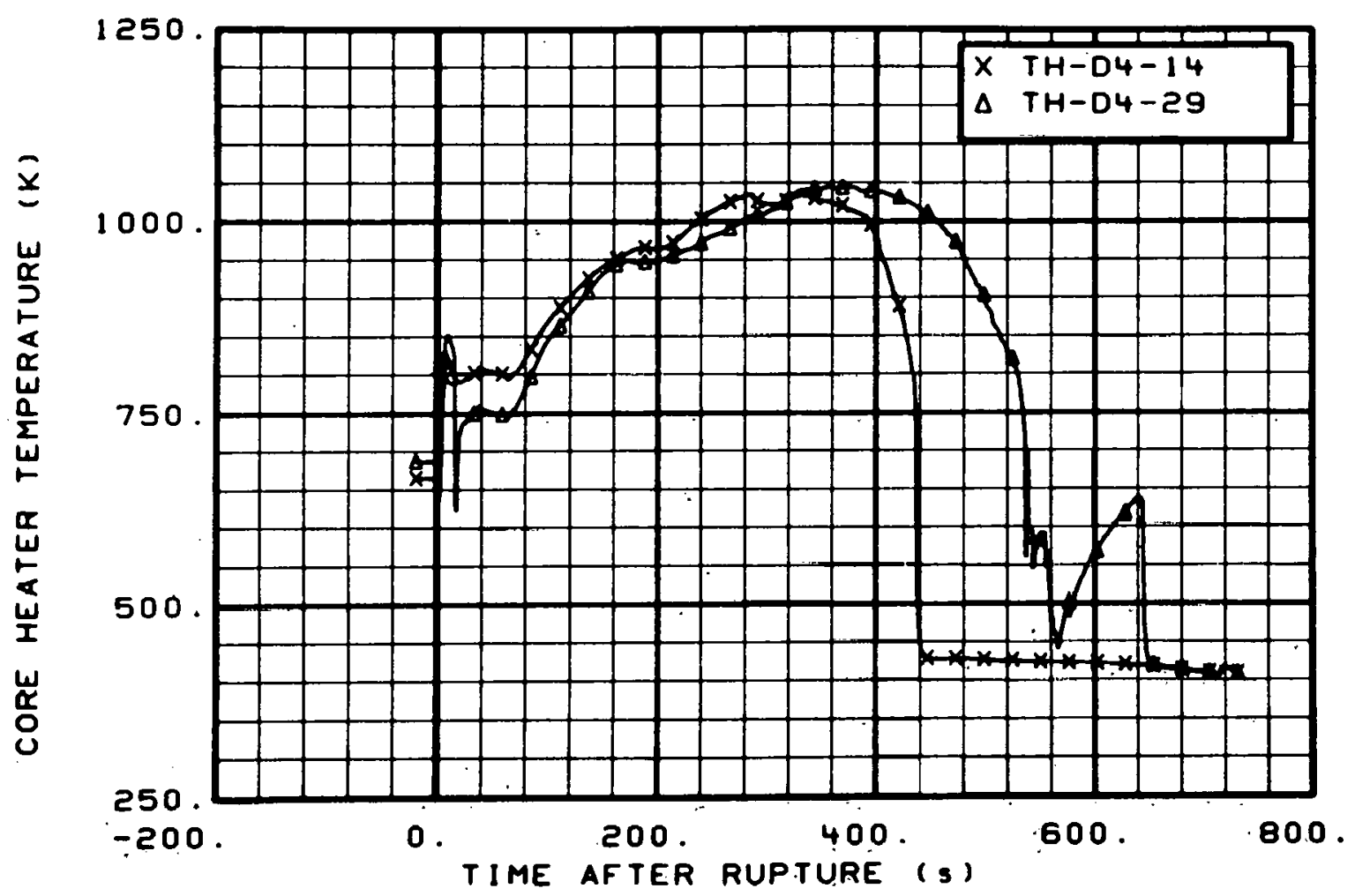

Fig. 77 Core heater temperature, Rod D-.4 (TH-D4-14 and TH-D4-29), from -20 to $736 \mathrm{~s}$.

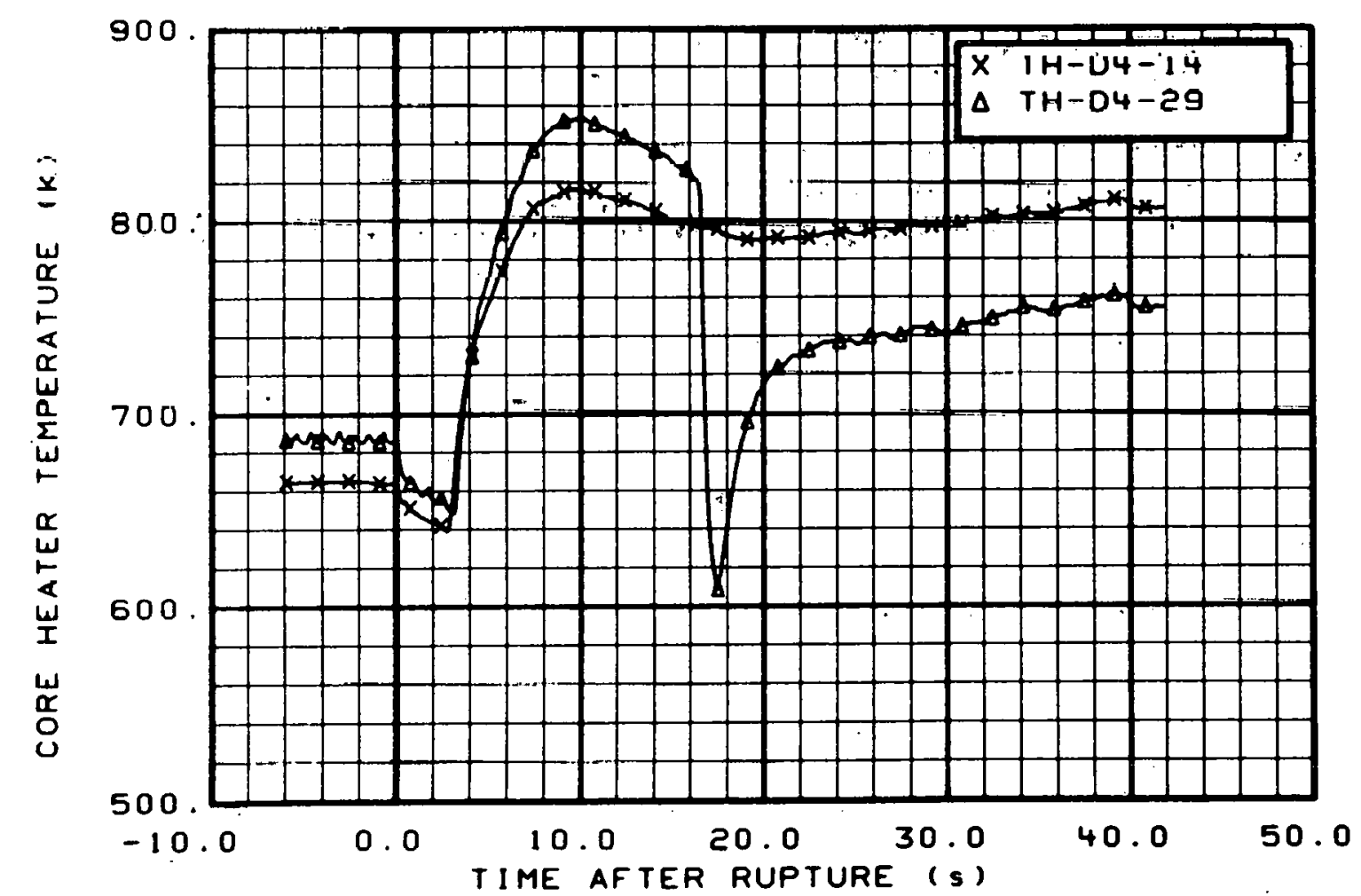

Fig. 78 Core heater temperature, Rod D-4 (TH-D4-14 and TH-D4-29), from -6 to $42 \mathrm{~s}$. 


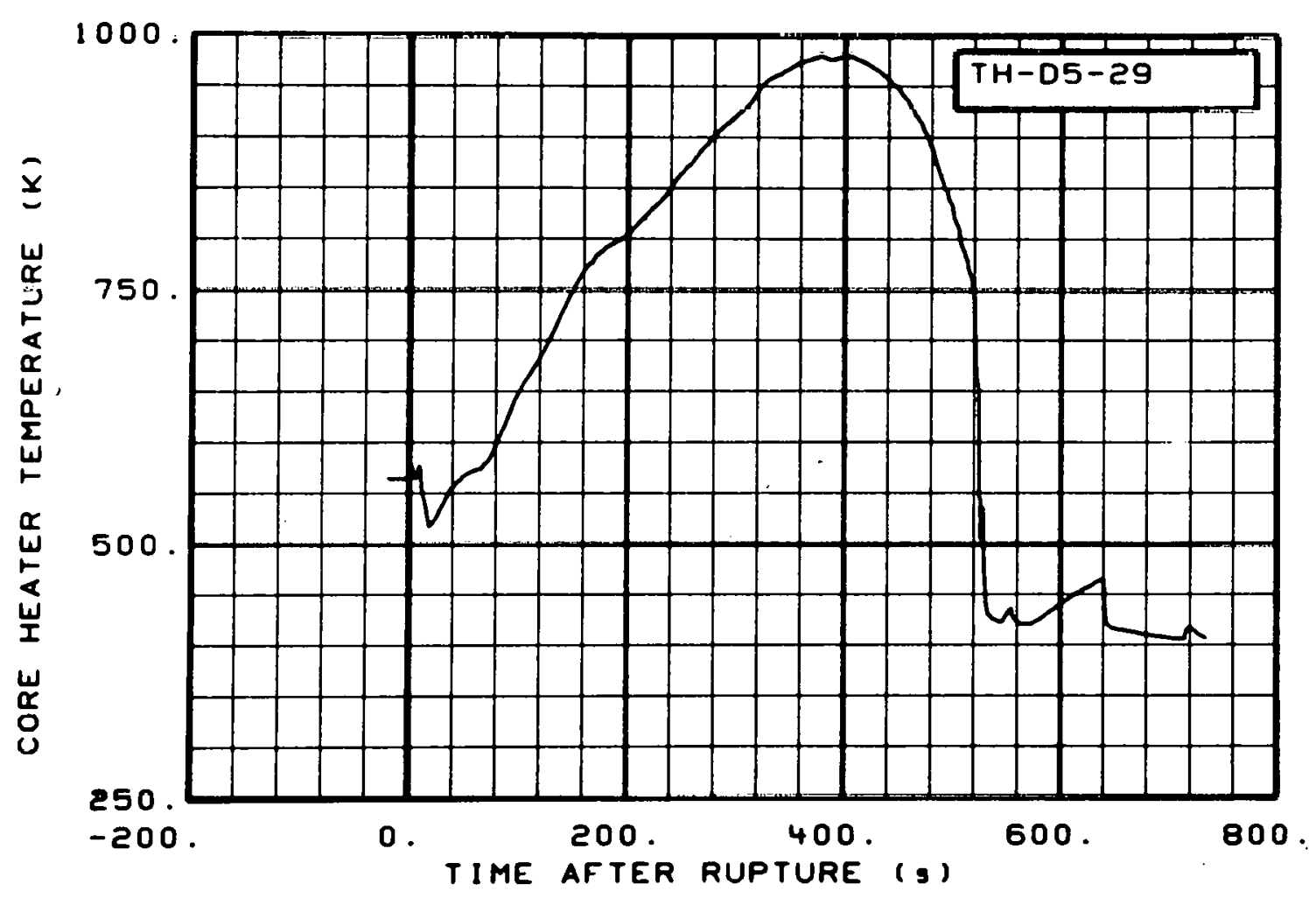

Fig. 79 Core heater temperature, Rod D-5 (TH-D5-29) from -20 to $736 \mathrm{~s}$.

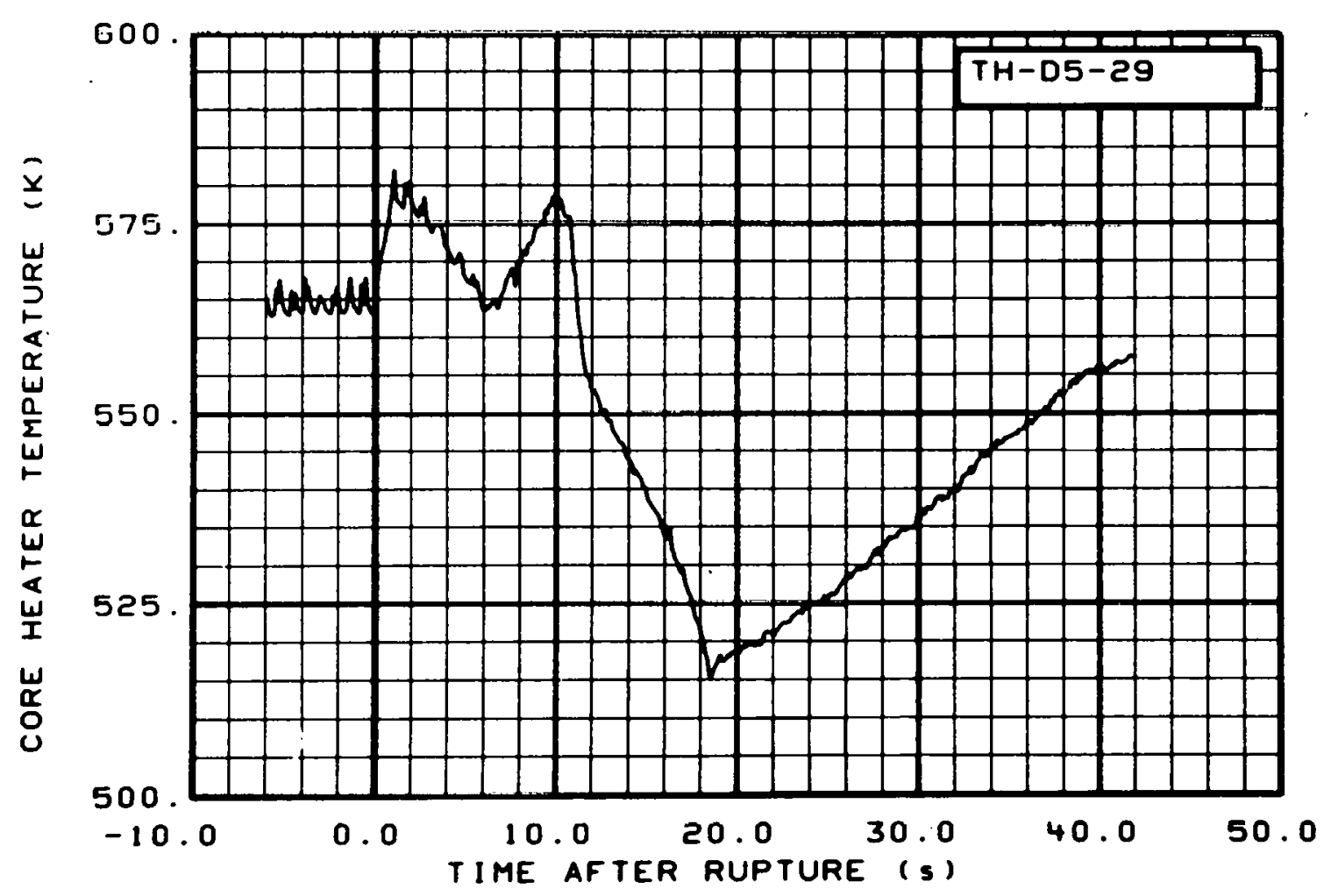

Fig. 80 Core heater temperature, Rod D-5 (TH-D5-29) from -6 to $42 \mathrm{~s}$. 


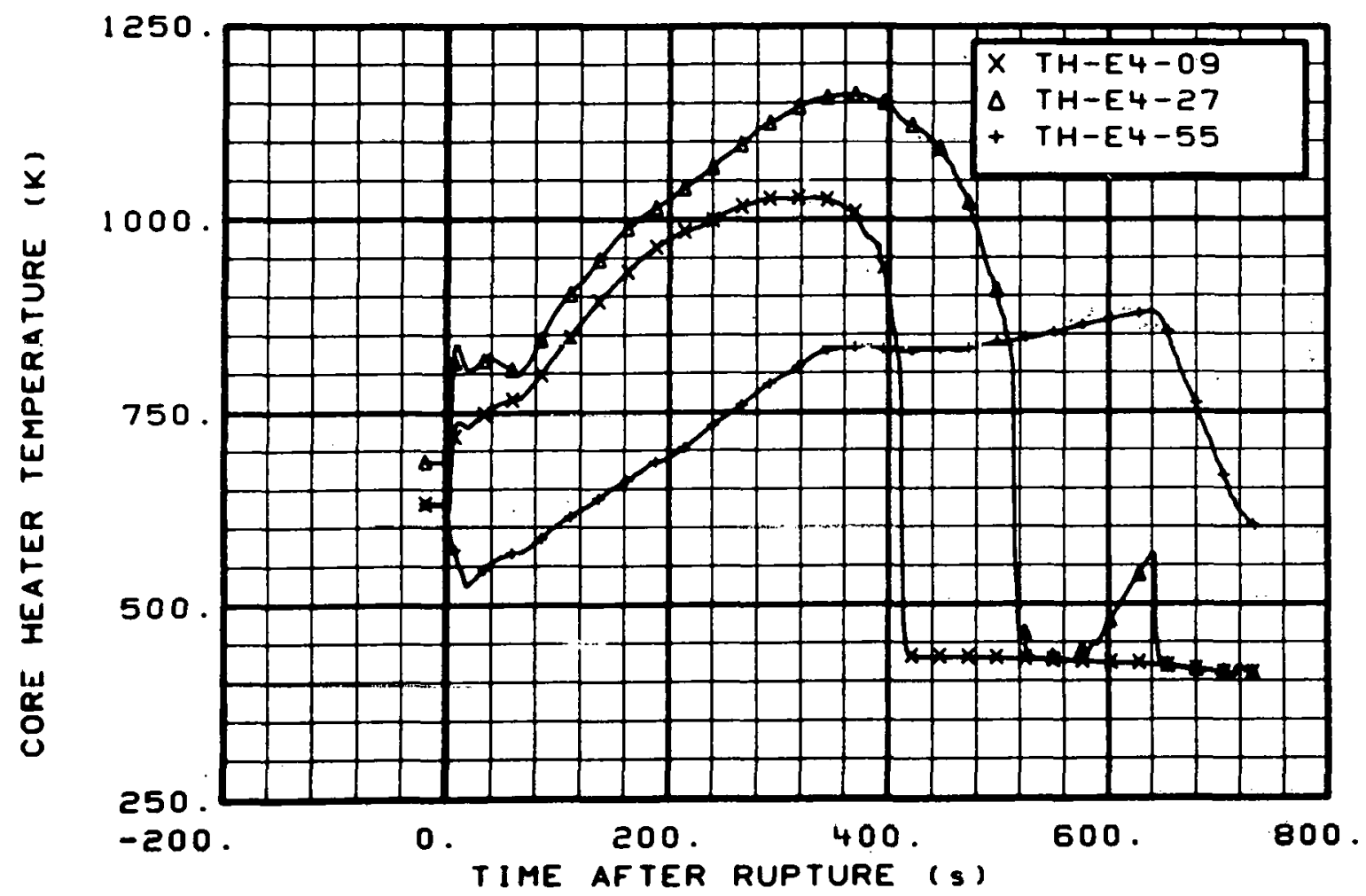

Fig. 81 Core heater temperature, Rod E-4 (TH-E4-09, TH-E4-27, and $\mathrm{TH}-\mathrm{E} 4-55)$, from -20 to $736 \mathrm{~s}$.

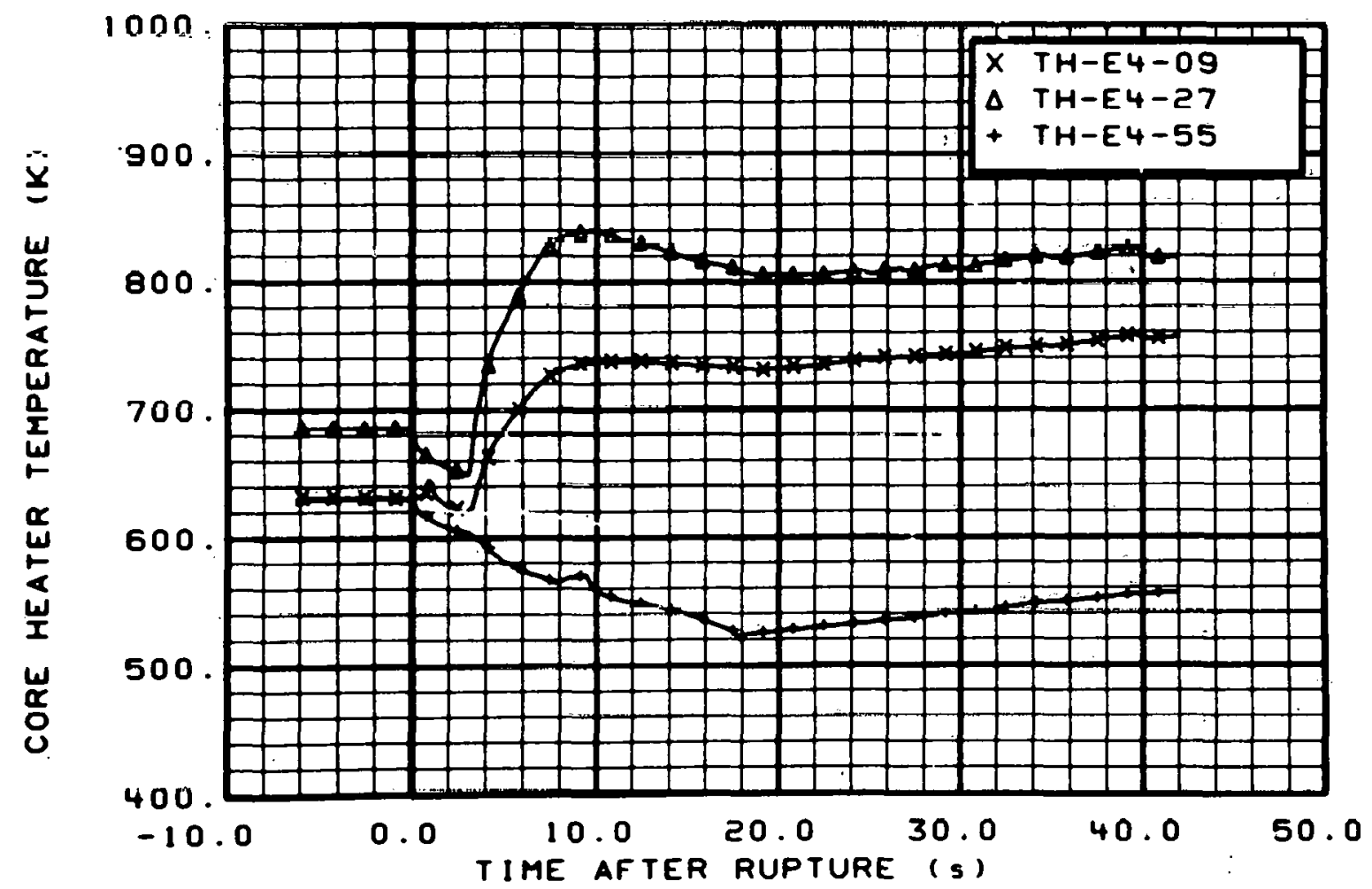

Fig. 82 Core heater temperature, Rod E-4 (TH-E4-09, TH-E4-27, and TH-E4-55), from -6 to $42 \mathrm{~s}$. 


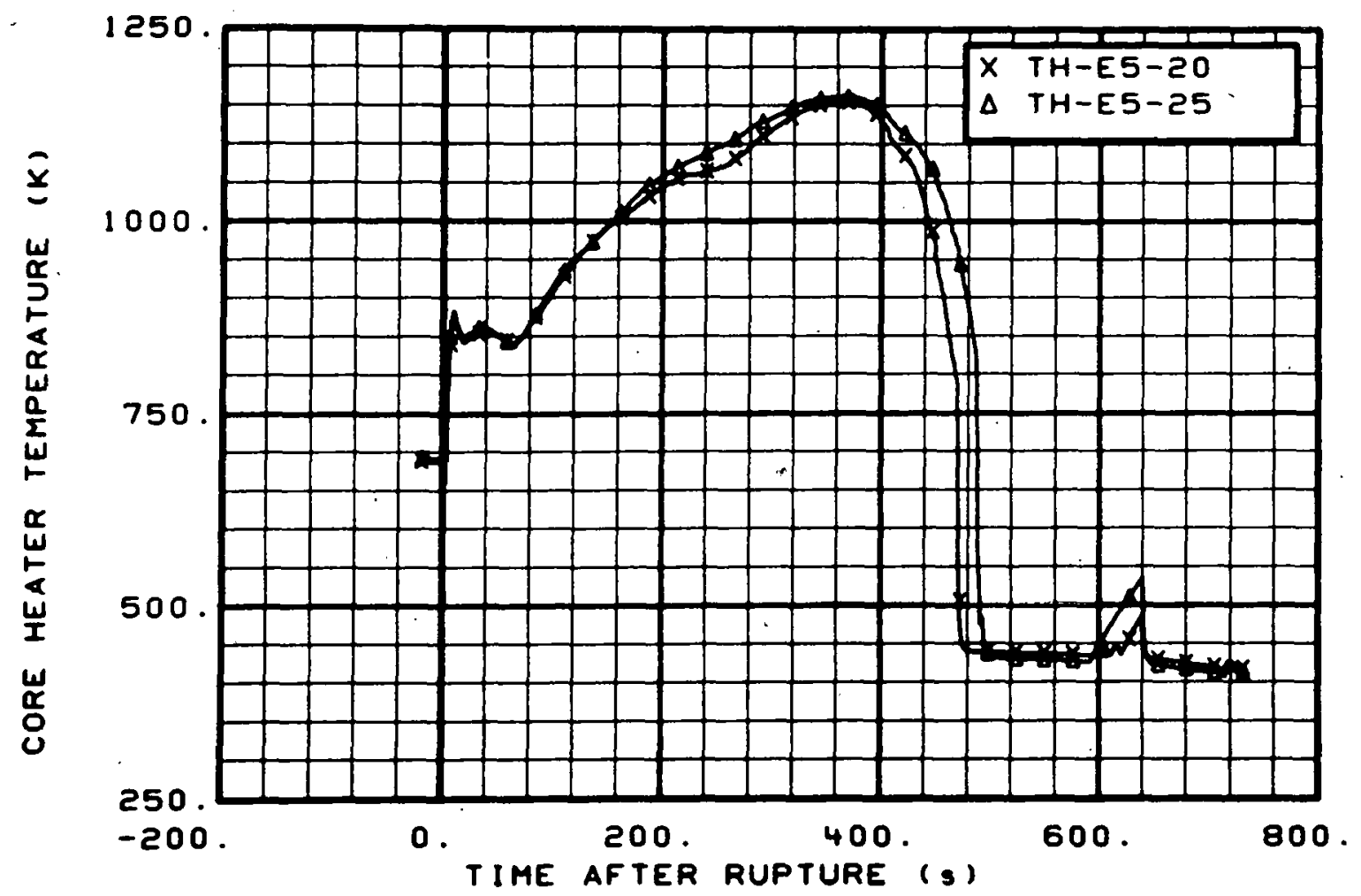

Fig. 83 Core heater temperature, Rod E-5 (TH-E5-20 and TH-E5-25), from -20 to $736 \mathrm{~s}$.

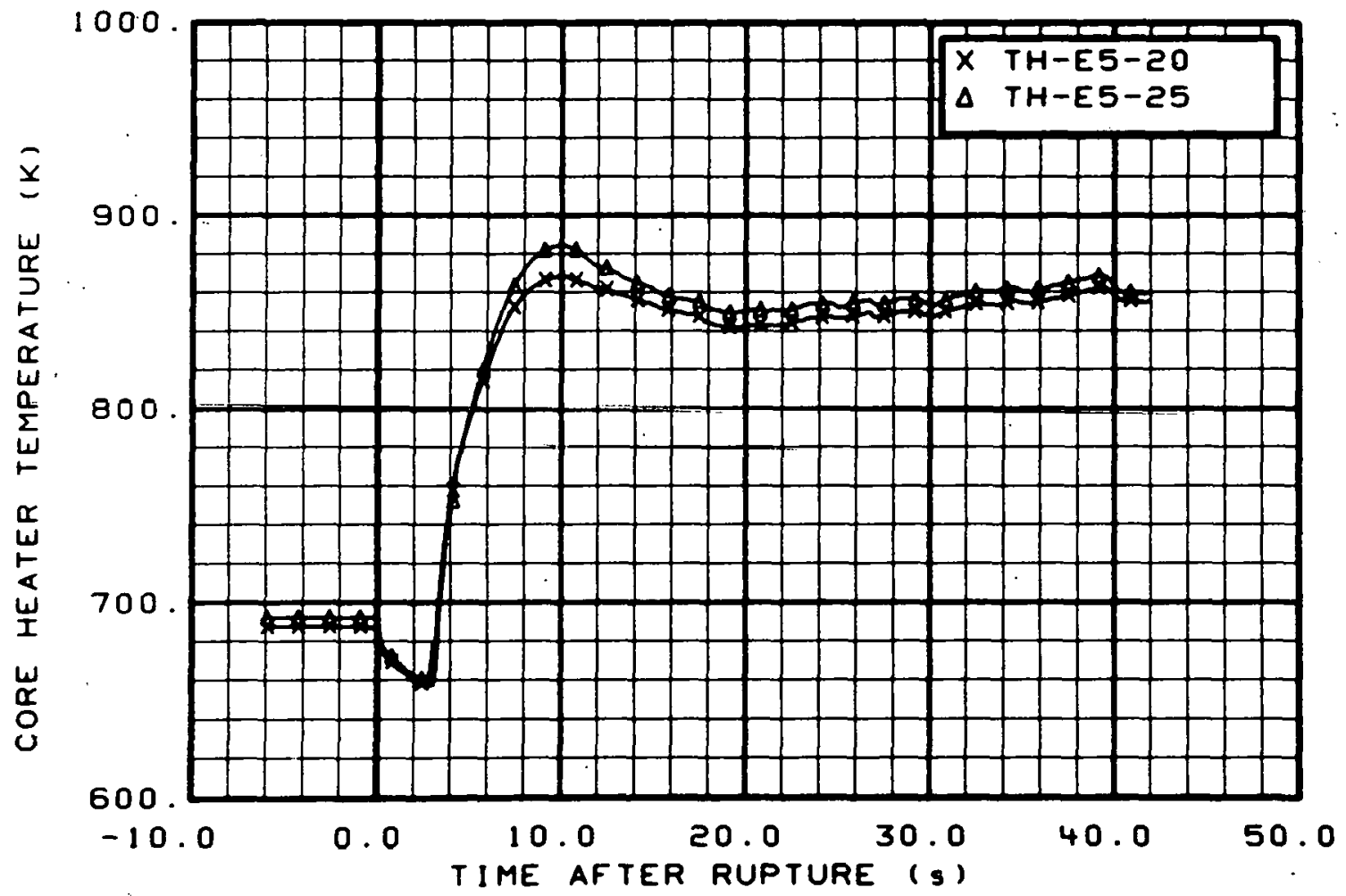

Fig. 84 Core heater temperature, Rod E-5 (TH-E5-20 and TH-E5-25), from -6 to $42 \mathrm{~s}$. 


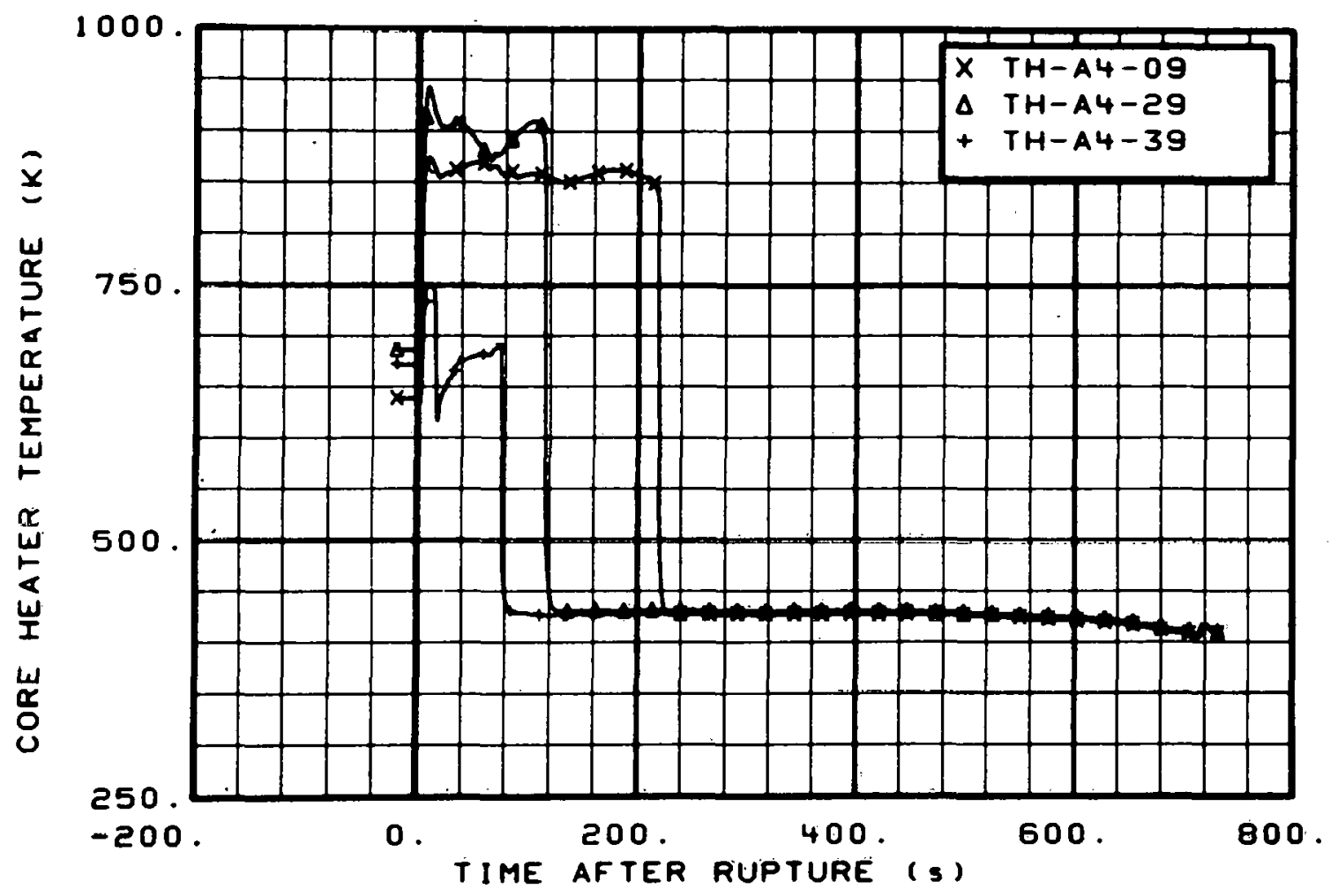

Fig. 85 Core heater temperature, Rod A-4 (TH-A4-09, TH-A4-29, and TH-A4-39), from -20 to $736 \mathrm{~s}$.

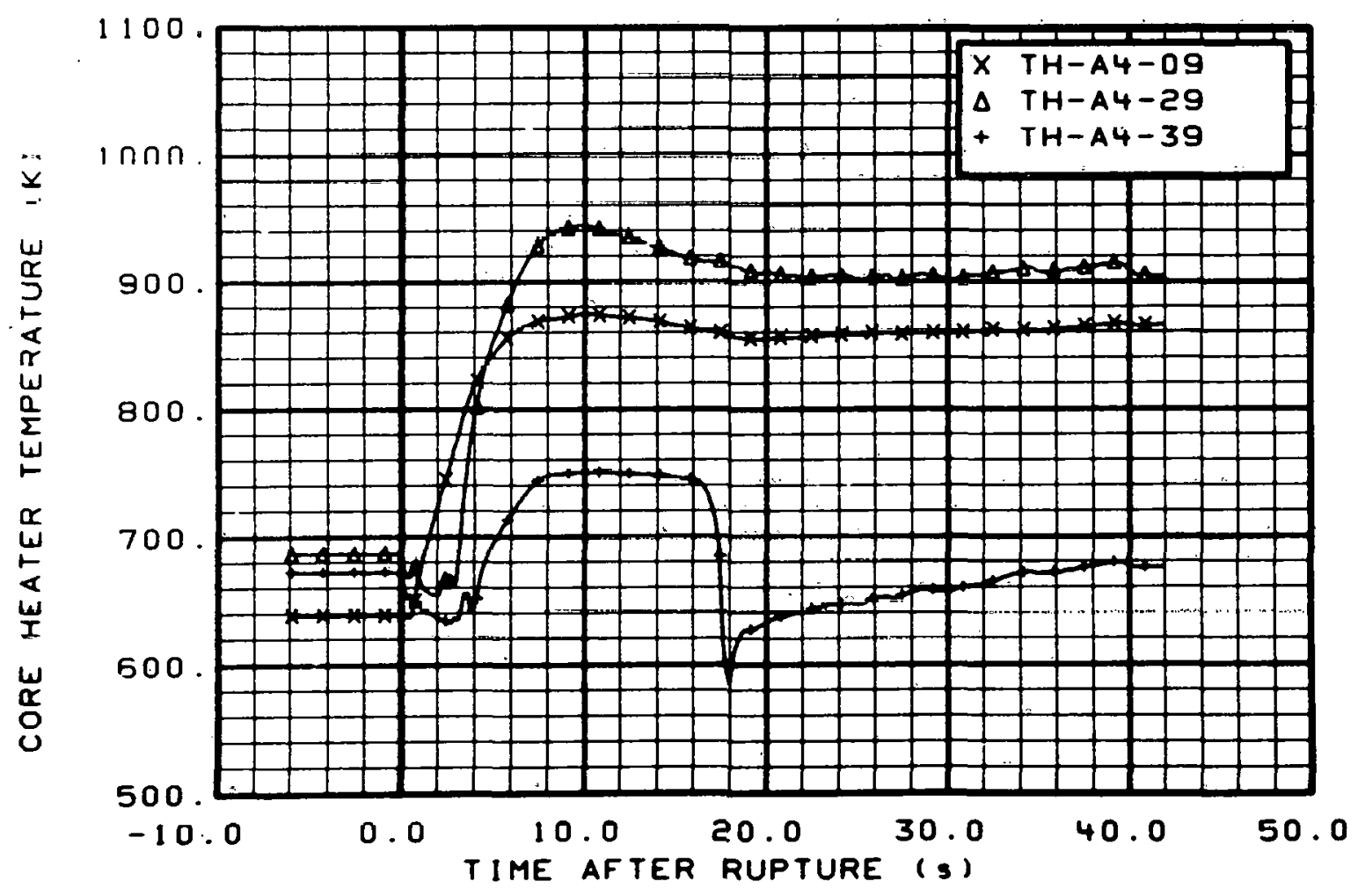

Fig. 86 Core heater temperature, Rod A-4 (TH-A4-09, TH-A4-29, and TH-A4-39), from -6 to $42 \mathrm{~s}$. 


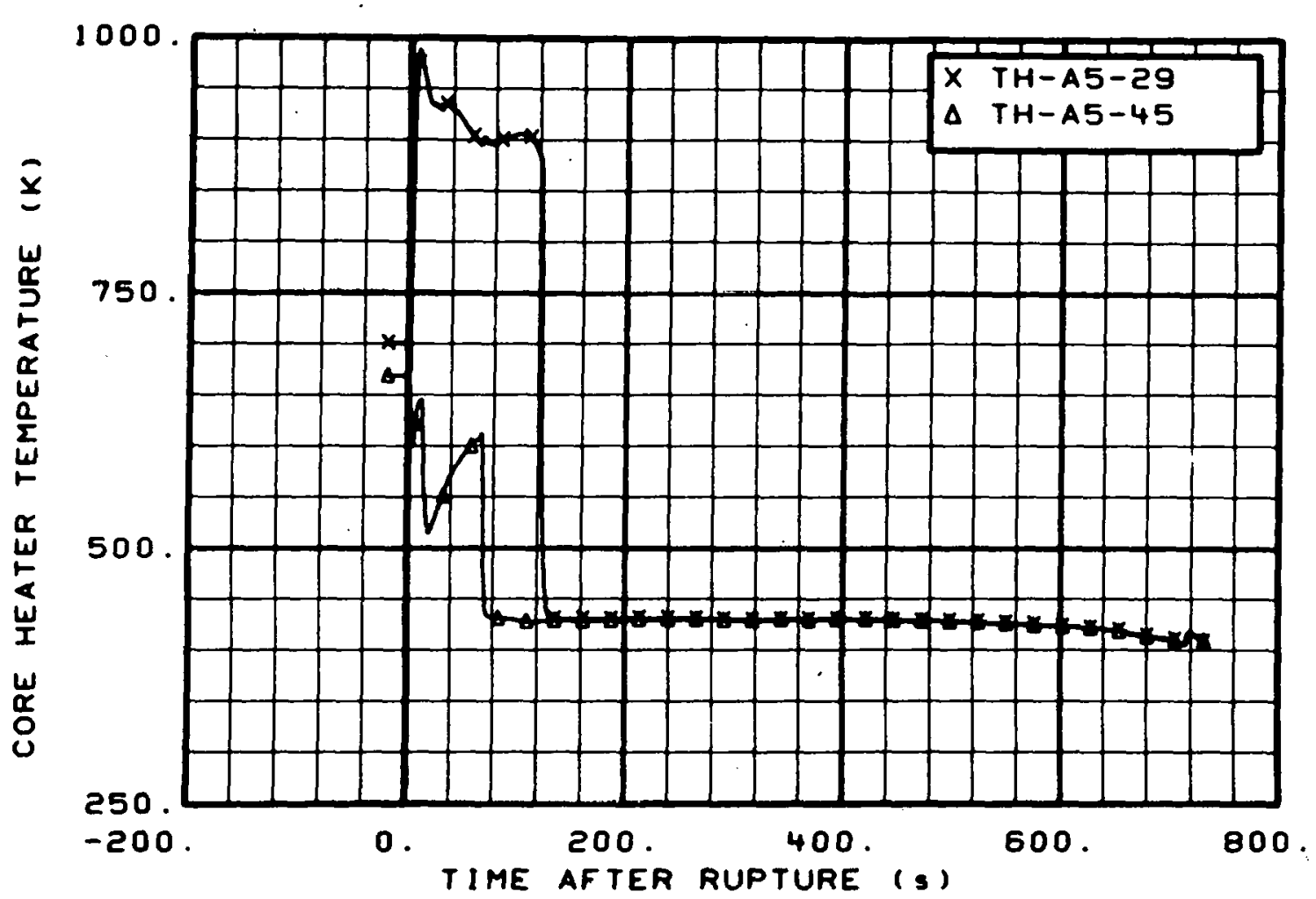

Fig. 87 Core heater temperature, Rod A-5 (TH-A5-29 and TH-A5-45), from -20 to $736 \mathrm{~s}$.

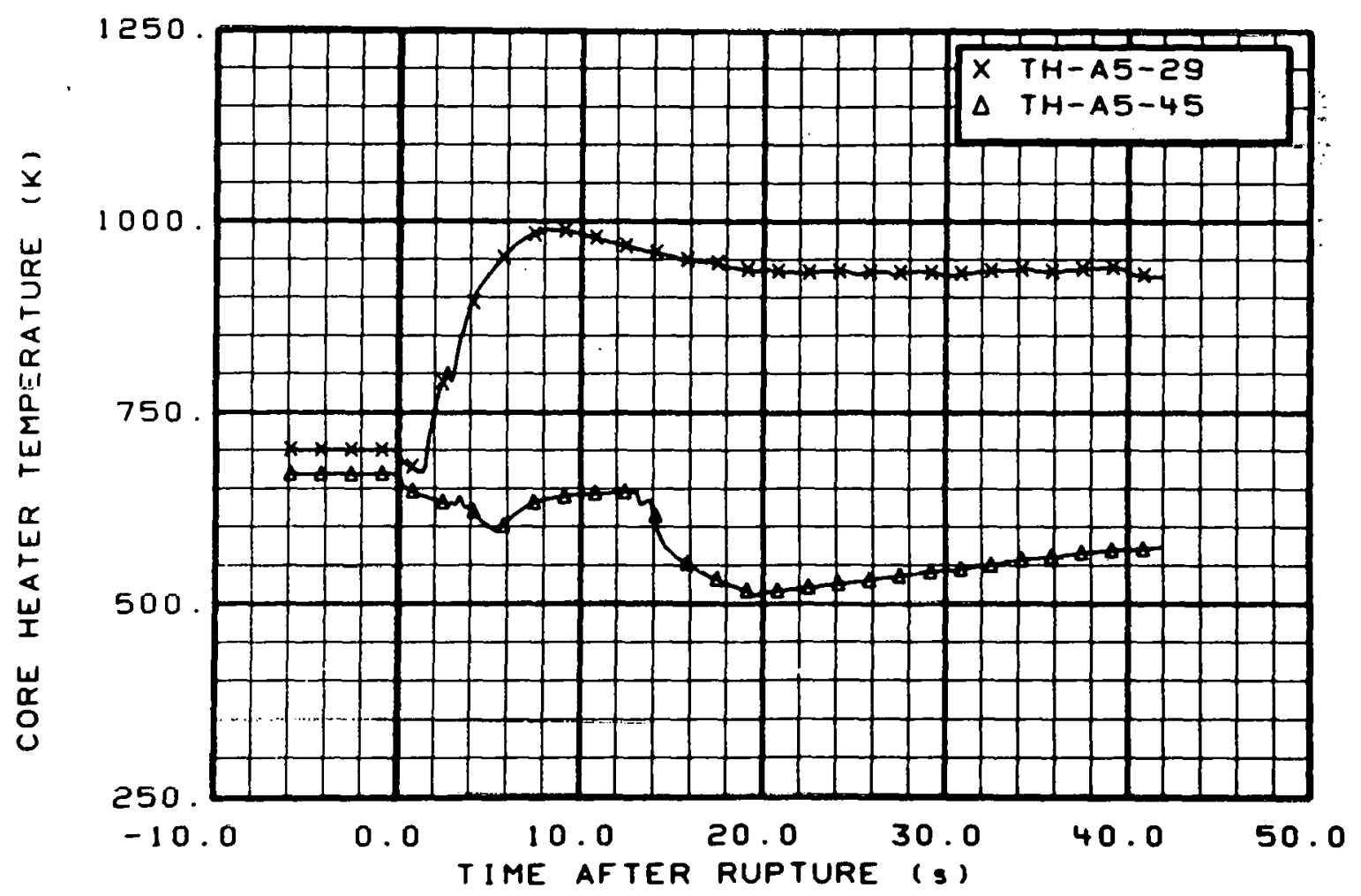

Fig. 88 Core heater temperature, Rod A-5 (TH-A5-29 and TH-A5-45), from -6 to $42 \mathrm{~s}$. 


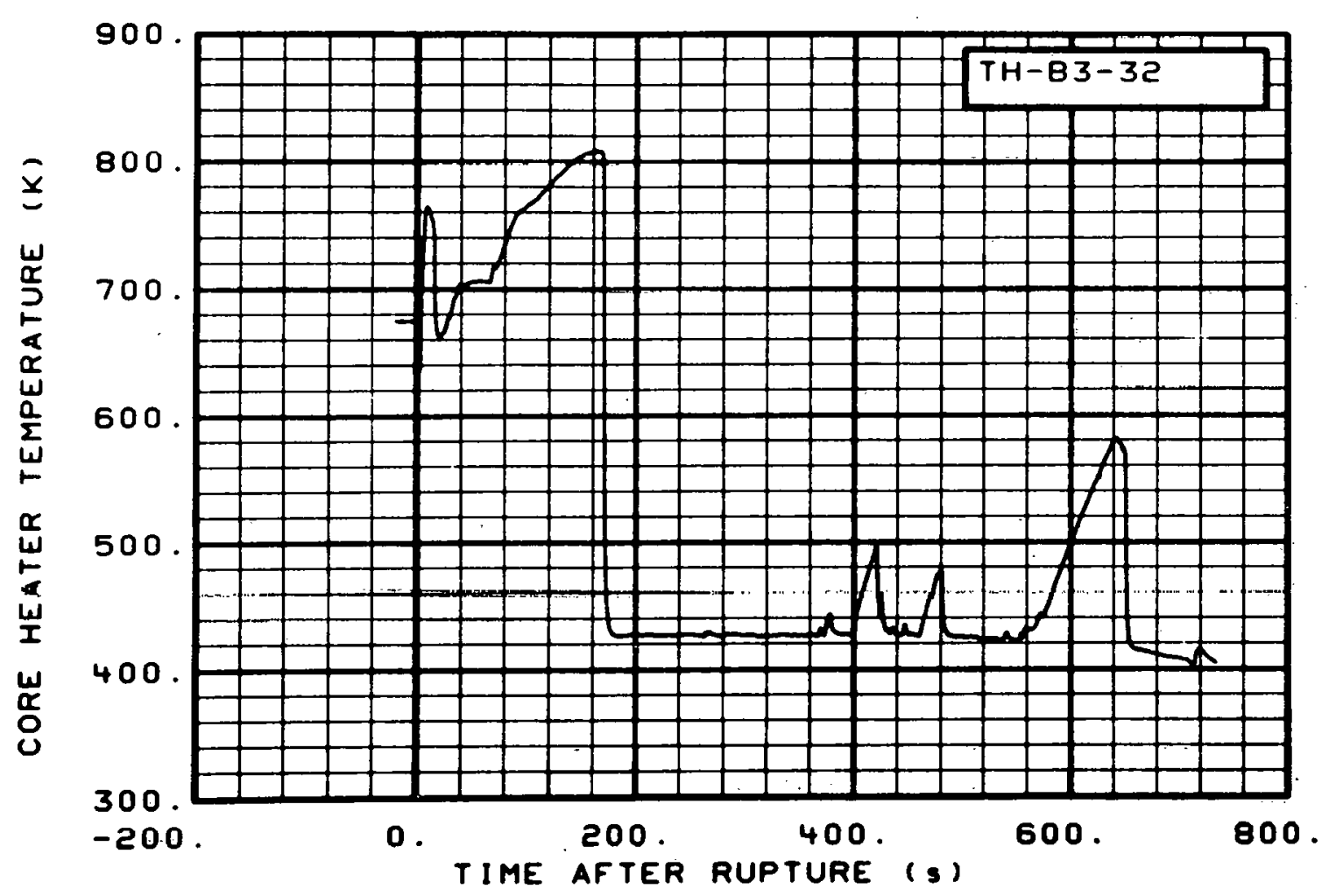

Fig. 89 Core heater temperature, Rod B-3 (TH-B3-32), from -20 to $736 \mathrm{~s}$.

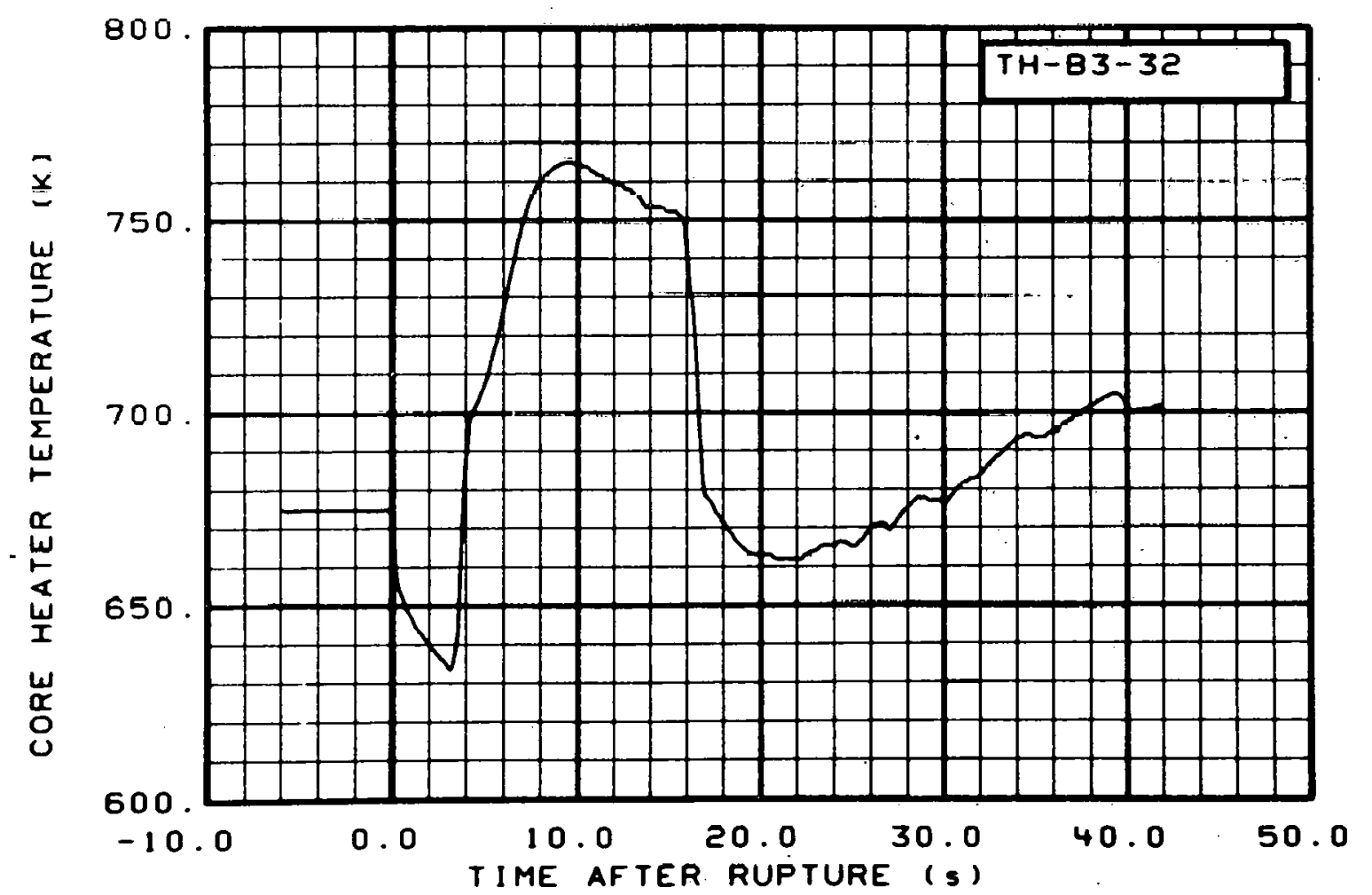

Fig. 90 Core heater temperature, Rod B-3 (TH-B3-32), from -6 to $42 \mathrm{~s}$. 


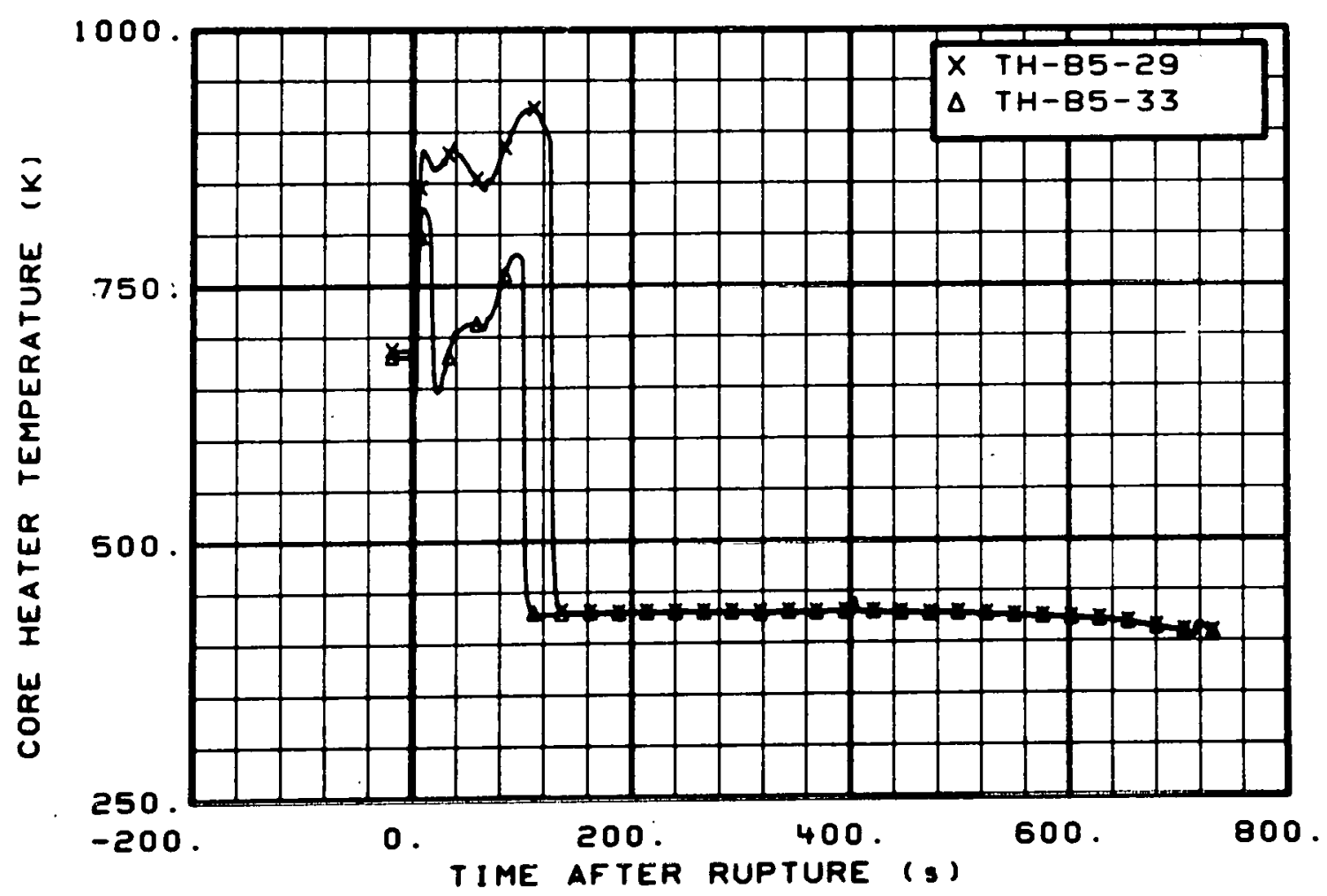

Fig. 91 Core heater temperature, Rod B-5 (TH-B5-29 and TH-B5-33), from -20 to $736 \mathrm{~s}$.

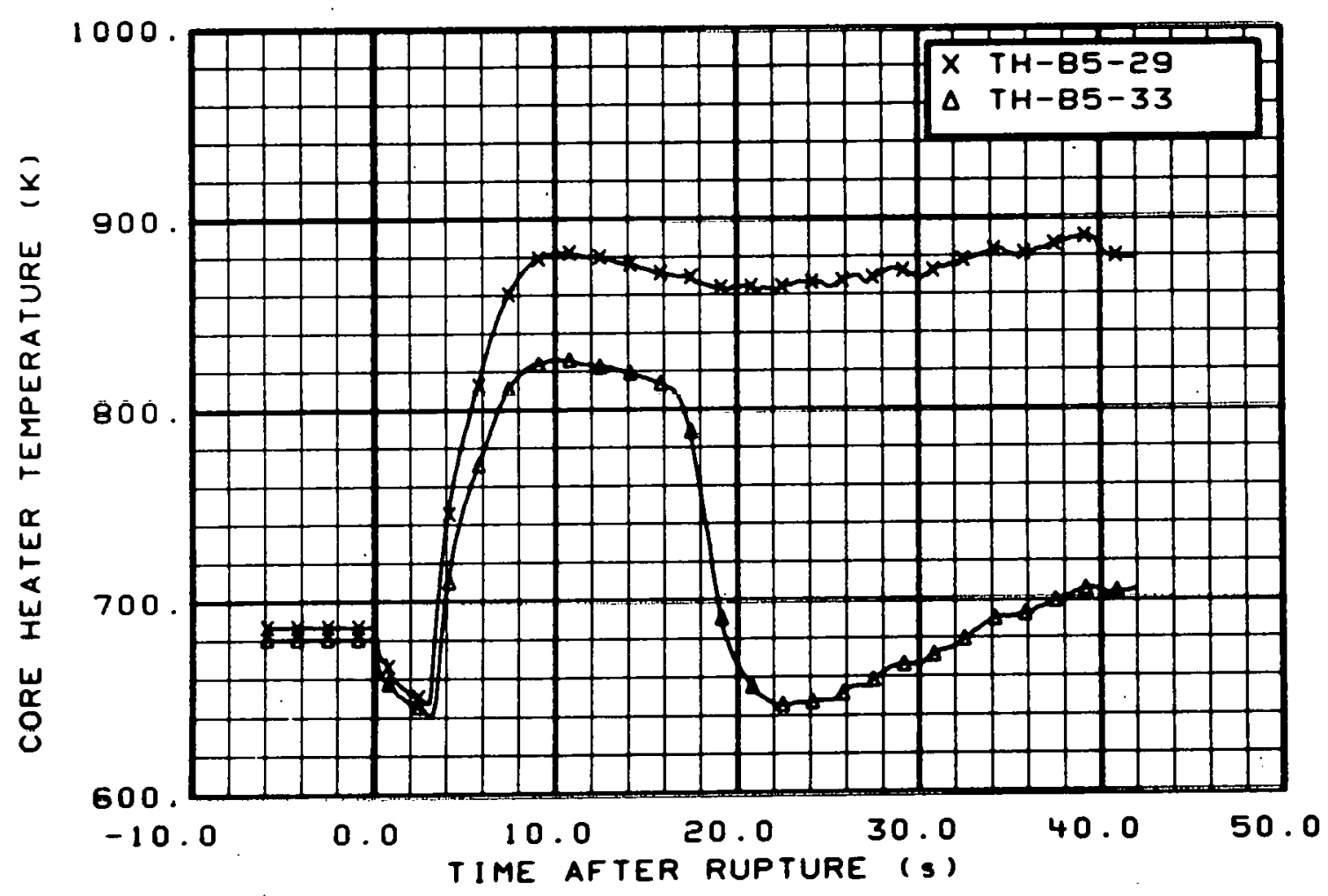

Fig. 92 Core heater temperature, Rod B-5 (TH-B5-29 and TH-B5-33), from -6 to $42 \mathrm{~s}$. 


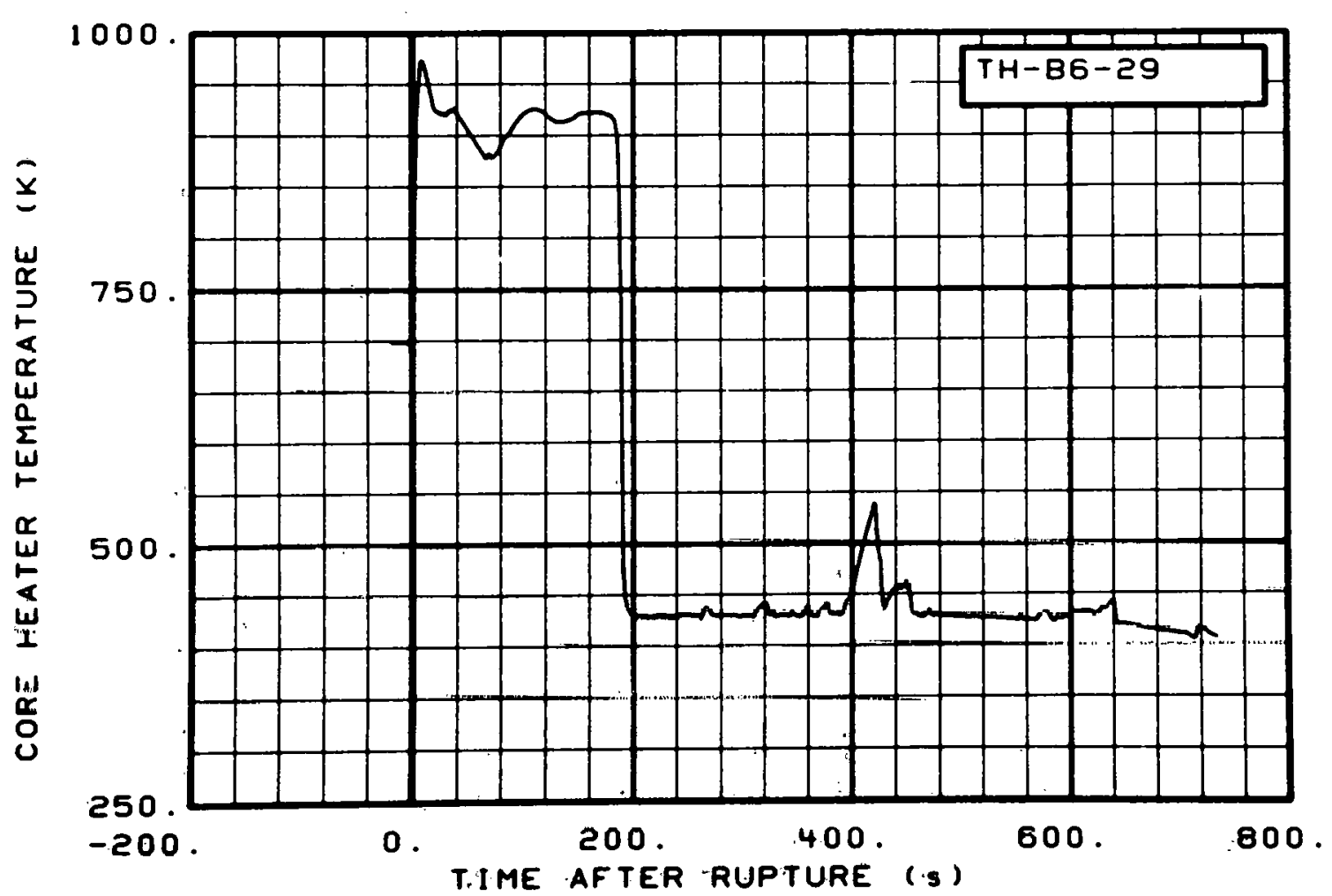

Fig. 93 Core heater temperature, Rod B-6 (TH-B6-29), from -20 to $736 \mathrm{~s}$.

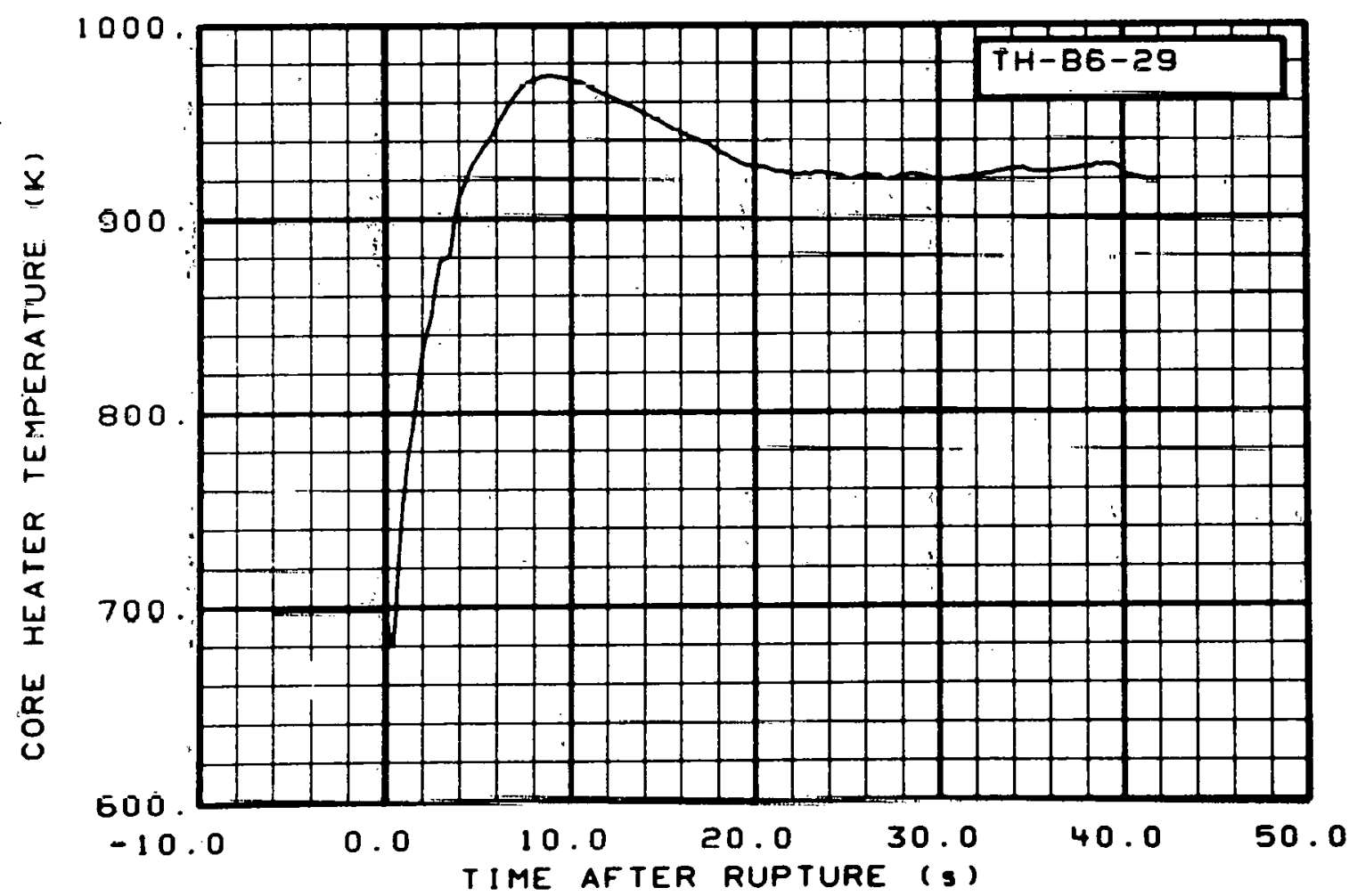

Fig. 94 Core heater temperature, Rod B-6 (TH-B6-29), from -6 to $42 \mathrm{~s}$. 


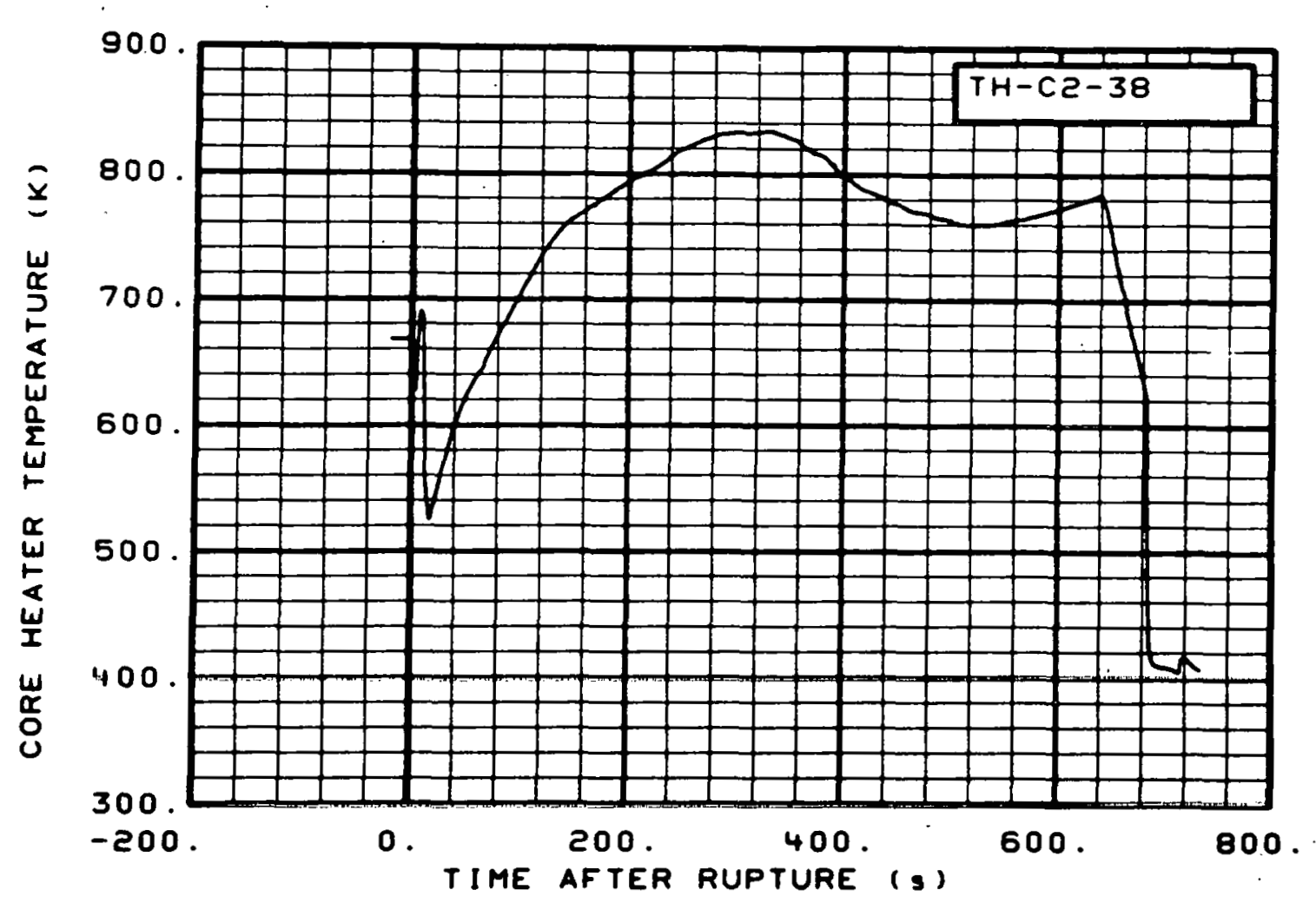

Fig. 95 Core heater temperature, Rod C-2 (TH-C2-38), from -20 to $736 \mathrm{~s}$.

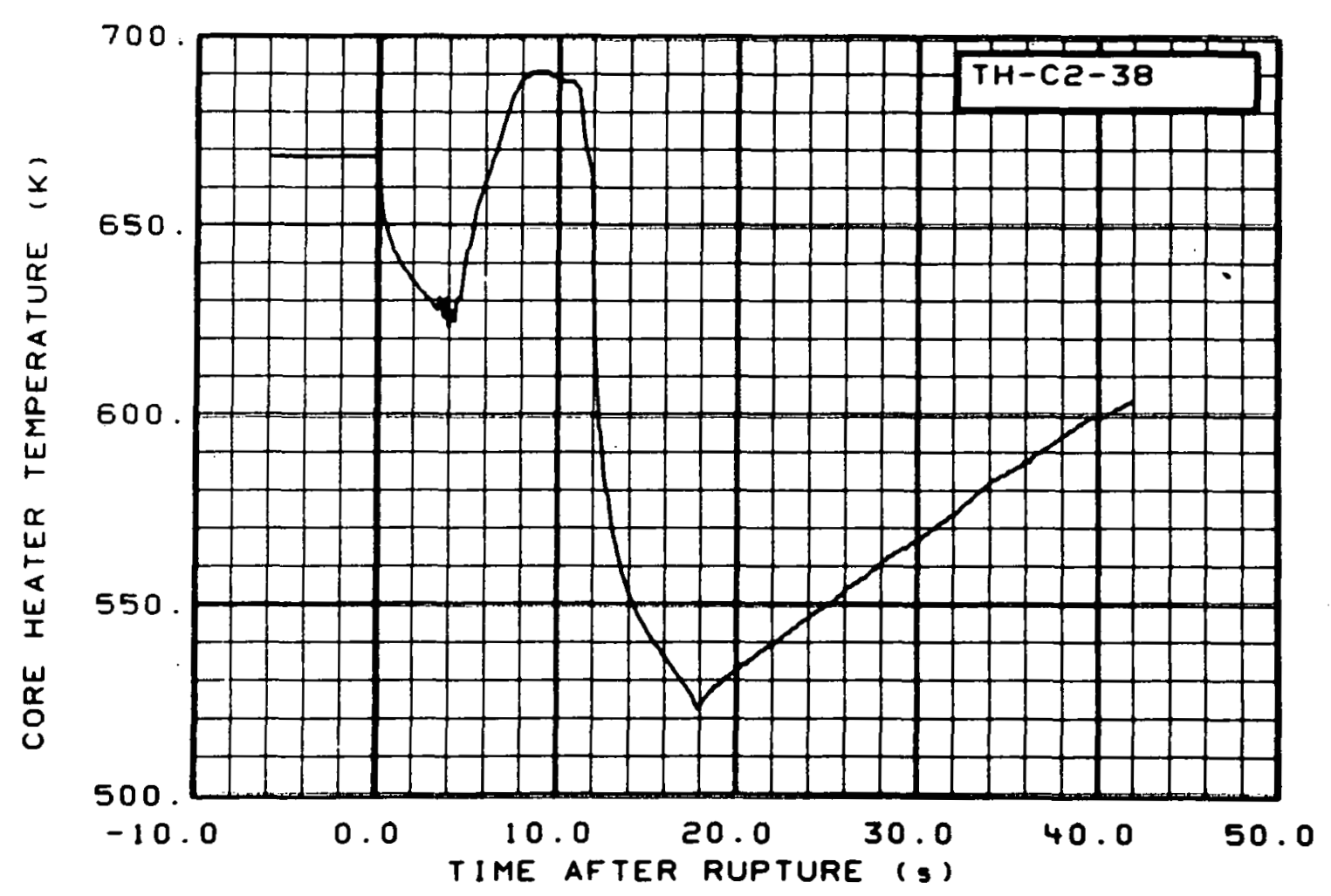

Fig. 96 Core heater temperature, Rod C-2 (TH-C2-38), from -6 to $42 \mathrm{~s}$. 


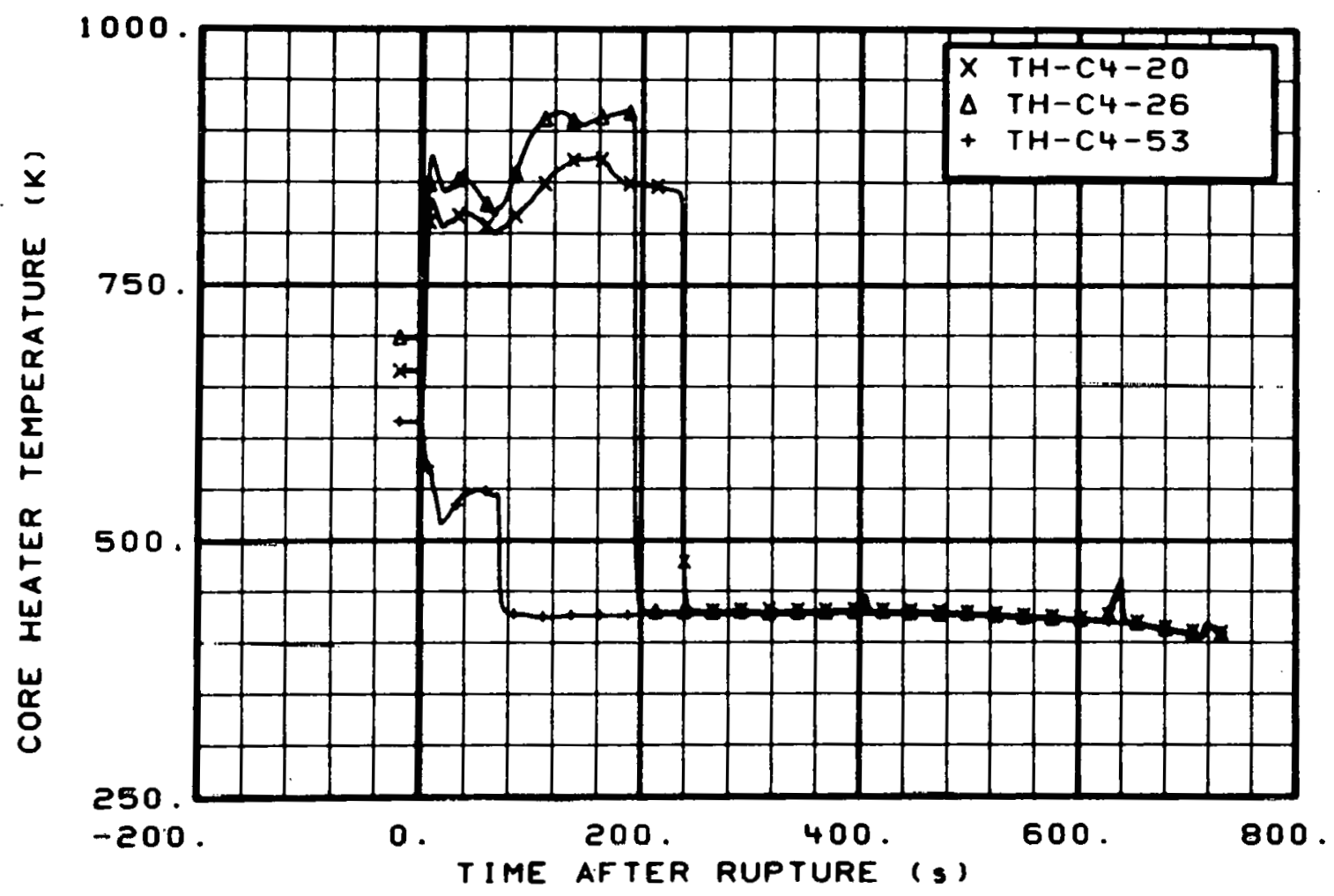

Fig. 97 Core heater temperature, Rod C-4 (TH-C4-20, TH-C4-26, and $\mathrm{TH}-\mathrm{C} 4-53)$, from -20 to $736 \mathrm{~s}$.

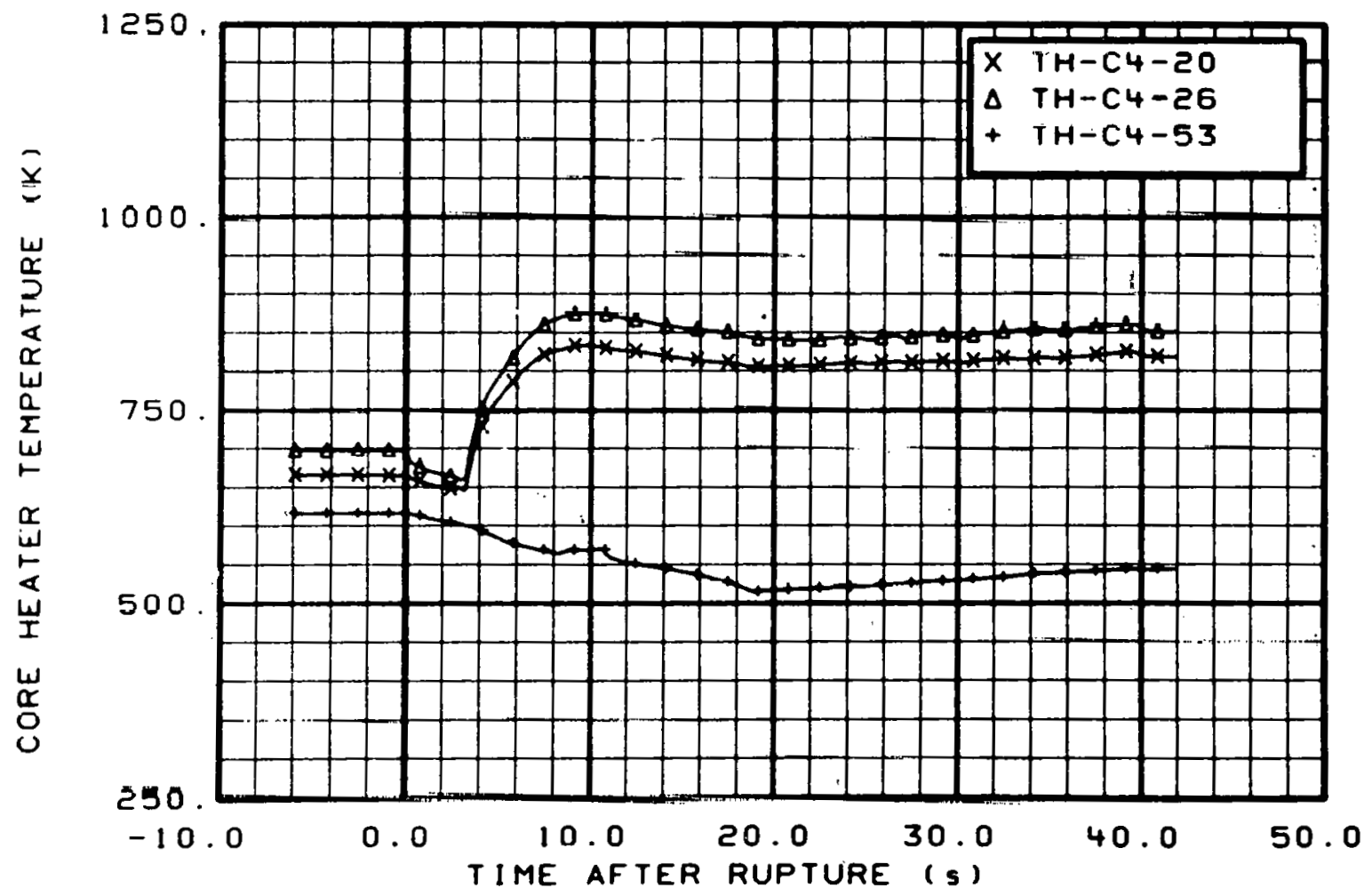

Fig. 98 Core heater temperature, Rod C-4 (TH-C4-20, TH-C4-26, and $\mathrm{TH}-\mathrm{C} 4-53)$, from -6 to $42 \mathrm{~s}$. 


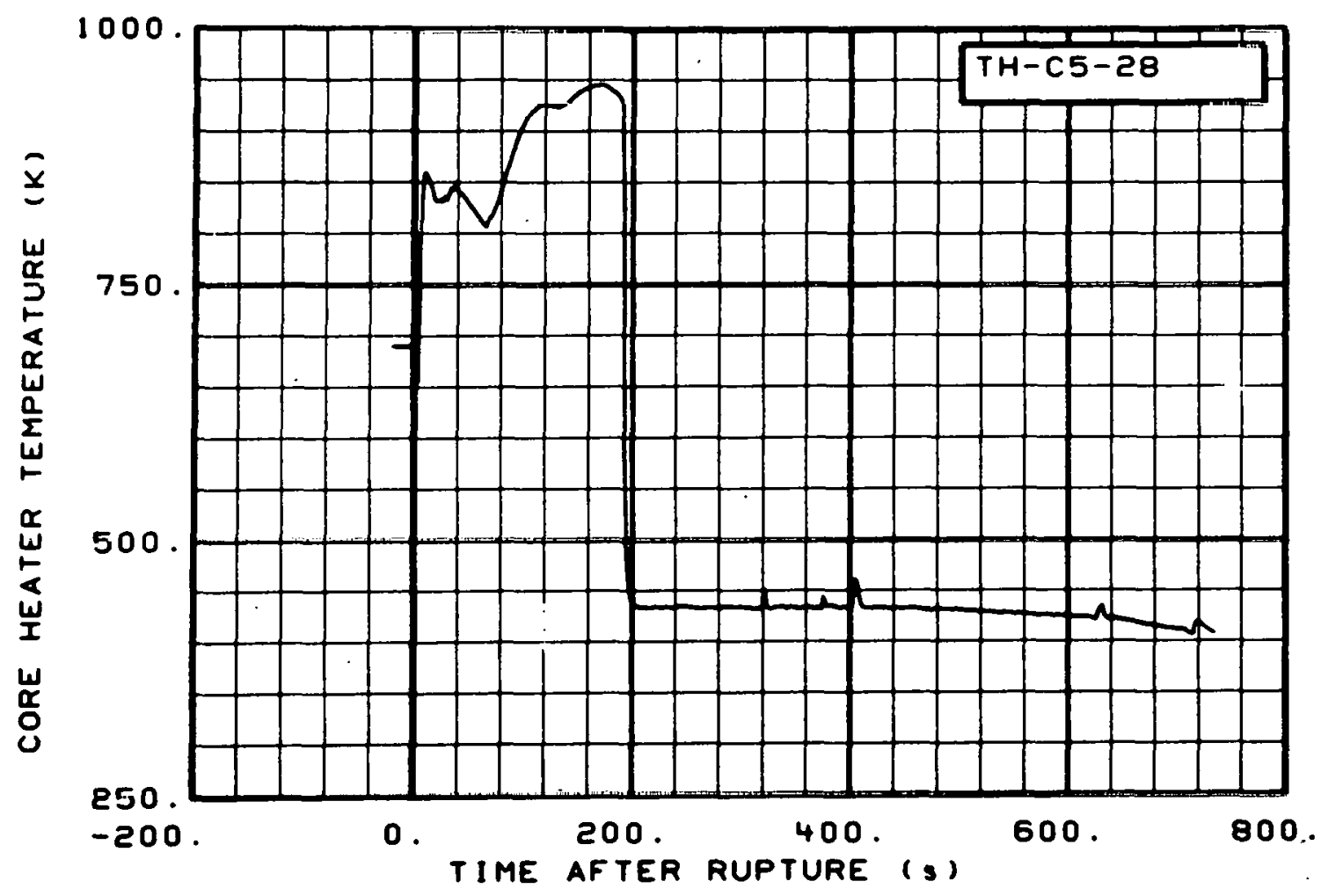

Fig. 99 Core heater temperature, Rod $\mathrm{C}-5$ (TH-C5-28), from -20 to $736 \mathrm{~s}$.

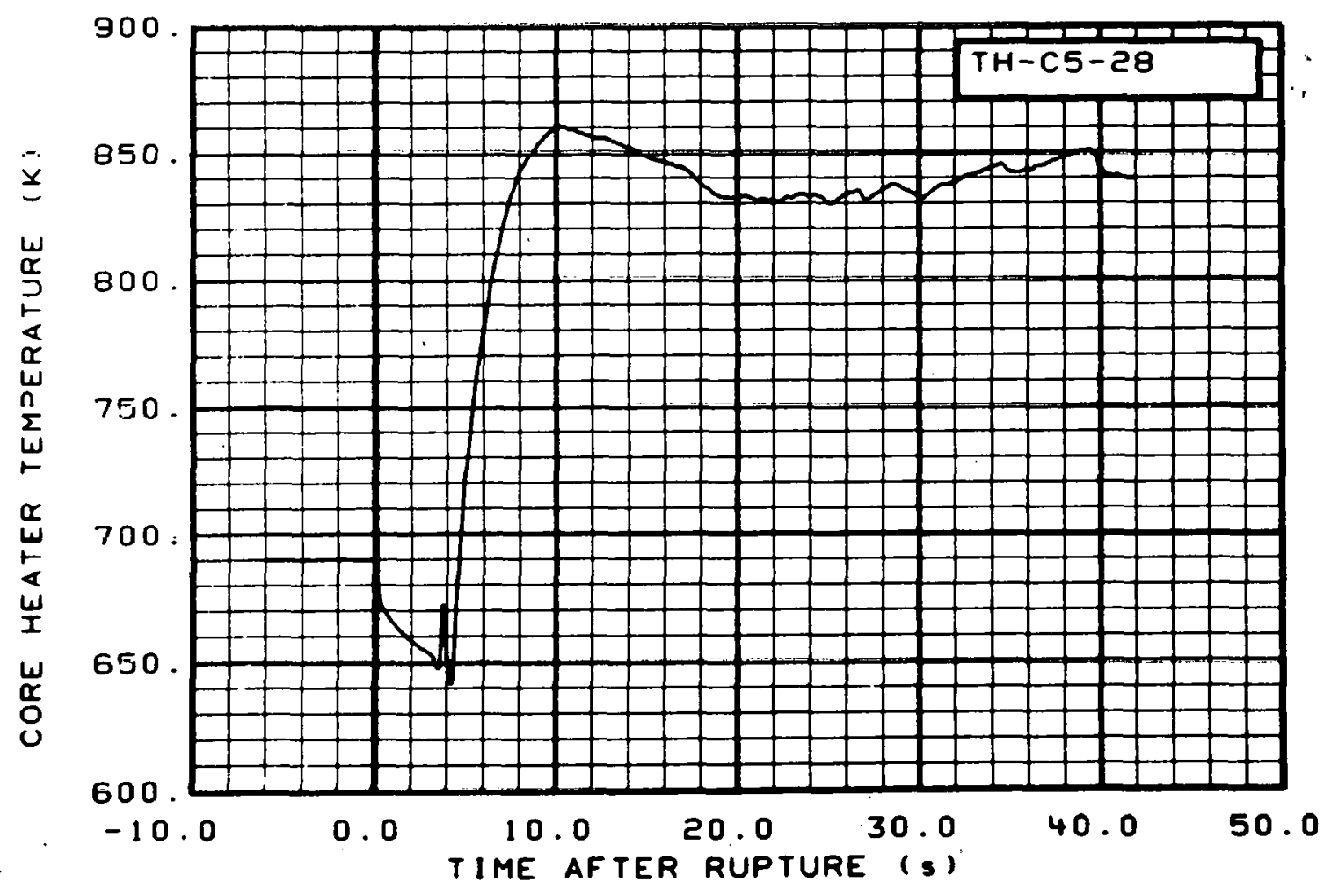

Fig. 100 Core heater temperature, Rod C-5 (TH-C5-28), from -6 to $42 \mathrm{~s}$. 


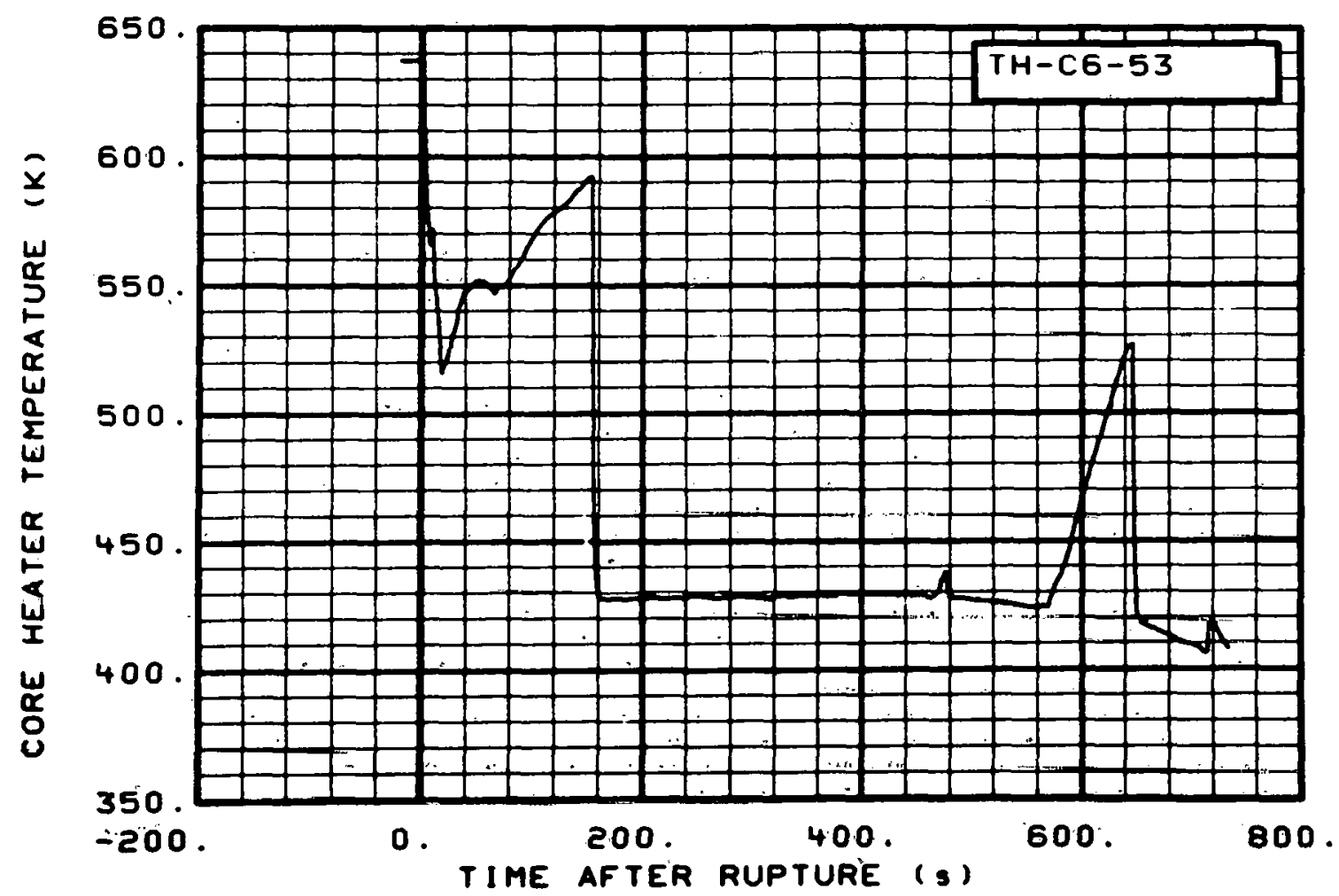

Fig. 101 Core heater temperature, Rod C-6 (TH-C6-53), from -20 to $736 \mathrm{~s}$.

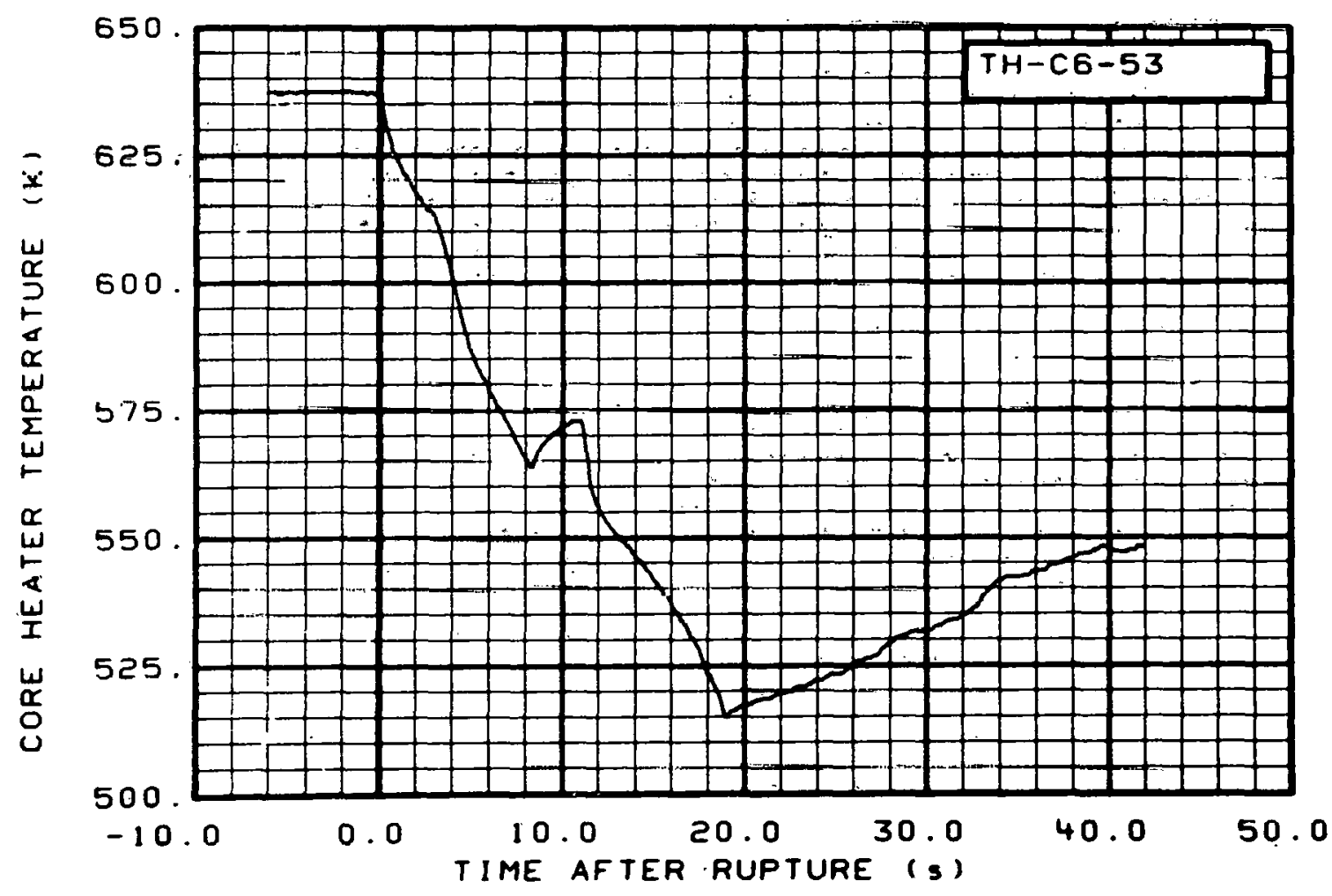

Fig. 102 Core heater temperature, Rod C-6 (TH-C6-53), from -6 to $42 \mathrm{~s}$. 


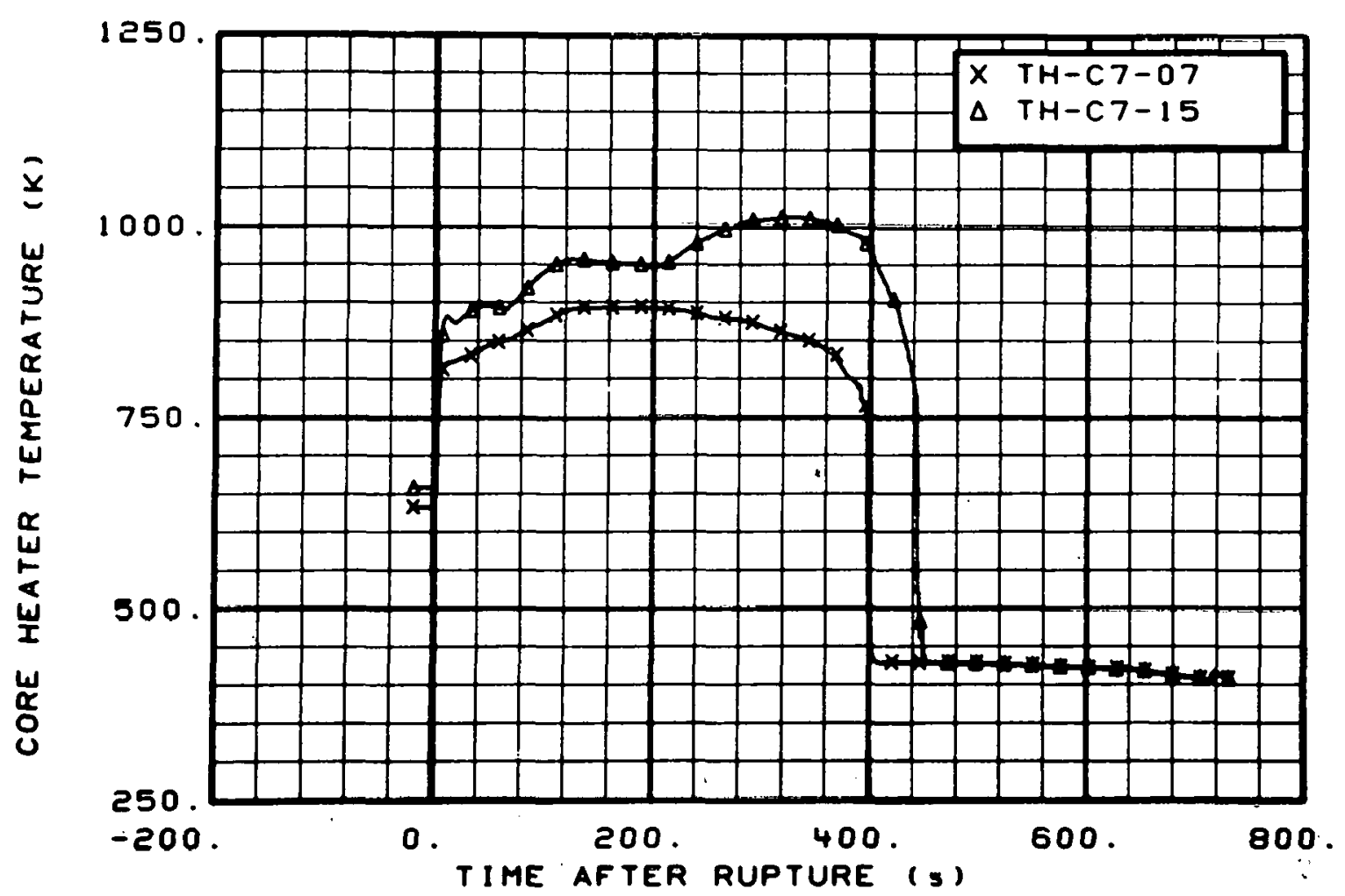

Fig. 103 Core heater temperature, Rod C-7 (TH-C7-07 and TH-C7-15), from -20 to $736 \mathrm{~s}$.

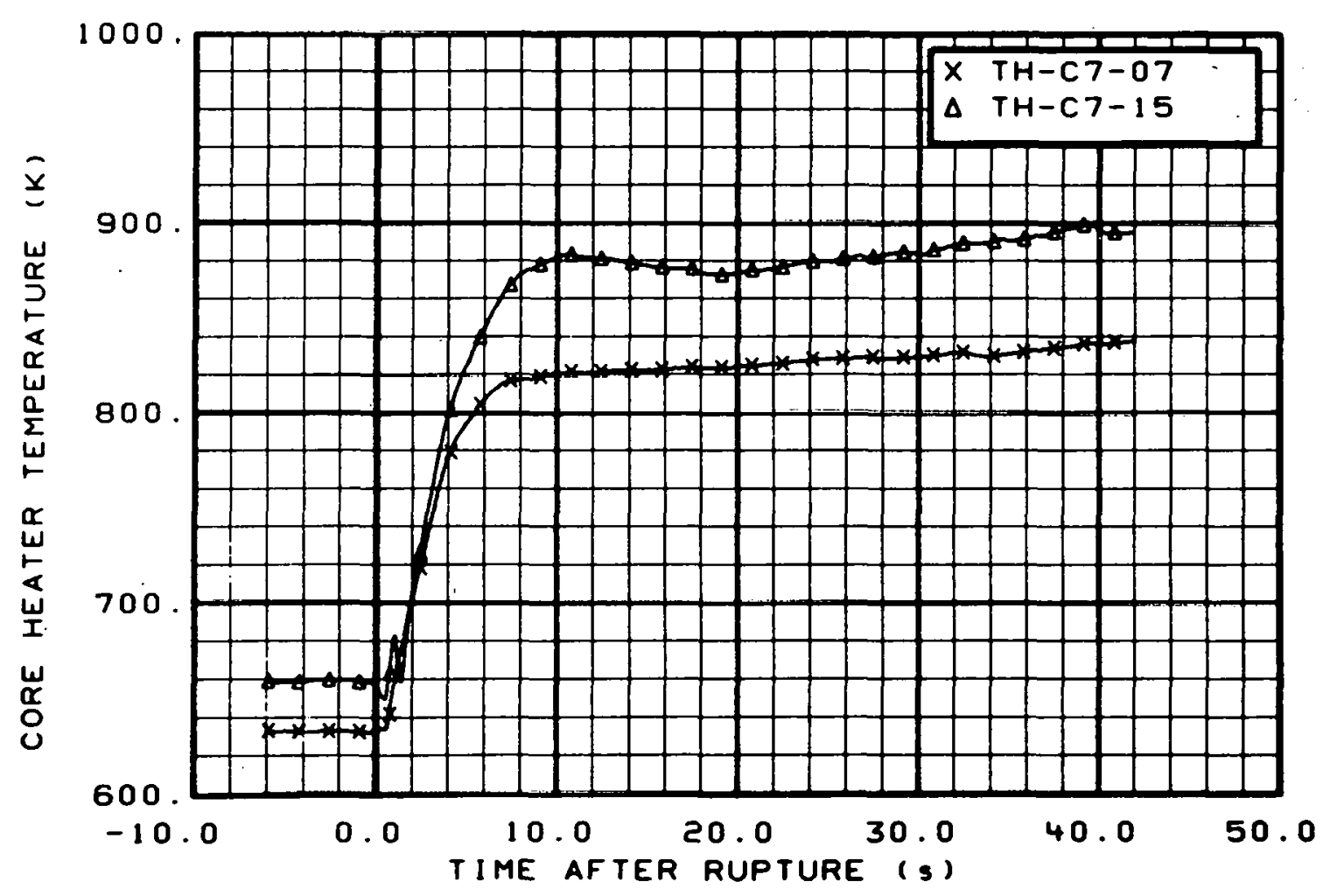

Fig. 104 Core heater temperature, Rod C-7 (TH-C7-07 and TH-C.7-15), from -6 to 42 s. 


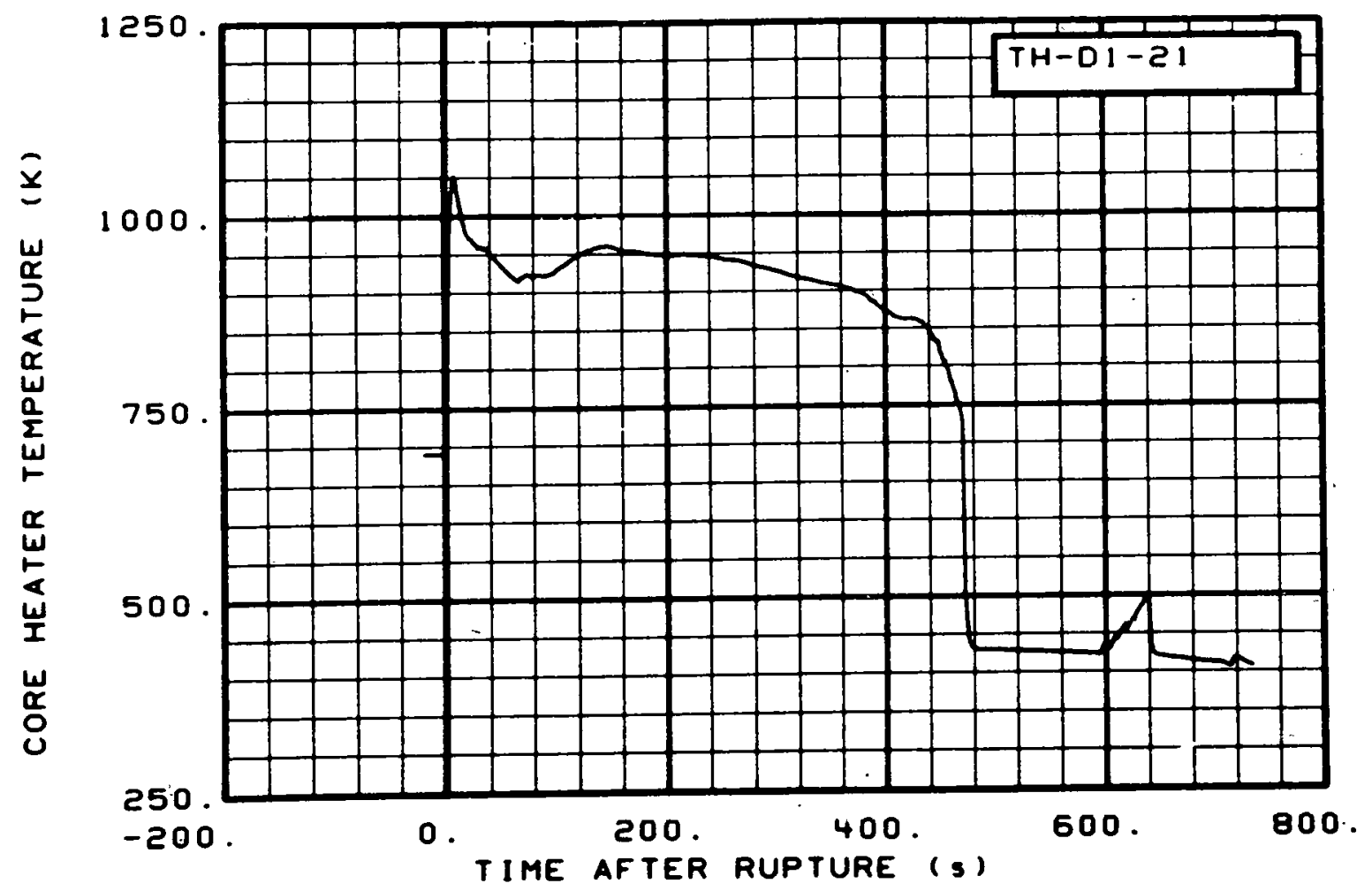

Fig. 105 Core heater temperature, Rod D-1 (TH-DI-21), from -20 to $736 \mathrm{~s}$.

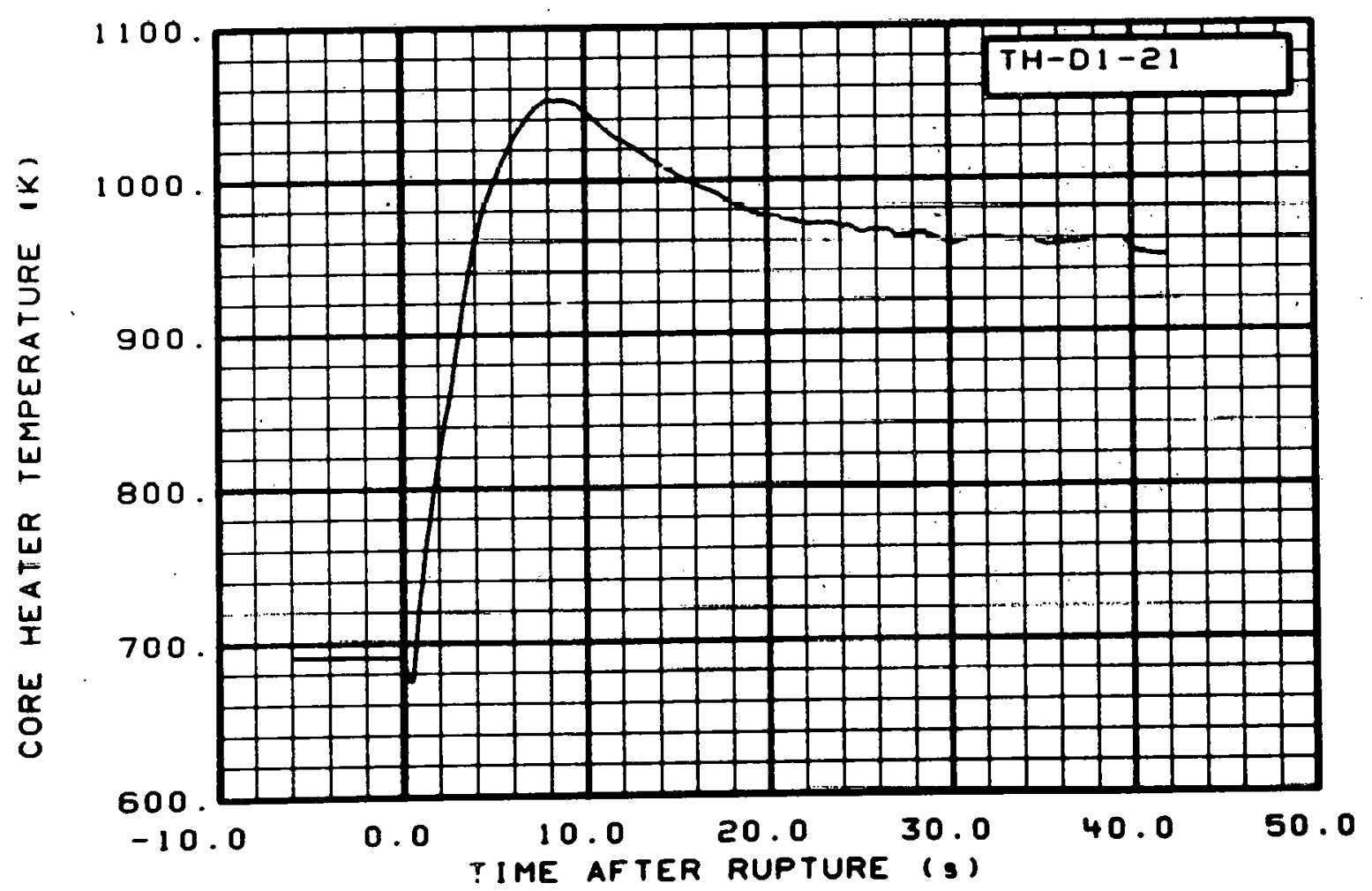

Fig. 106 Core heater temperature, Rod D-1 (TH-DI-21), from -6 to $42 \mathrm{~s}$. 


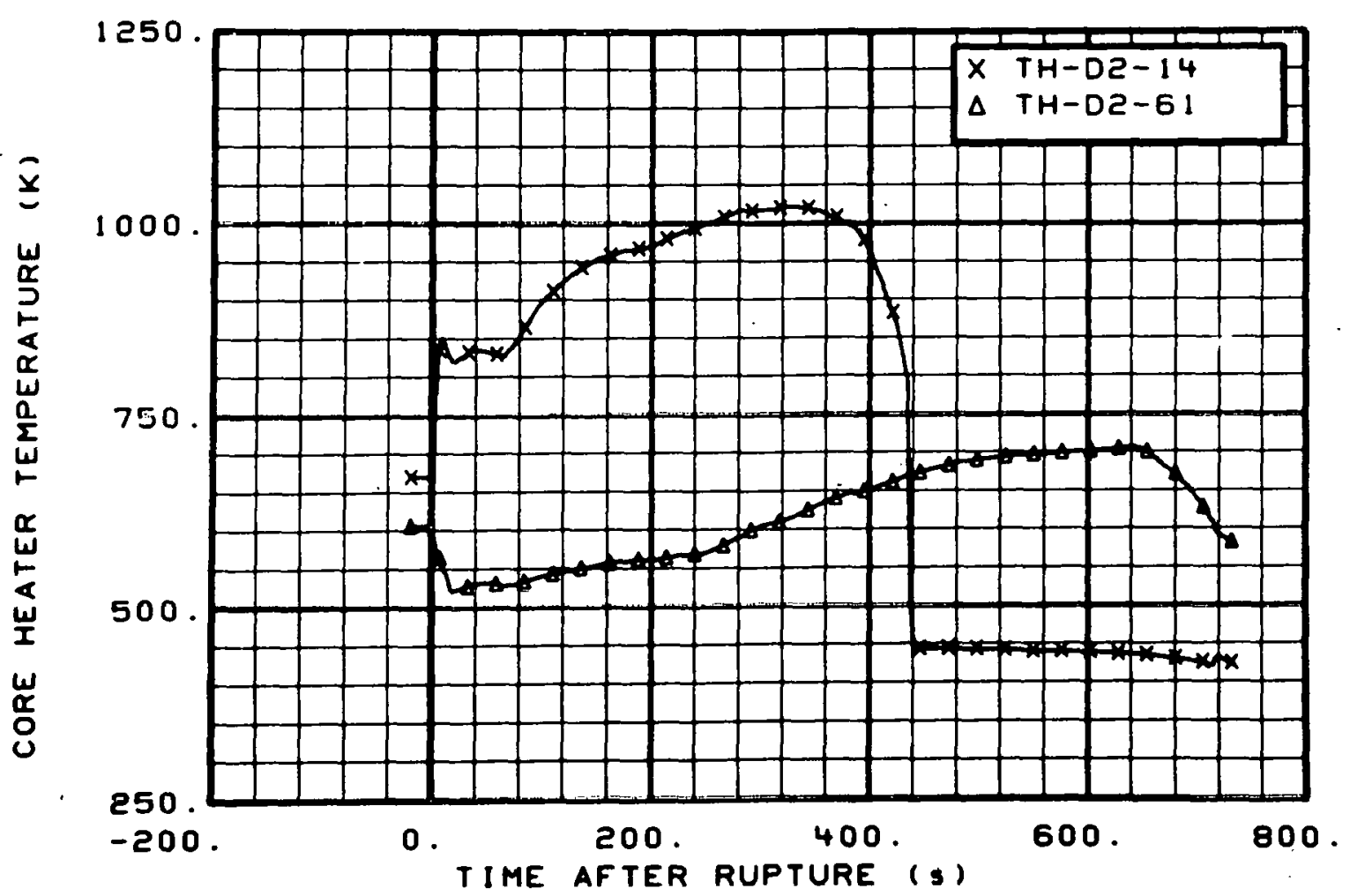

Fig. 107 Core heater temperature, Rod D-2 (TH-D2-14 and TH-D2-61), from -20 to $736 \mathrm{~s}$.

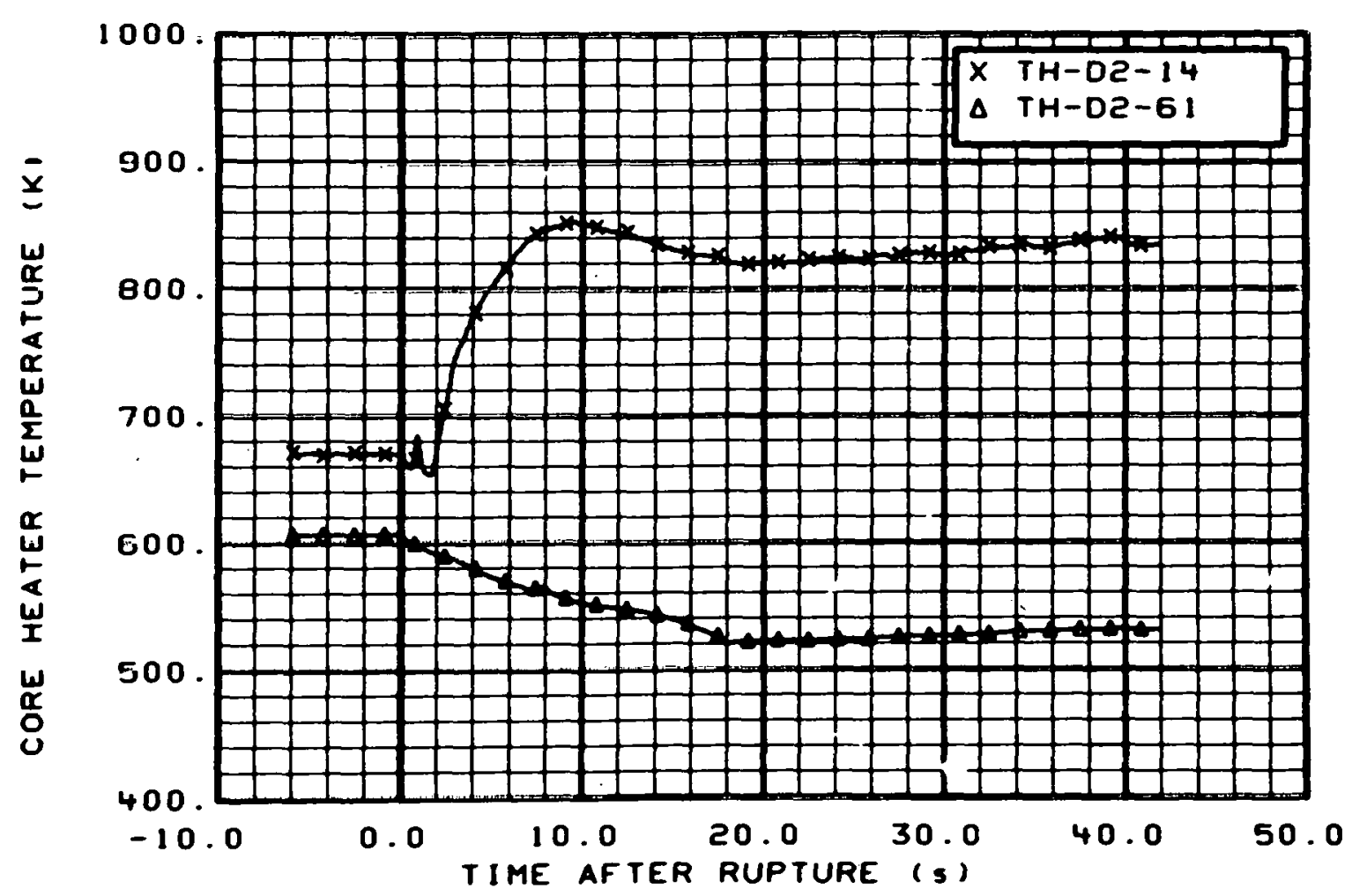

Fiq. 108 Core heater temperature, Rod D-2 (TH-D2-14 and TH-D2-61), from -6 to $42 \mathrm{~s}$. 


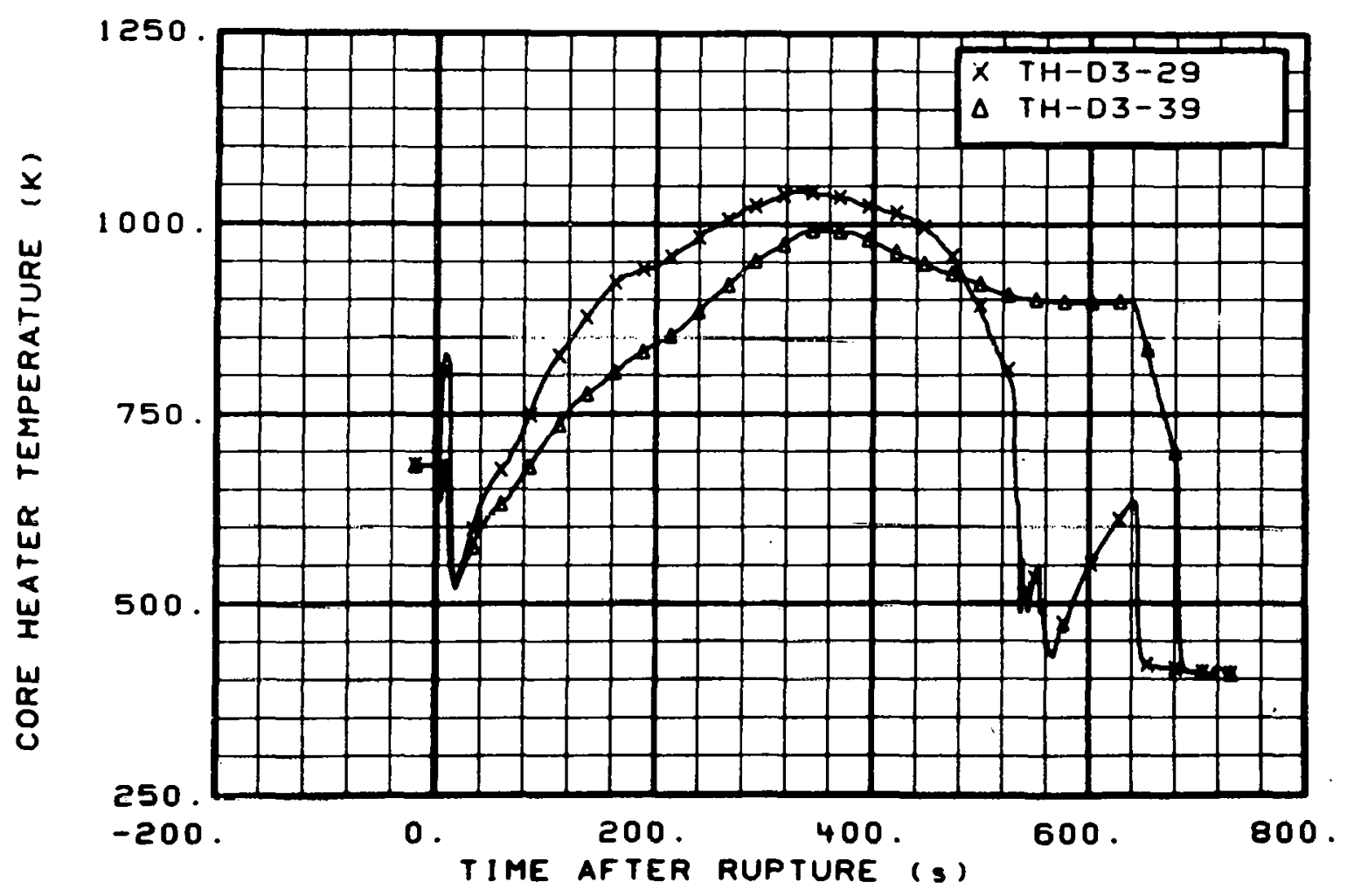

Fig. 109 Core heater temperature, Rod D-3 (TH-D3-29 and TH-D3-39), from -20 to $736 \mathrm{~s}$.

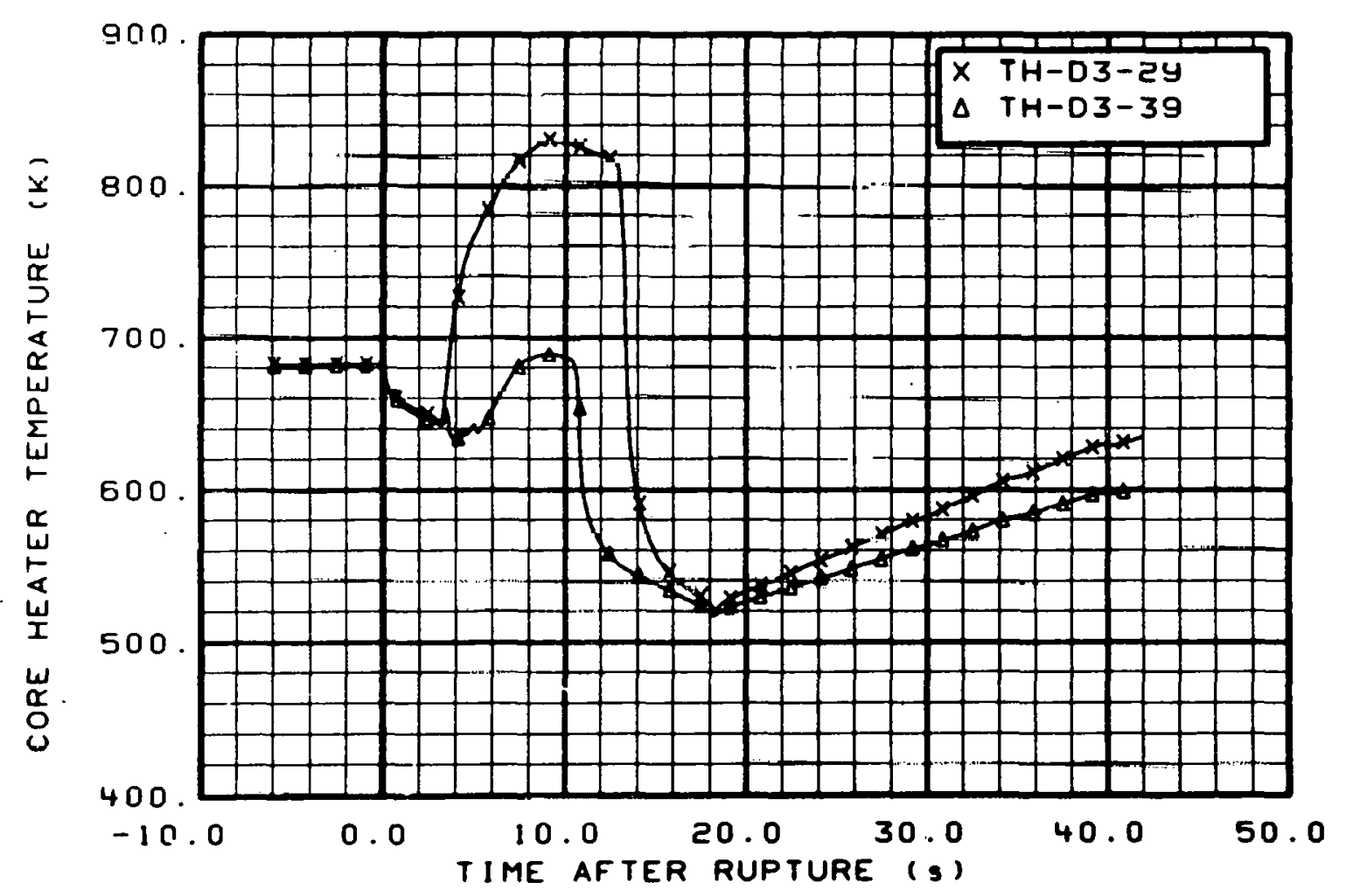

Fig. 110 Core heater temperature, Rod D-3 (TH-D3-29 and TH-D3-39), from -6 to $42 \mathrm{~s}$. 


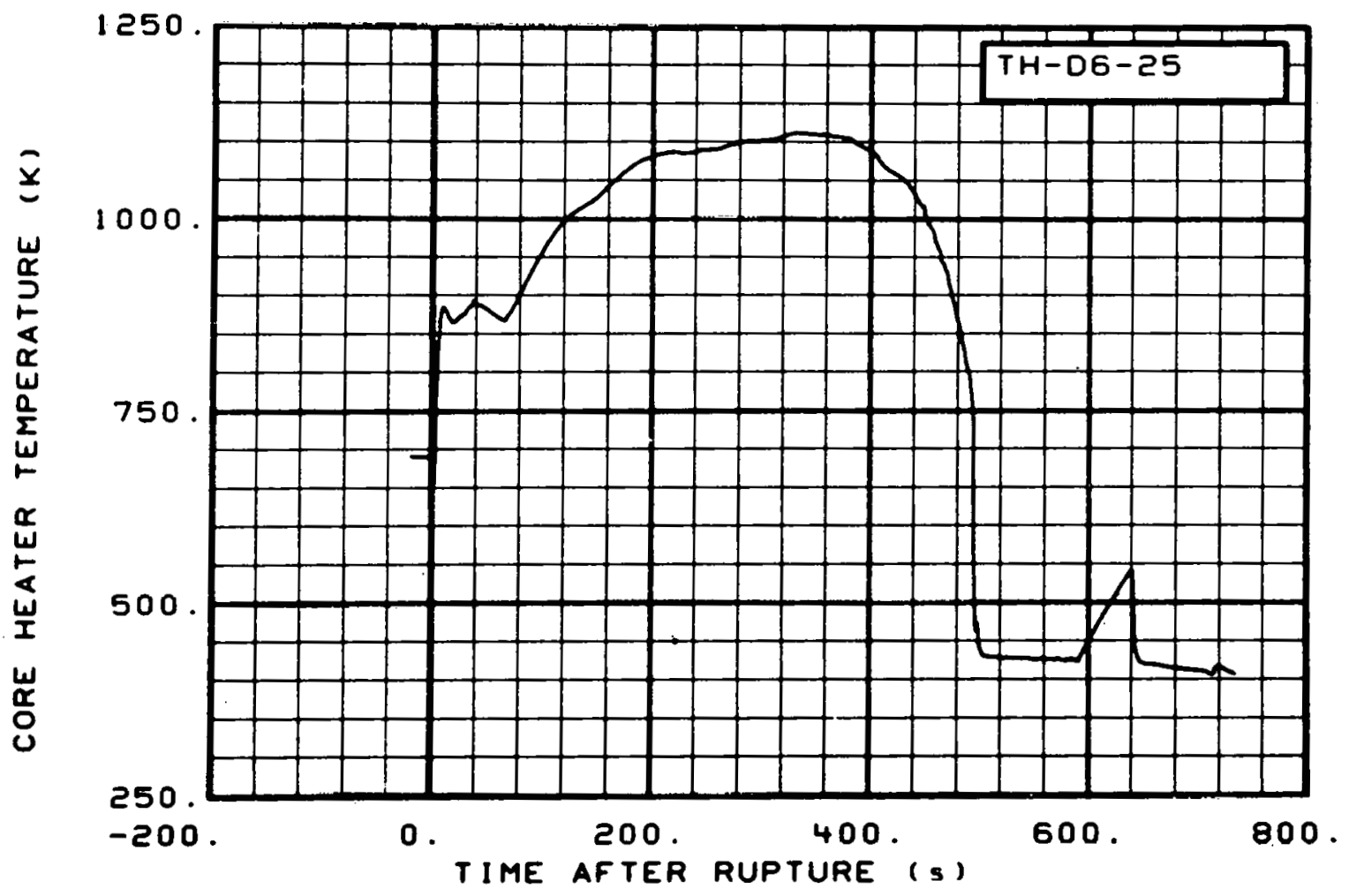

Fig. 111 Core heater temperature, Rod D-6 (TH-D6-25), from -20 to $736 \mathrm{~s}$.

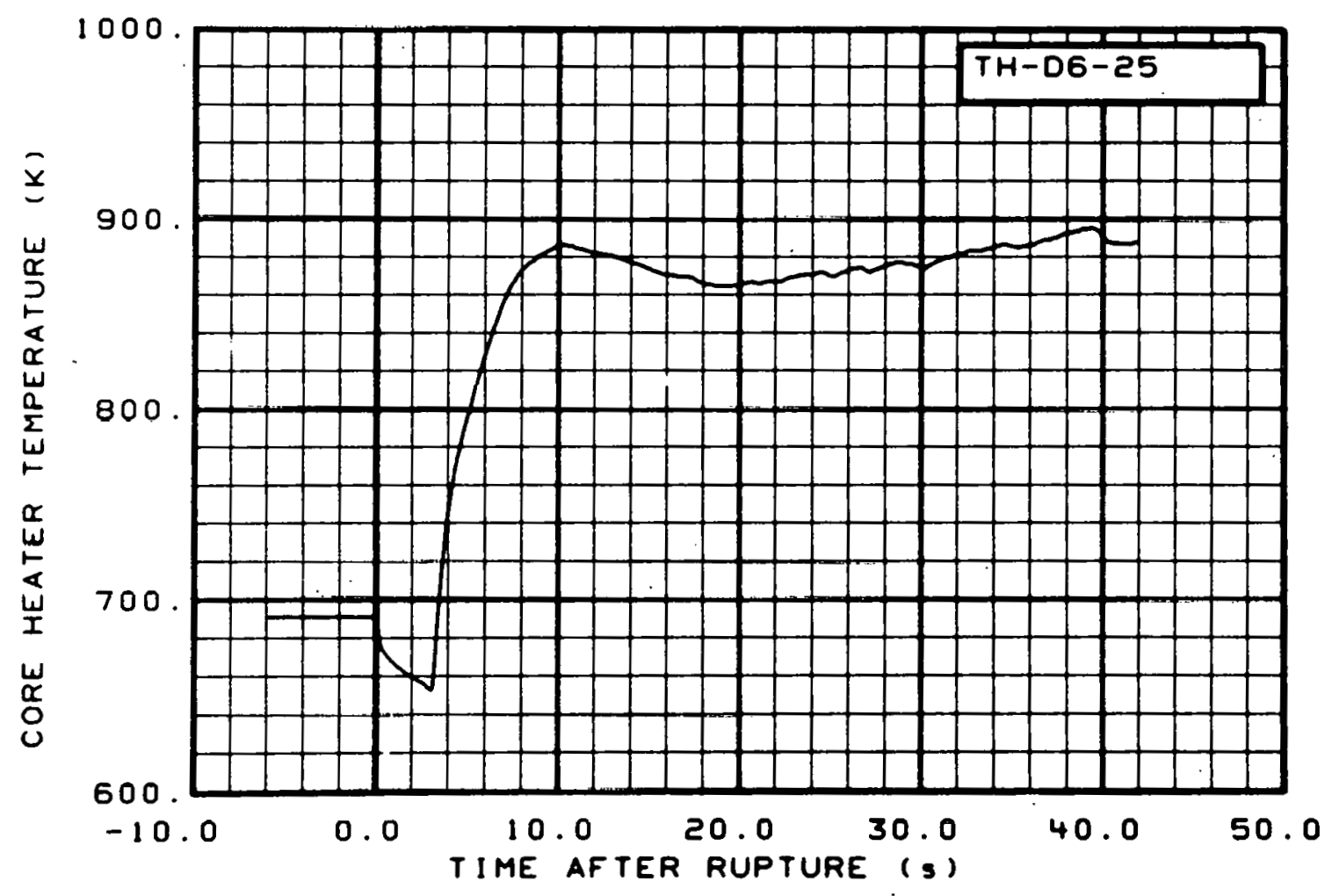

Fig. 112 Core heater temperature, Rod D-6 (TH-D6-25), from -6 to $42 \mathrm{~s}$. 


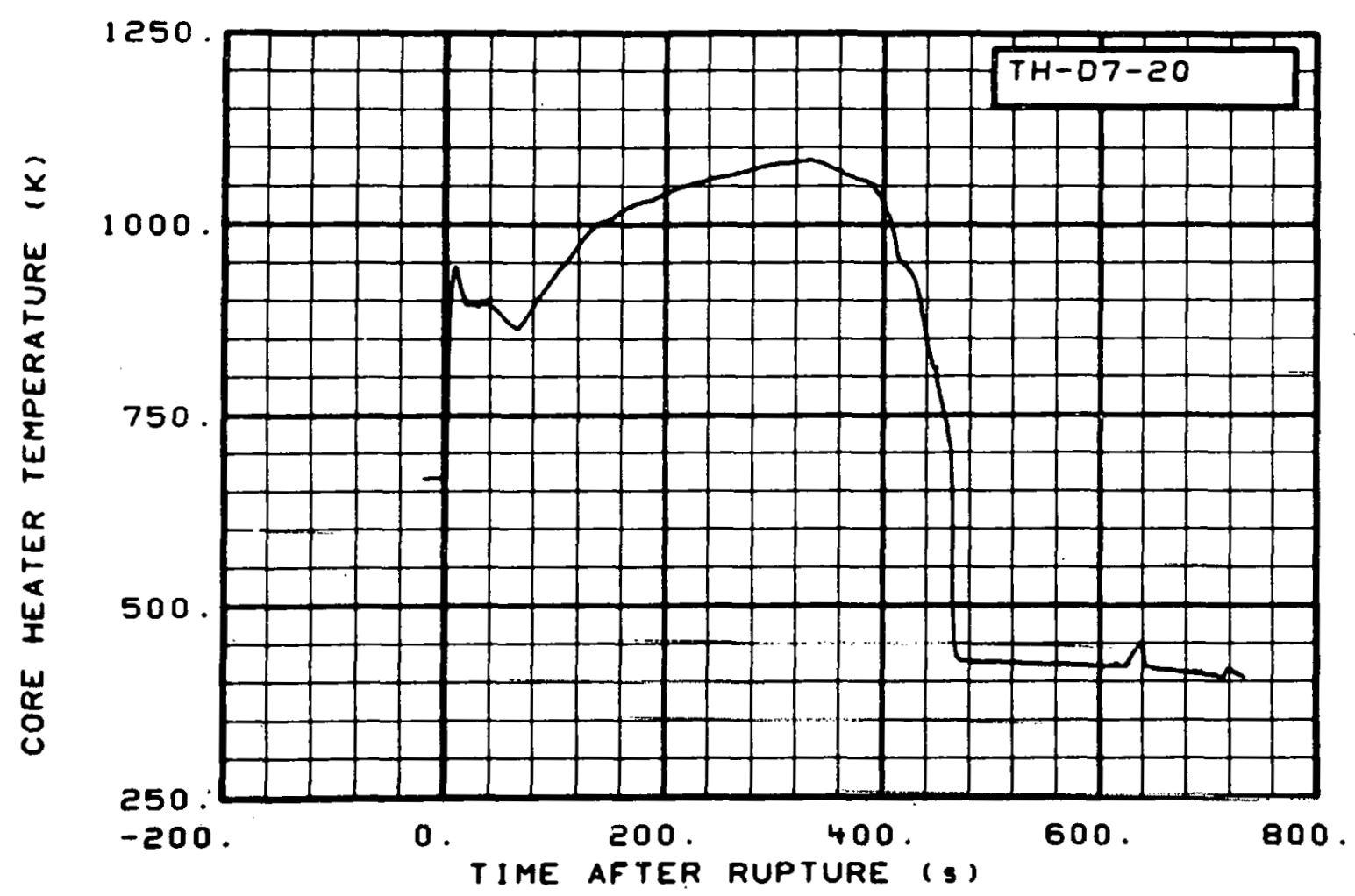

Fig. 113 Core heater temperature, Rod D-7 (TH-07-20), from -20 to $736 \mathrm{~s}$.

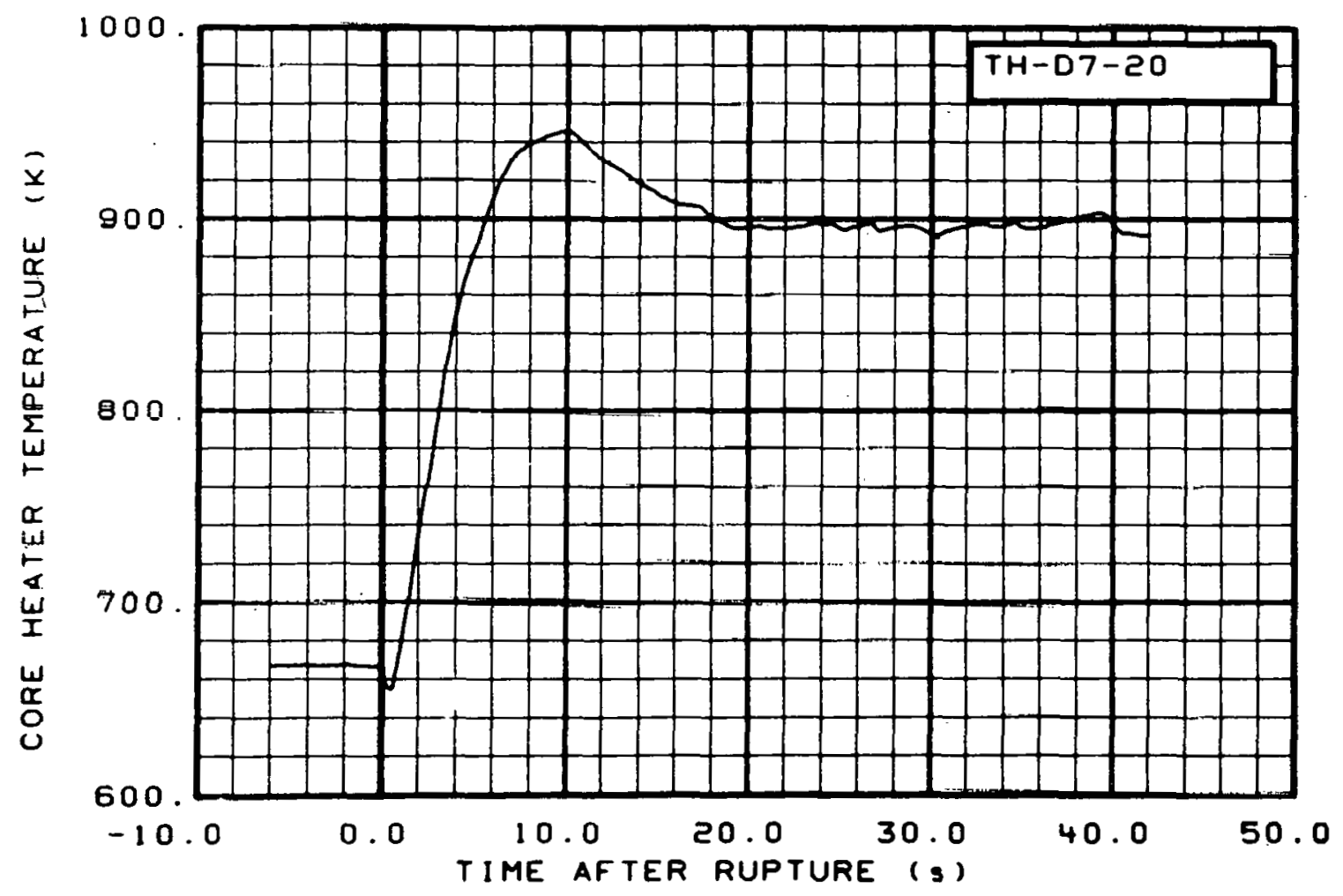

Fig. 114 Core heater temperature, Rod D-7 (TH-D7-20), from -6 to $42 \mathrm{~s}$. 


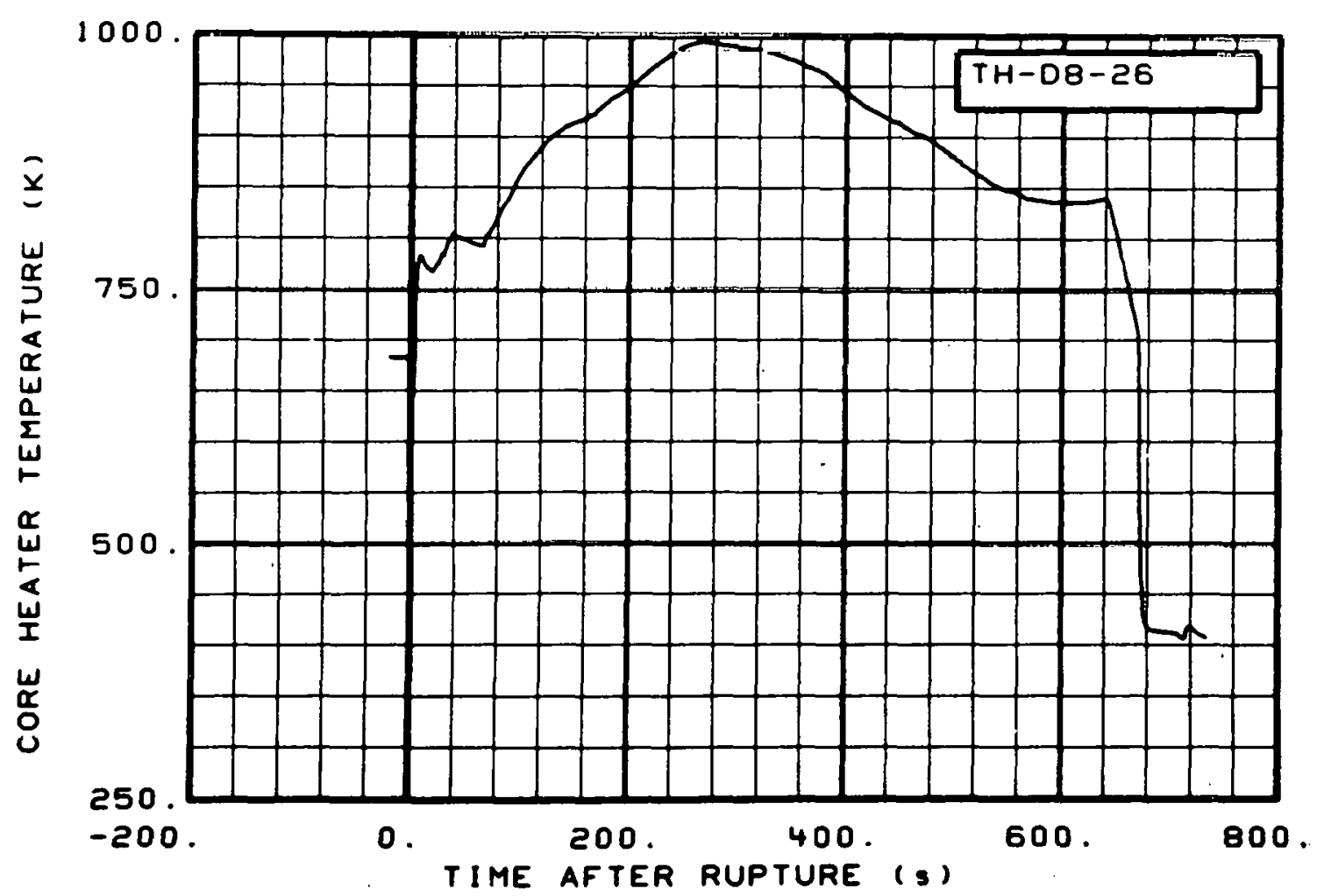

Fig. 115 Core heater temperature, Rod D-8 (TH-D8-26), from -20 to $736 \mathrm{~s}$ :

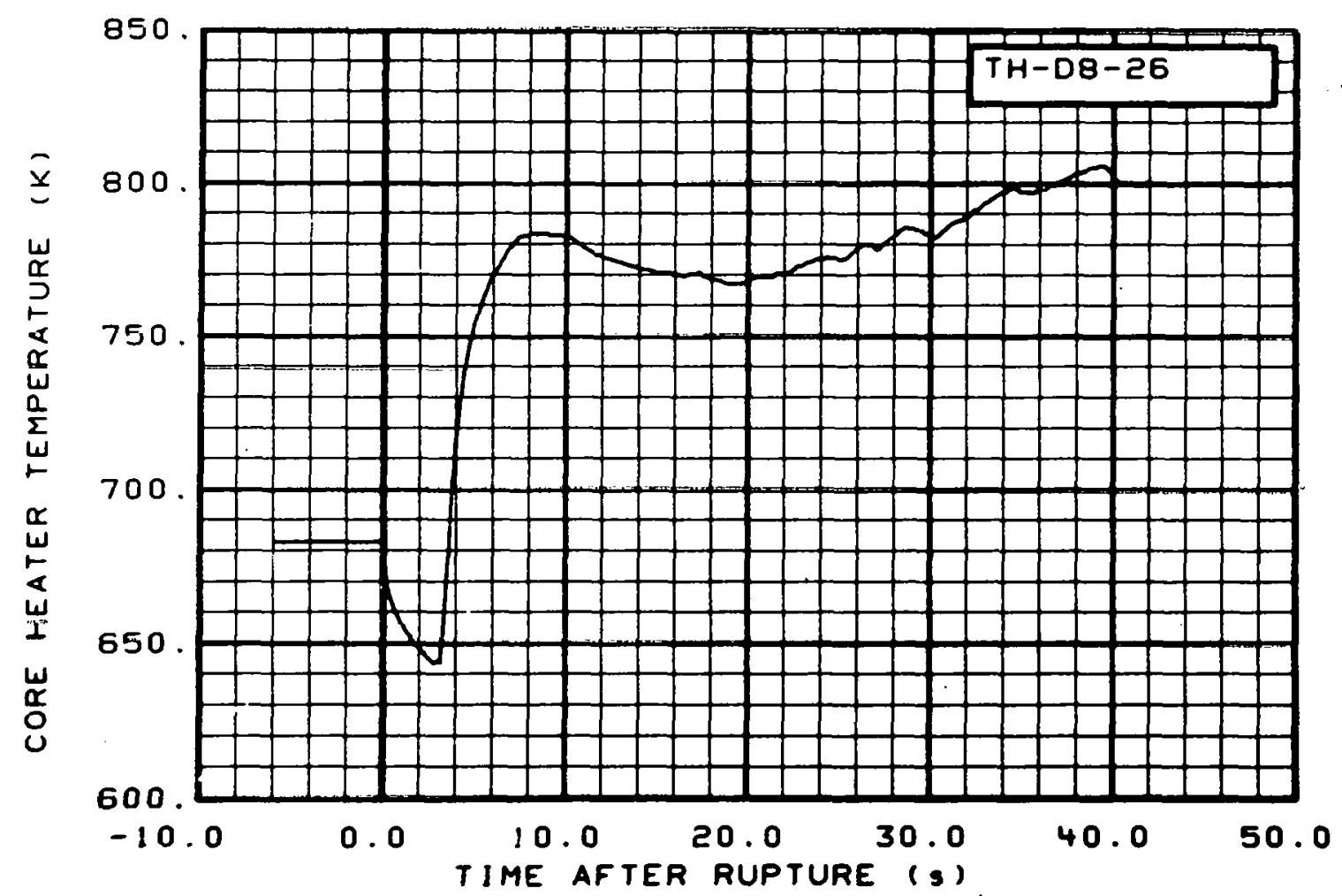

Fig. 116 Core heater temperature, Rud D-8 (TH-D8-26), from -6 to $42 \mathrm{~s}$. 


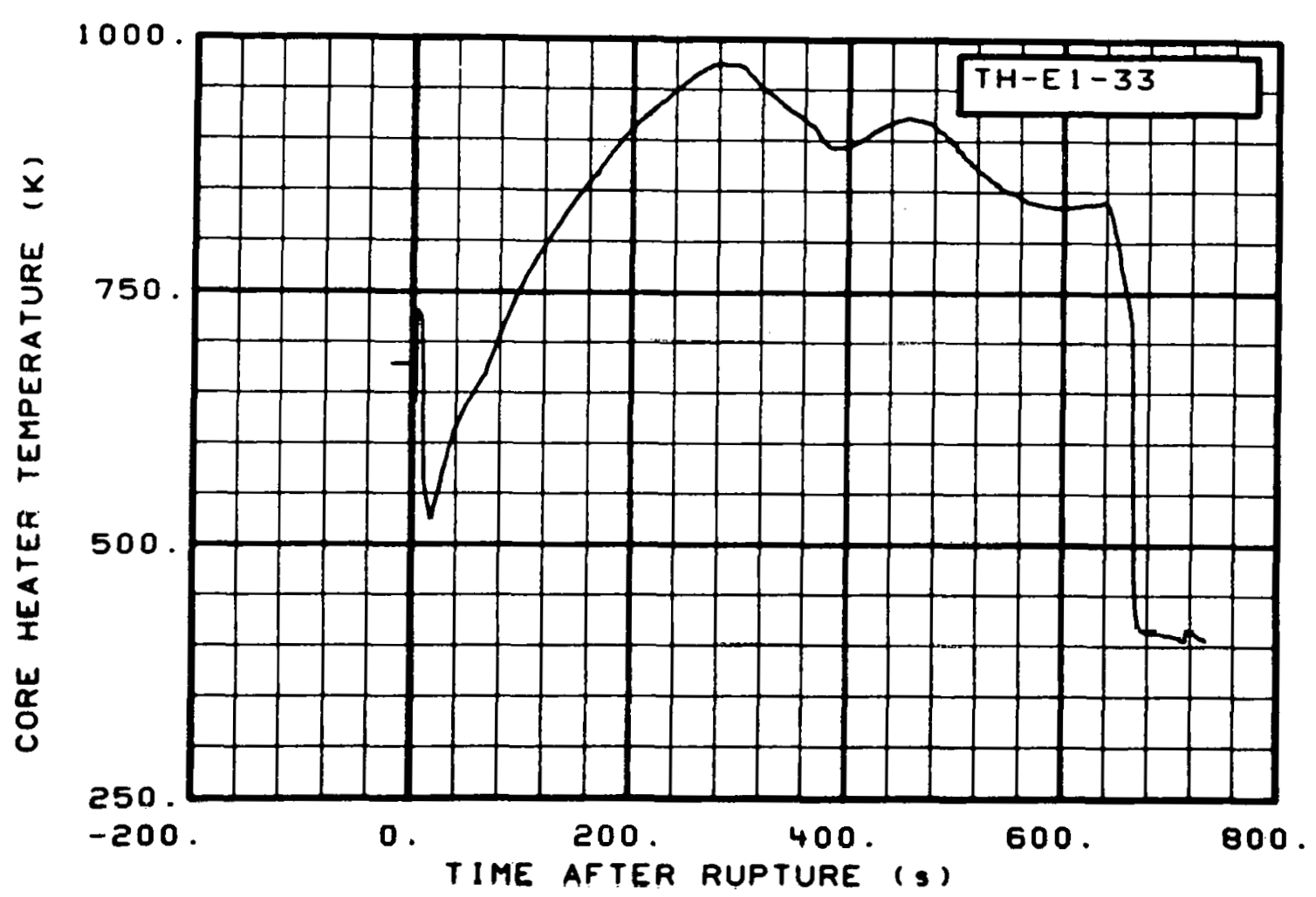

Fig. 117 Core heater temperature, Rod E-1 (TH-El-33), from -20 to $736 \mathrm{~s}$.

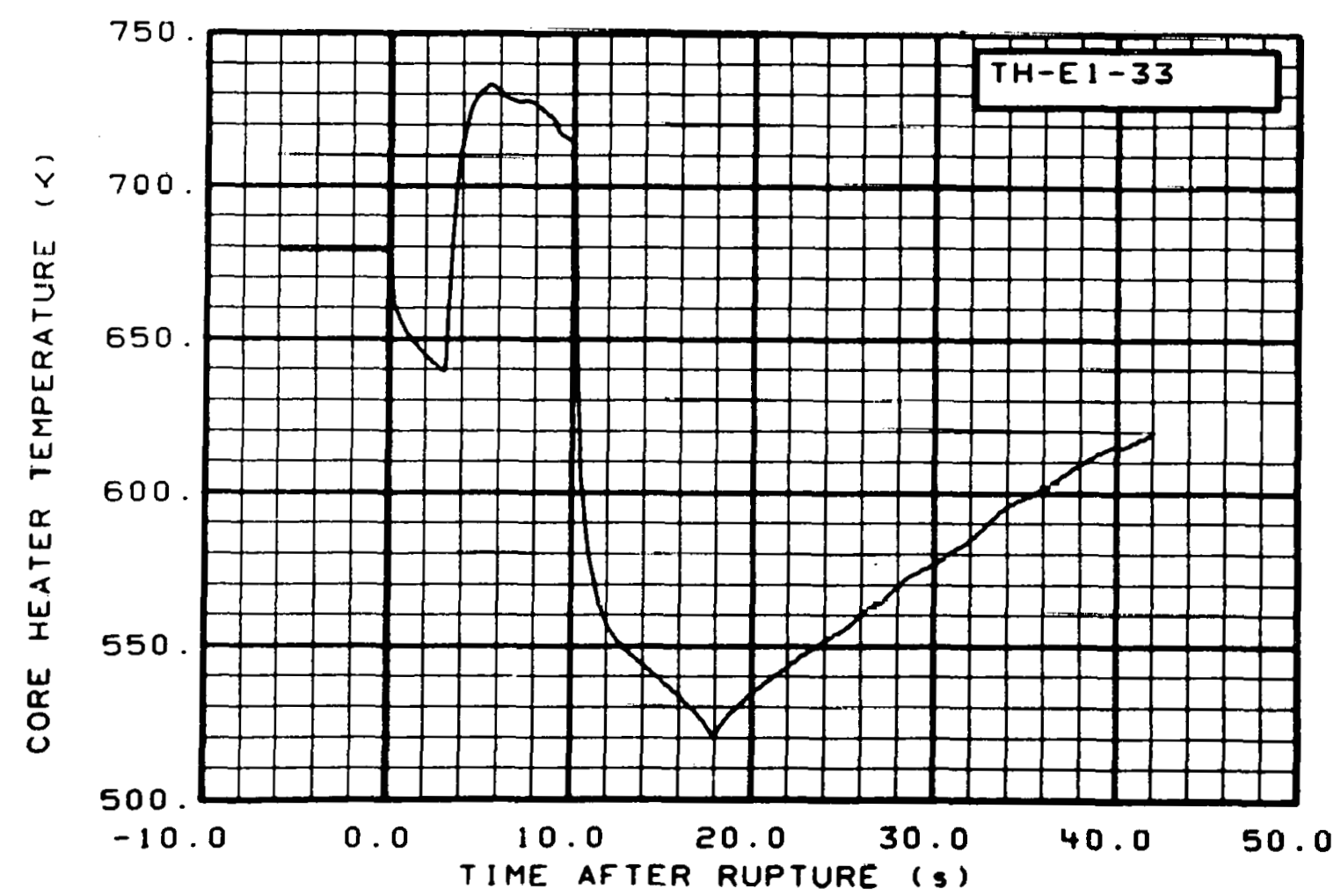

Fìg. 118 Core heater temperature, Rod E-1 (TH-El-33), from -6 to $42 \mathrm{~s}$. 


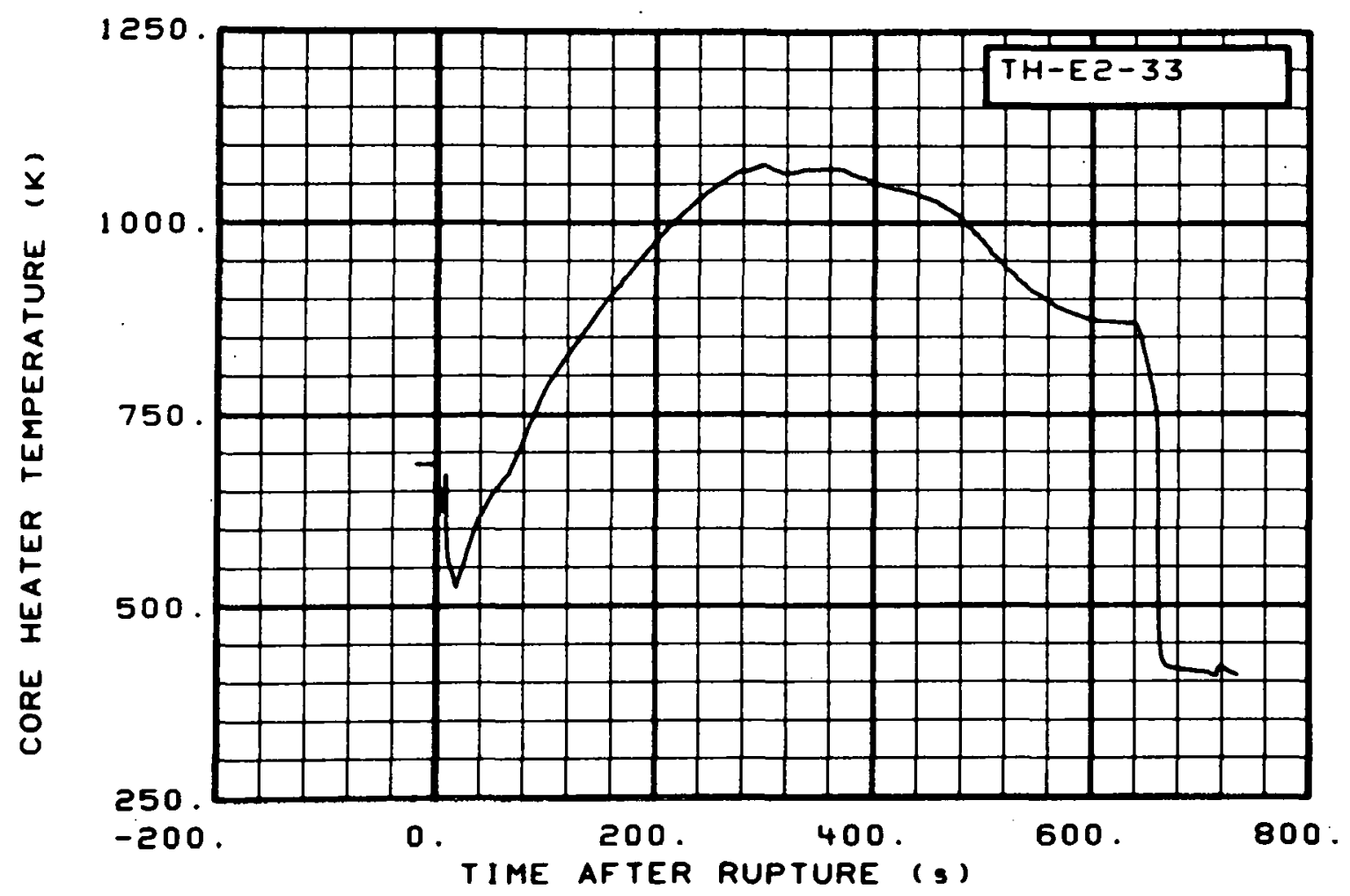

Fig. 119 Core heater temperature, Rod E-2 (TH-E2-33), from -20 to $736 \mathrm{~s}$.

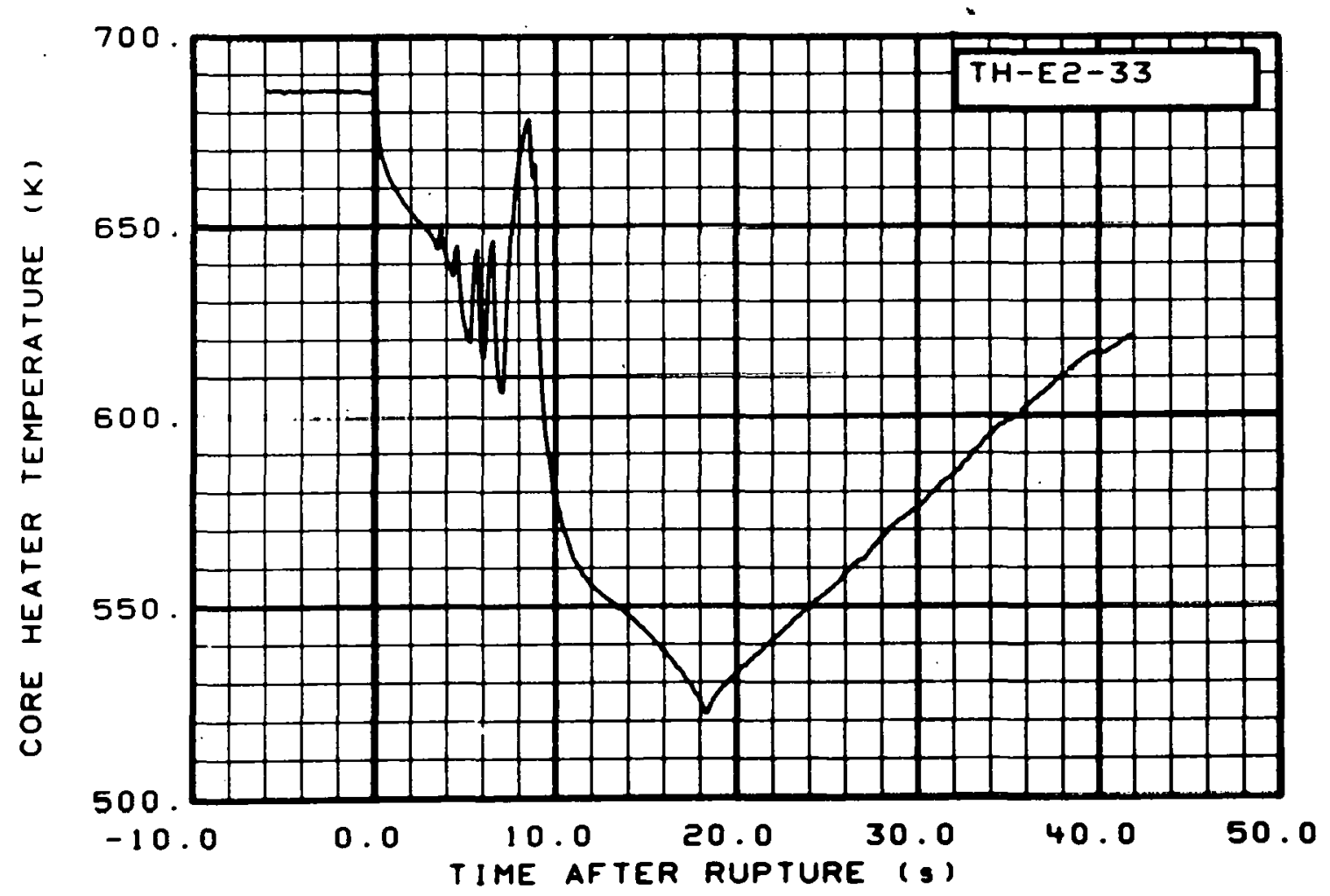

Fig. 120 Core heater temperature, Rod E-2 (TH-E2-33), from -6 to $42 \mathrm{~s}$. 


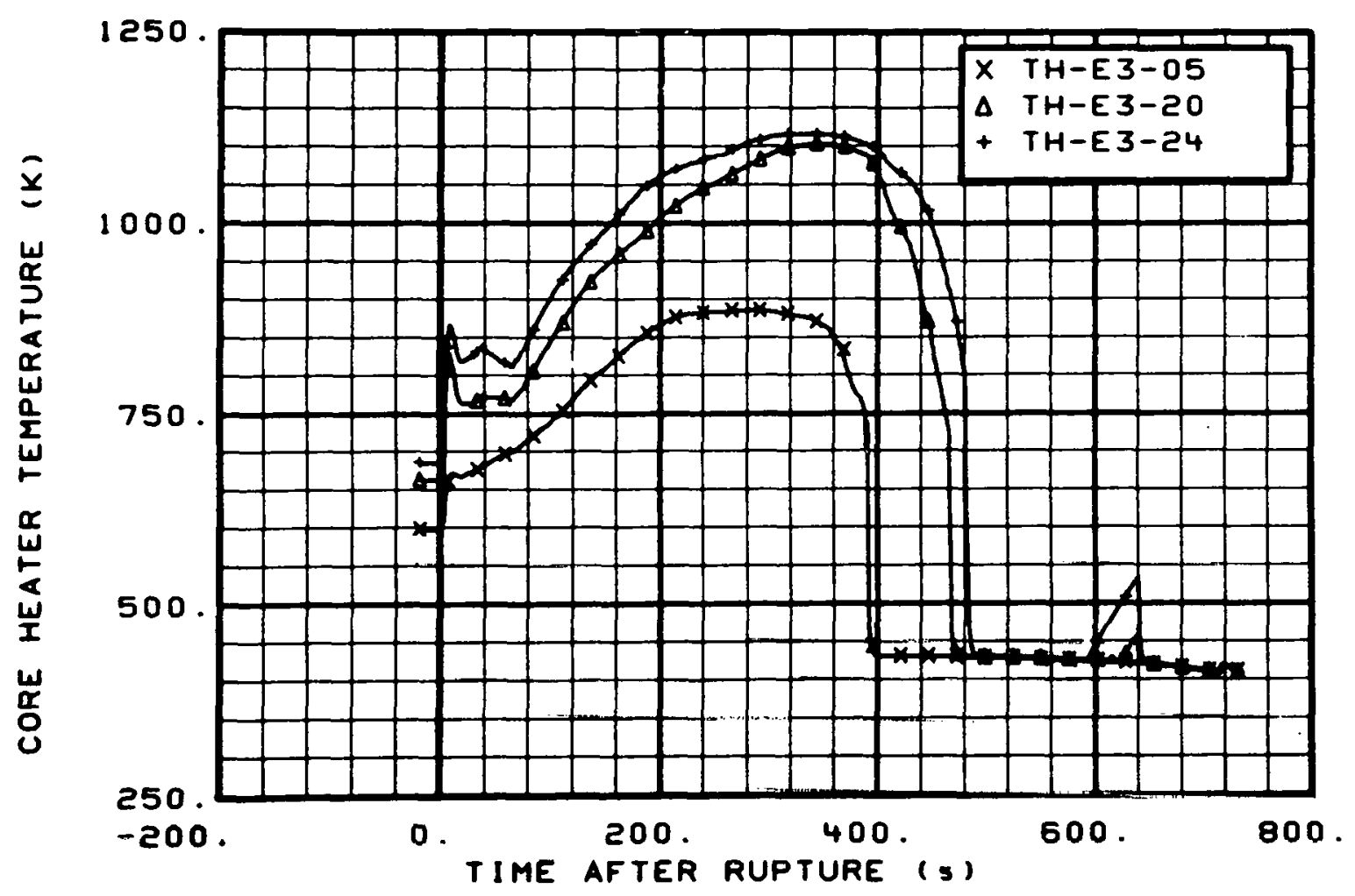

Fig. 121 Core heater temperature, Rod E-3 (TH-E3-05, TH-E3-20, and TH-E3-24), from -20 to $736 \mathrm{~s}$.

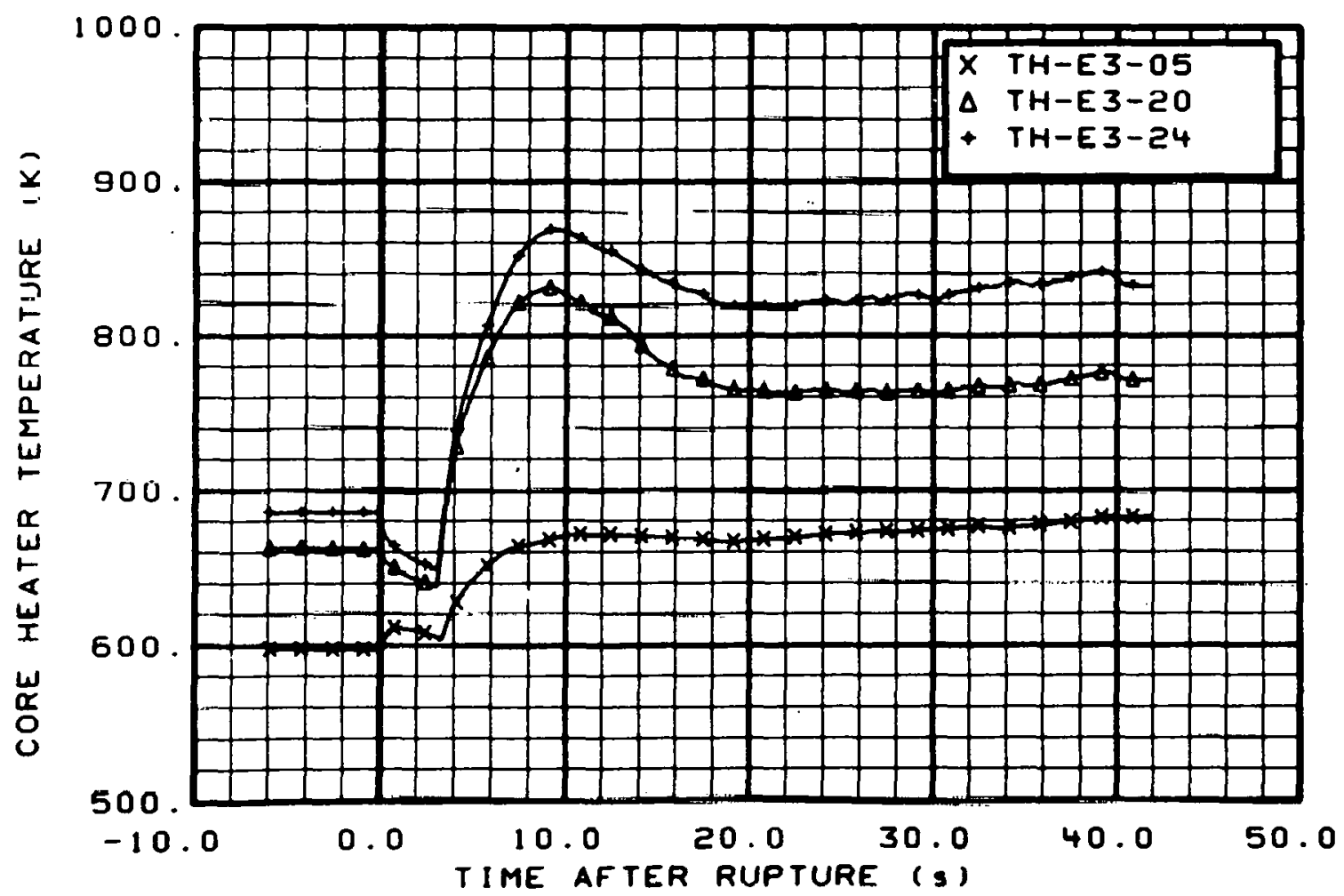

Fig. 122 Core heater temperature, Rod E-3 (TH-E3-05, TH-E3-20, and TH-E3-24), from -6 to $42 \mathrm{~s}$. 


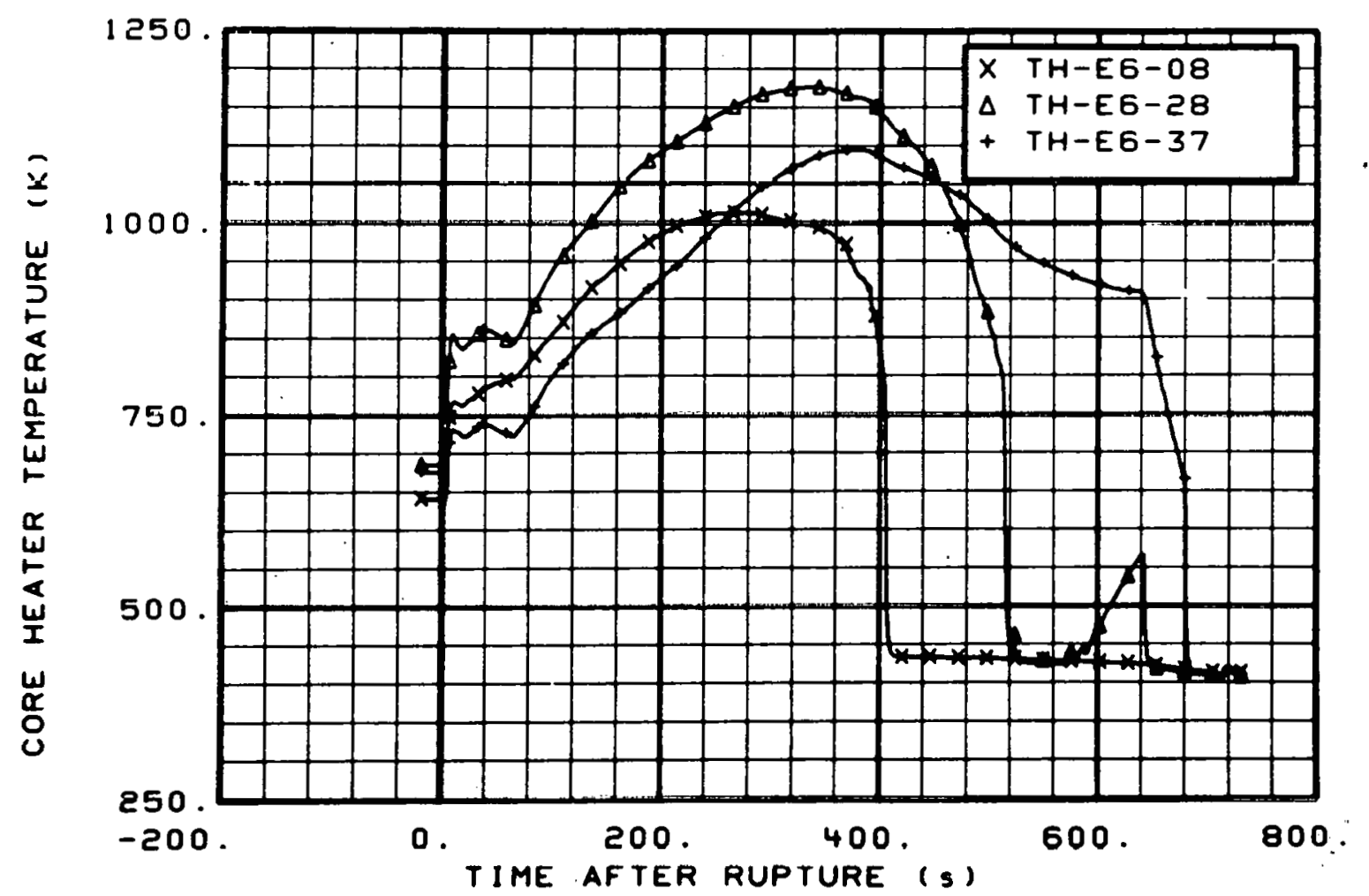

Fig. 123 Core heater temperature, Rod E-6 (TH-E6-08, TH-E6-28, and TH-E6-37), from -20 to $736 \mathrm{~s}$.

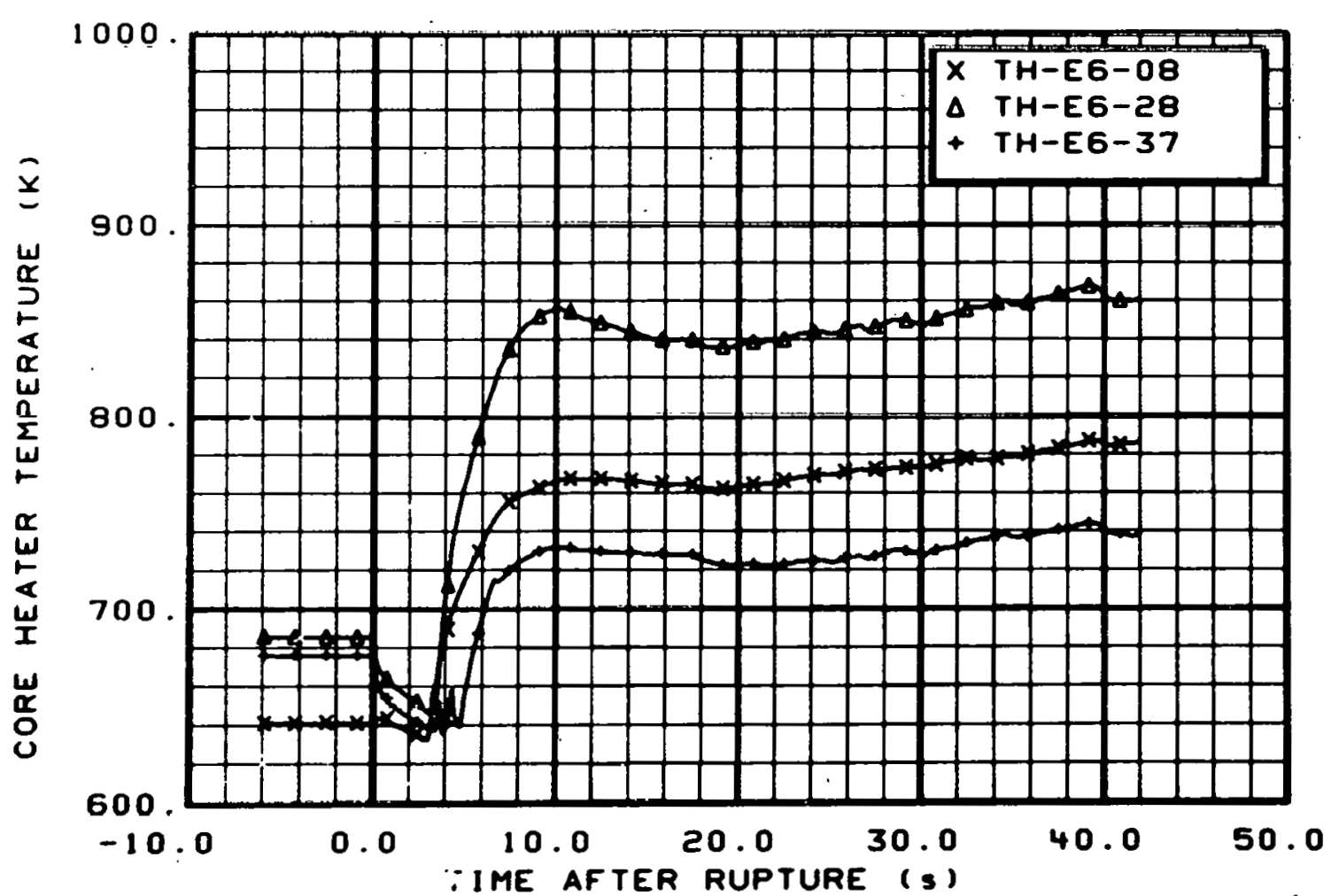

Fig. 124 Core heater temperature, Rod E-6 (TH-E6-08, TH-E6-28, and $\mathrm{TH}-\mathrm{E} 6-37$ ), from -6 to $42 \mathrm{~s}$. 


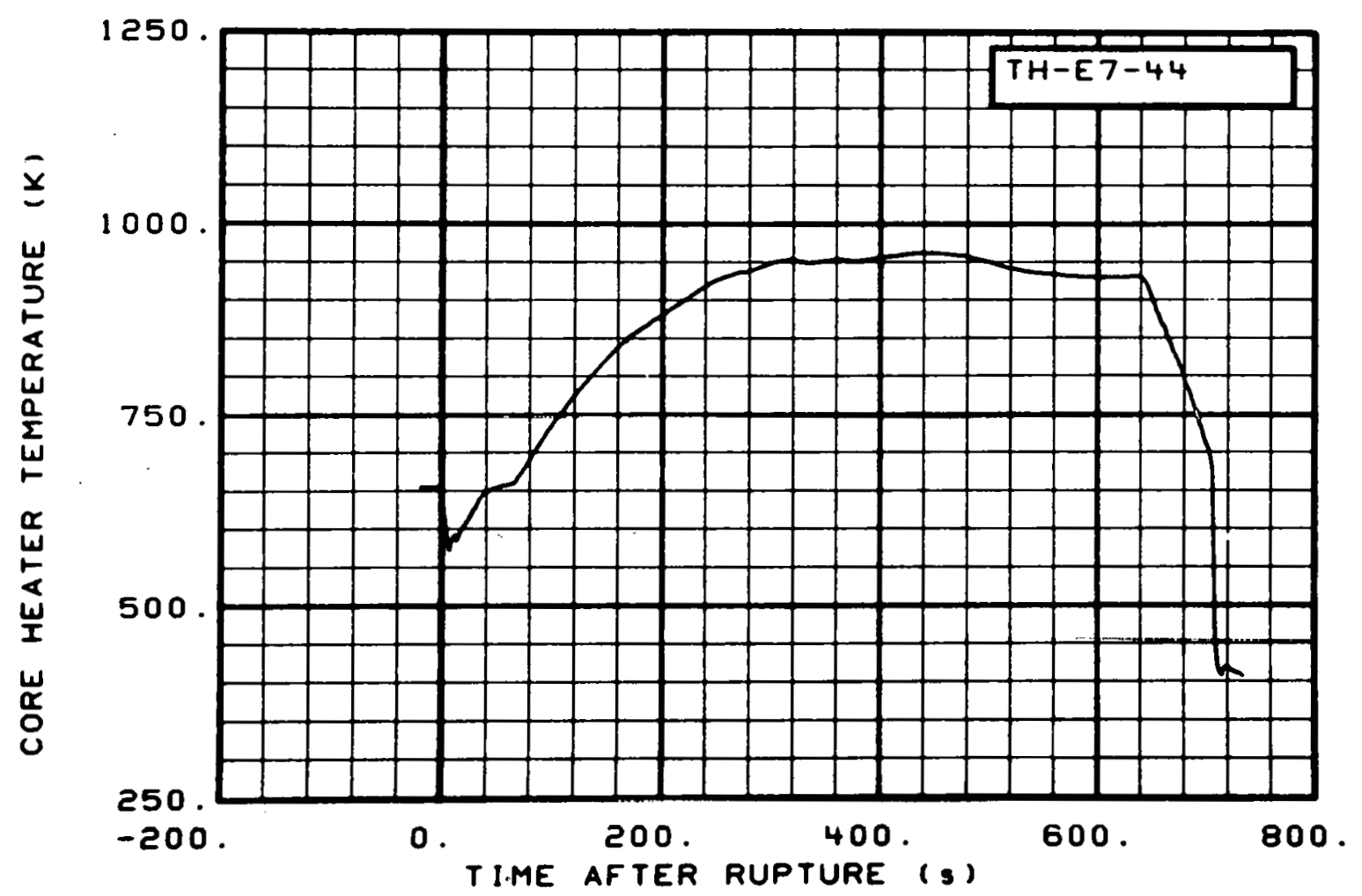

Fig. 125 Core heater temperature, Rod E-7 (TH-E7-44), from -20 to $736 \mathrm{~s}$.

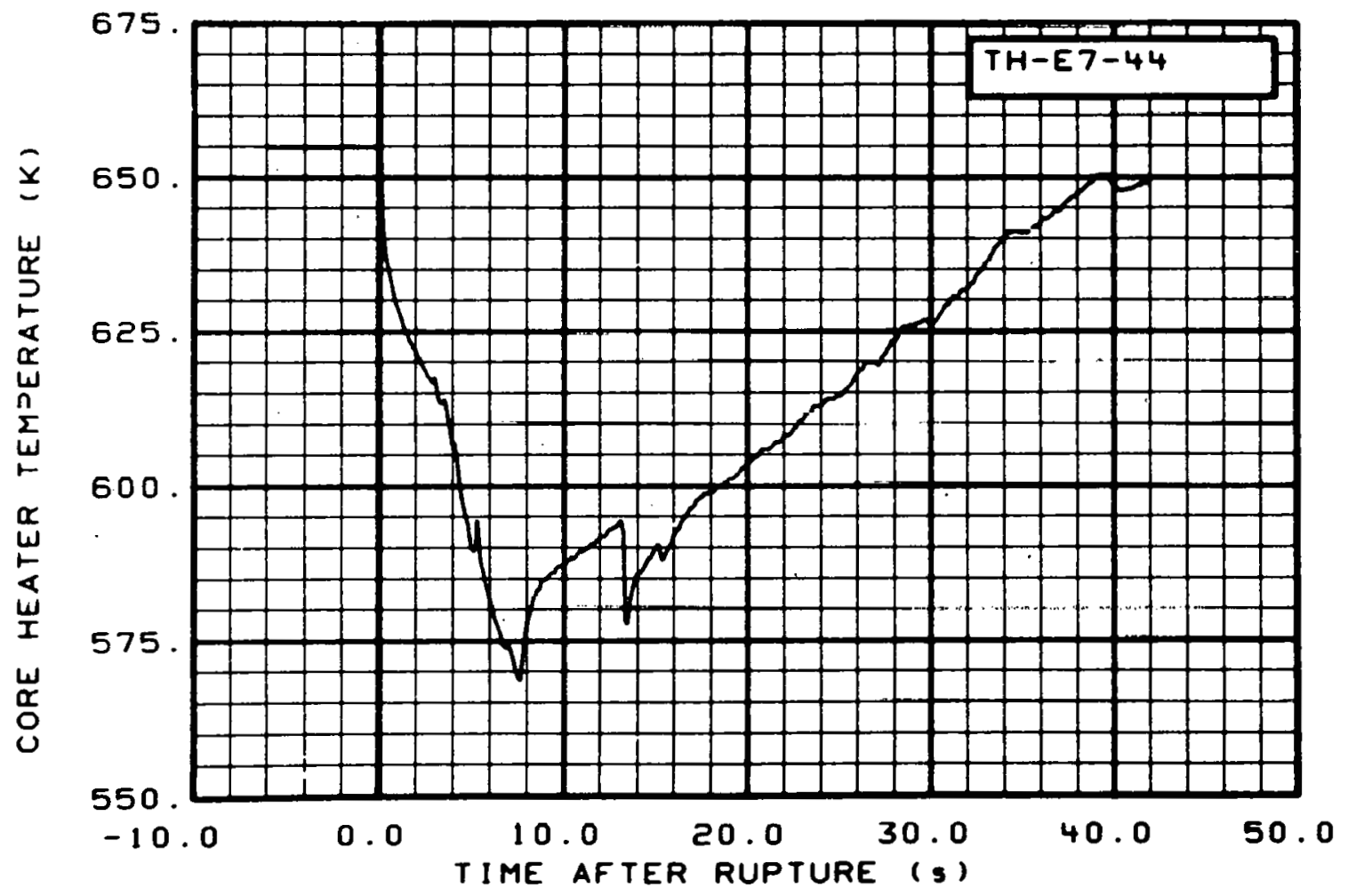

Fig. 126 Core heater temperature, Rod E-7 (TH-E7-44), from -6 to $42 \mathrm{~s}$. 


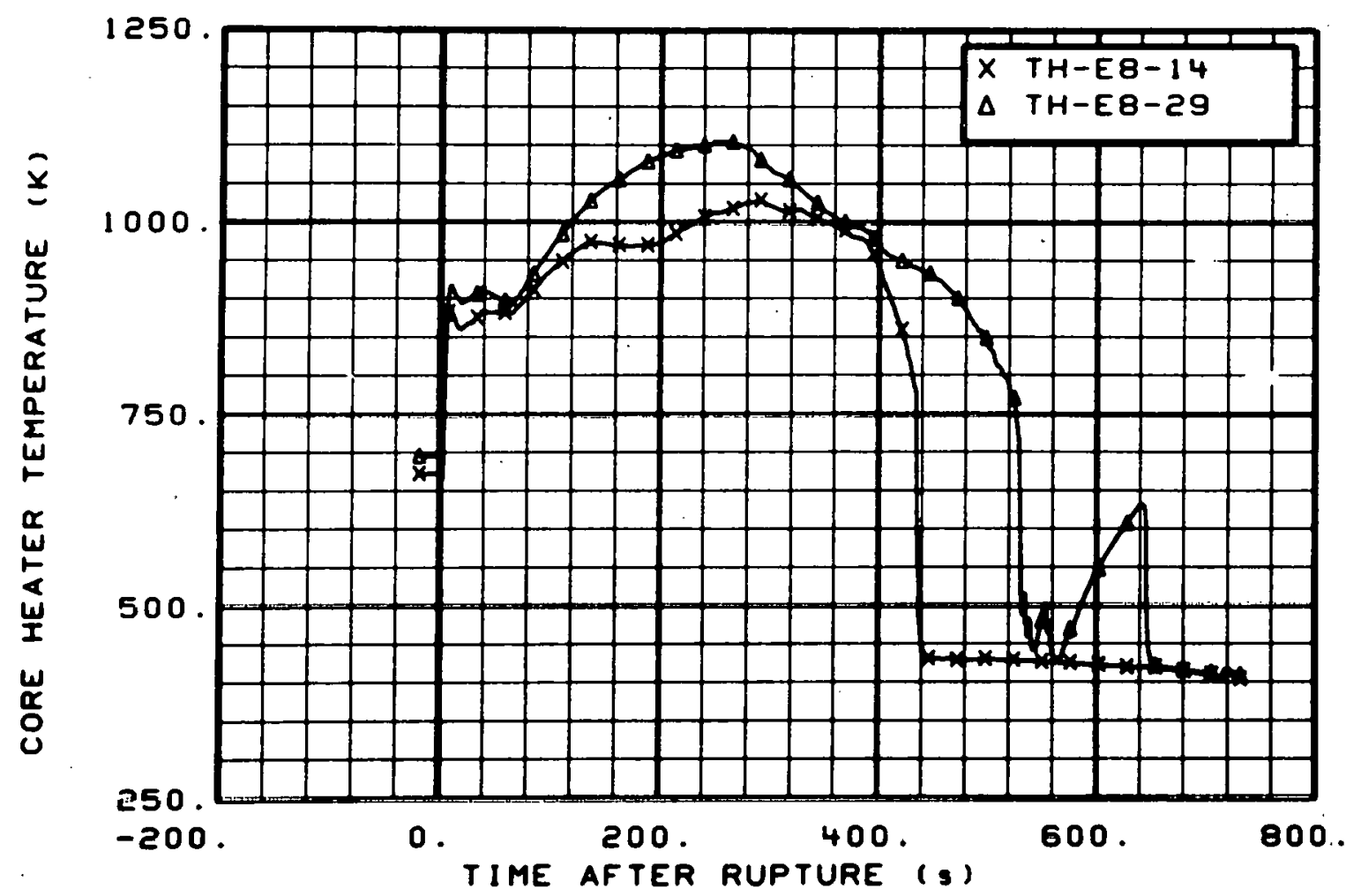

Fig. 127 Core heater temperature, Rod E-8 (TH-E8-14 and TH-E8-29), from -20 to $736 \mathrm{~s}$.

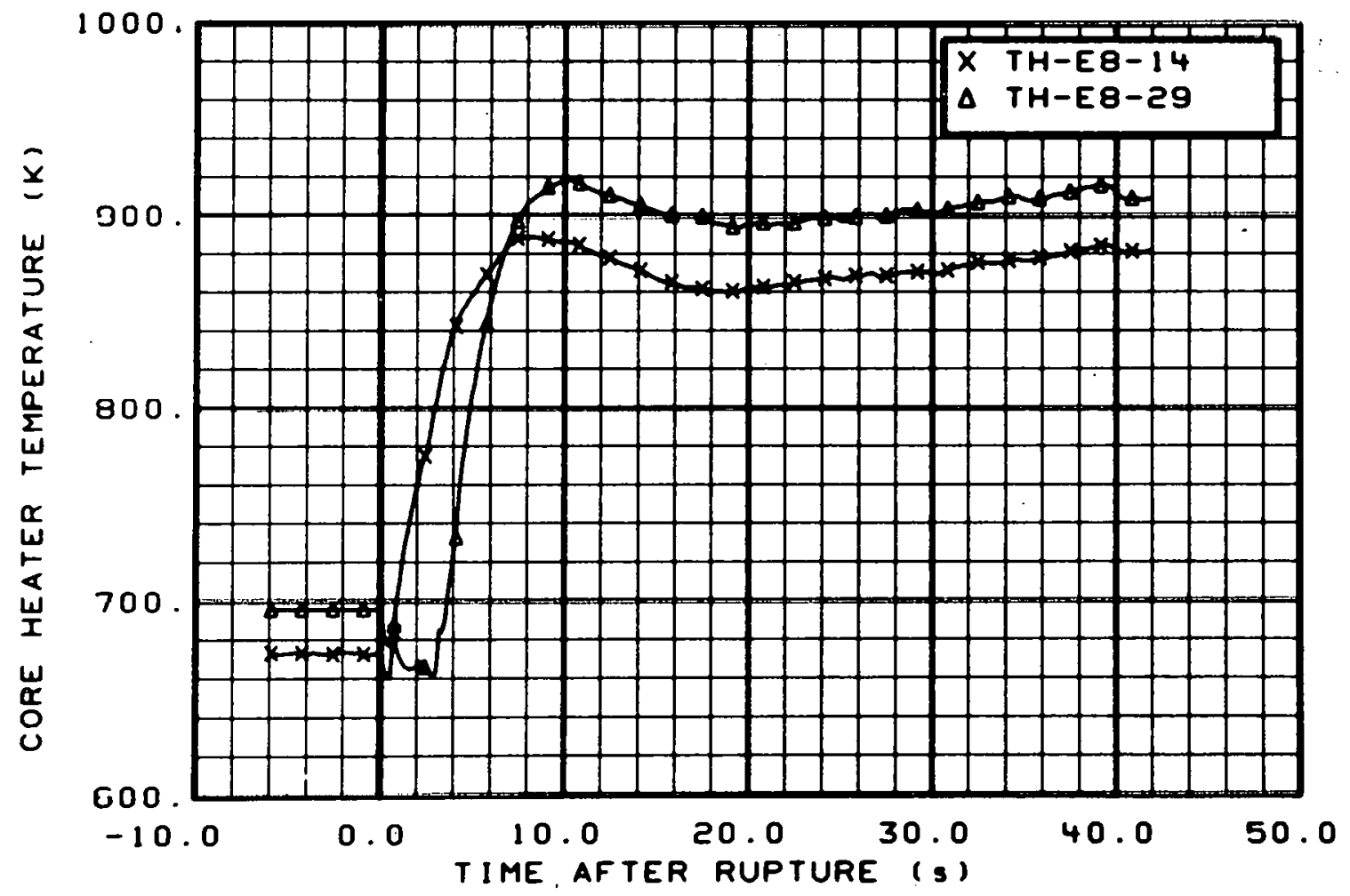

Fiy. 128 Core heater temperature, Rod E-8 (TH-E8-14 and TH-E8-29), from -6 to $42 \mathrm{~s}$. 


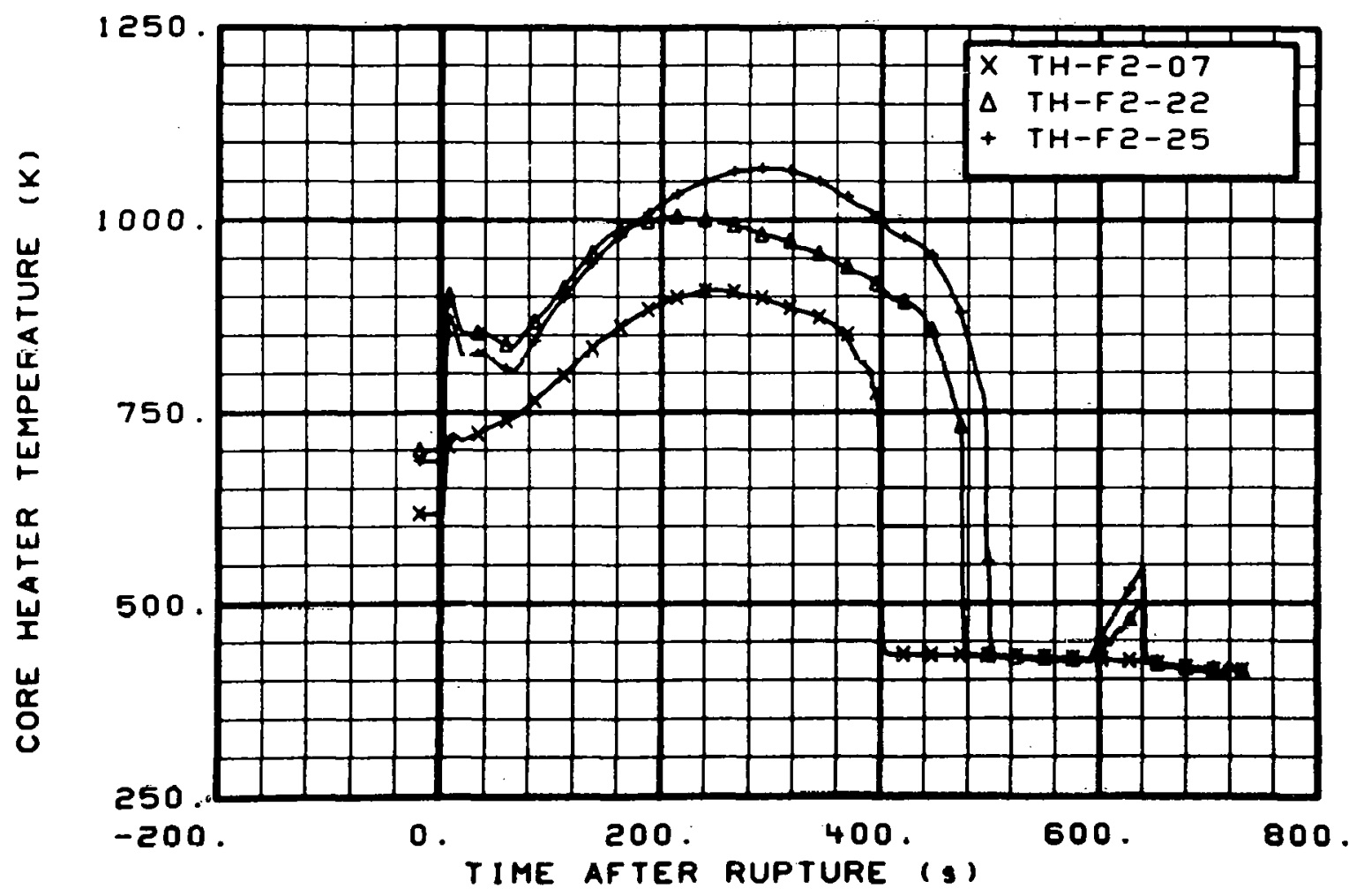

Fig. 129 Core heater temperature, Rod F-2 (TH-F2-07, TH-F2-22, and $\mathrm{TH}-\mathrm{F} 2-25)$, from -20 to $736 \mathrm{~s}$.

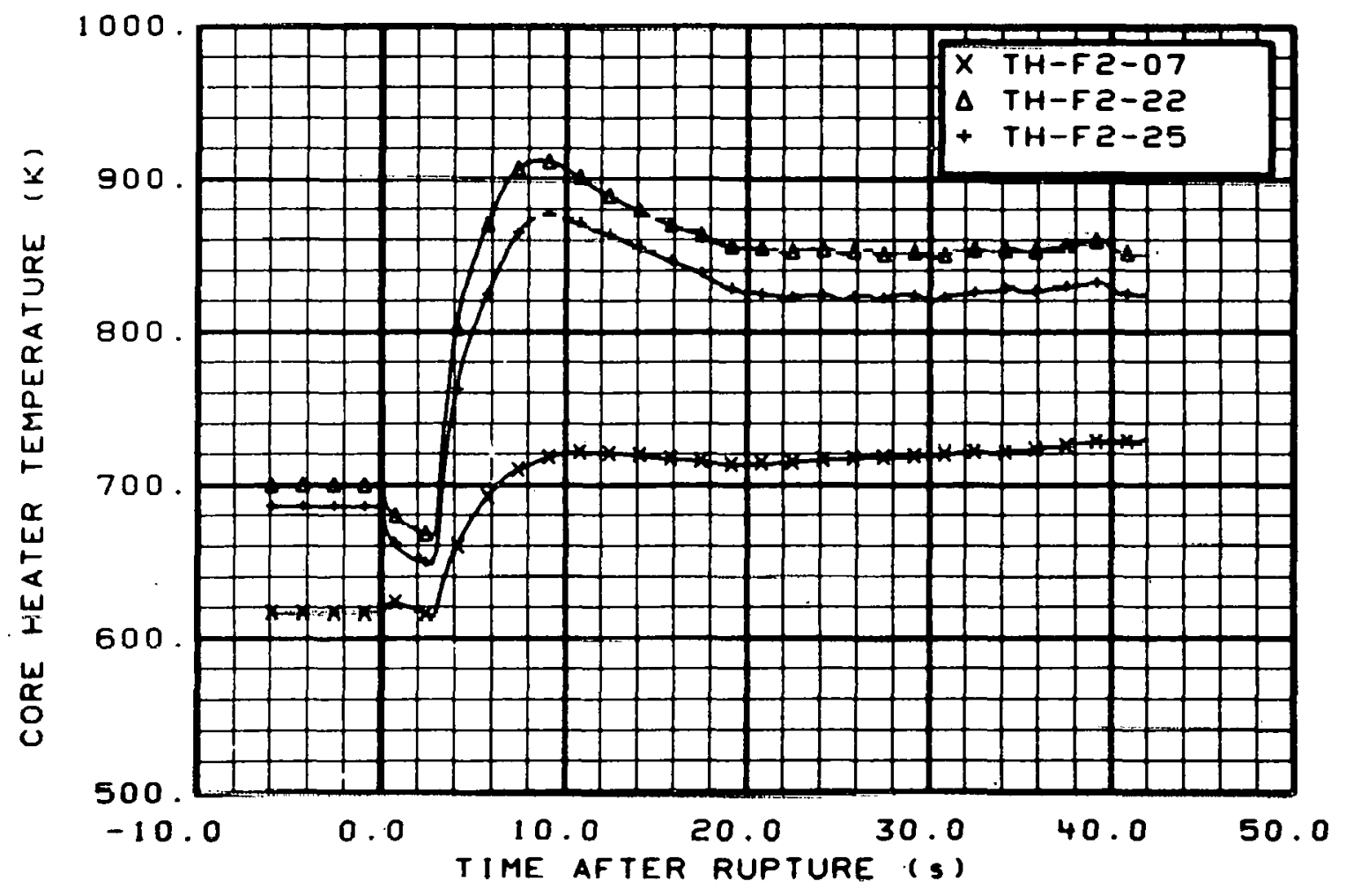

Fig. 130 Core heater temperature, Rod F-2 (TH-F2-07, TH-F2-22, and TH-F2-25), from -6 to $42 \mathrm{~s}$. 


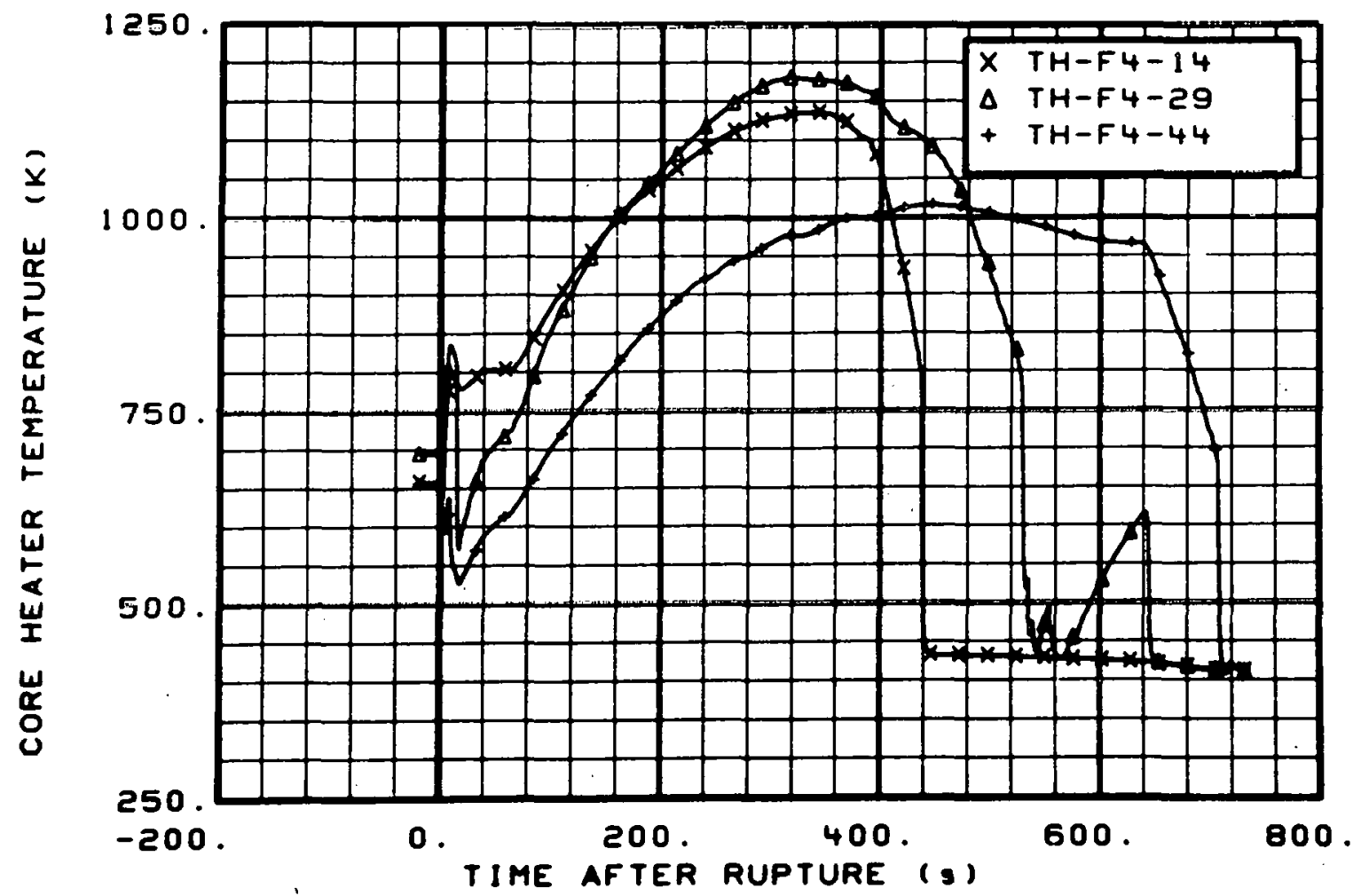

Fig. 131 Core heater temperature, Rod F-4 (TH-F4-14, TH-F4-29, and TH-F4-44), from -20 to $736 \mathrm{~s}$.

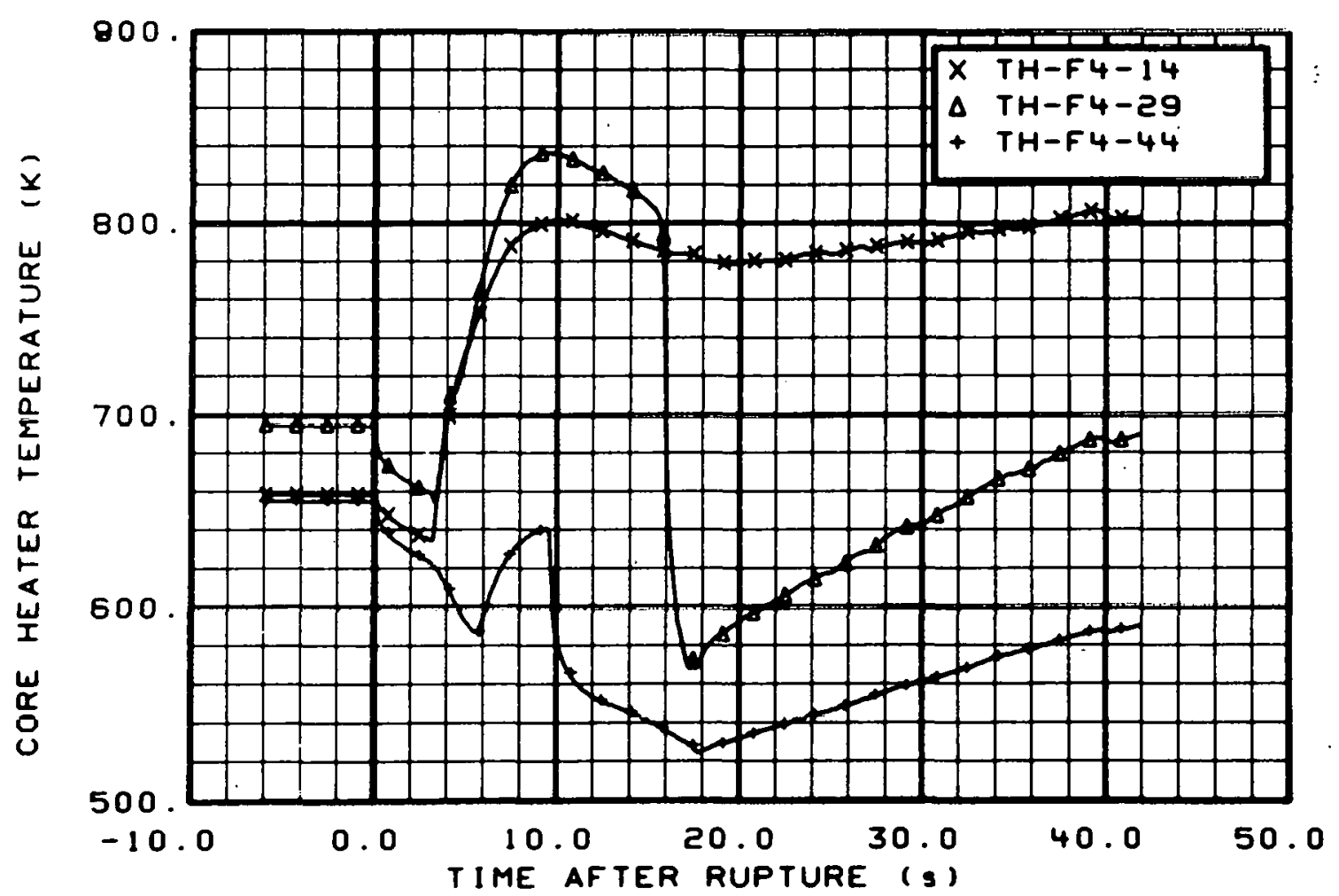

Fig, 132 Core heatẹ temperature, Rọd F-4 (TH-F4-14, TH-F4-29, and TH-F4-44), from -6 to $42 \mathrm{~s}$. 


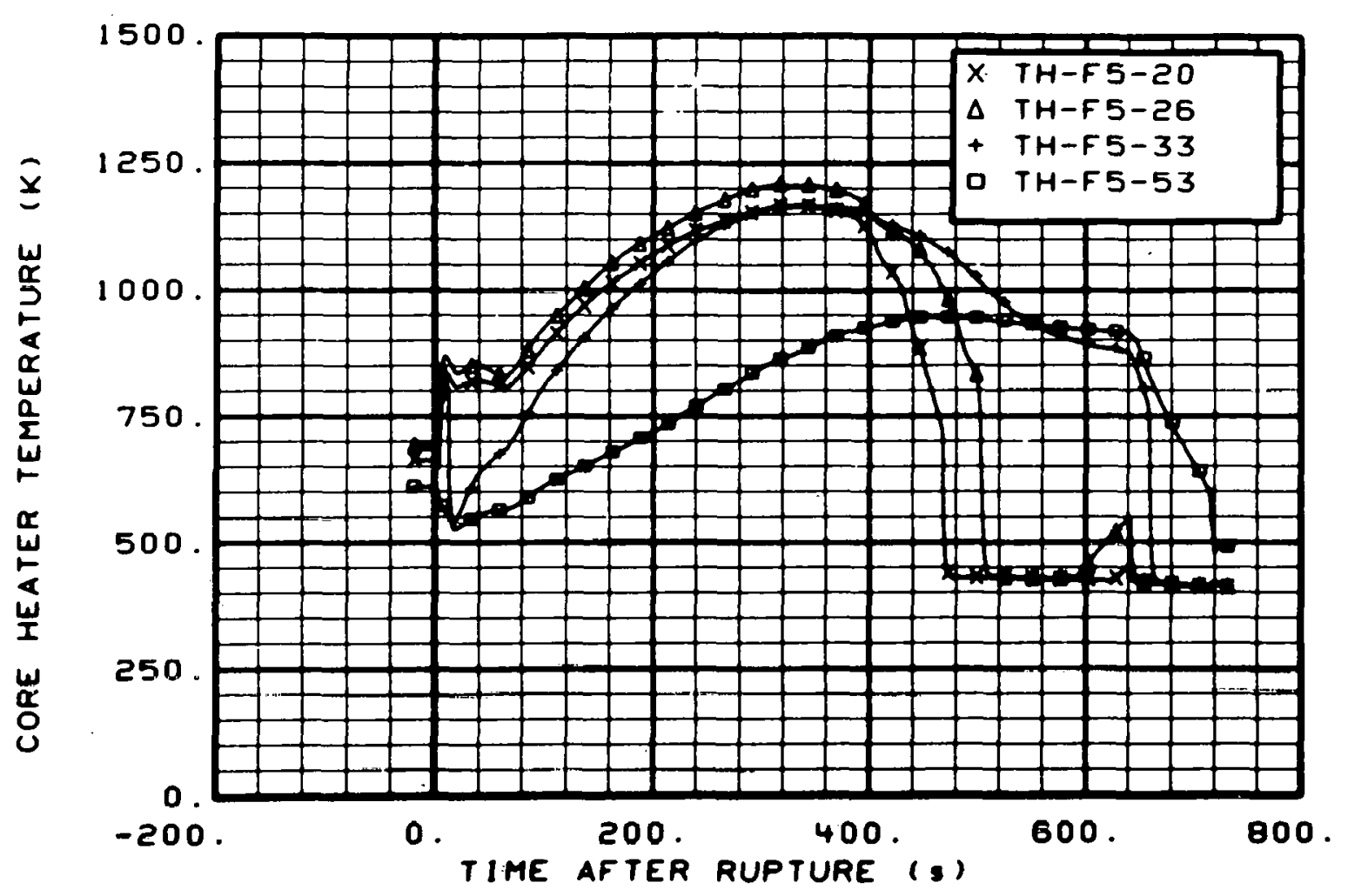

Fig. 133 Core heater temperature, Rod F-5 (TH-F5-20, TH-F5-26, TH-F5-33, and $\mathrm{TH}-\mathrm{F} 5-53$ ), from -20 to $736 \mathrm{~s}$.

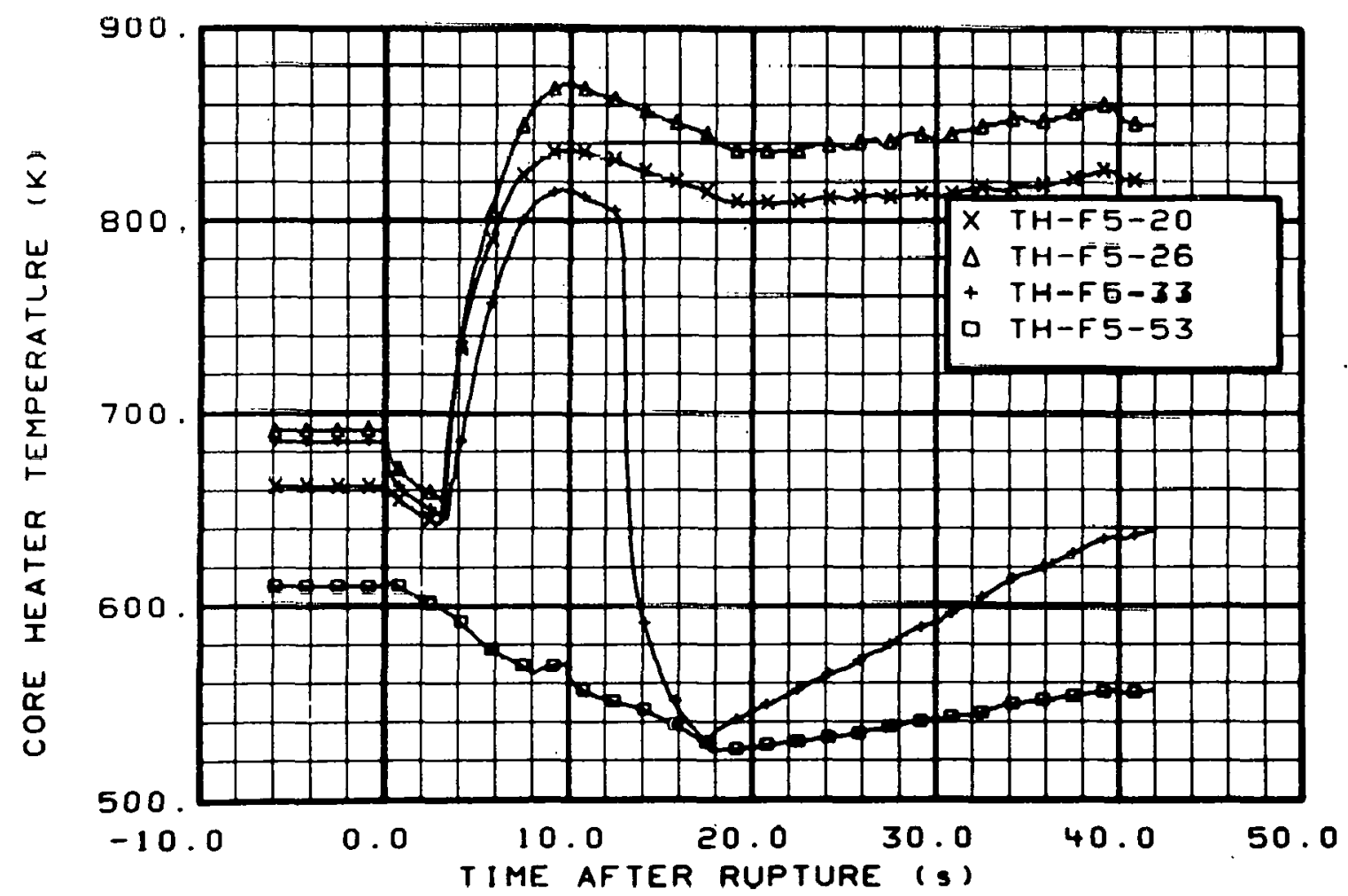

Fig. 134 Core heater temperature, Rod F-5 (TH-F5-20, TH-F5-26, TH-F5-33, and $T H-F 5-53$ ), from -6 to $42 \mathrm{~s}$. 


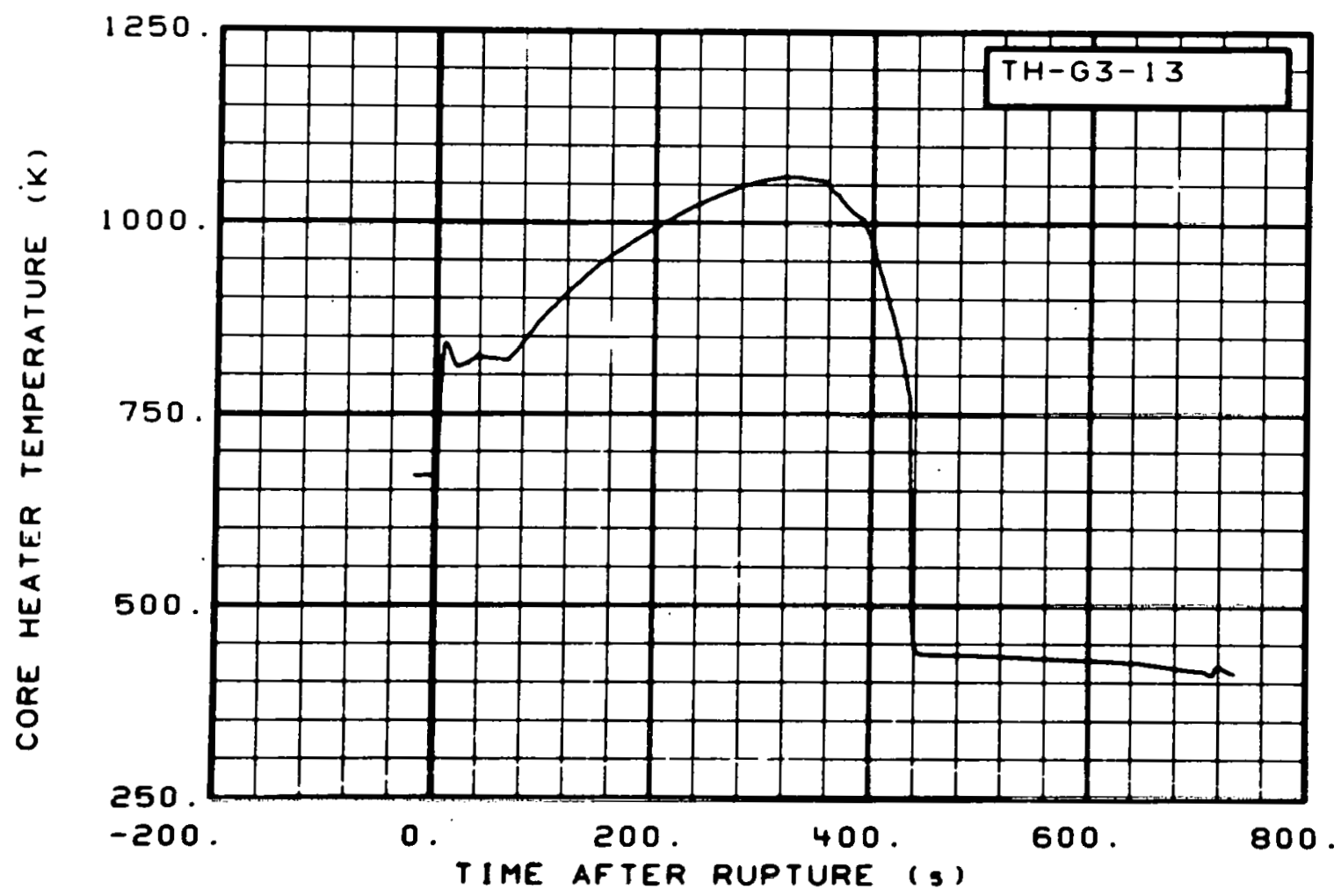

Fig. 135 Core heater temperature, Rod G-3 (TH-G3-13), from -20 to $736 \mathrm{~s}$.

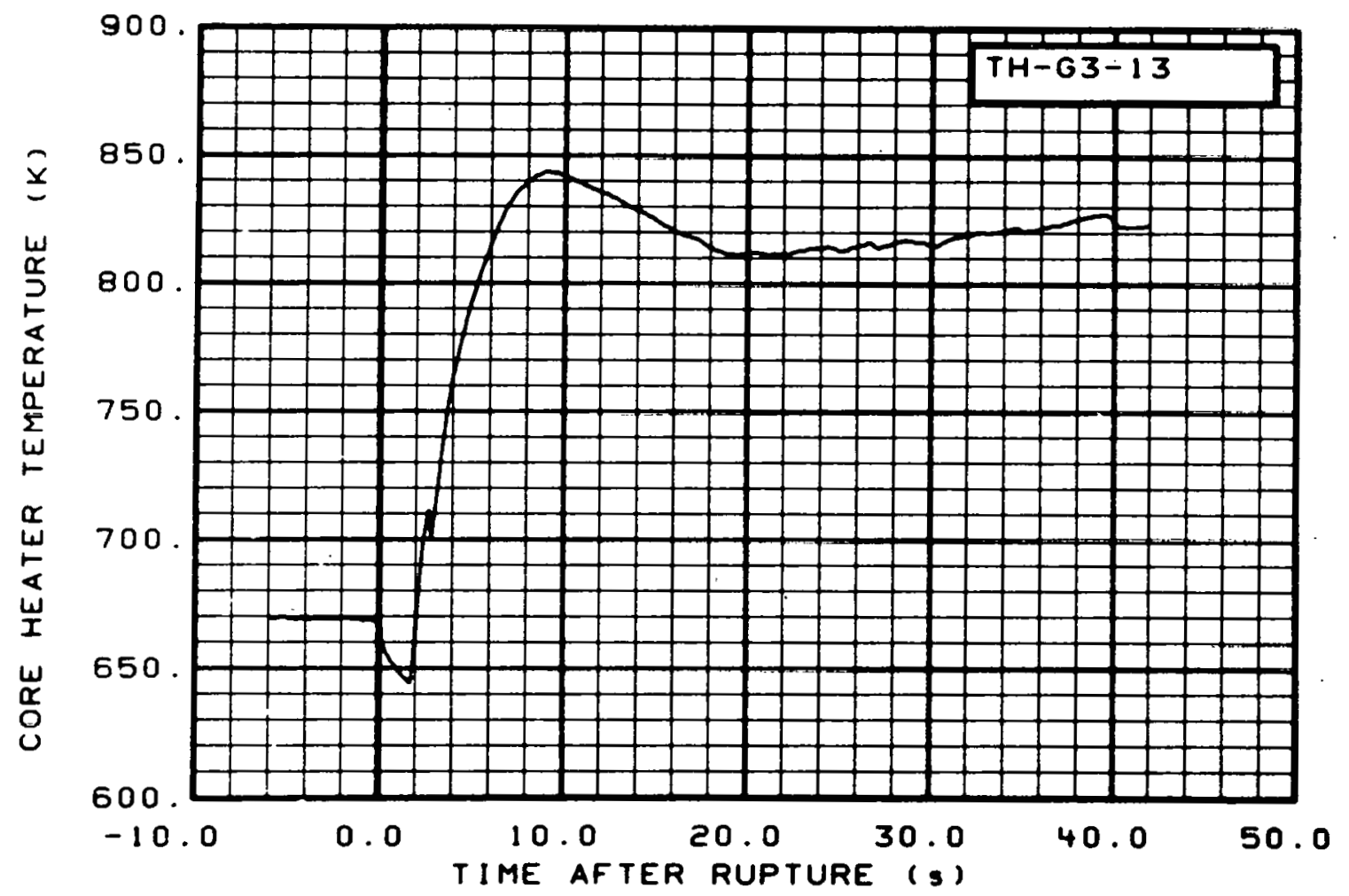

Fig. 136 Core heater temperature, Rod G-3 (TH-G3-13), from -6 to $42 \mathrm{~s}$. 


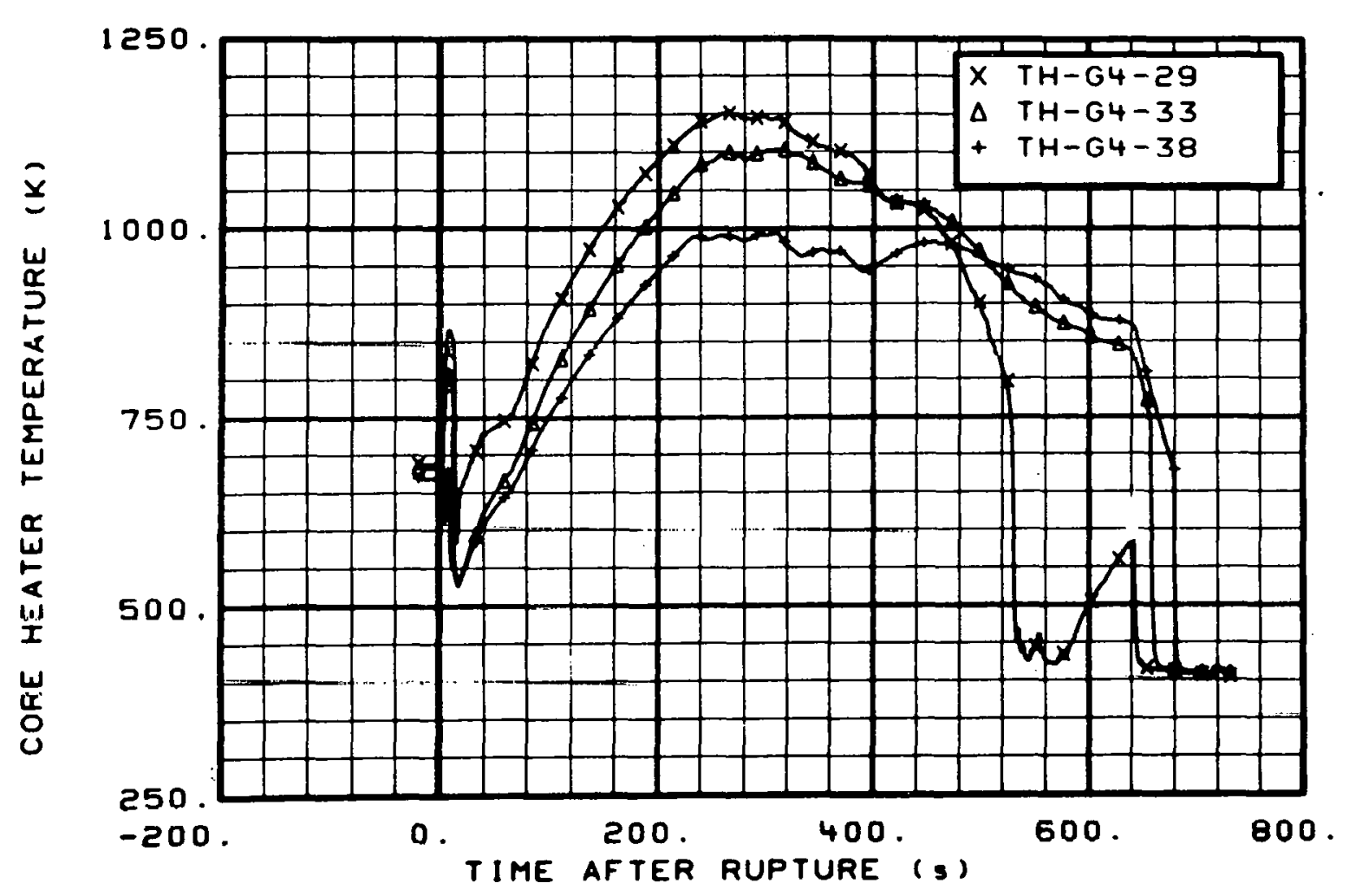

Fig. 137 Core heater temperature, Rod G-4 (TH-G4-29, TH-G4-33, and $\mathrm{TH}-\mathrm{G} 4-38$ ), from -20 to $736 \mathrm{~s}$.

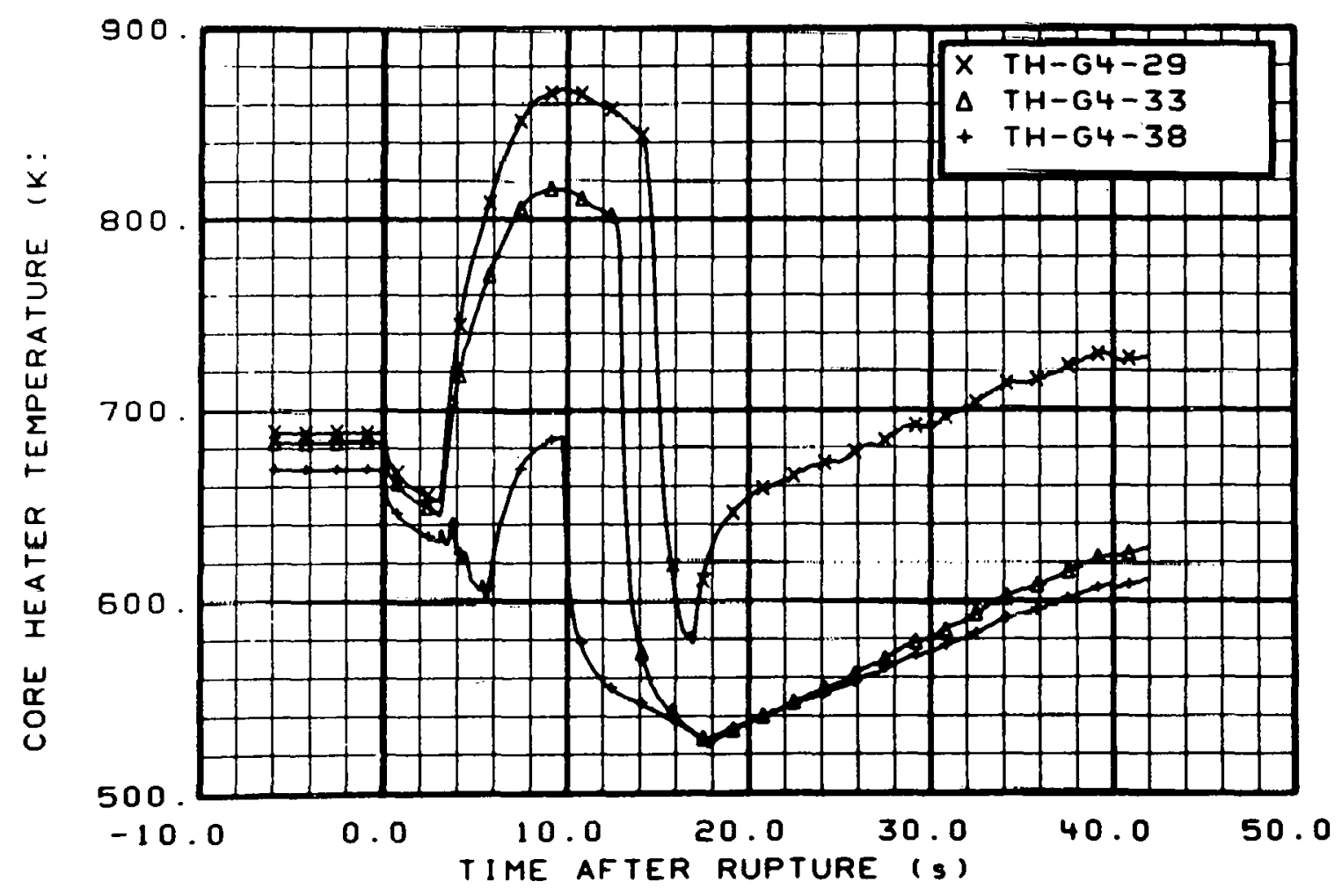

Fig. 138 Core heater temperature, Rod G-4 (TH-G4-29, TH-G4-33, and $\mathrm{TH}-\mathrm{G} 4-38$ ), from -6 to $42 \mathrm{~s}$. 


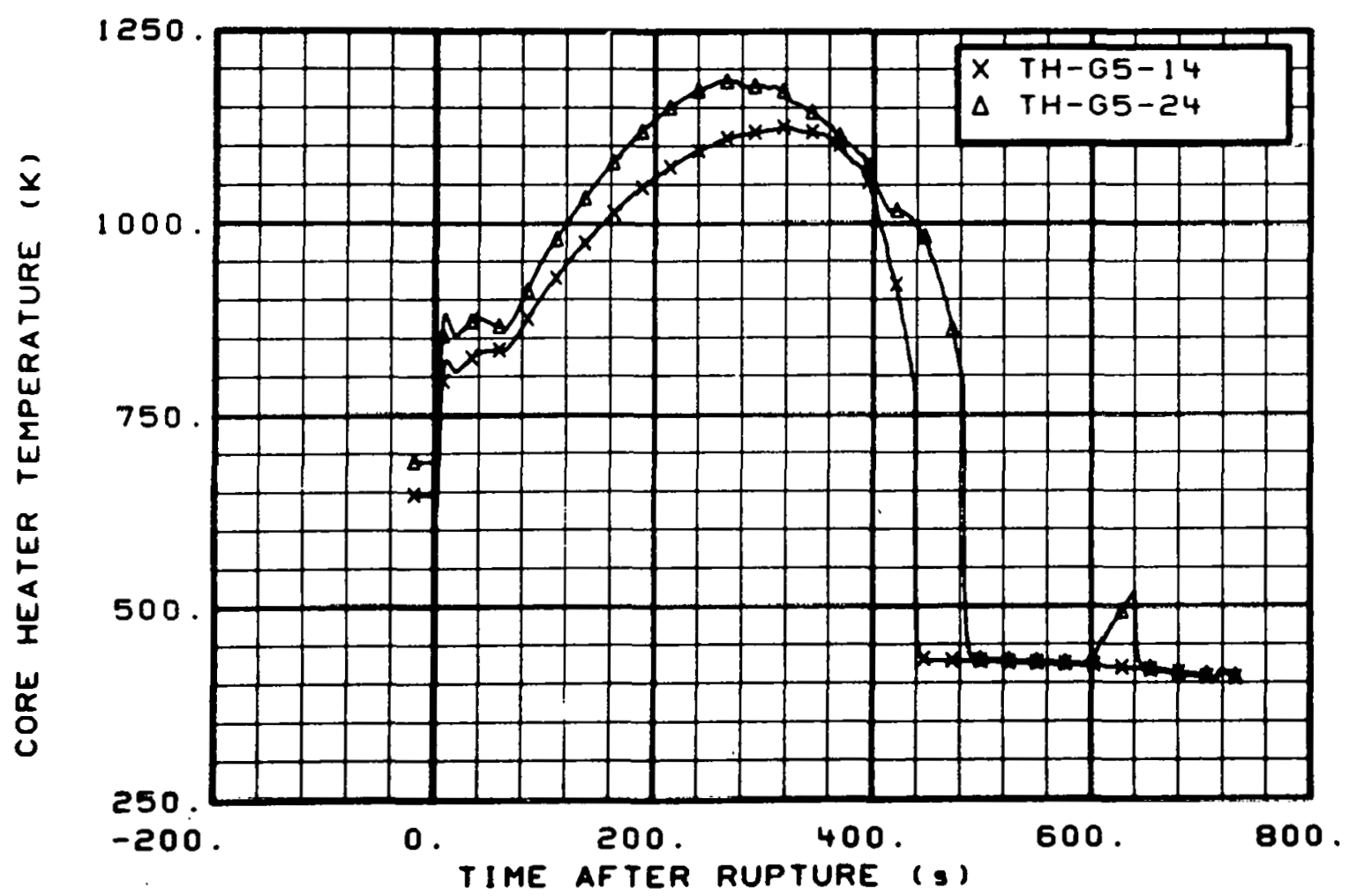

Fig. 139 Core heater temperature, Rod G-5 (TH-G5-14 and TH-G5-24), from -20 to $736 \mathrm{~s}$.

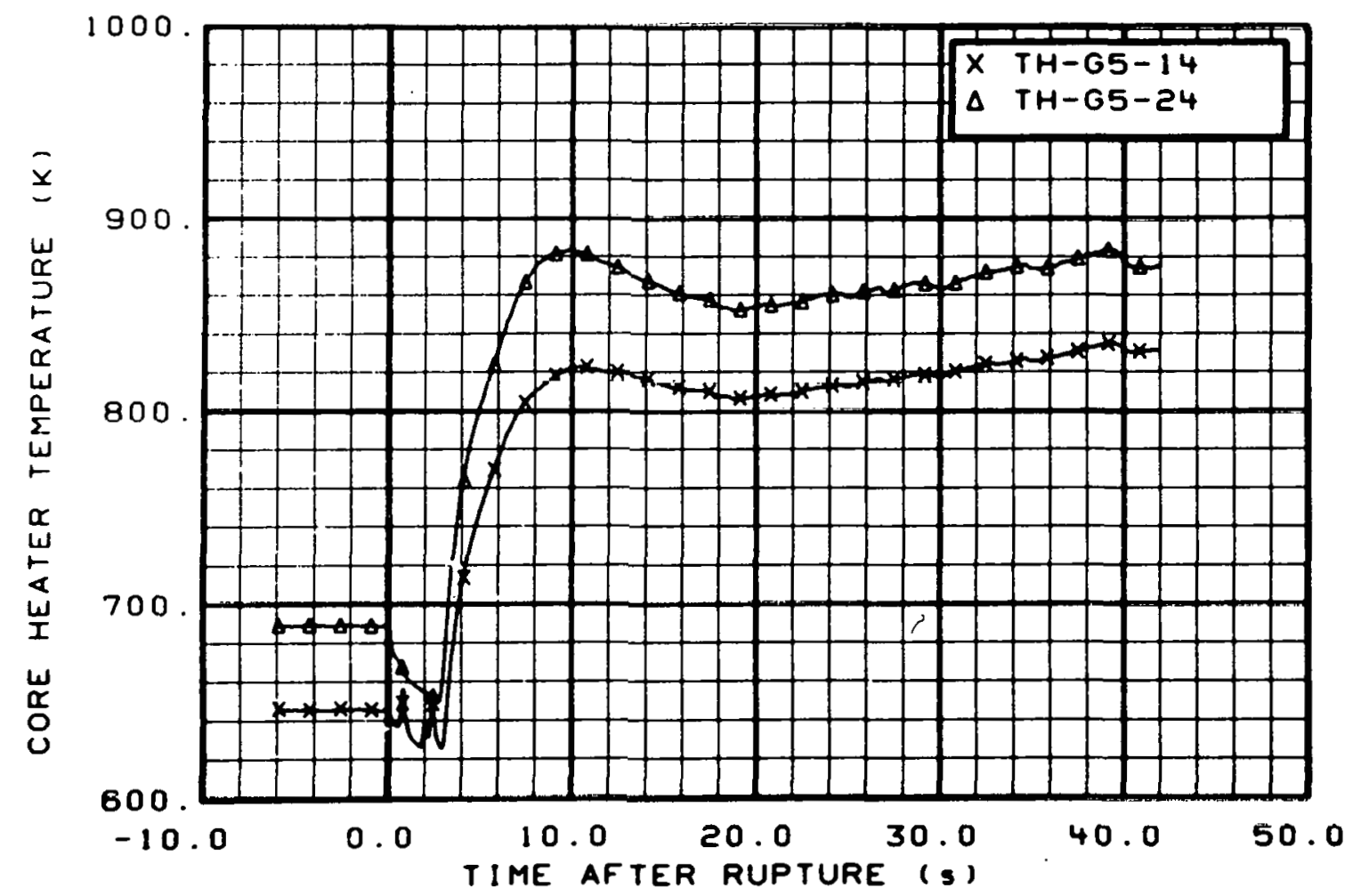

Fig. 140 Core heater temperature, Rod G-5 (TH-G5-14 and TH-G5-24), from -6 to $42 \mathrm{~s}$. 


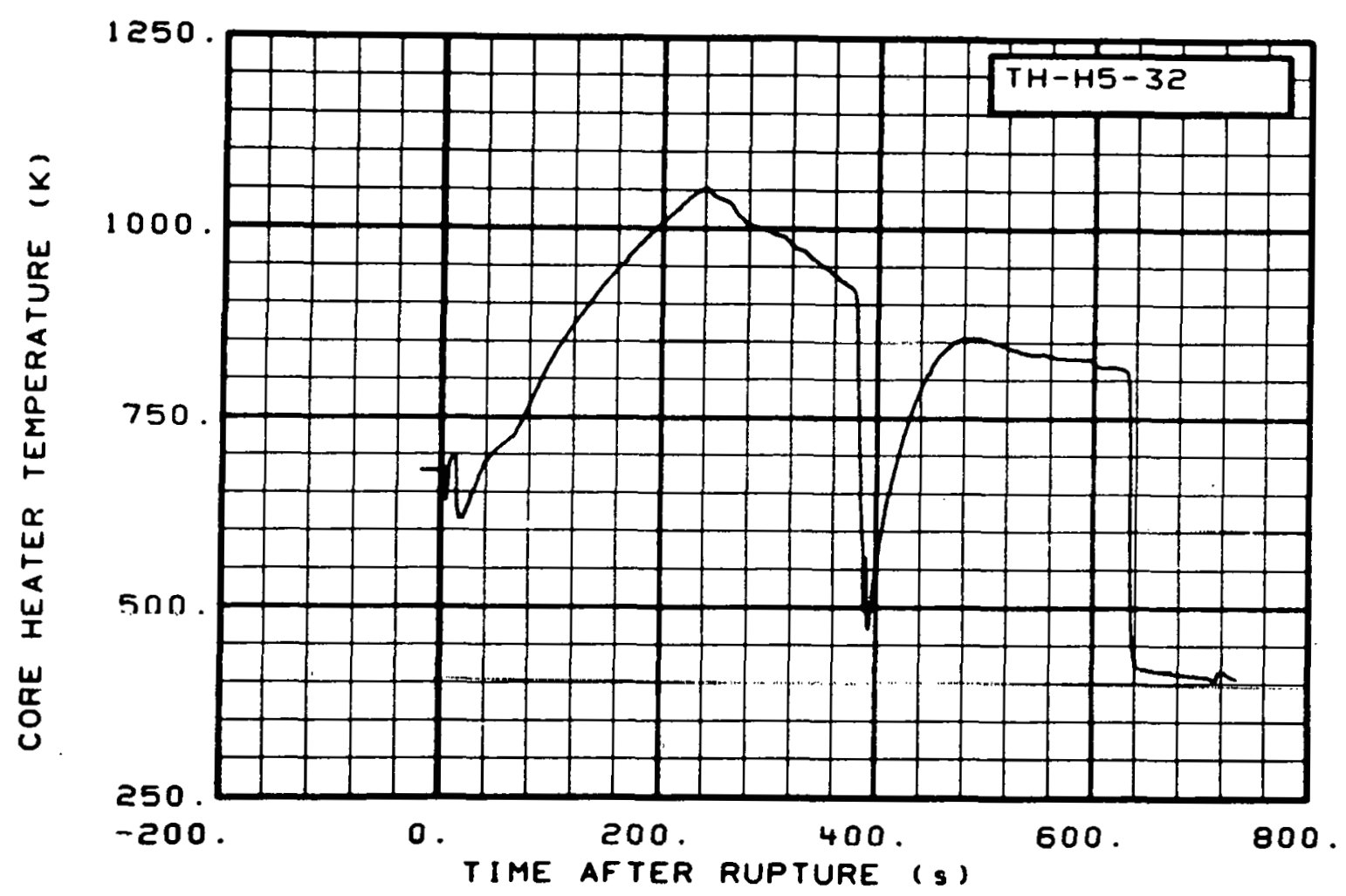

Fig. 141 Core heater temperature, Rod H-5 (TH-H5-32), from -20 to $736 \mathrm{~s}$.

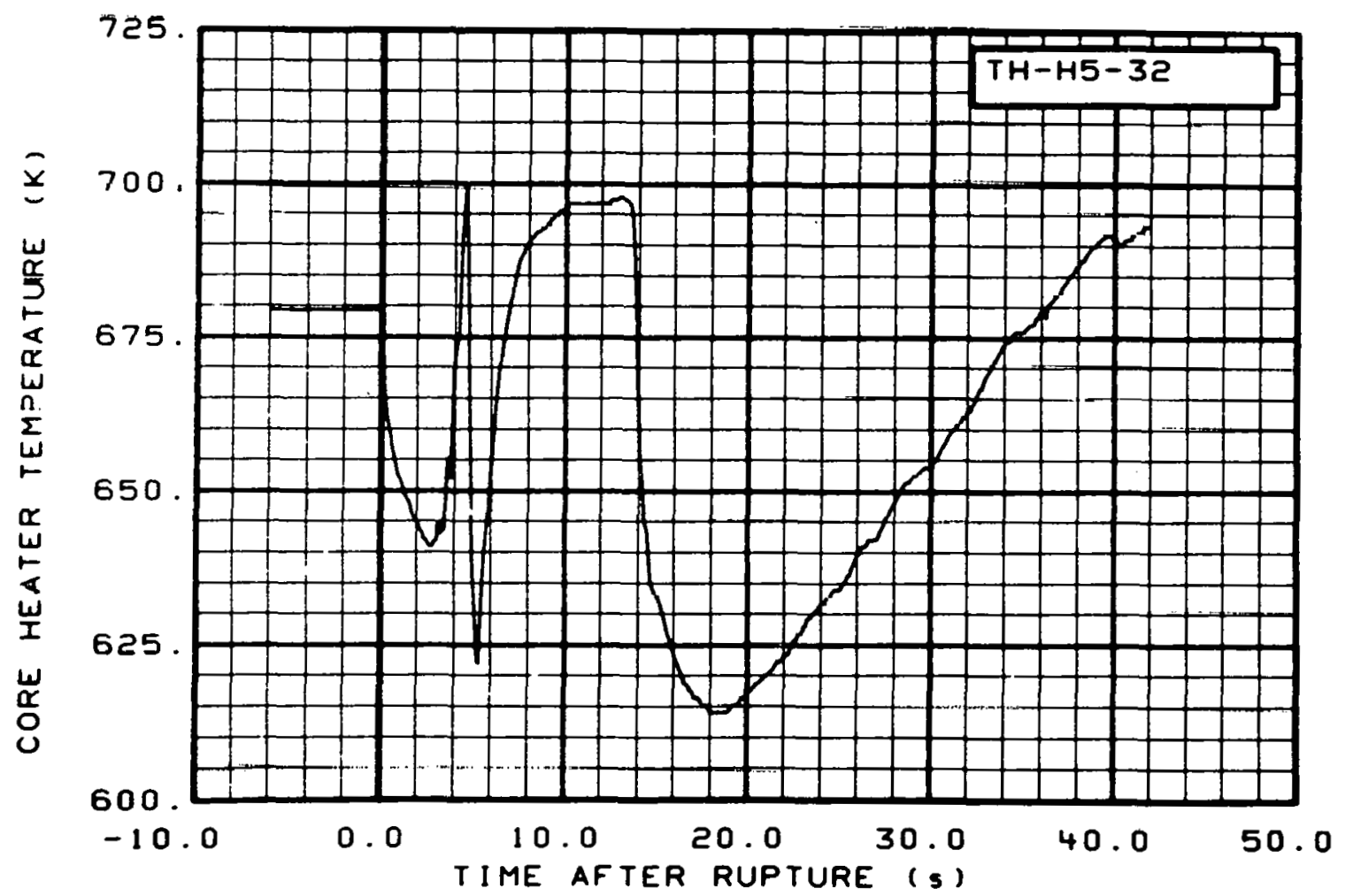

Fig. 142 Core heater temperature, Rod H-5 (TH-H5-32), from -6 to $42 \mathrm{~s}$. 


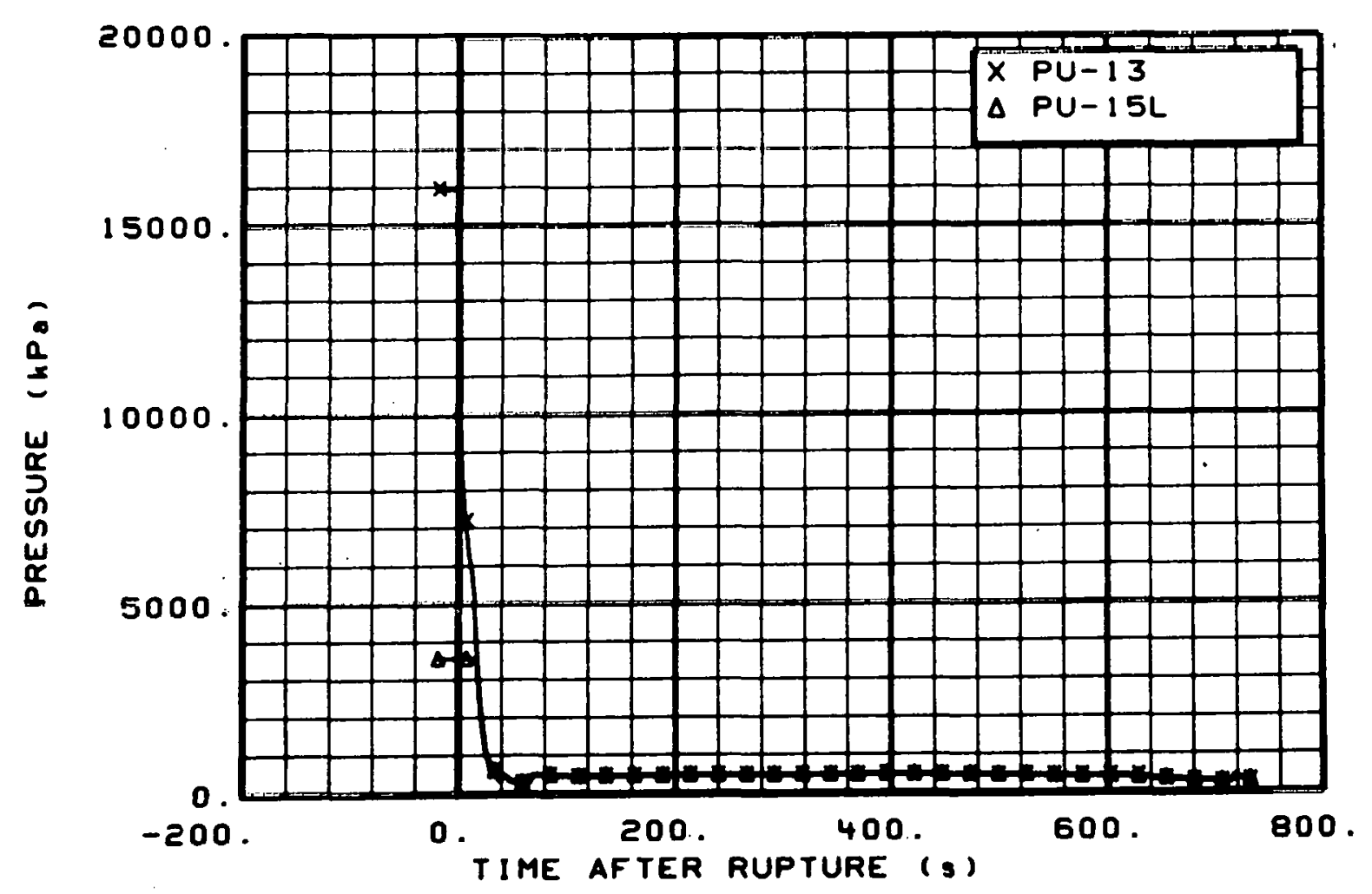

Fig. 143 Pressure in intact 100p (PU-13 and PU-15L), from -20 to $736 \mathrm{~s}$.

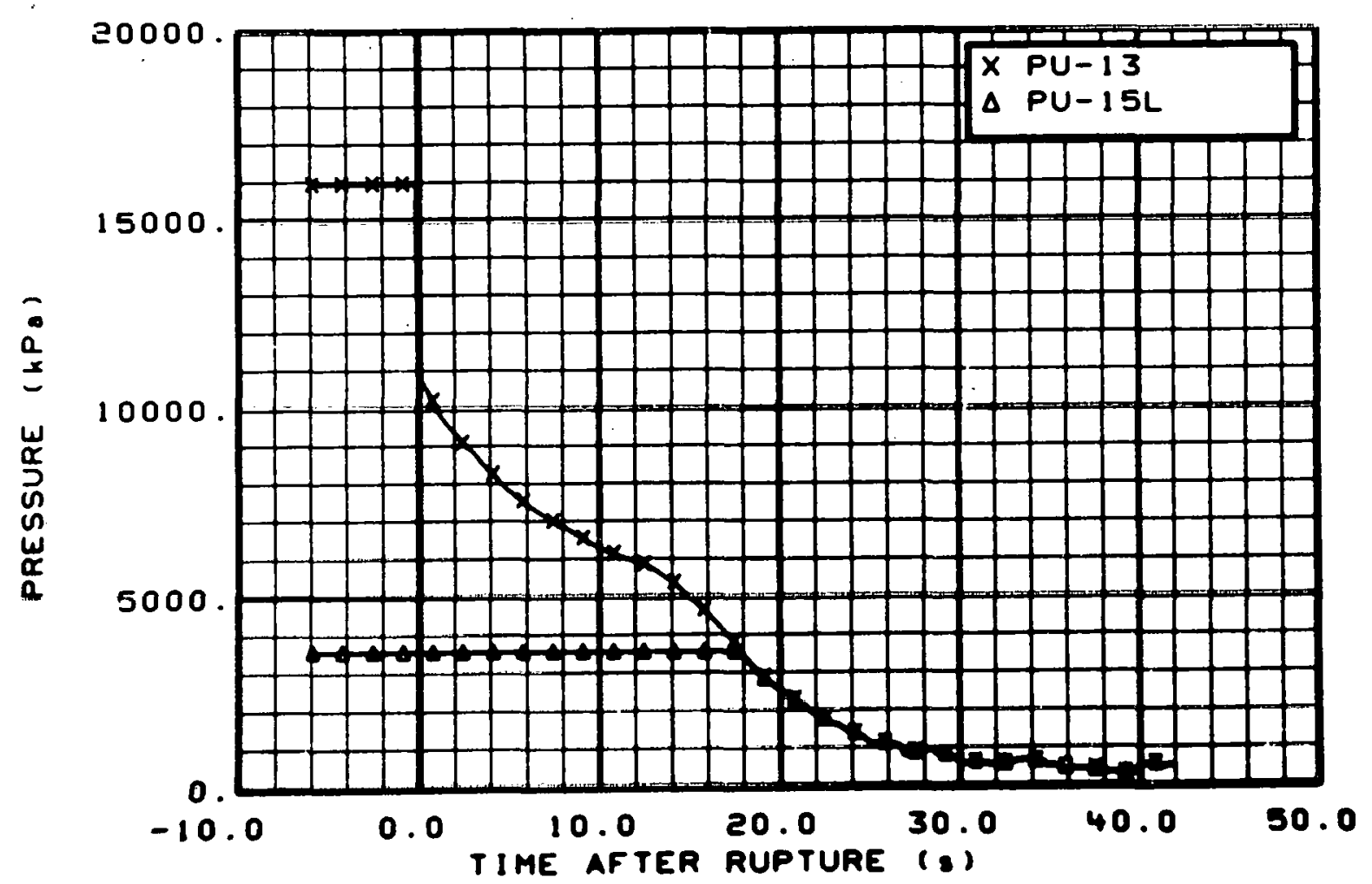

Fig. 144 Pressure in intact loop ( $P U=13$ and $P U=15 \mathrm{~L})$, from -6 to $42 \mathrm{~s}$. 


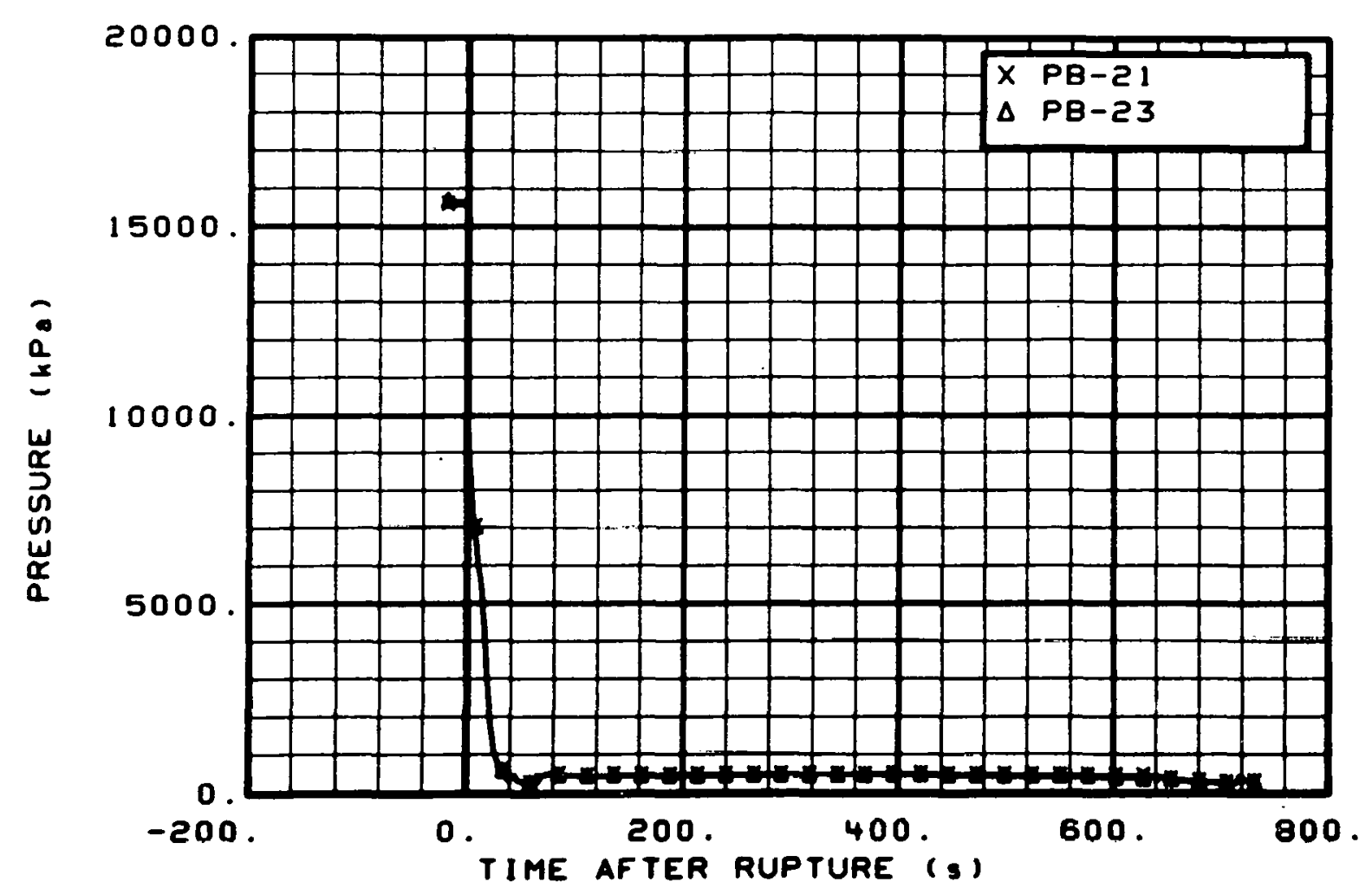

Fig. 145 Pressure in broken loop, vessel side (PB-21 and $P B-23)$, from -20 to $736 \mathrm{~s}$.

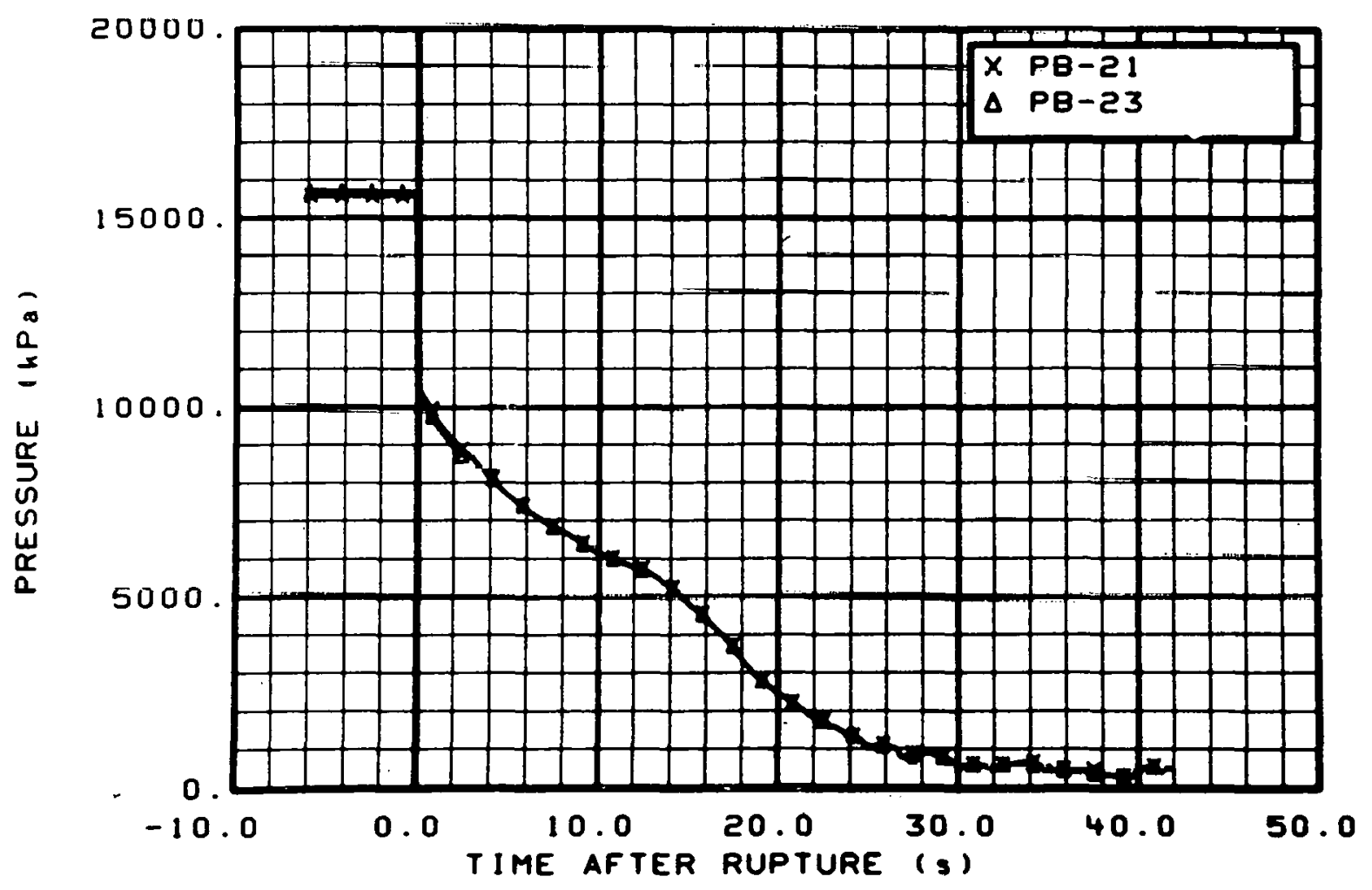

Fig. 146 Pressure in broken loop, vessel side (PB-21 and $P B-23)$, from -6 to $42 \mathrm{~s}$. 


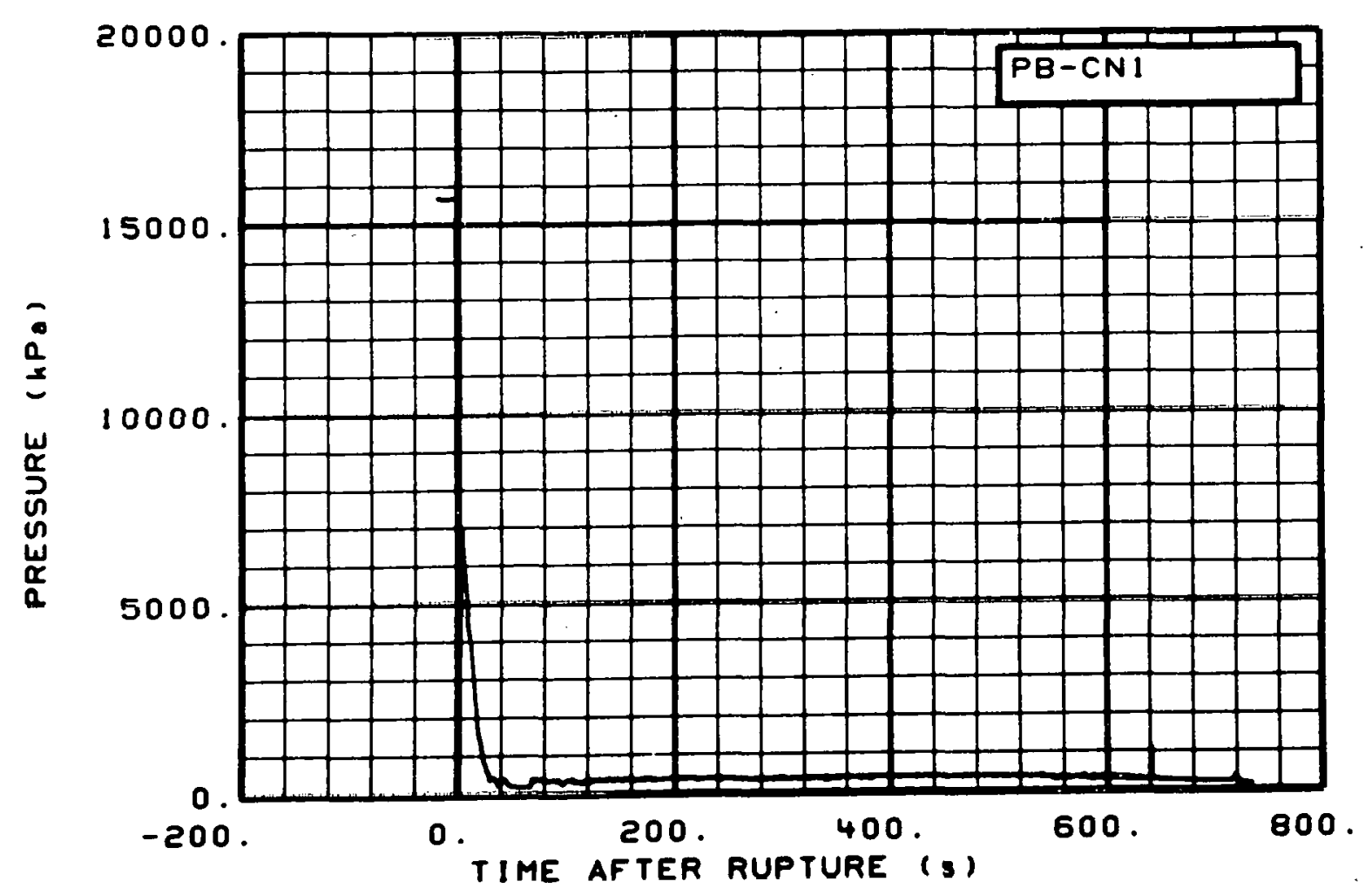

Fig. 147 Pressure in broken loop, vessel side (PB-CN1), from -20 to $736 \mathrm{~s}$.

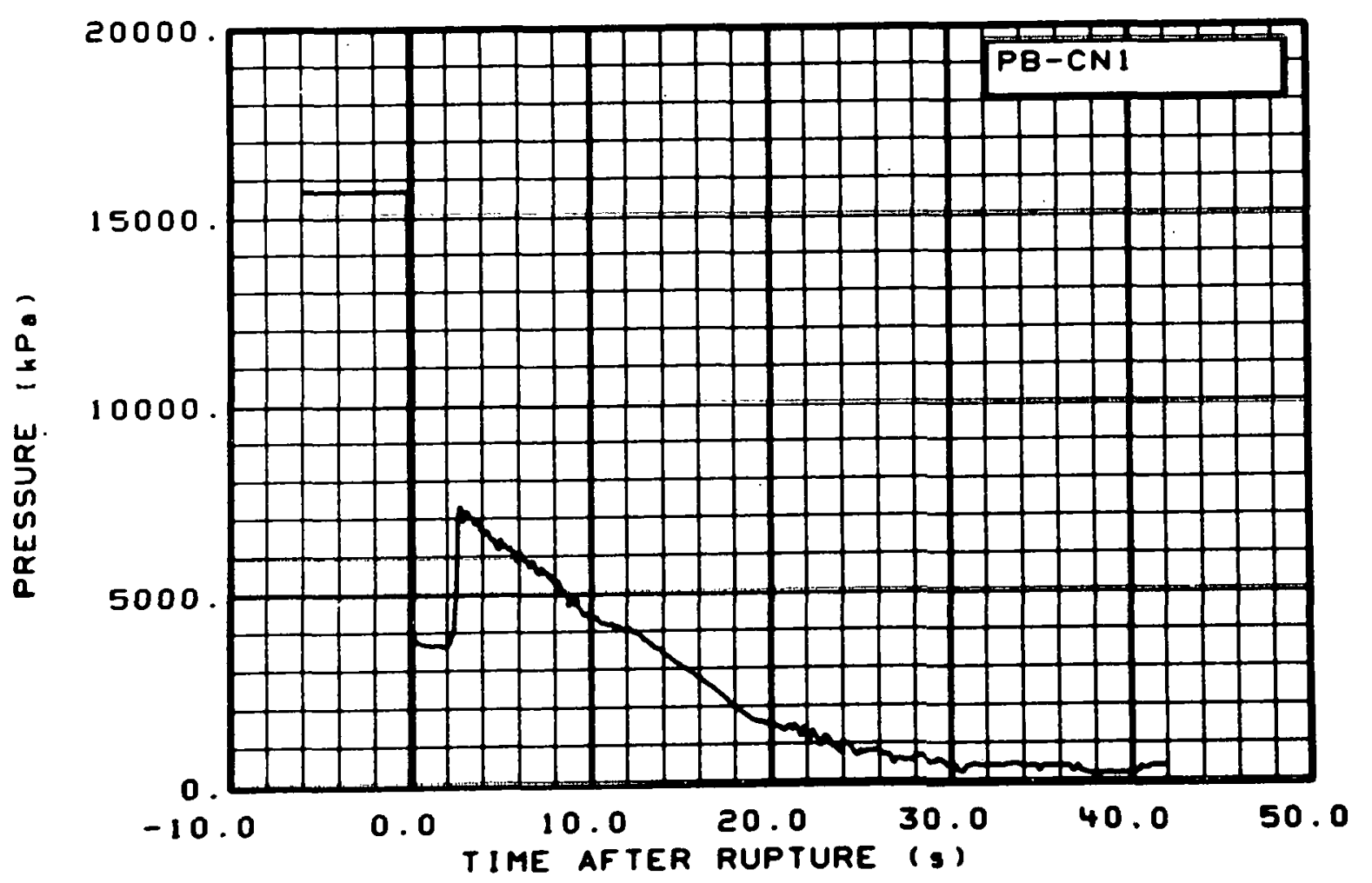

Fig. 148 Pressure in broken loop, vessel side (PB-CN1), from -6 to $42 \mathrm{~s}$. 


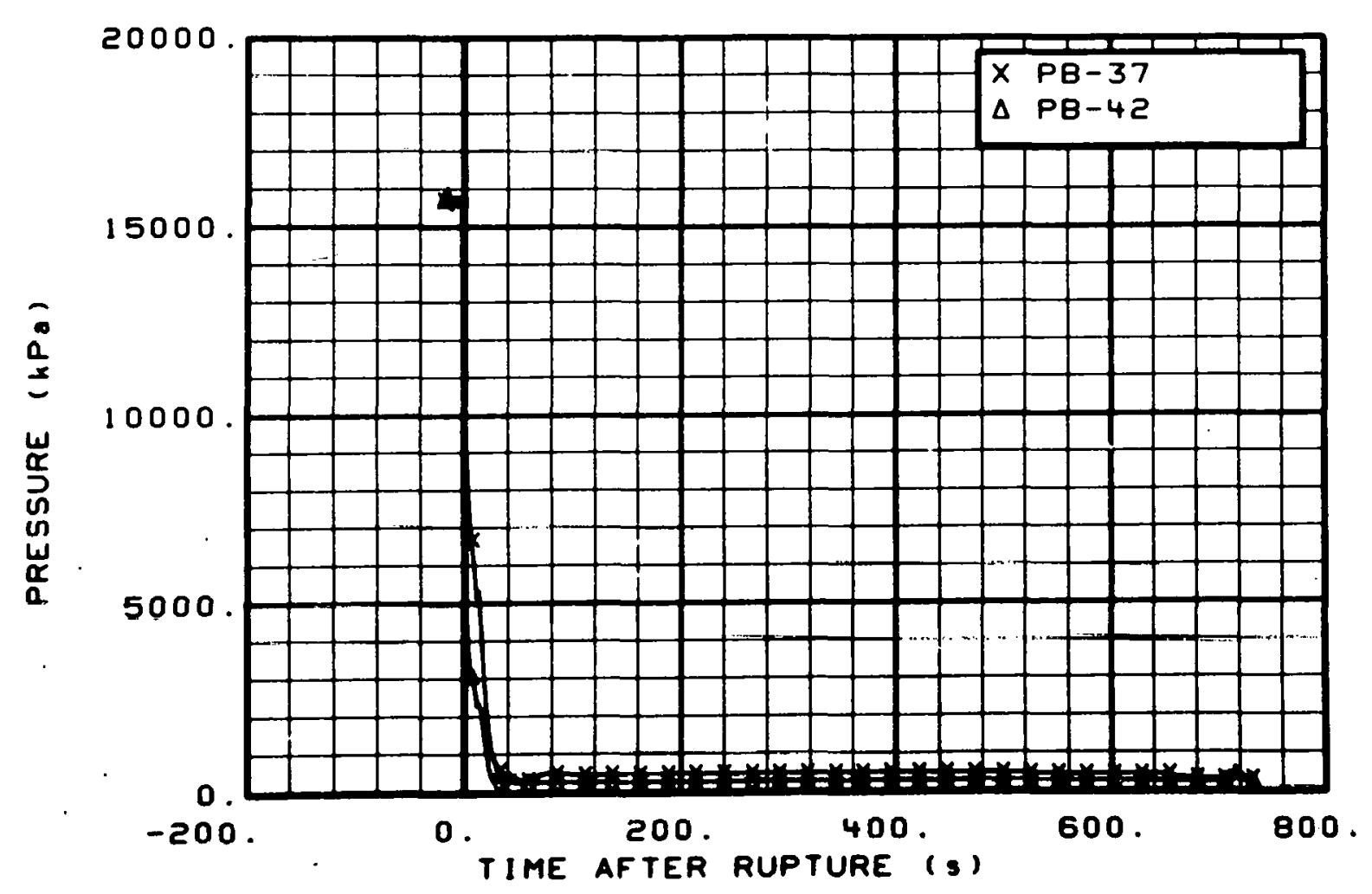

Fig. 149 Pressure in broken loop, pump side (PB-37 and PB-42), from -20 to $736 \mathrm{~s}$.

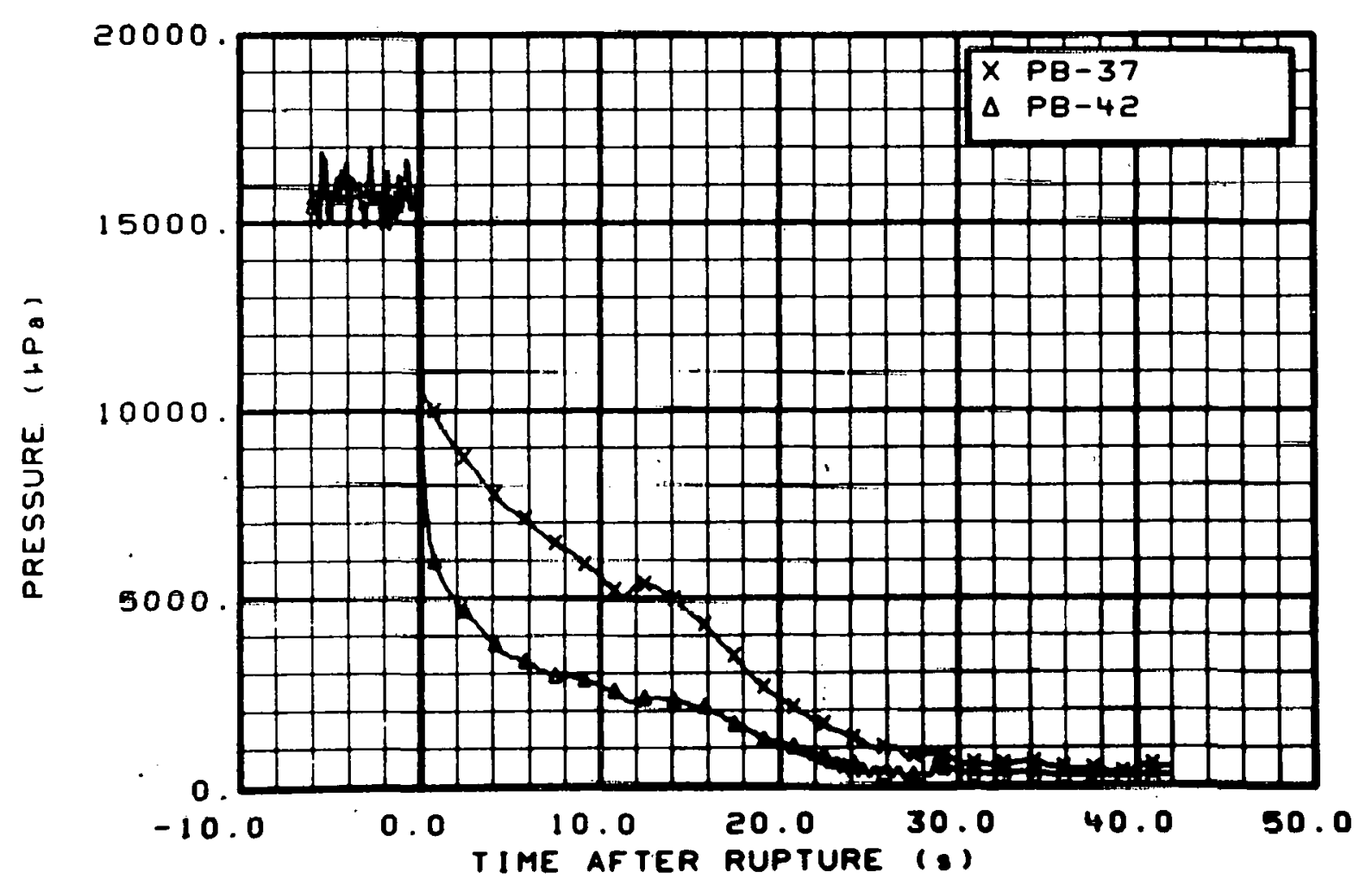

Fig. 150 Pressure in broken loop, pump side (PB-37 and PB-42), from -6 to $42 \mathrm{~s}$. 


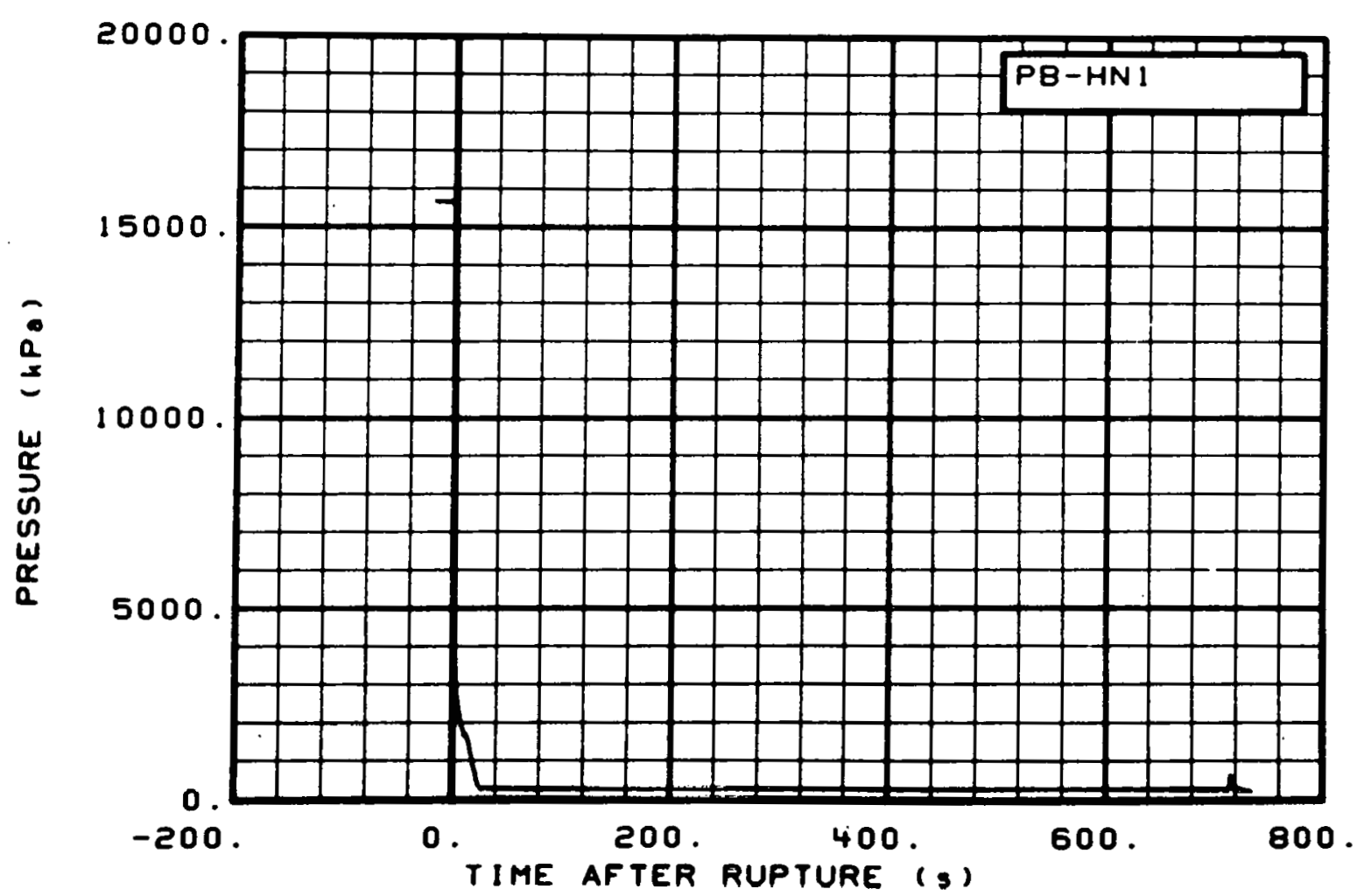

Fig. 151 Pressure in broken loop, pump side nozzle (PB-HN1), from -20 to $736 \mathrm{~s}$.

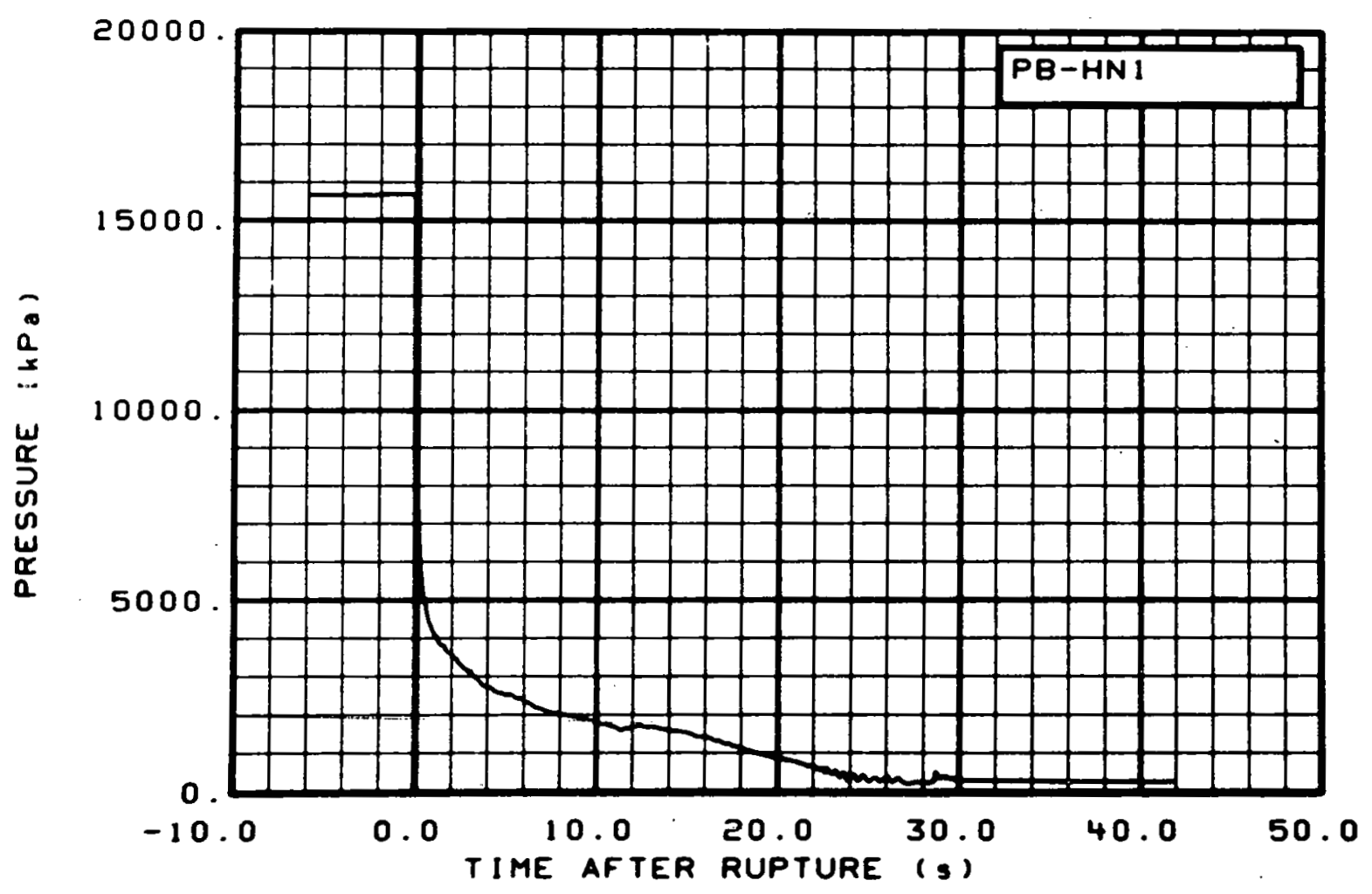

Fig. 152 Pressure in broken loop, pump side nozzle (PB-HNI), from -6 to $42 \mathrm{~s}$. 


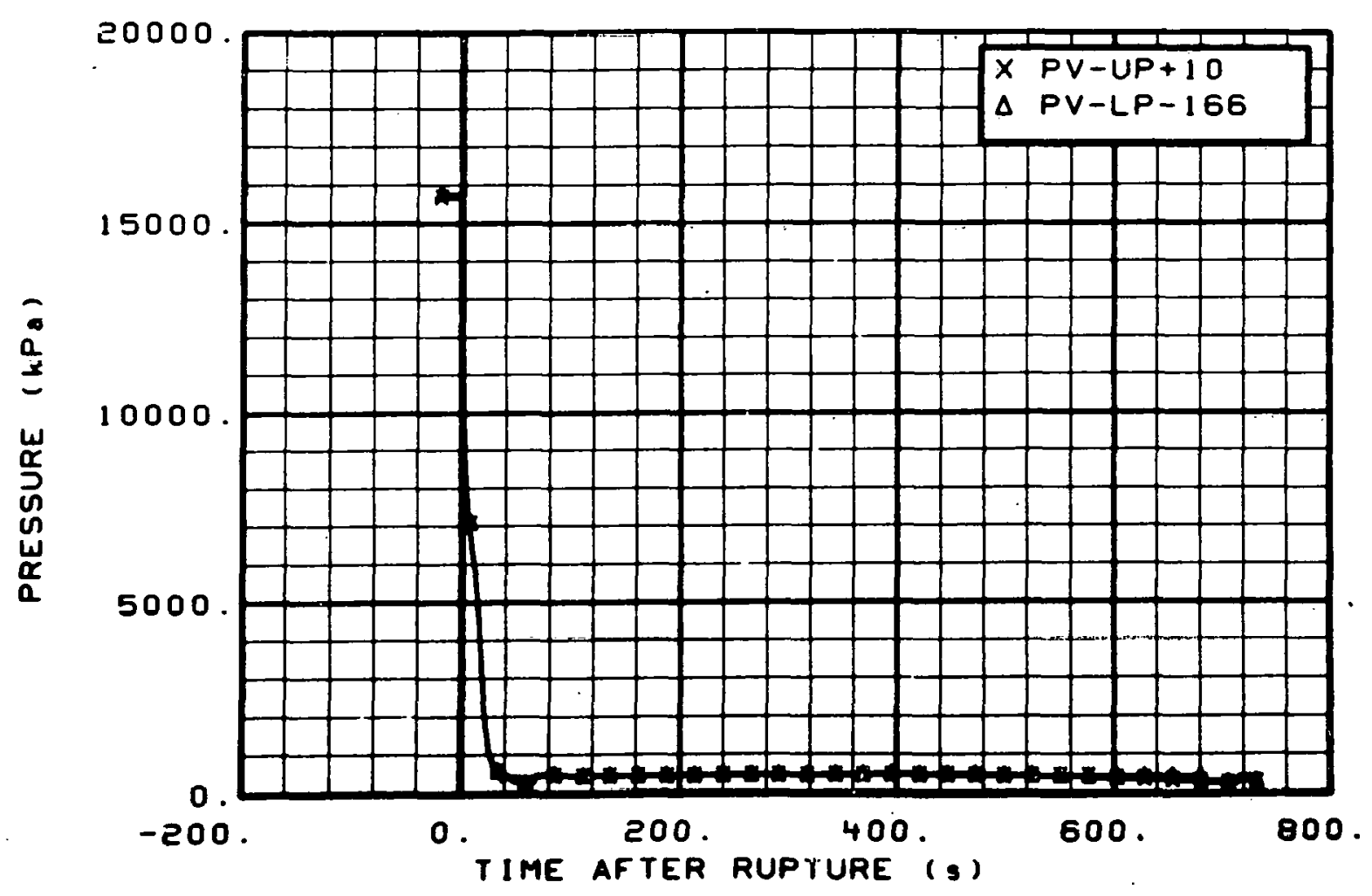

Fig. 153 Pressure in vessel (PV-UP+10 and PV-LP-166), from -20 to $736 \mathrm{~s}$.

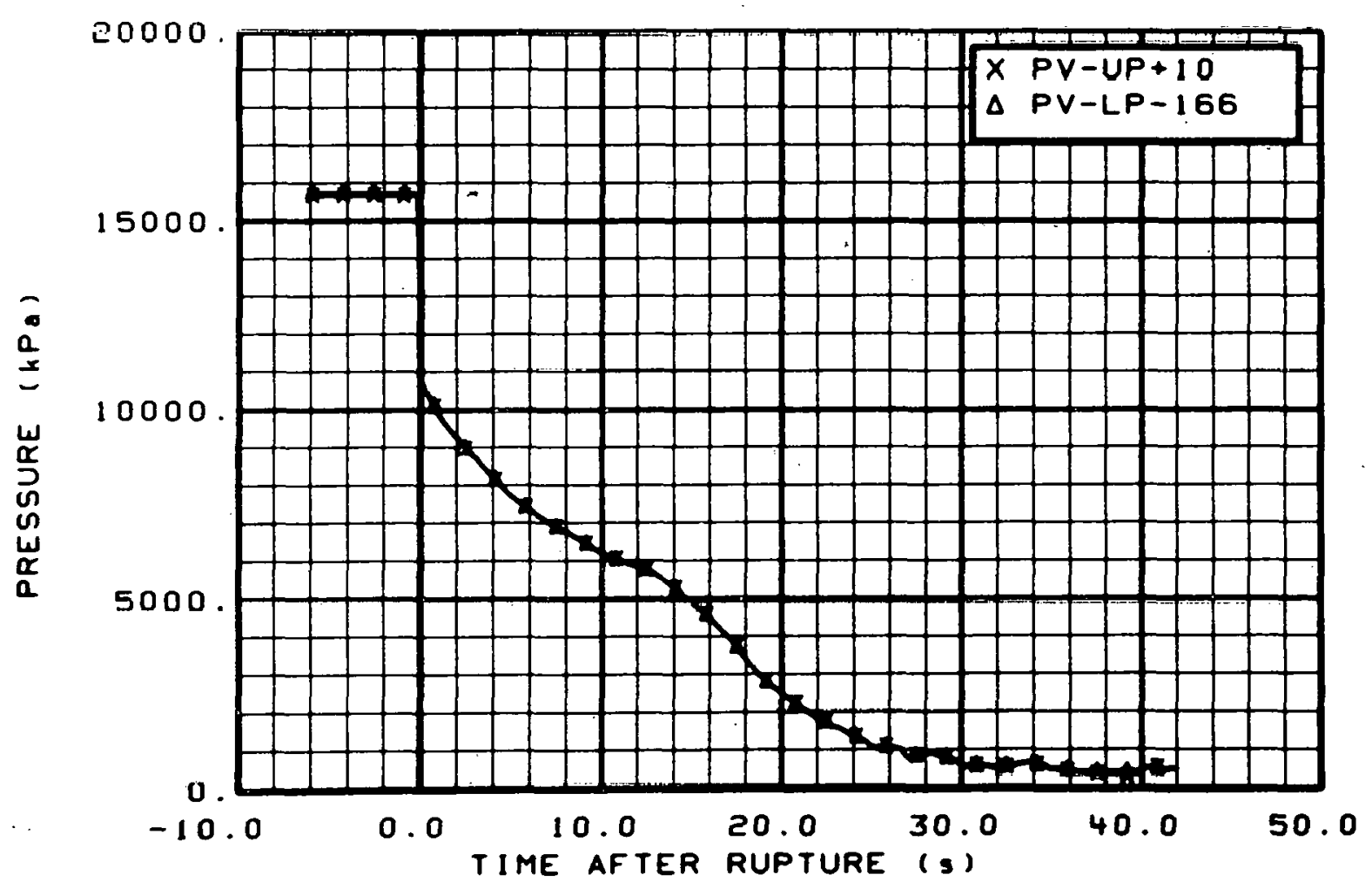

Fig. 154 Pressure in vesse] (PV-UP+10 and PV-LP-166), from -6 to $42 \mathrm{~s}$. 


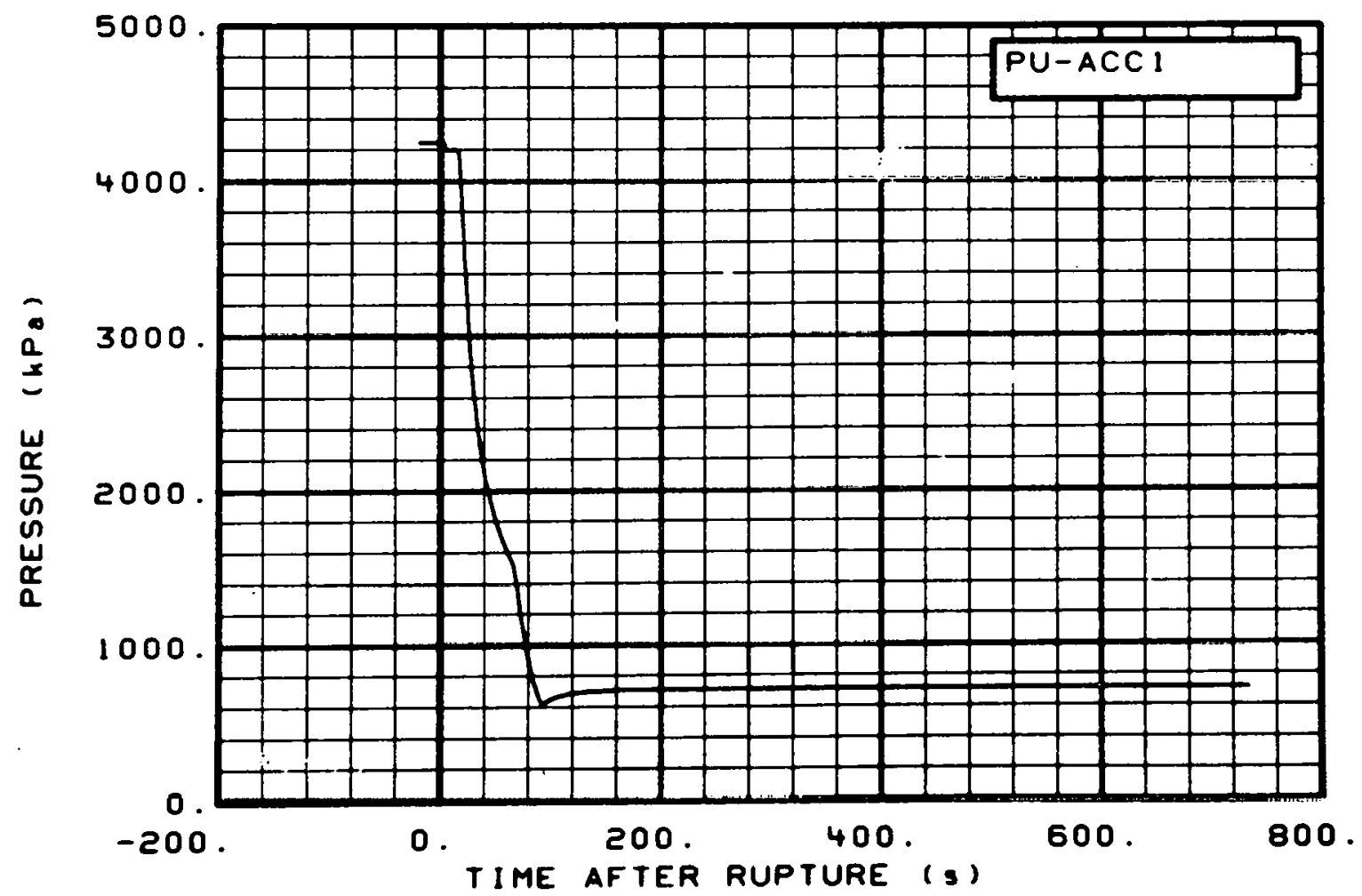

Fig. 155 Pressure in intact loop accumulator (PU-ACC1), from -20 to $736 \mathrm{~s}$.

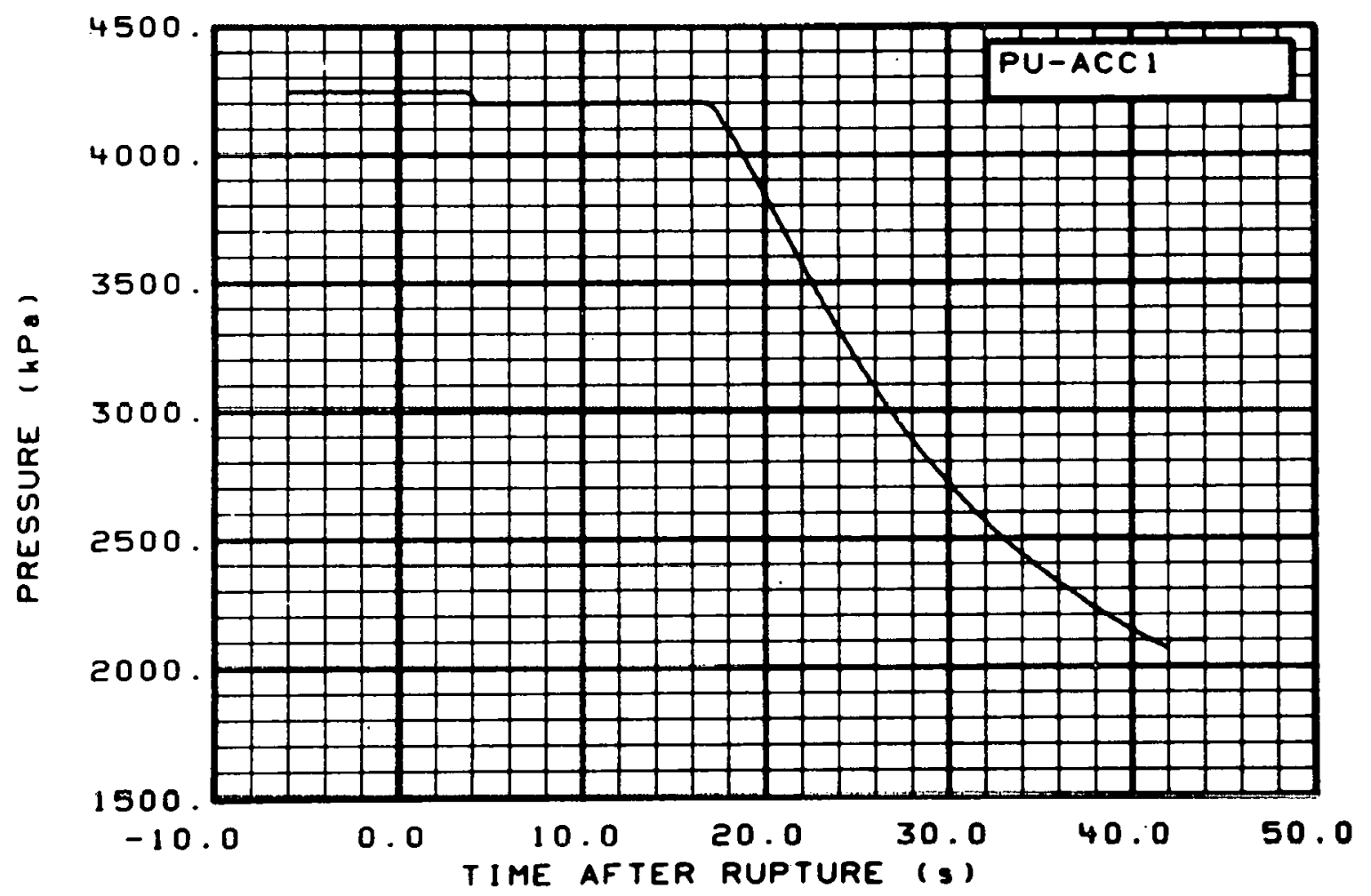

Fig. 156 Pressure in intact loop accumulator (PU-ACC1), from -6 to $42 \mathrm{~s}$. 


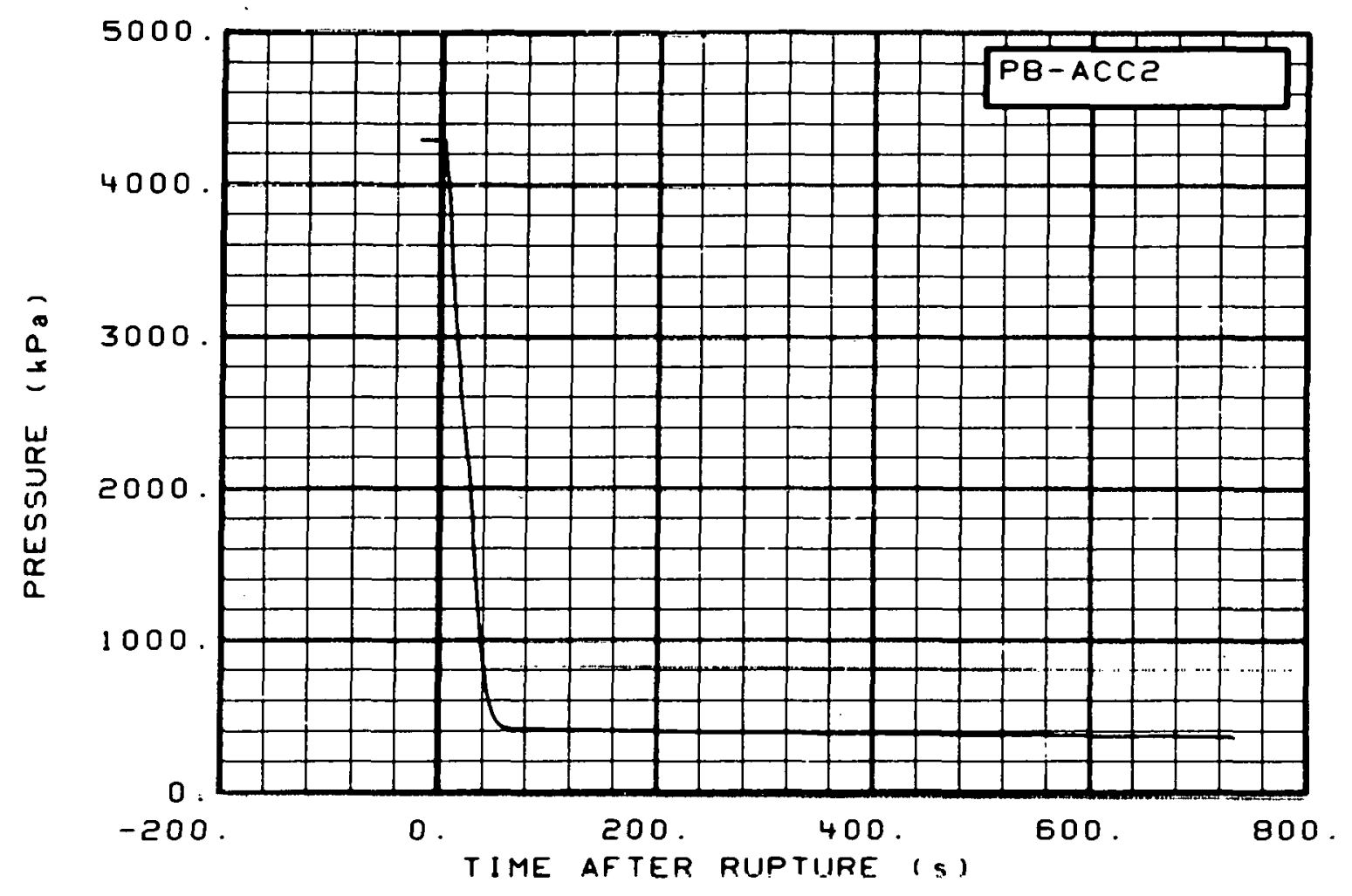

Fig. 157 Pressure in broken loop accumulator (PB-ACC2), from -20 to $736 \mathrm{~s}$.

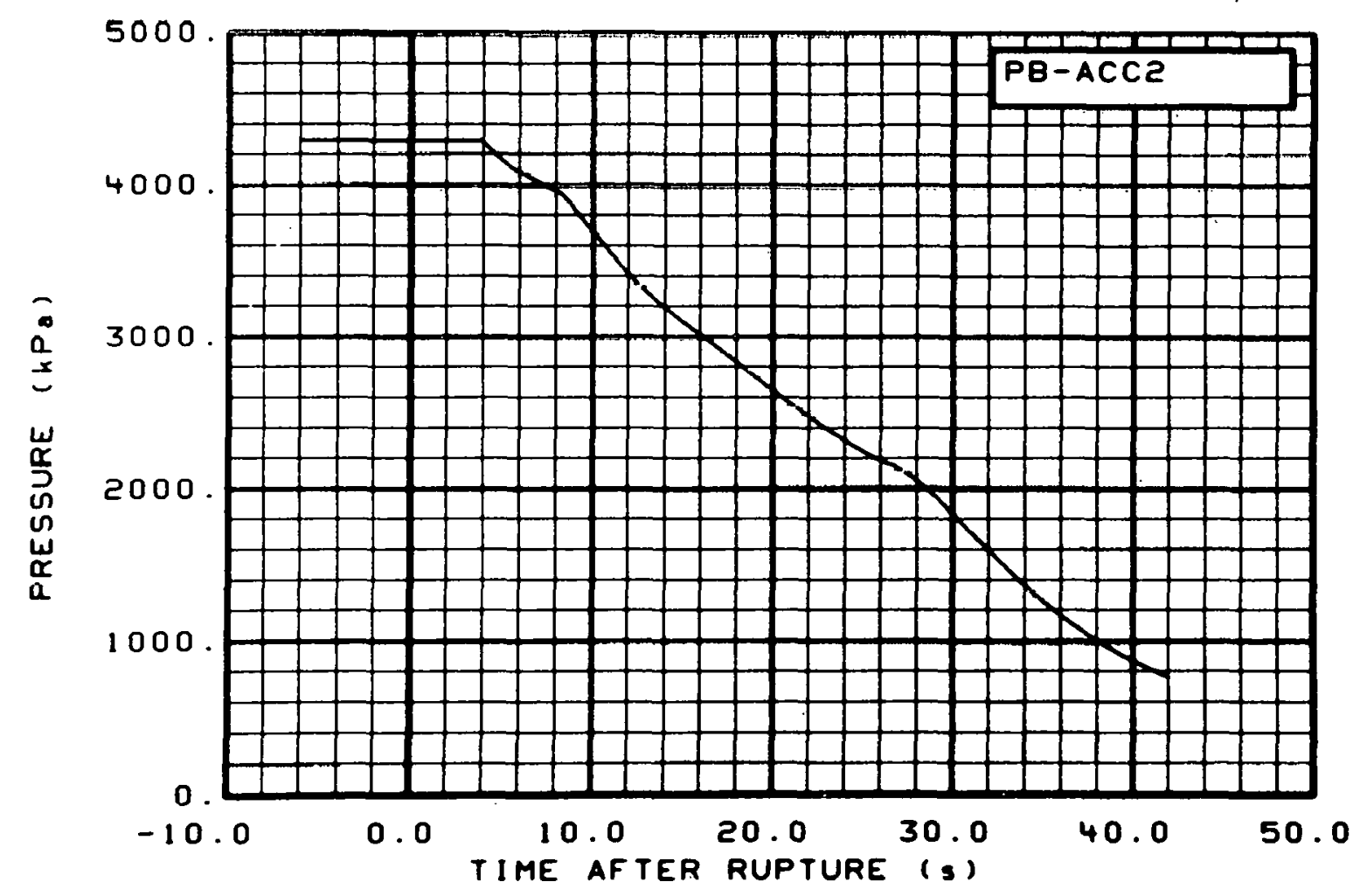

Fig. 158 Pressure in broken 100p accumulator (PB-ACC2), from -6 to $42 \mathrm{~s}$. 


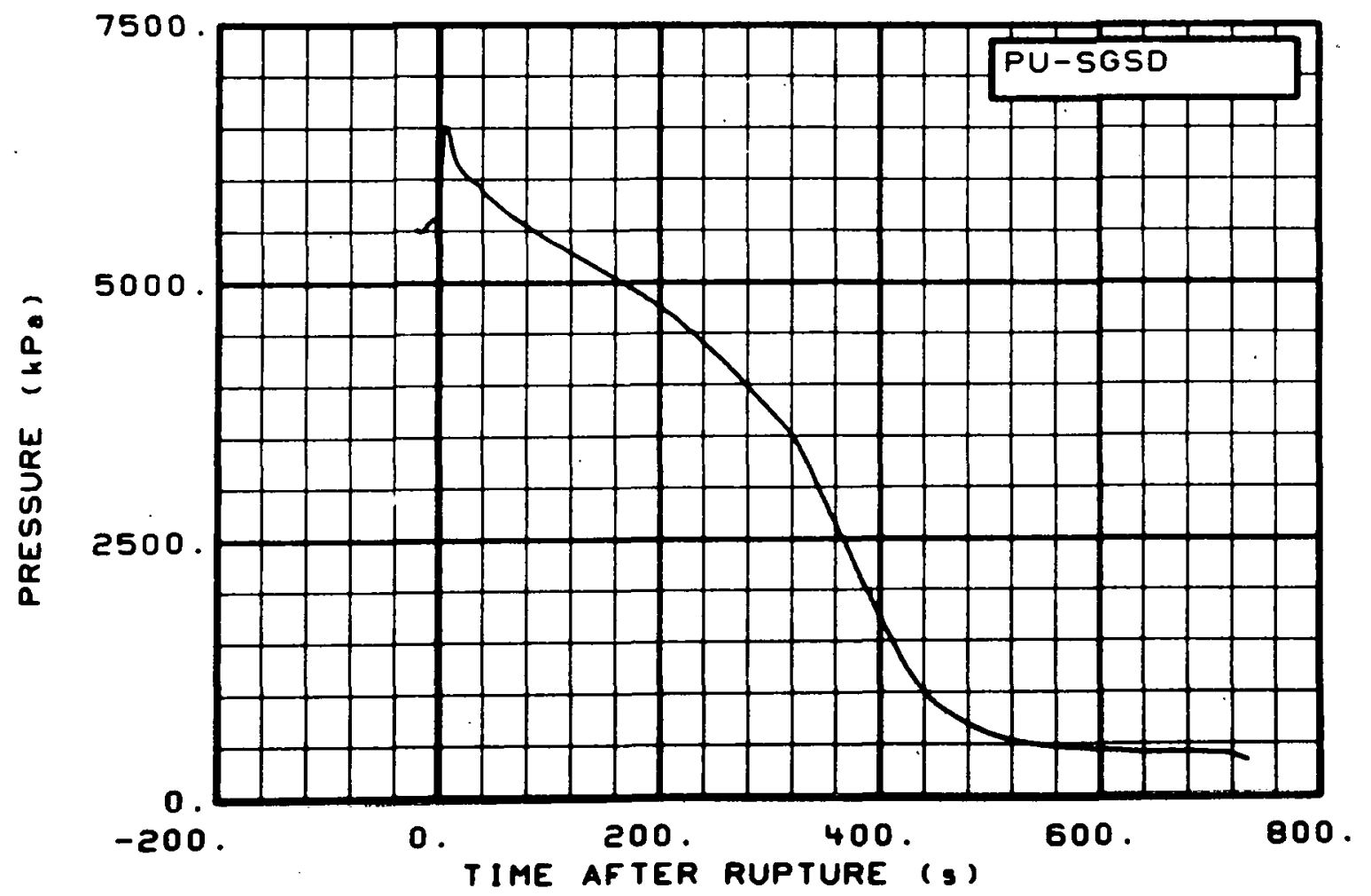

Fig. 159 Pressure in steam generator, secondary side (PU-SGSD), from -20 to $736 \mathrm{~s}$.

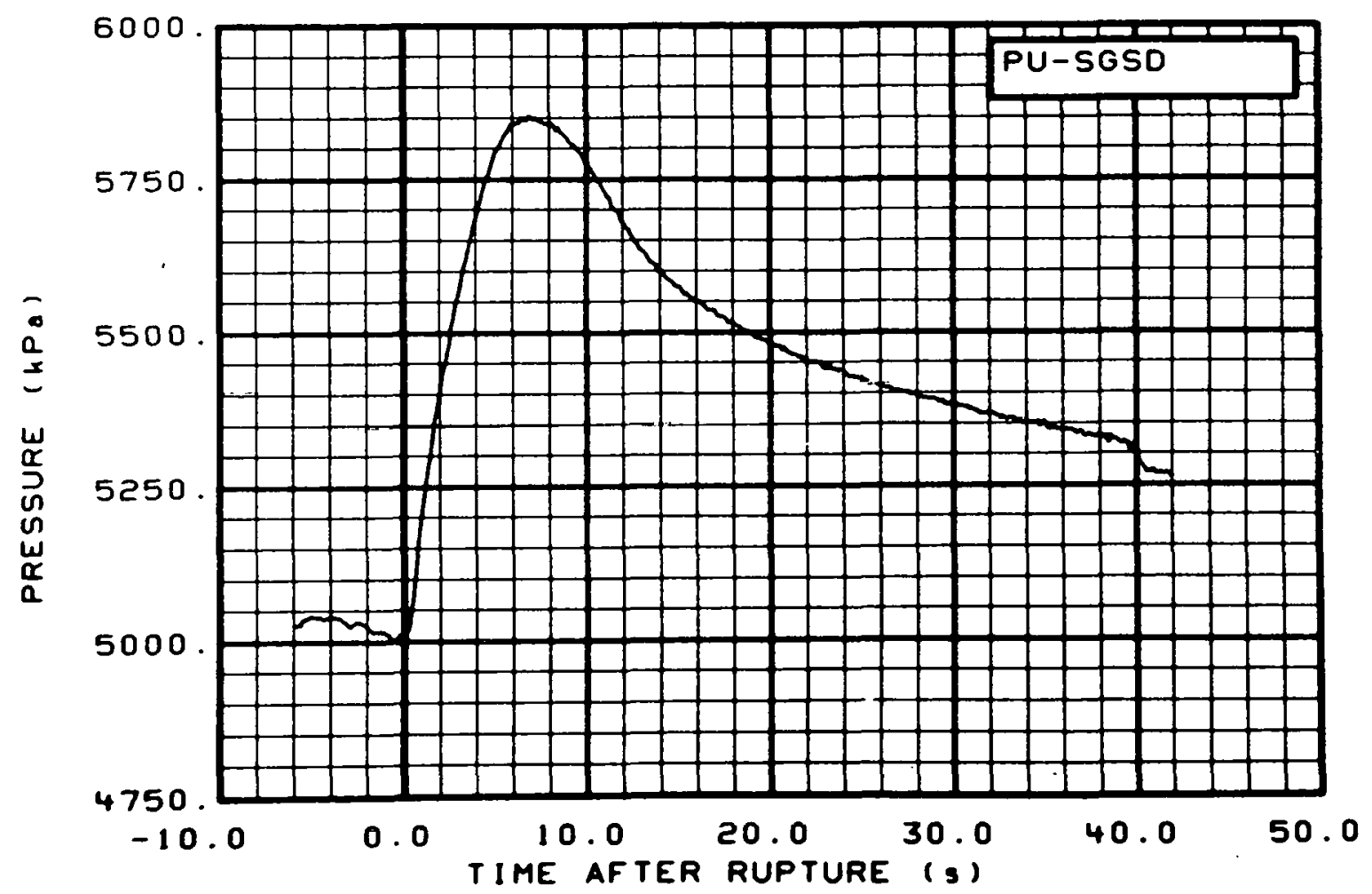

Fig. 160 Pressure in steam generator, secondary side (PU-SGSD), from -6 to $42 \mathrm{~s}$. 


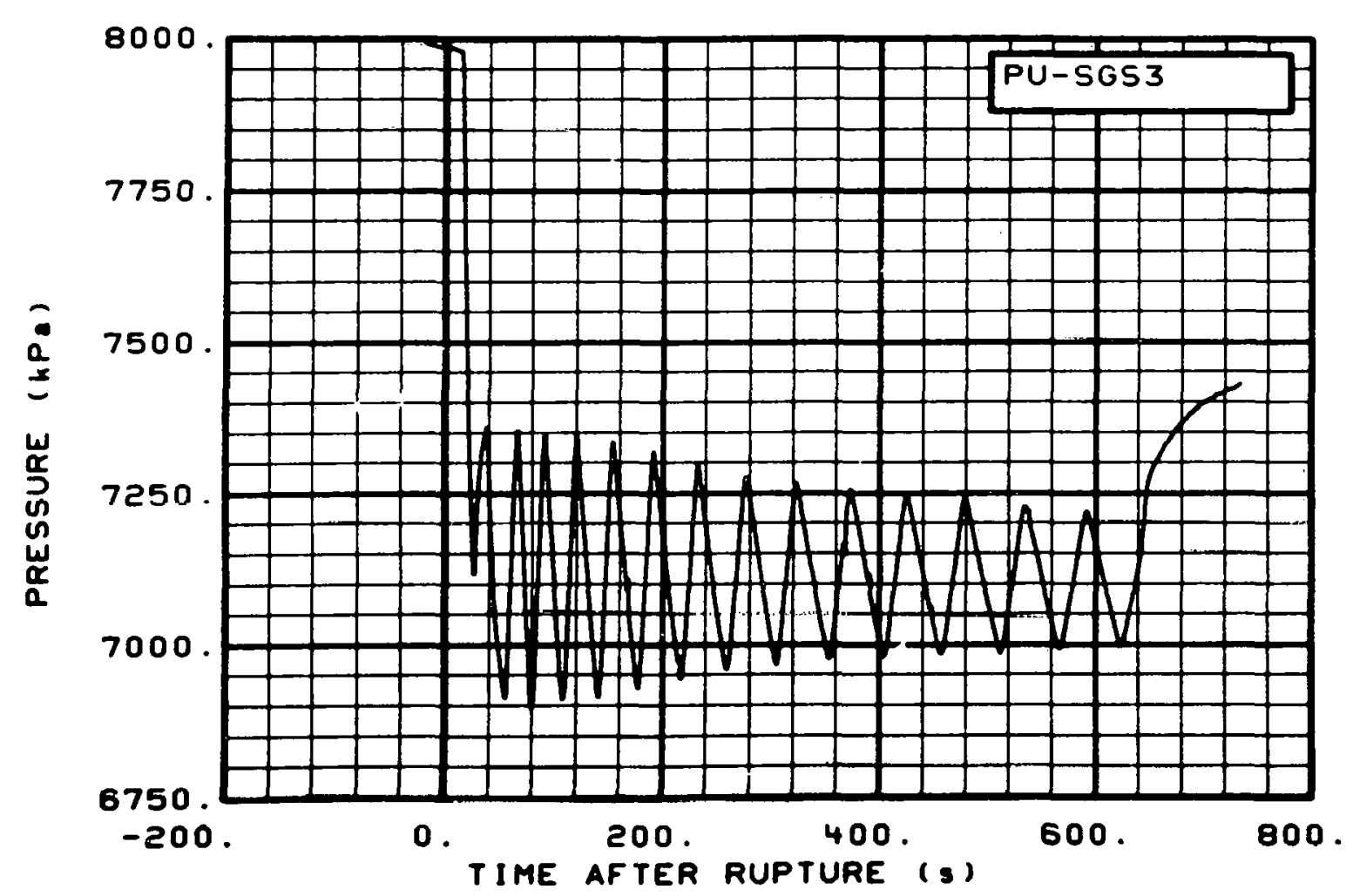

Fig. 161 Pressure in stean generator, secondary side (PU-SGS3), from -20 to $736 \mathrm{~s}$.

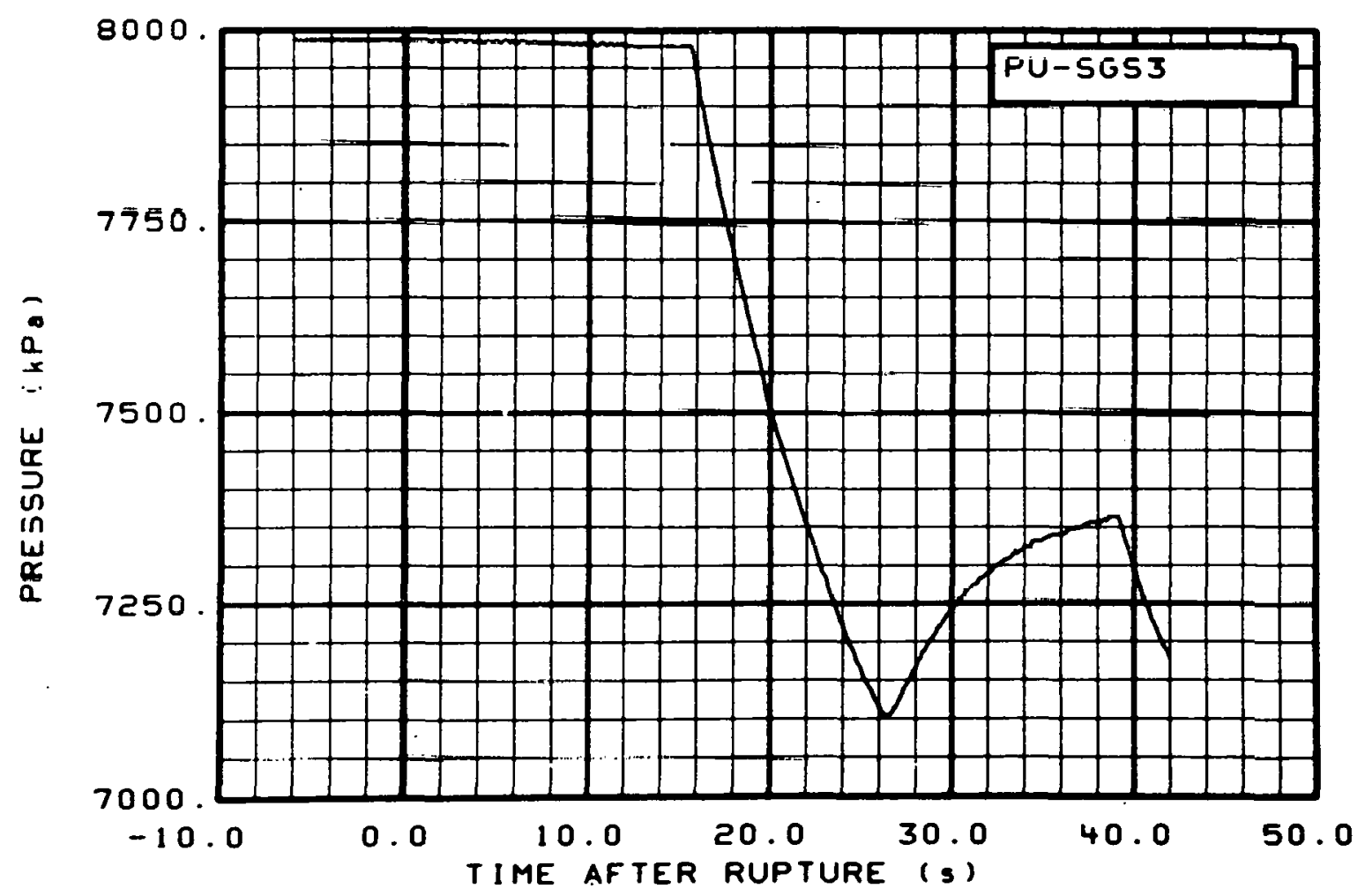

Fig. 162 Pressure in steam generator, secondary side (PU-SGS3), from -6 to $42 \mathrm{~s}$. 


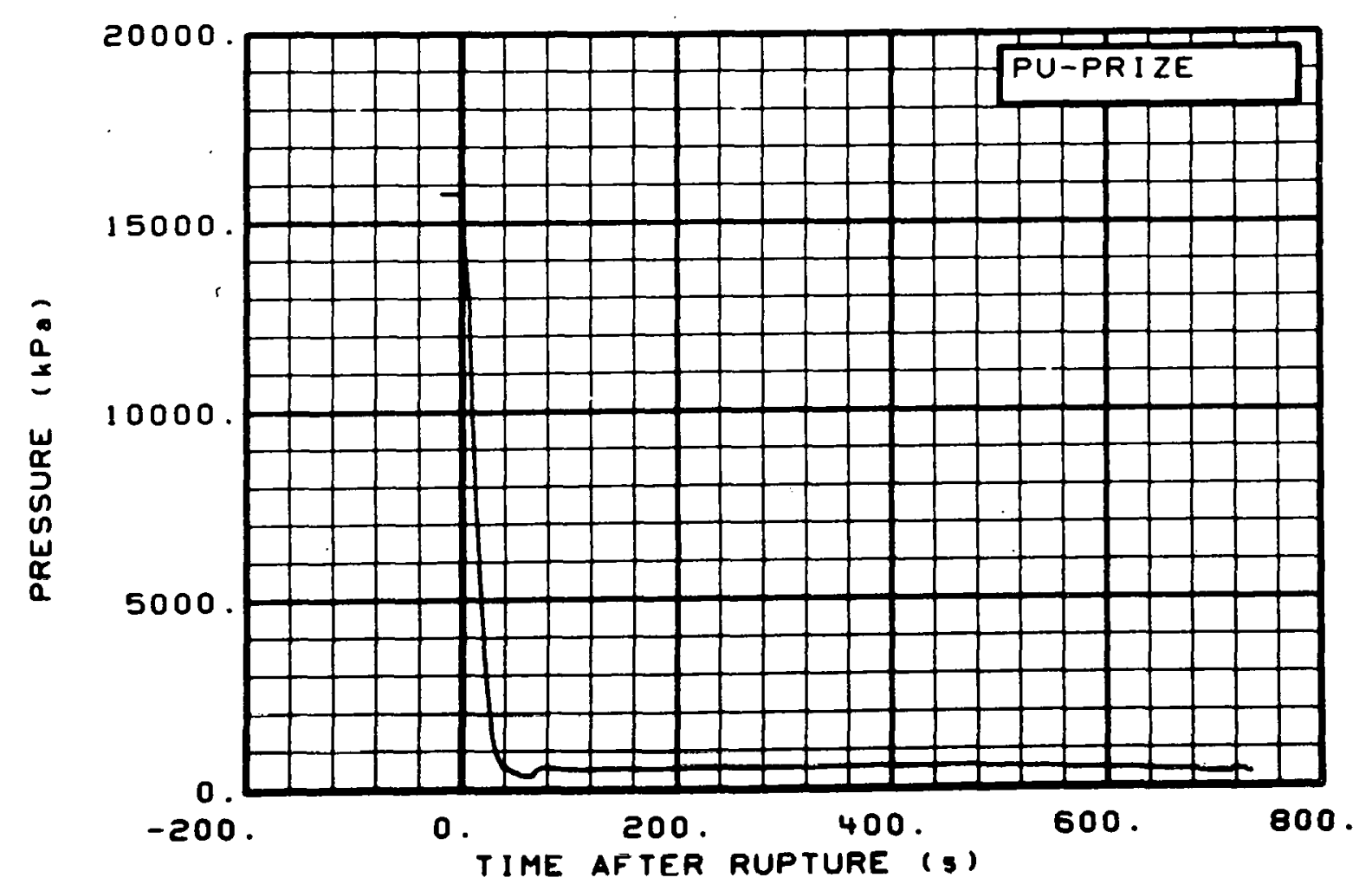

Fig. 163 Pressure in pressurizer (PU-PRIZE), from -20 to $736 \mathrm{~s}$.

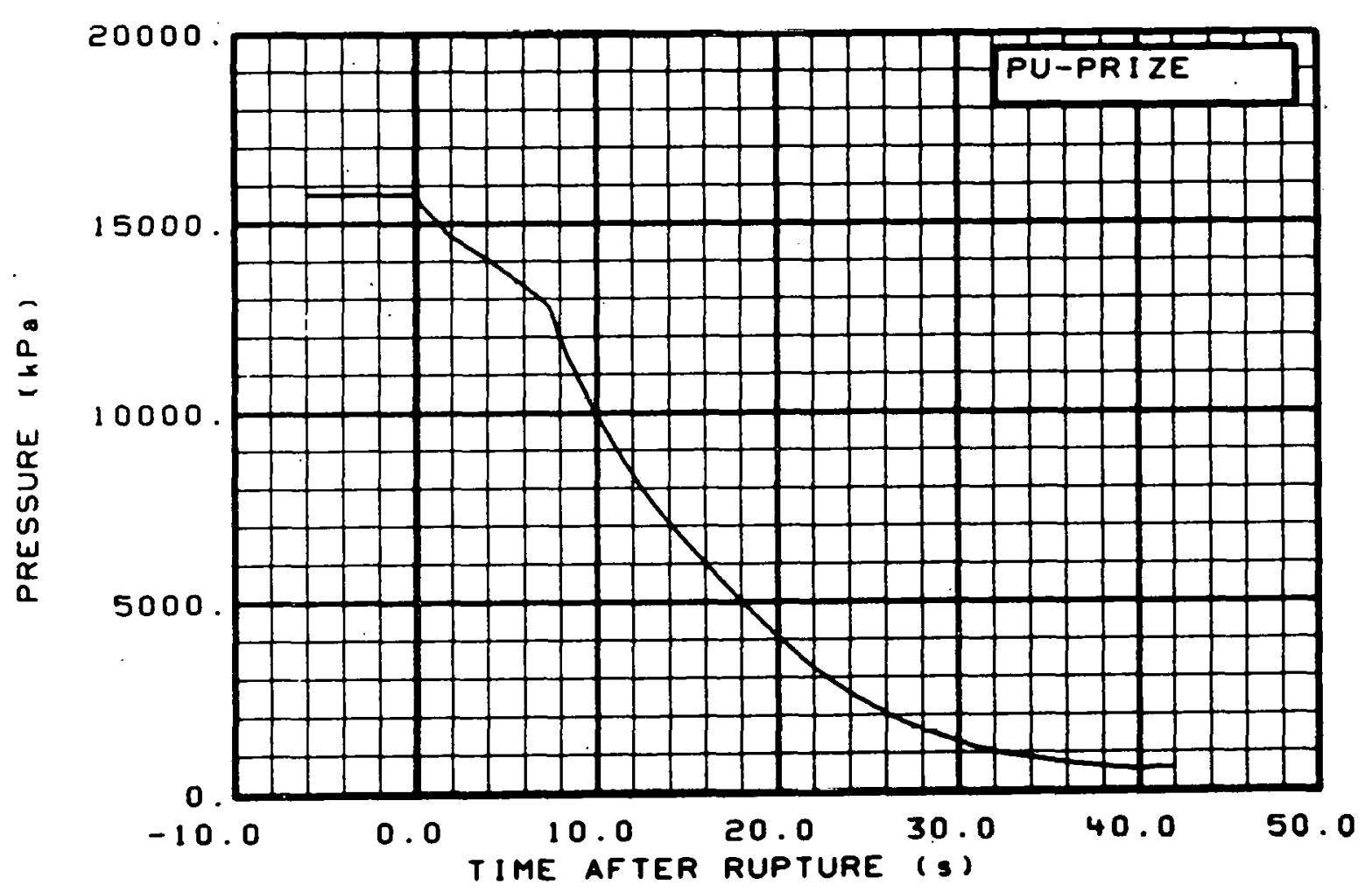

Fig. 164 Pressure in pressurizer (PU-PRIZE), from -6 to $42 \mathrm{~s}$. 


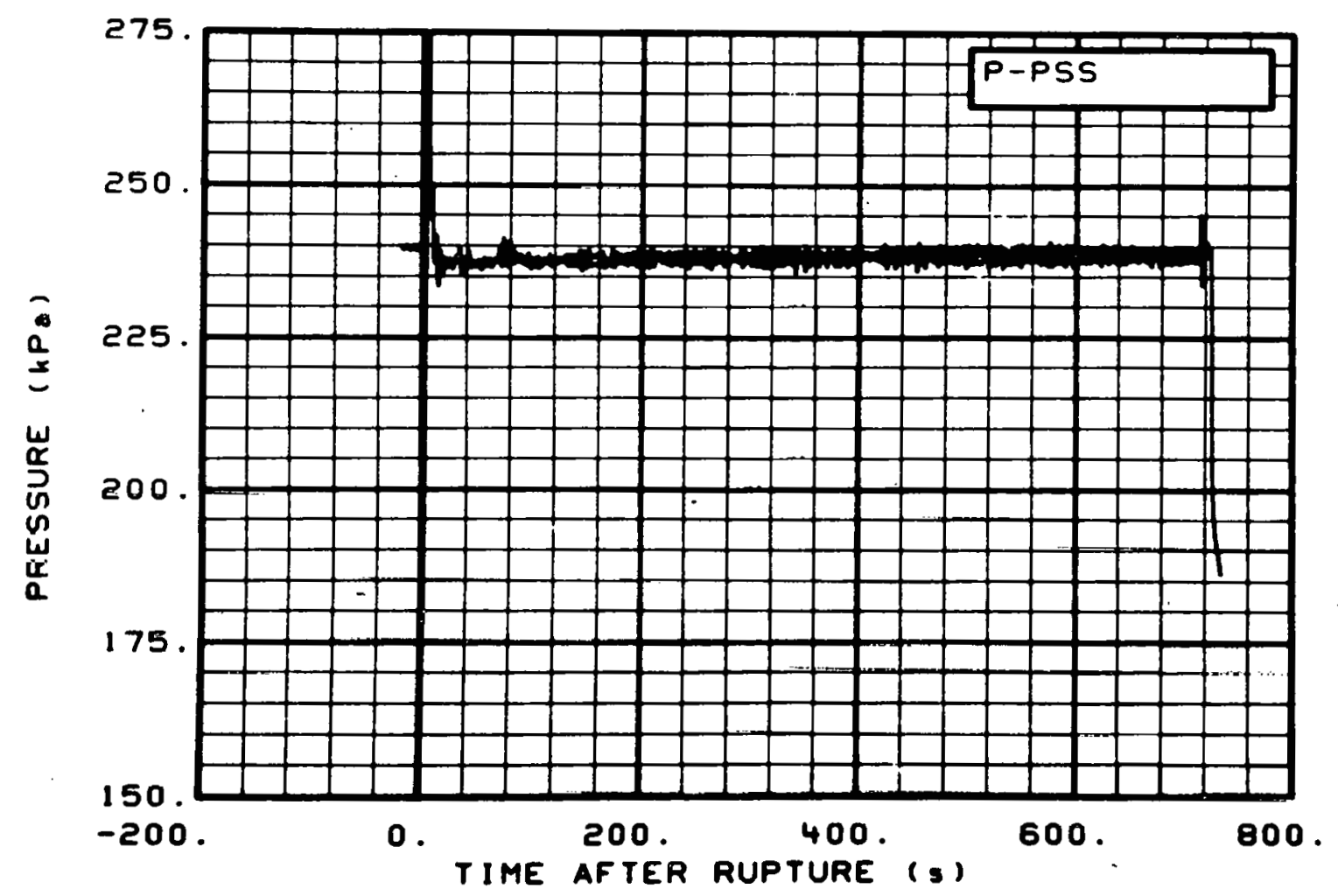

Fig. 165 Pressure in pressure suppression tank (P-PSS), from -20 to $736 \mathrm{~s}$.

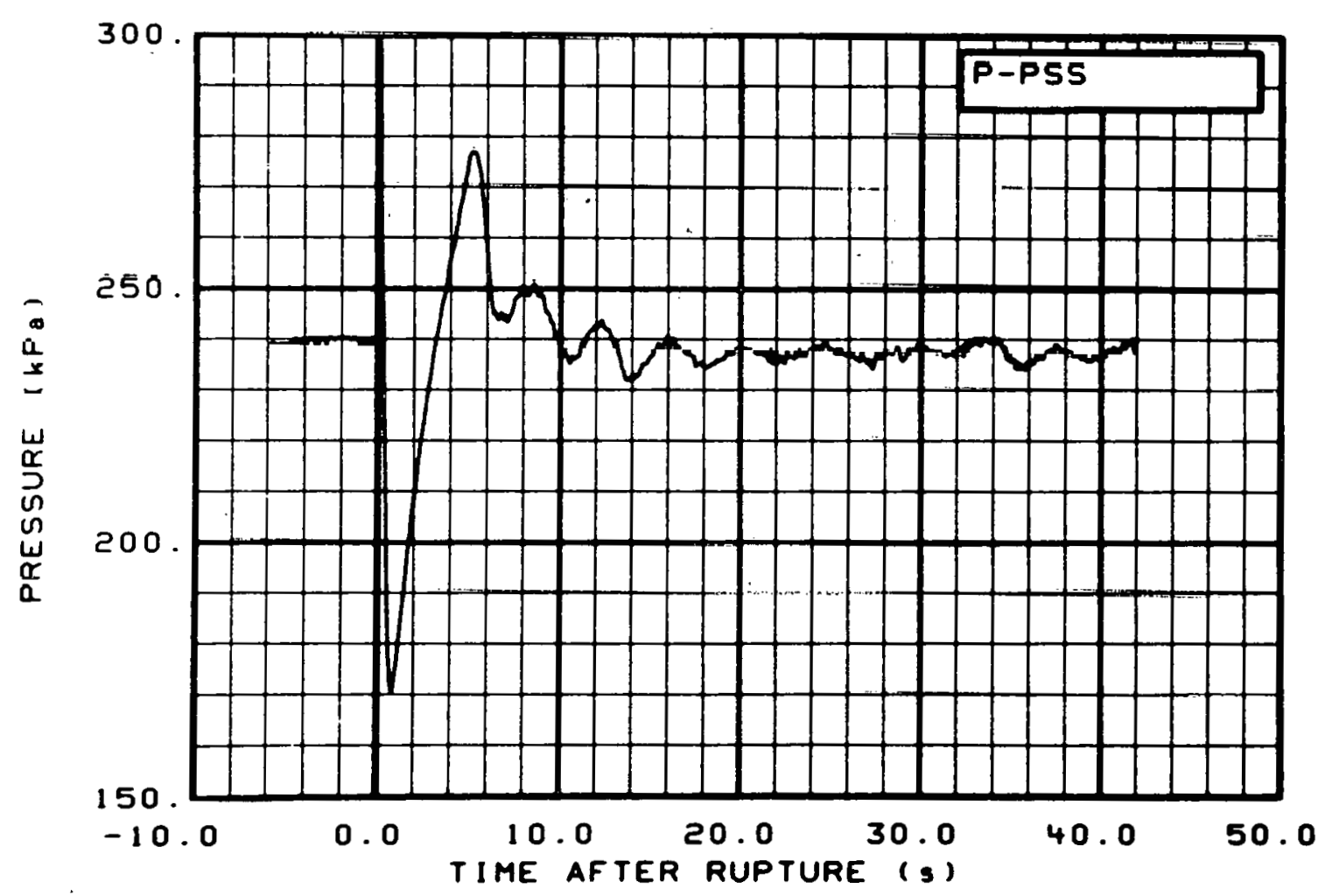

Fig. 166 Pressure in pressure suppression tank (P-PSS), from -6 to $42 \mathrm{~s}$. 


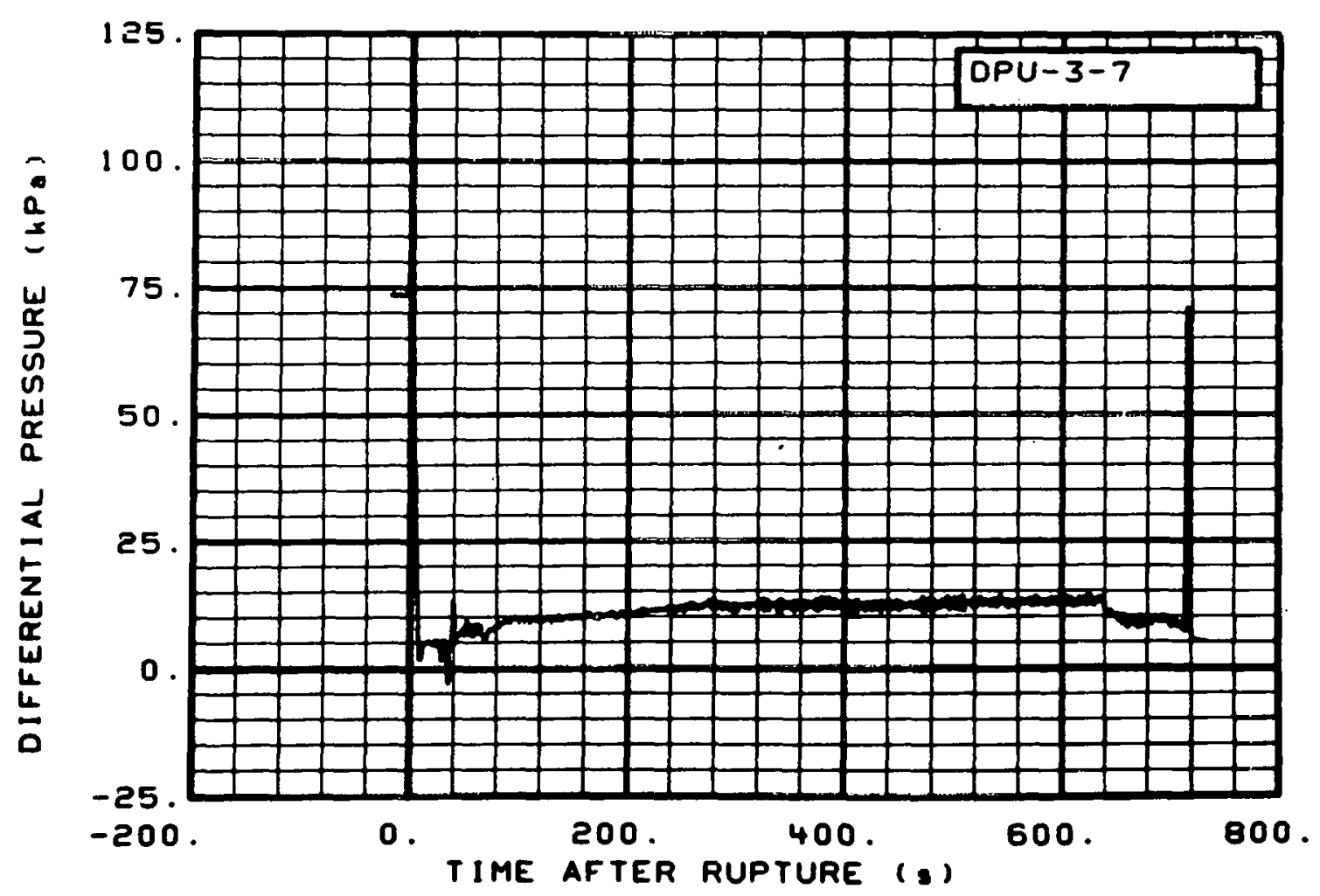

Fig. 167 Differential pressure in intact loop (DPU-3-7), from -20 to $736 \mathrm{~s}$.

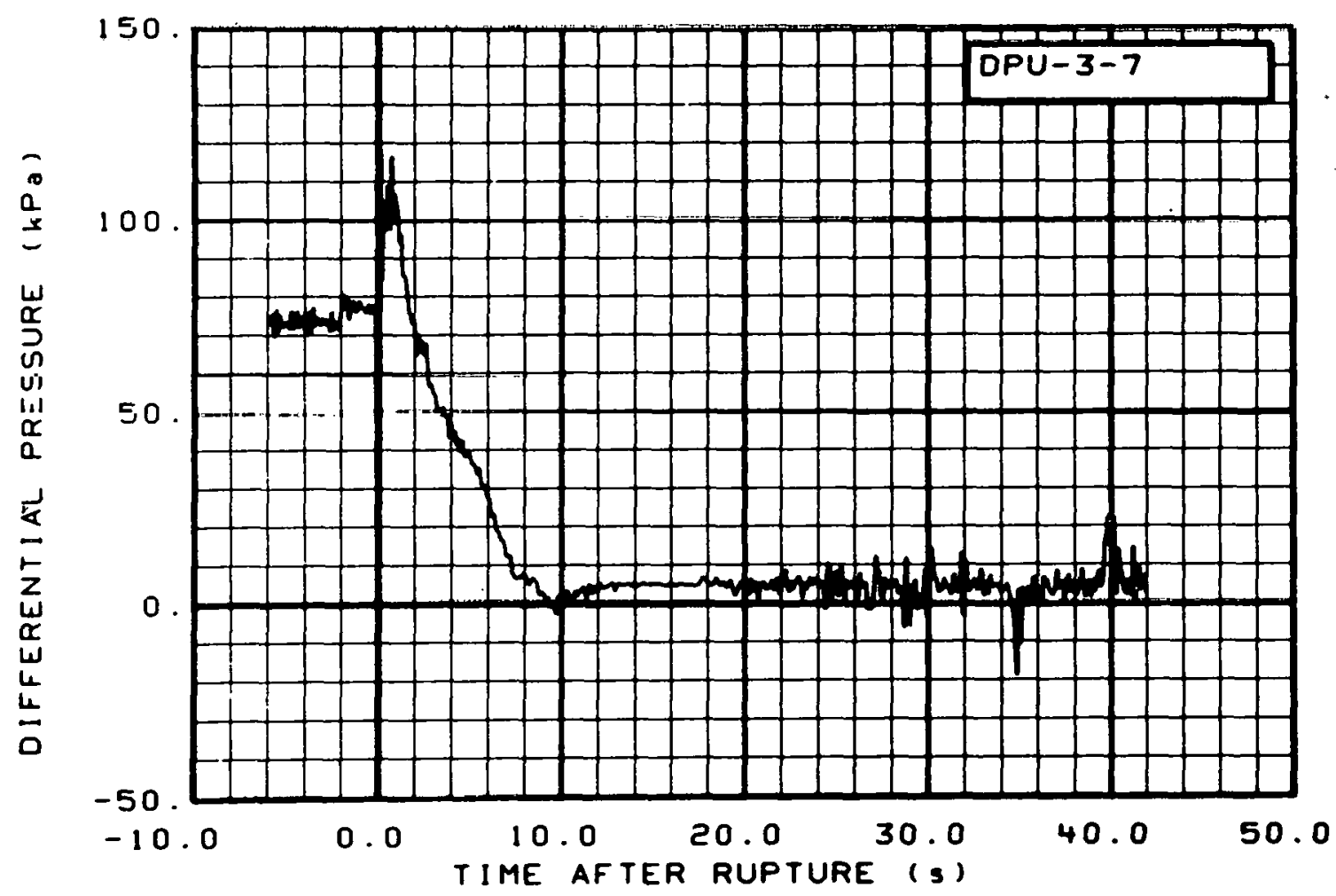

Fig. 168 Differential pressure in intact loop (DPU-3-7), from -6 to $42 \mathrm{~s}$. 


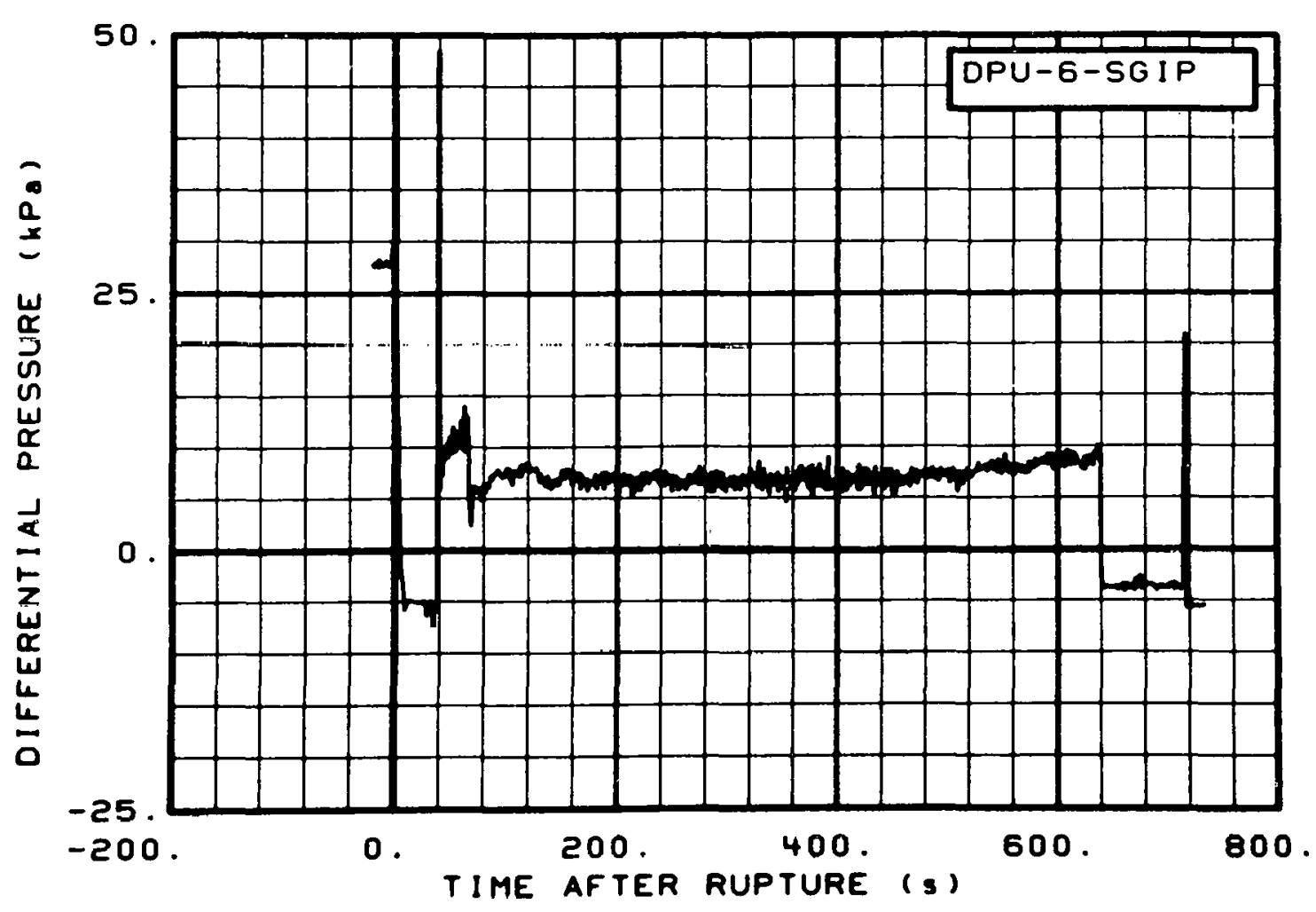

Fig. 169 Differential pressure in intact loop (DPU-6-SGIP), from -20 to $736 \mathrm{~s}$.

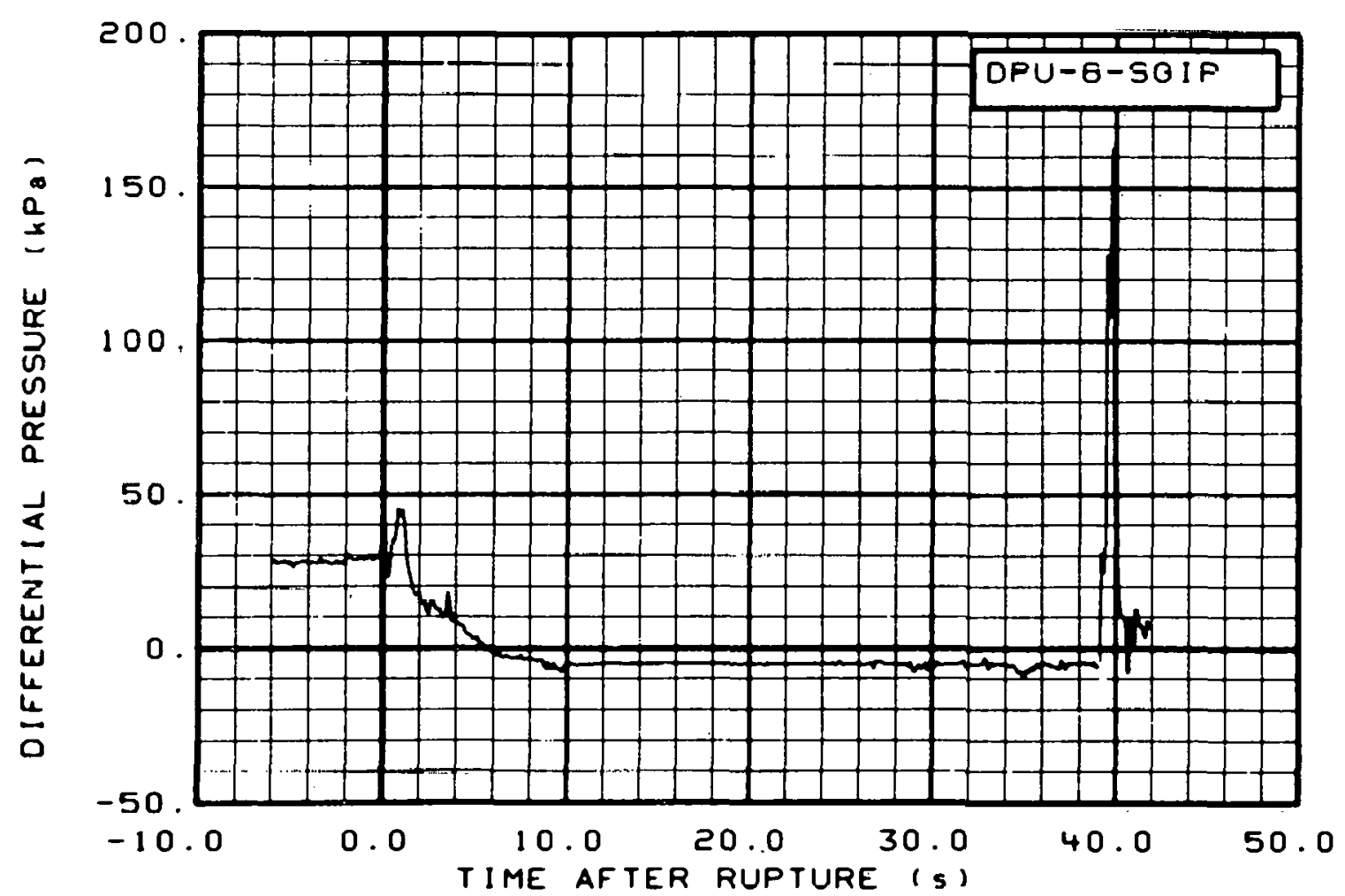

Fig. 170 Differential pressure in intact loop (DPU-6-SGIP), from -6 to $42 \mathrm{~s}$. 


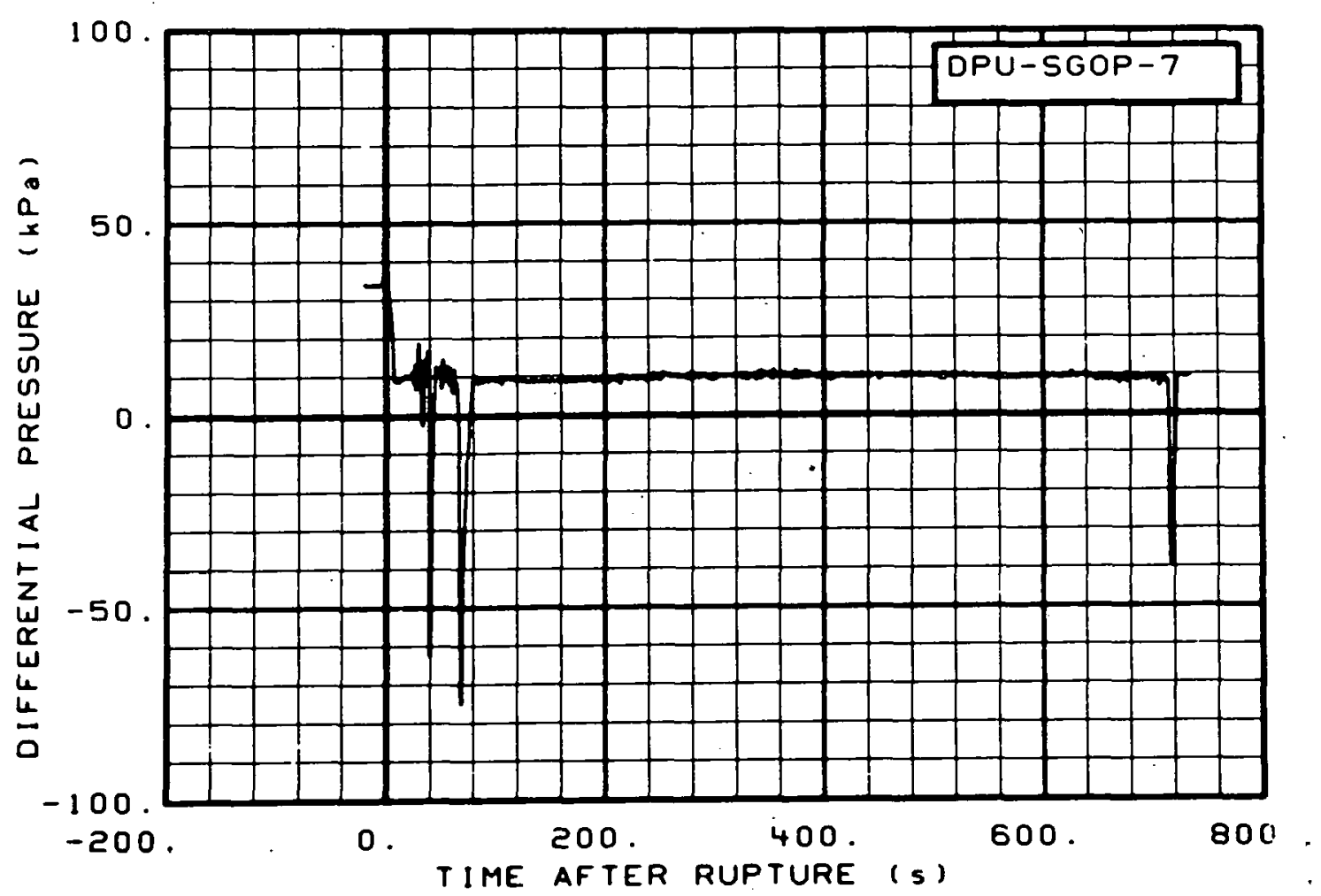

Fig. 171 Differential pressure in intact loop (DPU-SGOP-7), from -20 to $736 \mathrm{~s}$.

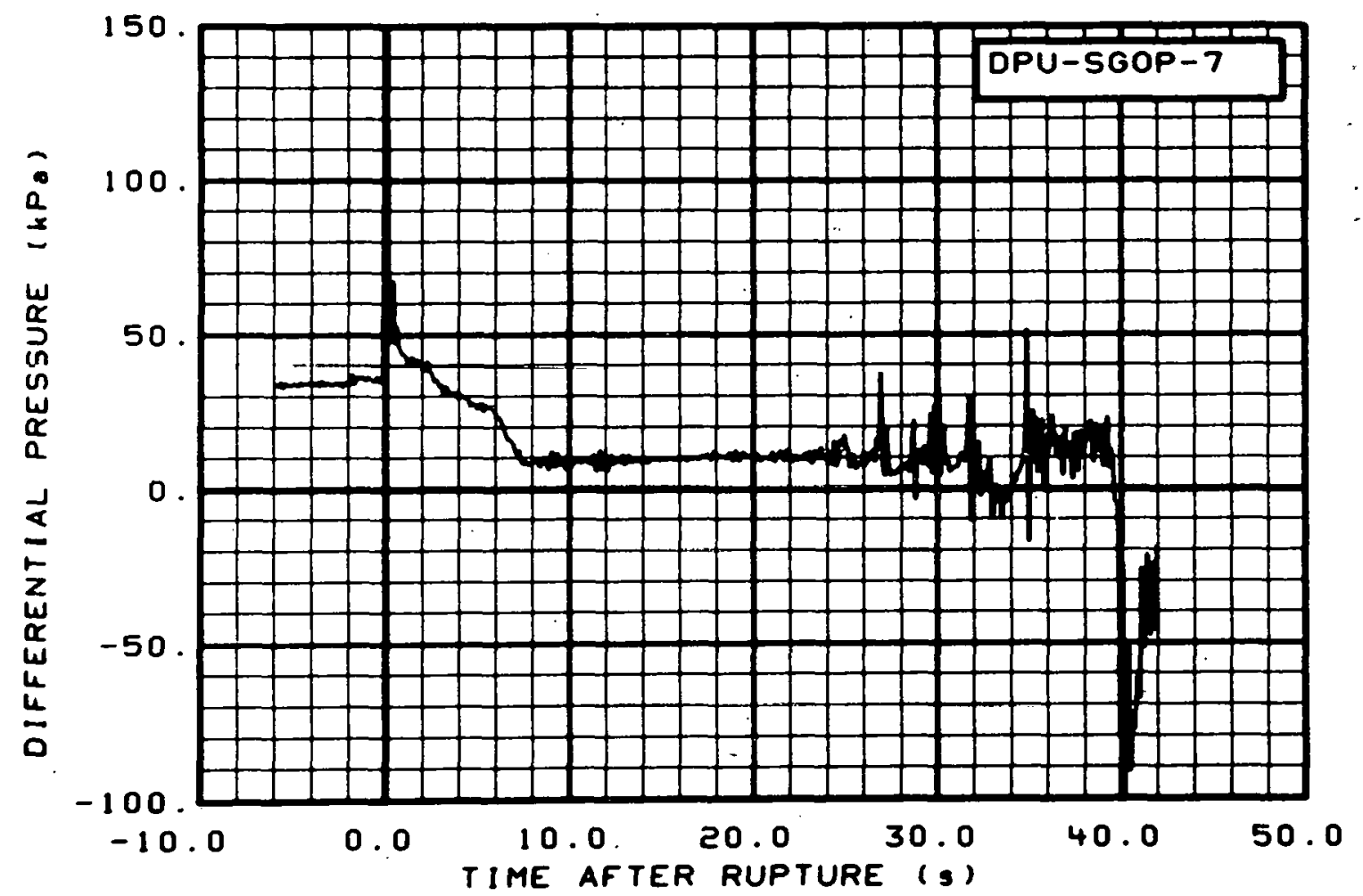

Fig. 172 Differential pressure in intact loop (DPIJ-SGOP-7), from -6 to $42 \mathrm{~s}$. 


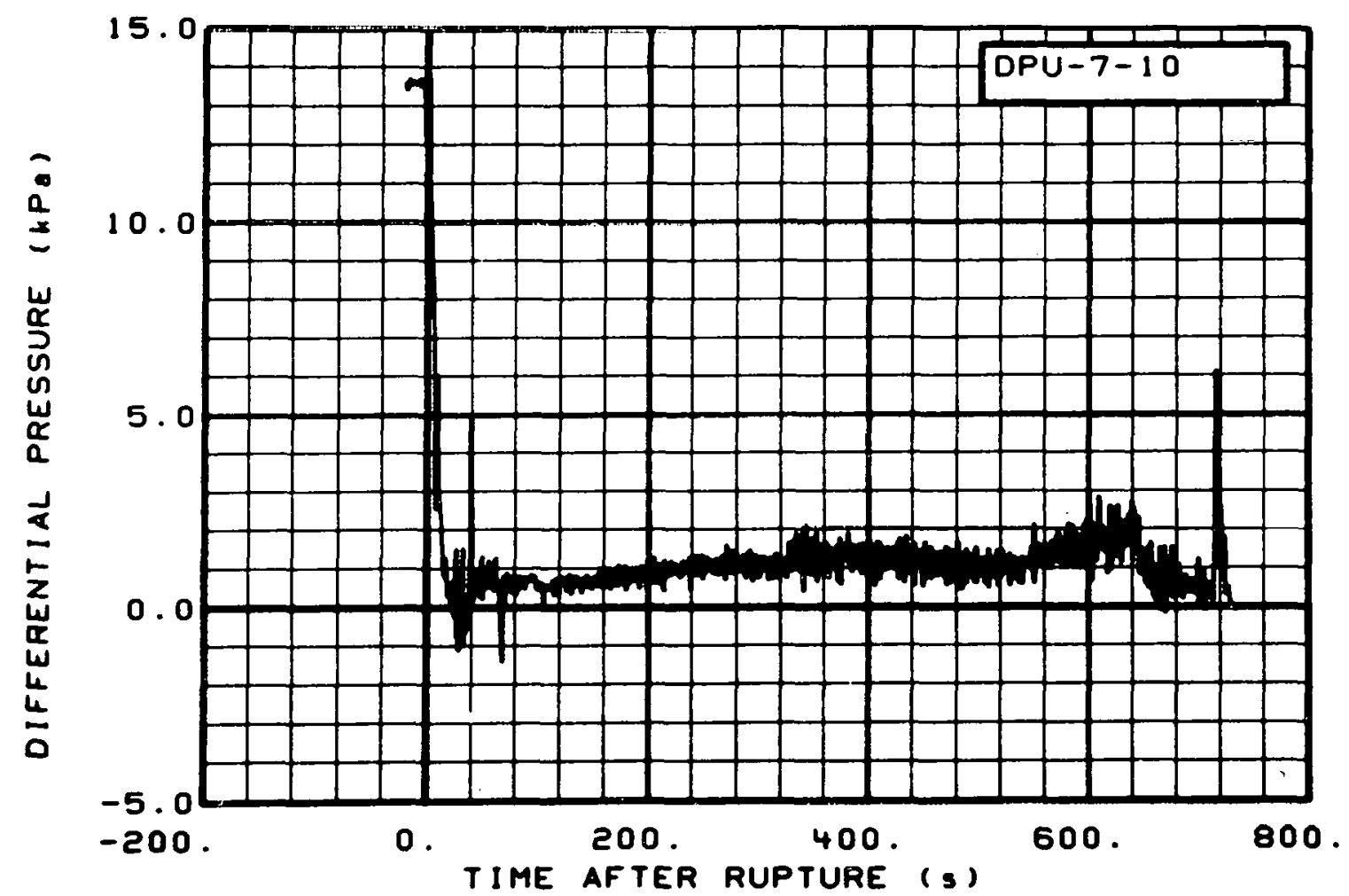

Fig. 173 Differential pressure in intact 100p (DPU-7-10), from -20 to $736 \mathrm{~s}$.

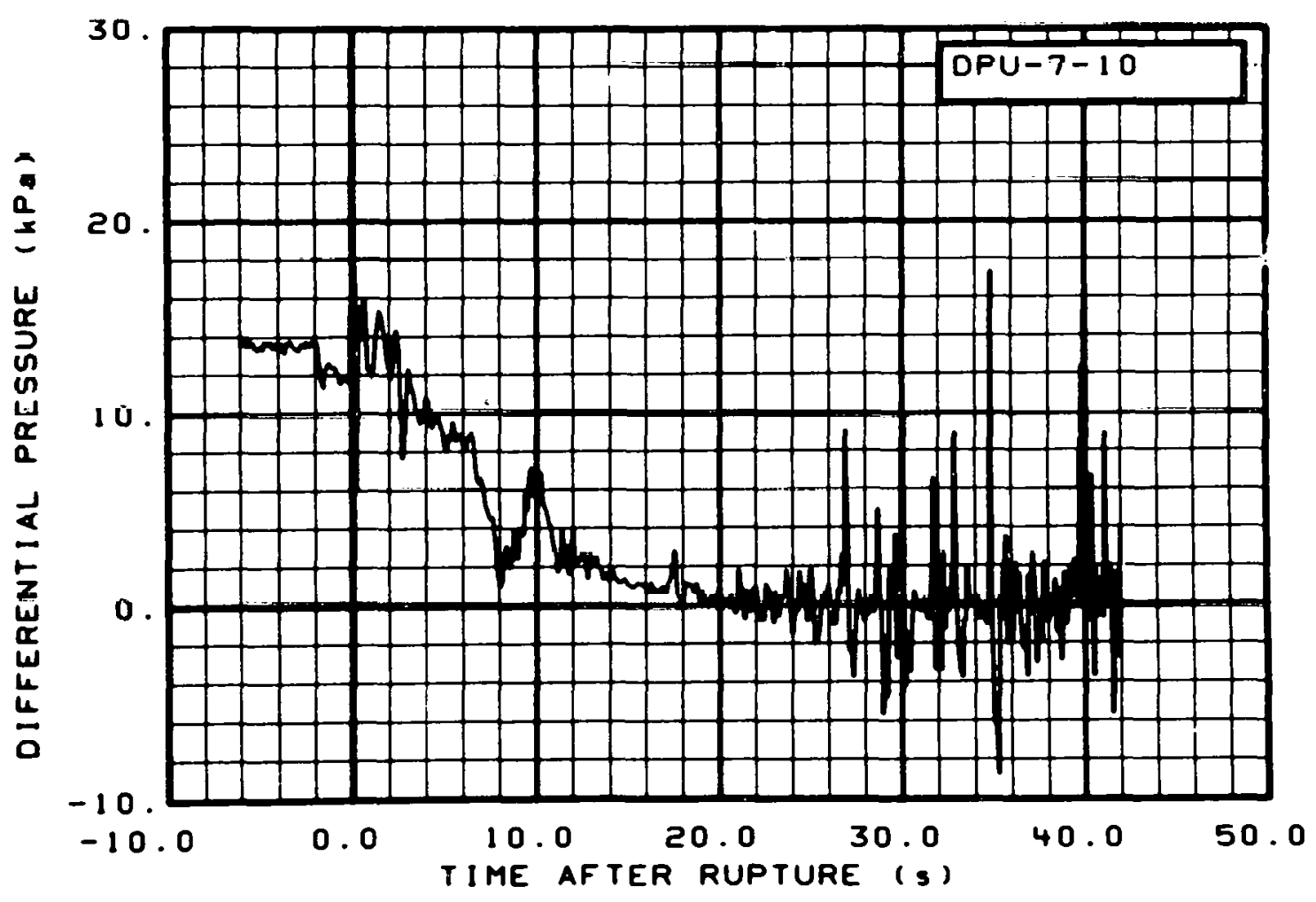

Fig. 174 Differential pressure in intact loop (DPU-7-10), from -6 to $42 \mathrm{~s}$. 


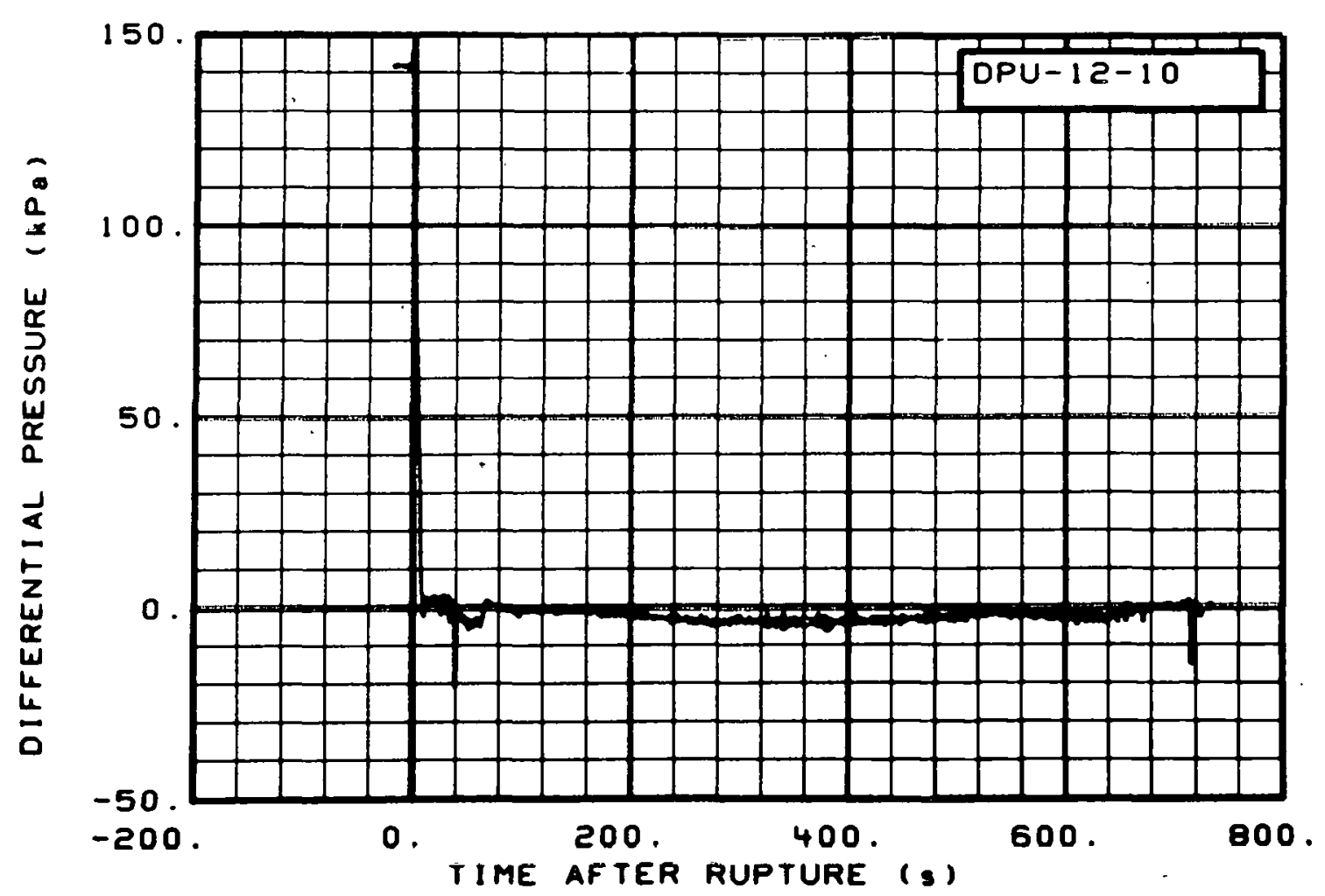

Fig. 175 Differential pressure in intact loop (DPU-12-10), from -20 to $736 \mathrm{~s}$.

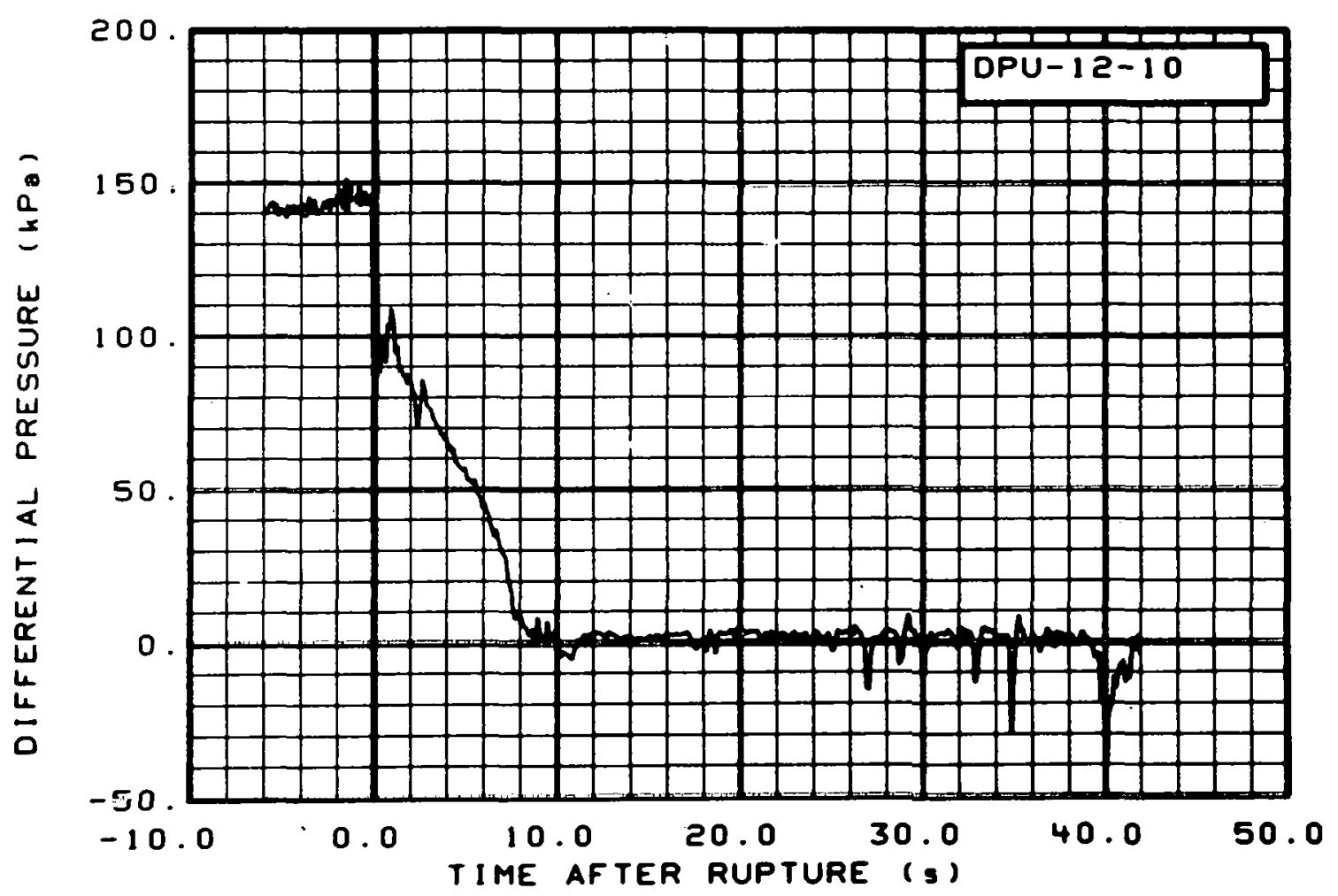

Fig. 176 Differential pressure in intact loop (DPU-12-10), from -6 to $42 \mathrm{~s}$. 


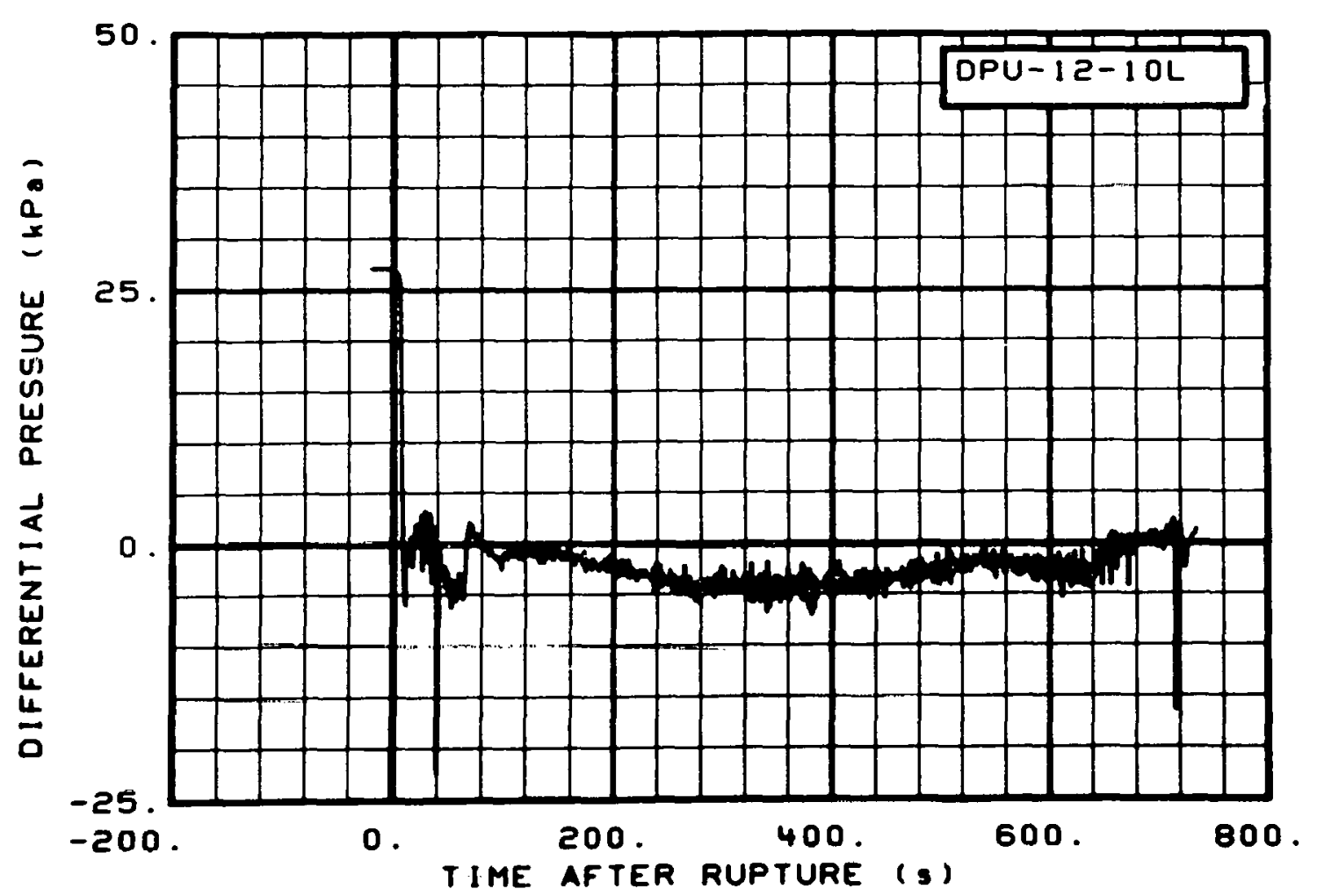

Fig. 177 Differential pressure in intact loop, low range (DPU-12-10L), from -20 to $736 \mathrm{~s}$.

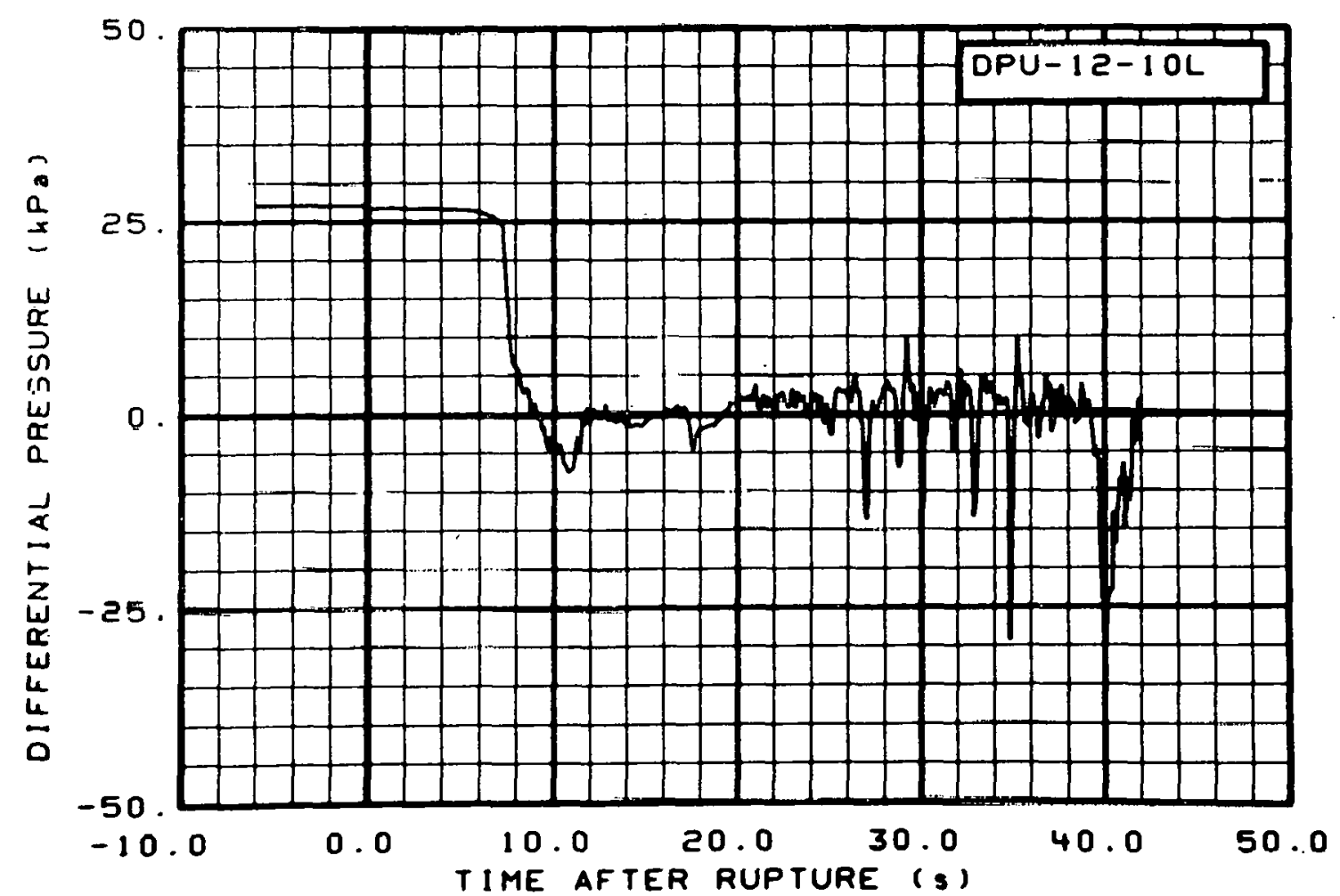

Fig. 178 Differential pressure in intact loop, low range (DPU-12-10L), from -6 to $42 \mathrm{~s}$. 


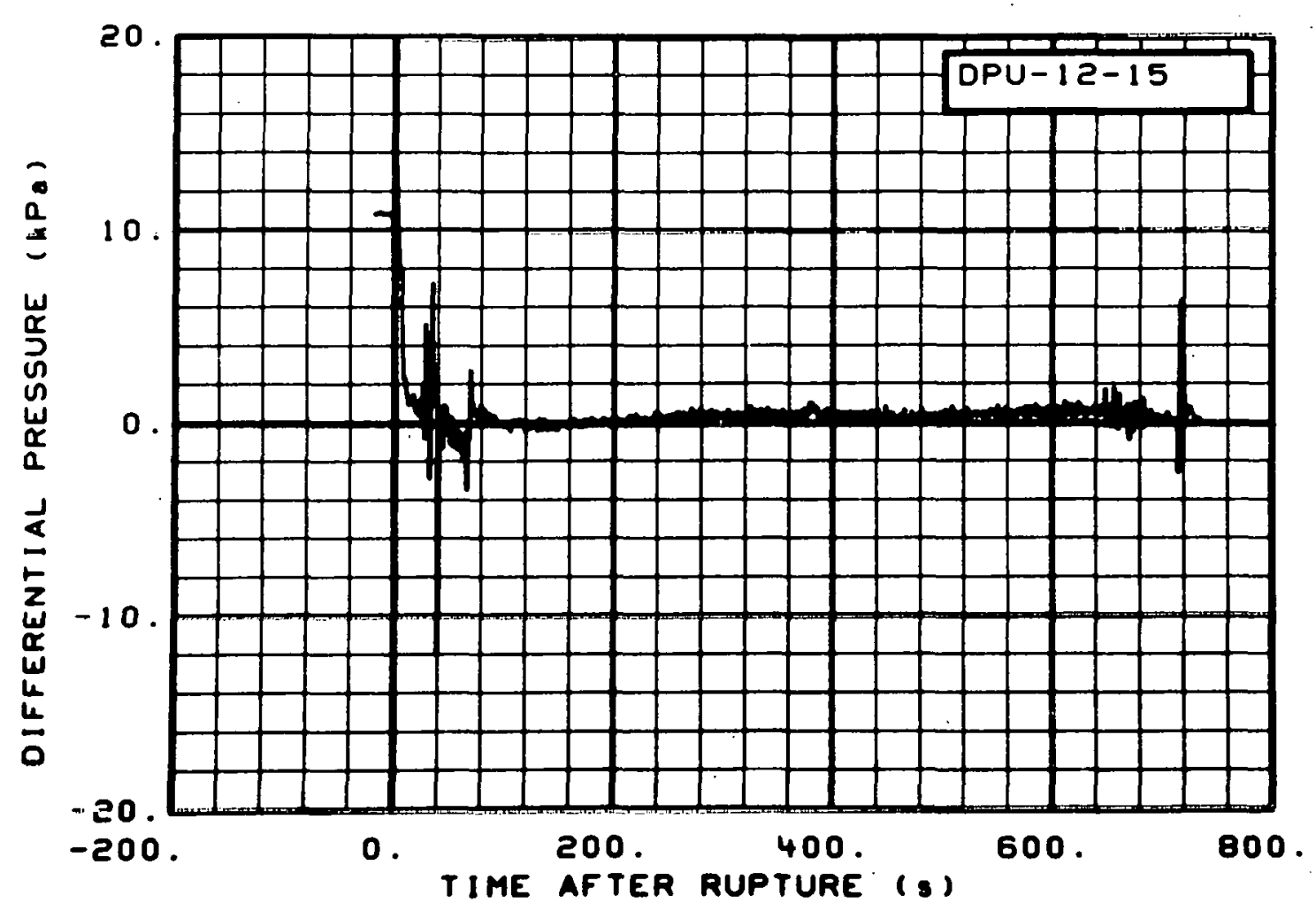

Fig. 179 Differential pressure in intact loop (DPU-12-15), from -20 to $736 \mathrm{~s}$.

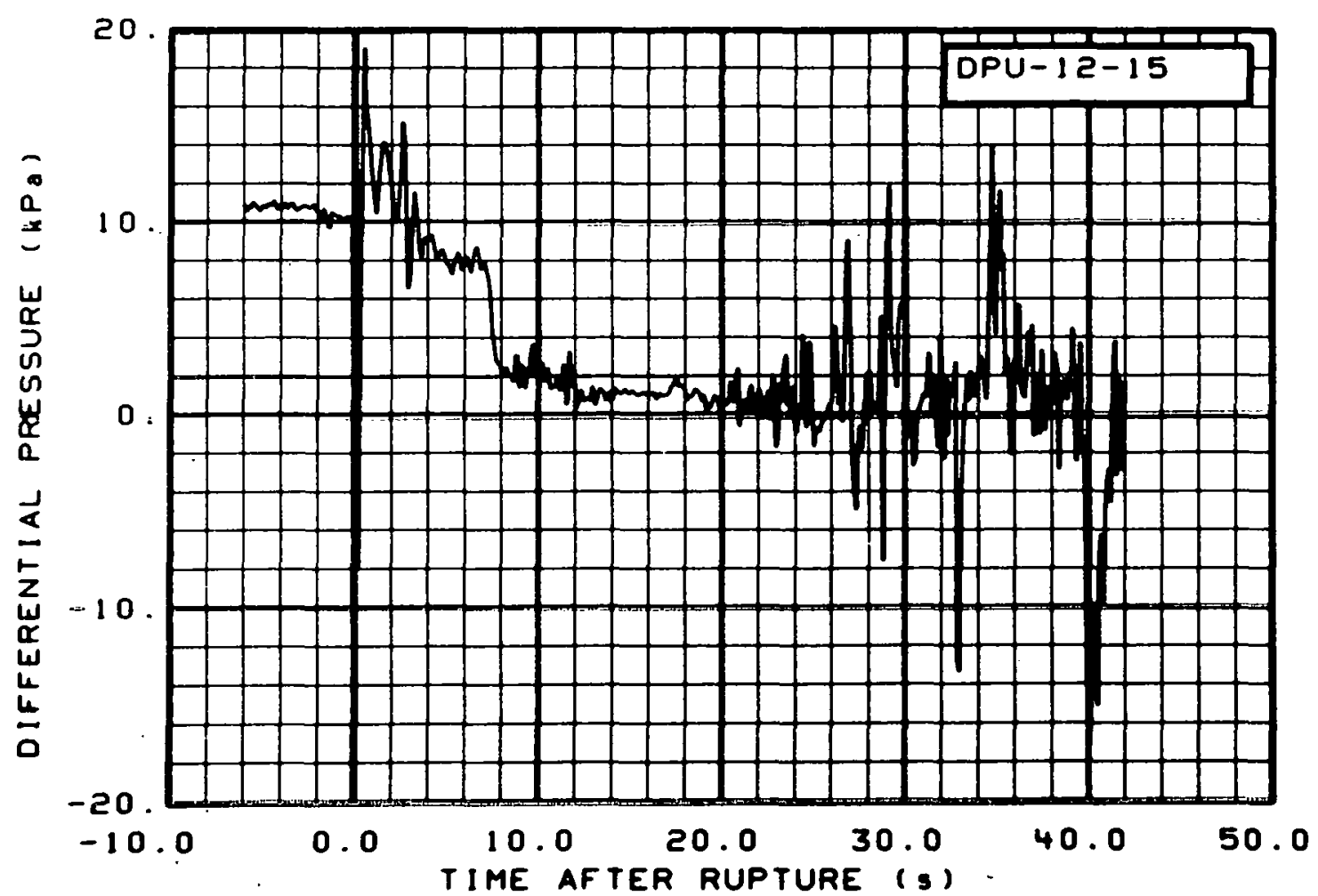

Fig. 180 Differential pressure in intact 1oop (DPU-12-15), from -6 to $42 \mathrm{~s}$. 


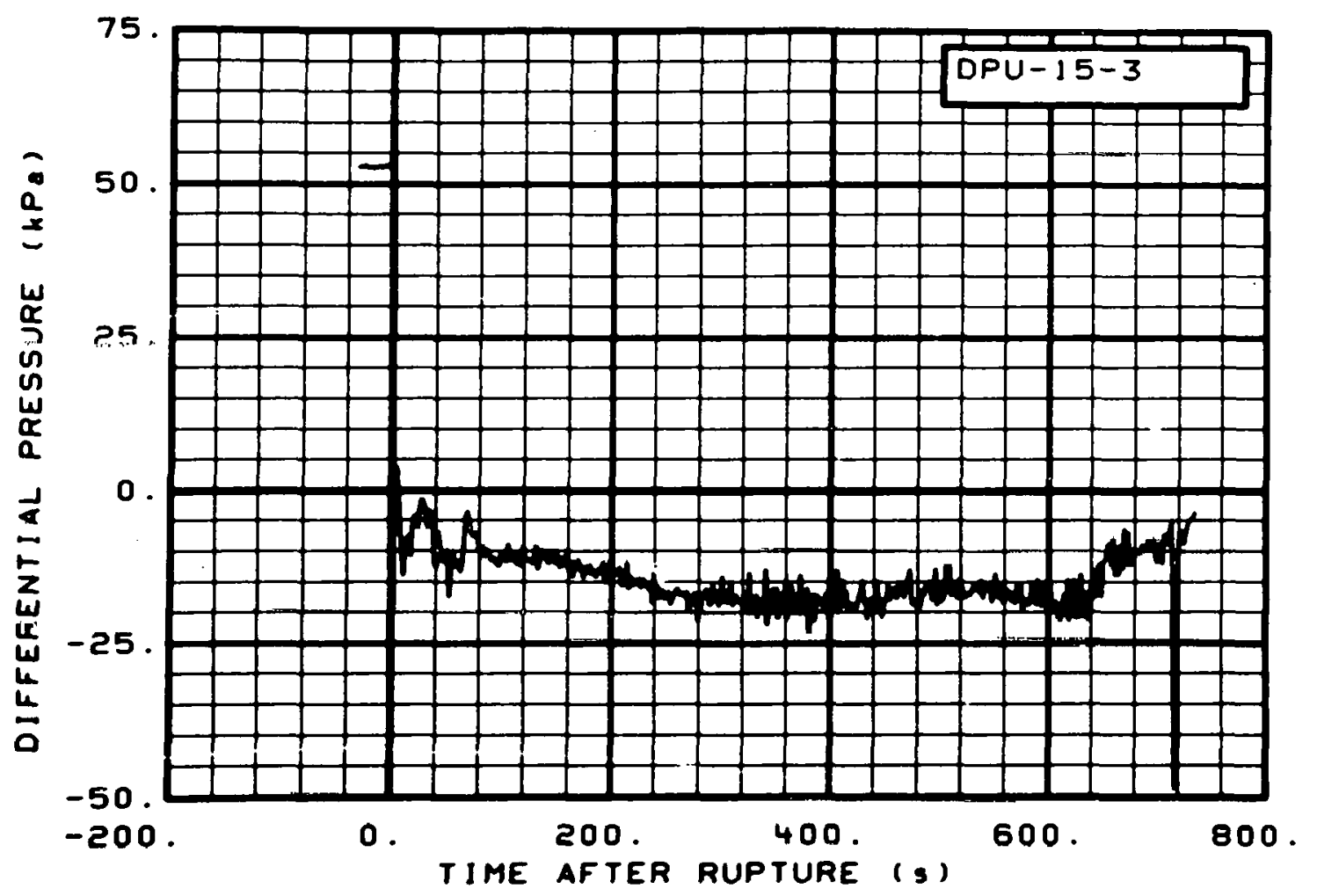

Fig. 181 Differential pressure in intact loop (DPU-15-3), from -20 to $736 \mathrm{~s}$.

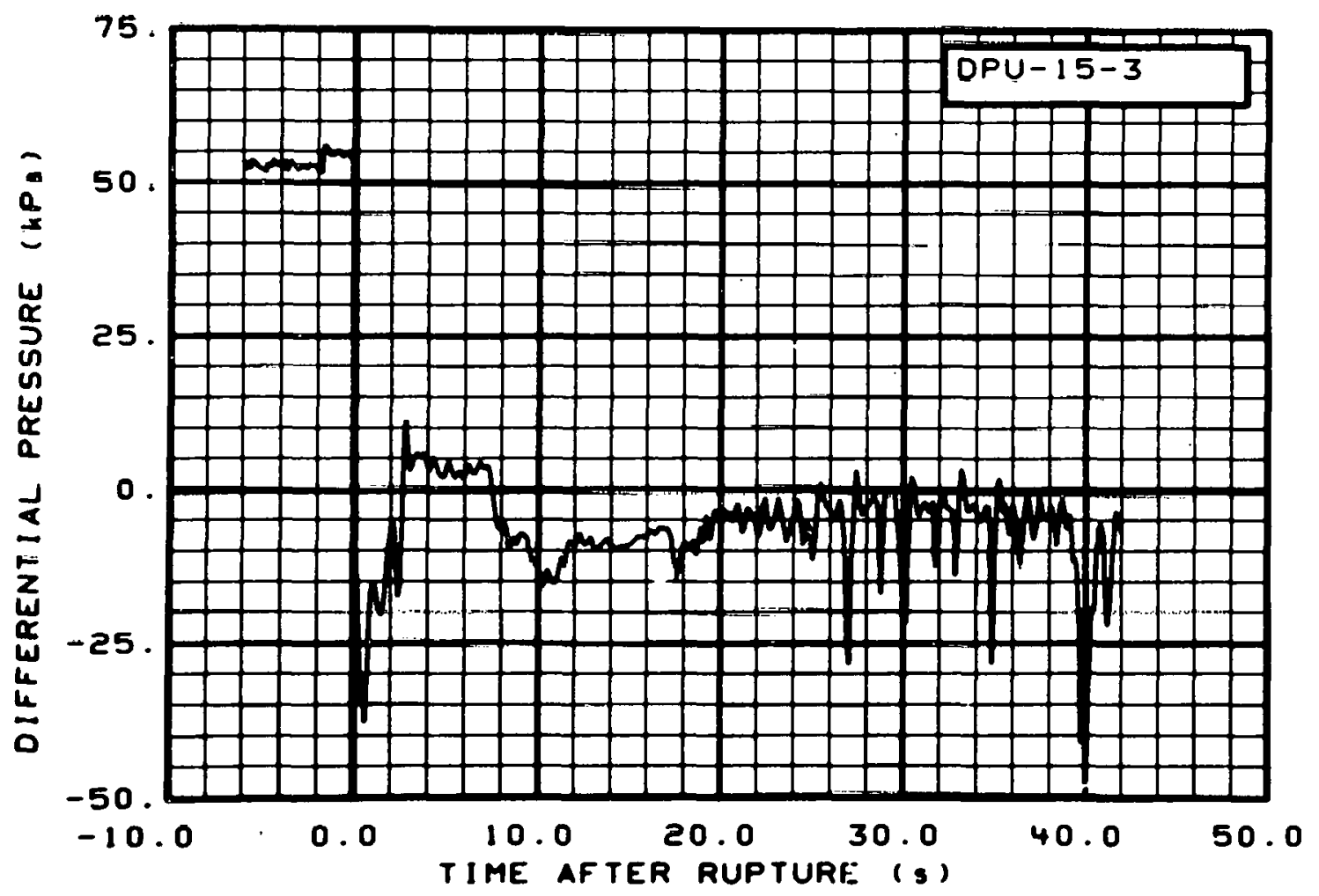

Fig. 182 Differential pressure in intact loop (DPU-15-3), from -6 to $42 \mathrm{~s}$. 


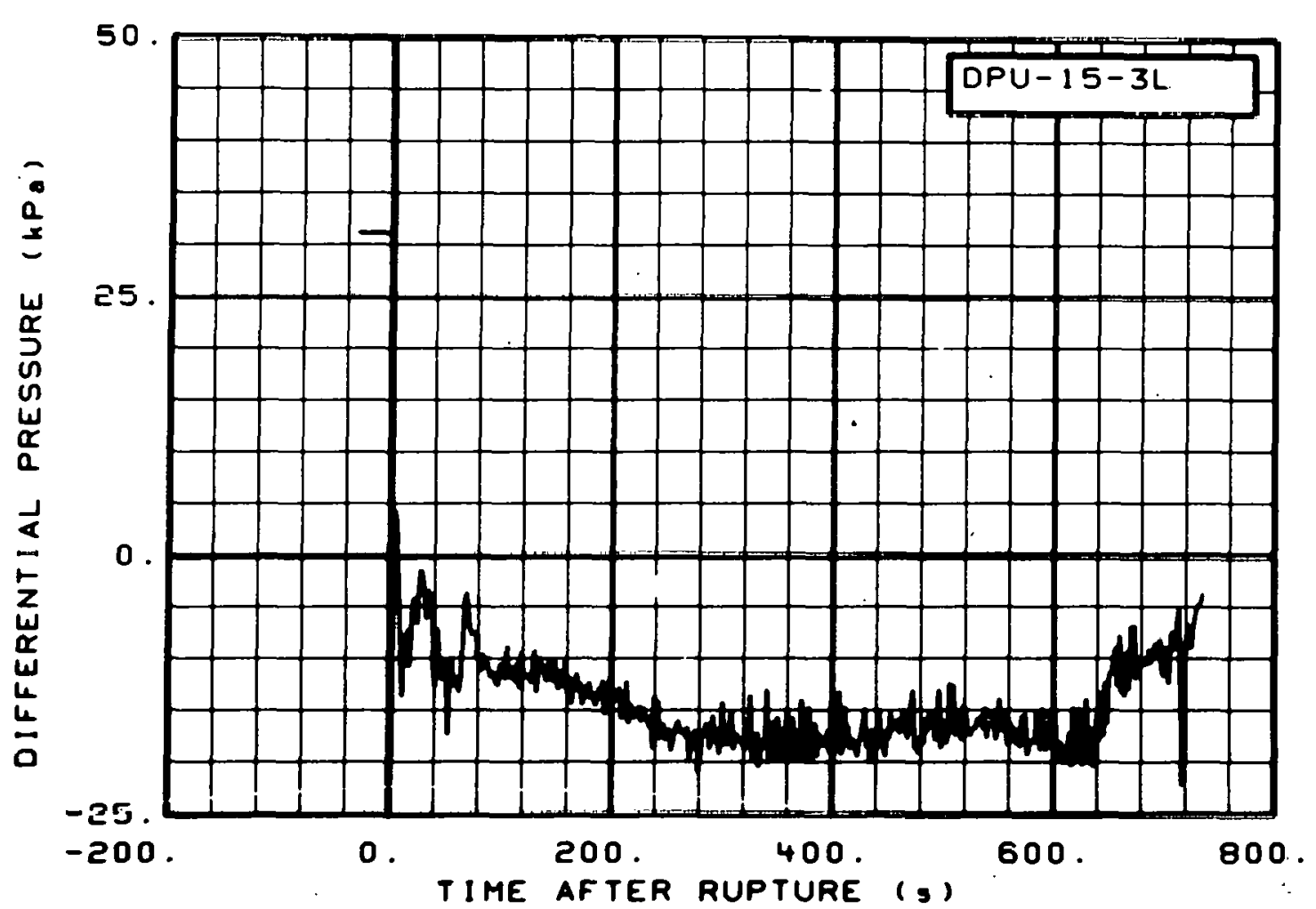

Fig. 183 Differential pressure in intact loop, low range (DPU-15-3L), from -20 to $736 \mathrm{~s}$.

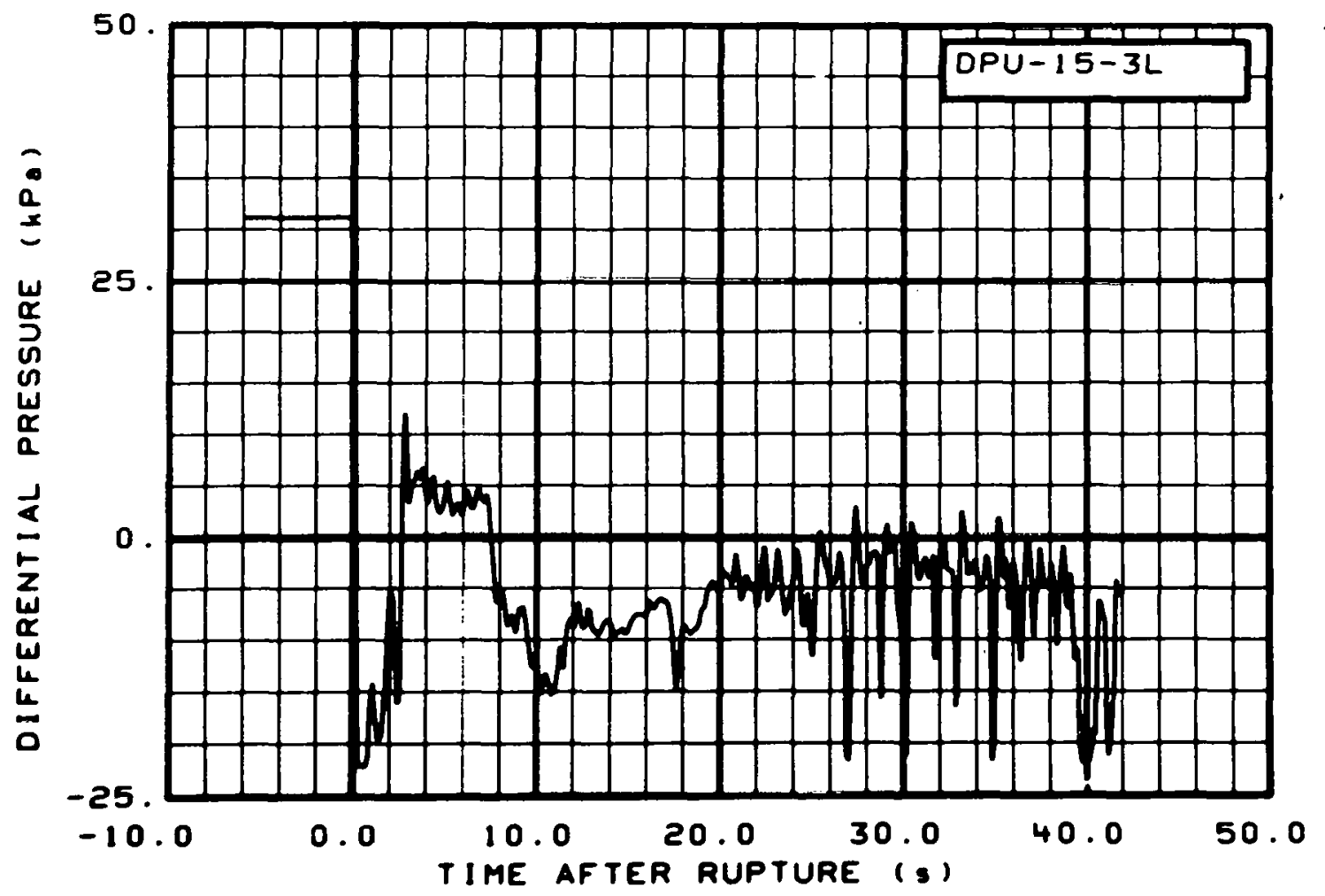

Fig. 184 Differential pressure in intact loop, low range (DPU-15-3L), from -6 to $42 \mathrm{~s}$. 


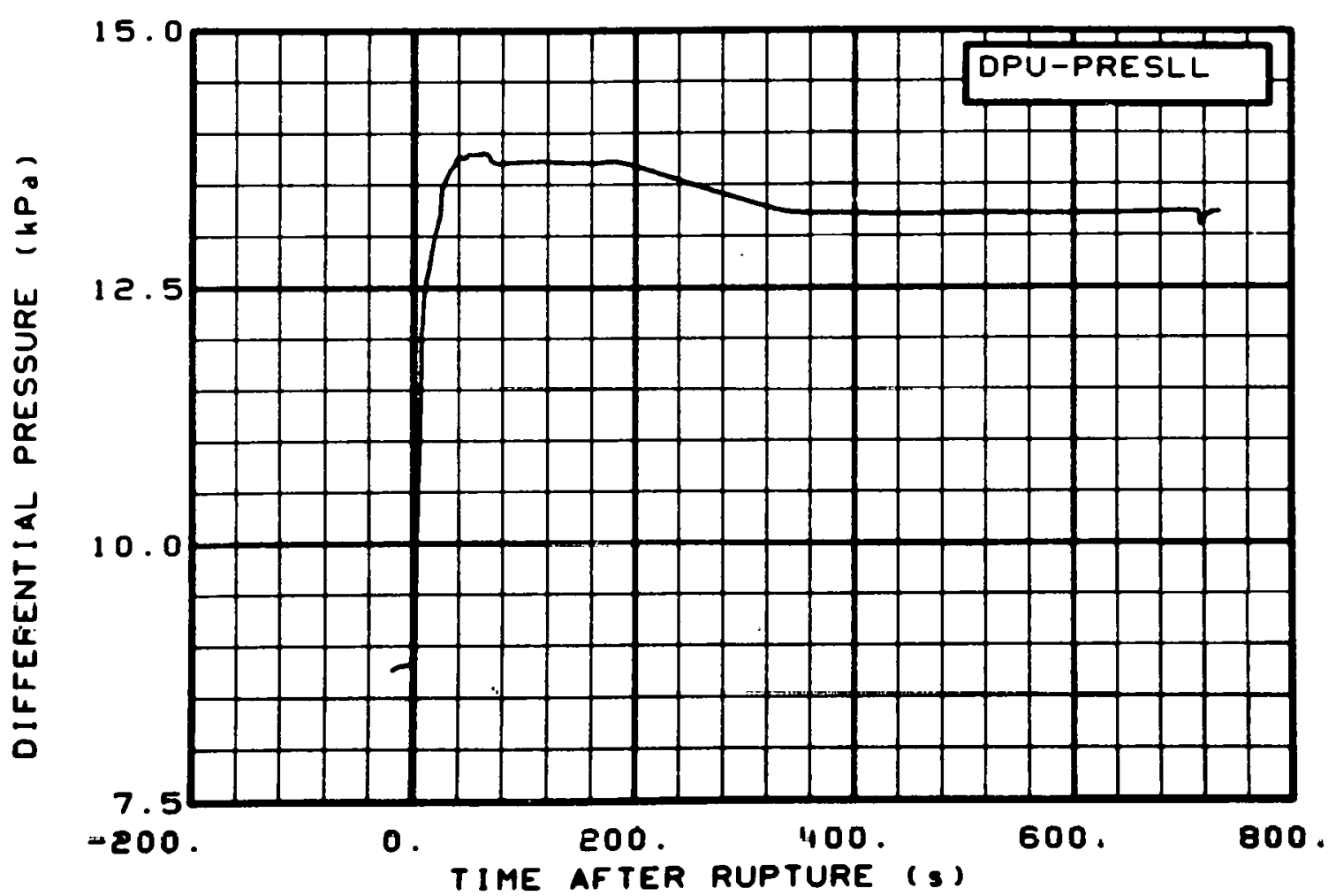

Fig. 185 Differential pressure in intact loop (DPU-PRESLL), from -20 to $736 \mathrm{~s}$.

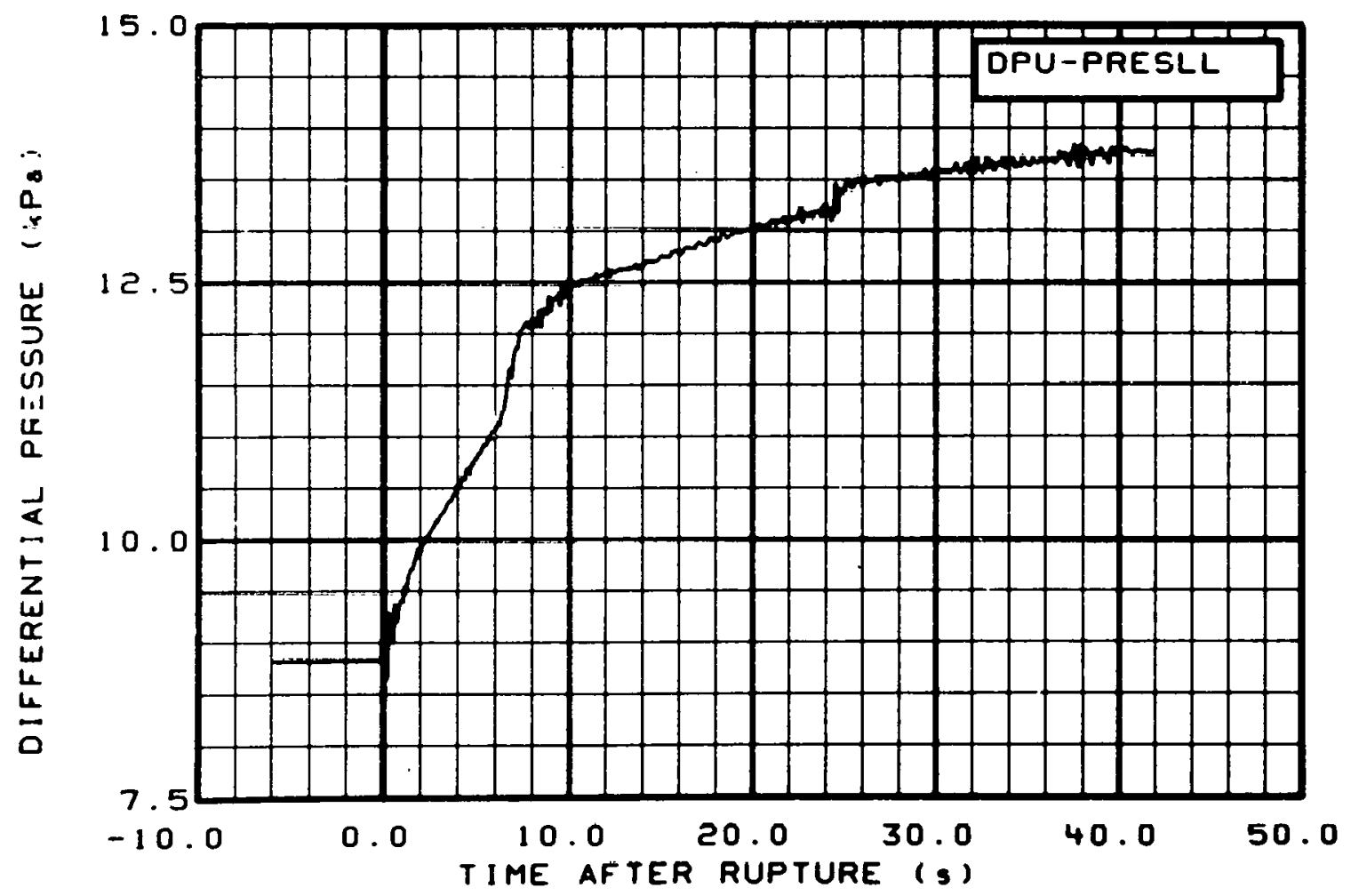

Fig. 186 Differential pressure in intact loop (DPU-PRESLL), from -6 to $42 \mathrm{~s}$. 


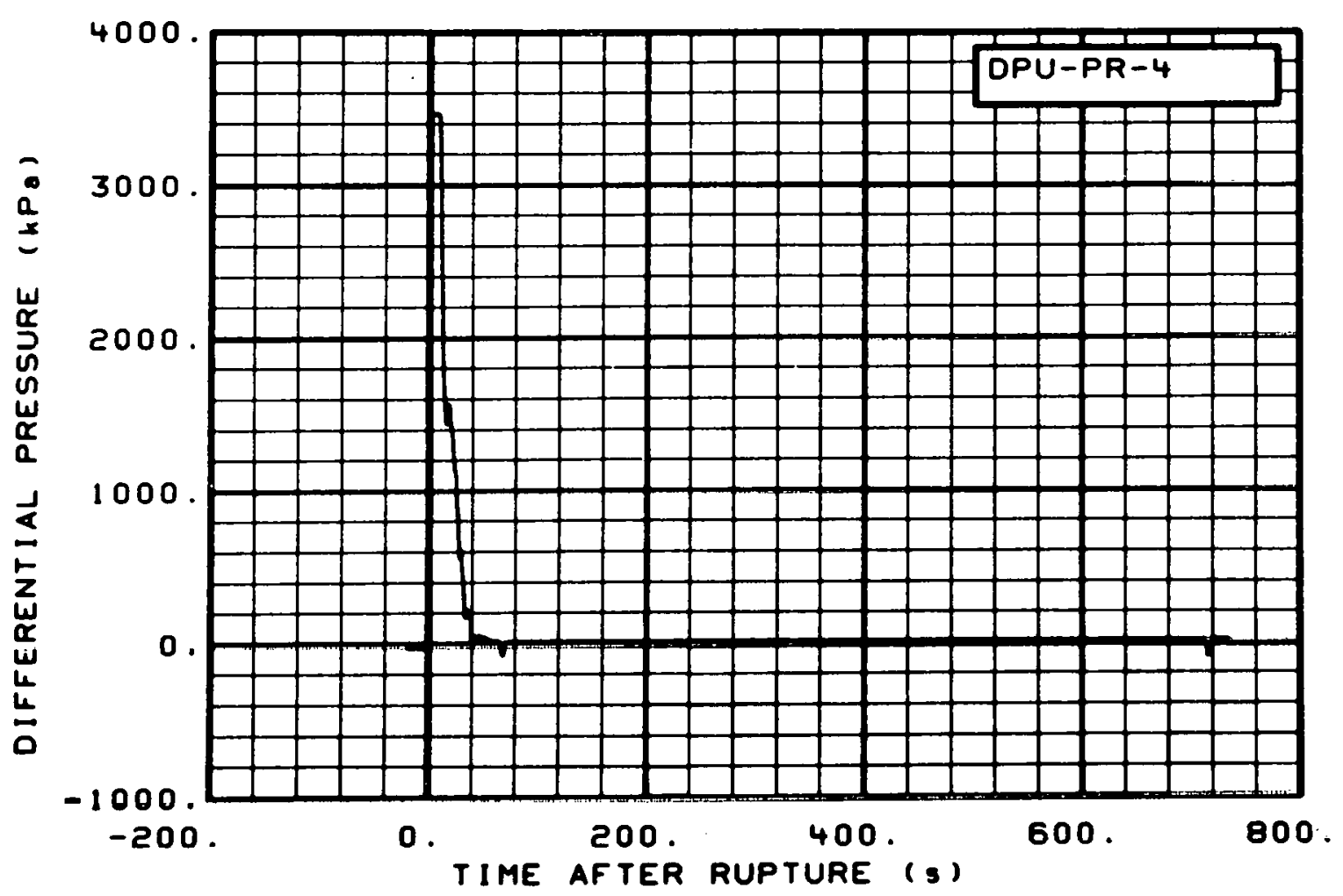

Fig. 187 Differential pressure in intact loop (DPU-PR-4), from -20 to $736 \mathrm{~s}$.

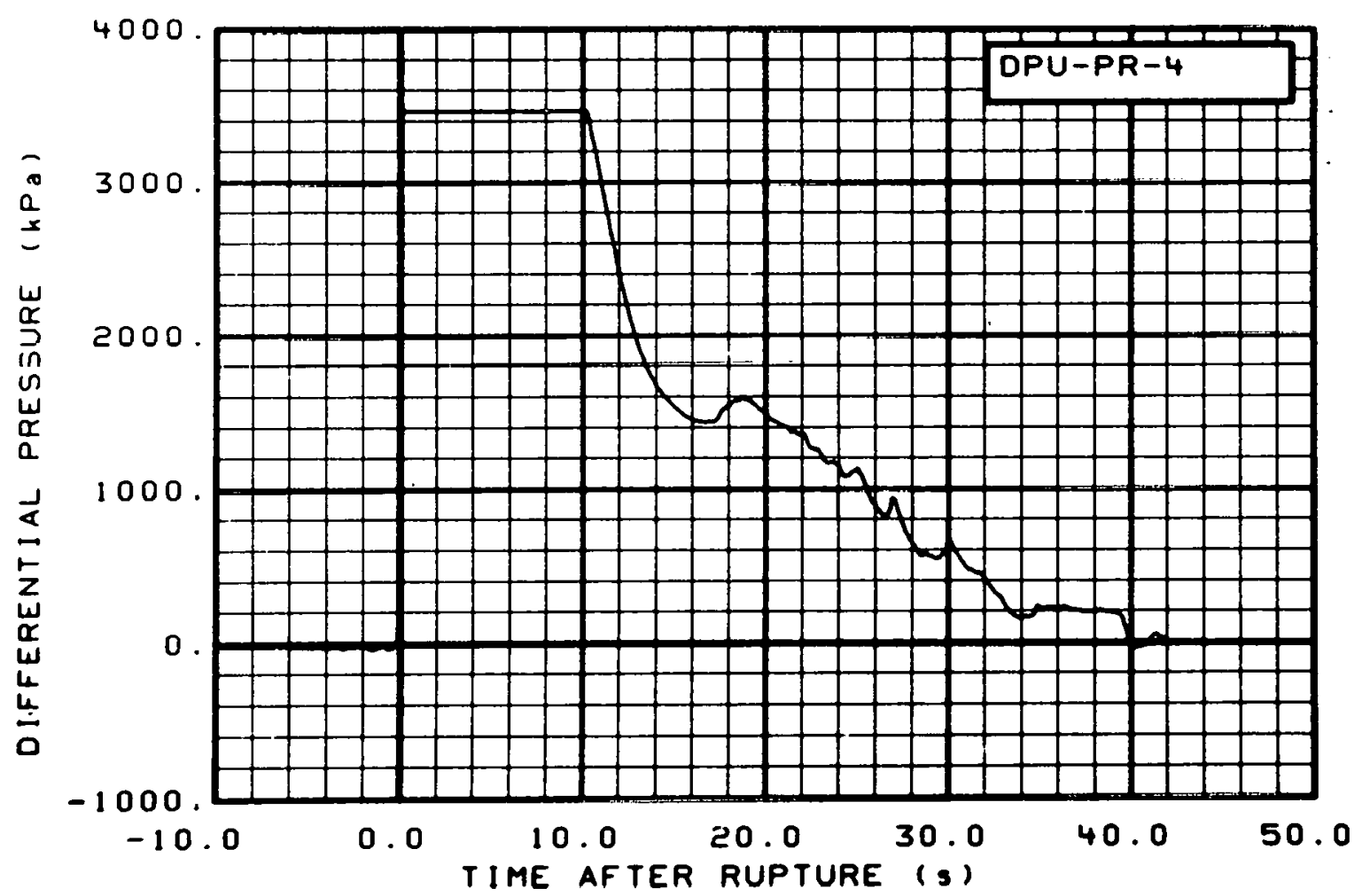

Fig. 188 Differential pressure in intact loop (DPU-PR-4), from -6 to $42 \mathrm{~s}$. 


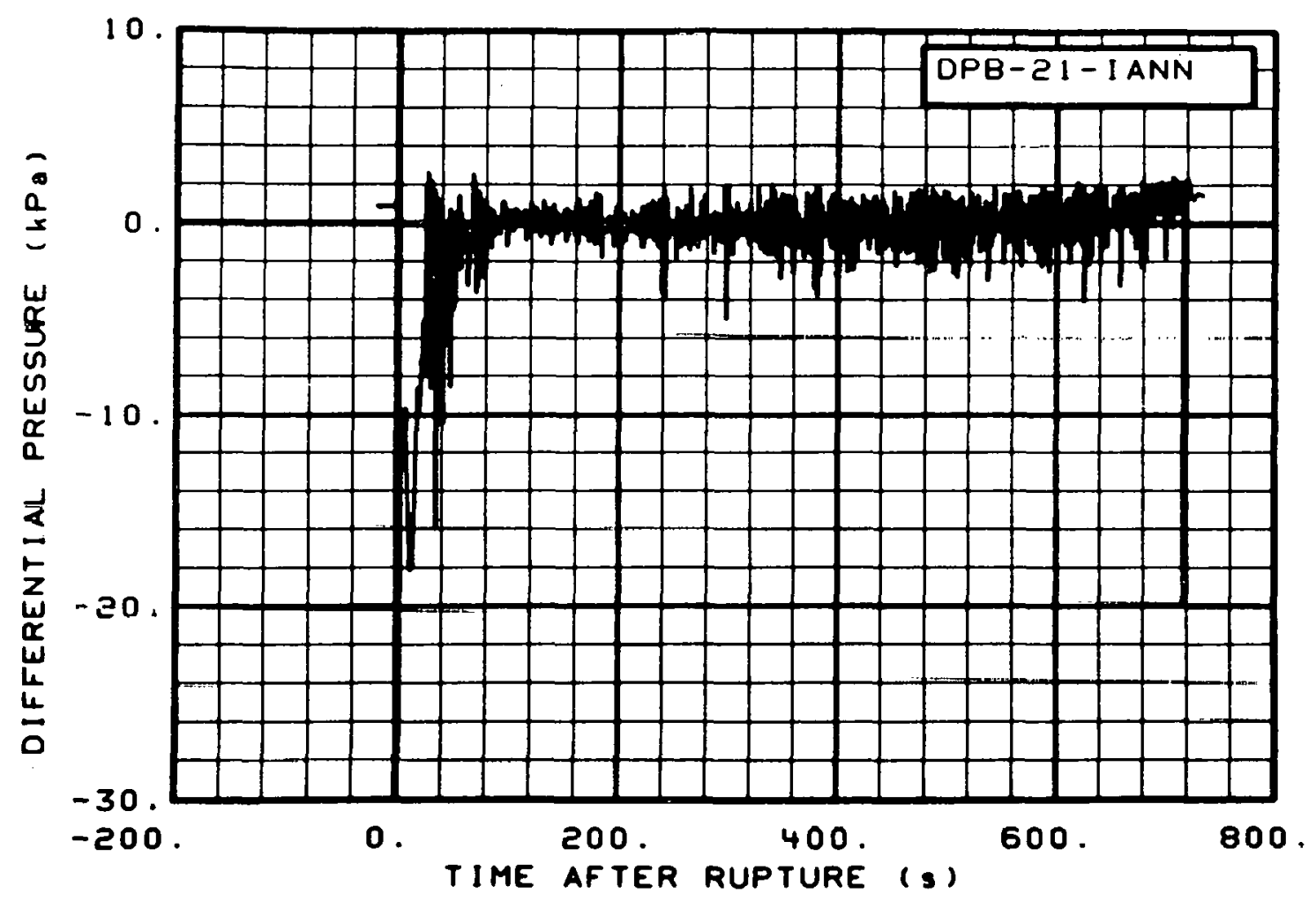

Fig. 189 Differential pressure in broken loop (DPB-21-IANN), from -20 to $736 \mathrm{~s}$.

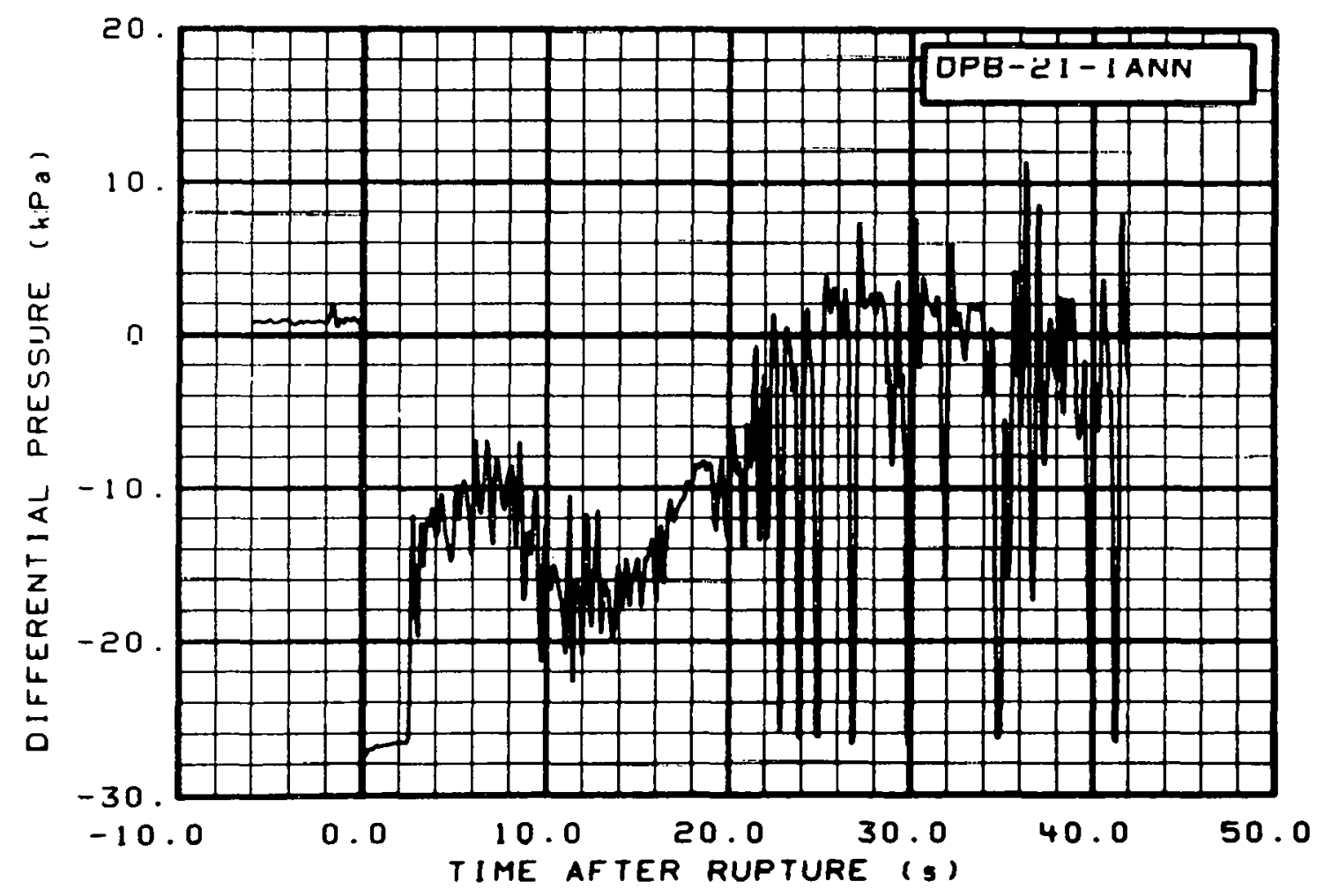

Fig. 190 Differential pressure in broken loop (DPB-21-IANN), from -6 to $42 \mathrm{~s}$. 


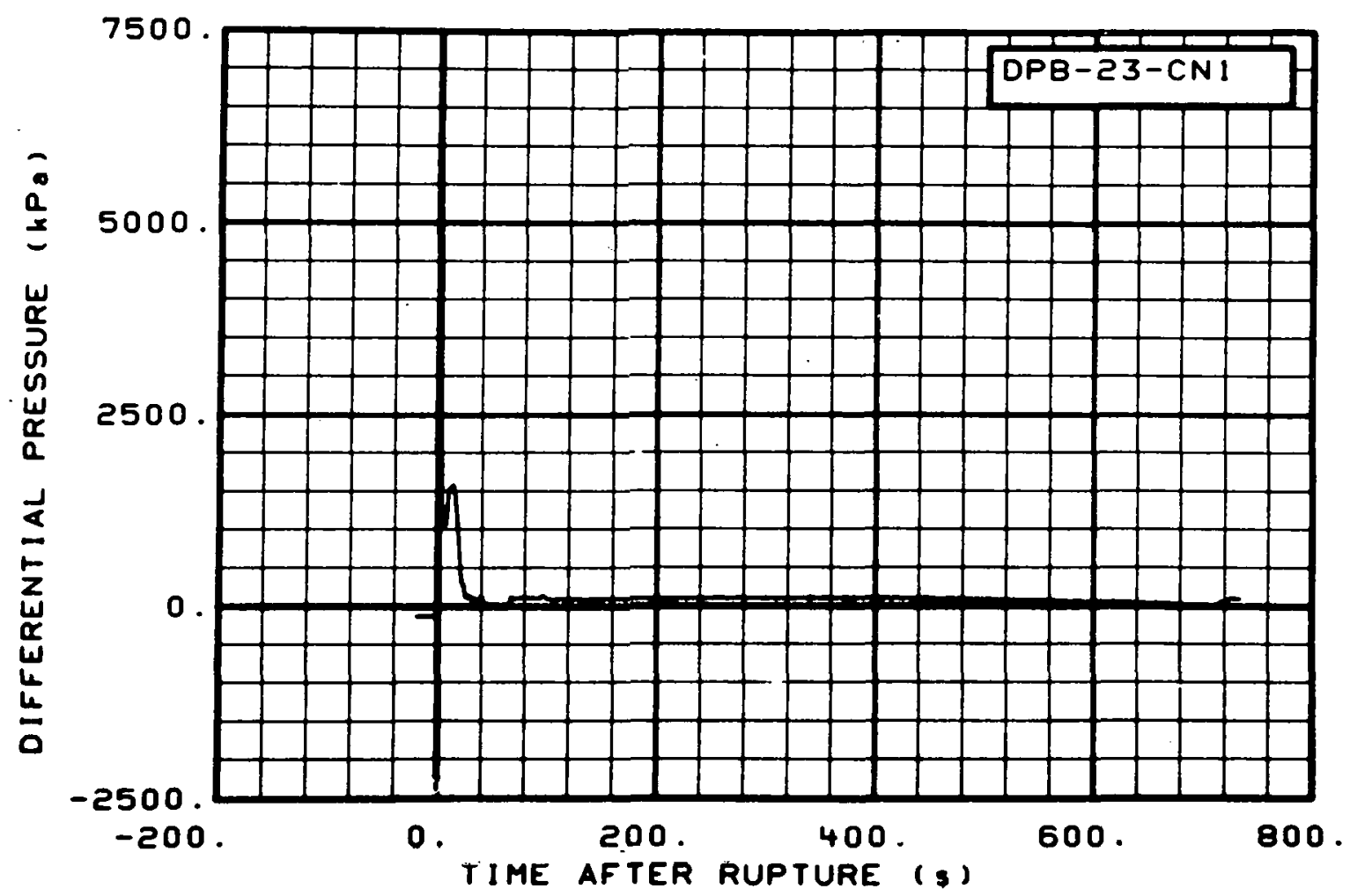

Fig. 191 Differential pressure in broken loop (DPB-23-CN1), from -20 to $736 \mathrm{~s}$.

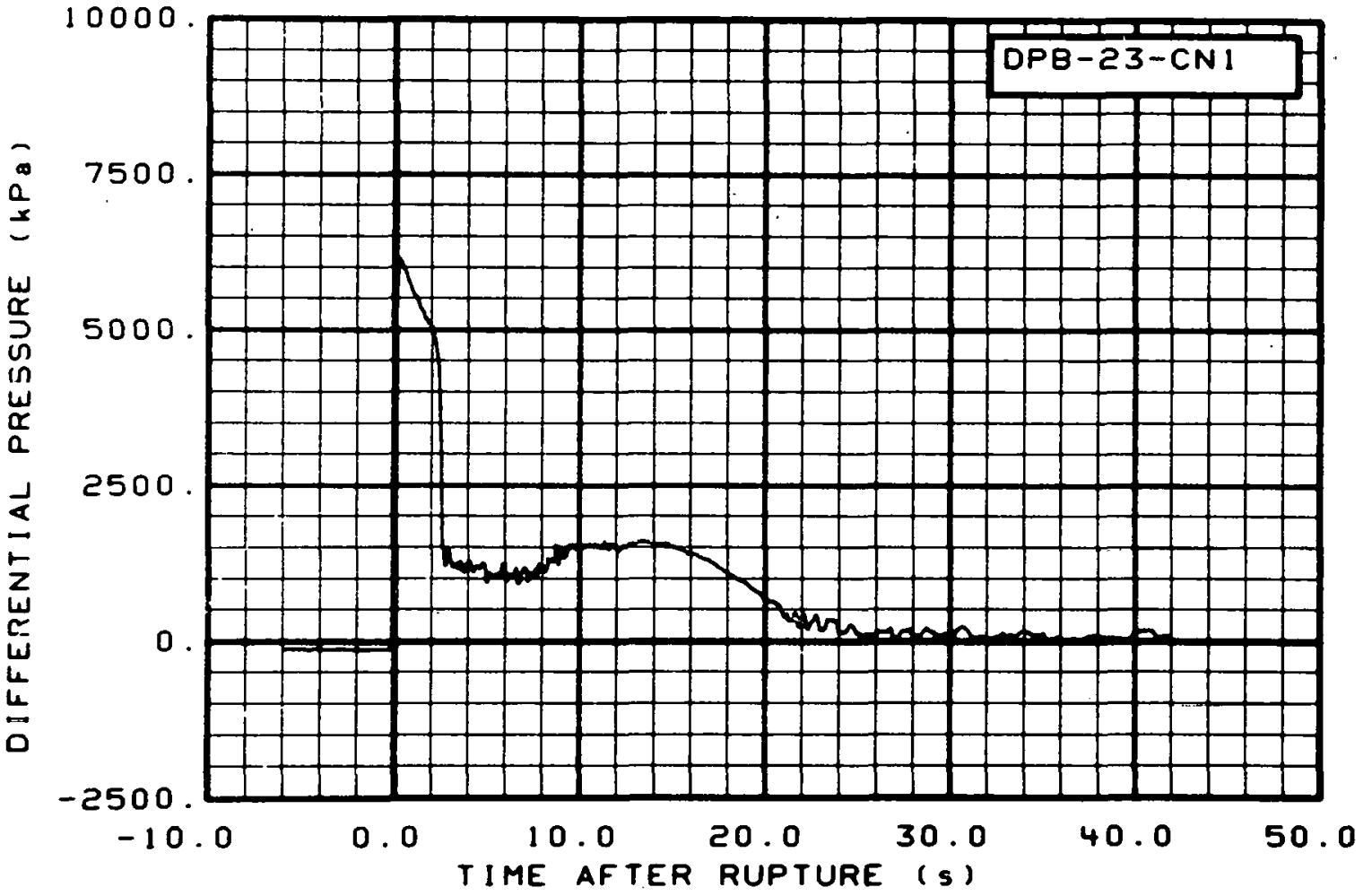

Fig. 192 Differential pressure in broken loop (DPB-23-CN1), from -6 to $42 \mathrm{~s}$. 


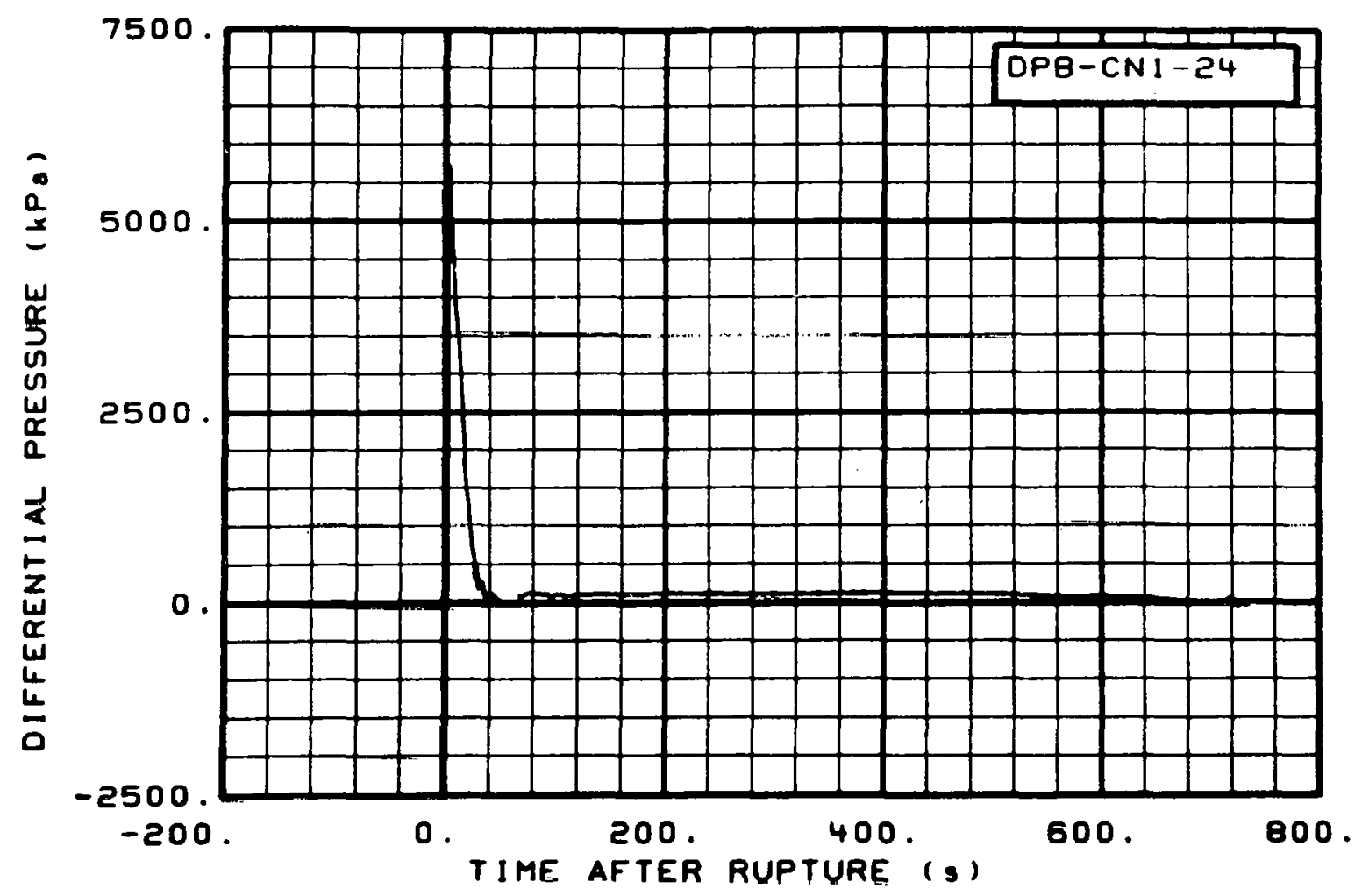

Fig. 193 Differential pressure in broken loop (DPB-CN1-24), from -20 to $736 \mathrm{~s}$.

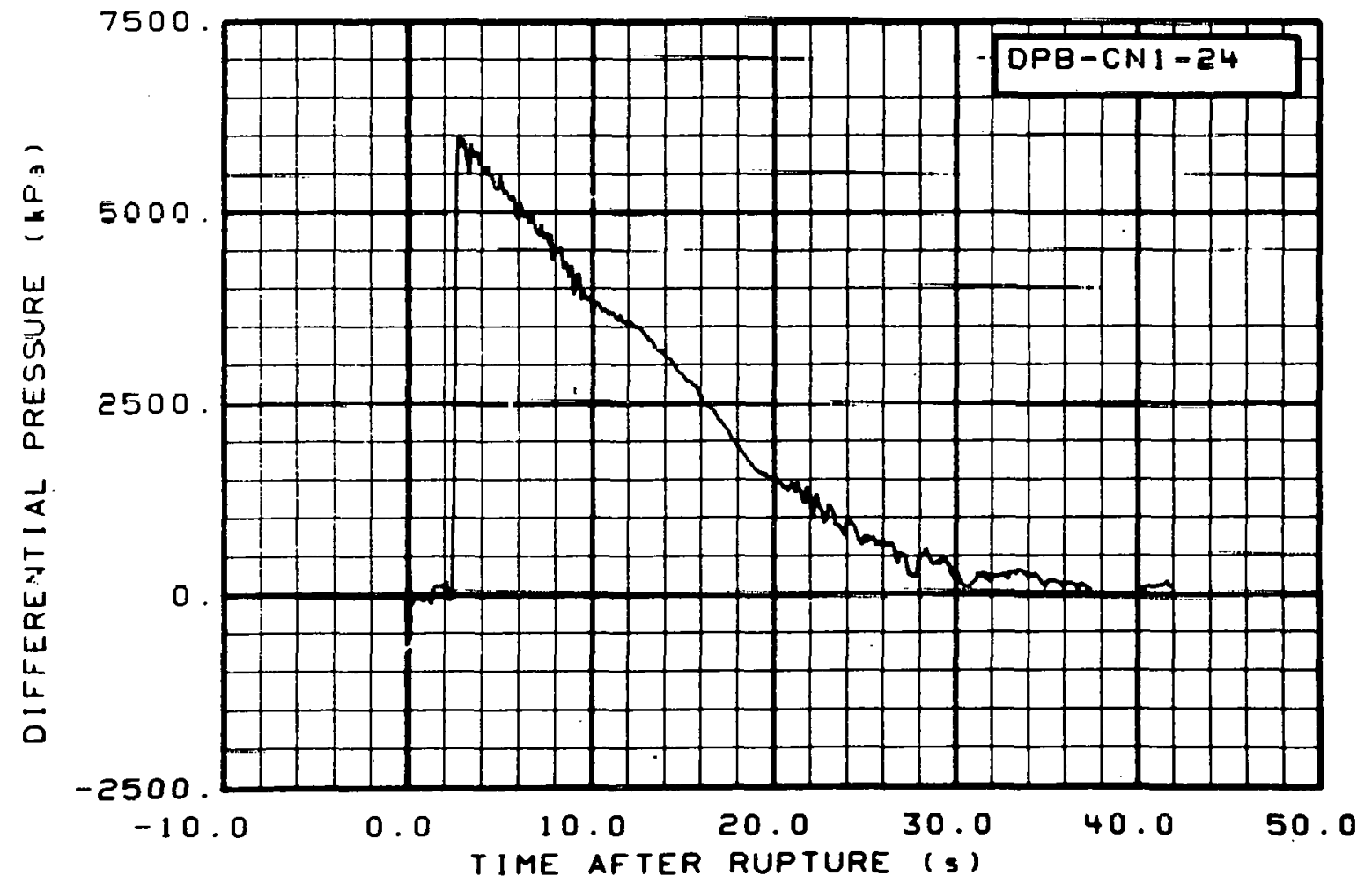

Fig. 194 Differential pressure in broken loop (DPB-CN1-24), from -6 to $42 \mathrm{~s}$. 


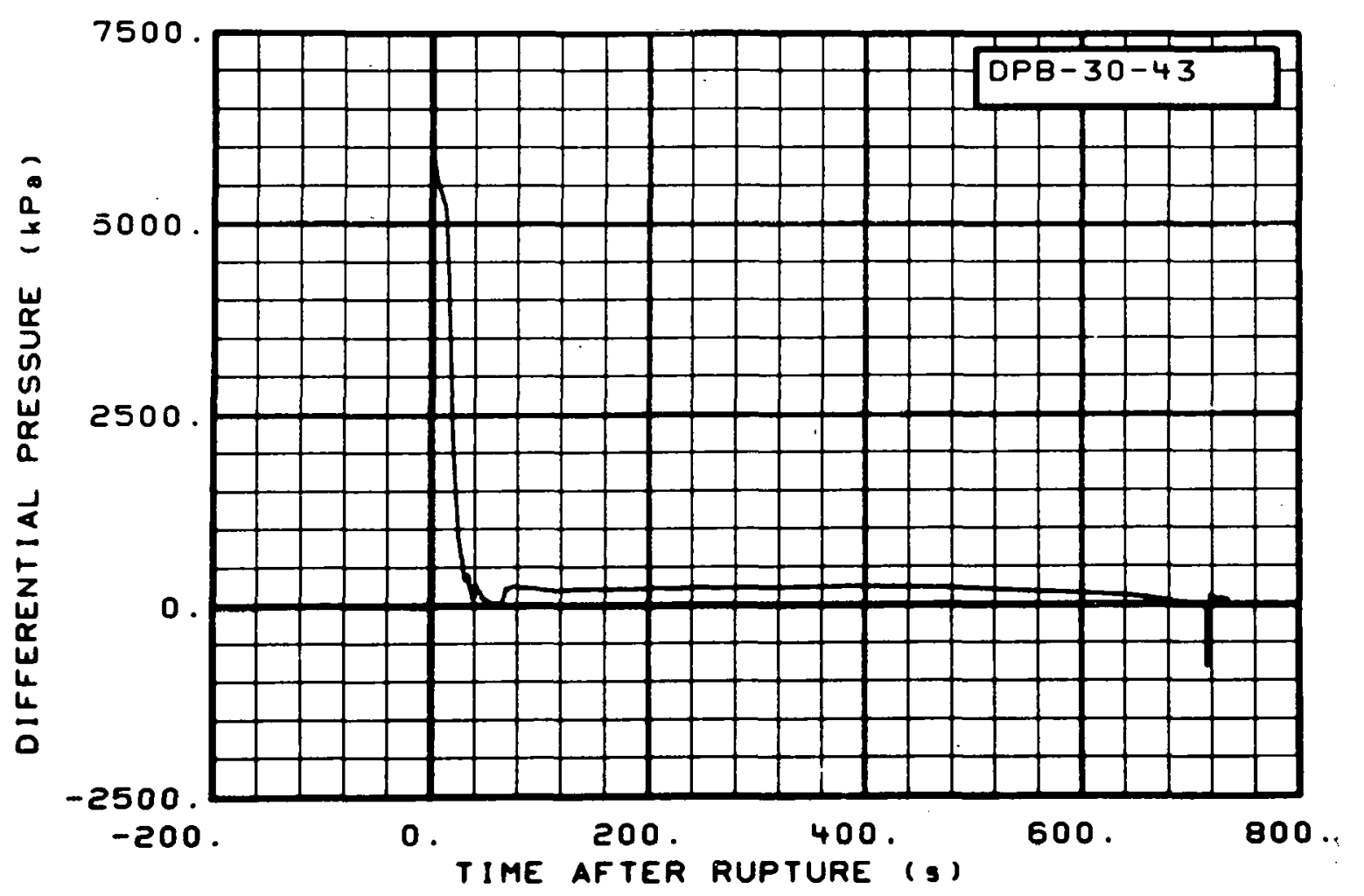

Fig. 195 Differential pressure in broken loop (DPB-30-43), from -20 to $736 \mathrm{~s}$.

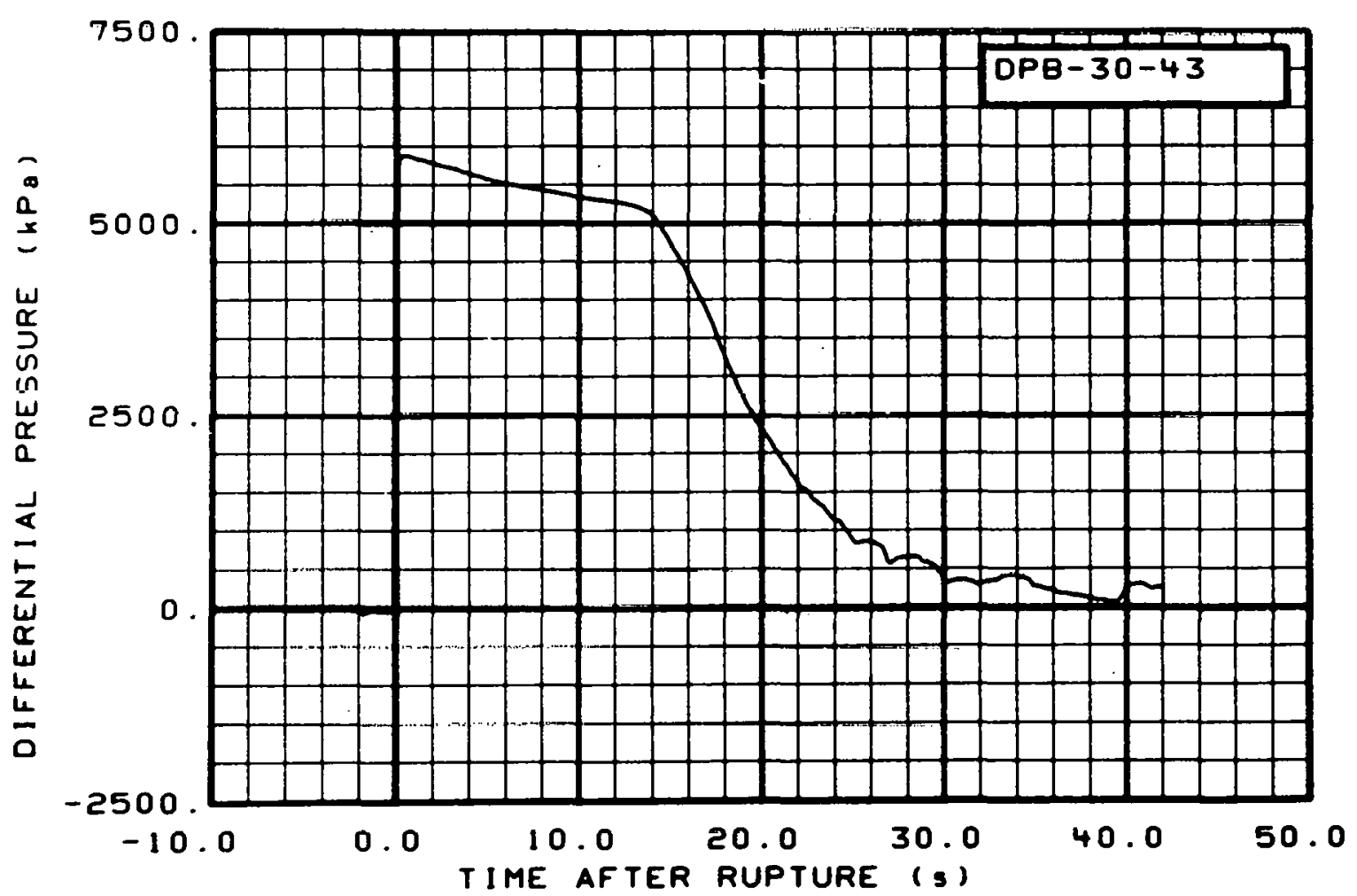

Fig. 196 Differential pressure in broken loop (DPB-30-43), from -6 to $42 \mathrm{~s}$. 


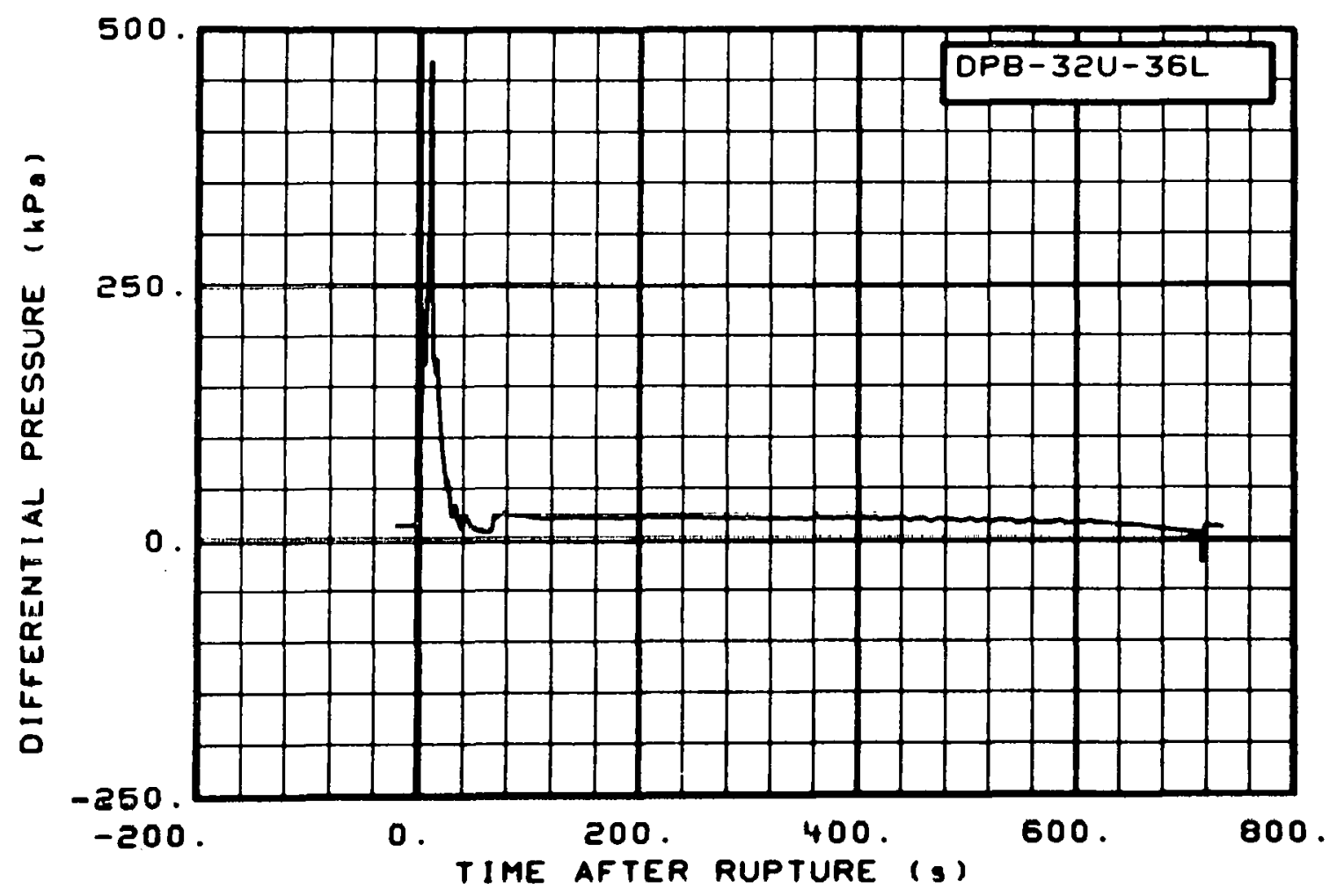

Fig. 197 Differential pressure in broken 10op (DPB-32U-36L), from -20 to $736 \mathrm{~s}$.

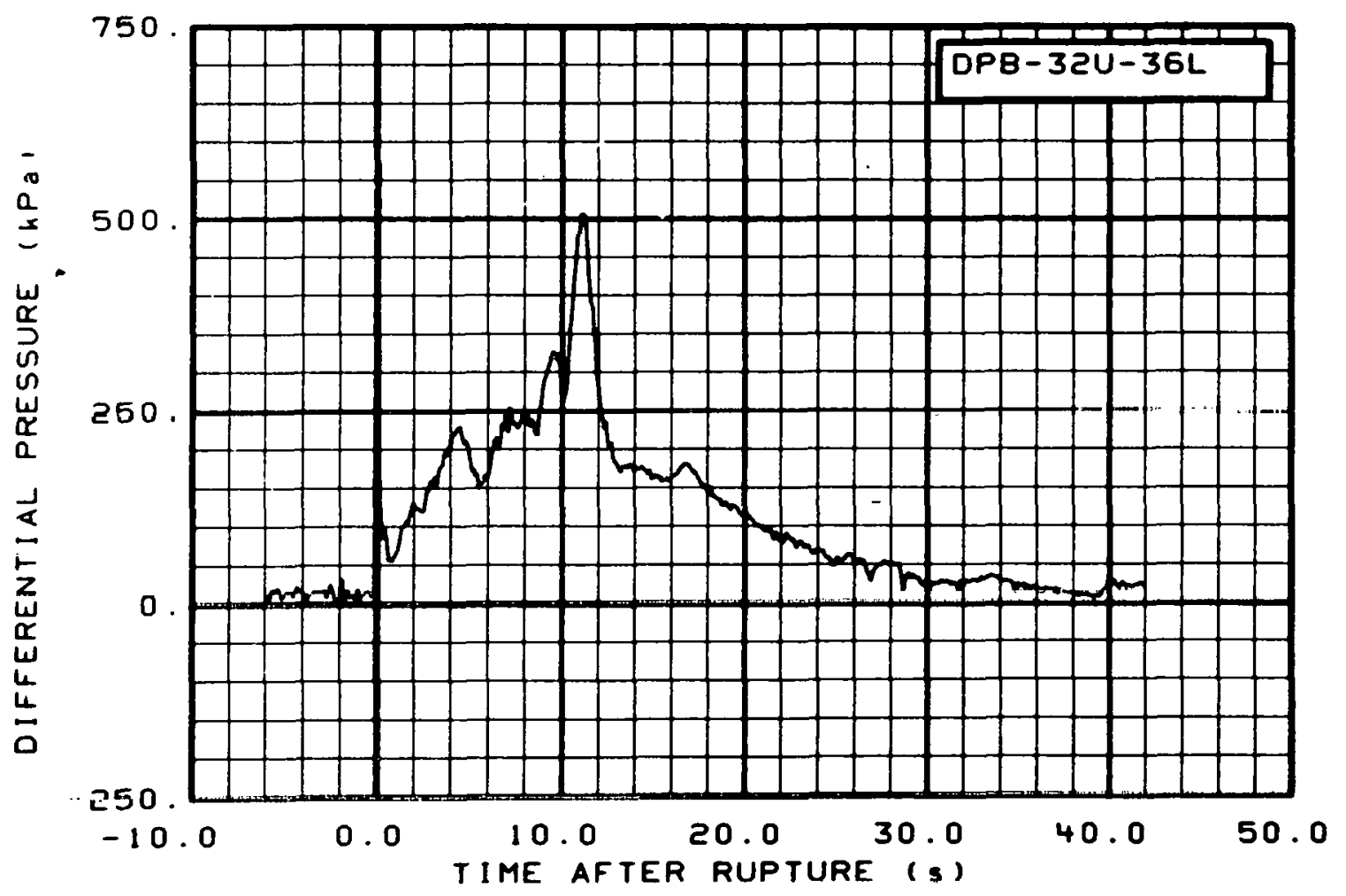

Fig. 198 Differential pressure in broken loop (DPB-32U-36L), from -6 to $42 \mathrm{~s}$. 


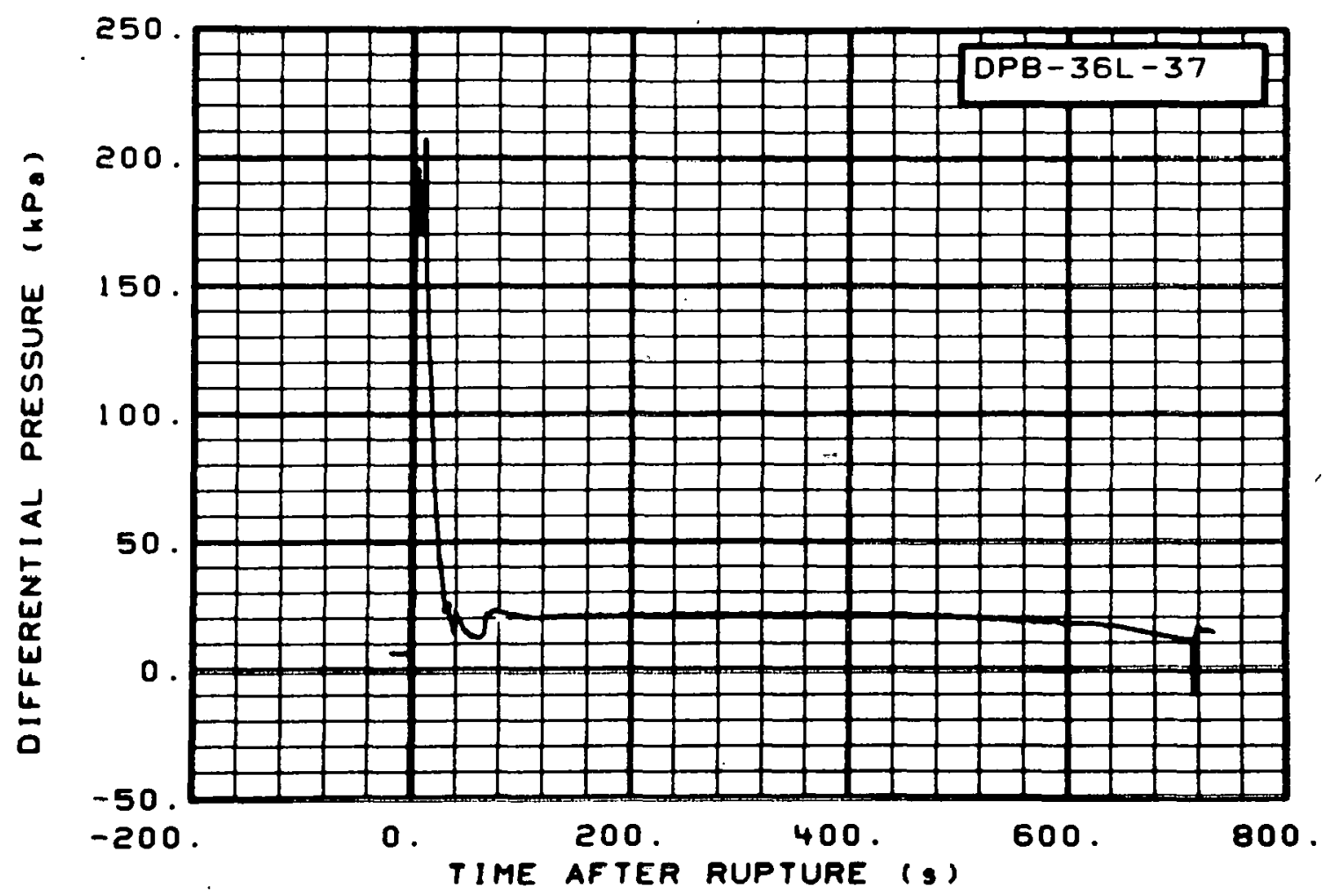

Fig. 199 Differential pressure in broken loop (DPB-36L-37), from -20 to $736 \mathrm{~s}$.

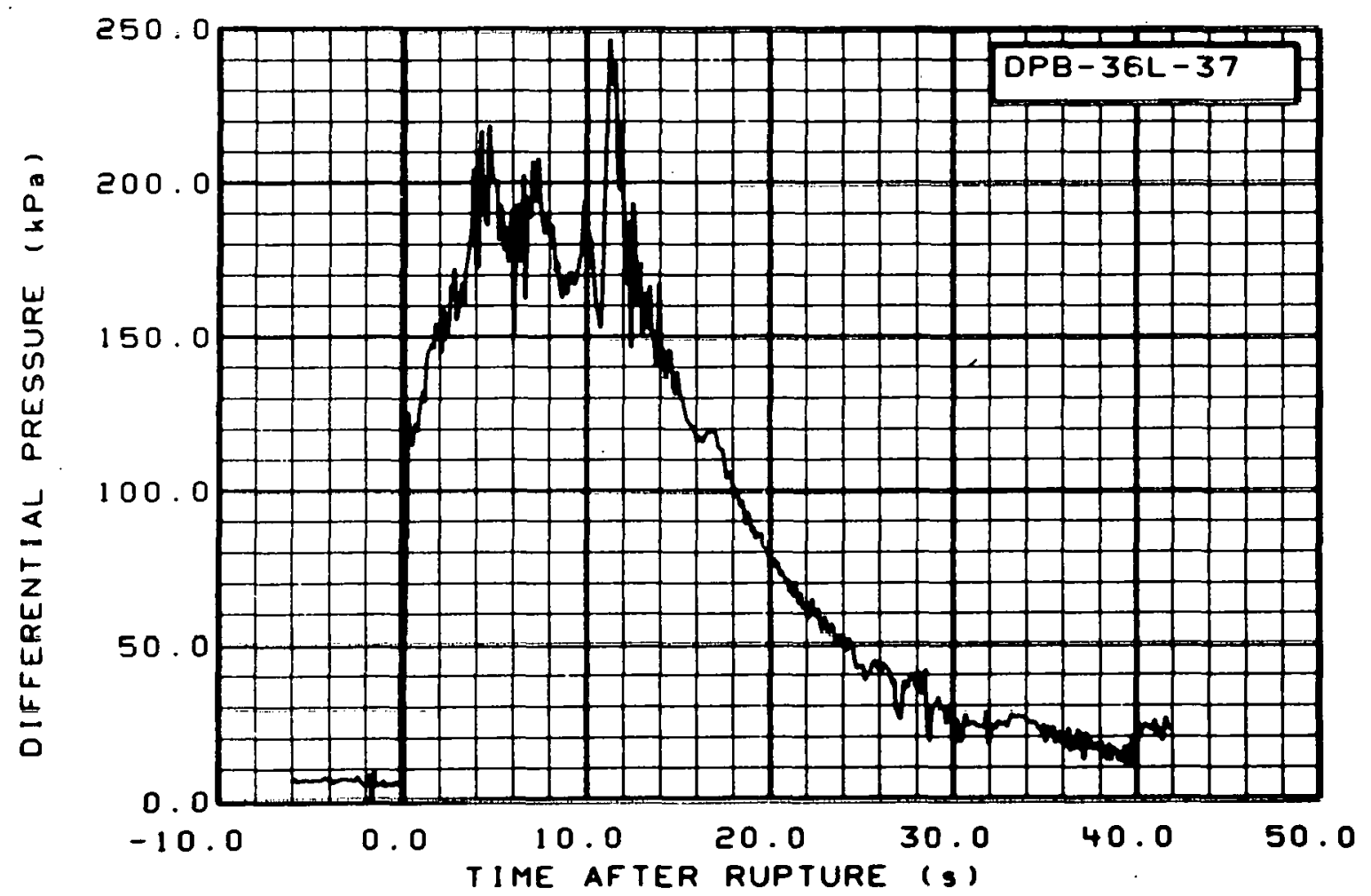

Fig. 200 Differential pressure in broken loop (DPB-36L-37), from -6 to $42 \mathrm{~s}$. 


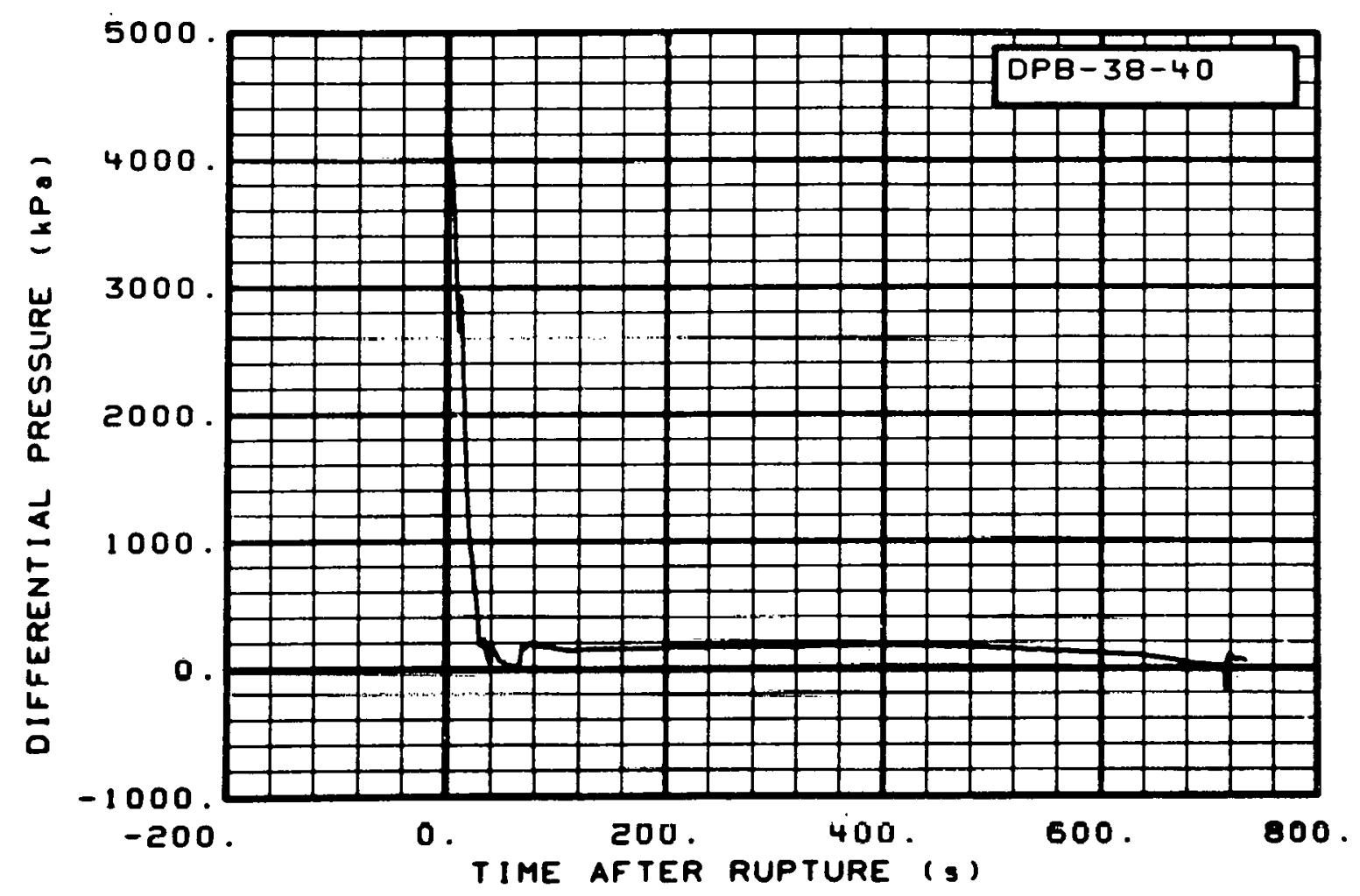

Fig. 201 Differential pressure in broken 1oop (DPB-38-40), from -20 to $736 \mathrm{~s}$.

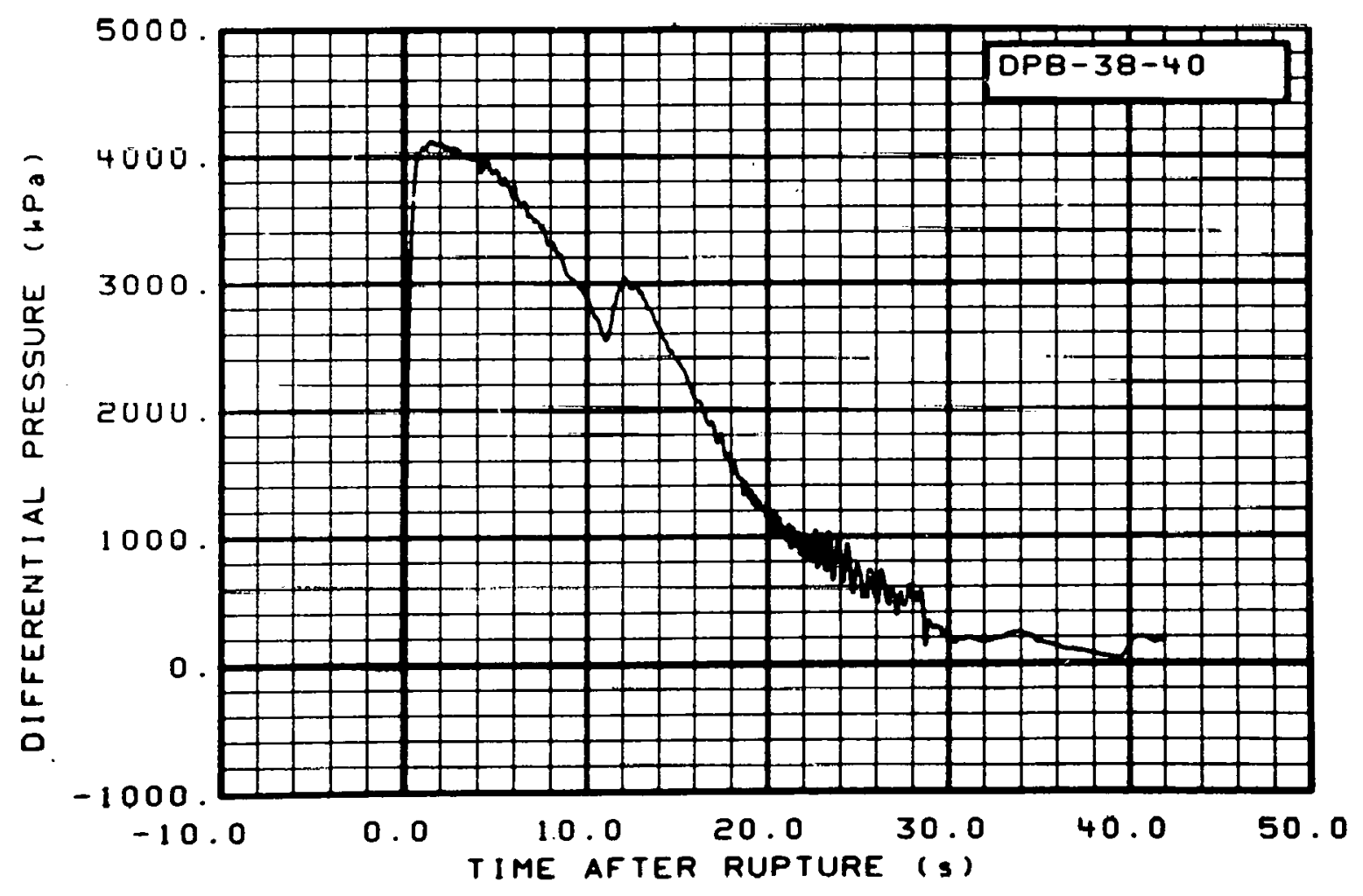

Fig. 202 Differential pressure in broken loop (DPB-38-40), from -6 to $42 \mathrm{~s}$. 


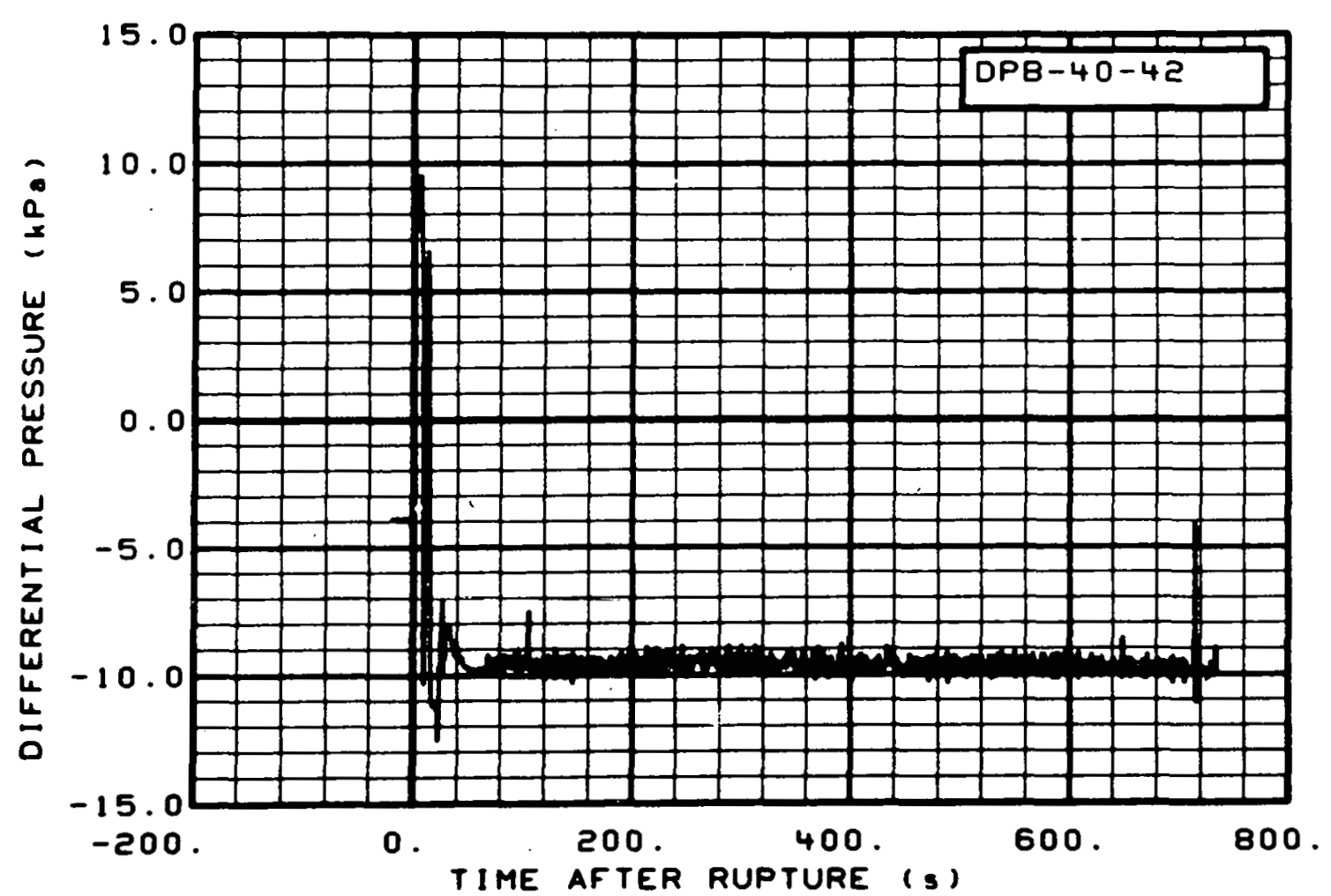

Fig. 203 Differential pressure in broken loop (DPB-40-42), from -20 to $736 \mathrm{~s}$.

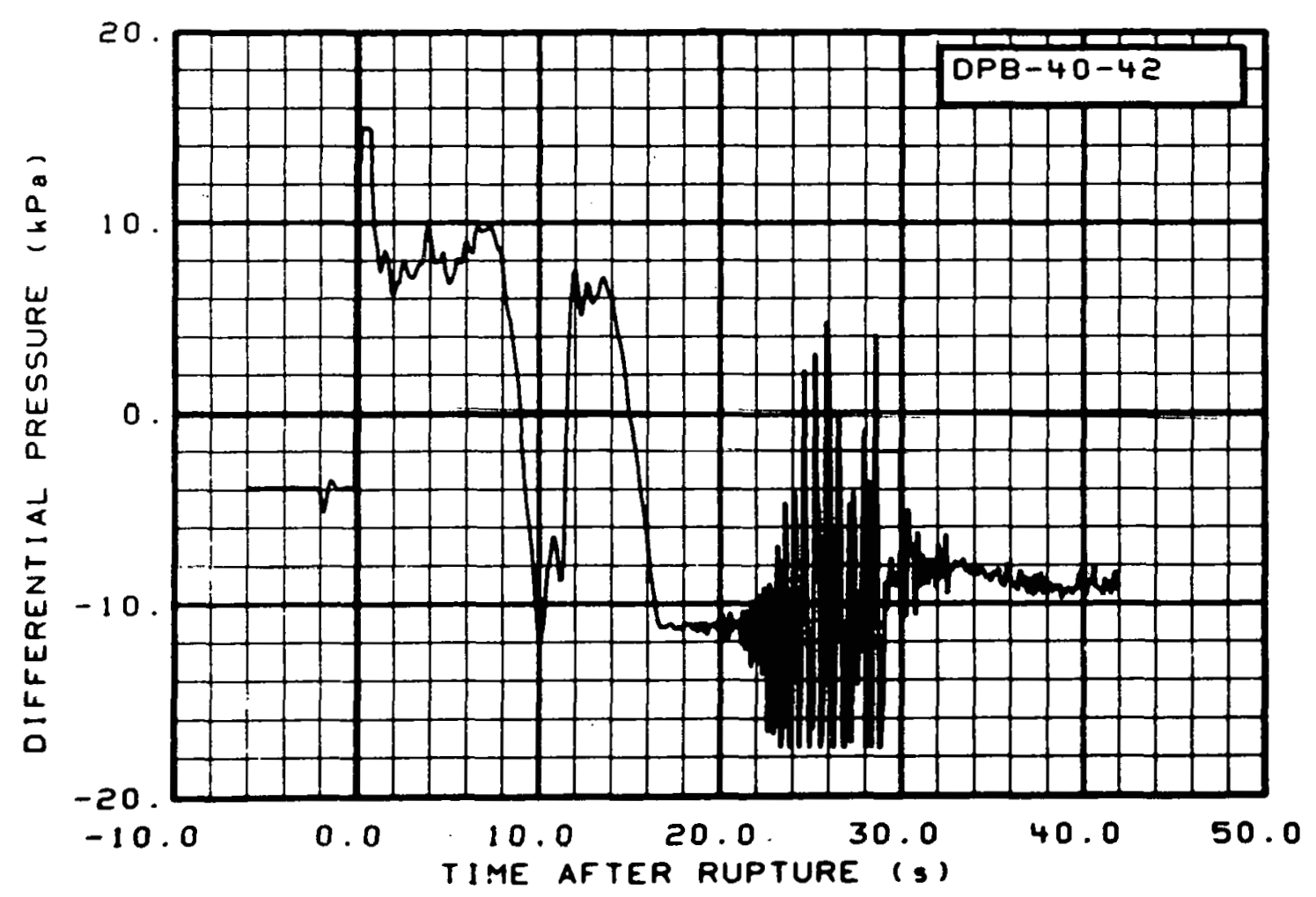

Fig. 204 Differential pressure in broken loop (DPB-40-42), from -6 to $42 \mathrm{~s}$. 


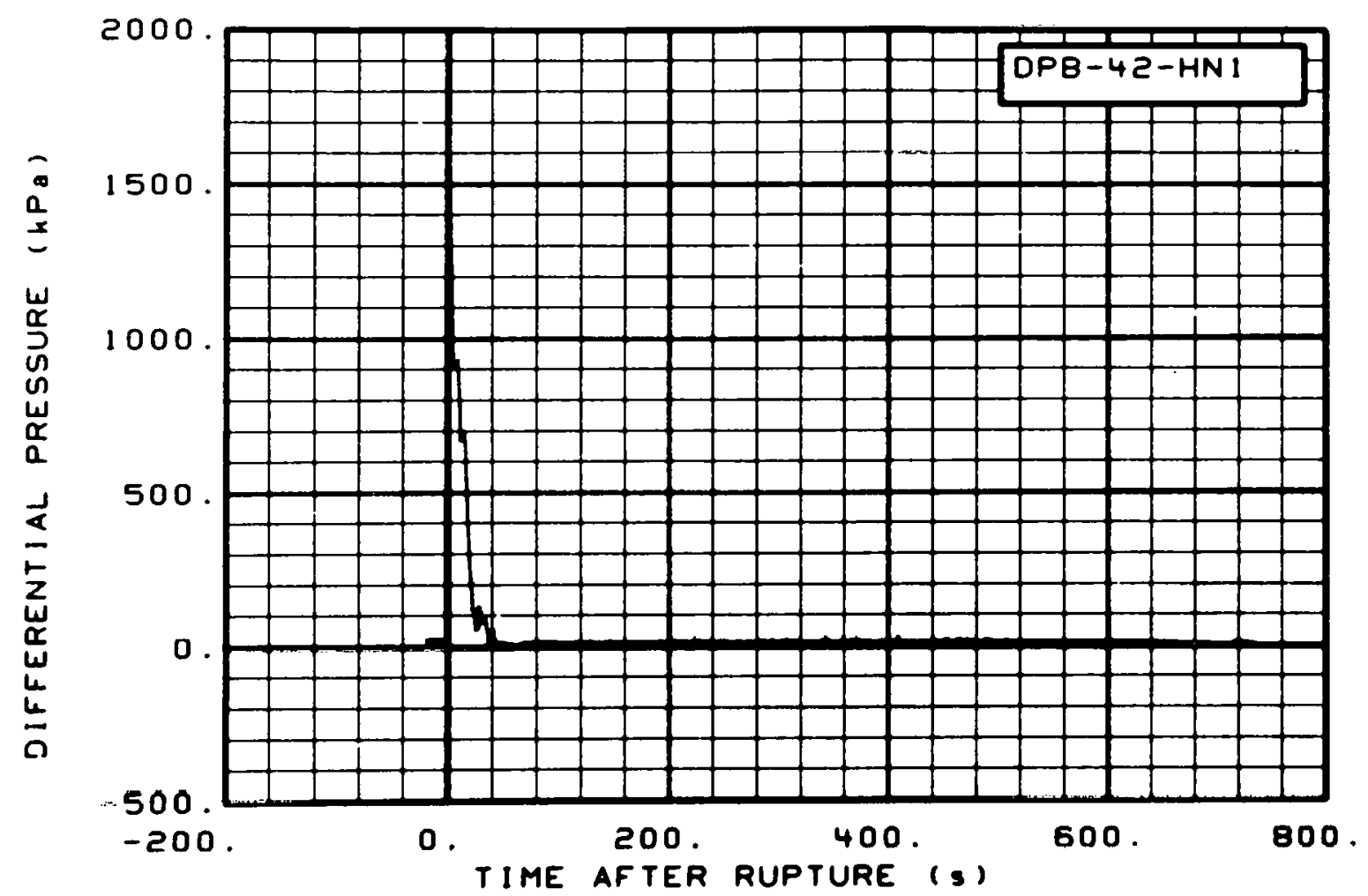

Fig. 205 Differential pressure in broken loop (DPB-42-HN1), from -20 to $736 \mathrm{~s}$.

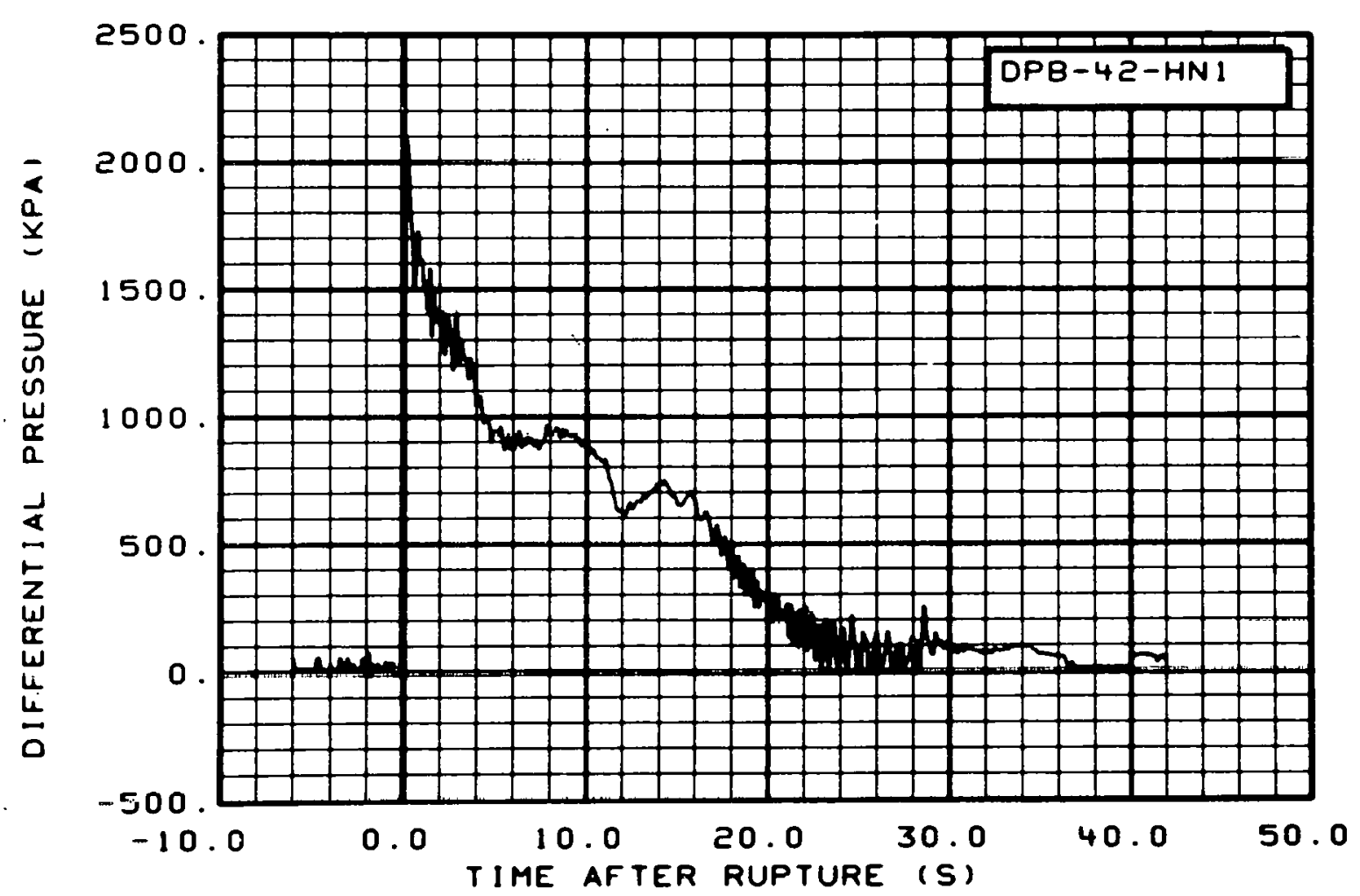

Fig. 206 Differential pressure in broken loop (DPB-42-HN1), from -6 to $42 \mathrm{~s}$. 


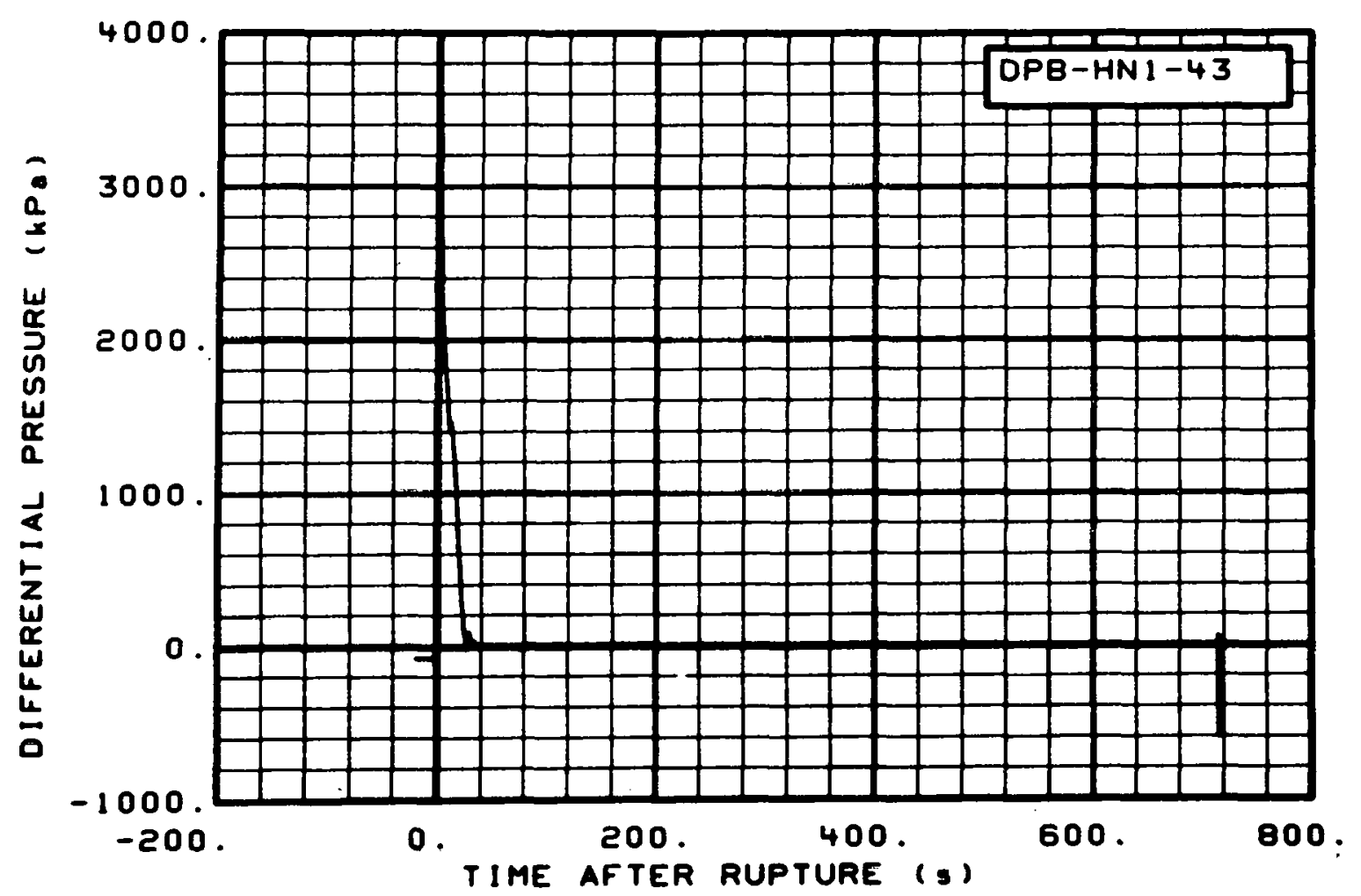

Fig. 207 Differential pressure in broken loop (DPB-HN1-43), from -20 to $736 \mathrm{~s}$.

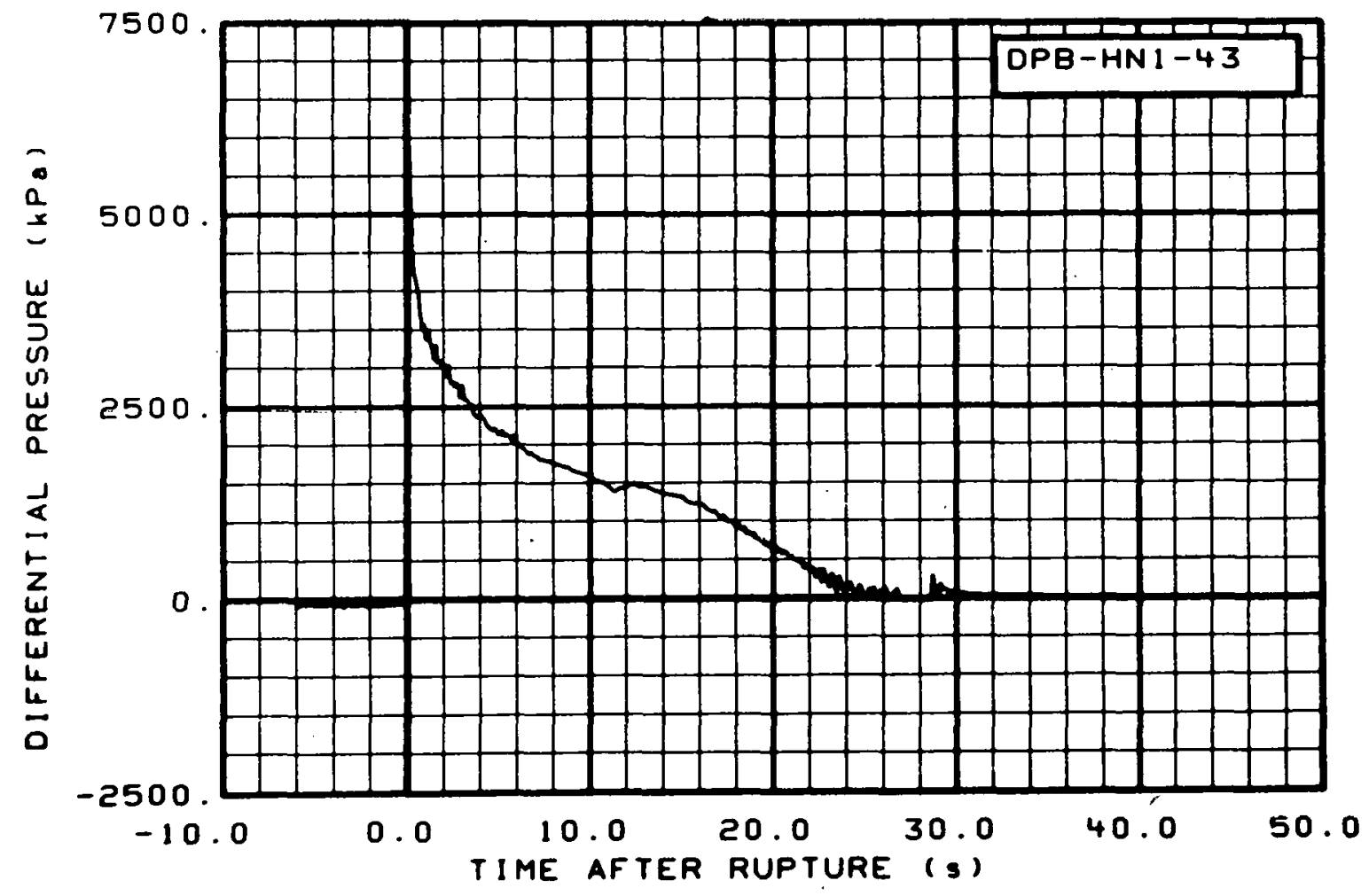

Fig. 208 Differential pressure in broken loop (DPB-HN1-43), from -6 to $42 \mathrm{~s}$. 


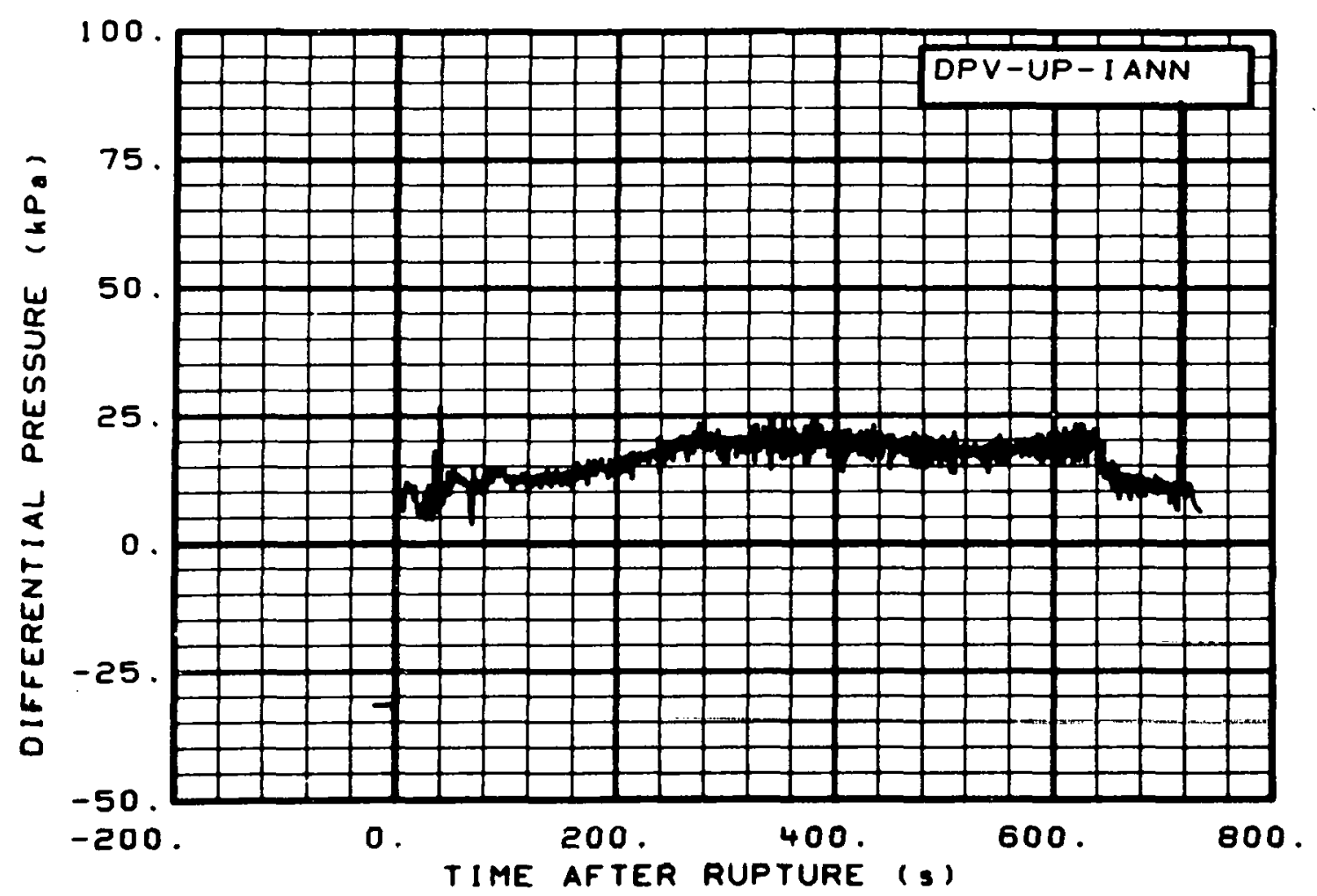

Fig. 209 Differential pressure in vessel (DPV-UP-IANN), from -20 to $736 \mathrm{~s}$.

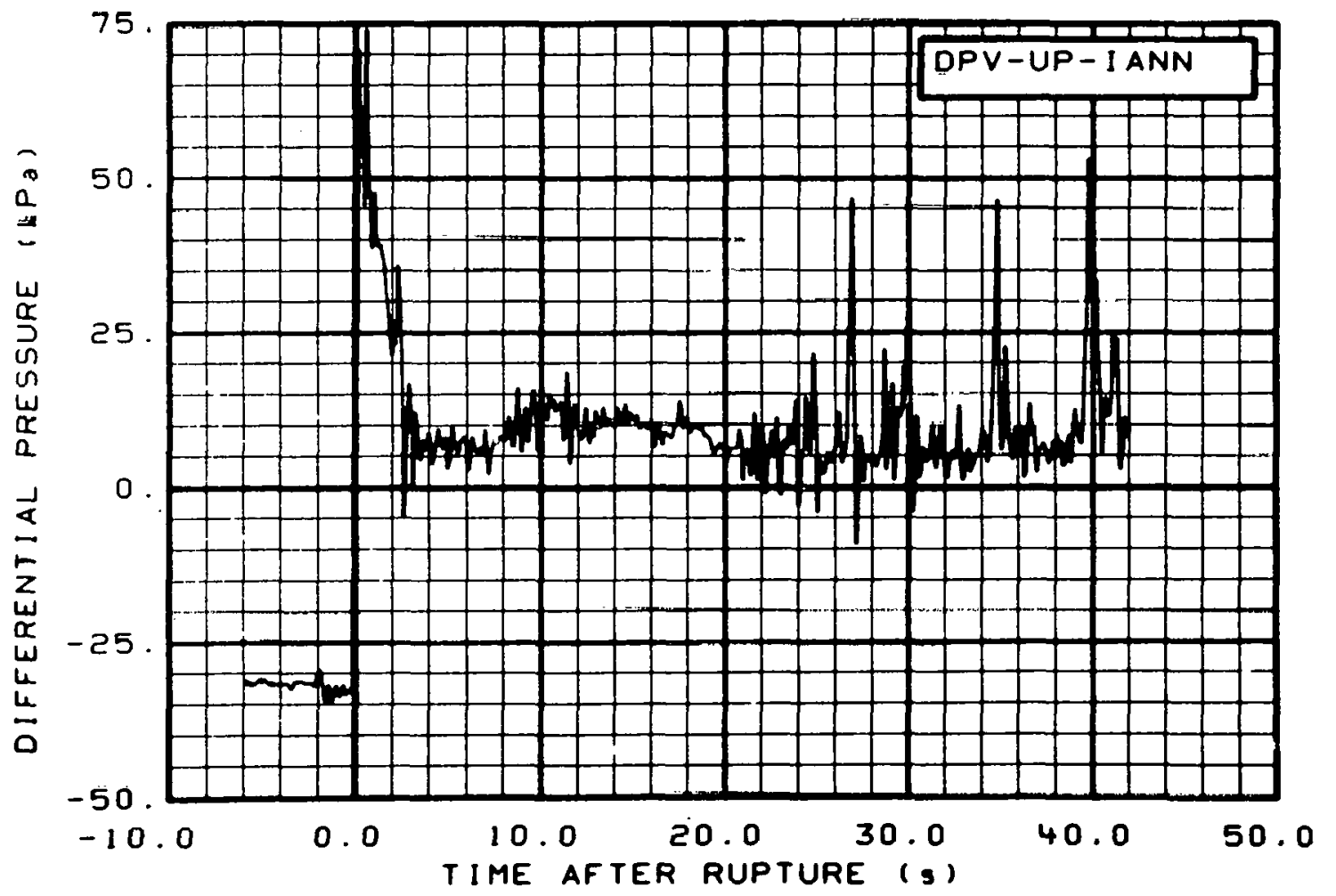

Fig. 210 Differential pressure in vessel (DPV-UP-IANN), from -6 to $42 \mathrm{~s}$. 


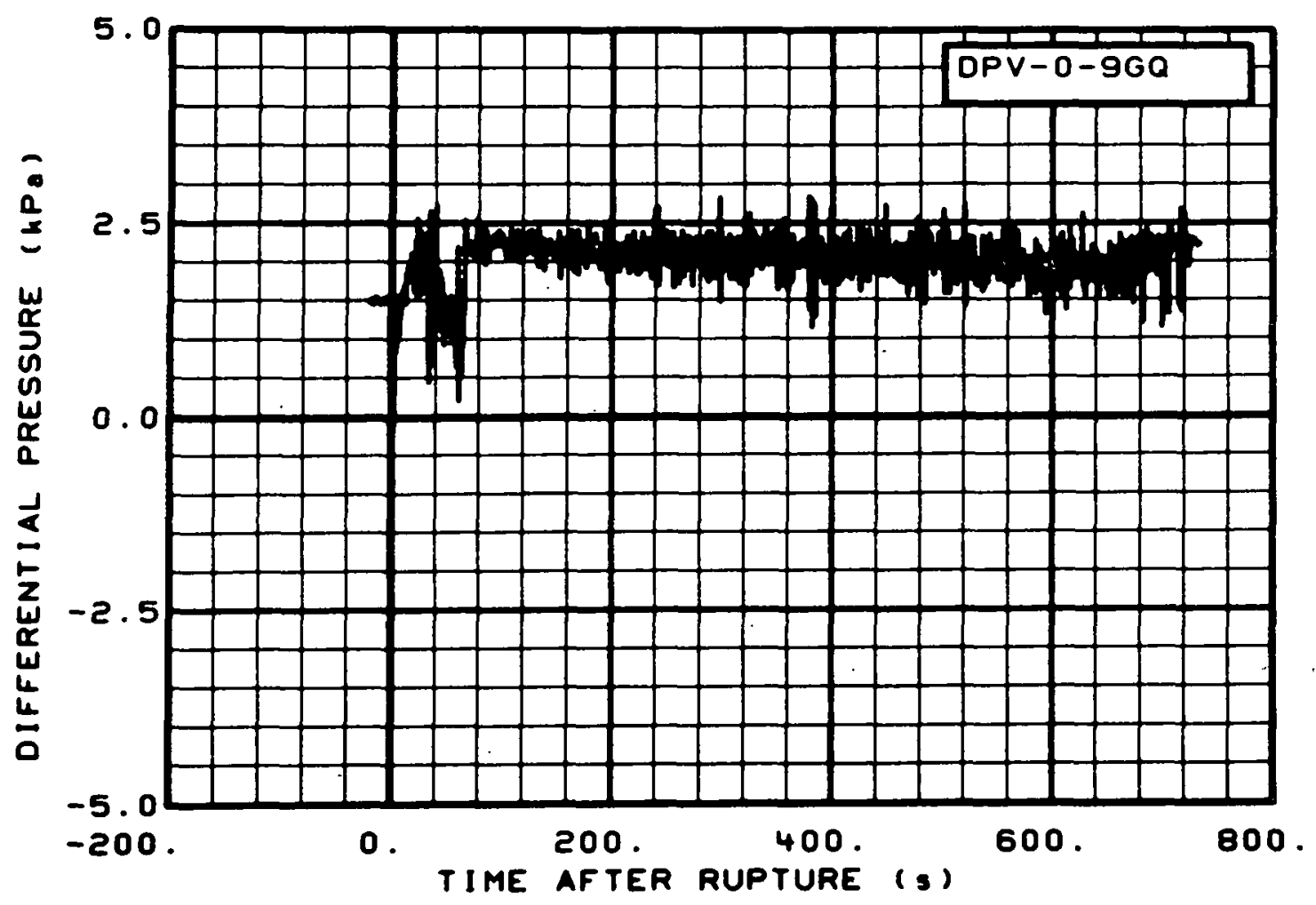

Fig. 211 Differential pressure in vessel (DPV-0-9GQ), from -20 to $736 \mathrm{~s}$.

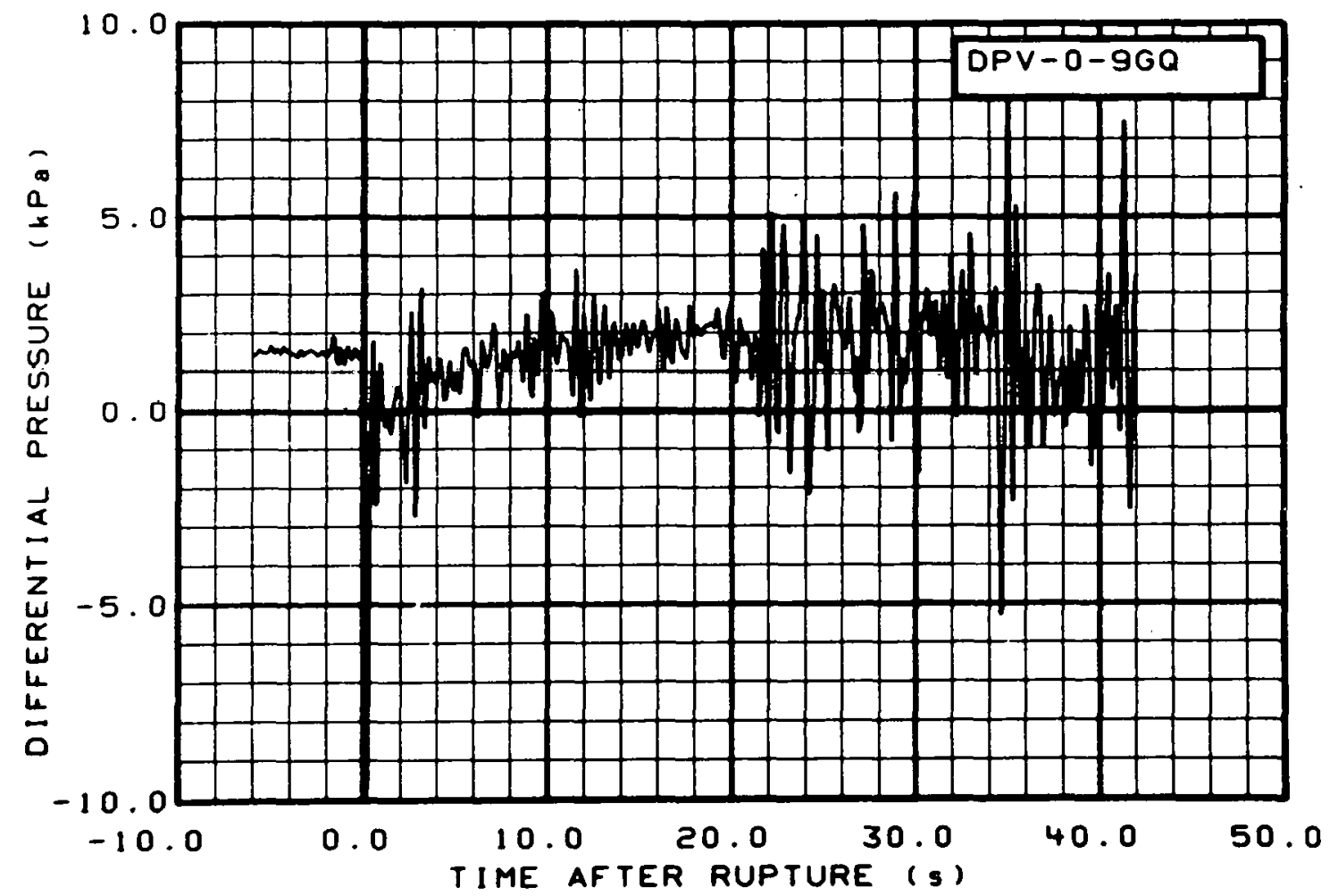

Fig. 212 Differential pressure in vessel (DPV-0-9GQ), from -6 to $42 \mathrm{~s}$. 


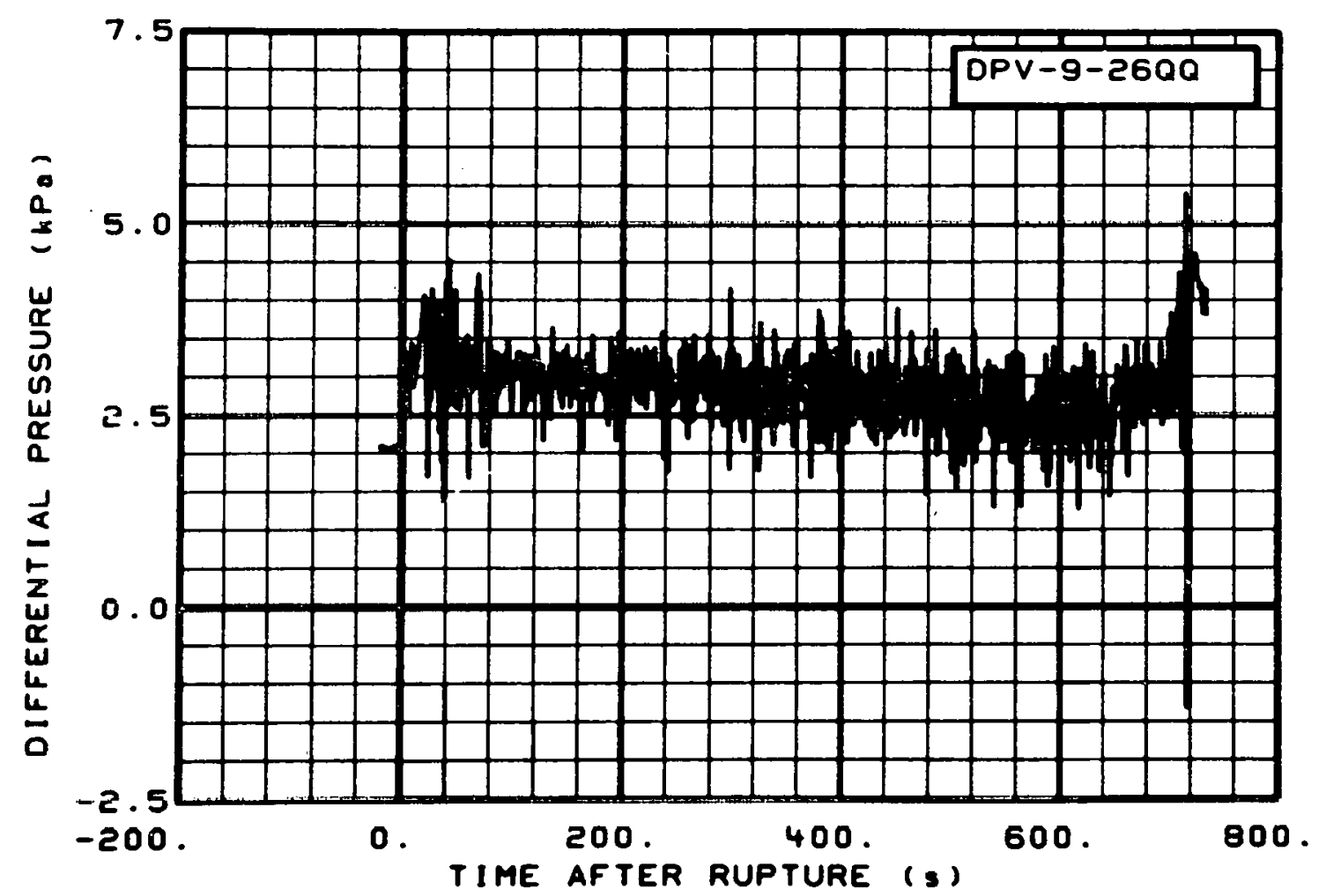

Fig. 213 Differential pressure in vessel (DPV-9-26QQ), from -20 to $736 \mathrm{~s}$.

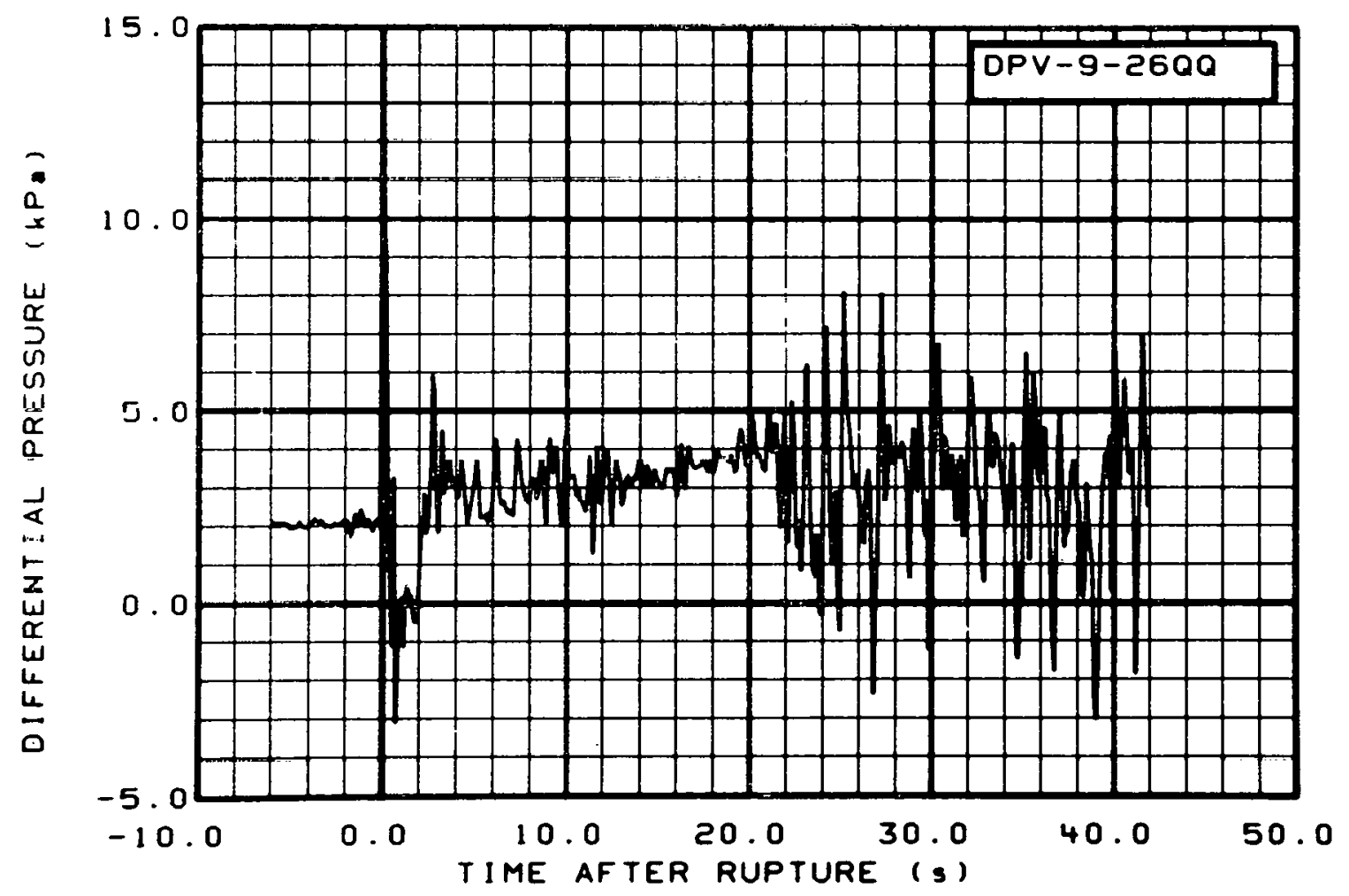

Fig. 214 Differential pressure in vessel (DPV-9-26QQ), from -6 to $42 \mathrm{~s}$. 


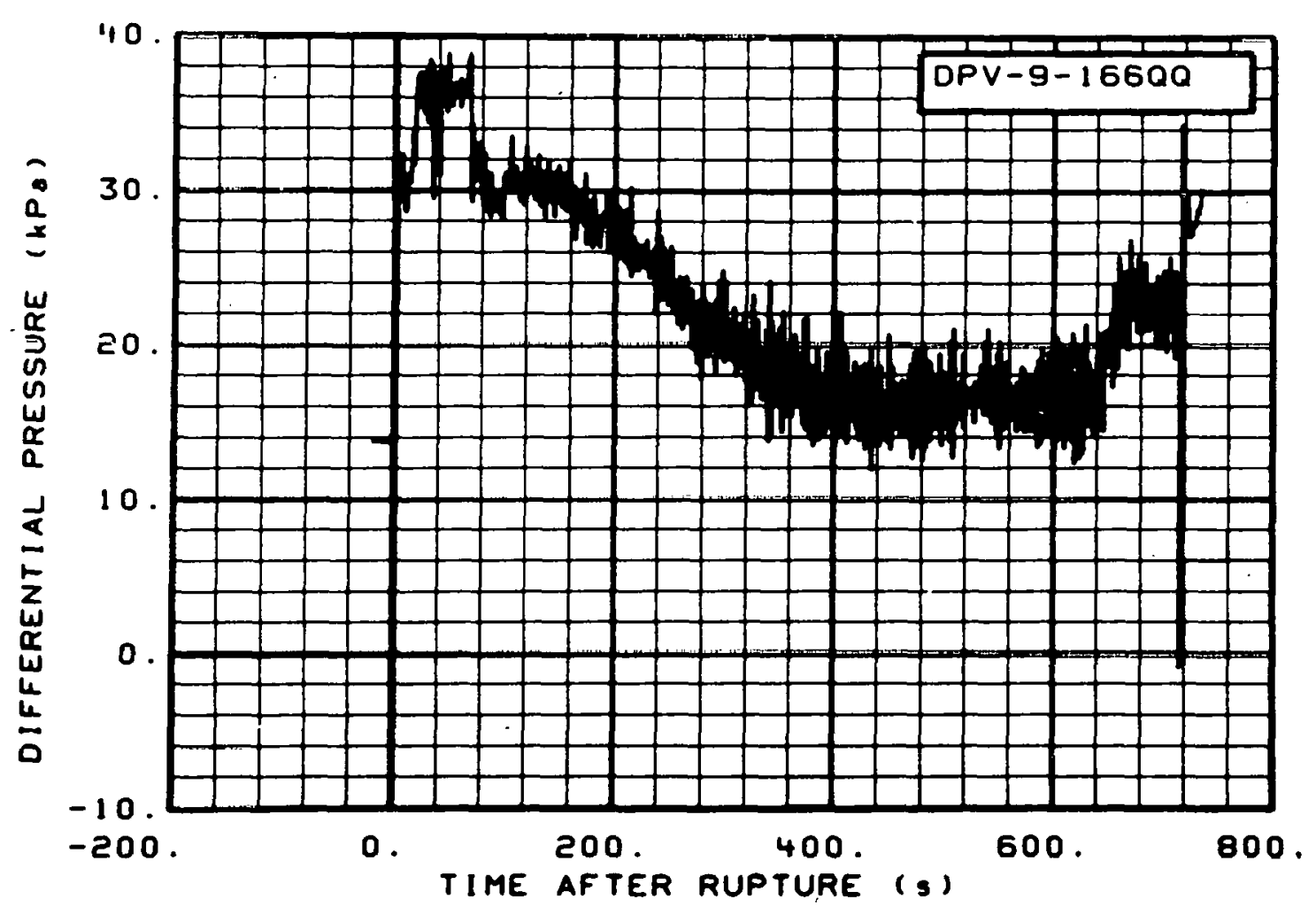

Fig. 215 Differential pressure in vessel (DPV-9-166QQ), from -20 to $736 \mathrm{~s}$.

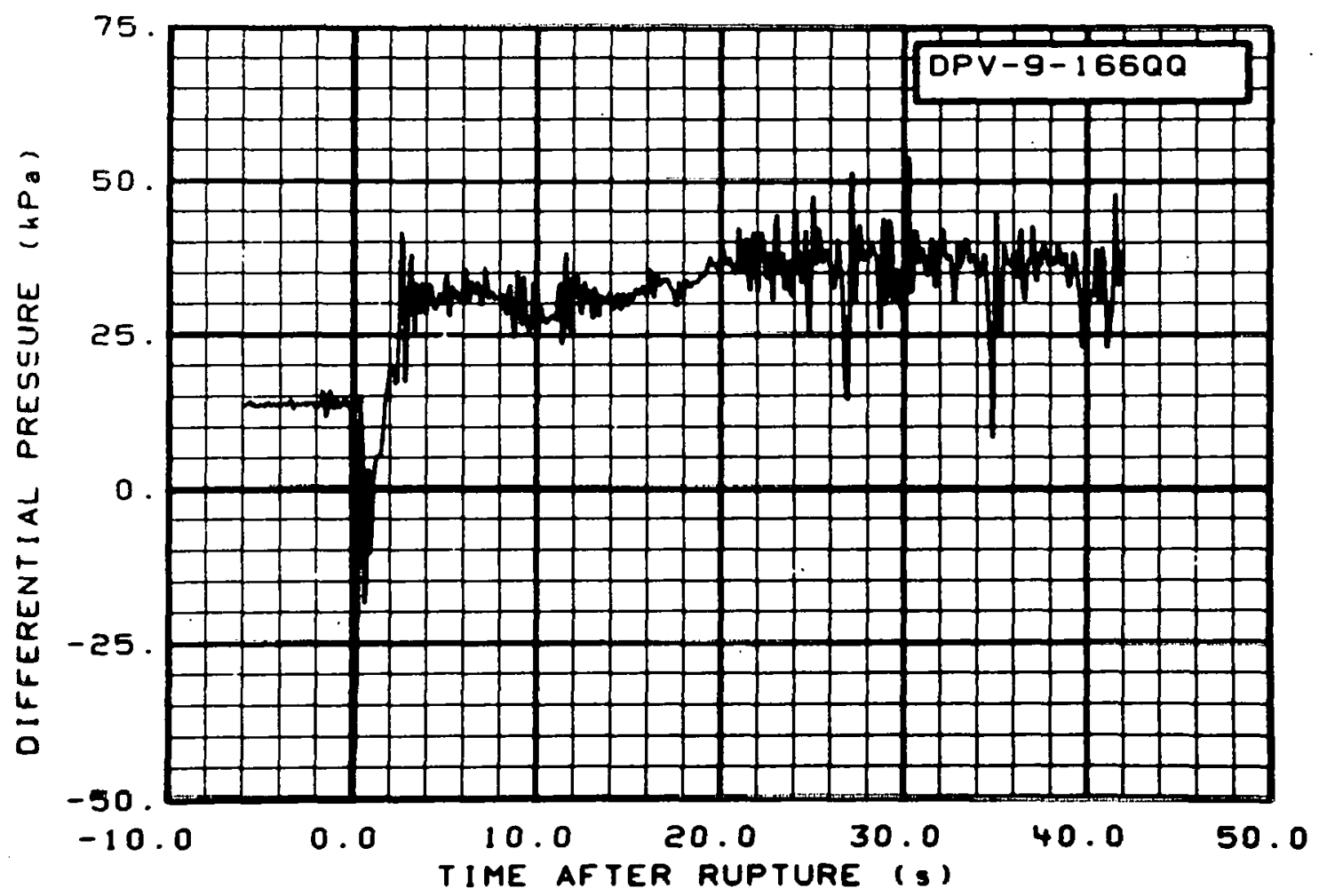

Fig. 216 Differential pressure in vessel (DPV-9-1660Q), from -6 to $42 \mathrm{~s}$. 


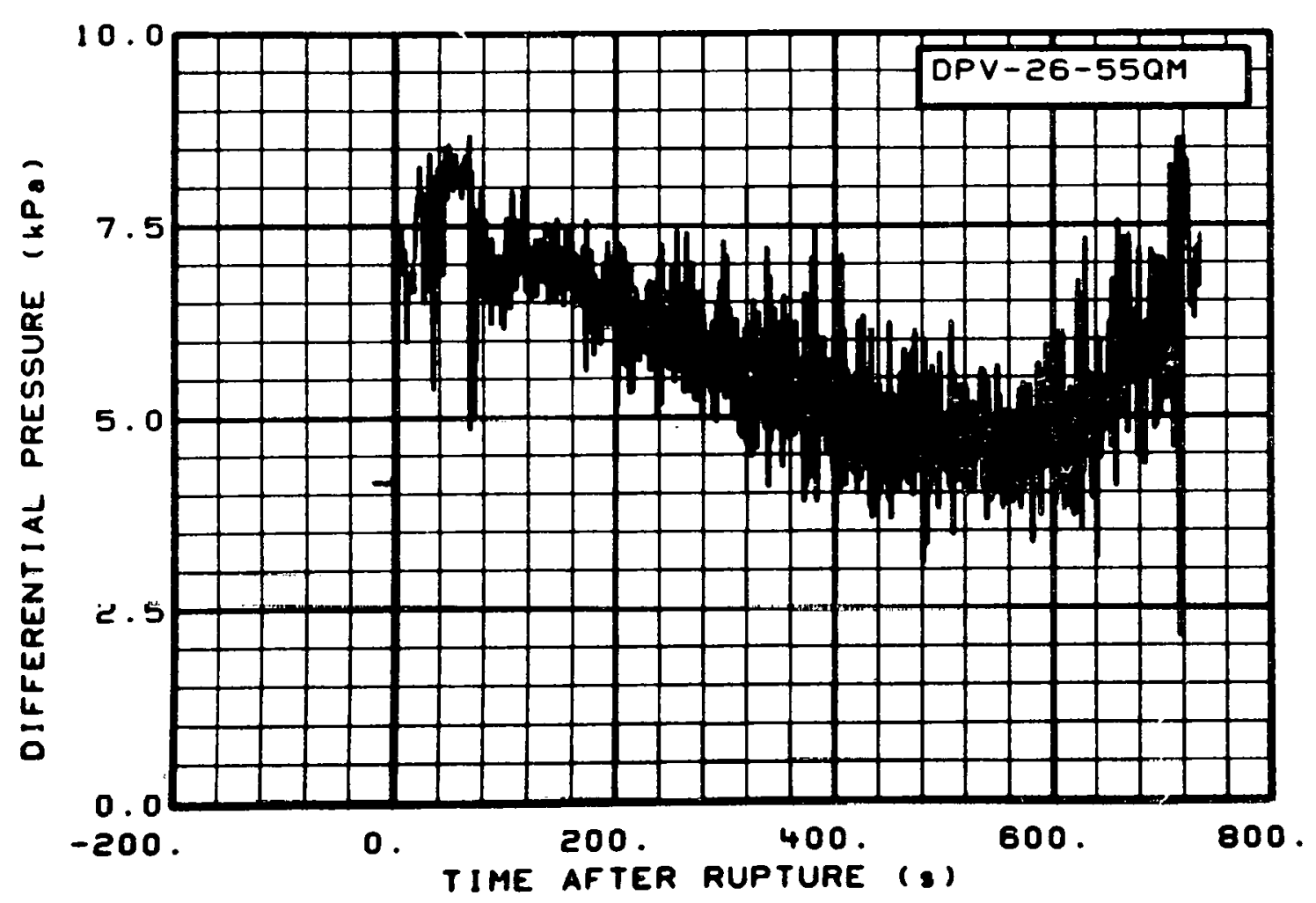

Fig. 217 Differential pressure in vesse1 (DPV-26-55QM), from -20 to $736 \mathrm{~s}$.

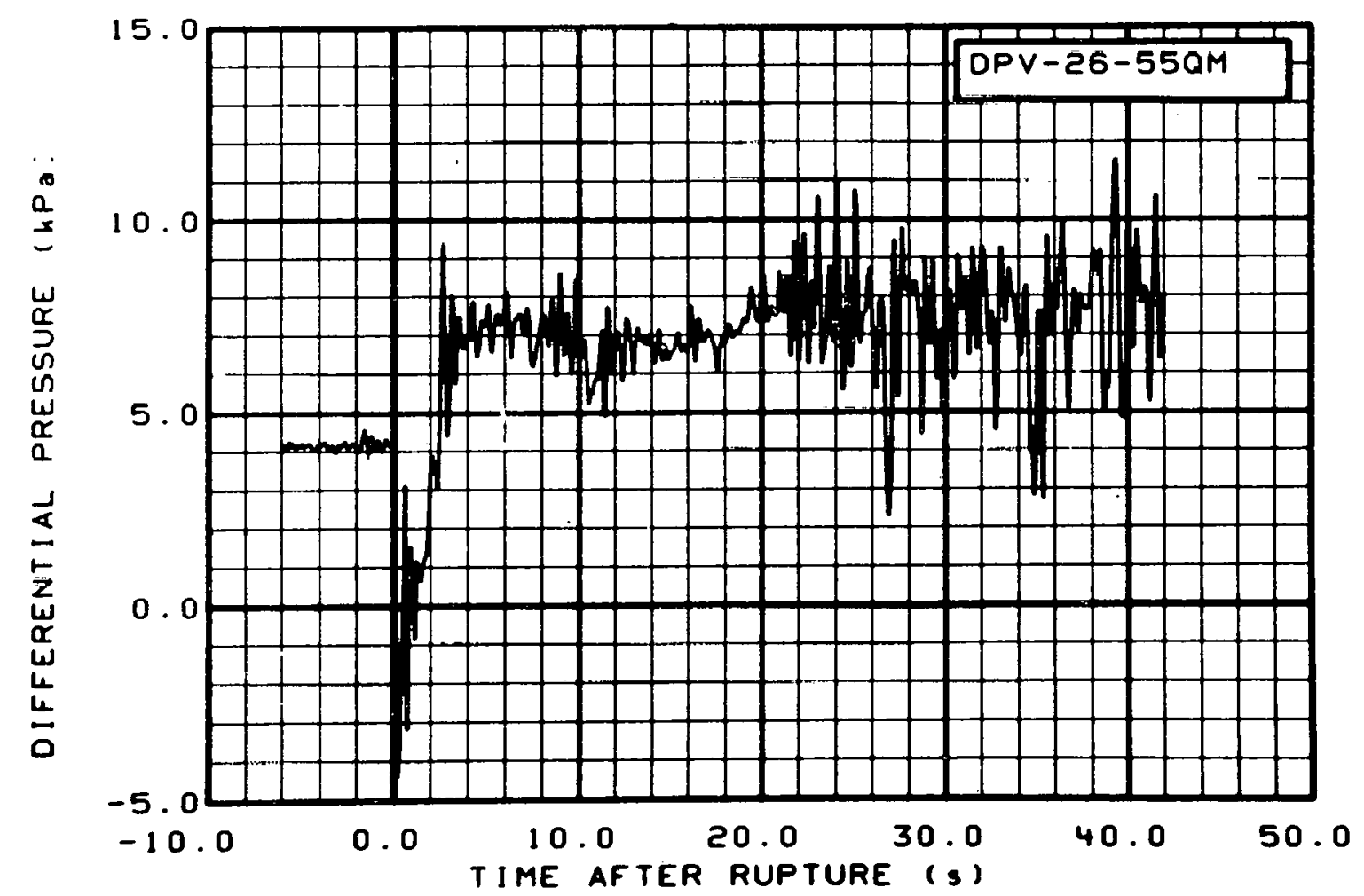

Fig. 218 Differential pressure in vessel (DPV-26-55QM), from -6 to $42 \mathrm{~s}$. 


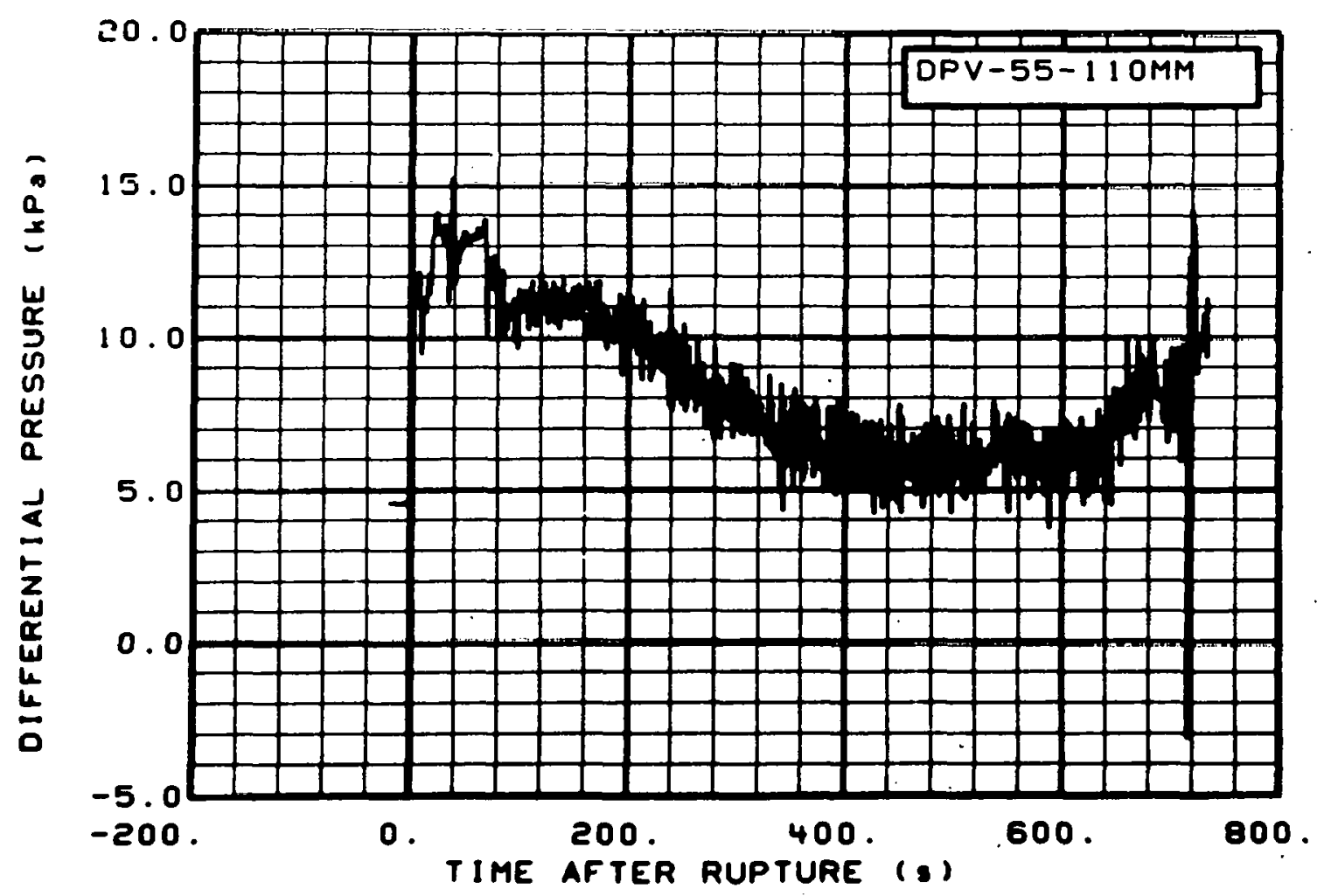

Fig. 219 Differential pressure in vesse1 (DPV-55-110MM), from -20 to $736 \mathrm{~s}$.

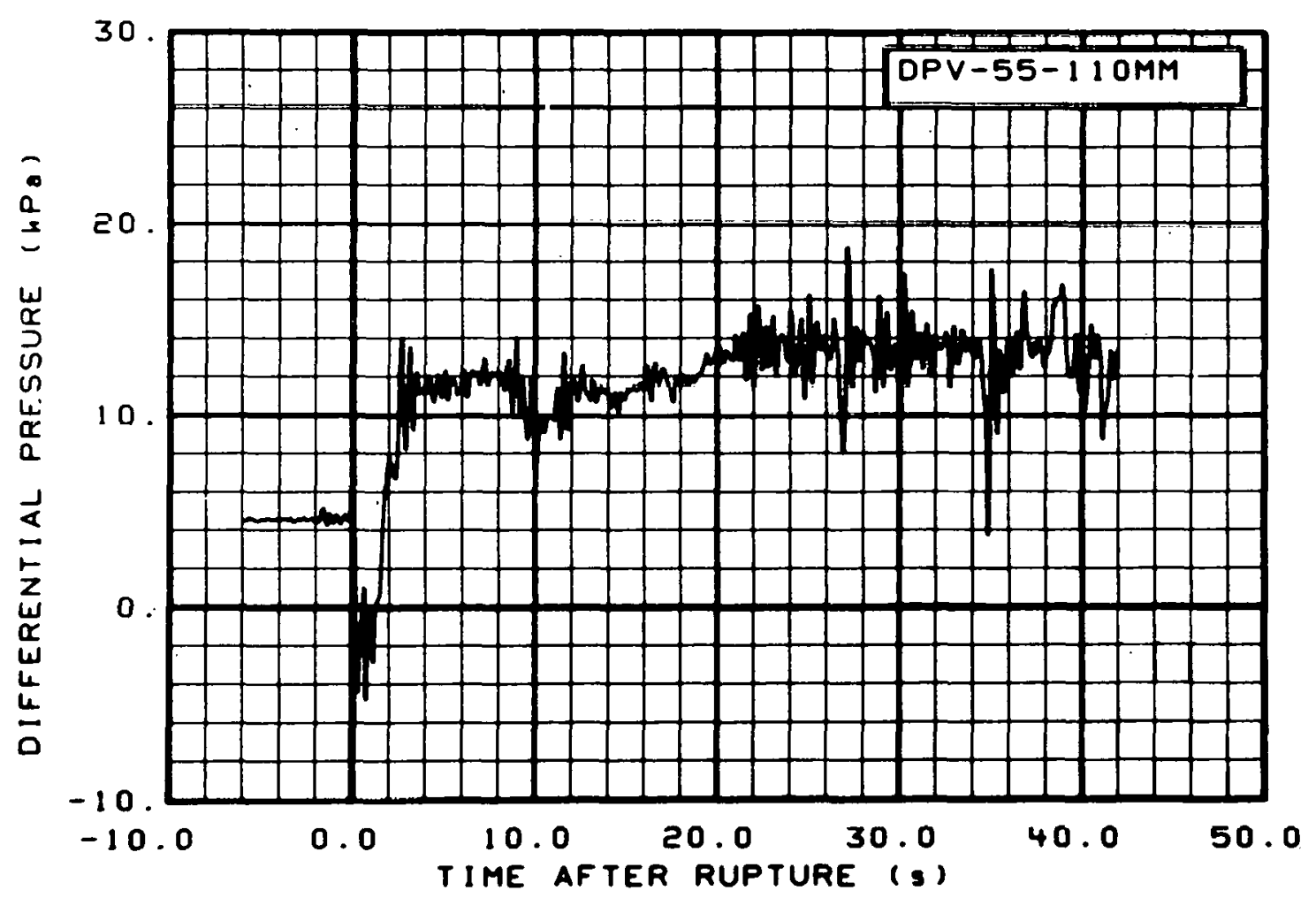

Fig. 220 Differential pressure in vessel (DPV-55-110MM), from -6 to $42 \mathrm{~s}$. 


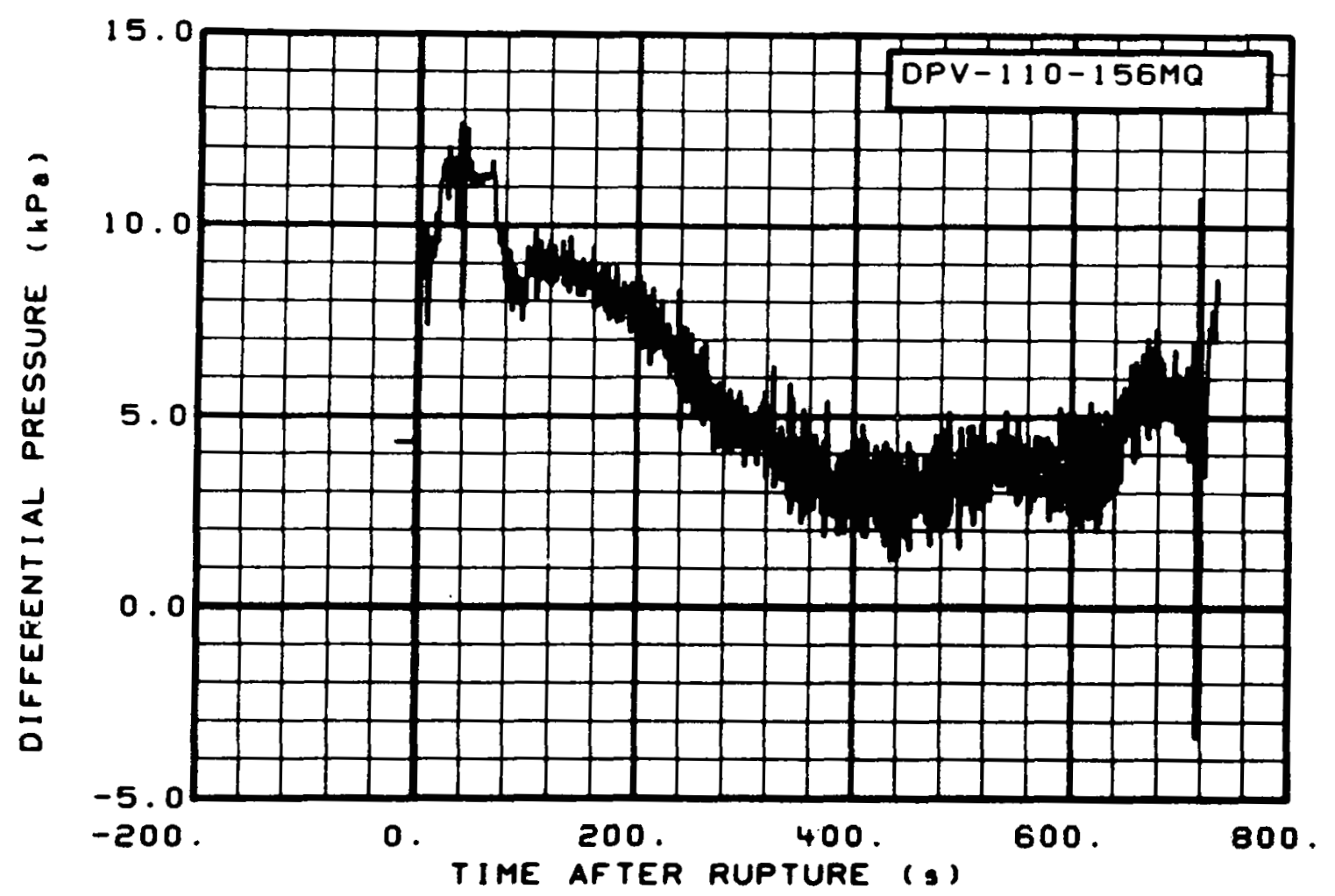

Fig. 221 Differential pressure in vessel (DPV-110-156MQ), from -20 to $736 \mathrm{~s}$.

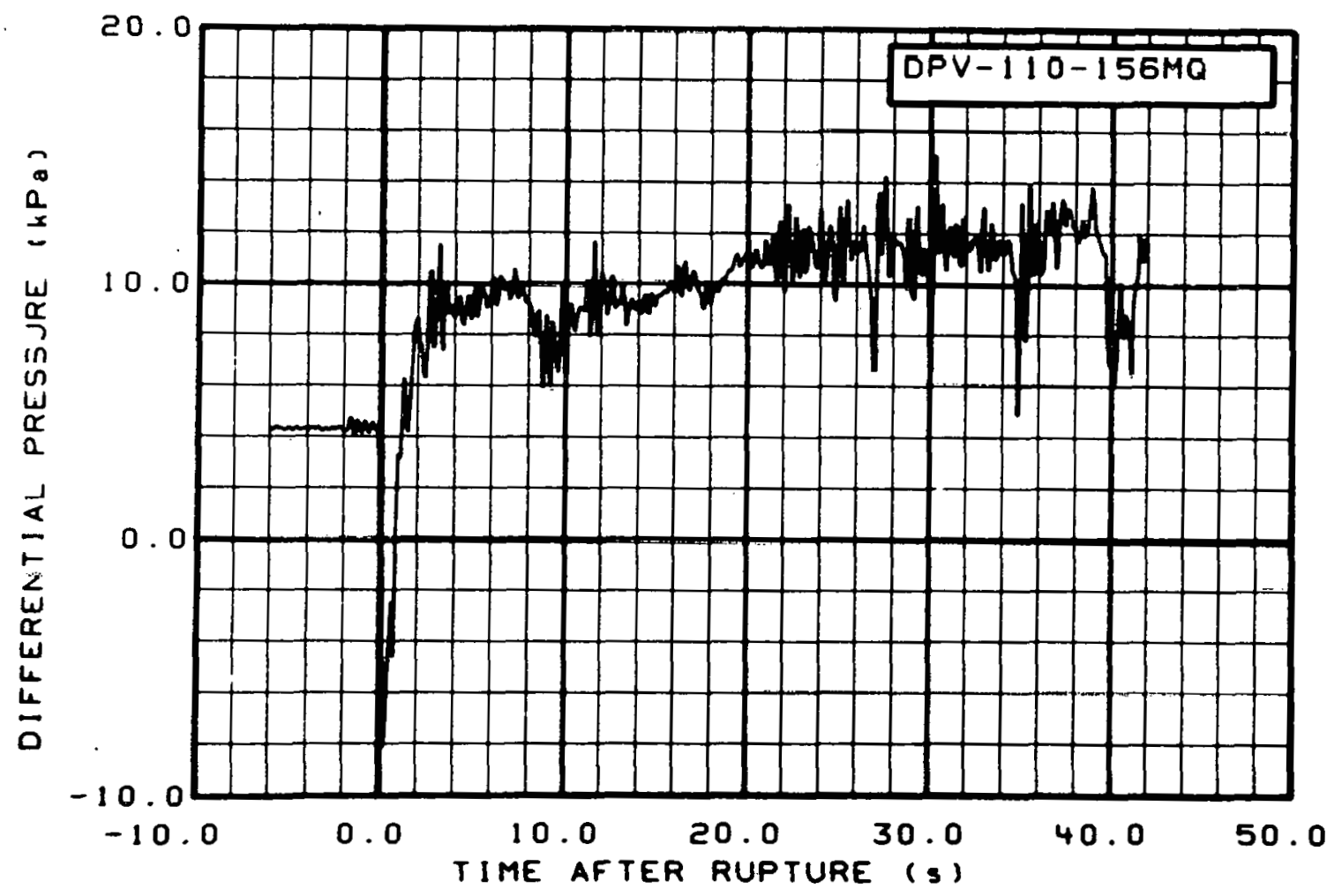

Fig. 222 Differential pressure in vessel (DPV-110-156MQ), from -6 to 42 s. 


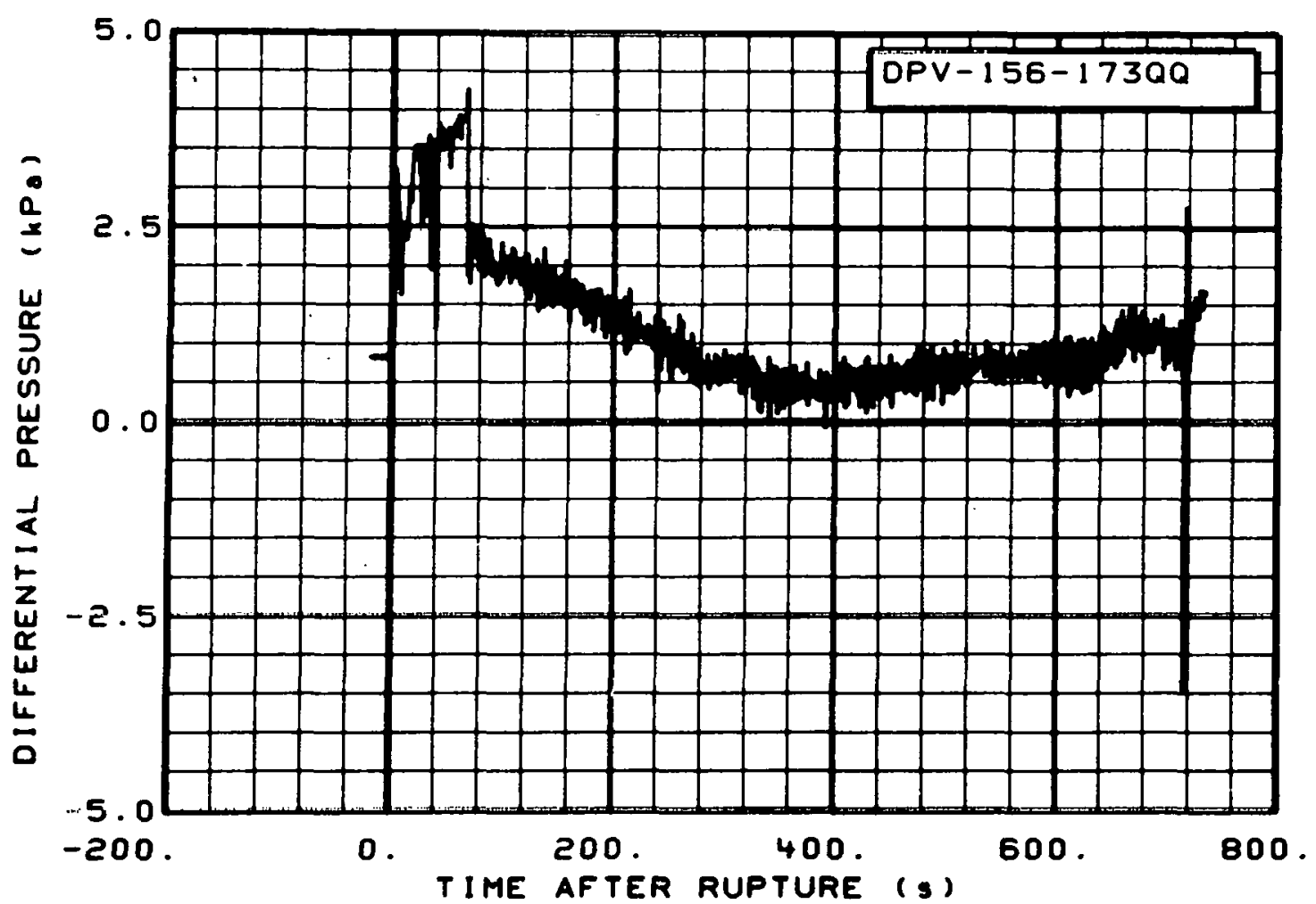

Fig. 223 Differential pressure in vessel (DPV-156-173QQ), from -20 to $736 \mathrm{~s}$.

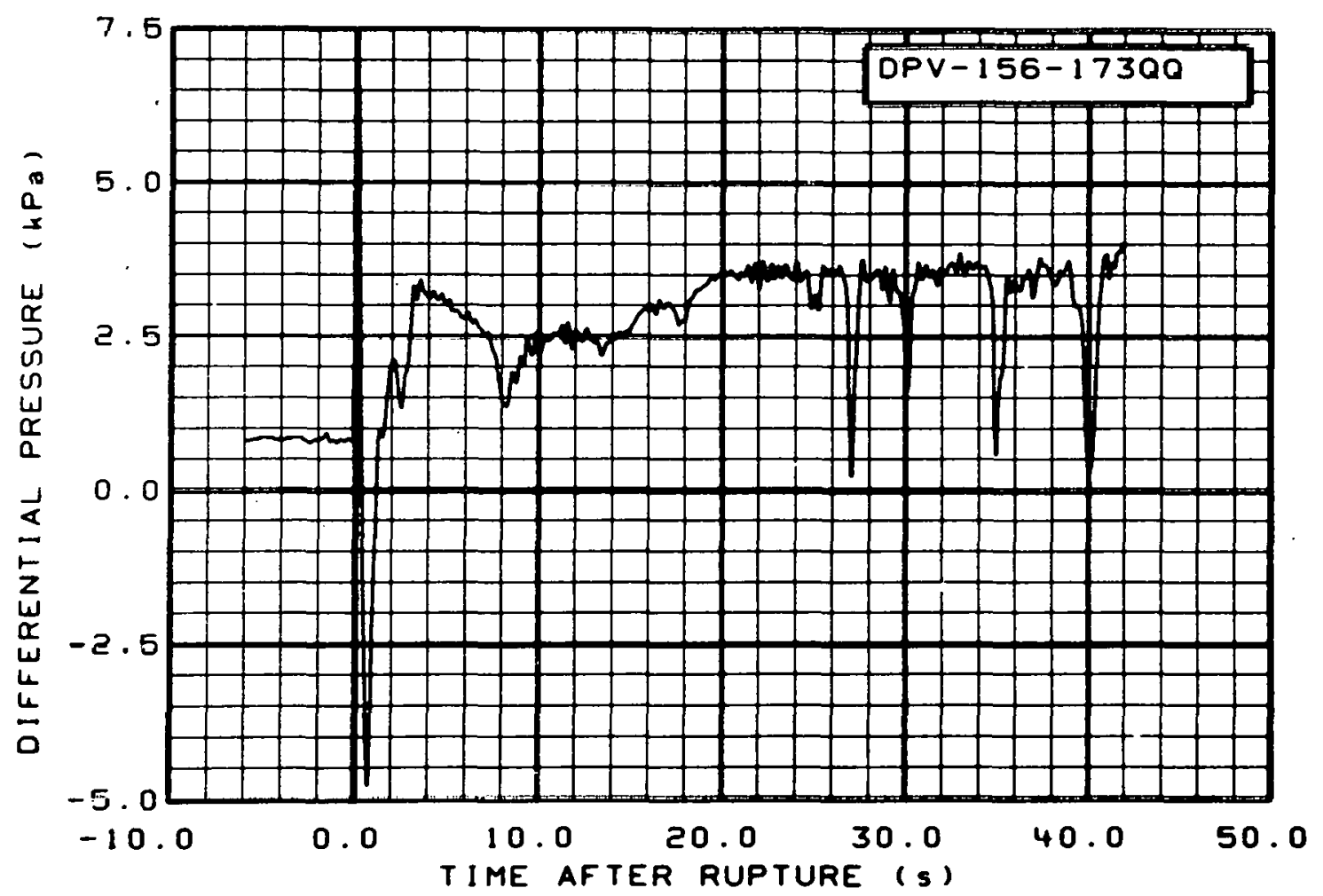

Fig. 224 Differential pressure in vessel (DPV-156-173QQ), from -6 to $42 \mathrm{~s}$. 


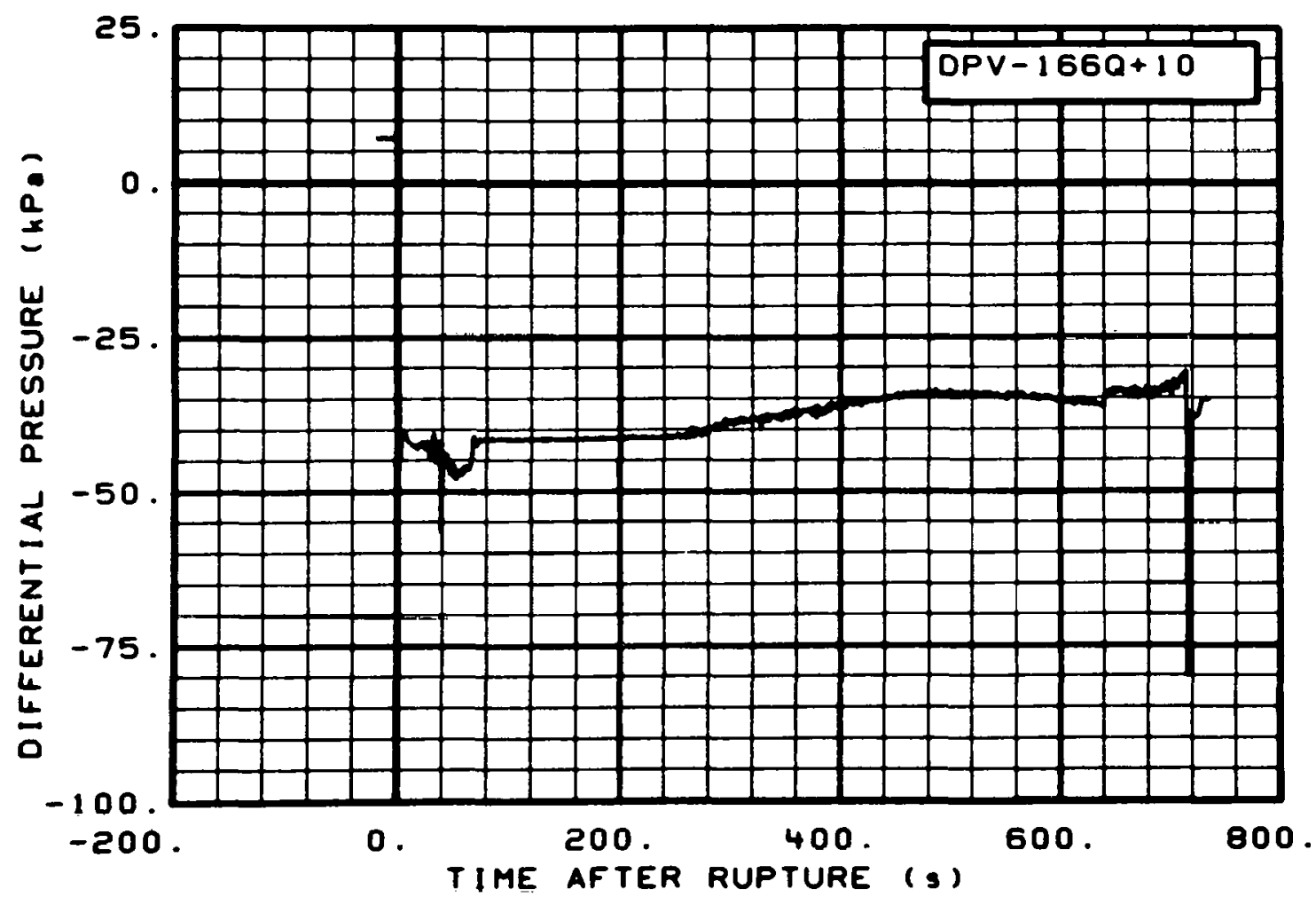

Fig. 225 Differential pressure in vessel (DPV-166Q+10), from -20 to $736 \mathrm{~s}$.

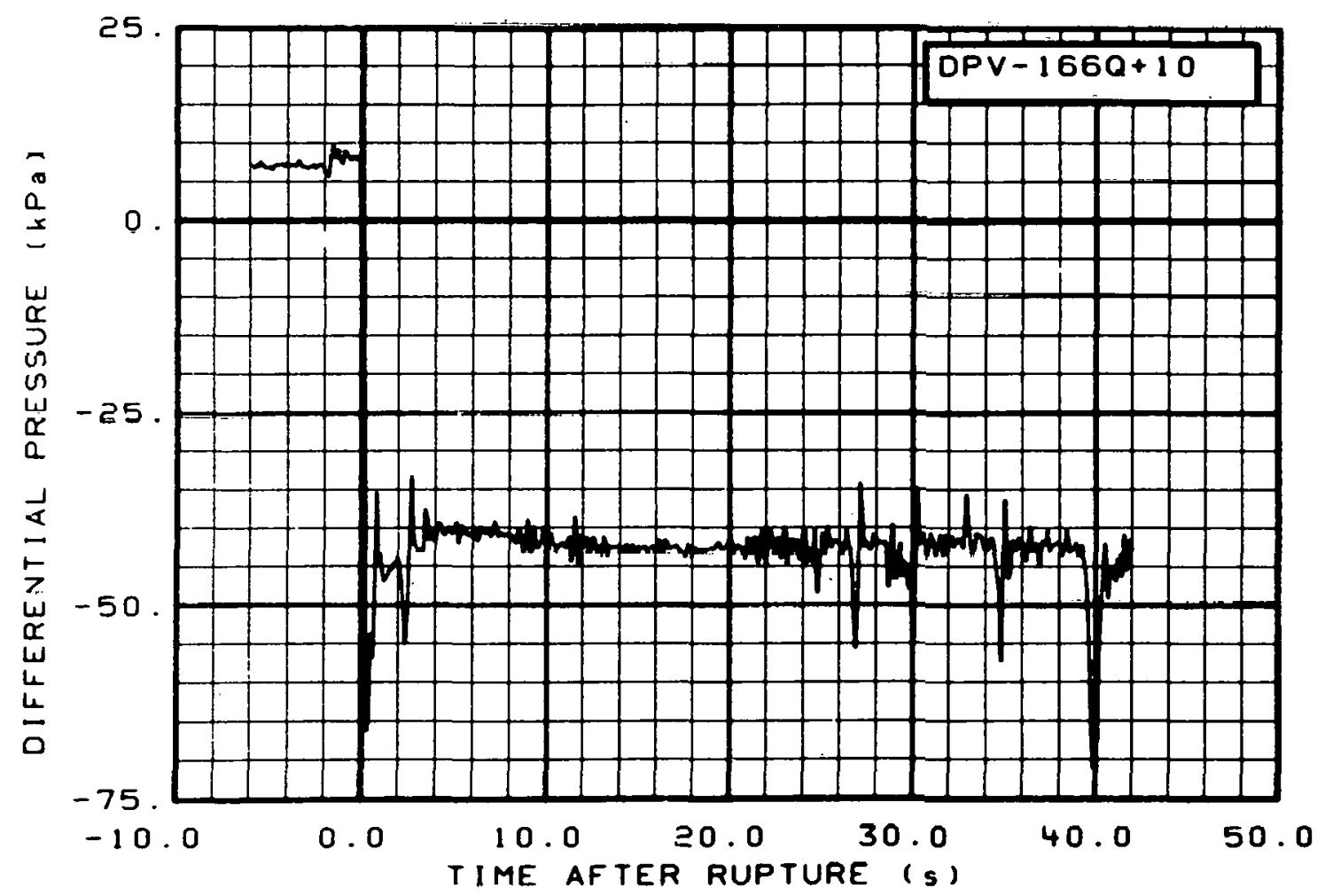

Fig. 226 Differential pressure in vessel (DPV-166Q+10), from -6 to $42 \mathrm{~s}$. 


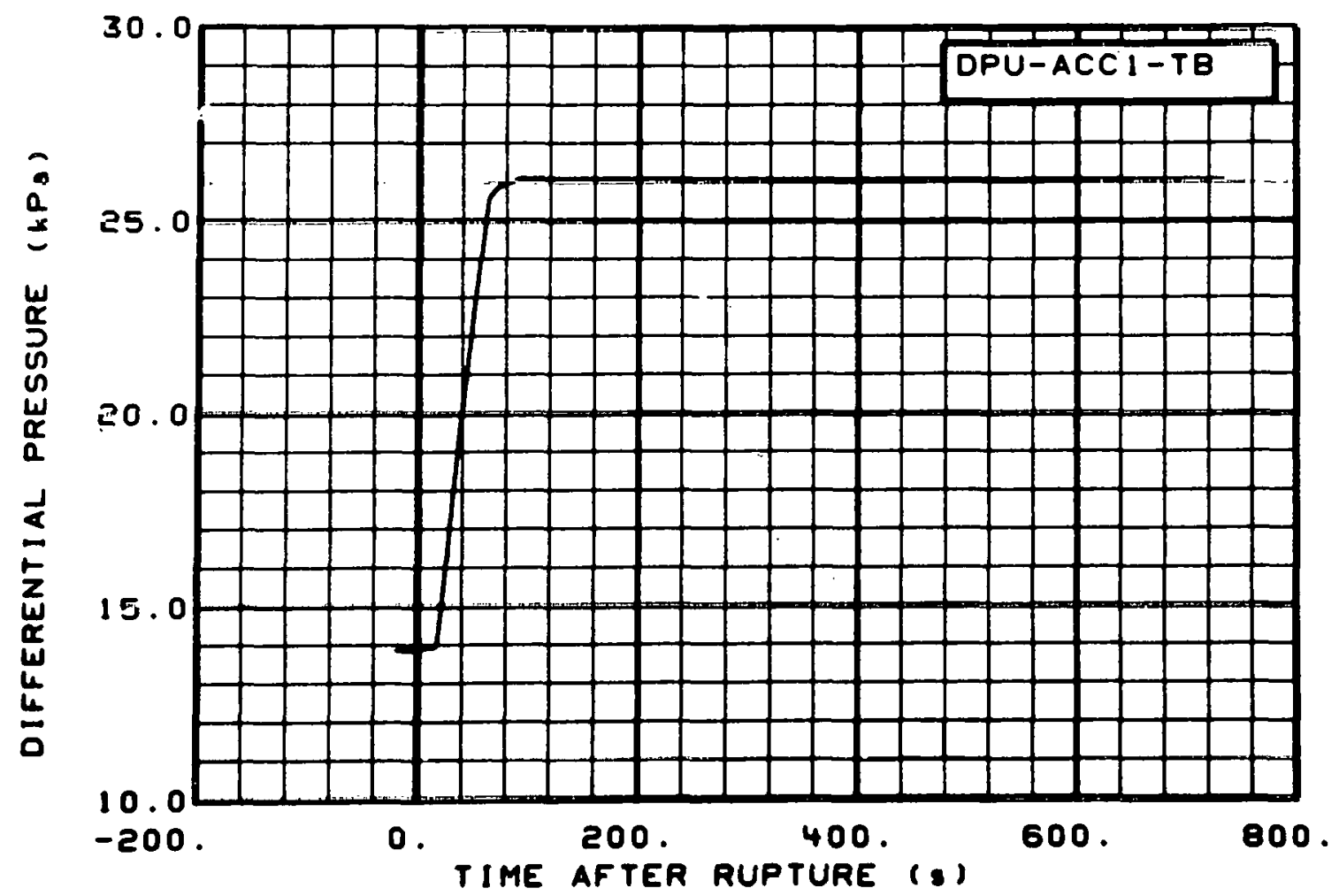

Fig. 227 Differential pressure in intact loop accumulator (DPU-ACC1-TB), from -20 to $736 \mathrm{~s}$.

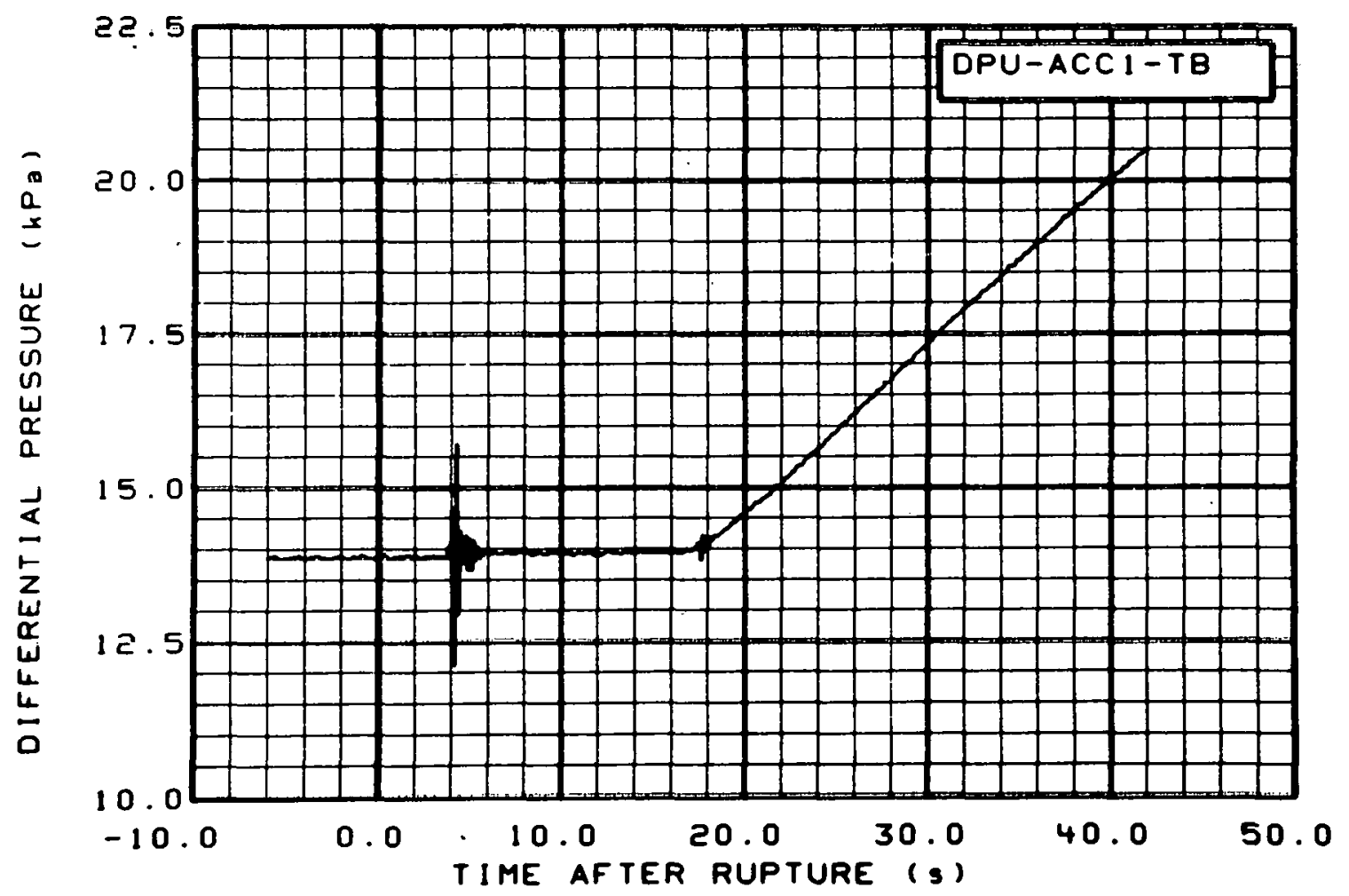

Fig. 228 Differential pressure in intact 100p accumulator (DPU-ACC I-TB), from -6 to $42 \mathrm{~s}$. 


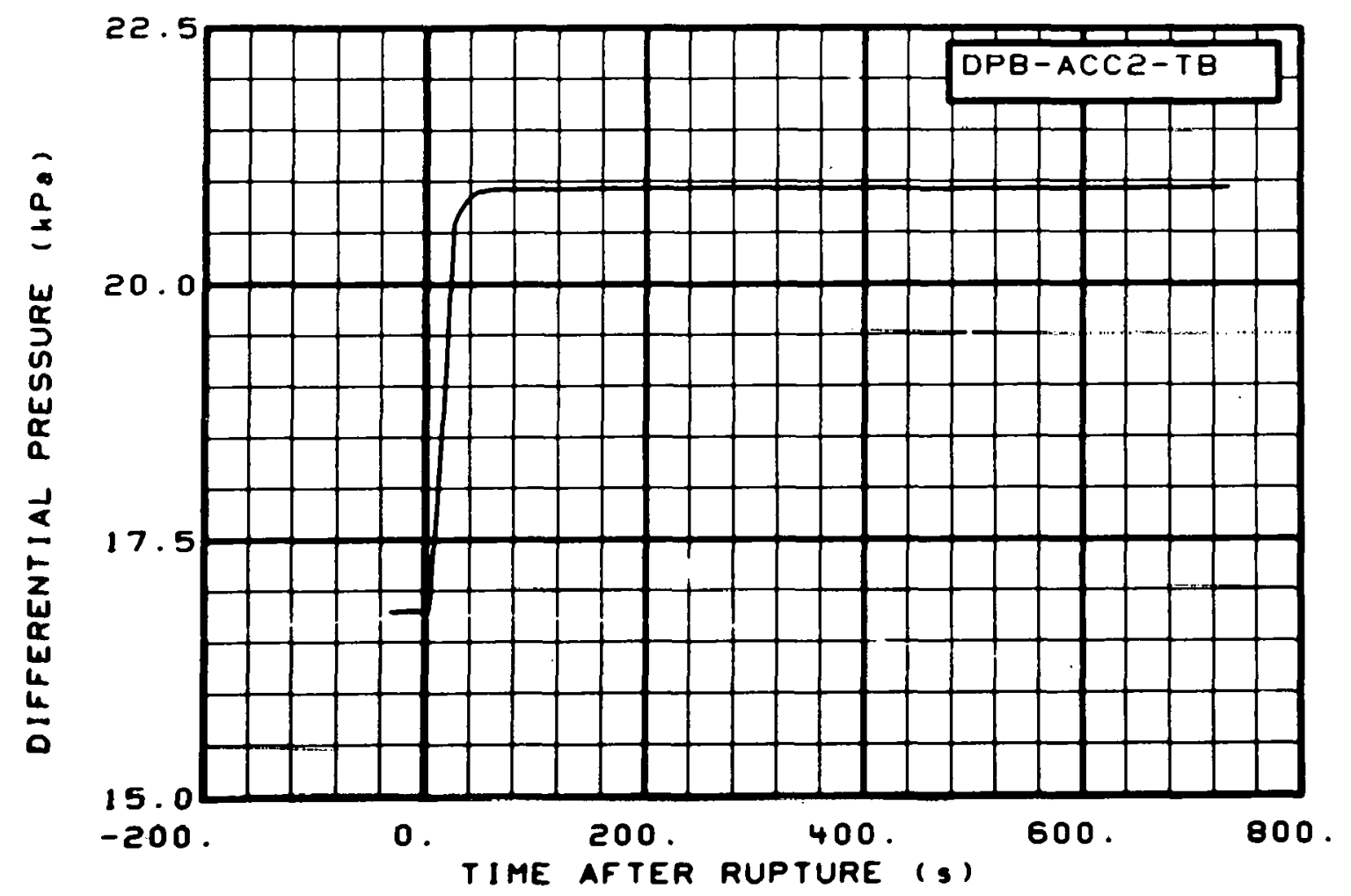

Fig. 229 Differential pressure in broken loop accumulator (DPB-ACC2-TB), from -20 to $736 \mathrm{~s}$.

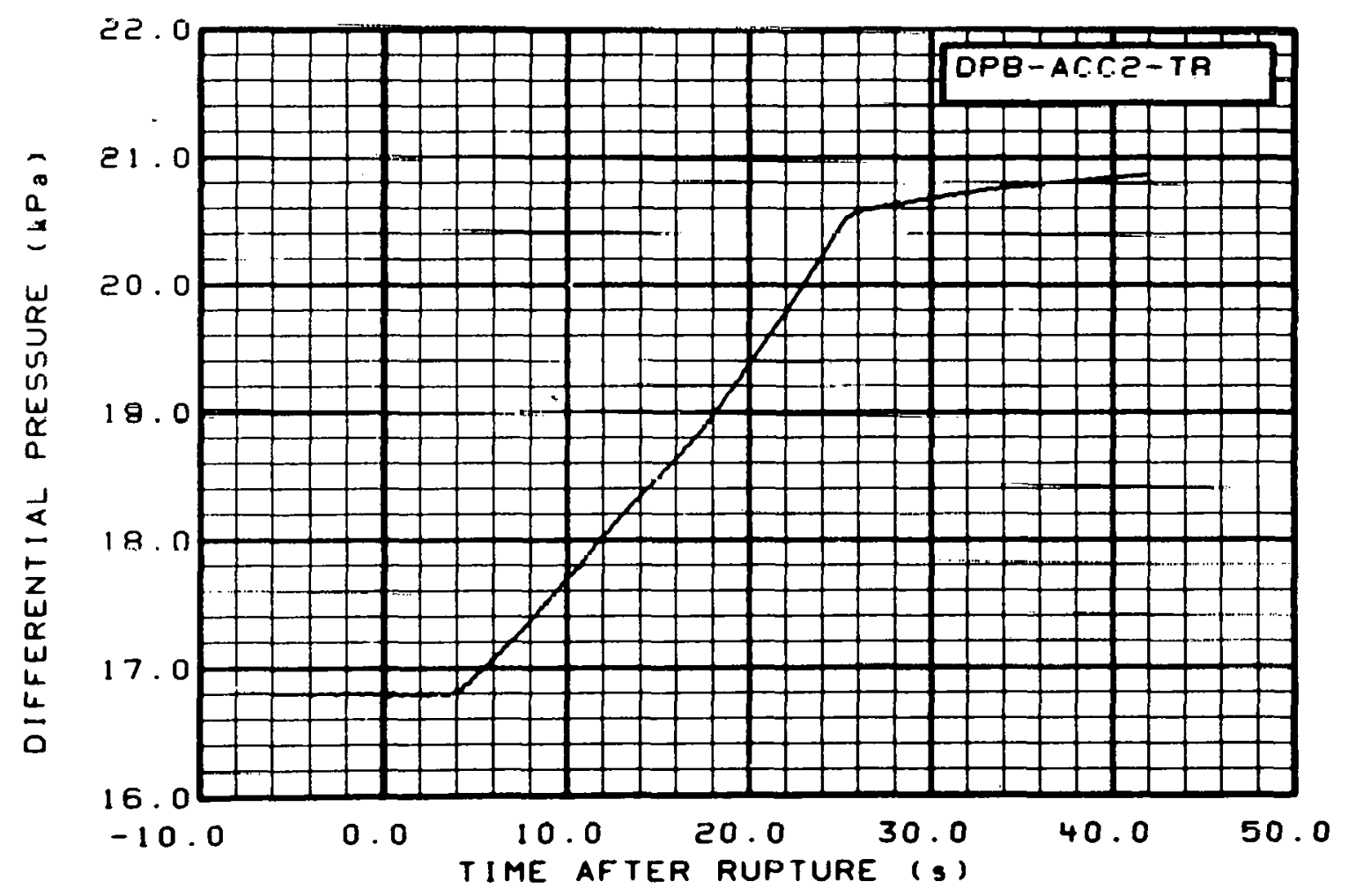

Fig. 230 Differential pressure in broken loop accumulator (DPB-ACC2-TB), from -6 to $42 \mathrm{~s}$. 


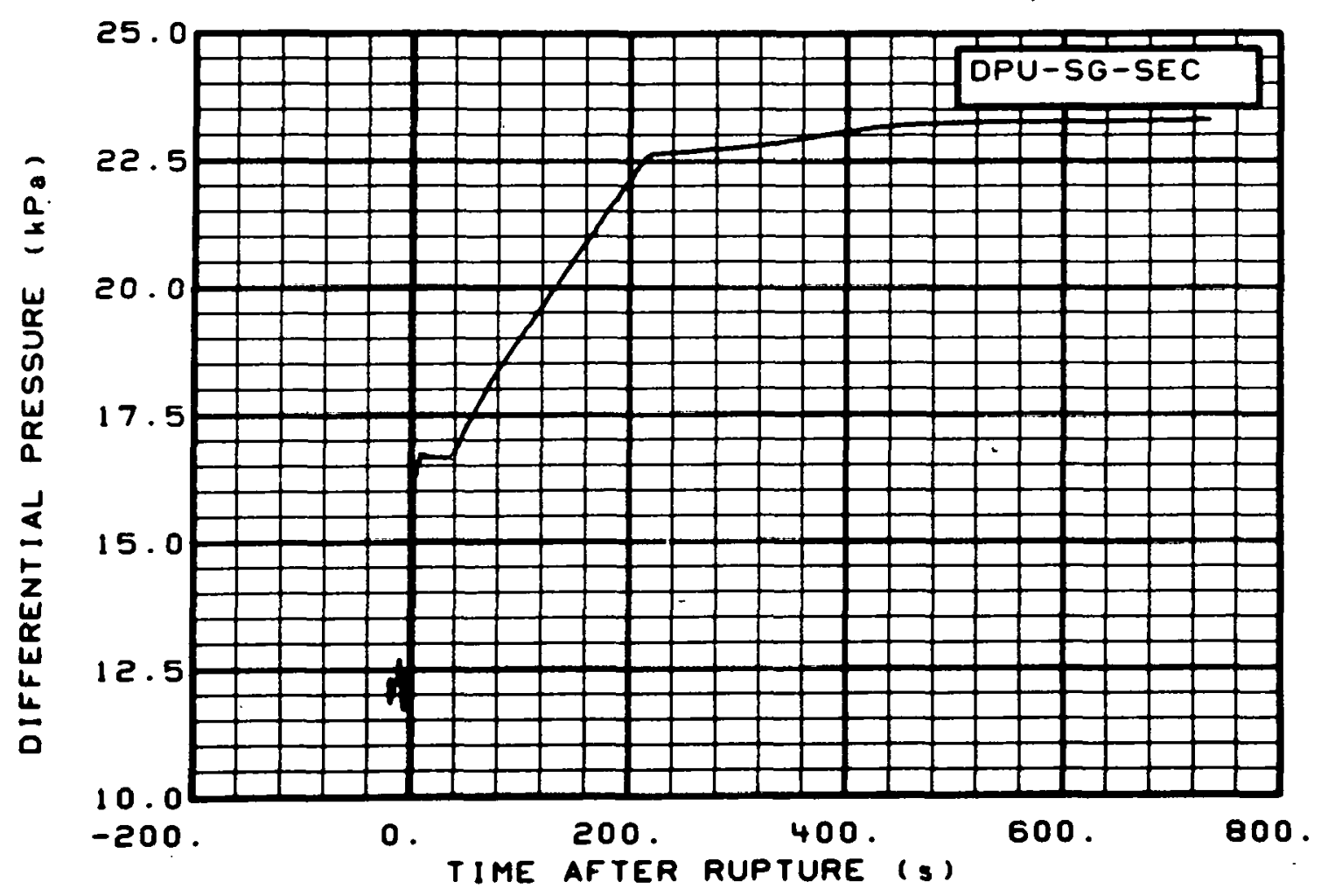

Fig. 231 Differential pressure in steam generator secondary (DPU-SG-SEC), from -20 to $736 \mathrm{~s}$.

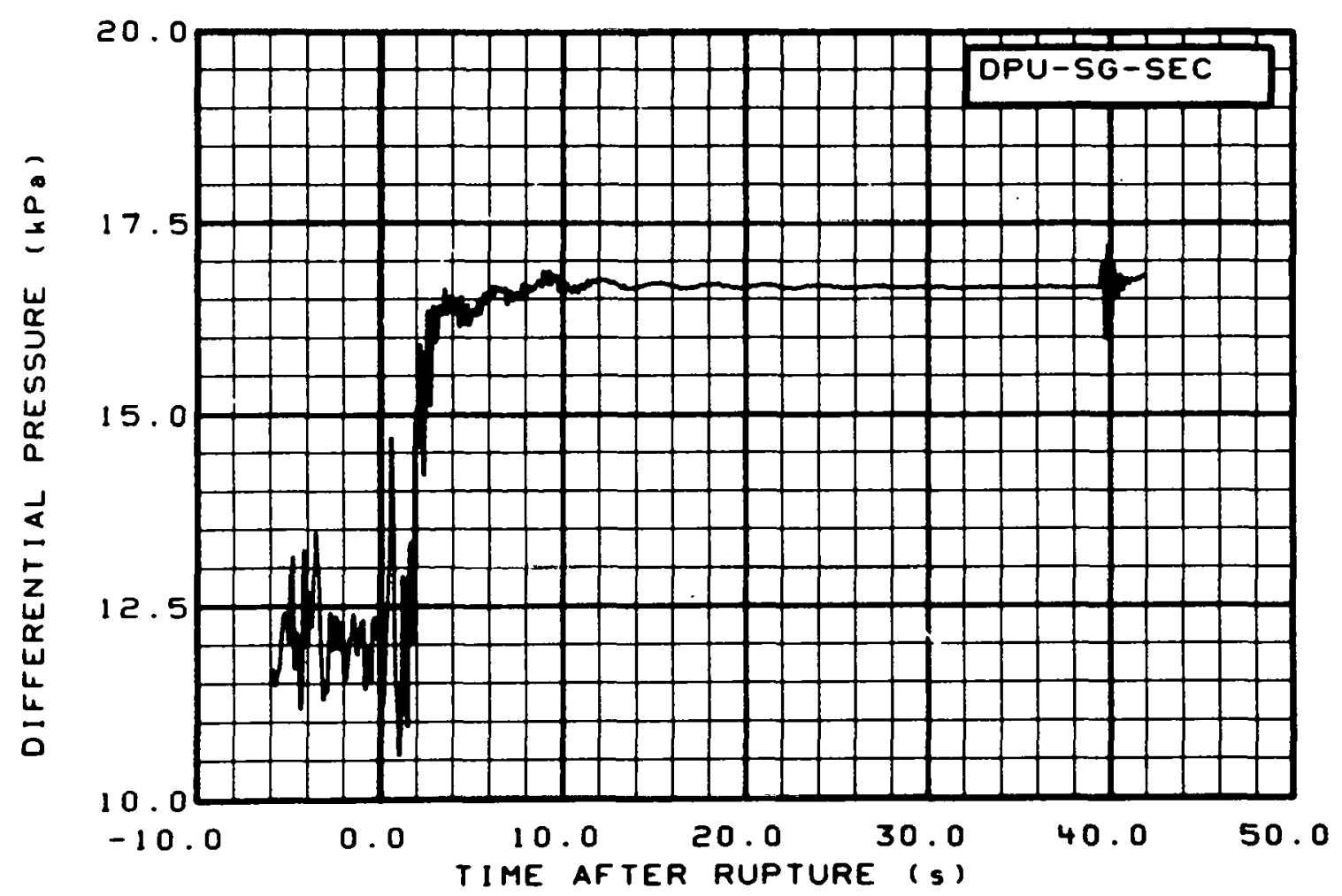

Fig. 232 Differential pressure in steam generator secondary (DPU-SG-SEC), from -6 to $42 \mathrm{~s}$. 


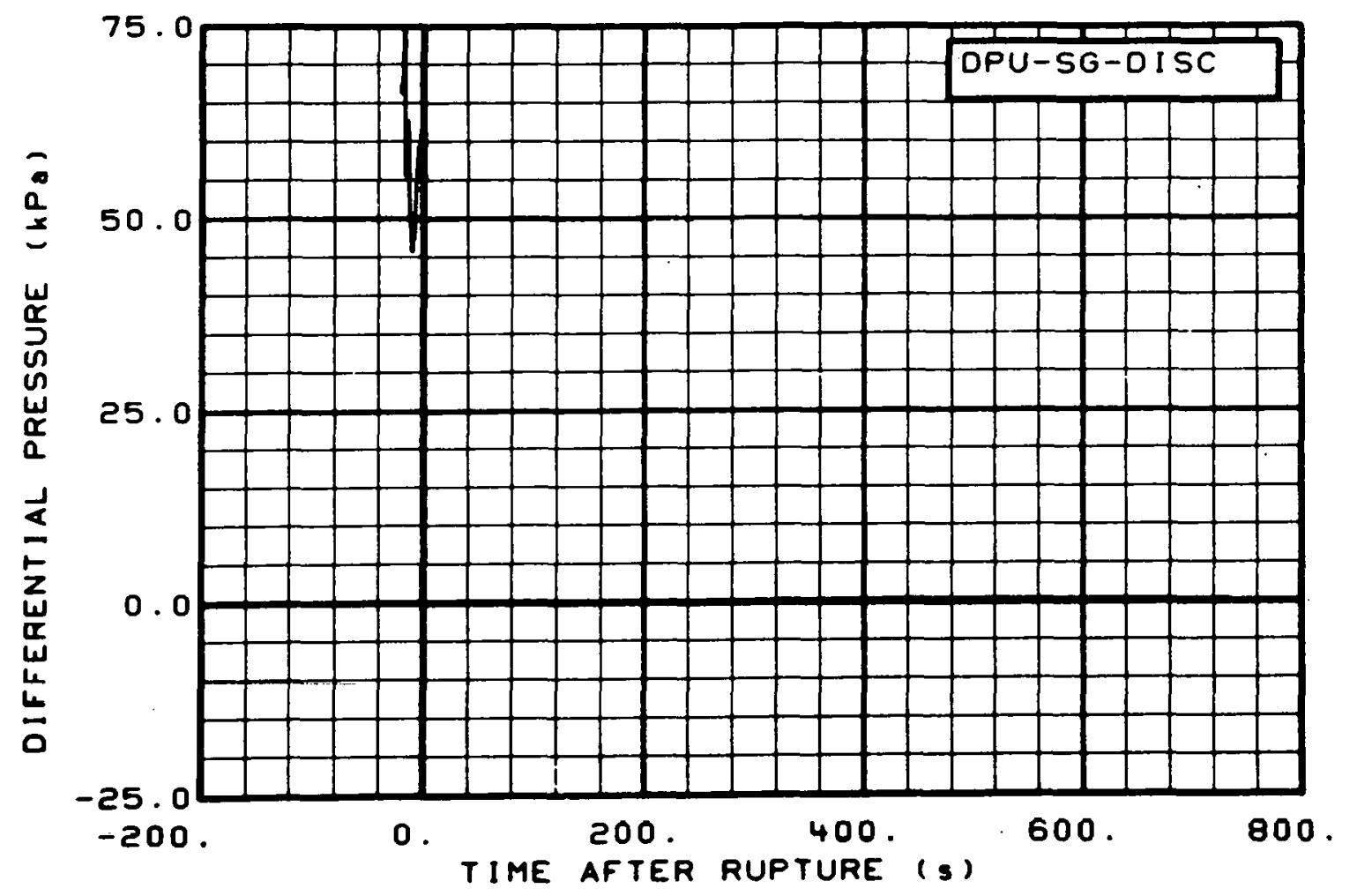

Fig. 233 Differential pressure across steam generator outlet orifice (DPU-SG-DISC), from -20 to $736 \mathrm{~s}$.

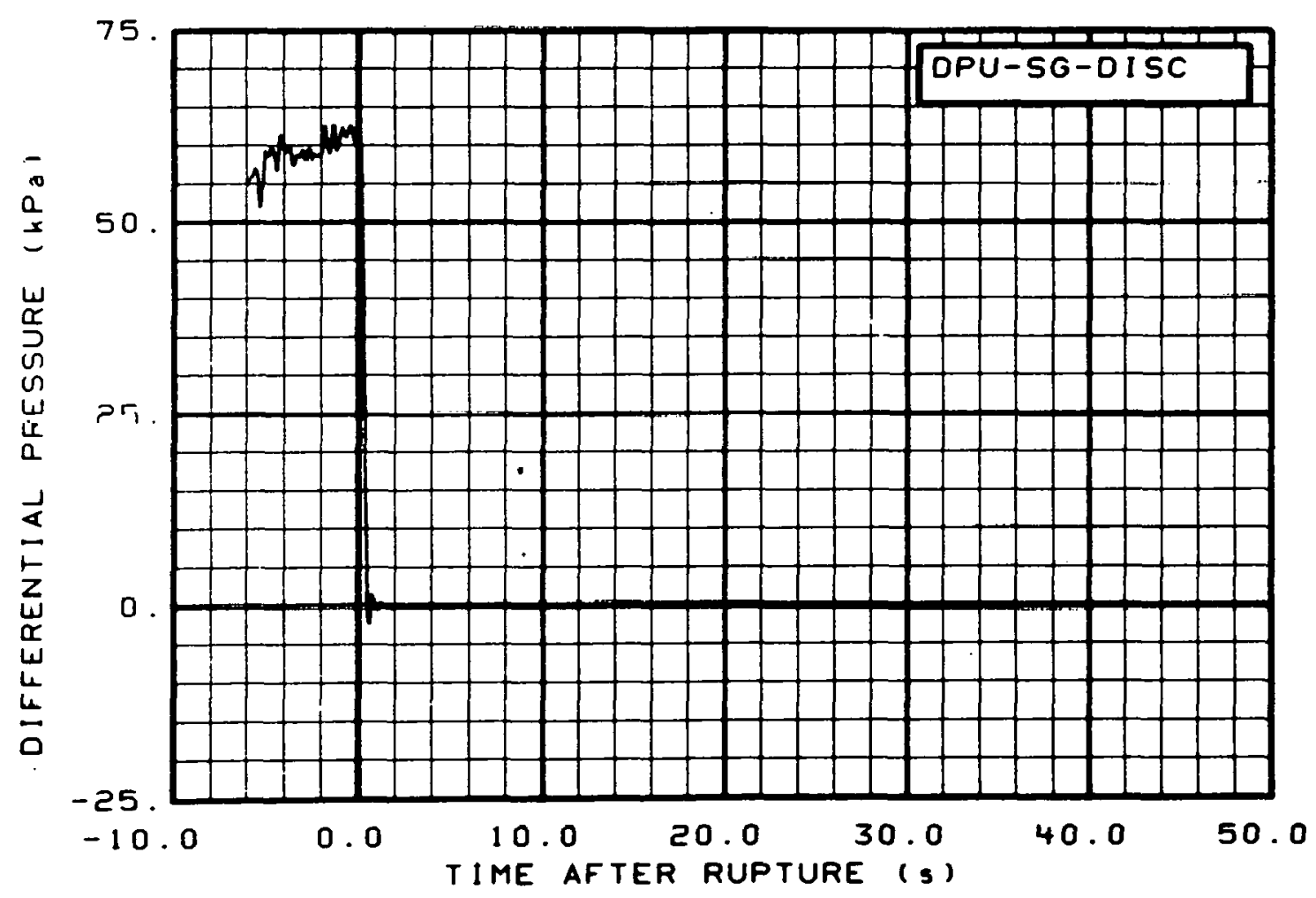

Fig. 234 Differential pressure across steam generator outlet orifice (DPU-SG-DISC), from -6 to $42 \mathrm{~s}$. 


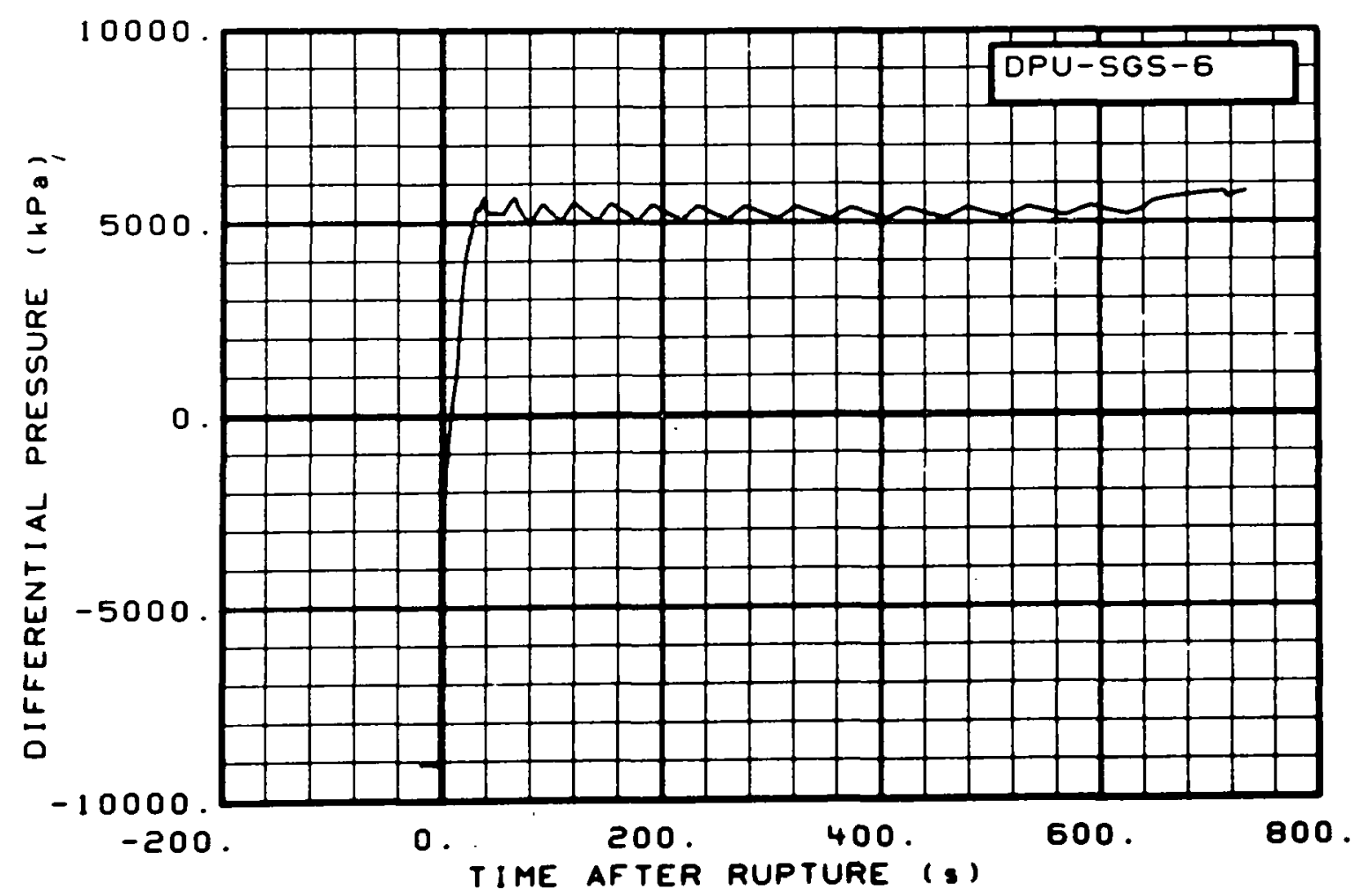

Fig. 235 Differential pressure between simulated rupture injection line and Spool 6 (DPU-SGS-6), from -20 to $736 \mathrm{~s}$.

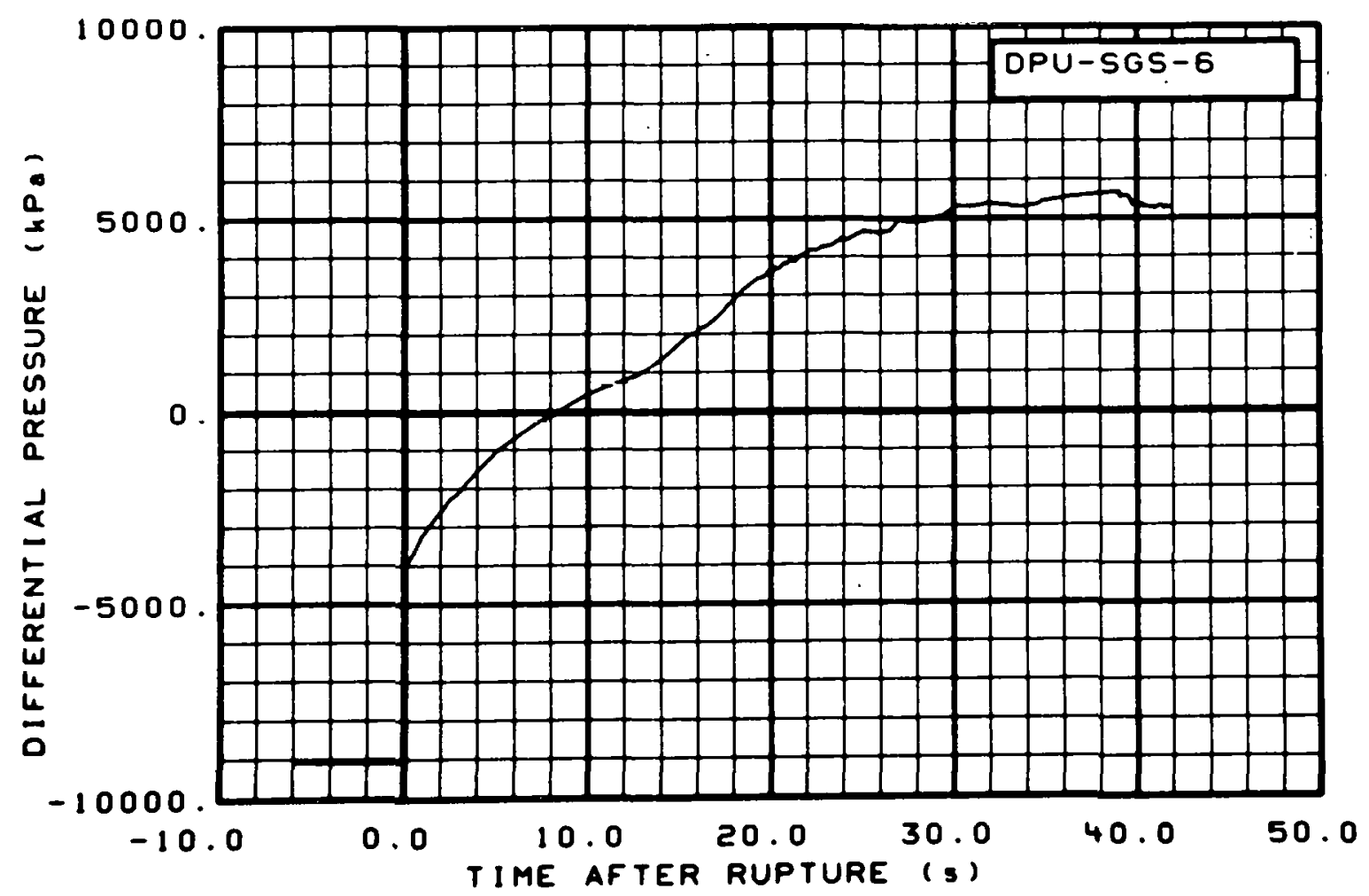

Fig. 236 Differential pressure between simulated rupture injection line and Spool 6 (DPU-SGS-6, from -6 to $42 \mathrm{~s}$. 


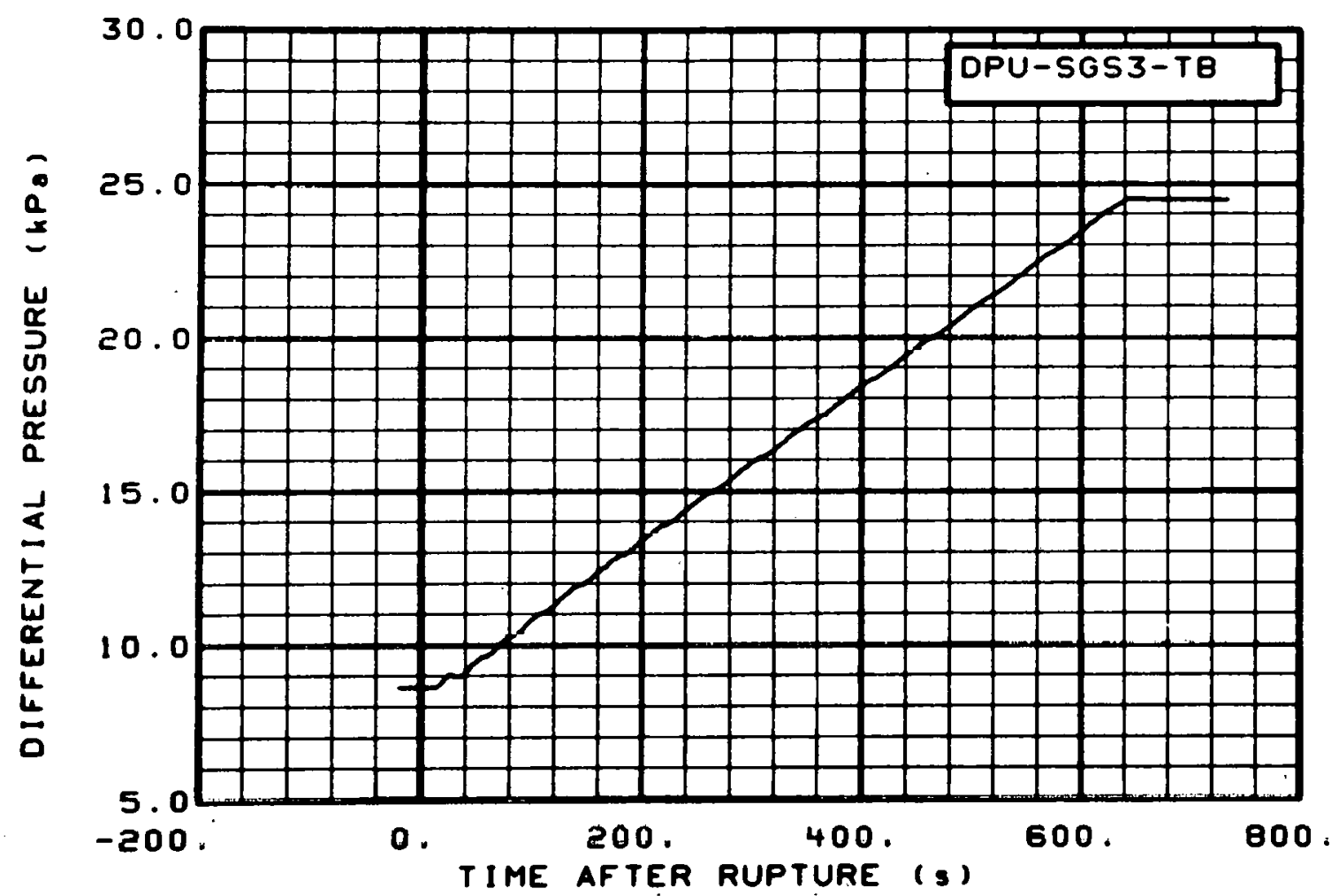

Fig. 237 Differential pressure in intact loop accumulator (DPU-SGS3-TB), from -20 to $736 \mathrm{~s}$.

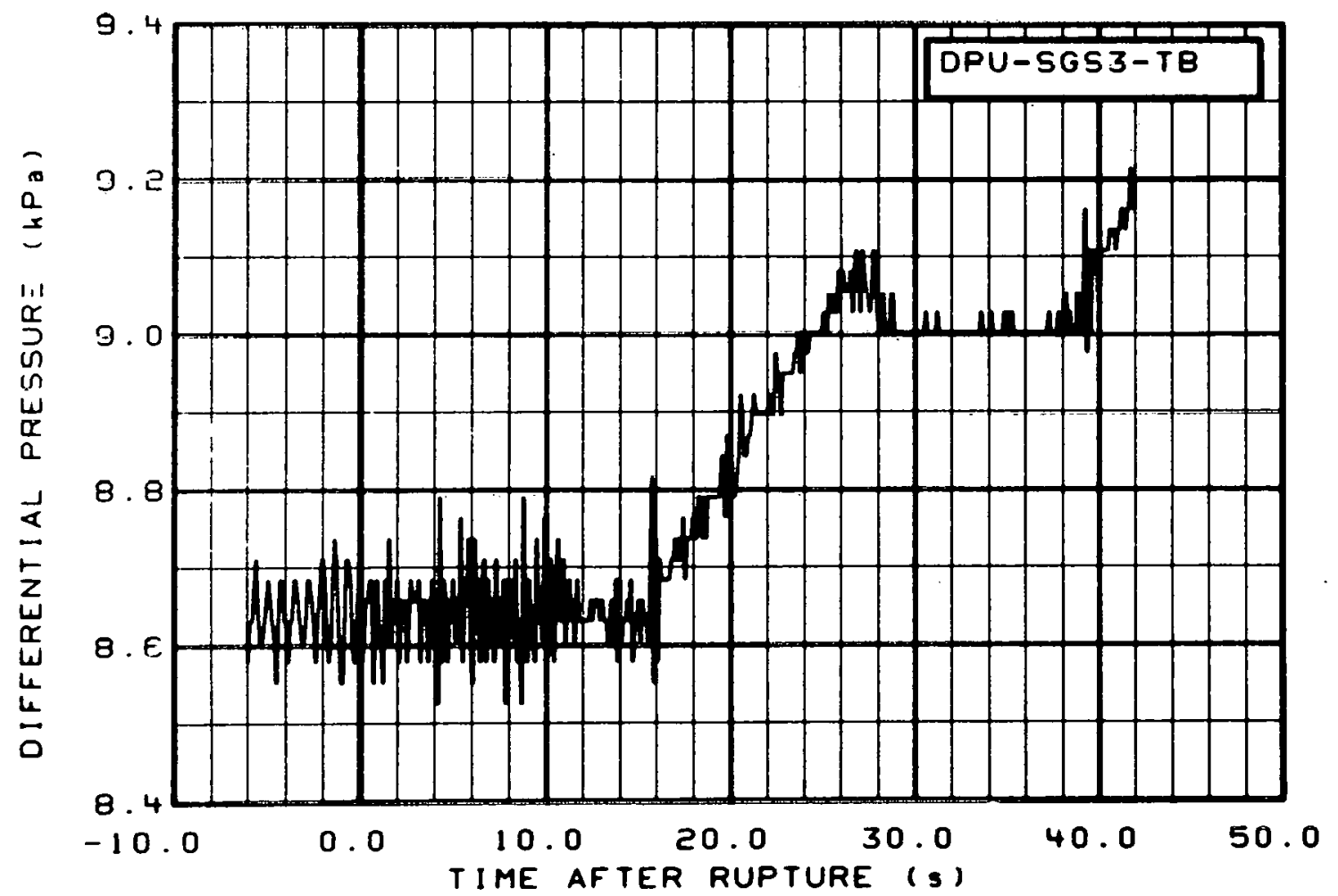

Fig. 238 Differential pressure in intact loop accumulator (DPU-SGS3-TB), from -6 to $42 \mathrm{~s}$. 


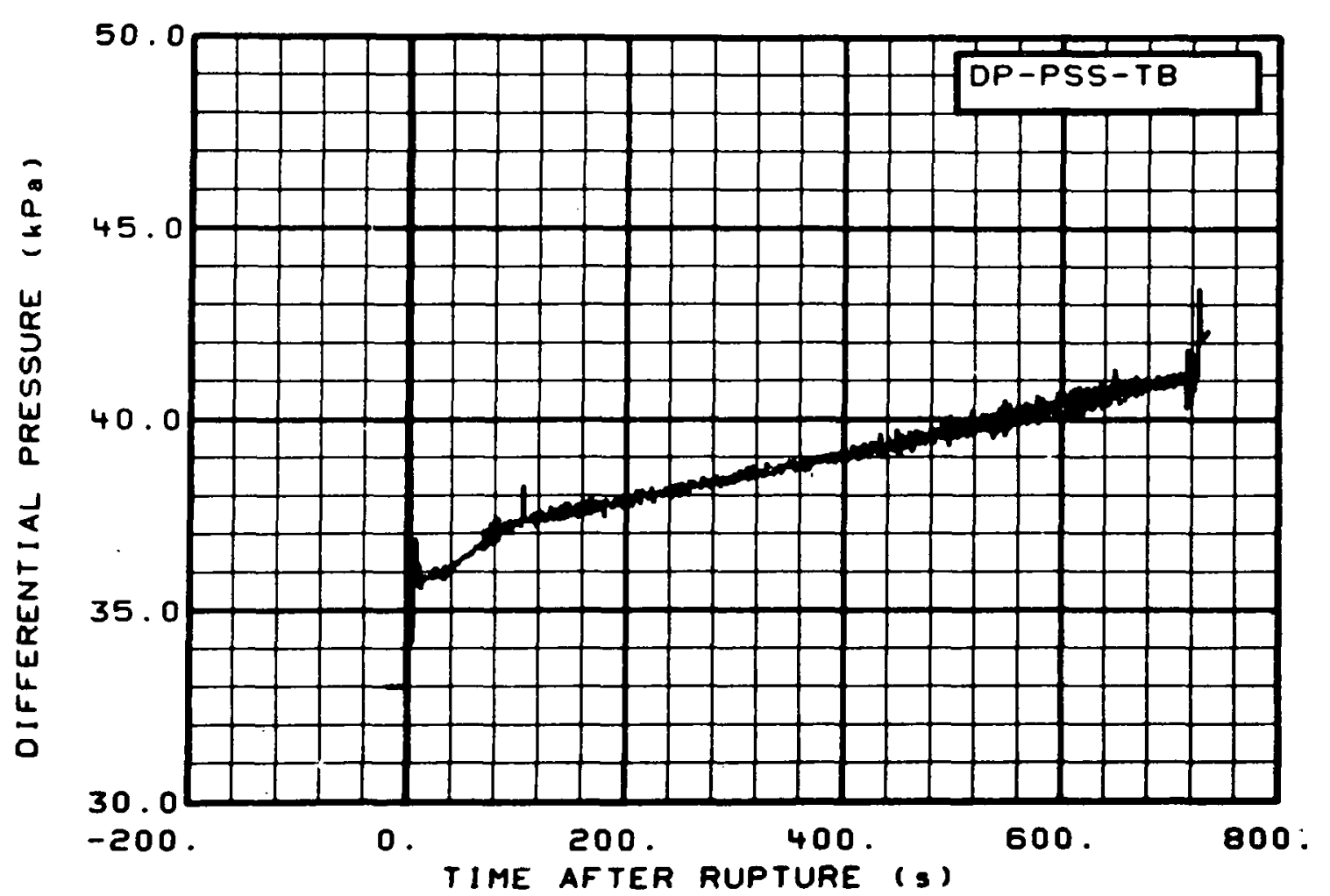

Fig. 239 Differential pressure in pressure suppression tank (DP-PSS-TB), from -20 to $736 \mathrm{~s}$.

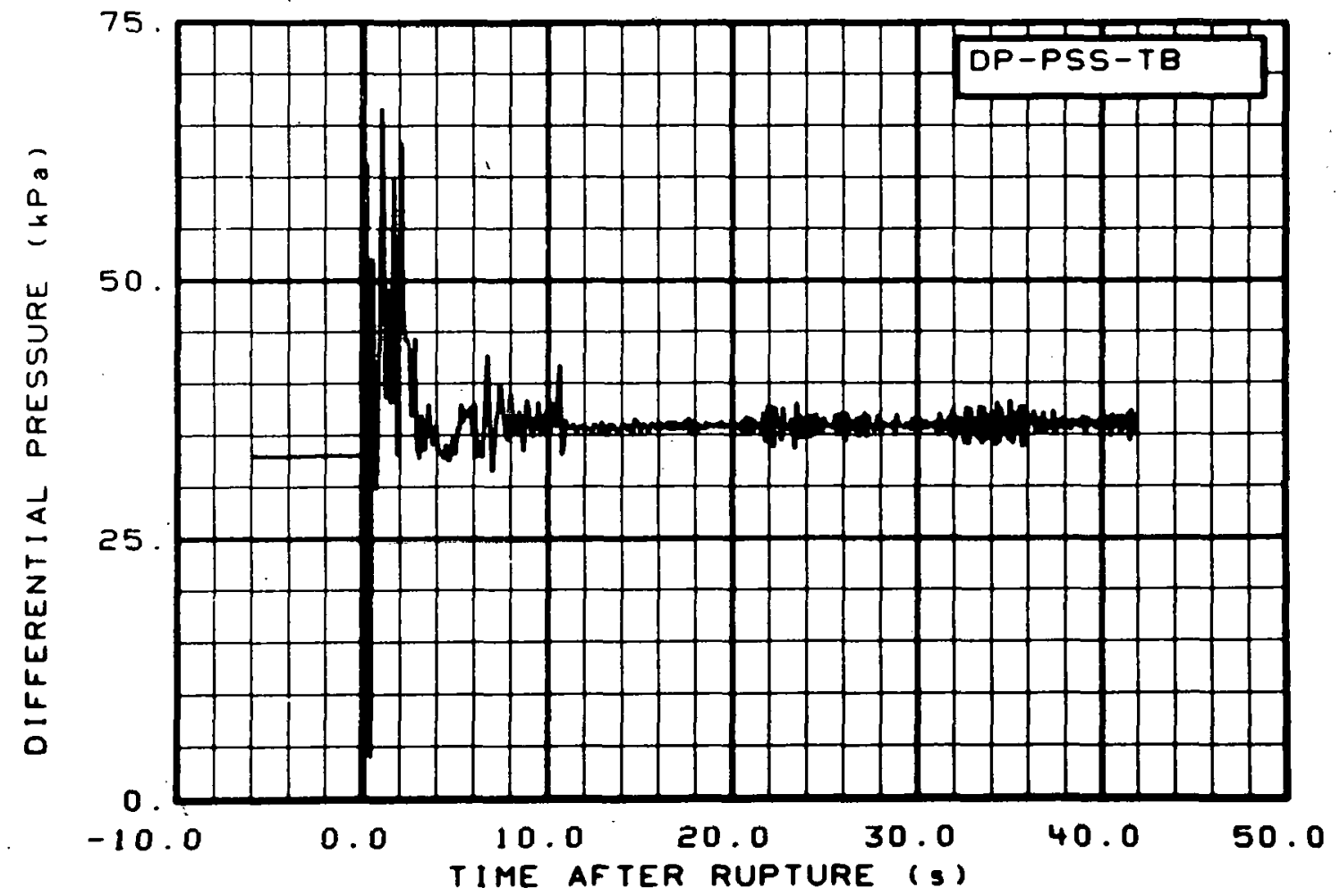

Fig. 240 Differential pressure in pressure suppression tank (DP-PSS-TB), from -6 to $42 \mathrm{~s}$. 


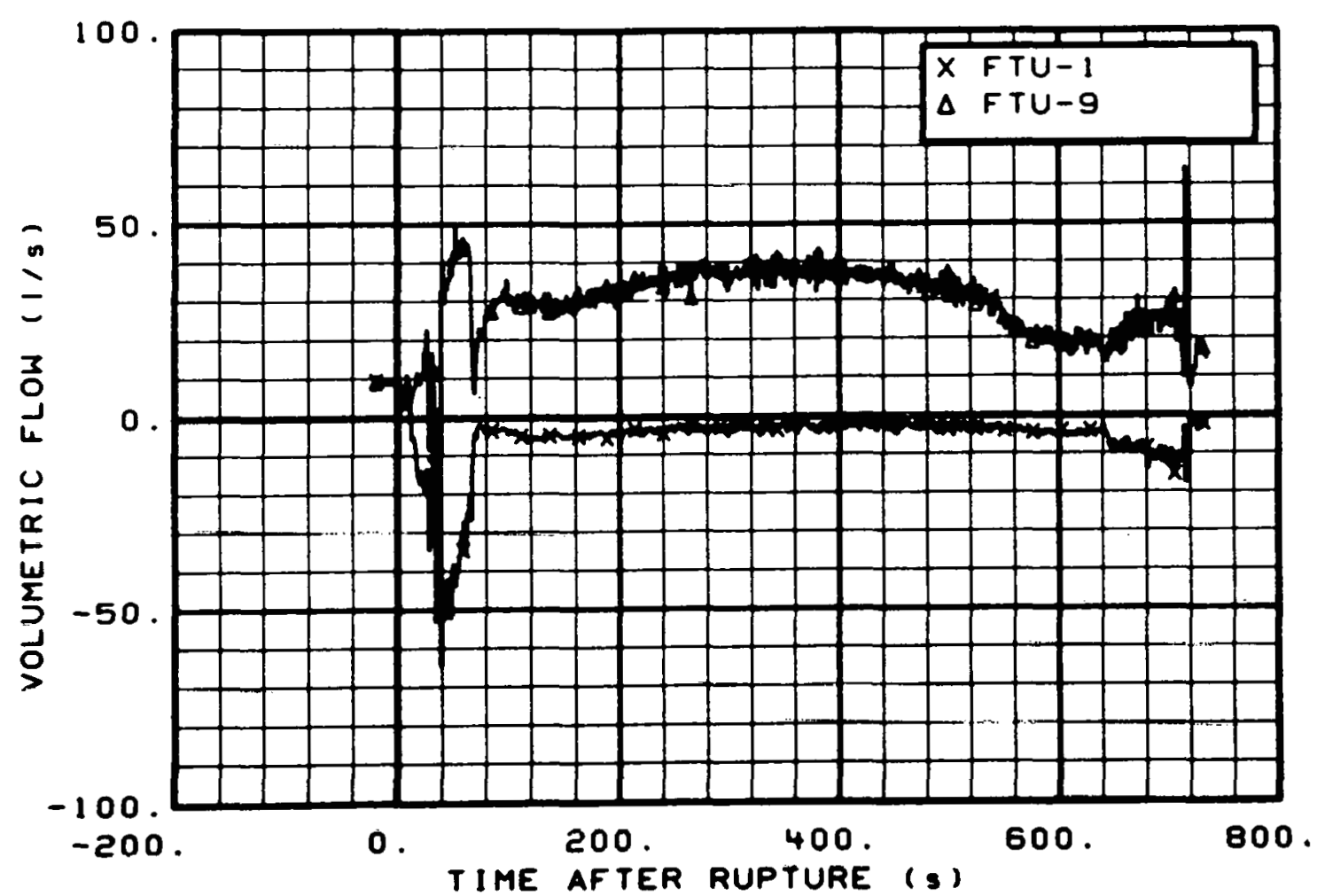

Fig. 241 Volumetric flow in intact loop (F̈UU-1 and FTU-9), from -20 to $736 \mathrm{~s}$.

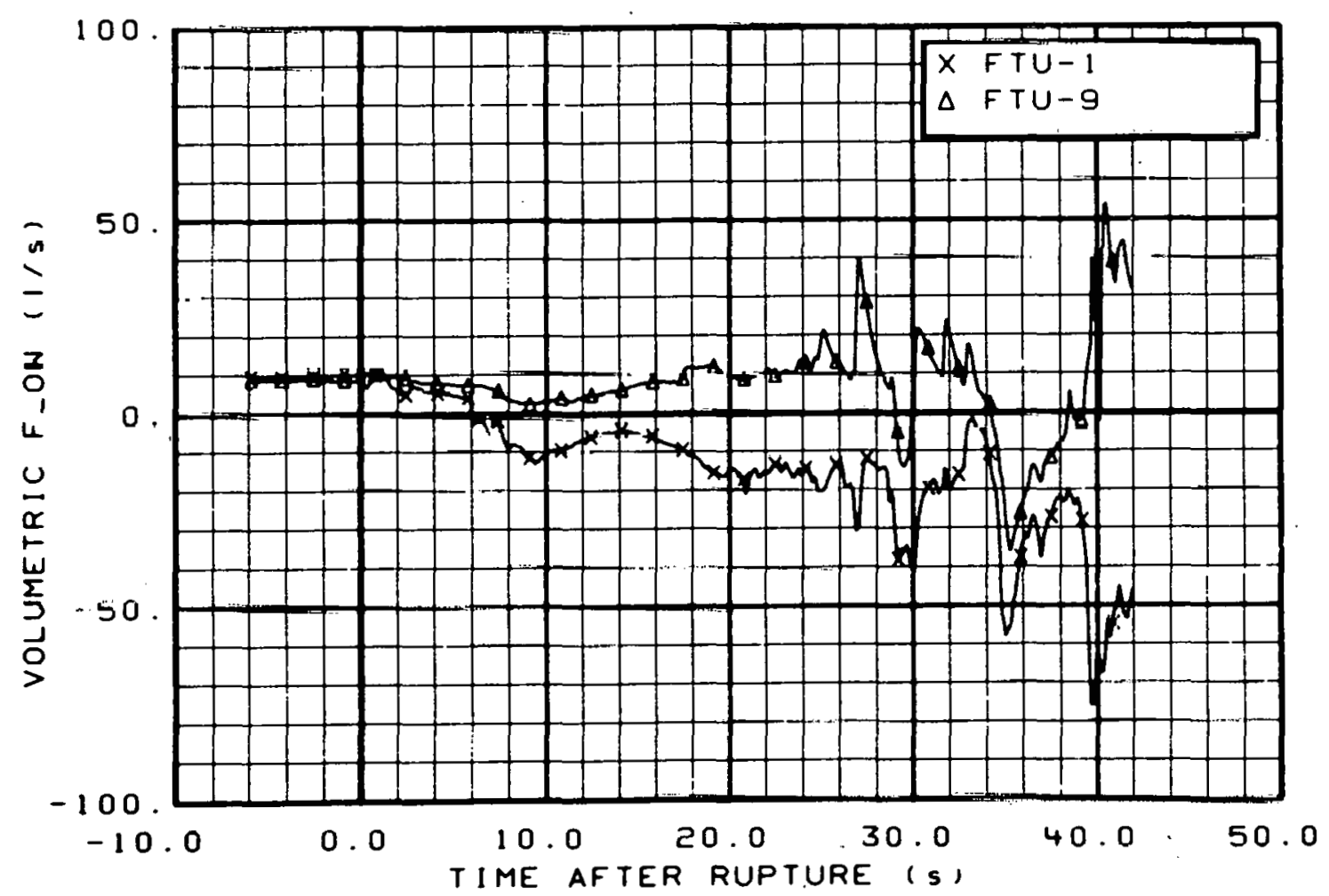

Fig. 242 Volumetric flow in intact loop (FTU-1 and FTU-9), from -6 to $42 \mathrm{~s}$. 


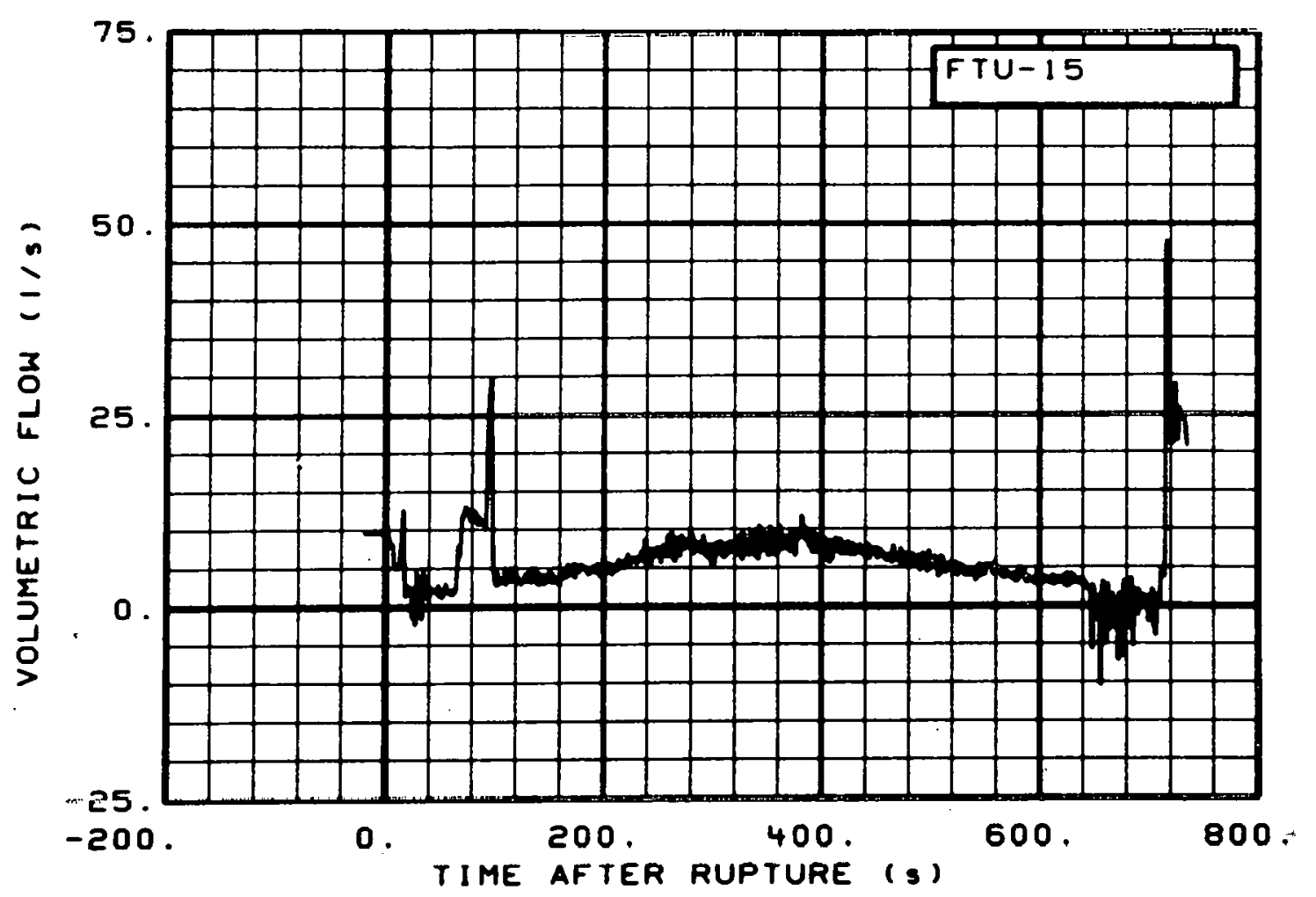

Fig. 243 Volumetric flow in intact loop (FTU-15), from -20 to $736 \mathrm{~s}$ :

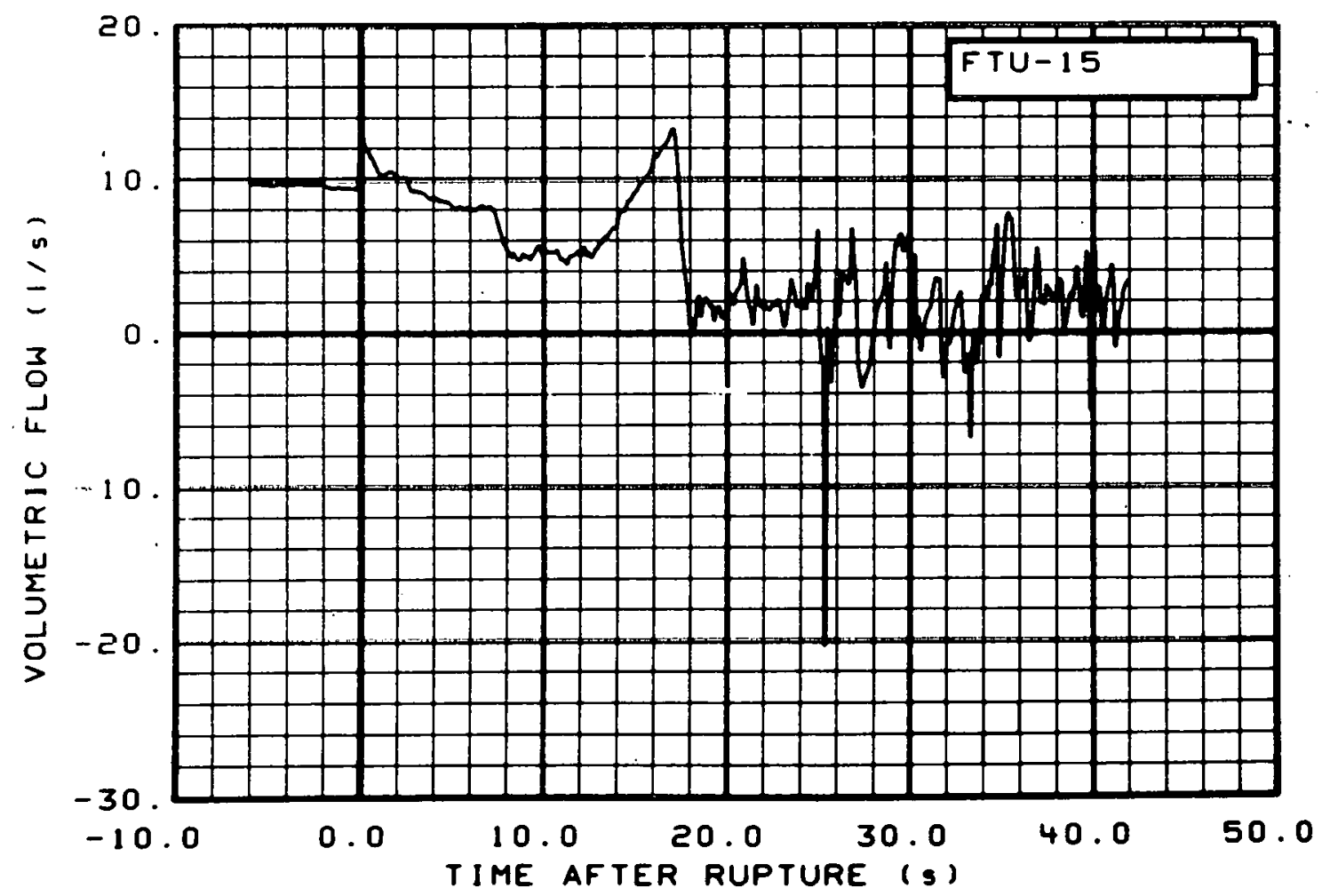

Fig. 244 Volumetric flow in intact loop (FTU-15), from -6 to $42 \mathrm{~s}$. 


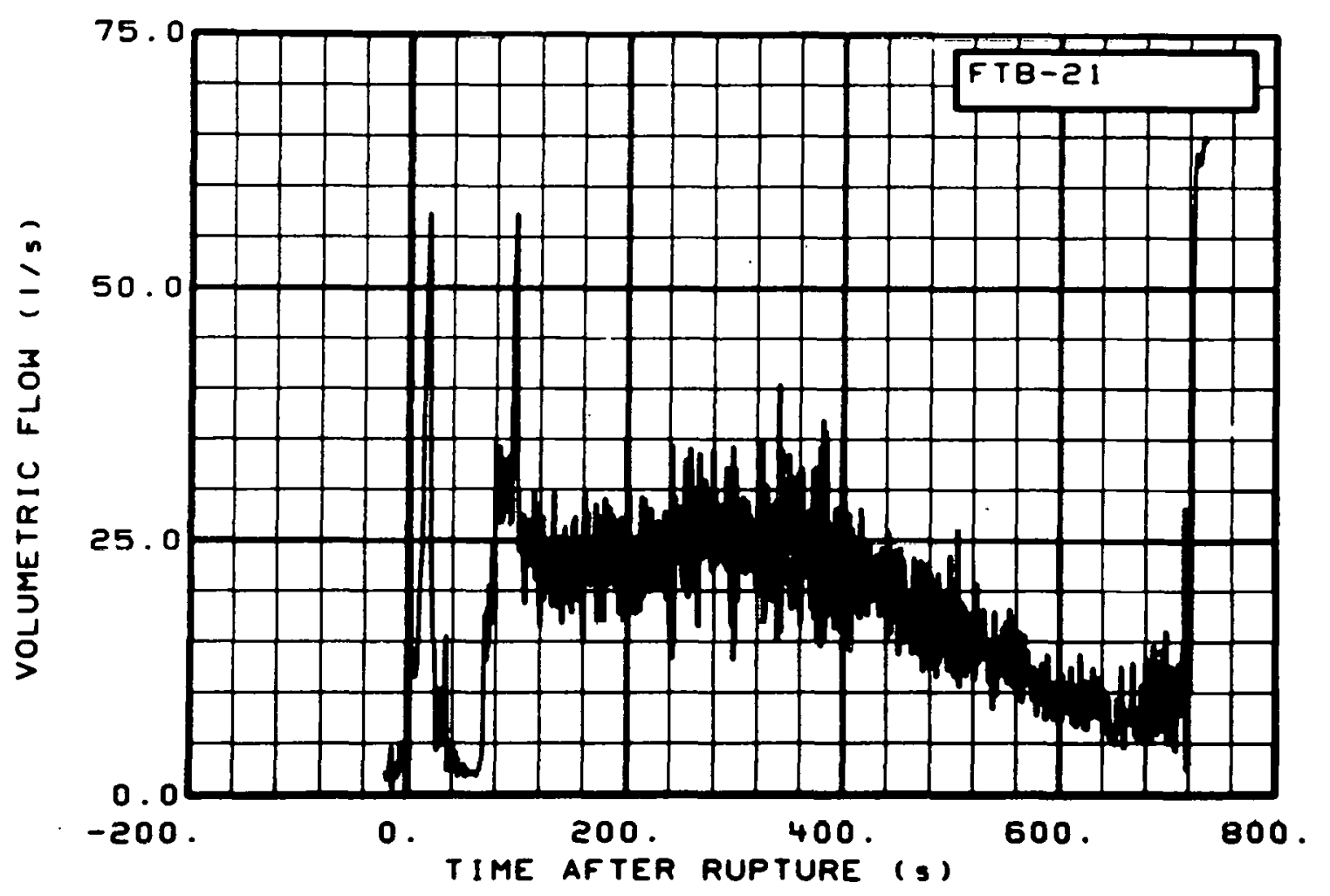

Fig. 245 Volumetric flow in broken loop (FTB-21), from -20 to $736 \mathrm{~s}$.

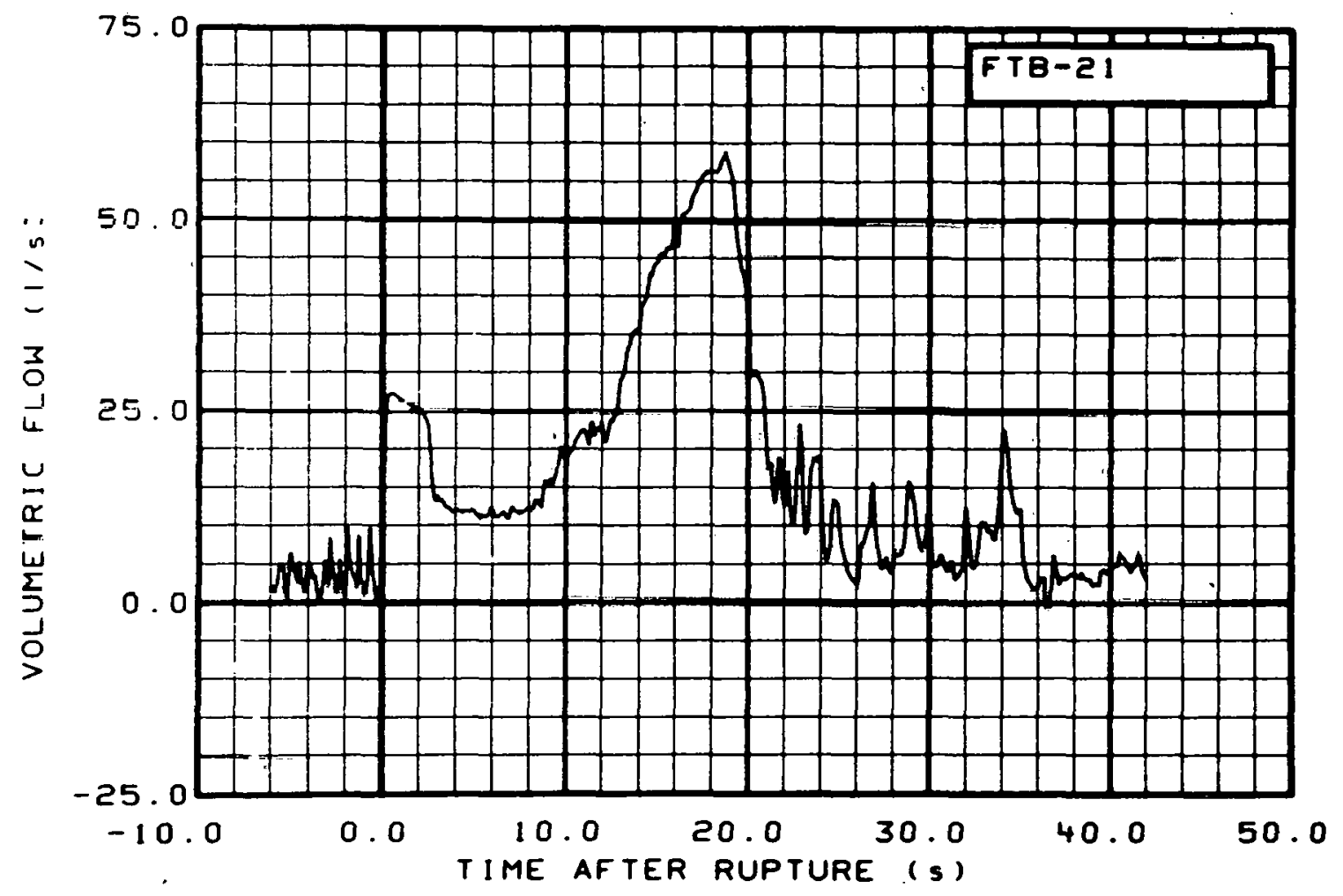

Fig. 246 Volumetric flow in broken loop (FTB-21), from -6 to $42 \mathrm{~s}$. 


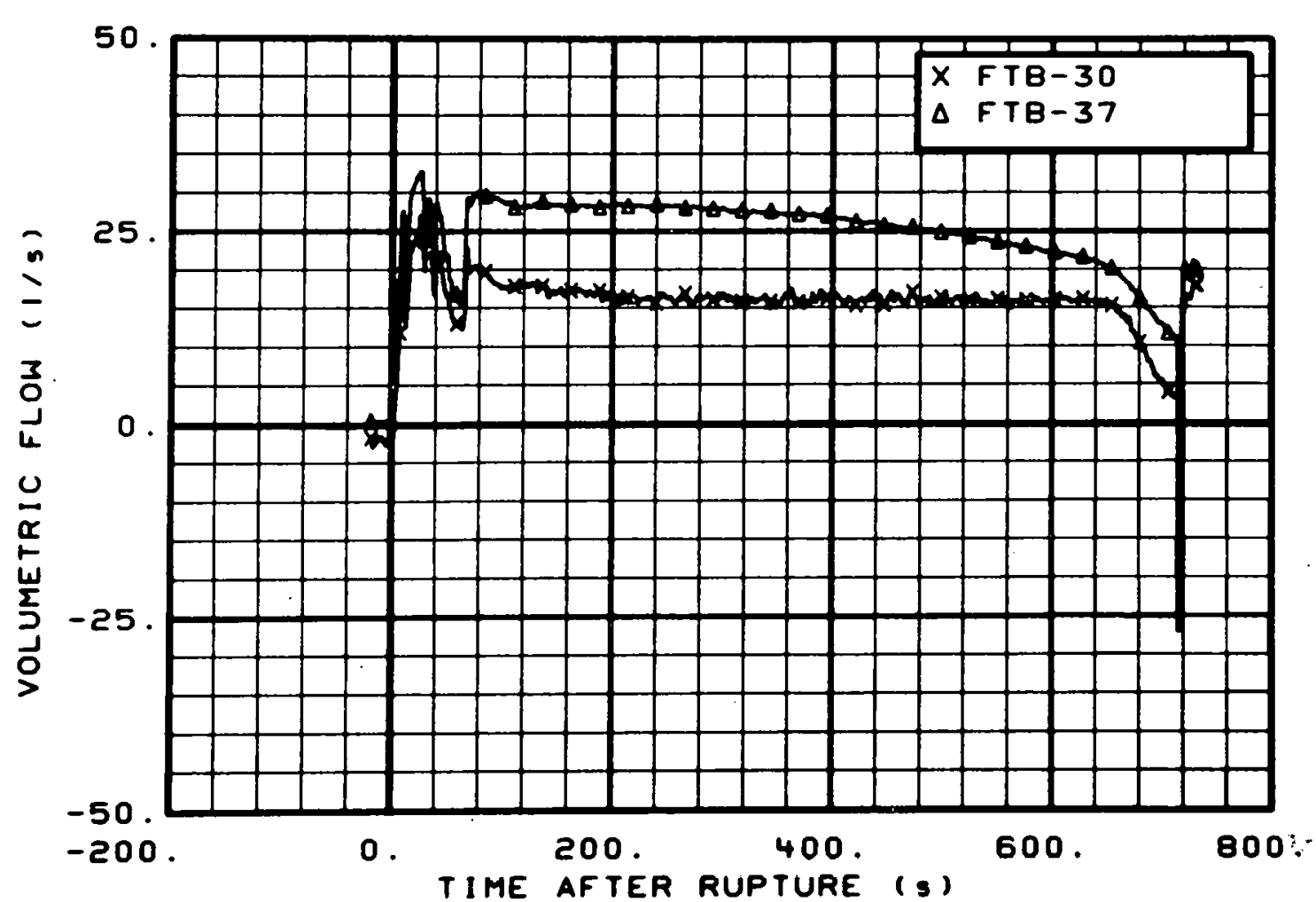

Fig. 247 Volumetric flow in broken loop. (FTB-30 and FTB-37), from -20 to $736 \mathrm{~s}$.

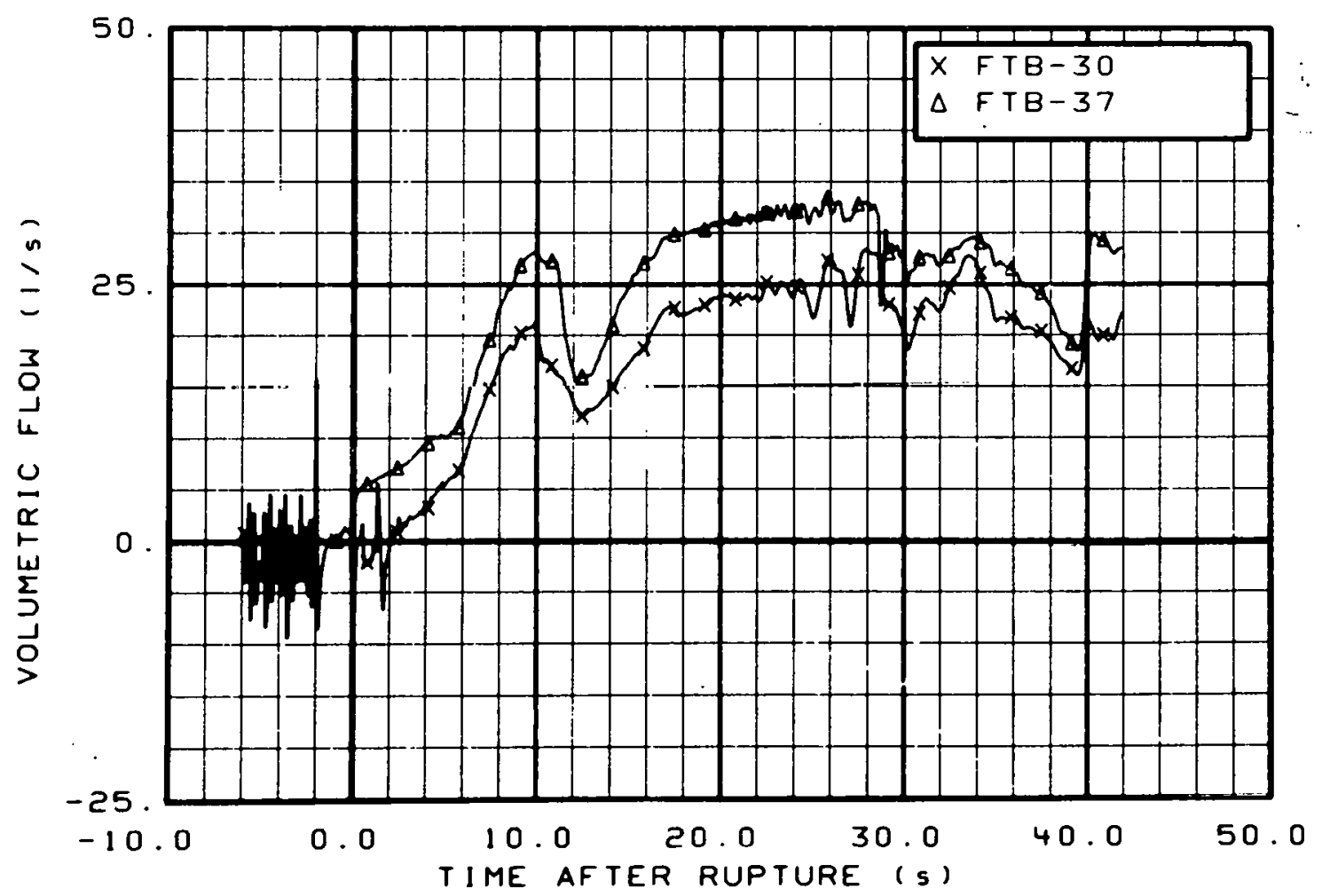

Fig. 248 Volumetric flow in broken loop (FTB-30 and FTB-37), from -6 to $42 \mathrm{~s}$. 


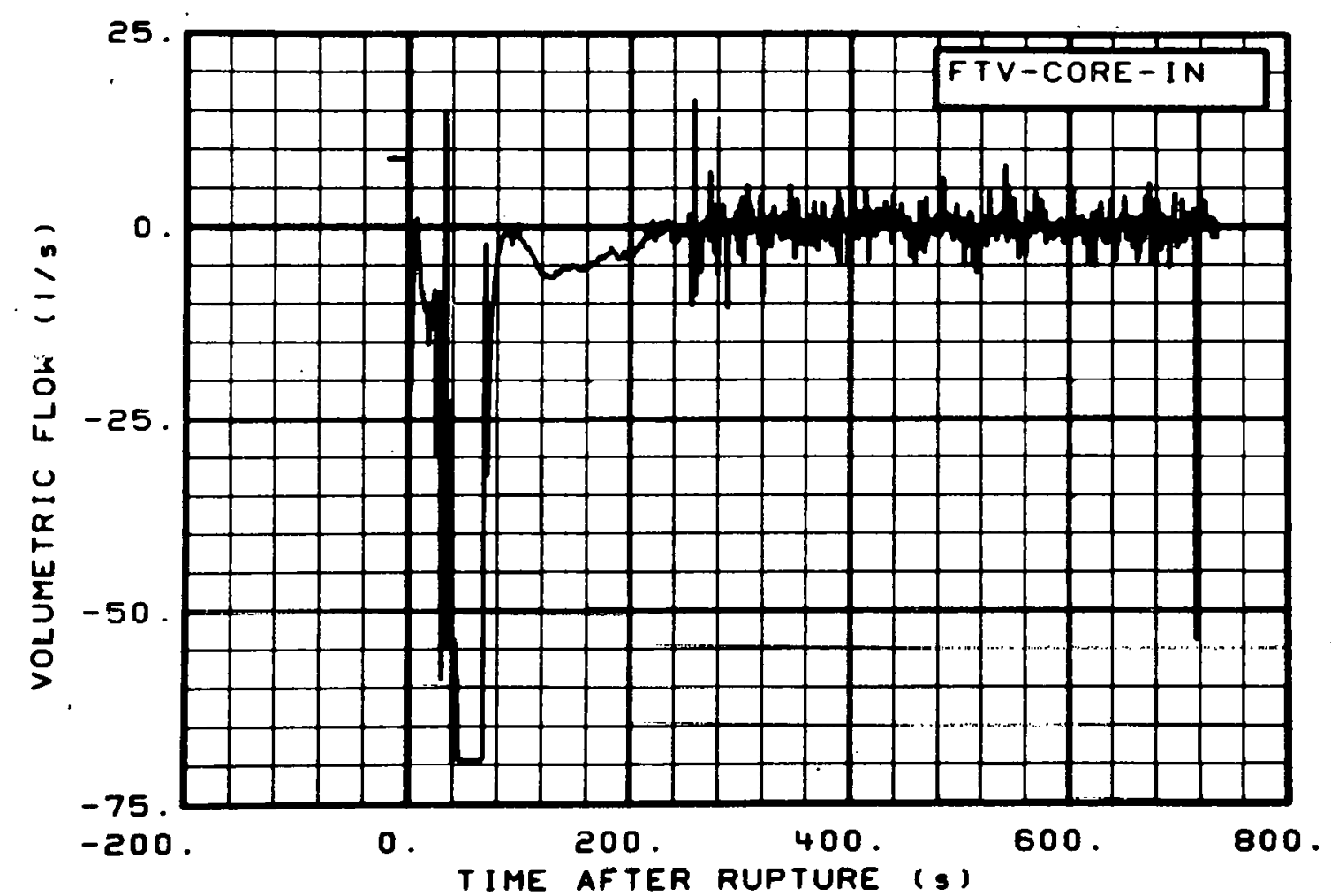

Fig. 249.Volumetric flow in core entrance (FTV-CORE-IN), from -20 to $736 \mathrm{~s}$.

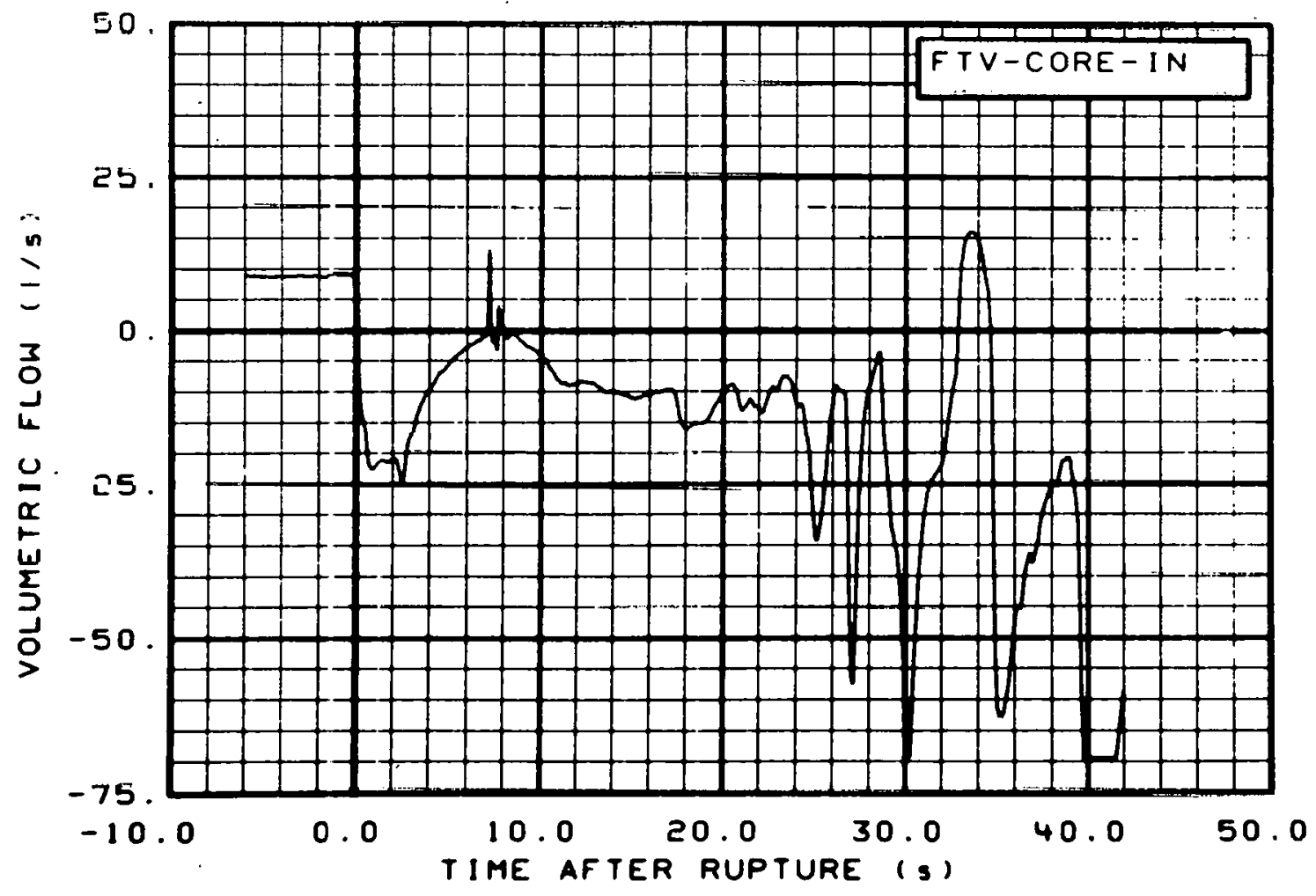

Fig. 250 Volumetric flow in core entrance (FTV-CORE-IN), from -6 to $42 \mathrm{~s}$. 


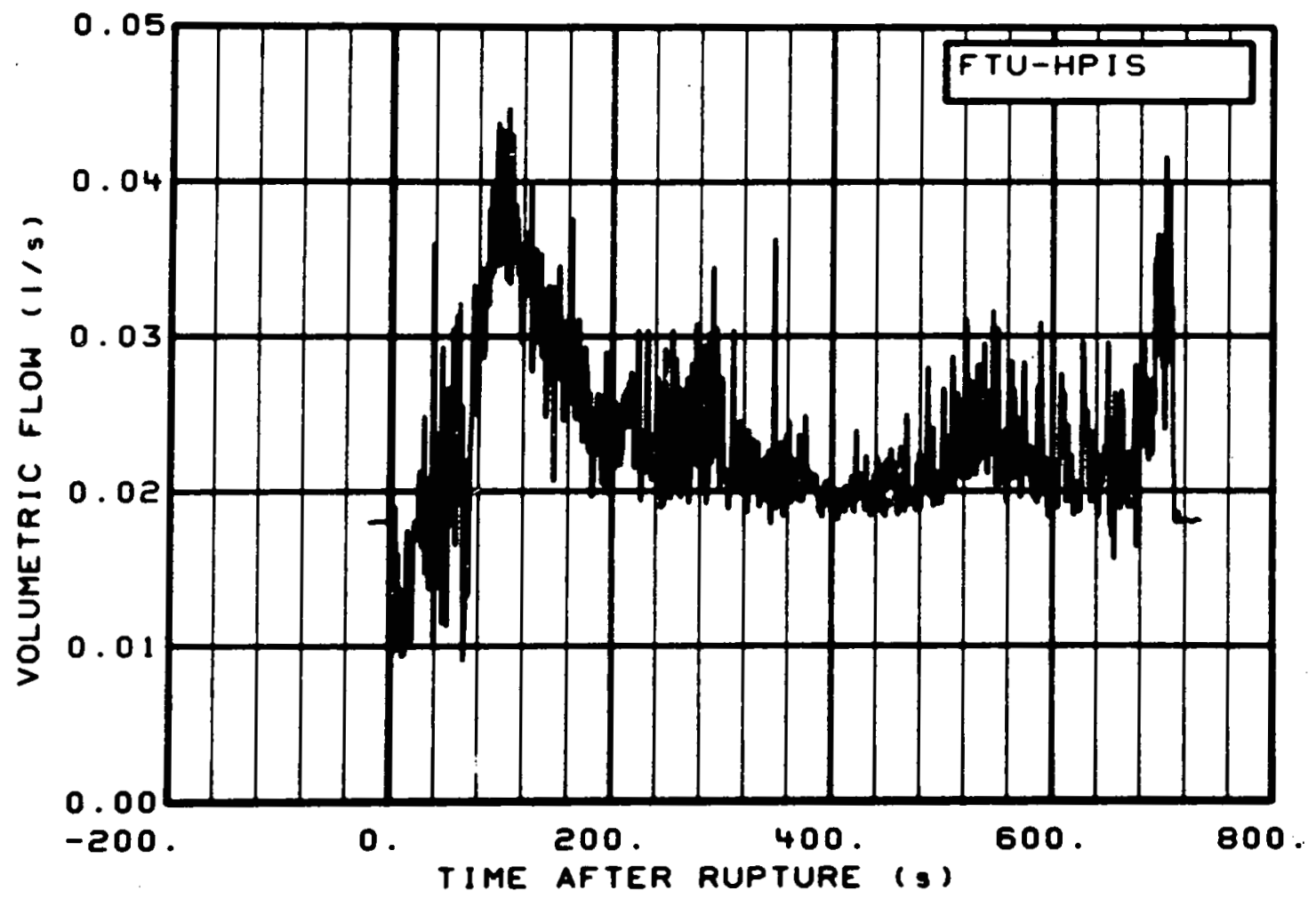

Fig. 251 Volumetric flow in intact loop high pressure injection line (FTU-HPIS), from -20 to $736 \mathrm{~s}$.

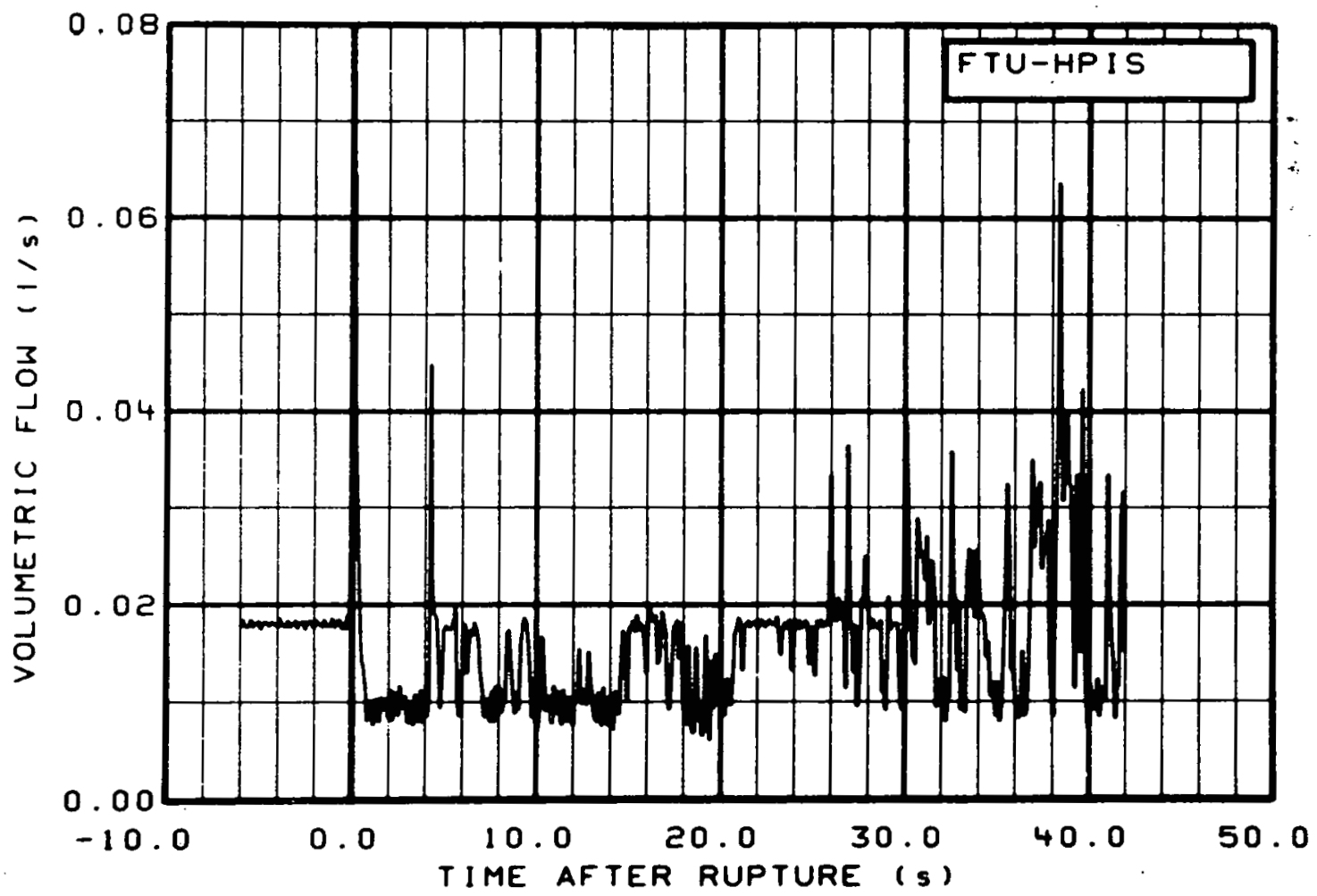

Fig. 252 Volumetric flow in intact loop high pressure injection line (FTU-HPIS), from -6 to $42 \mathrm{~s}$. 


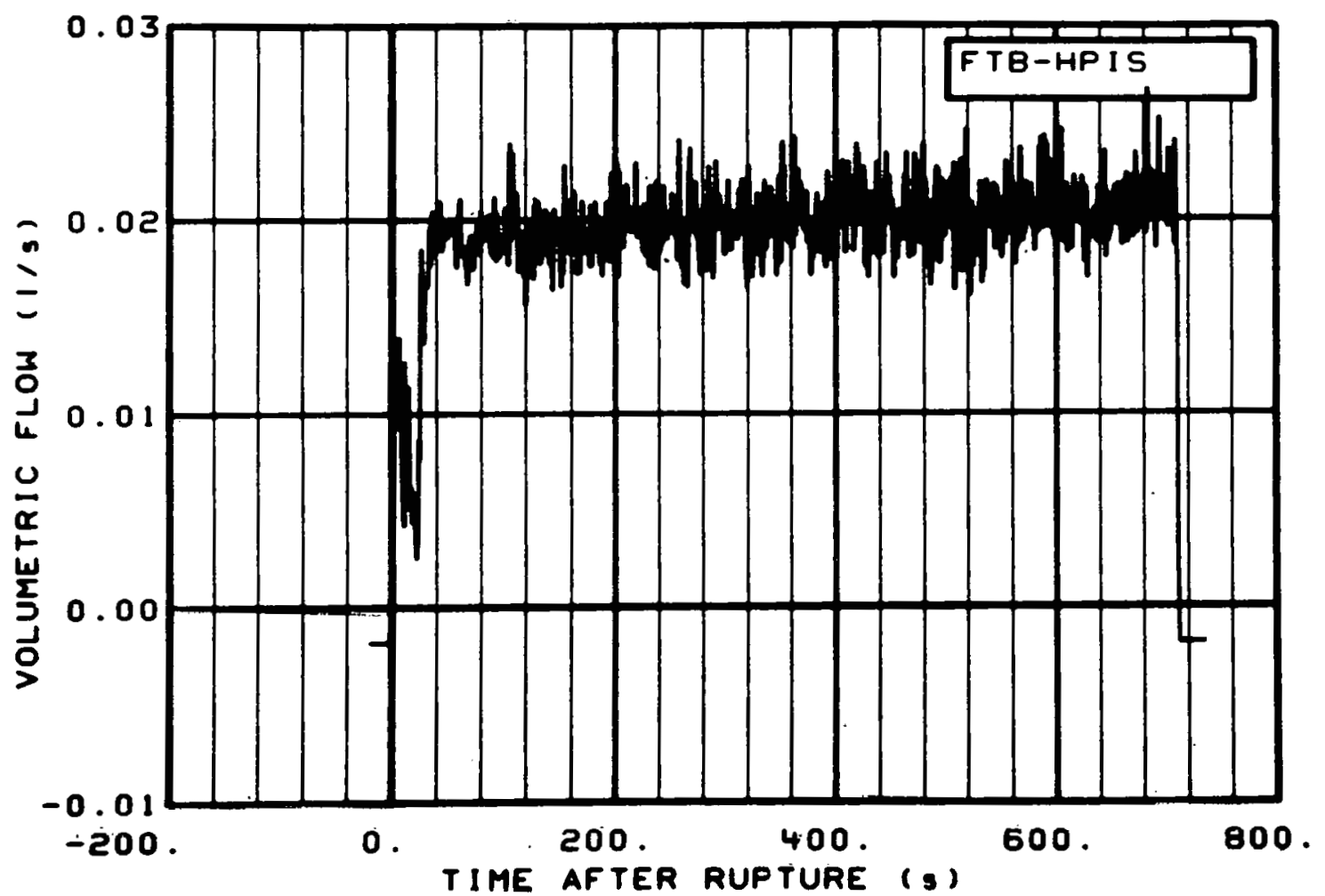

Fig. 253 Volumetric flow in broken loop high pressure injection line (FTB-HPIS), from -20 to $736 \mathrm{~s}$.

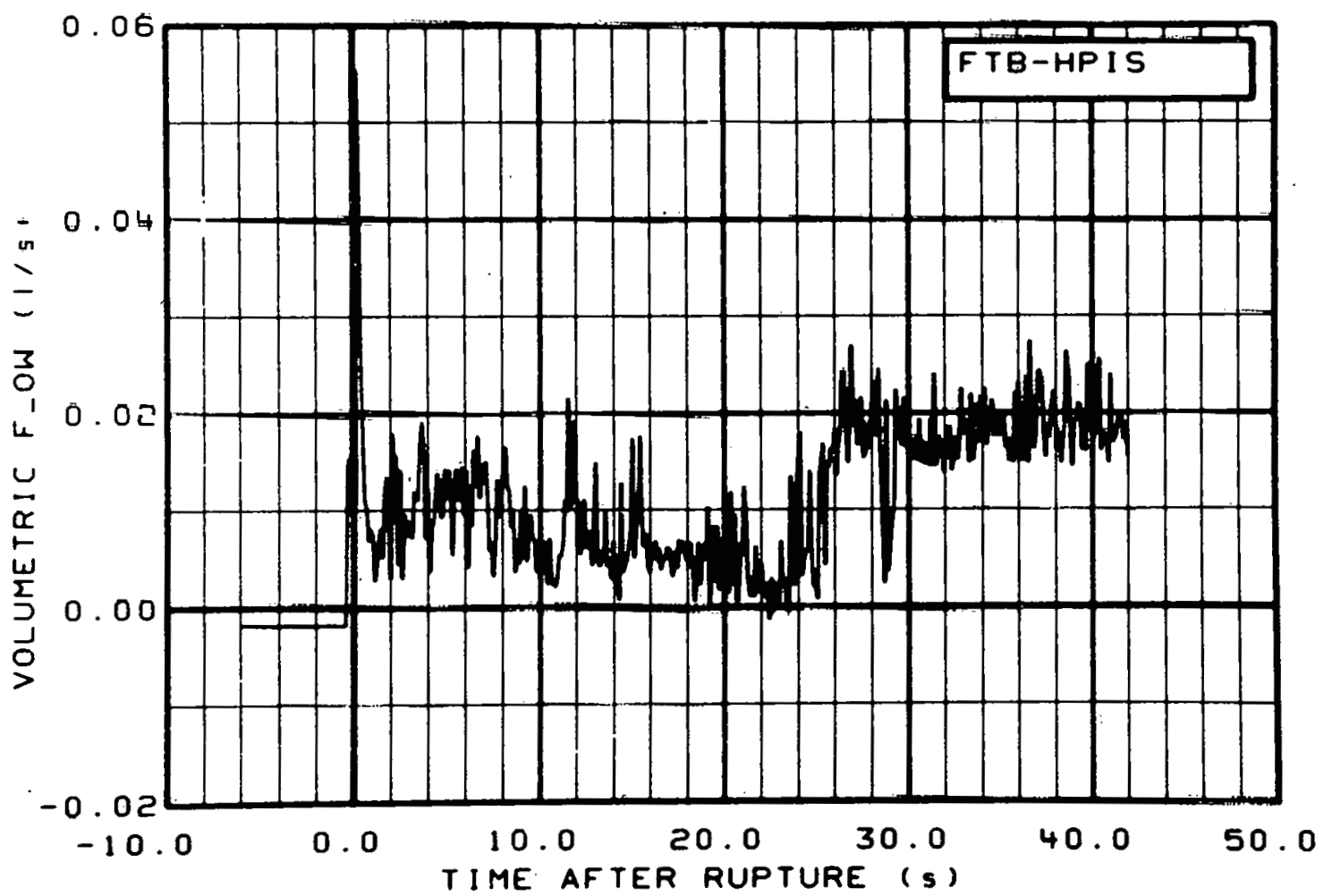

Fig. 254 Volumetric flow in broken loop high pressure injection line (FTB-HPIS), from -6 to $42 \mathrm{~s}$. 


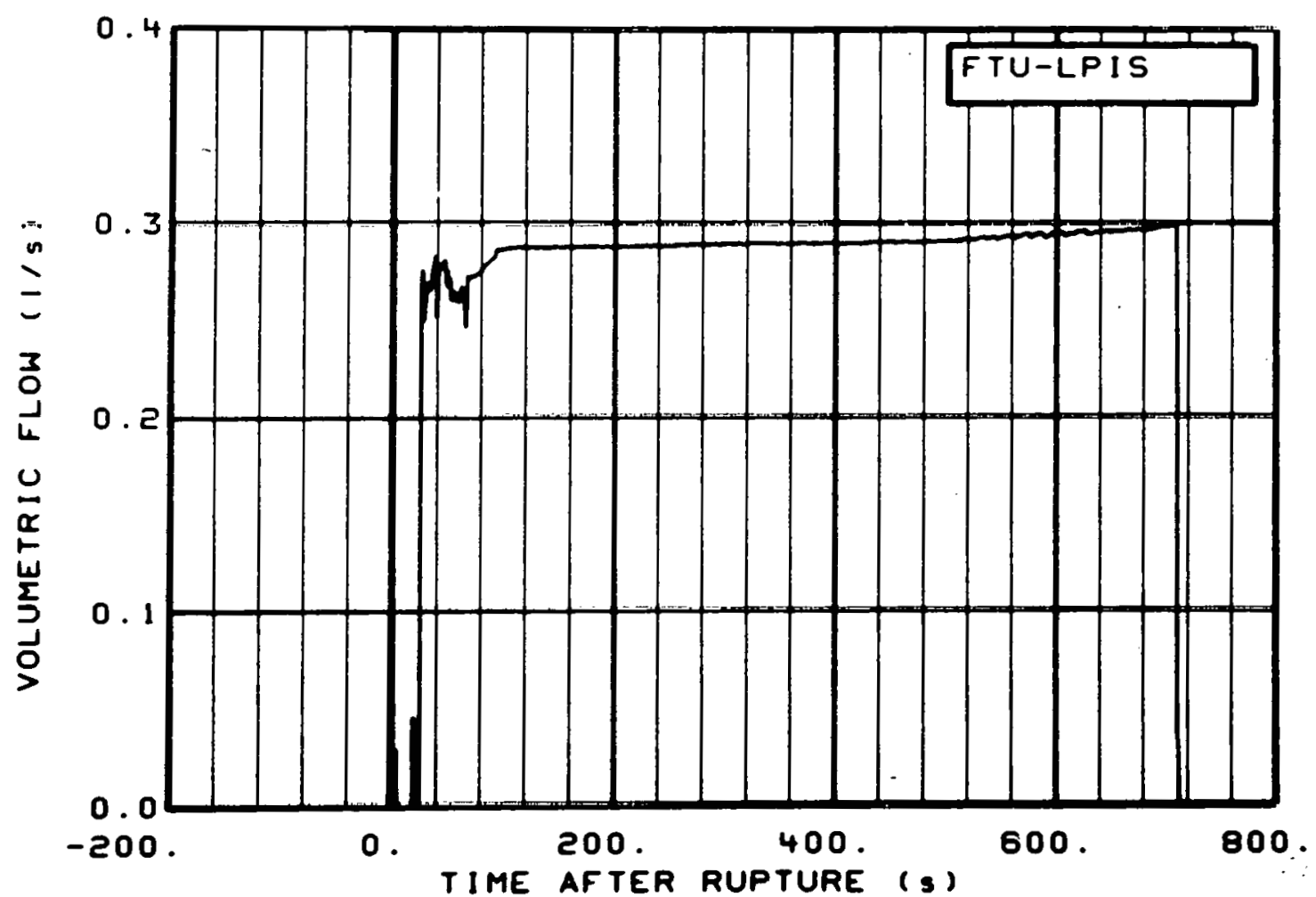

Fig. 255 Volumetric flow in intact loop low pressure injection line: (FTU-LPIS), from -20 to $736 \mathrm{~s}$.

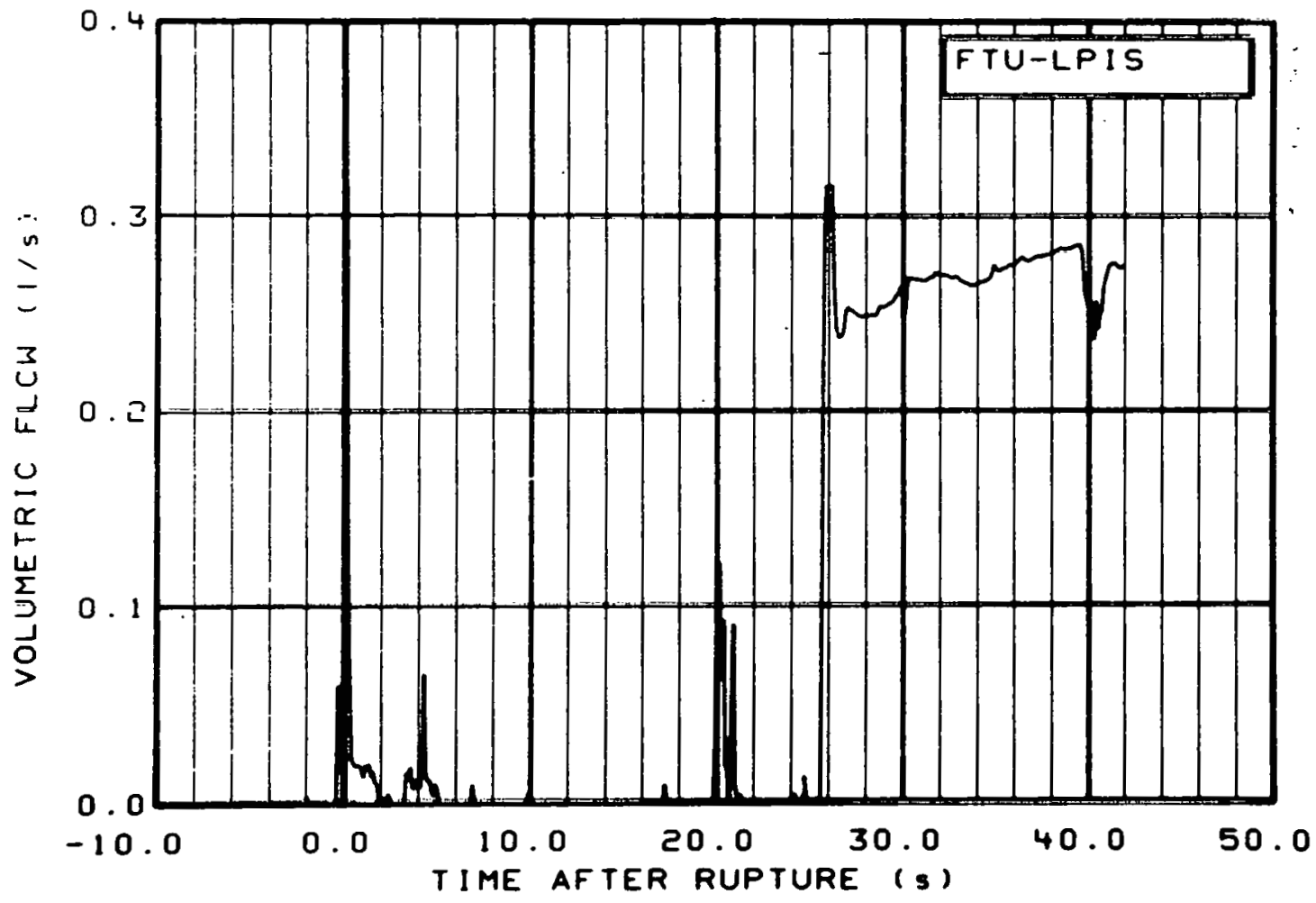

Fig. 256 Volumetric flow in intact loop low pressure injection line (FTU-LPIS), from -6 to $42 \mathrm{~s}$. 


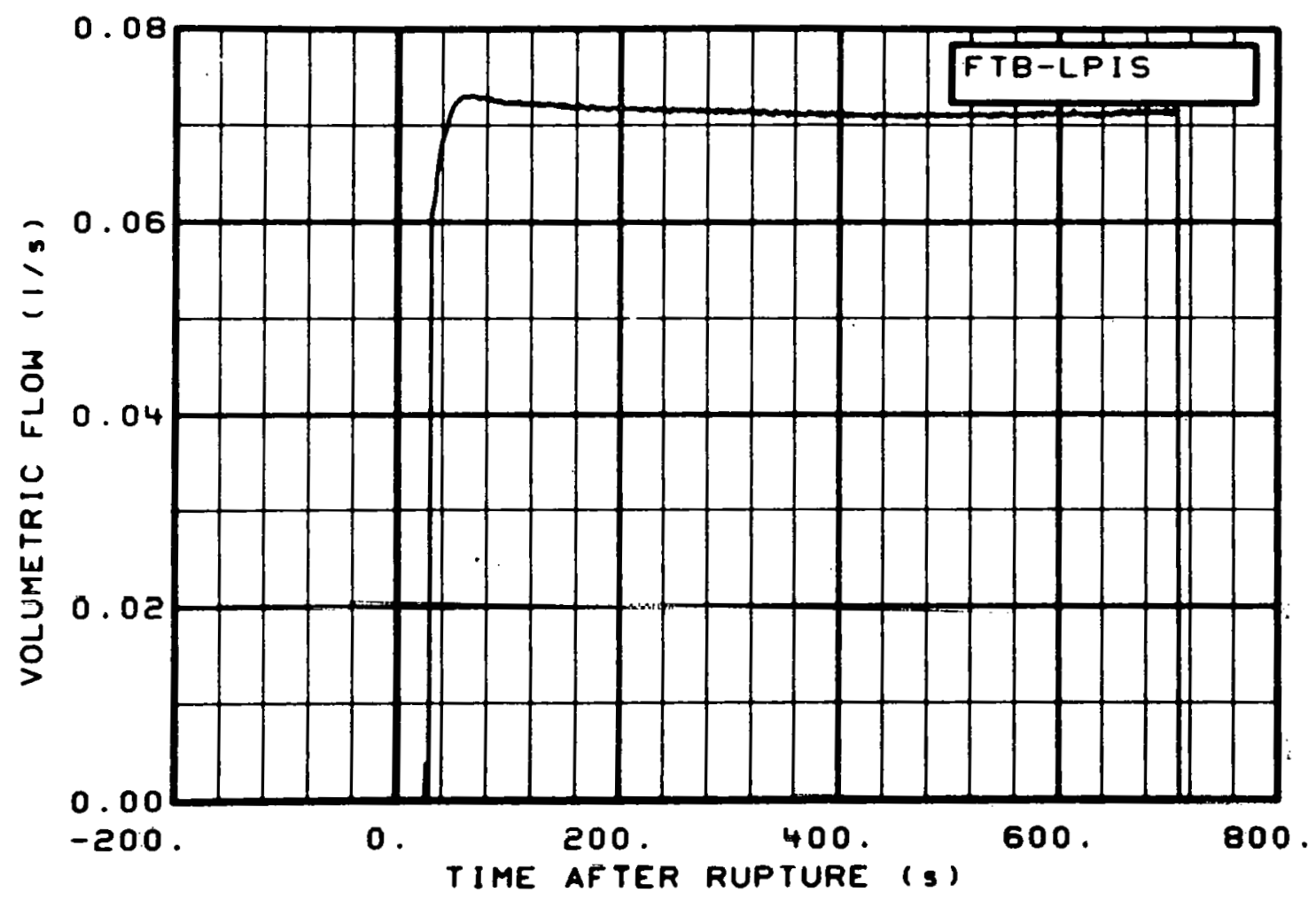

Fig. 257 Volumetric flow in broken loop low pressure injection line (FTB-LPIS), from -20 to $736 \mathrm{~s}$.

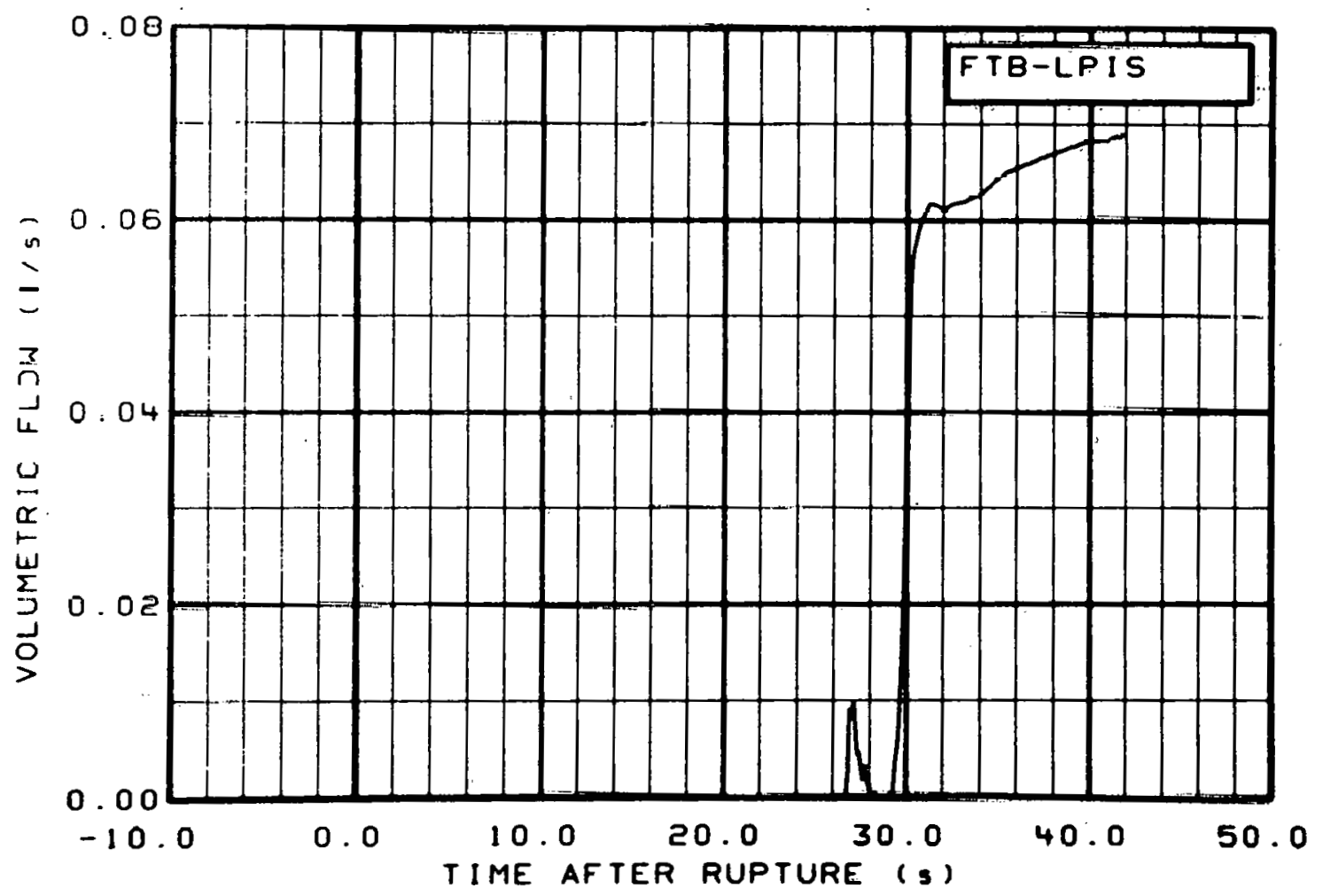

Fig. 258 Volumetric flow in broken loop low pressure injection line (FTB-LPIS), from -6 to $42 \mathrm{~s}$. 


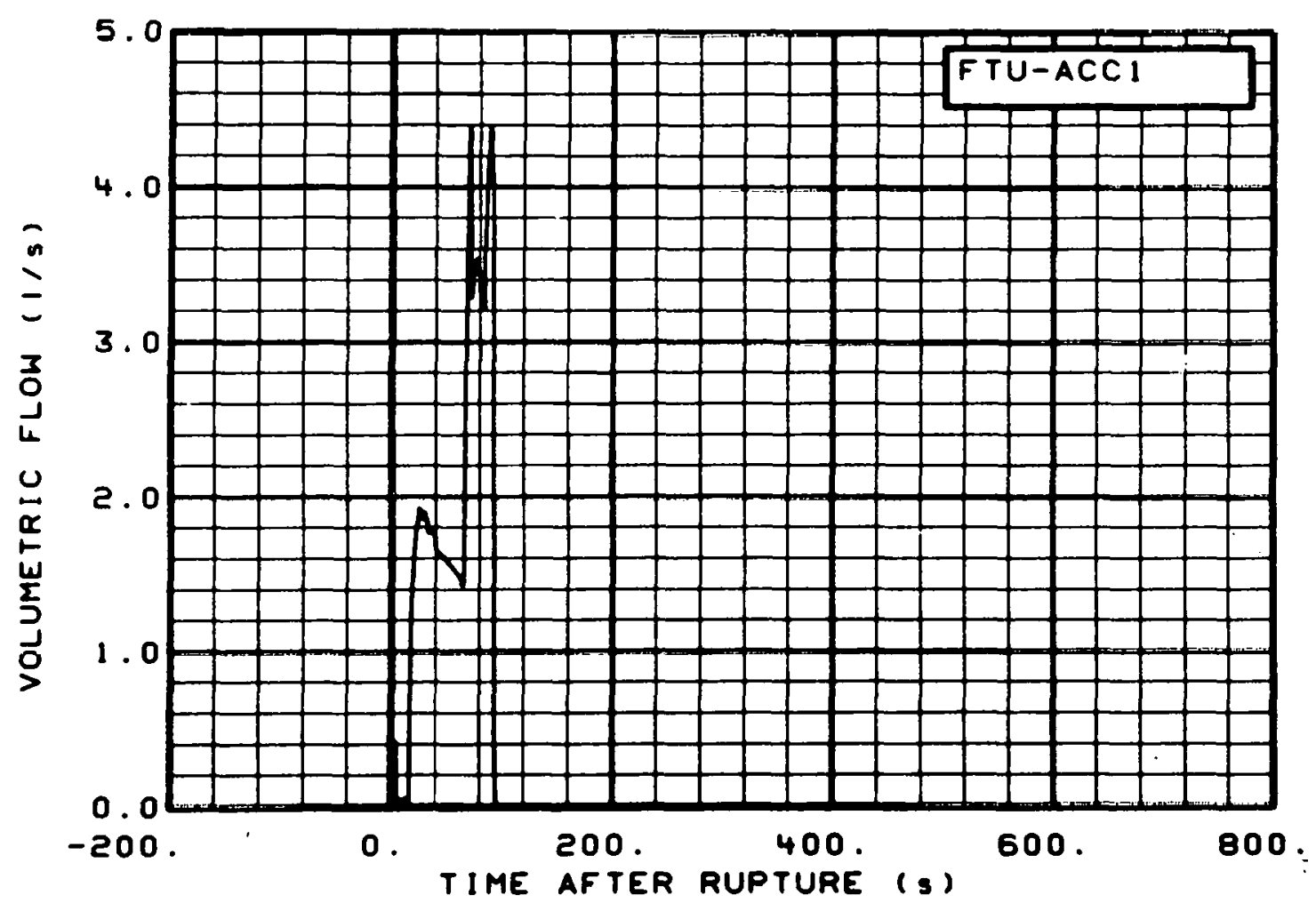

Fig. 259 Volumetric flow in intact loop accumulator discharge line : (FTU-ACCT), from -20 to $736 \mathrm{~s}$.

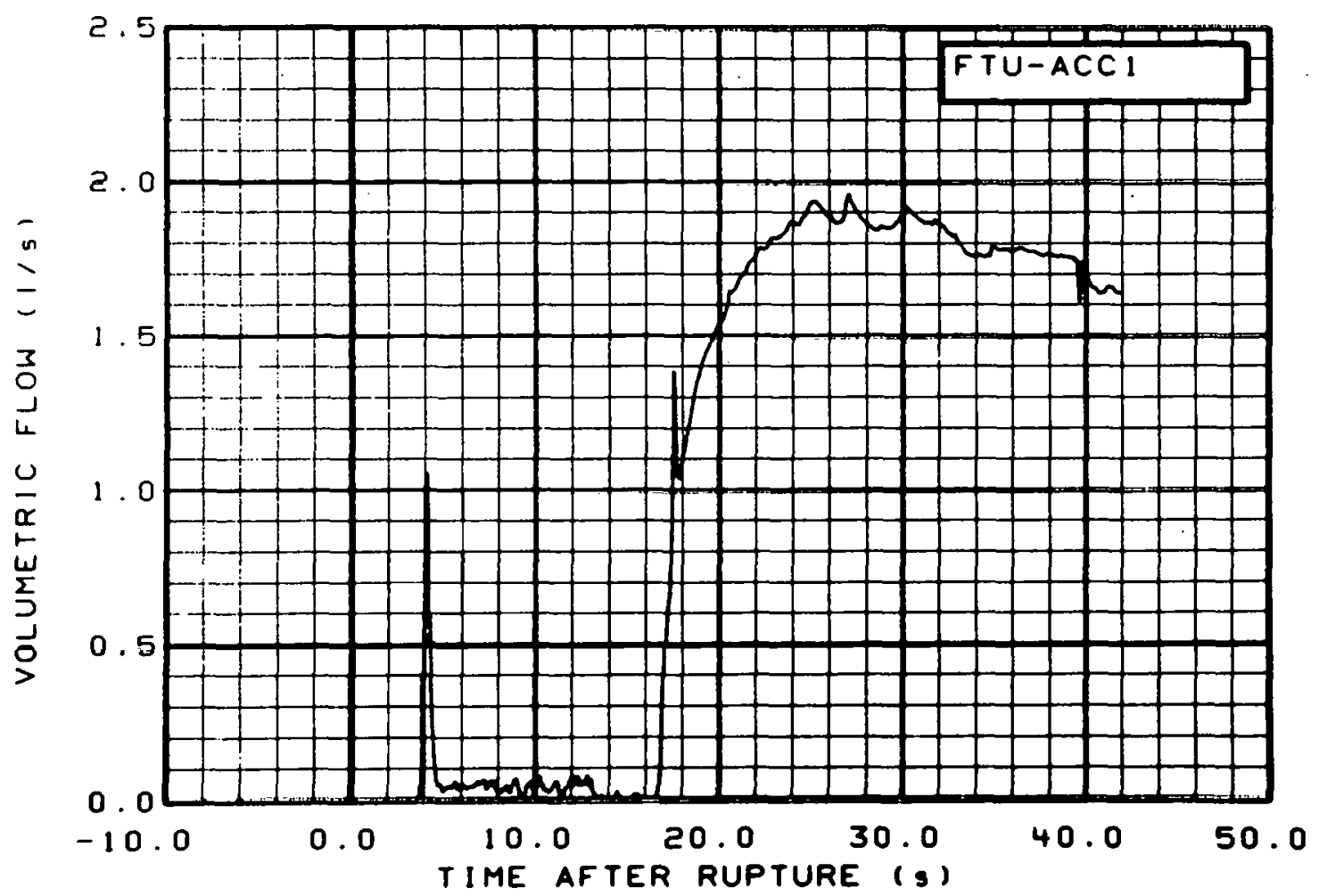

Fig. 260 Volumetric flow in intact loop accumulator discharge line (FTU-ACC1), from -6 to $42 \mathrm{~s}$. 


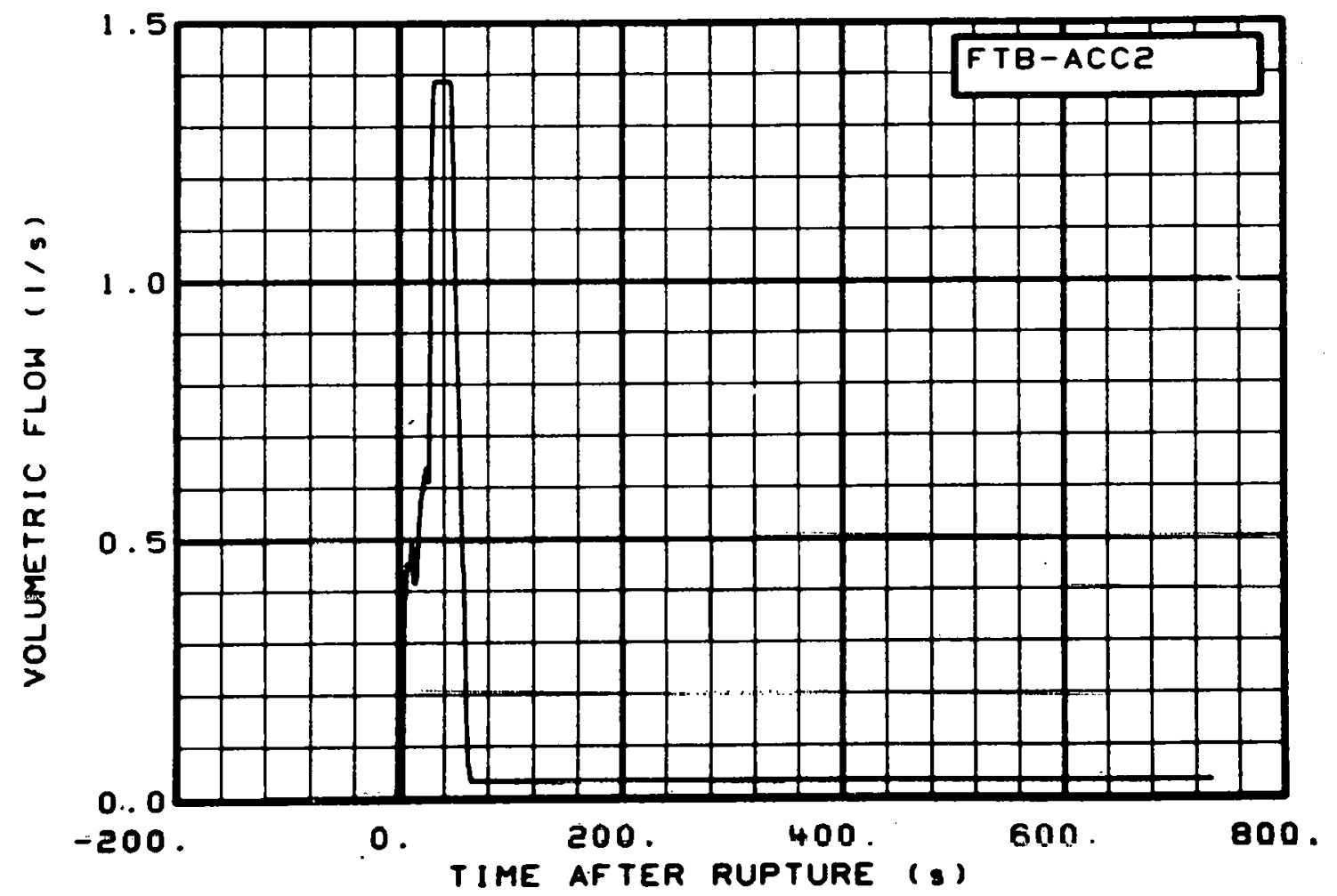

Fig. 261 Volumetric flow in broken loop accumulator discharge line (FTB-ACC2), from -20 to $736 \mathrm{~s}$.

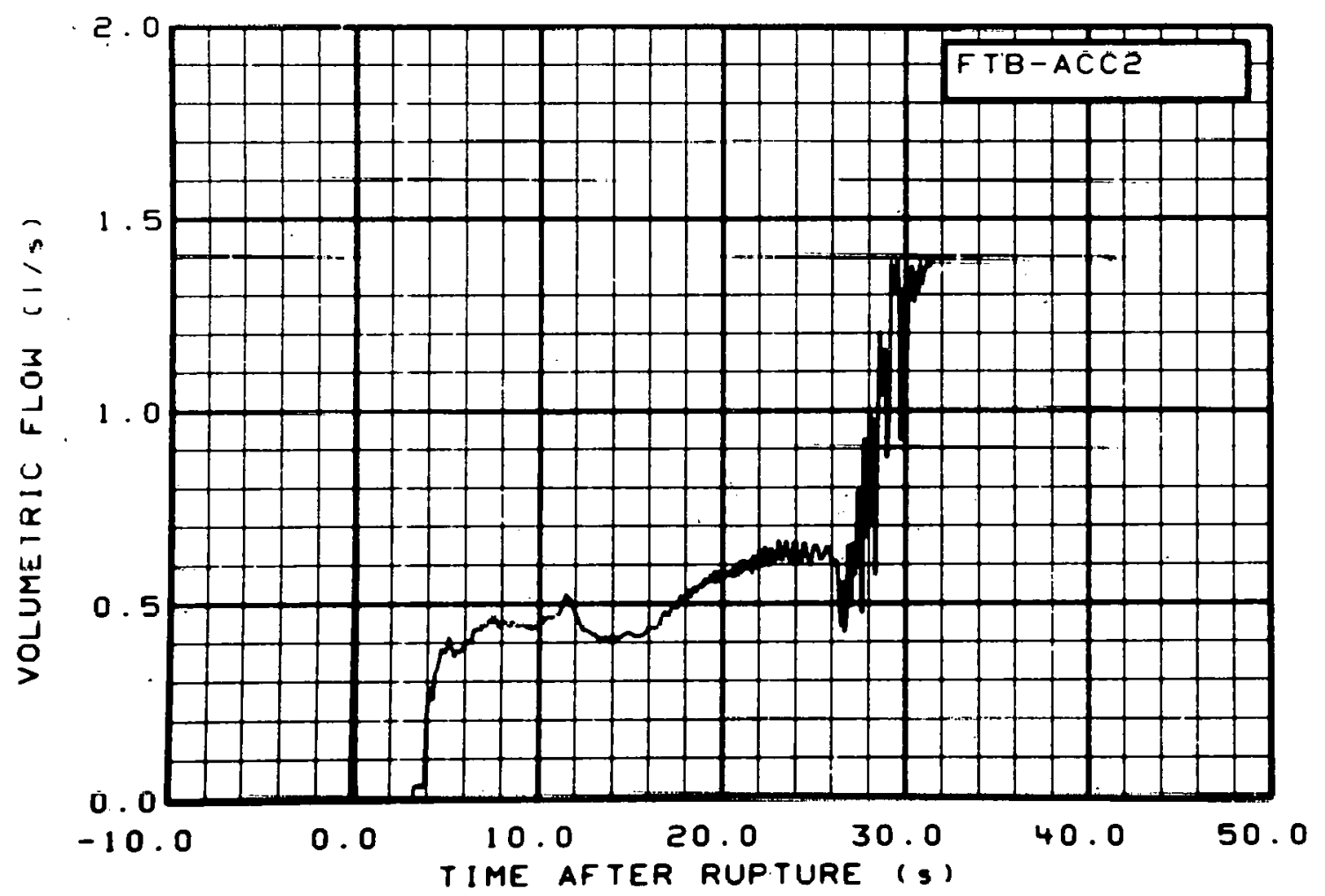

Fig. 262 Volumetric flow in broken loop accumulator discharge line (FTB-ACC2), from -6 to $42 \mathrm{~s}$. 


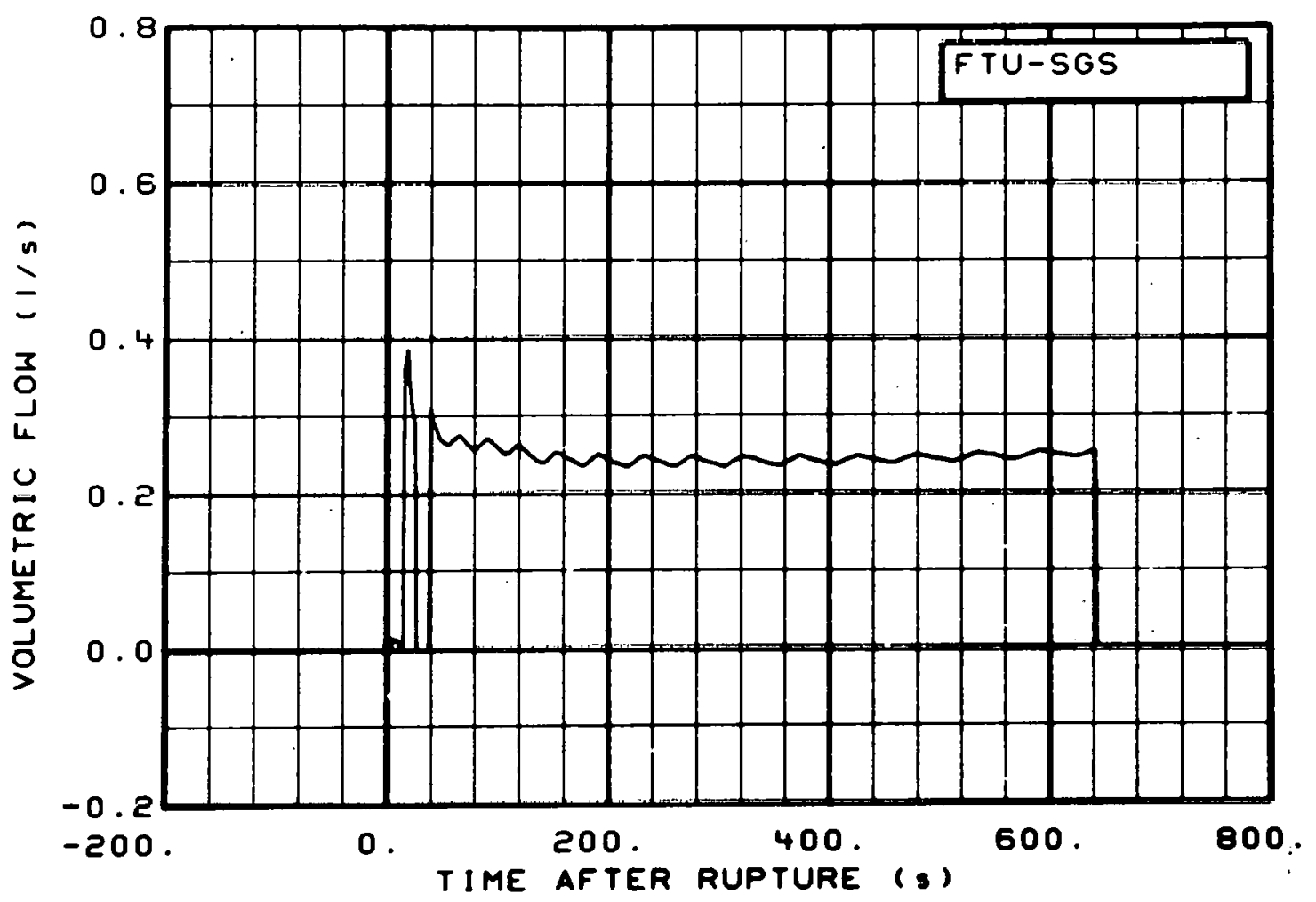

Fig. 263 Volumetric flow in intact loop steam generator (FTU-SGS), from -20 to $736 \mathrm{~s}$.

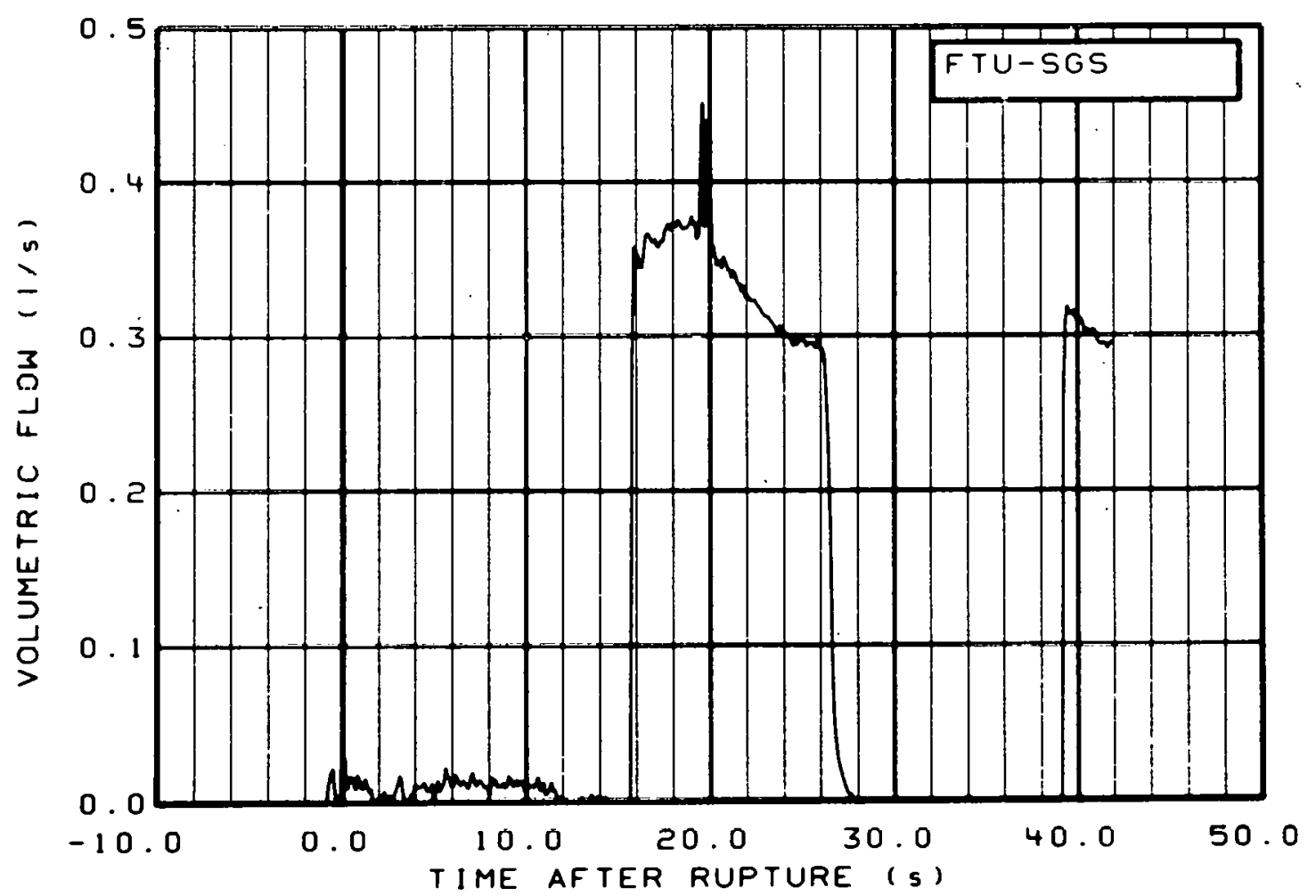

Fig. 264 Volumetric flow in intact loop steam generator (FTU-SGS), from -6 to $42 \mathrm{~s}$. 


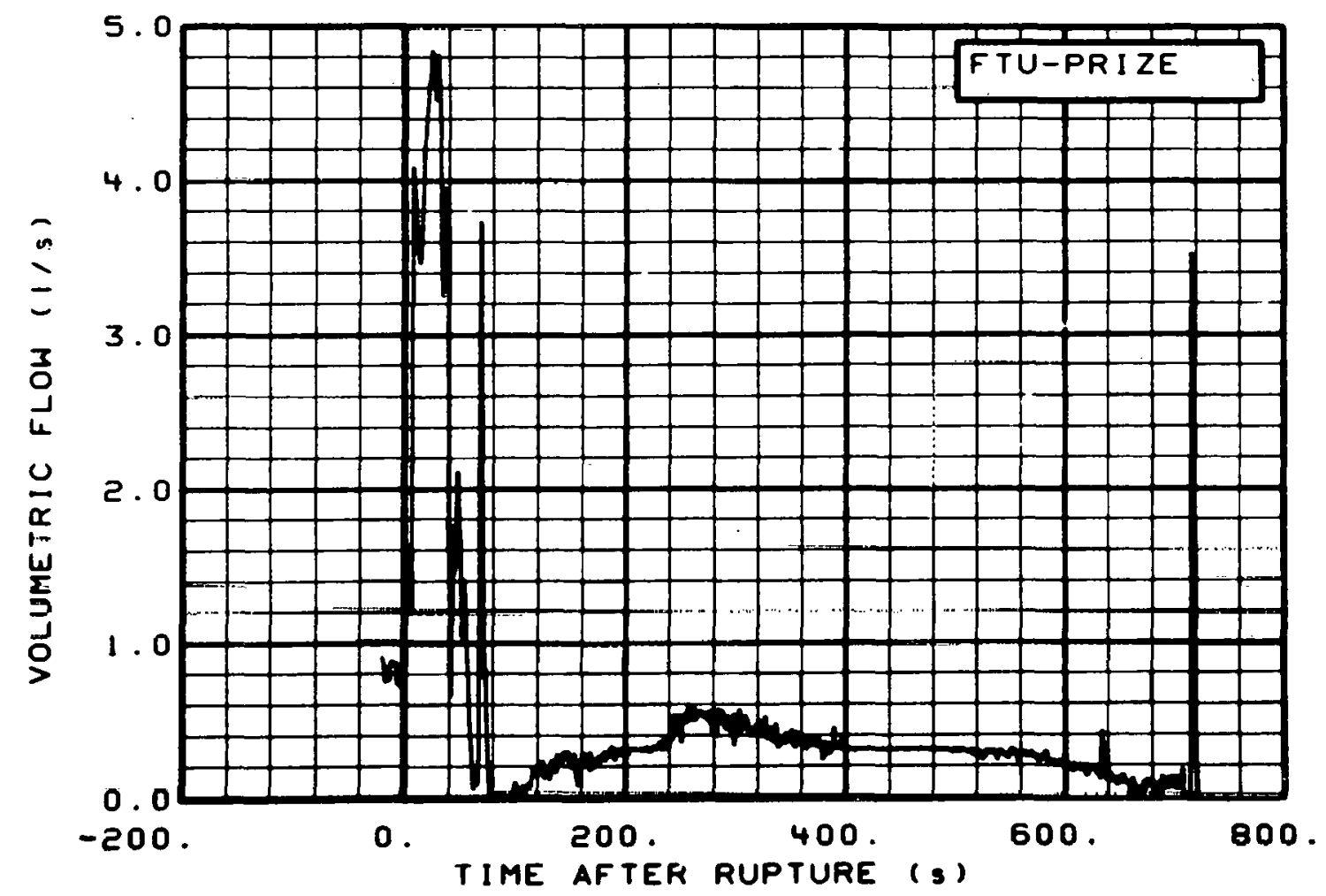

Fig. 265 Volumetric flow from pressurizer (FTU-PRIZE), from -20 to $736 \mathrm{~s}$.

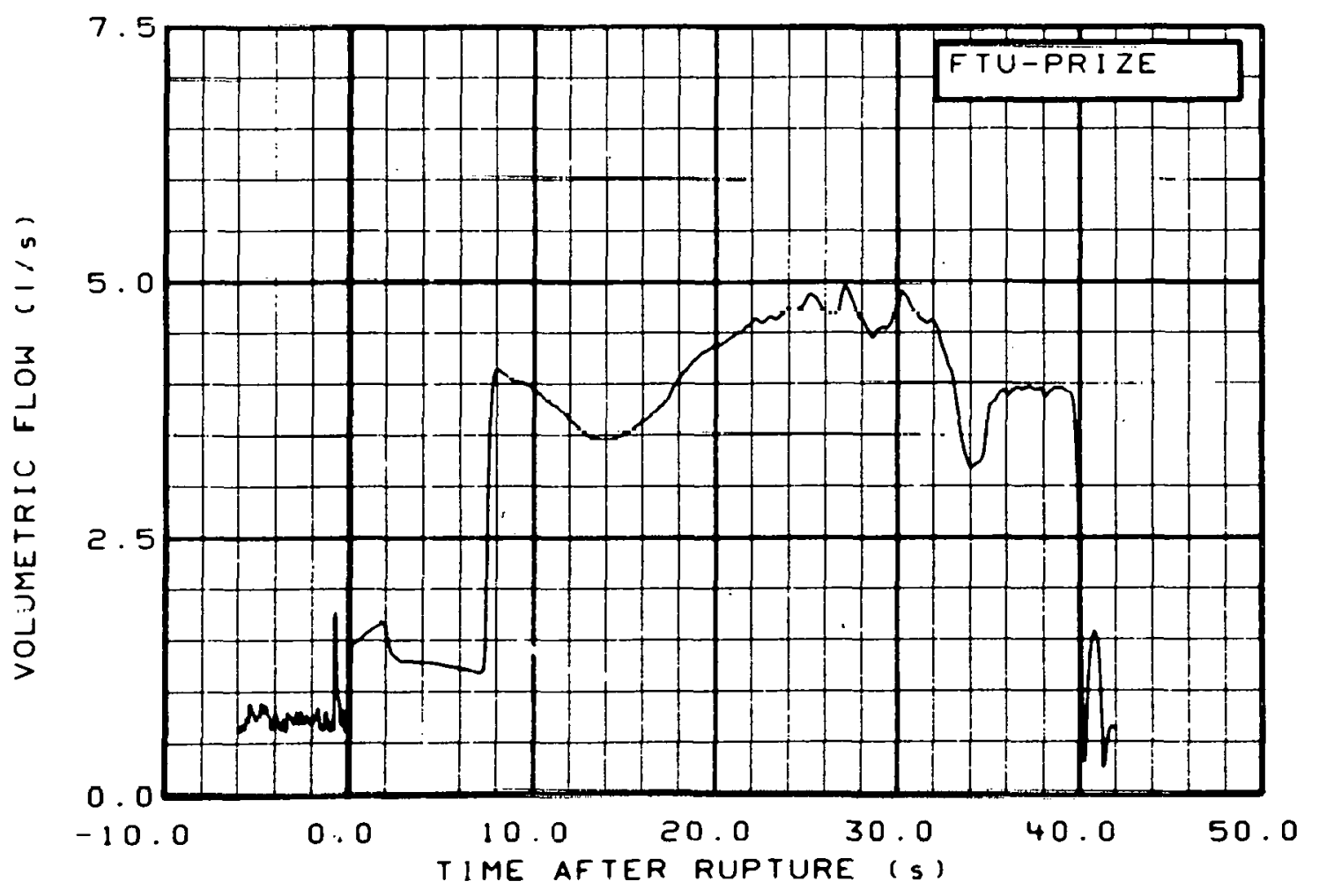

Fig. 266 Volumetric flow from pressurizer (FTU-PRIZE), from -6 to $42 \mathrm{~s}$. 


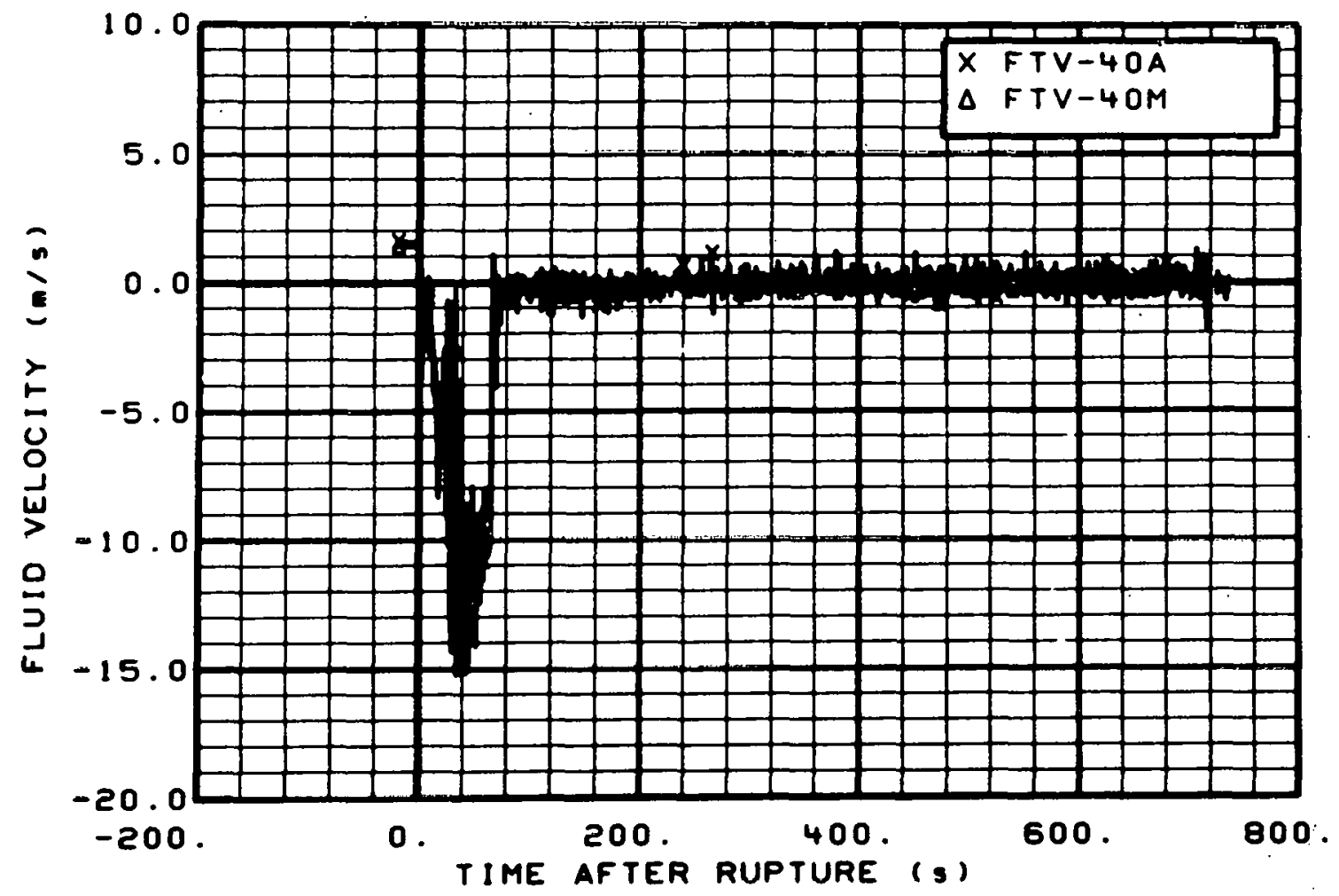

Fig. 267 Fluid velocity in vessel (FTV-40A and FTV-40M), from -20 to $736 \mathrm{~s}$.

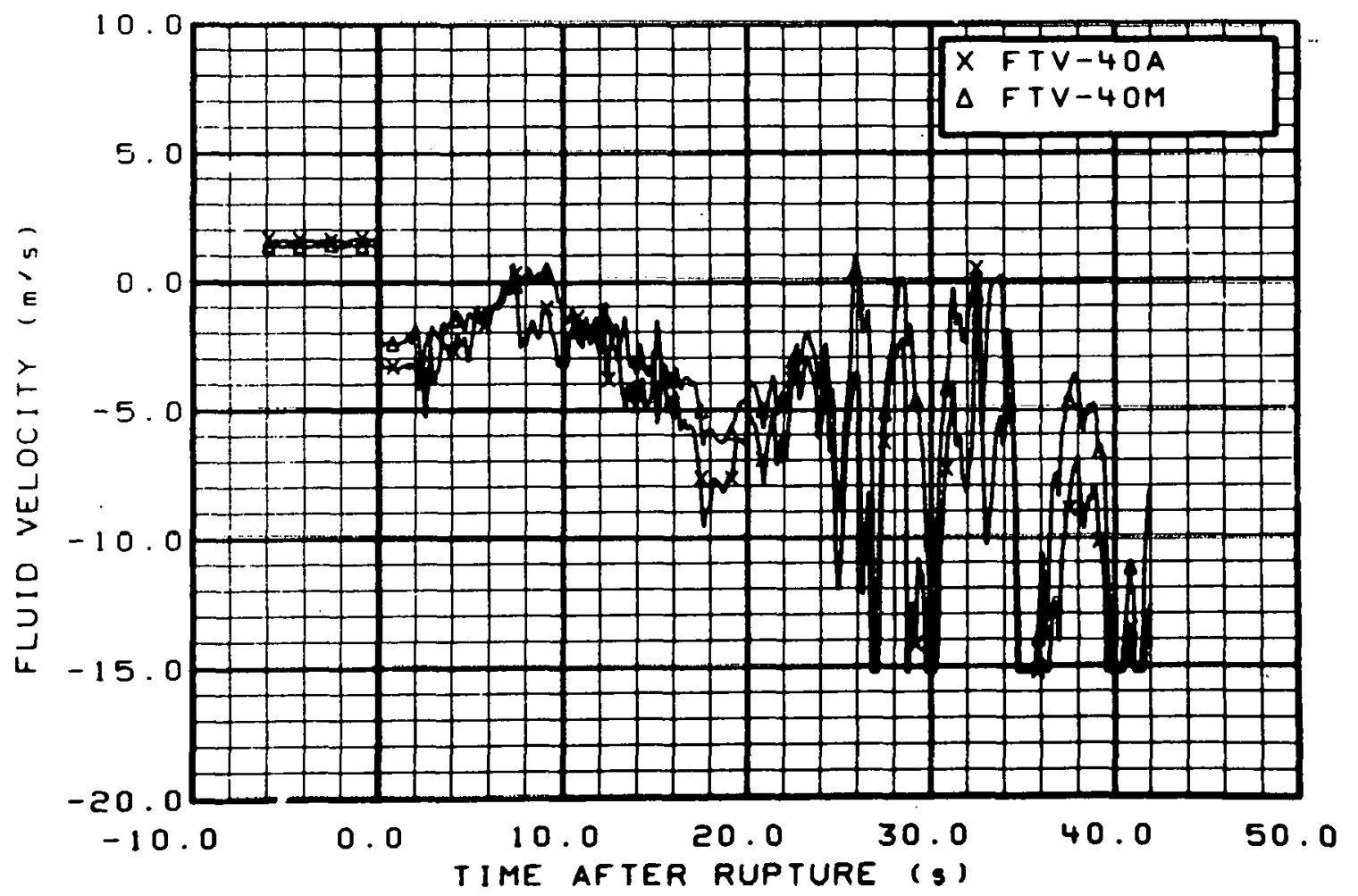

Fig. 268 Fluid velocity in vessel (FTV-40A and FTV-40M), from -6 to $42 \mathrm{~s}$. 


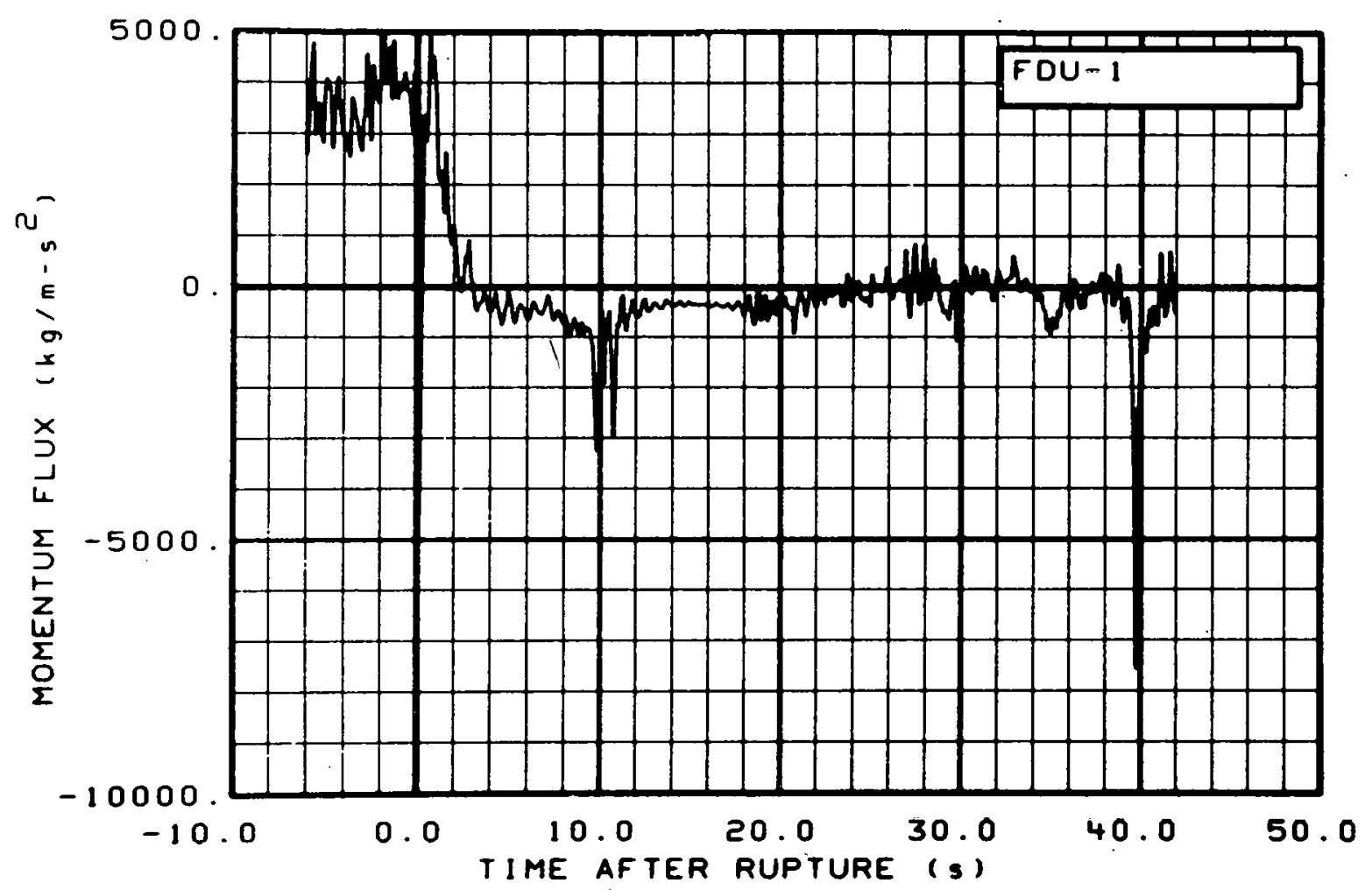

Fig. 269 Momentum flux in intact loop (FDU-1), from -6 to $42 \mathrm{~s}$.

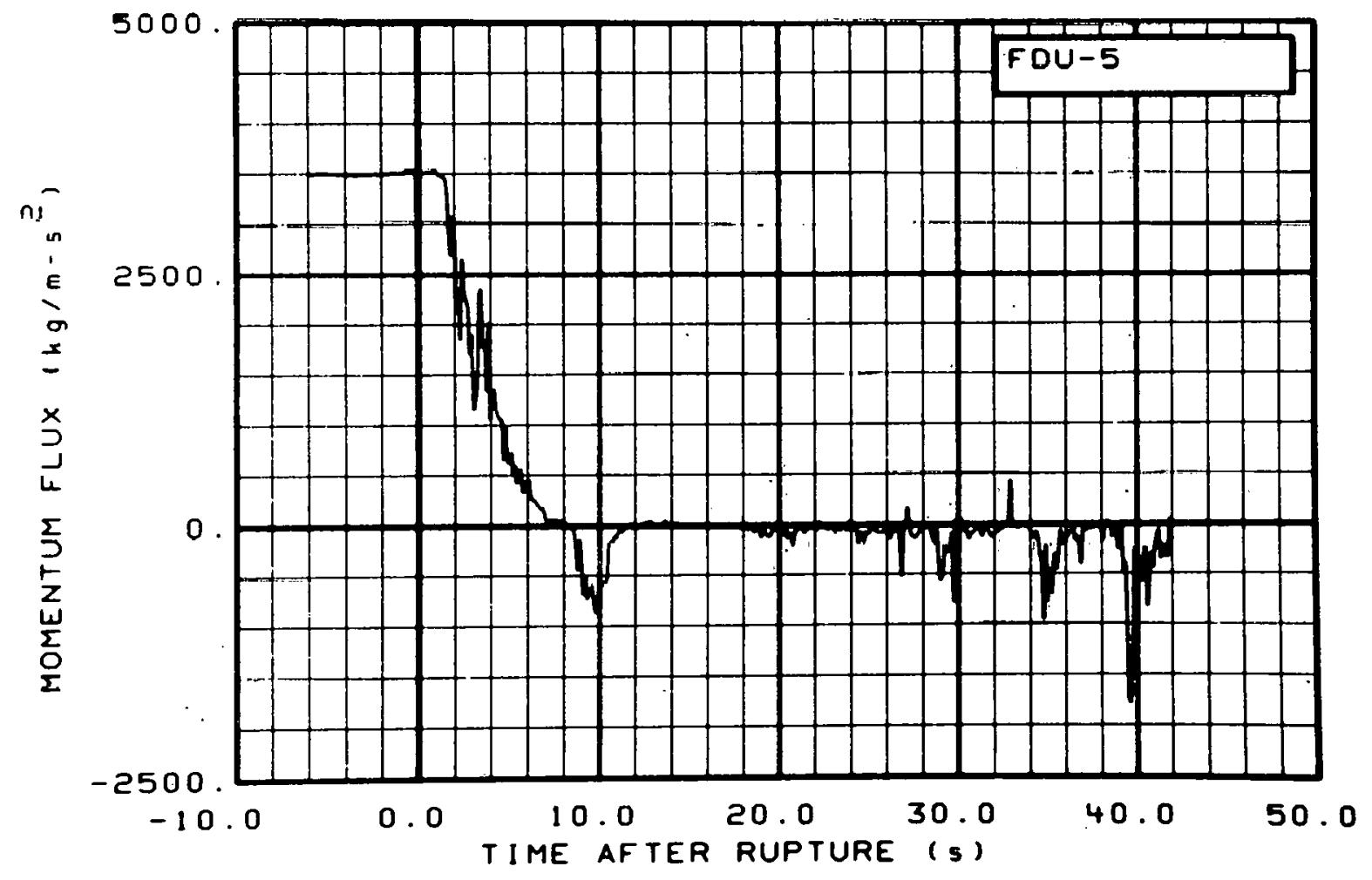

Fig. 270 Momentum flux in intact loop (FDU-5), from -6 to $42 \mathrm{~s}$. 


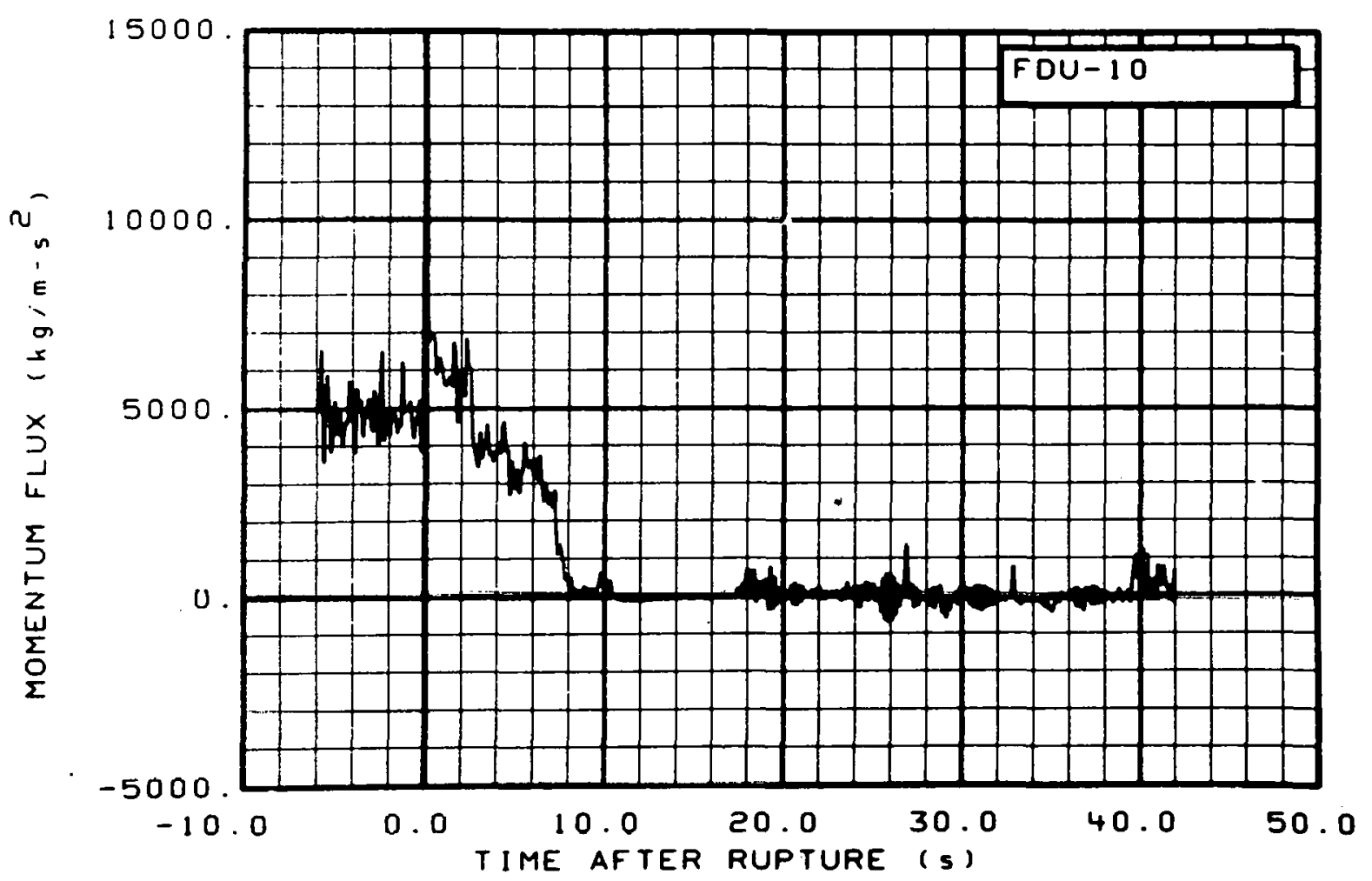

Fig. 271 Momentum flux in intact 1oop (FDU-10), from -6 to $42 \mathrm{~s}$.

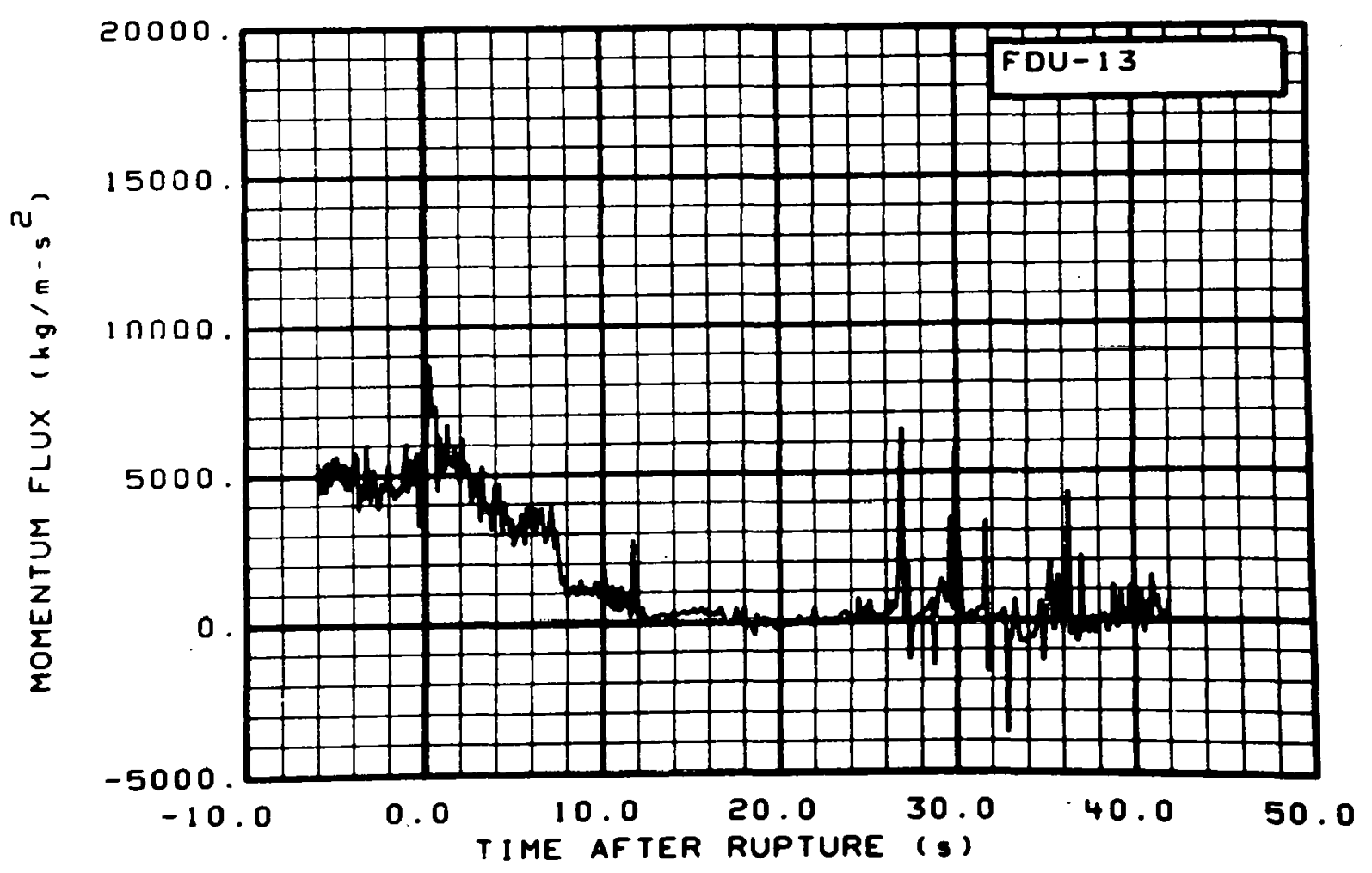

Fig. 272 Momentum flux in intact loop (FDU-13), from -6 to $42 \mathrm{~s}$. 


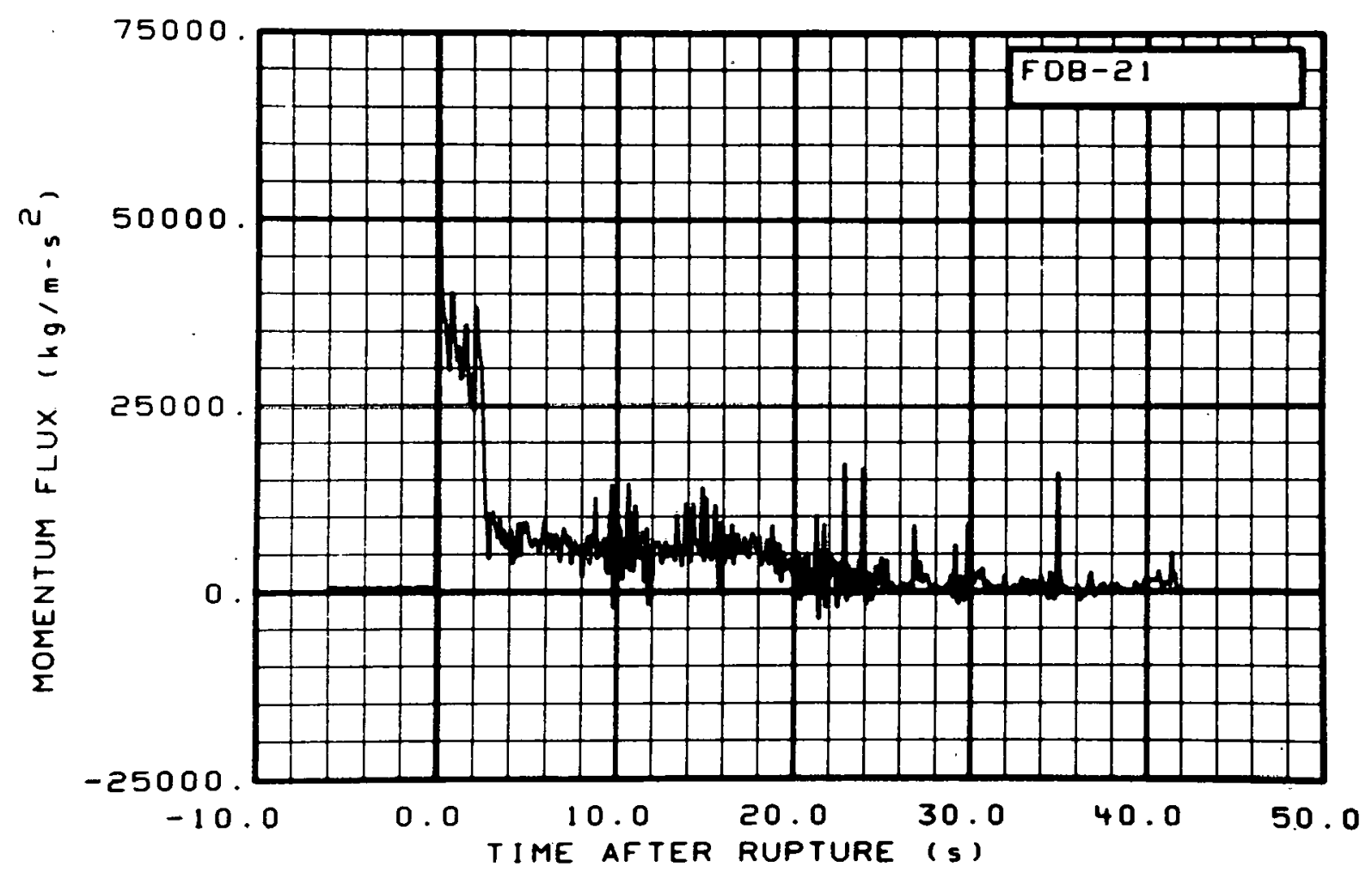

Fig. 273 Momentum flux in broken loop (FDB-21), from -6 to $42 \mathrm{~s}$.

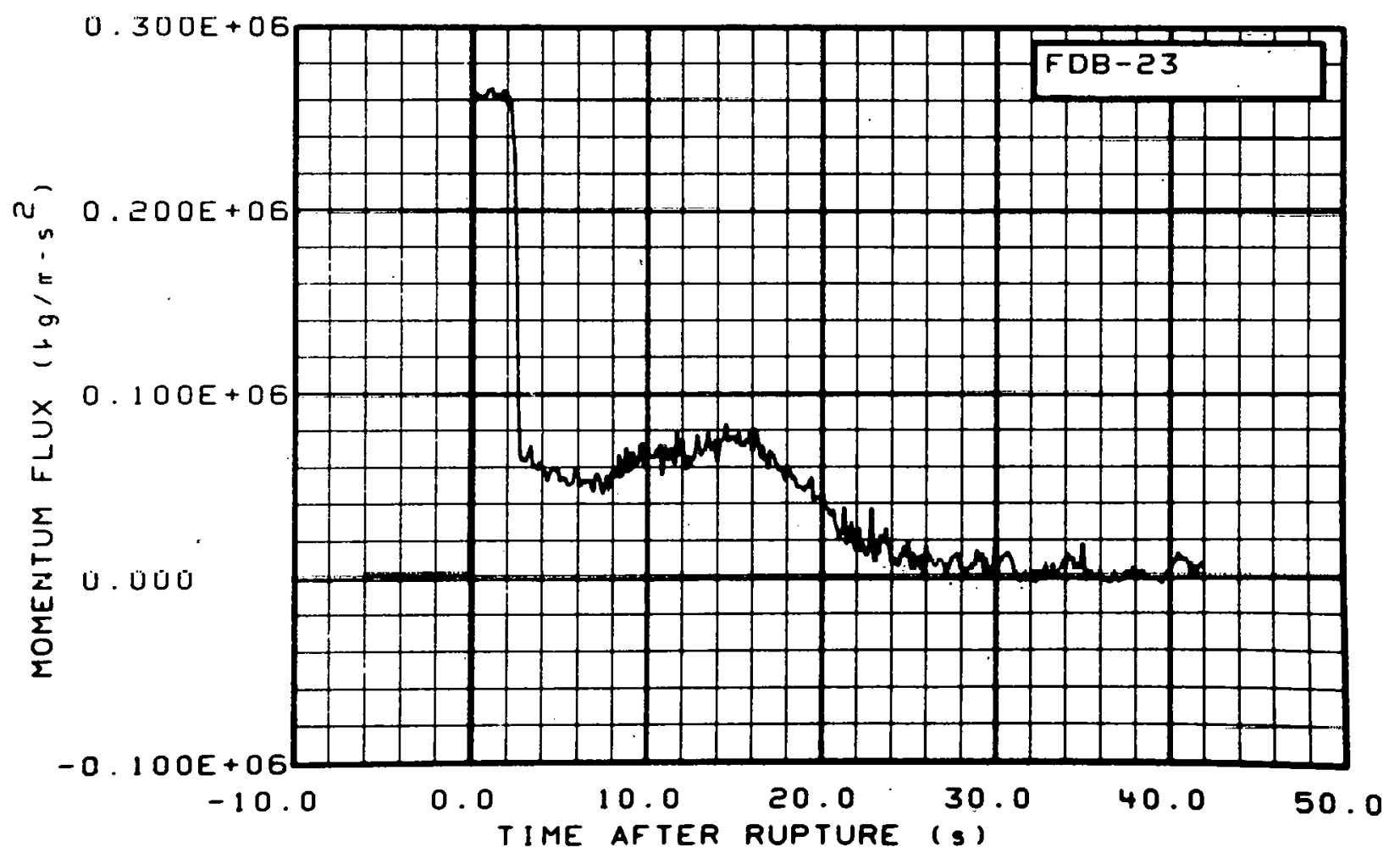

Fig. 274 Momentum flux in broken loop (FDB-23), from -6 to $42 \mathrm{~s}$. 


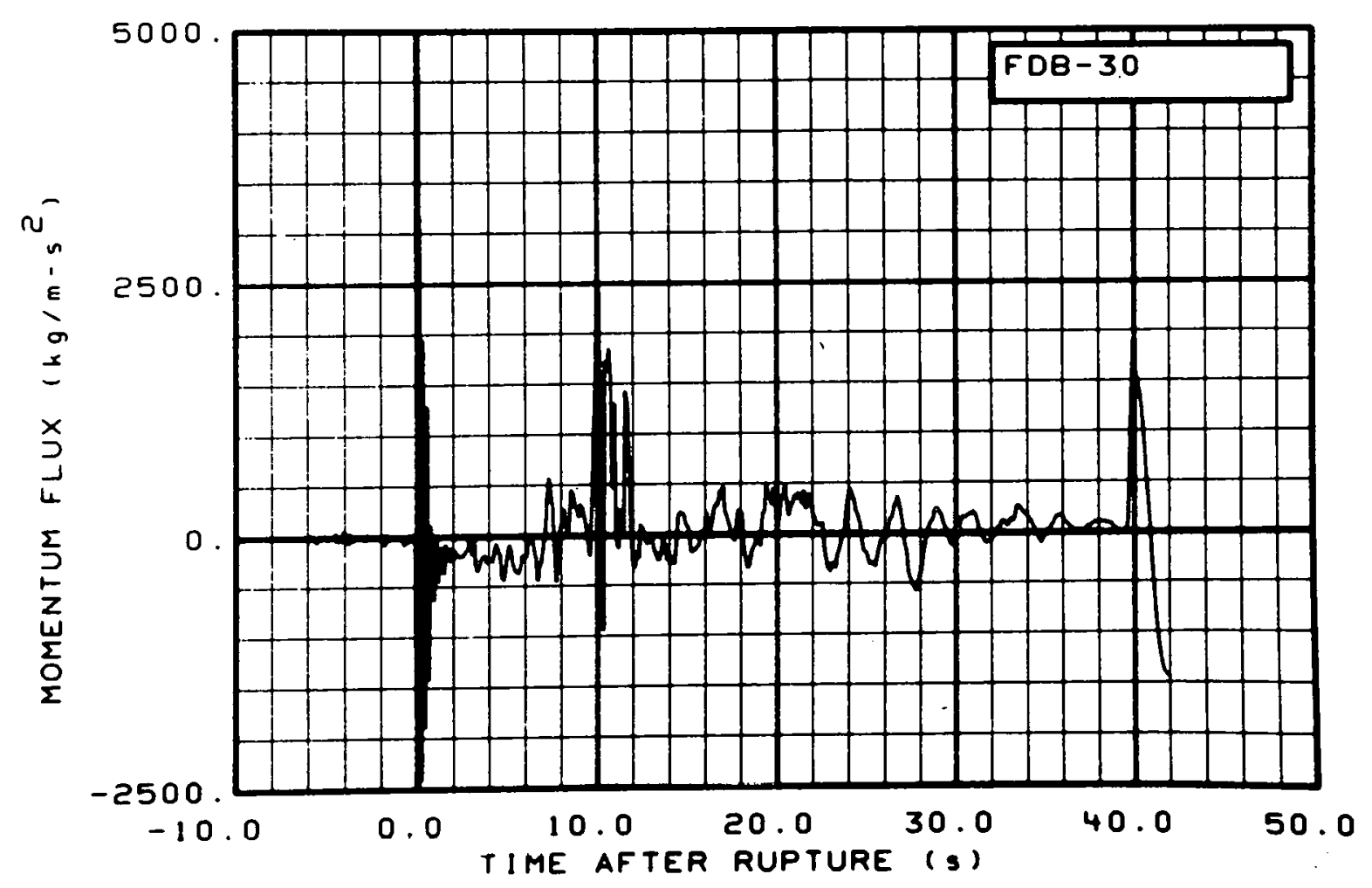

Fig. 275 Momentum flux in broken loop (FDB-30), from -6 to $42 \mathrm{~s}$.

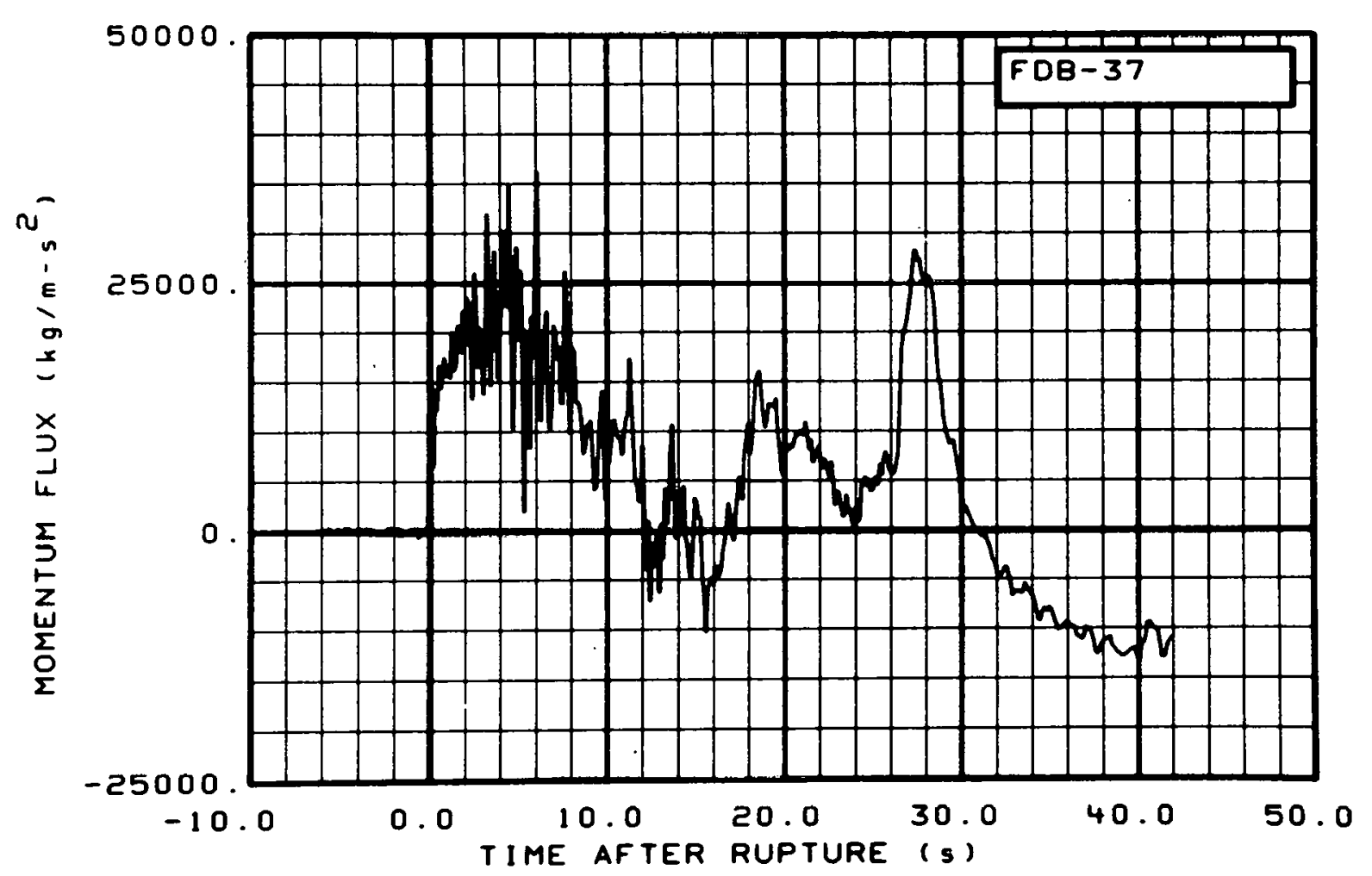

Fig. 276 Mnmentum flux in broken loop (FDB-37), from -6 to $42 \mathrm{~s}$. 


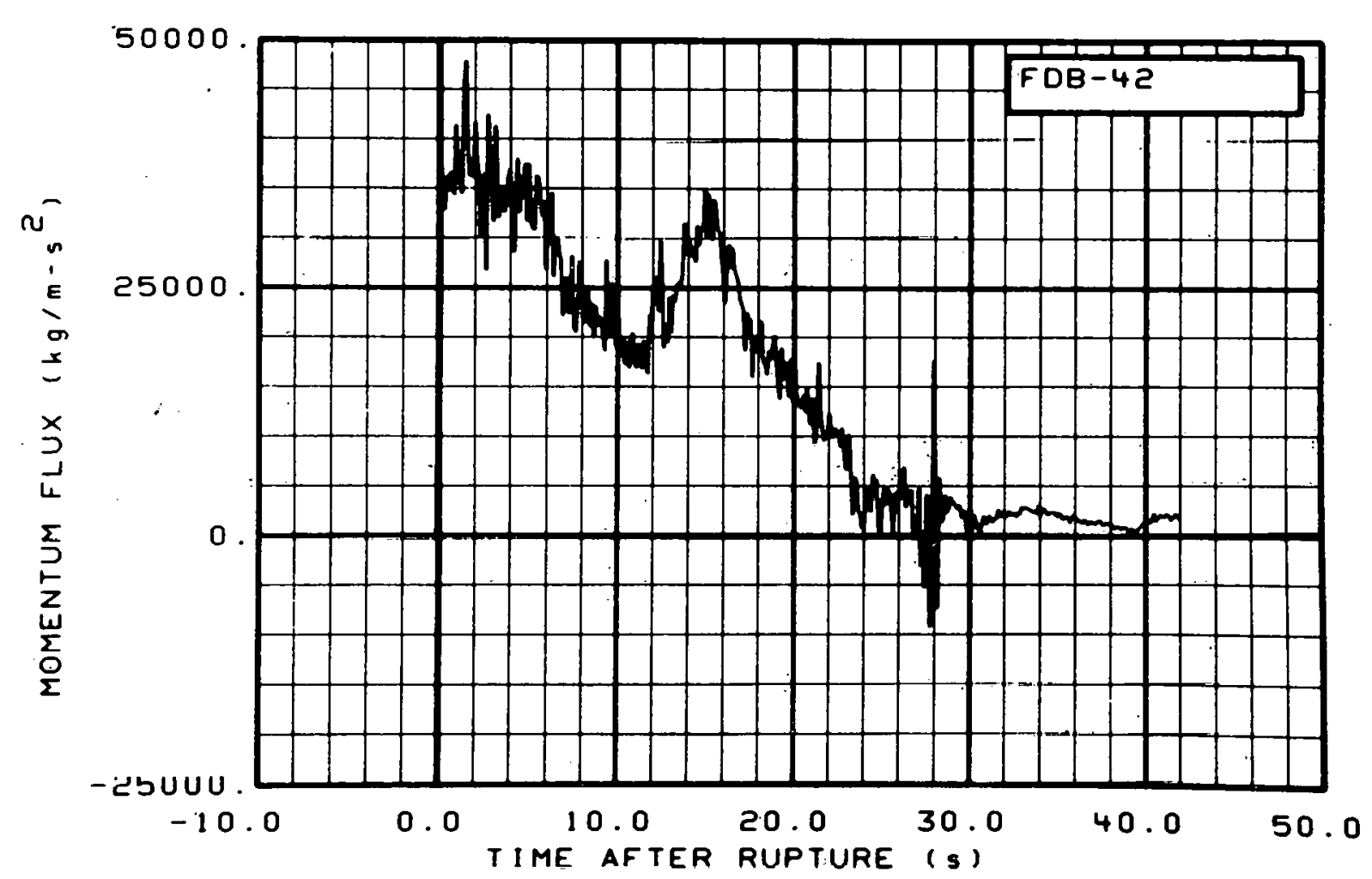

Fig. 277 Momentum flux in broken loop (FDB-42), from -6 to $42 \mathrm{~s}$. 


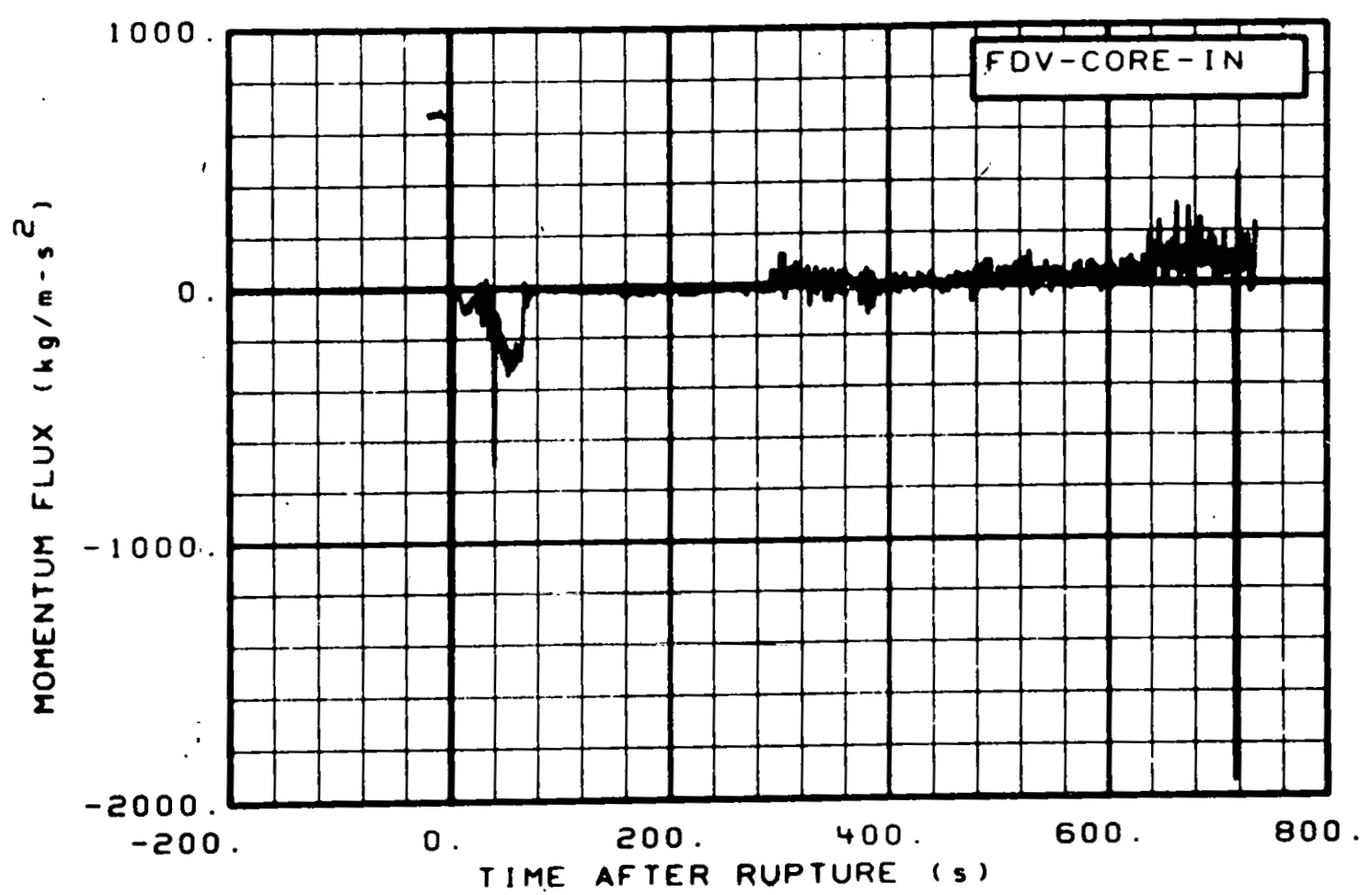

Fig. 278 Momentum flux in core entrance (FDV-CORE-IN), from -20 to $736 \mathrm{~s}$.

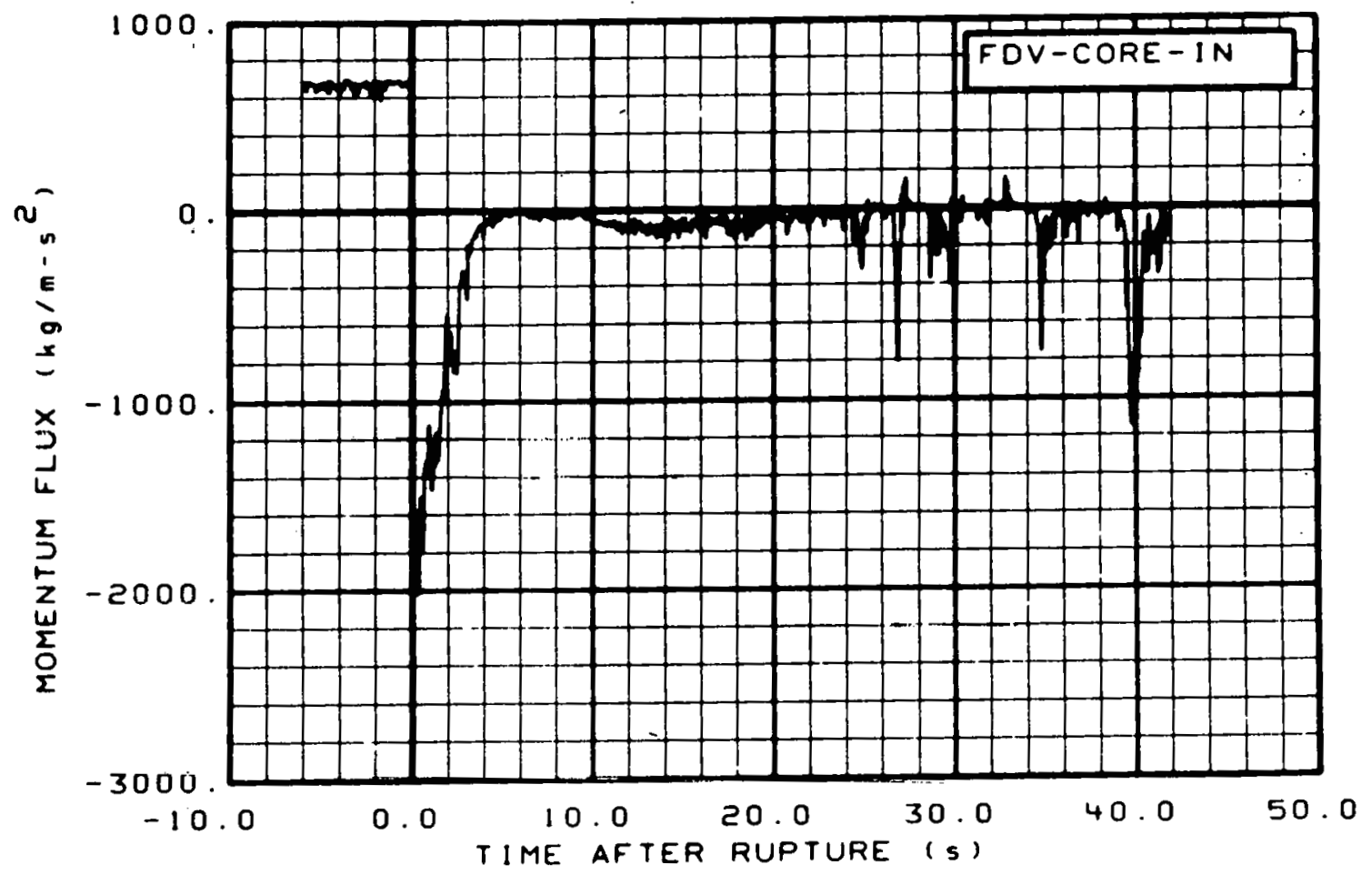

Fig. 279 Momentum fiux in core entrance (FDV-CORE-IN), from -6 to $42 \mathrm{~s}$. 


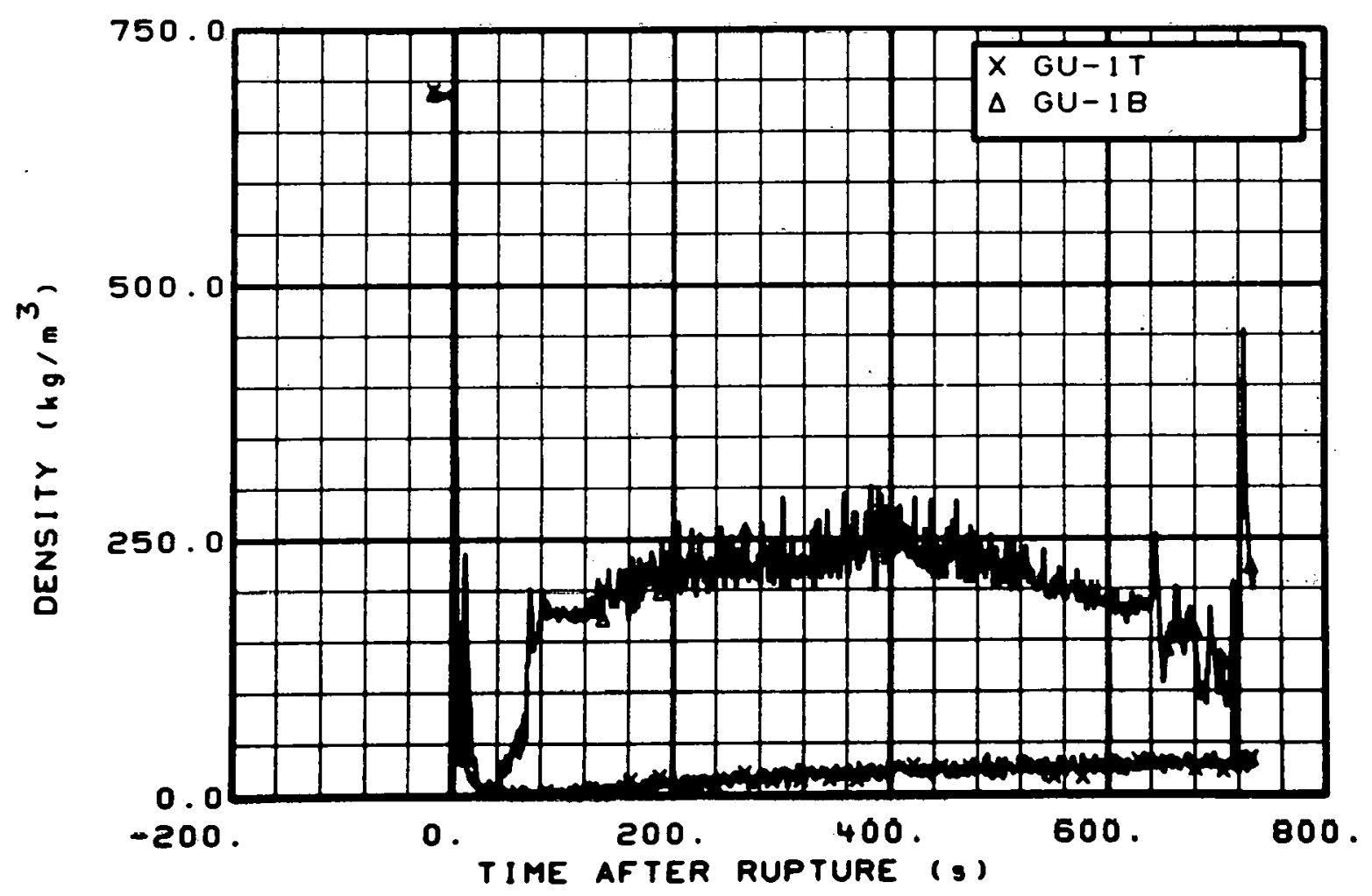

Fig. 280 Density in intact loop (GU-IT and GU-1B), from -20 to $736 \mathrm{~s}$.

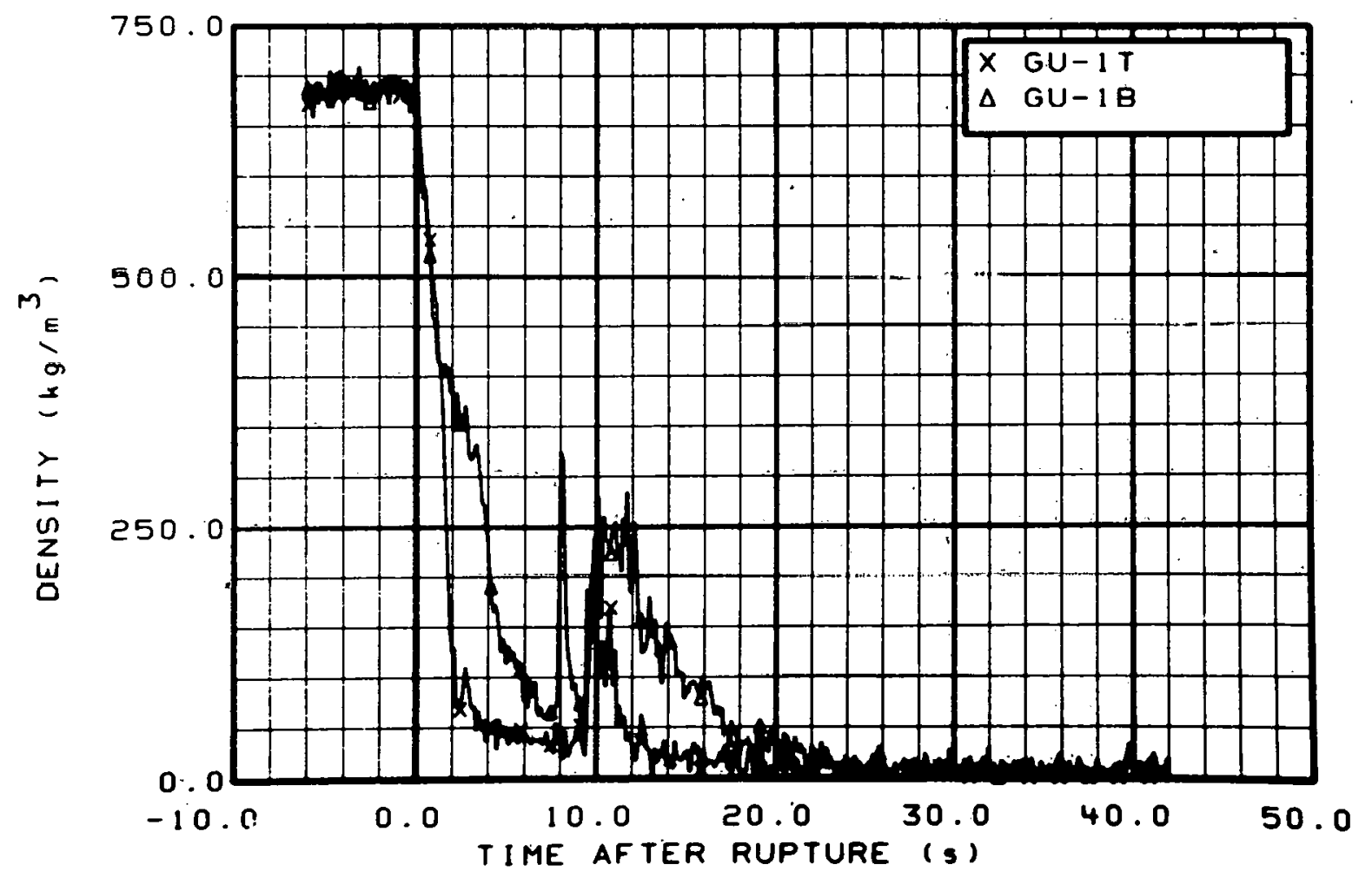

Fig. 281 Density in intact loop (GU-1T and GU-1B), from -6 to $42 \mathrm{~s}$. 


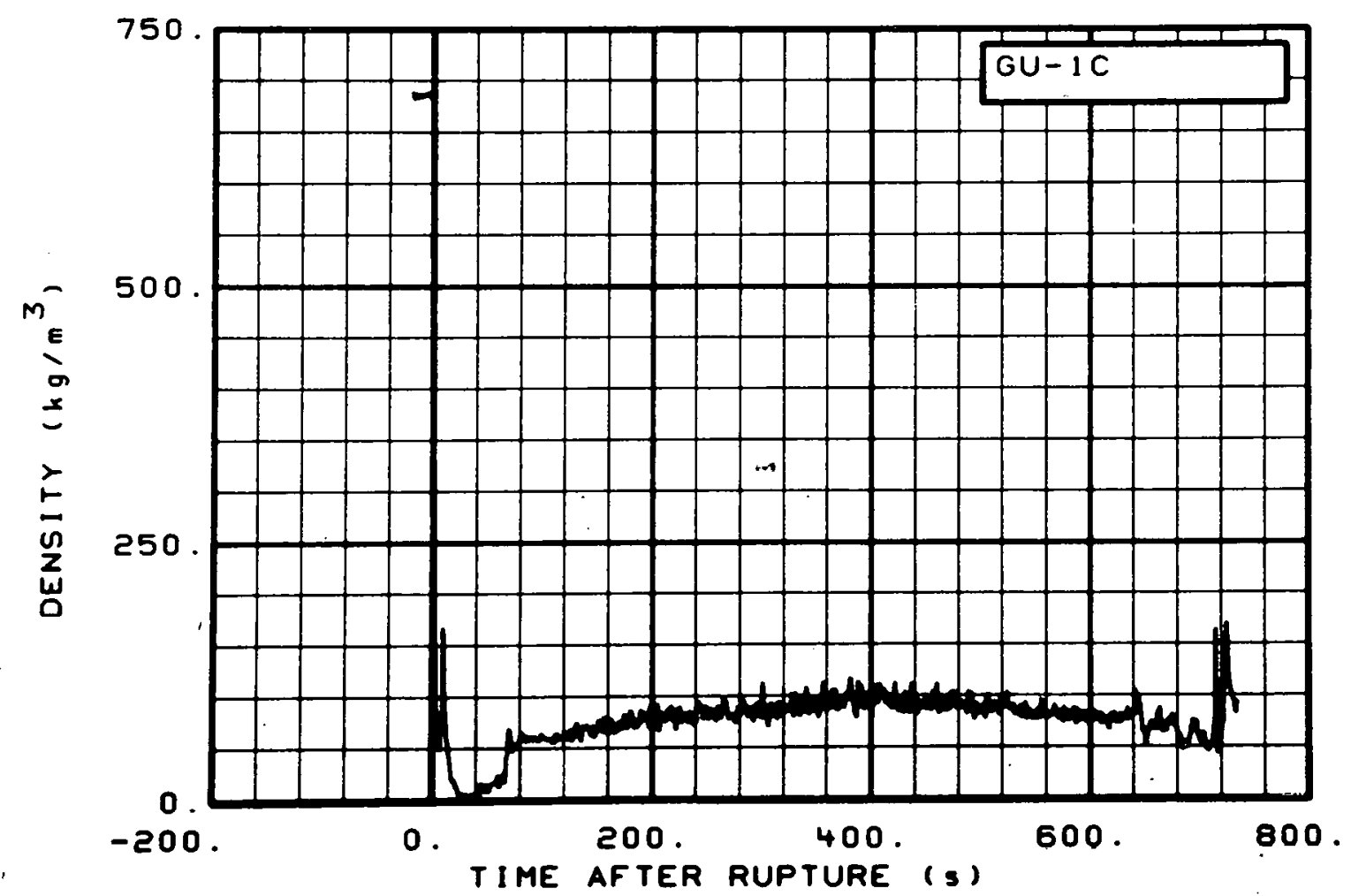

Fig. 282 Density in intact loop (GU-1C), from -20 to $736 \mathrm{~s}$.

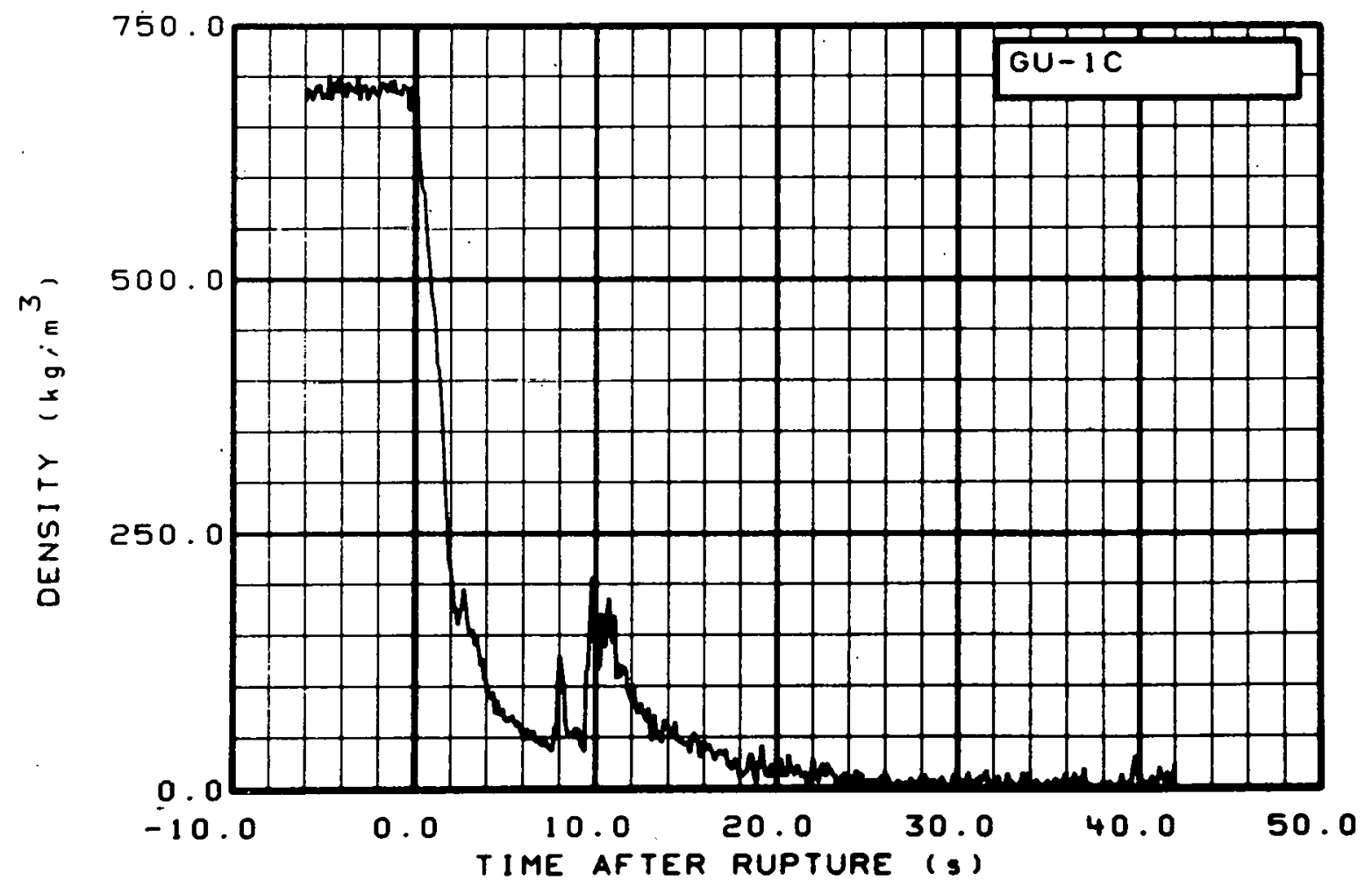

Fig. 283 Density in intact loop (GU-TC), from -6 to $42 \mathrm{~s}$. 


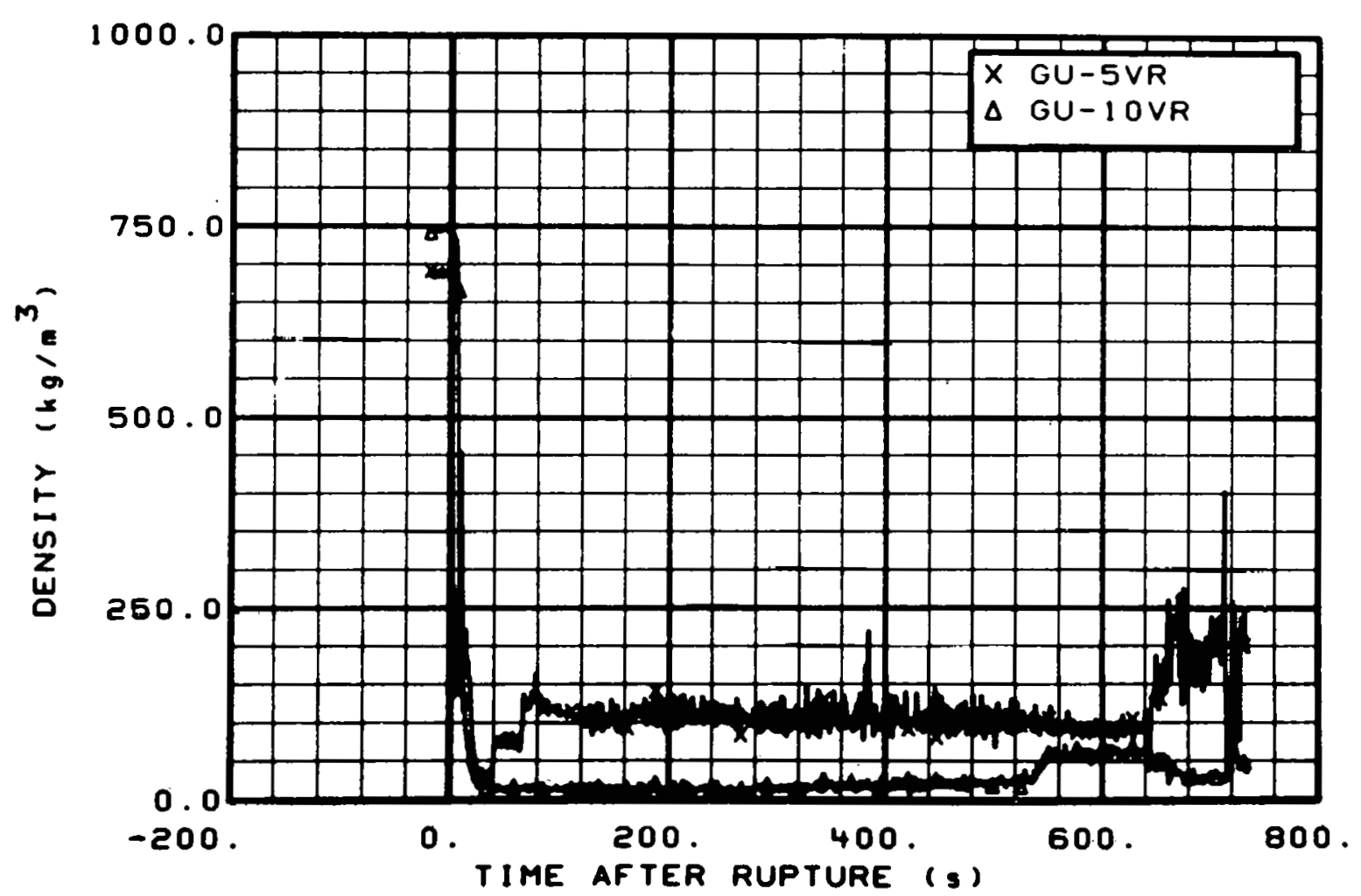

Fig. 284 Density in intact loop (GU-5VR and GU-10VR), from -20 to $736 \mathrm{~s}$.

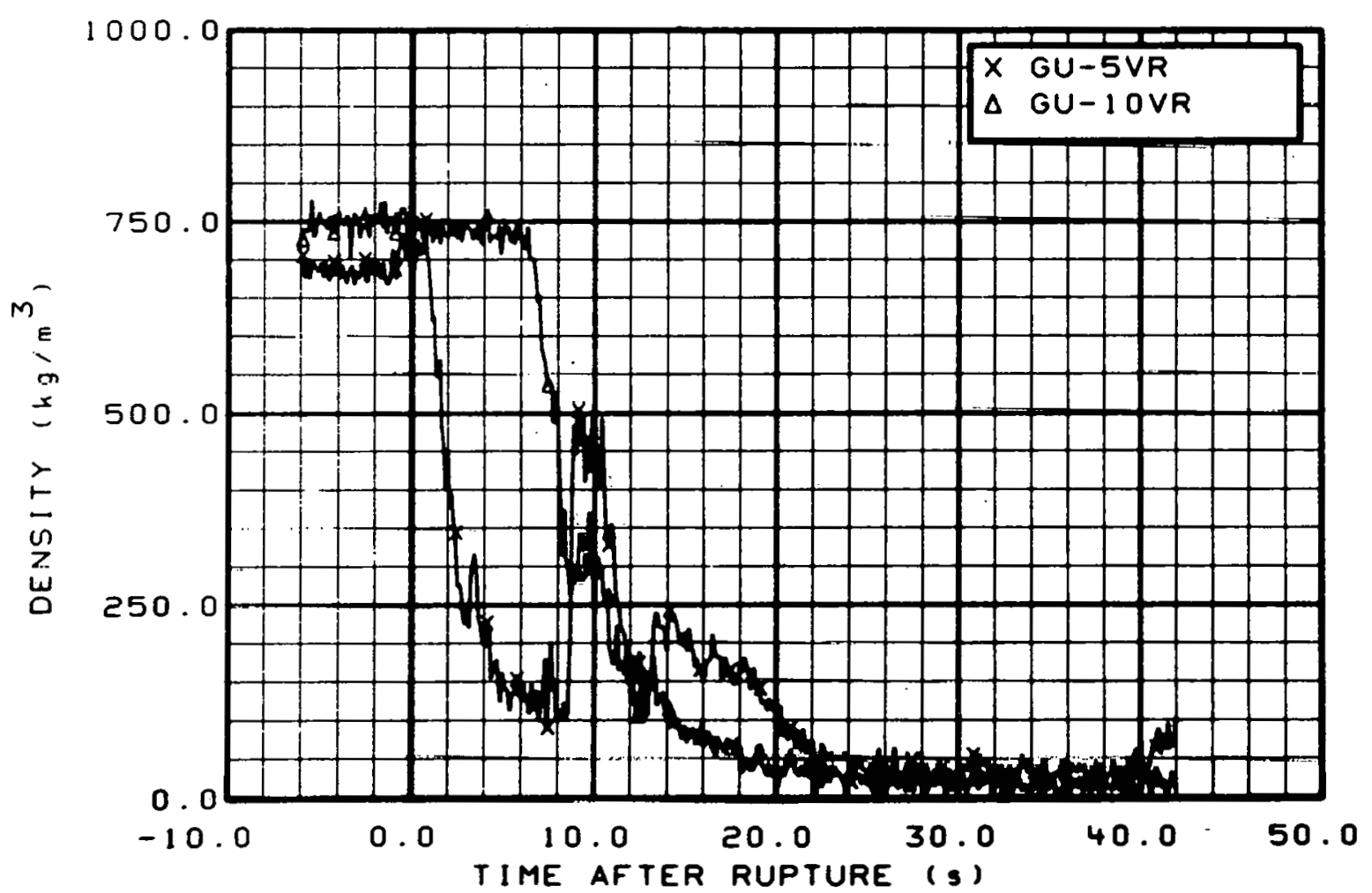

Fig. 285 Density in intact 100p (GU-5VR and GU-10VR), from -6 to $42 \mathrm{~s}$. 


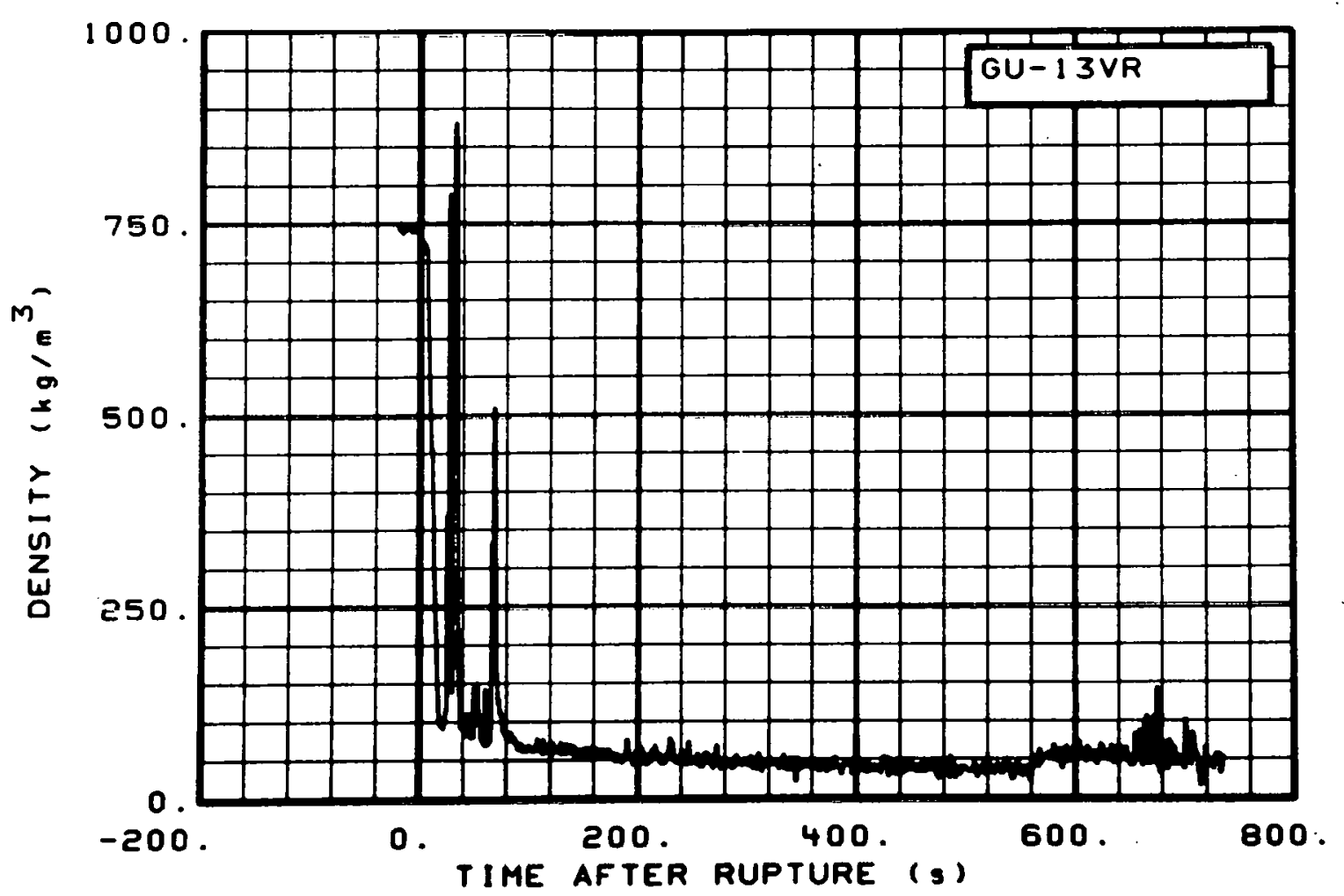

Fig. 286 Density in intact loop (GU-13VR), from -20 to $736 \mathrm{~s}$.

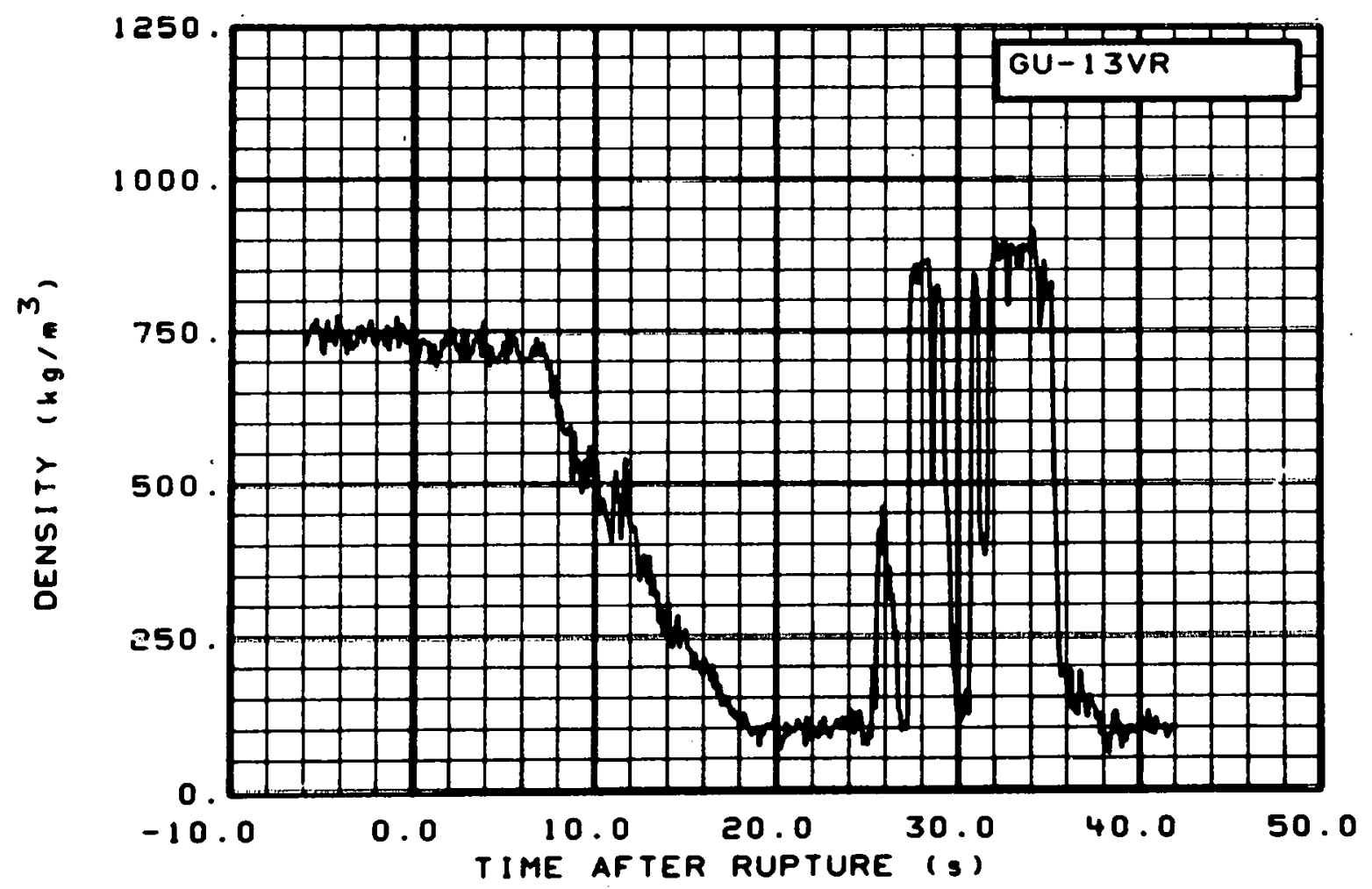

Fig. 287 Density in intact loop (GU-13VR), from -6 to $42 \mathrm{~s}$. 


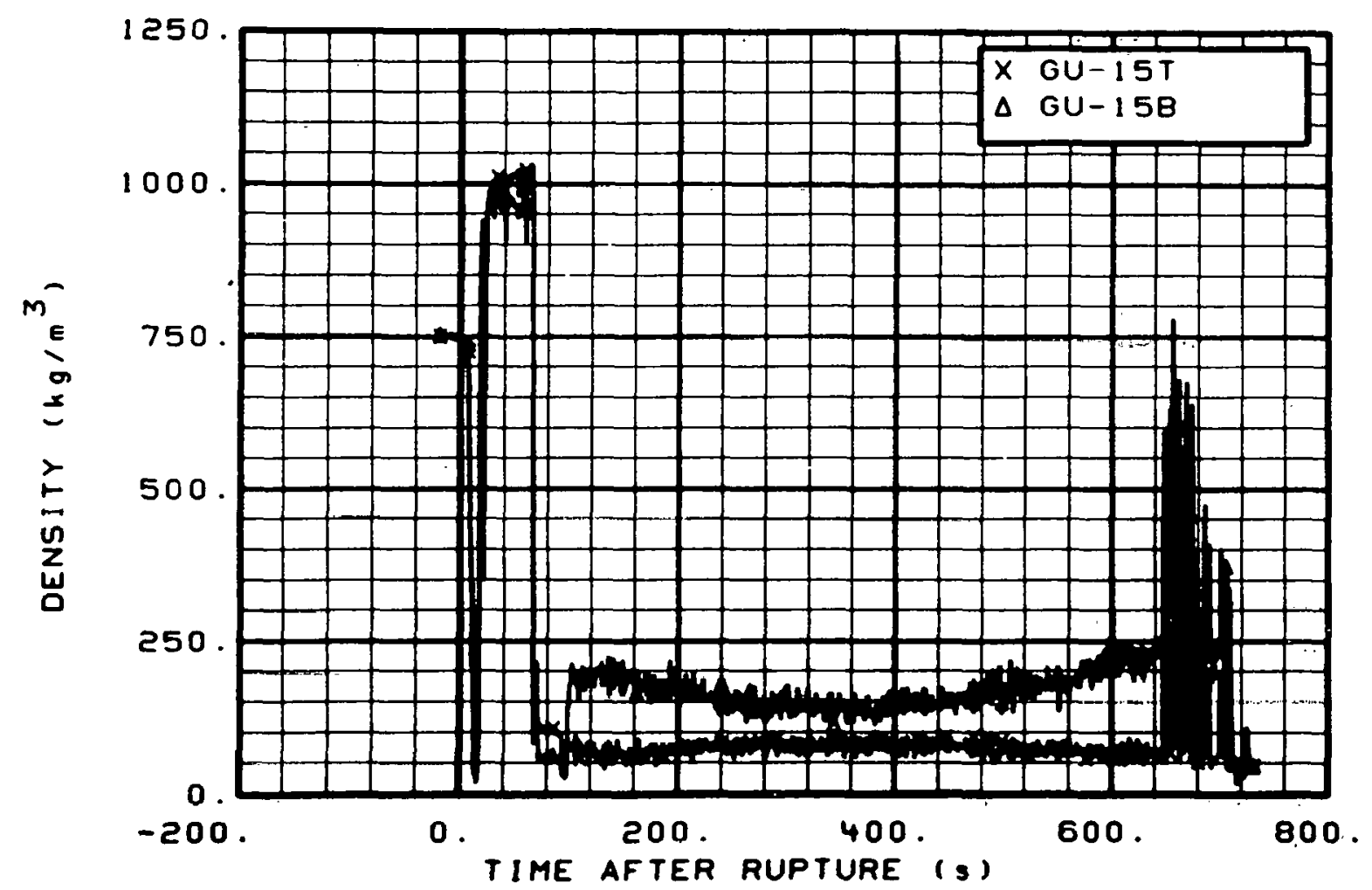

Fig. 288 Density in intact 10op (GU-15T and GU-15B), from -20 to $736 \mathrm{~s}$.

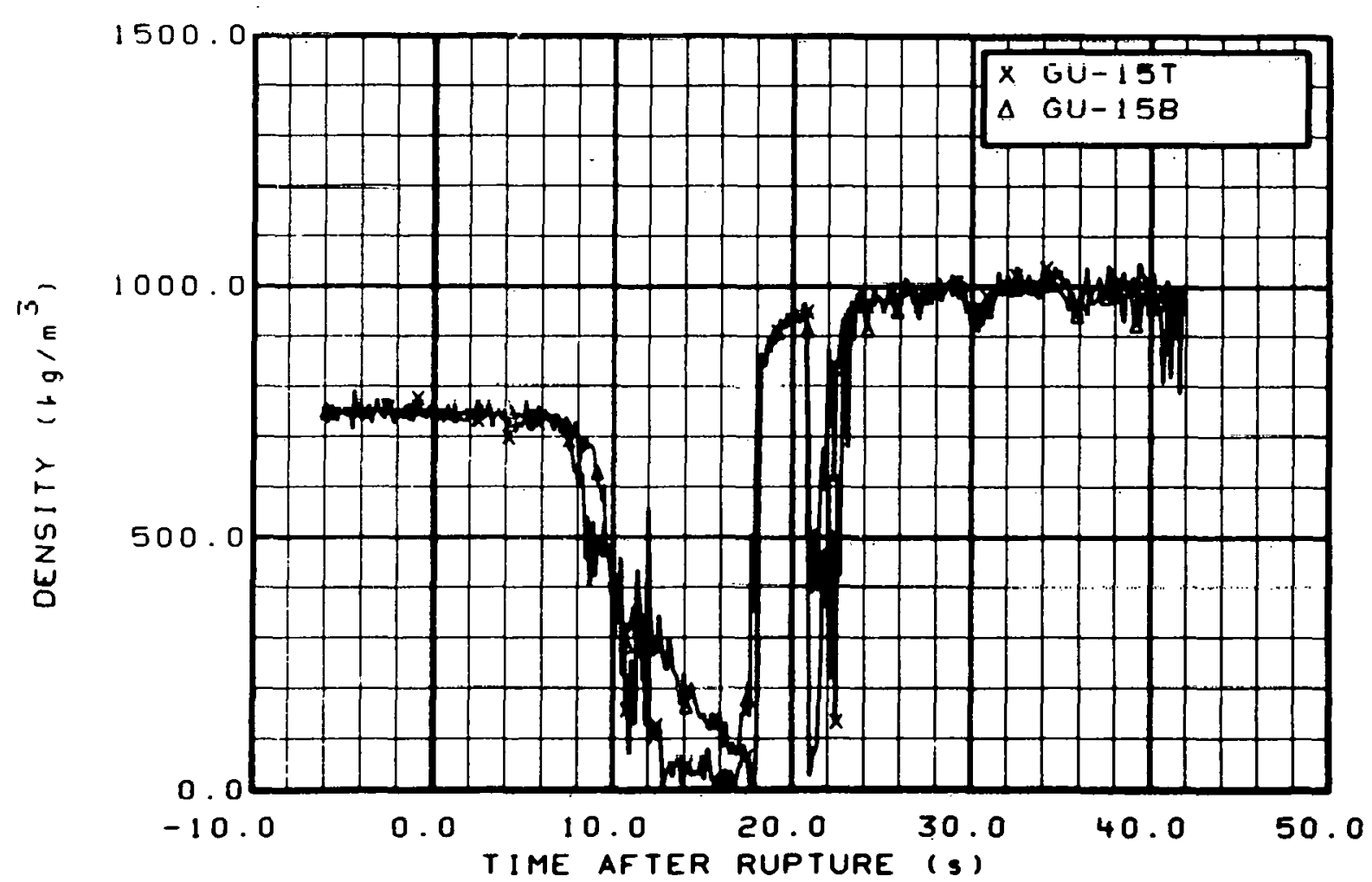

Fig. 289 Density in intact loop (GU-15T and GU-15B), from -6 to $42 \mathrm{~s}$. 


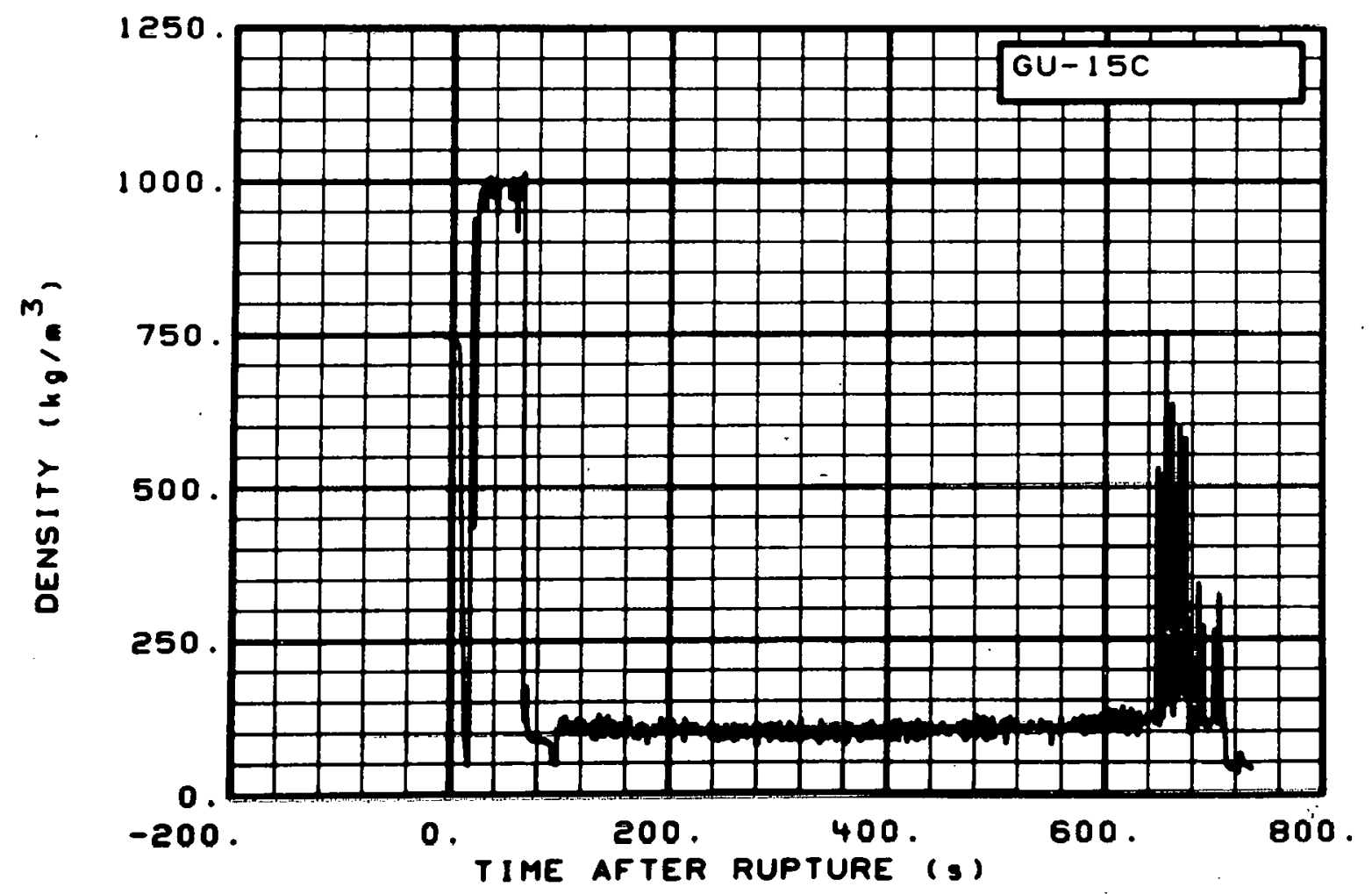

Fig, 290 Density in intact 1oop (GU-15C), from -20 to $736 \mathrm{~s}$.

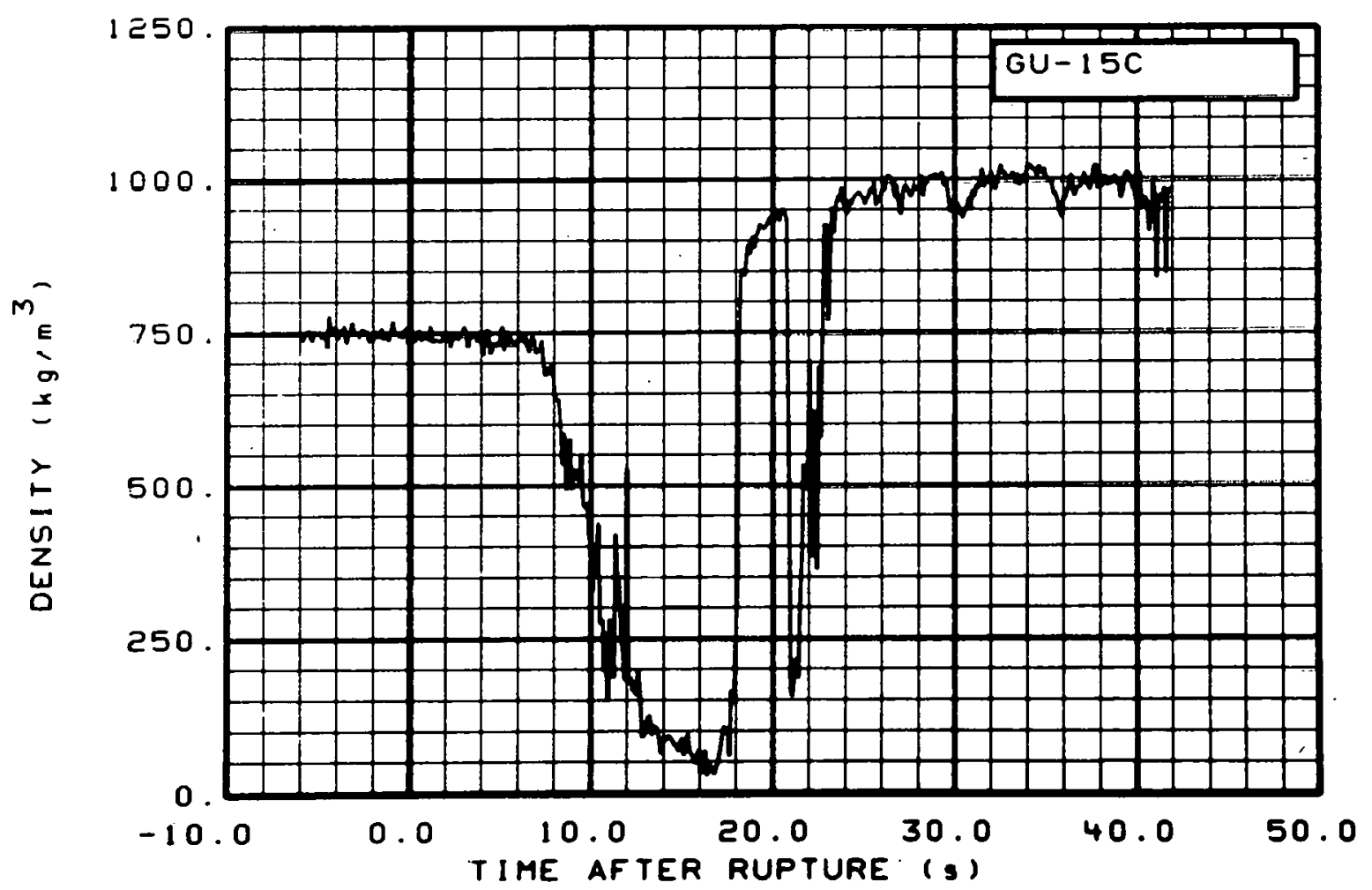

Fig. 291 Density in intact loop (GU-15C), from -6 to $42 \mathrm{~s}$. 


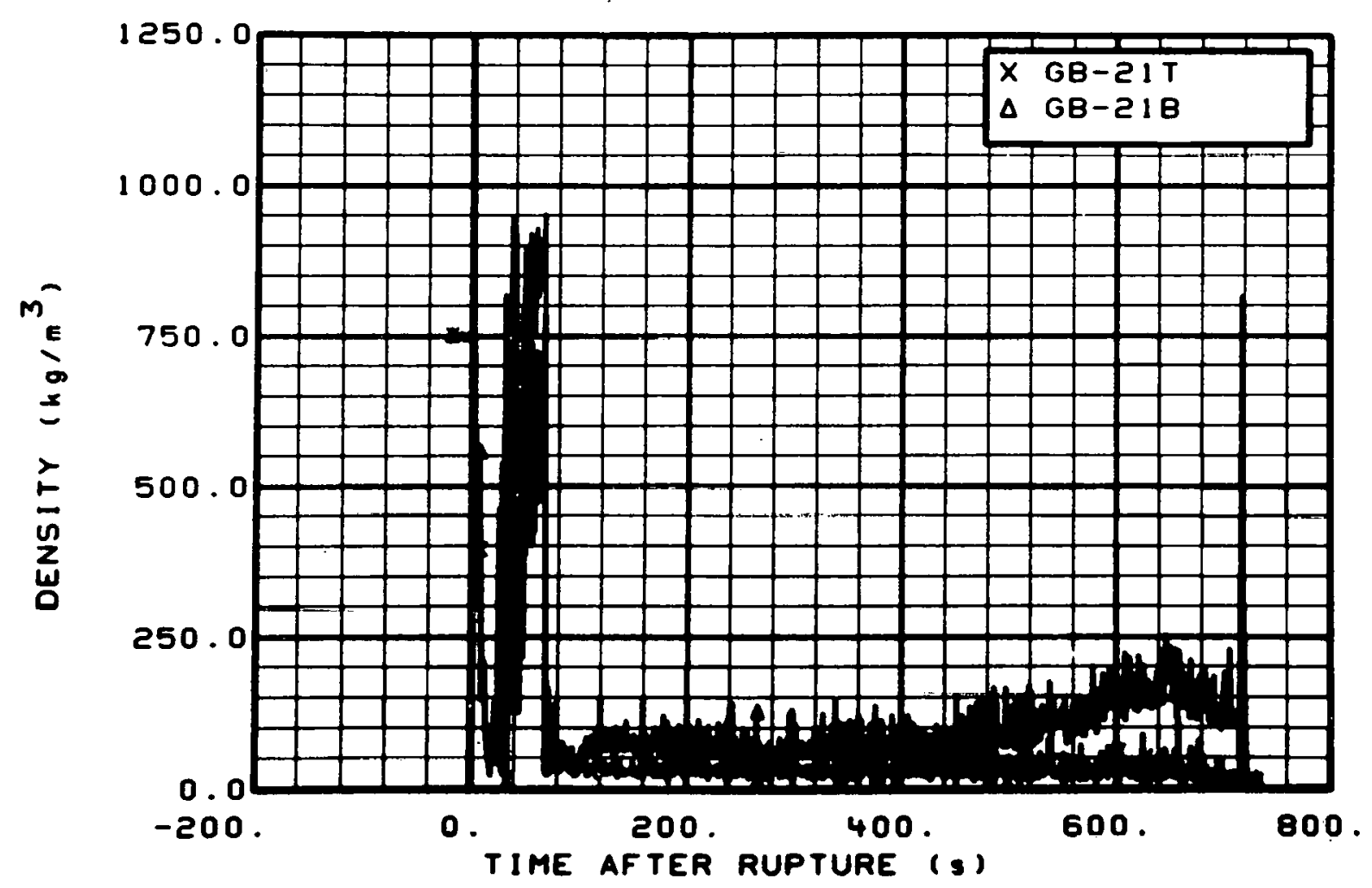

Fig. 292 Density in broken loop (GB-21T and GB-21B), from -20 to $736 \mathrm{~s}$.

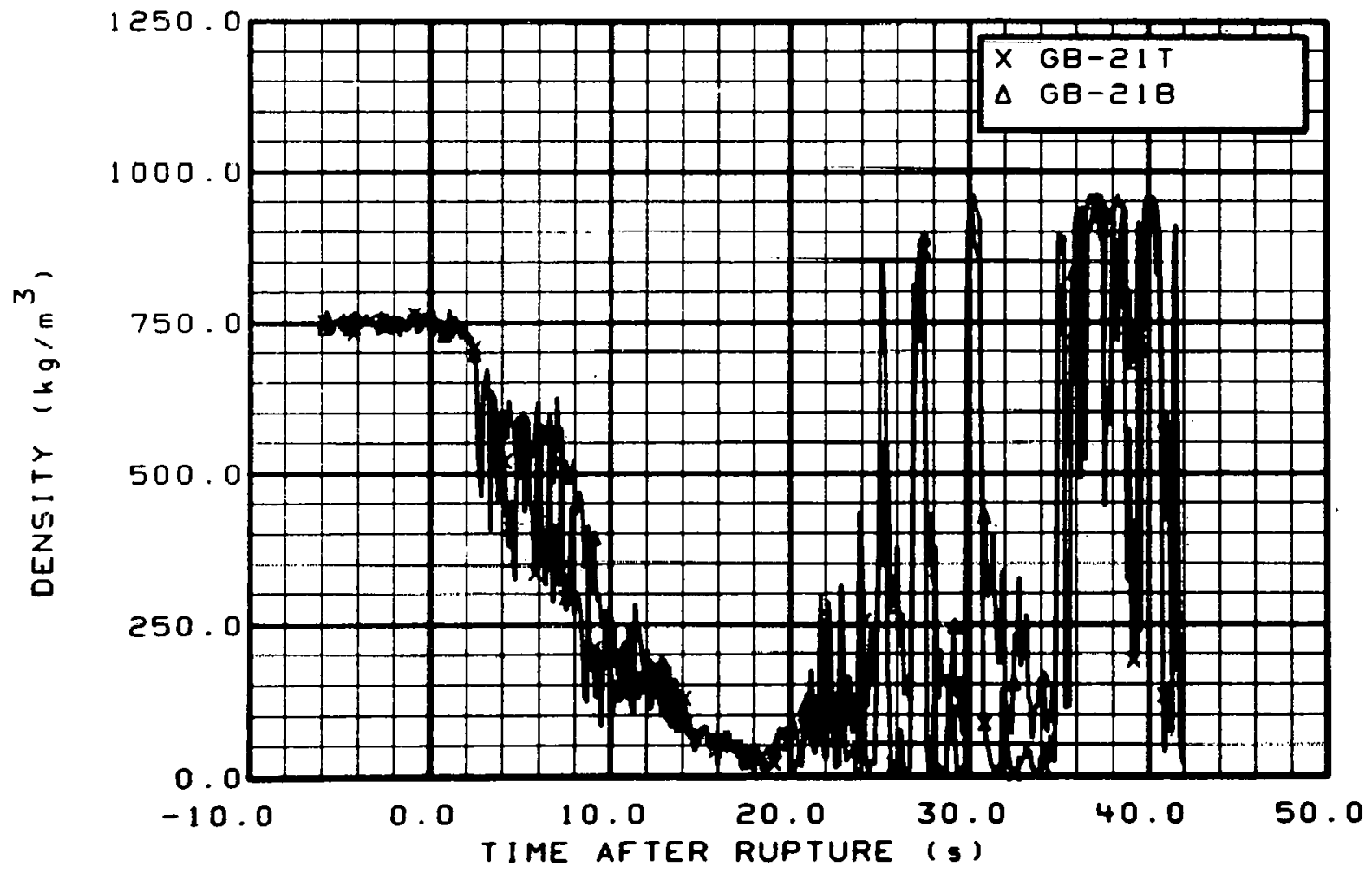

Fig. 293 Density in broken loop (GB-21T and GB-21B), from -6 to $42 \mathrm{~s}$. 


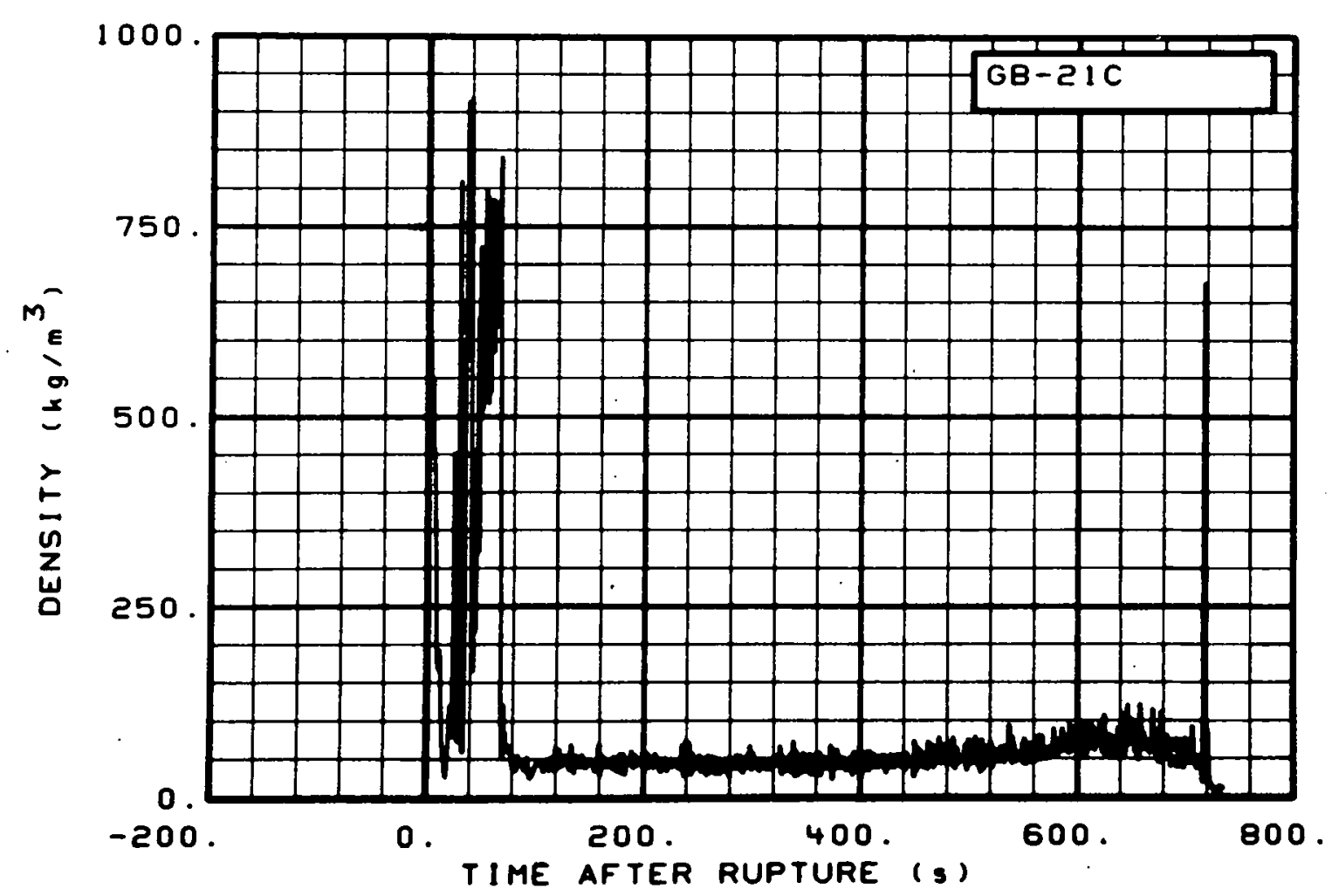

Fig. 294 Density in broken loop (GB-21C), from -20 to $736 \mathrm{~s}$.

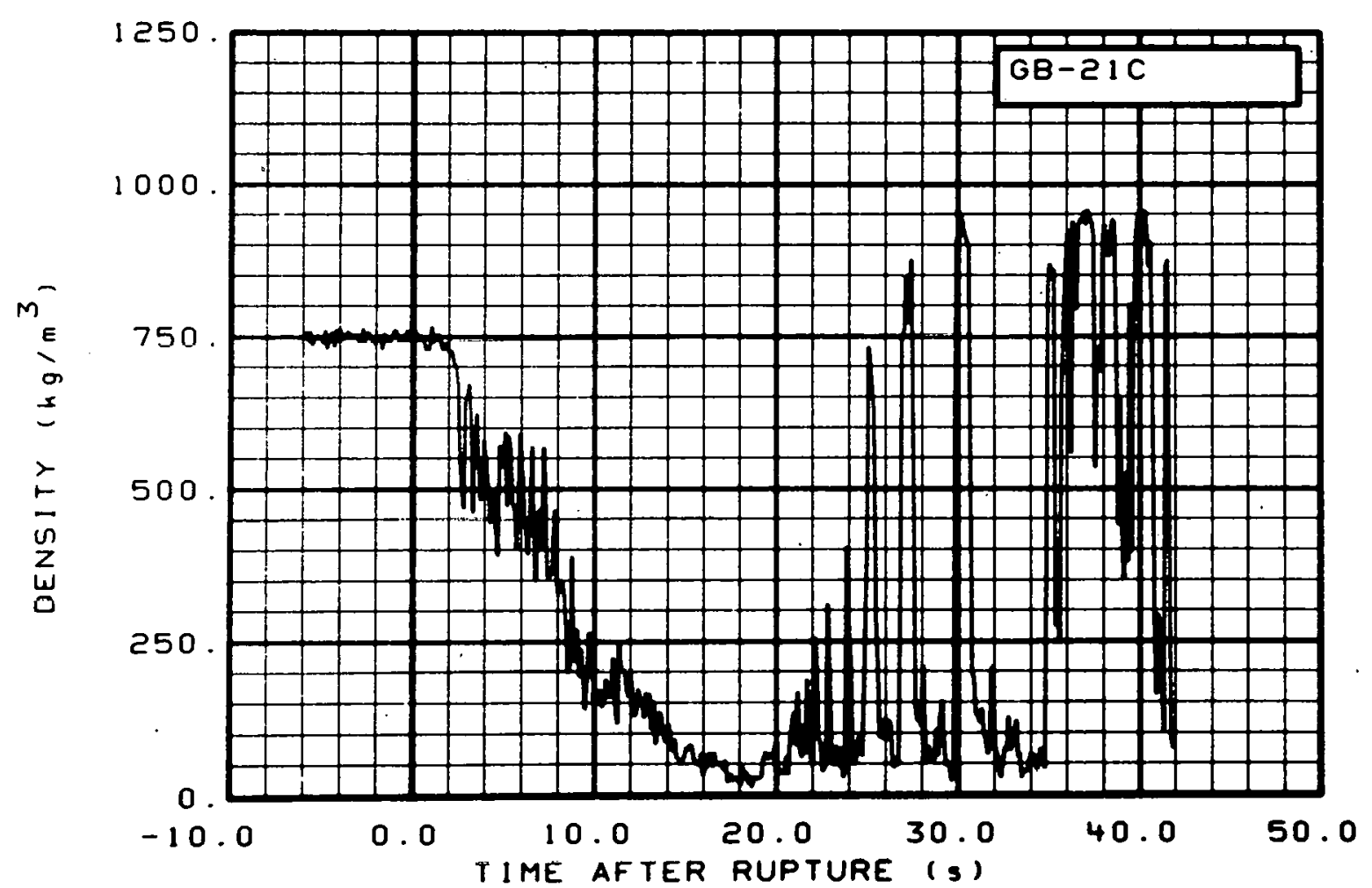

Fig. 295 Density in broken loop (GB-21C), from -6 to $42 \mathrm{~s}$. 


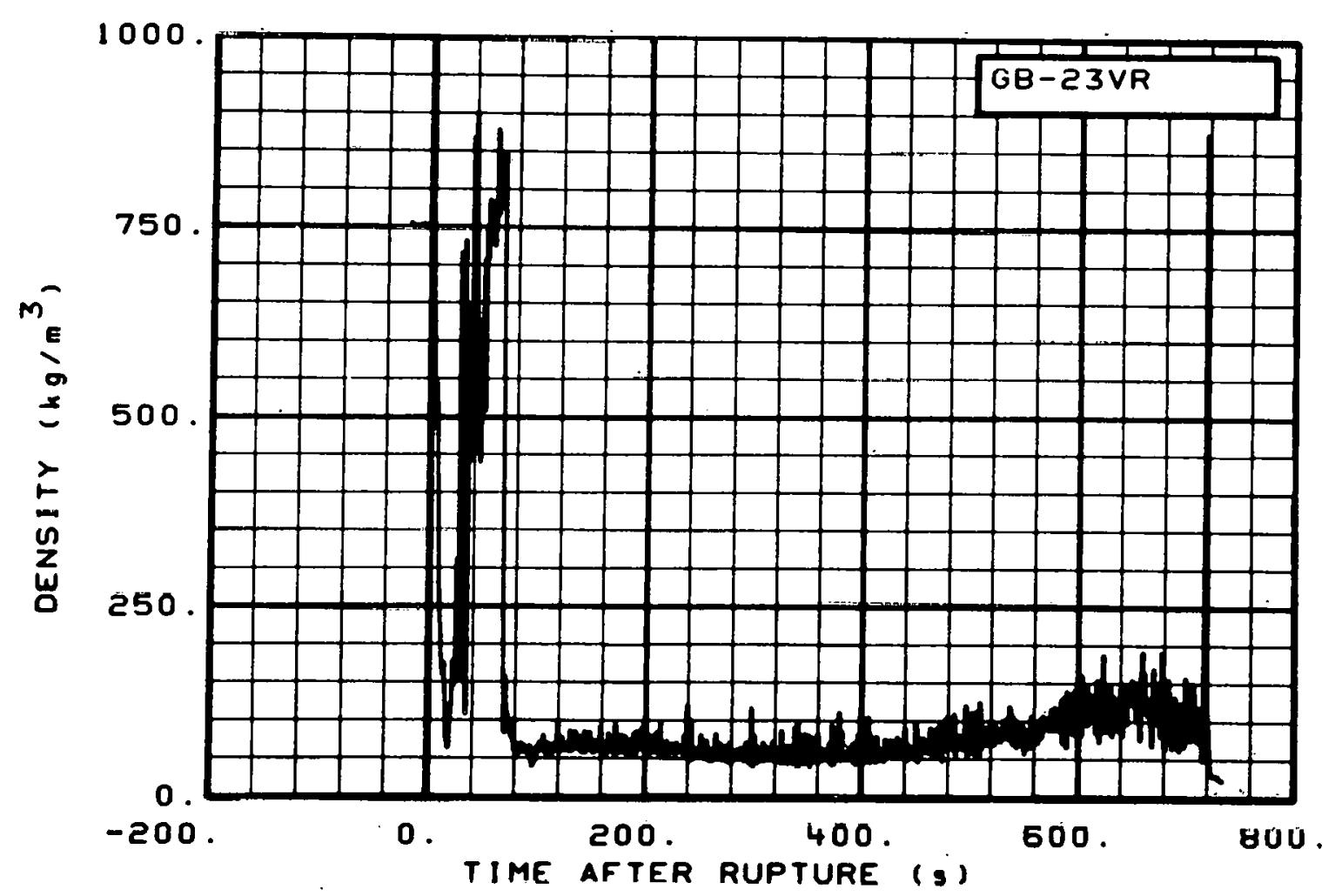

Fig. 296 Density in broken loop (GB-23VR), from -20 to $736 \mathrm{~s}$.

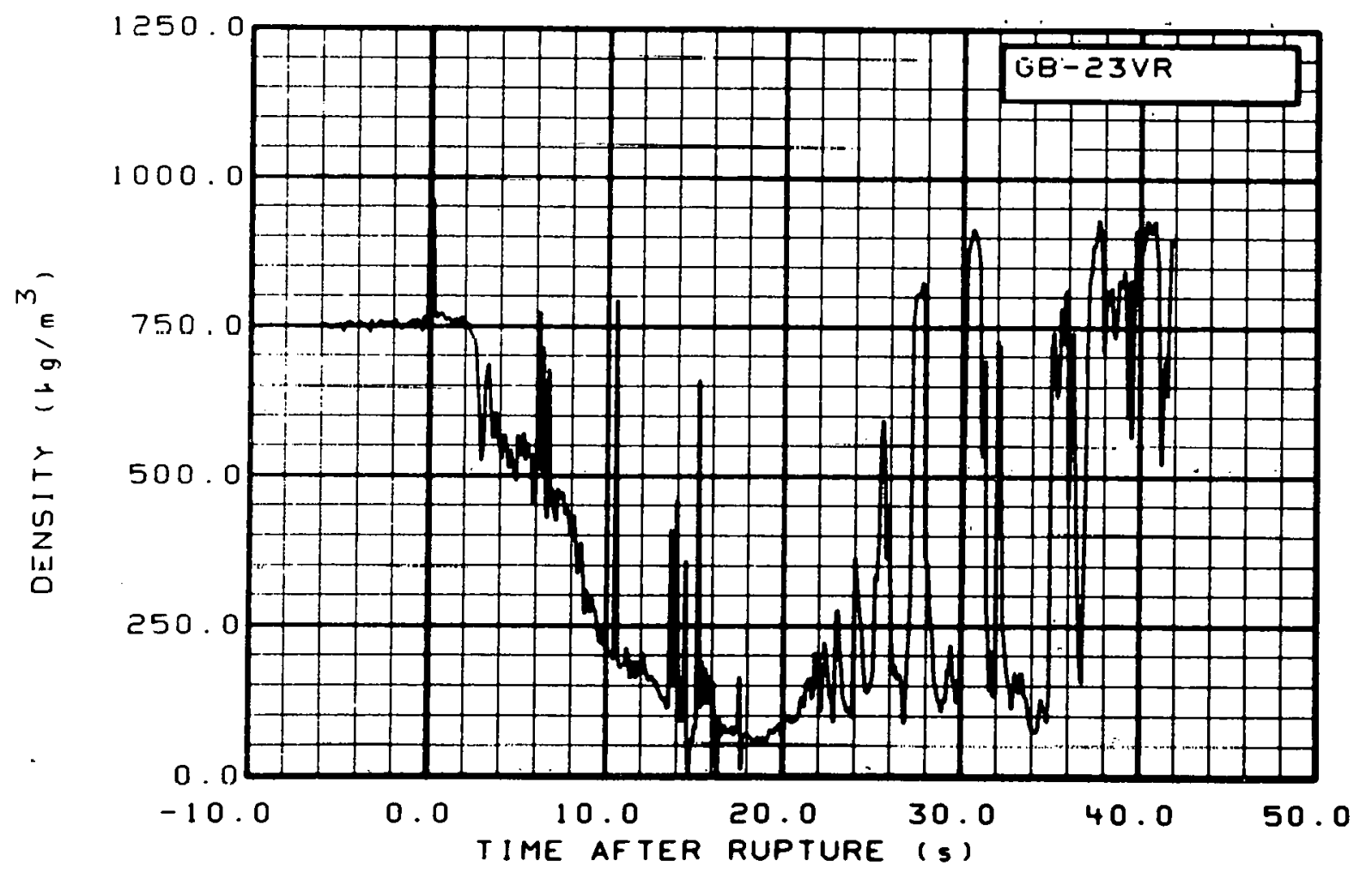

Fig. 297 Density in broken 10op (GB-23VR), from -6 to $42 \mathrm{~s}$. 


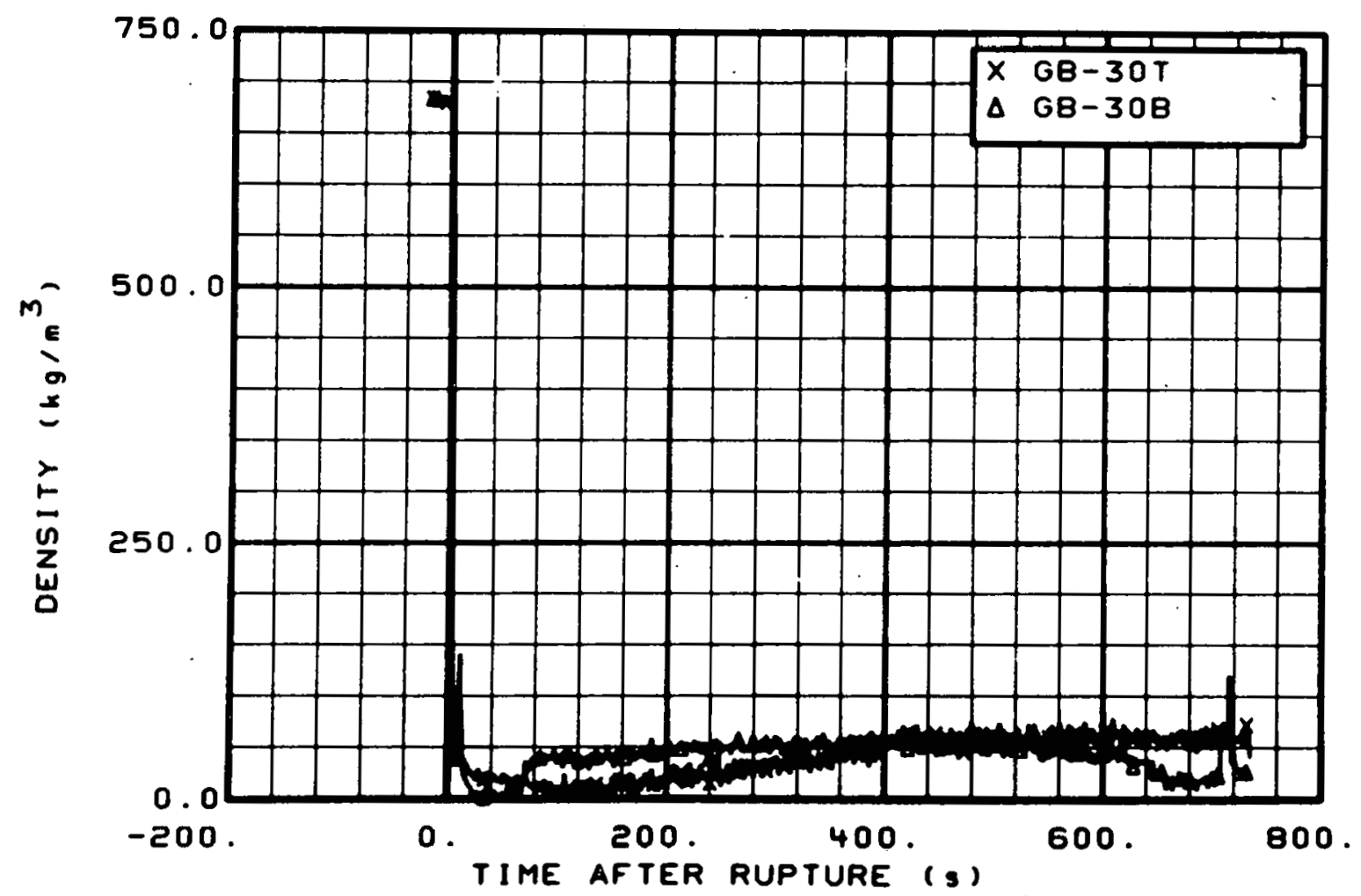

Fig. 298 Density in broken loop (GB-30T and GB-30B), from -20 to $736 \mathrm{~s}$.

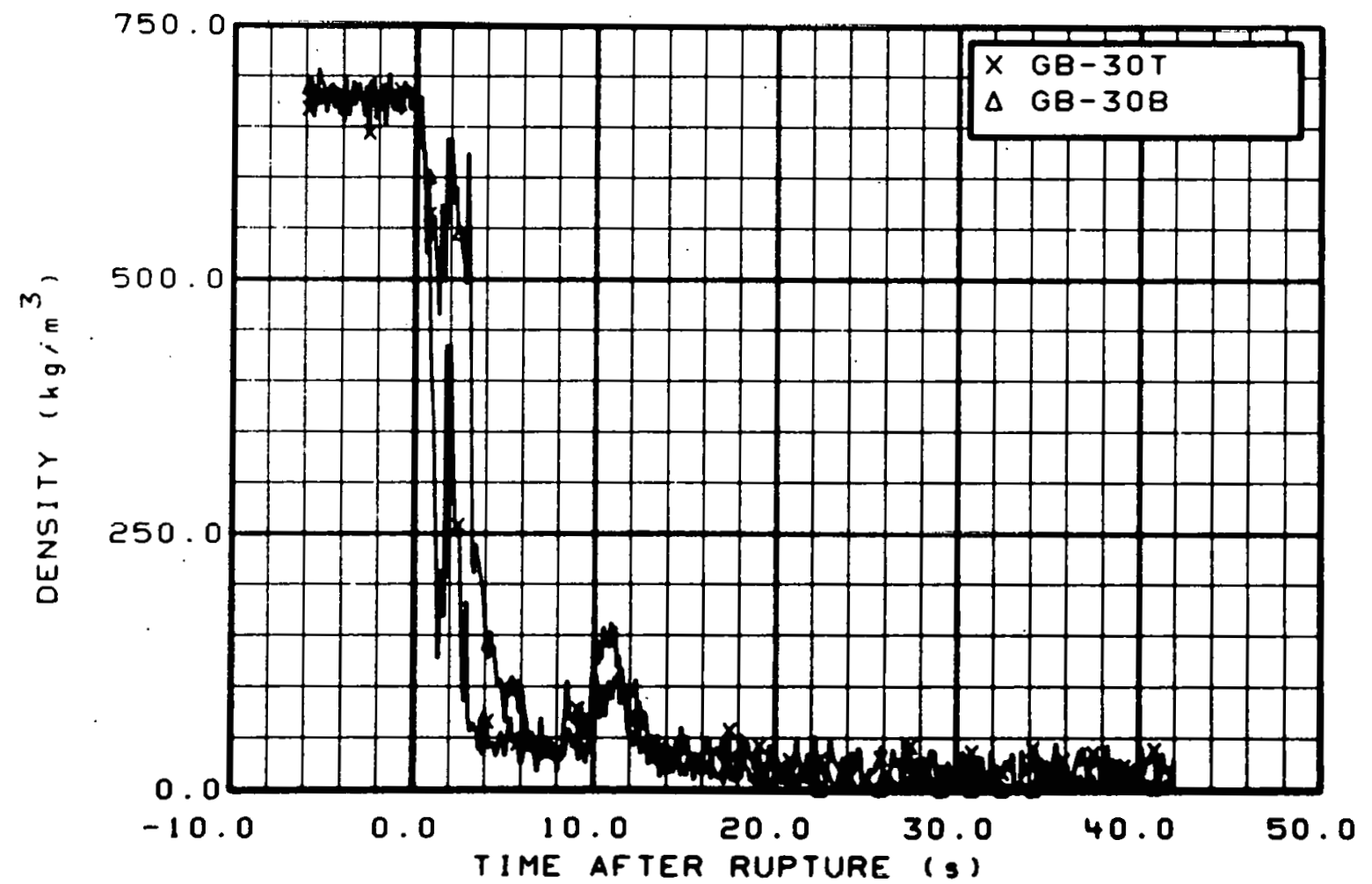

Fig. 299 Density in broken loop (GB-30T and GB-30B), from -6 to $42 \mathrm{~s}$. 


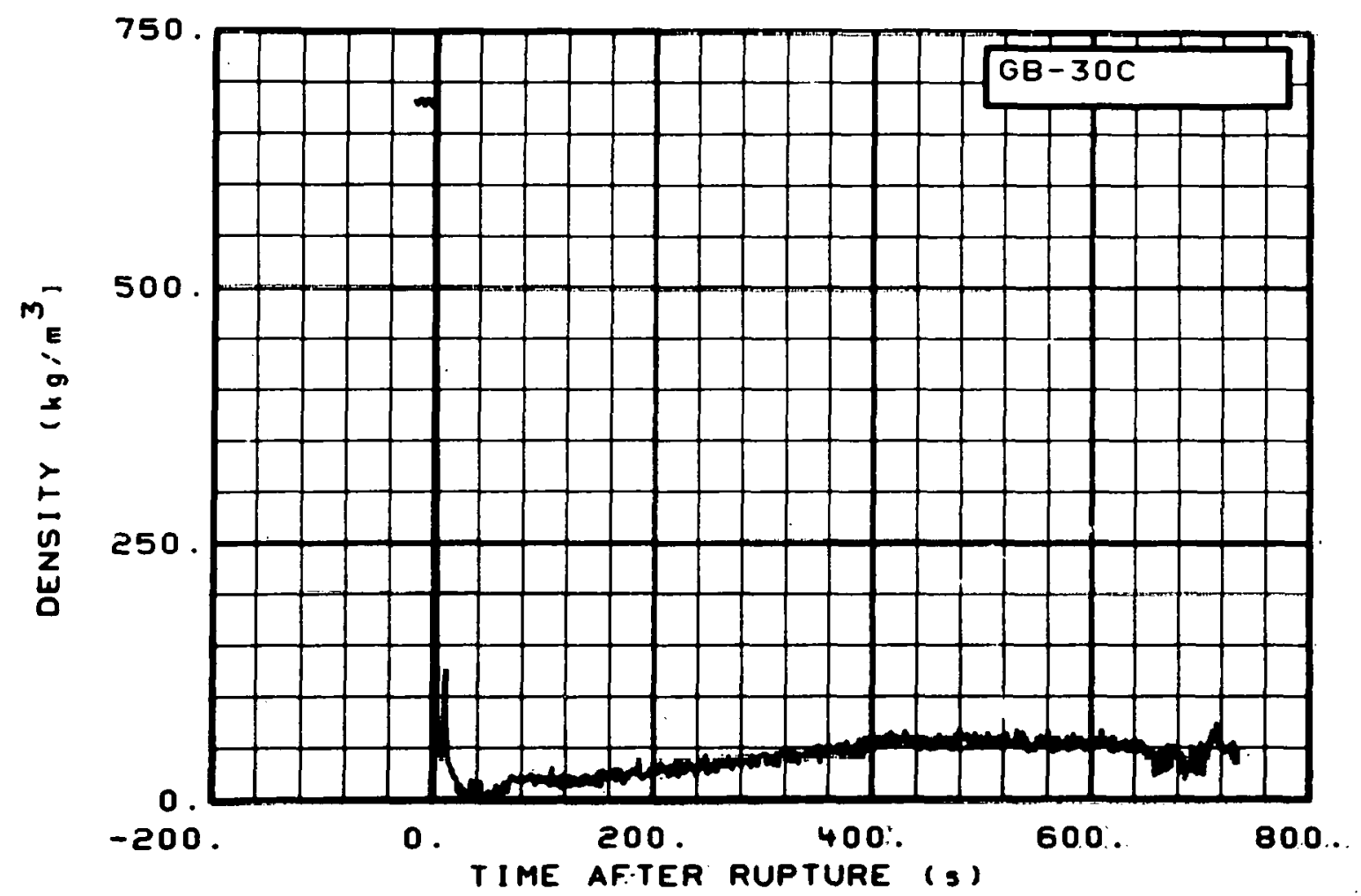

Fig. 300 Density in broken loop (GB-30C), from -20 to $736 \mathrm{~s}$.

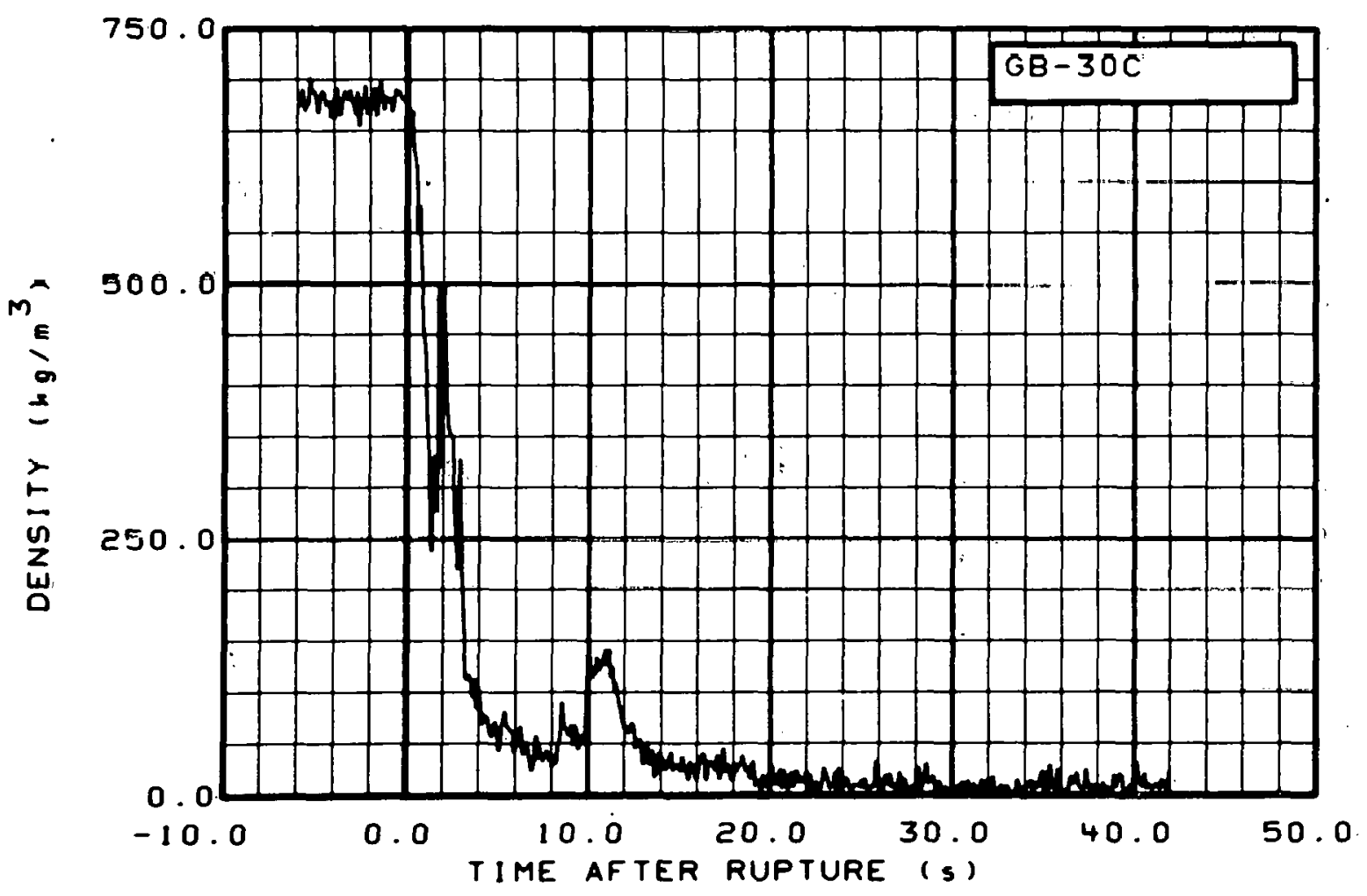

Fig. 301 Density in broken Toop (GB-30C), from -6 to $42 \mathrm{~s}$. 


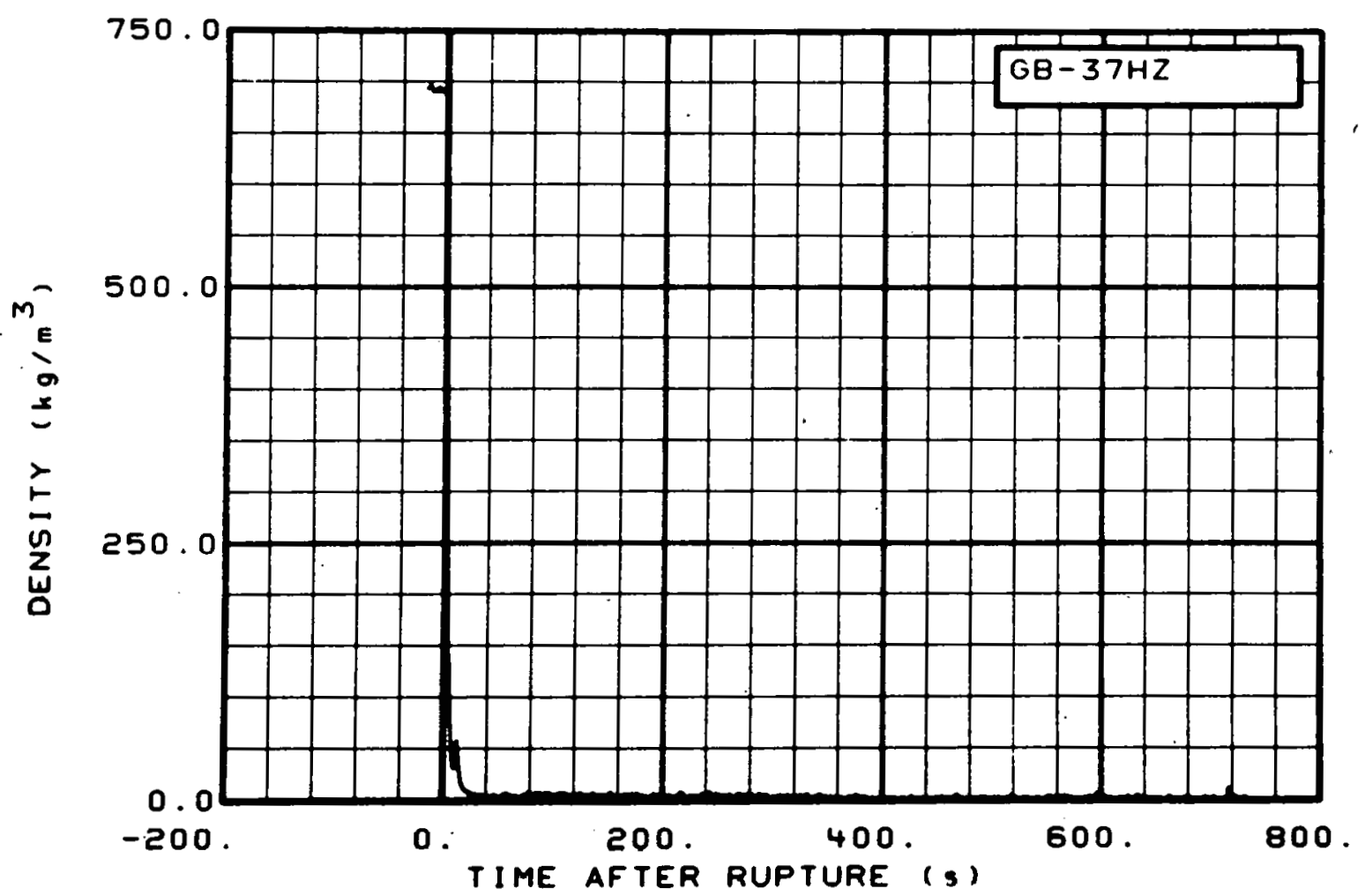

Fig. 302 Density in broken loop (GB-37HZ), from -20 to $736 \mathrm{~s}$.

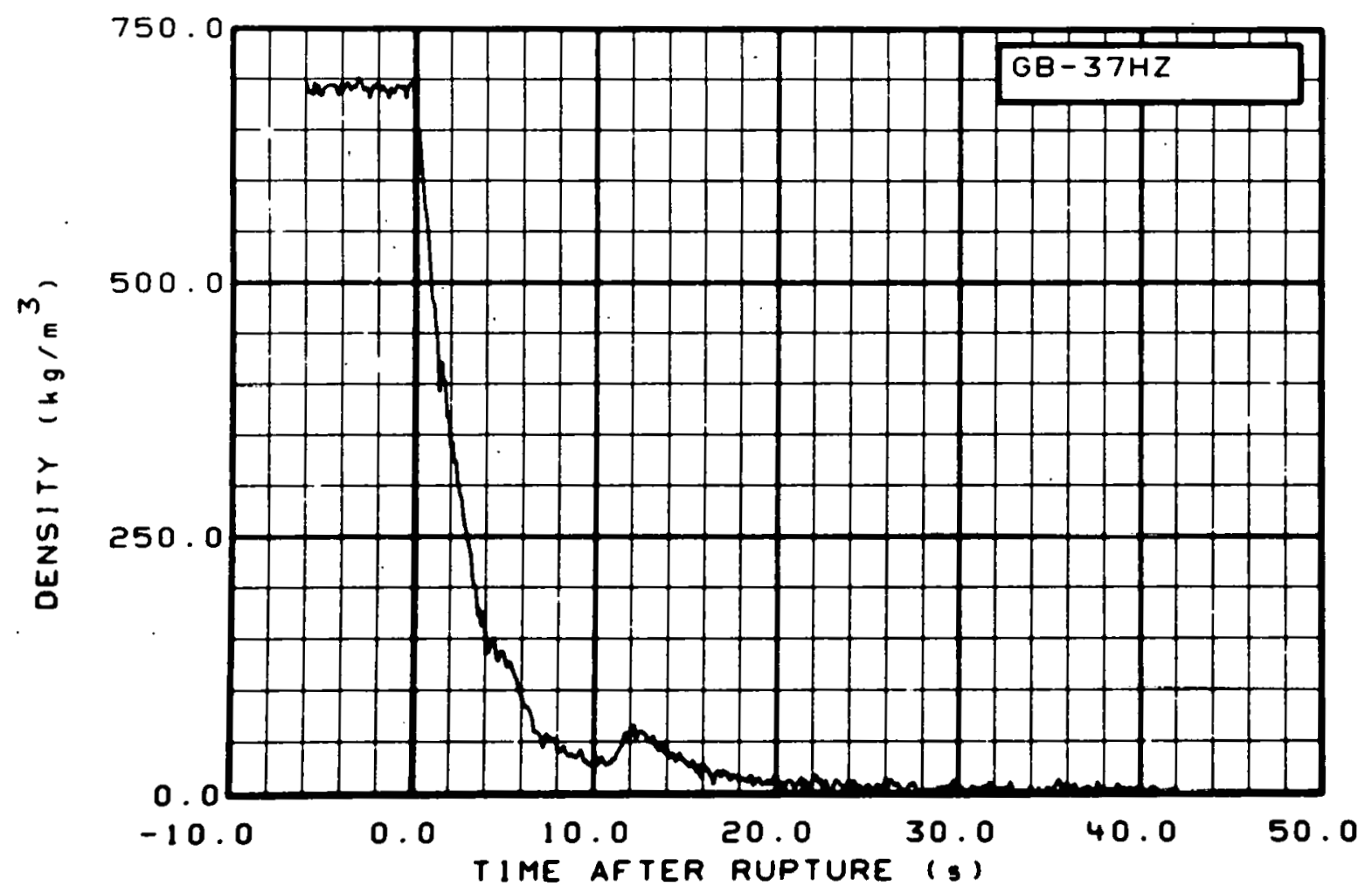

Fig. 303 Density in broken loop (GB-37HZ), from -6 to $42 \mathrm{~s}$. 


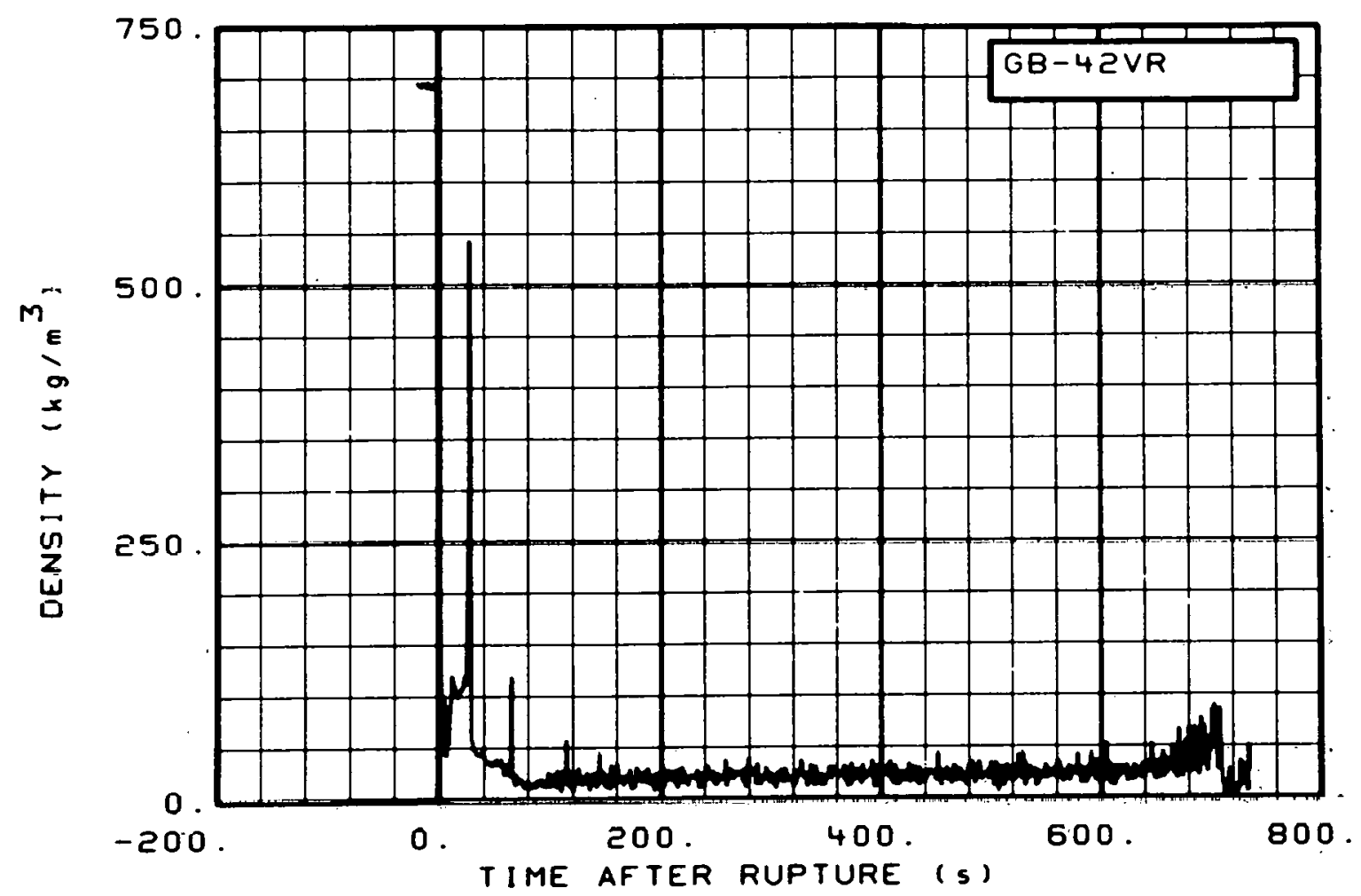

Fig. 304 Density in broken loop (GB-42VR), from -20 to $736 \mathrm{~s}$.

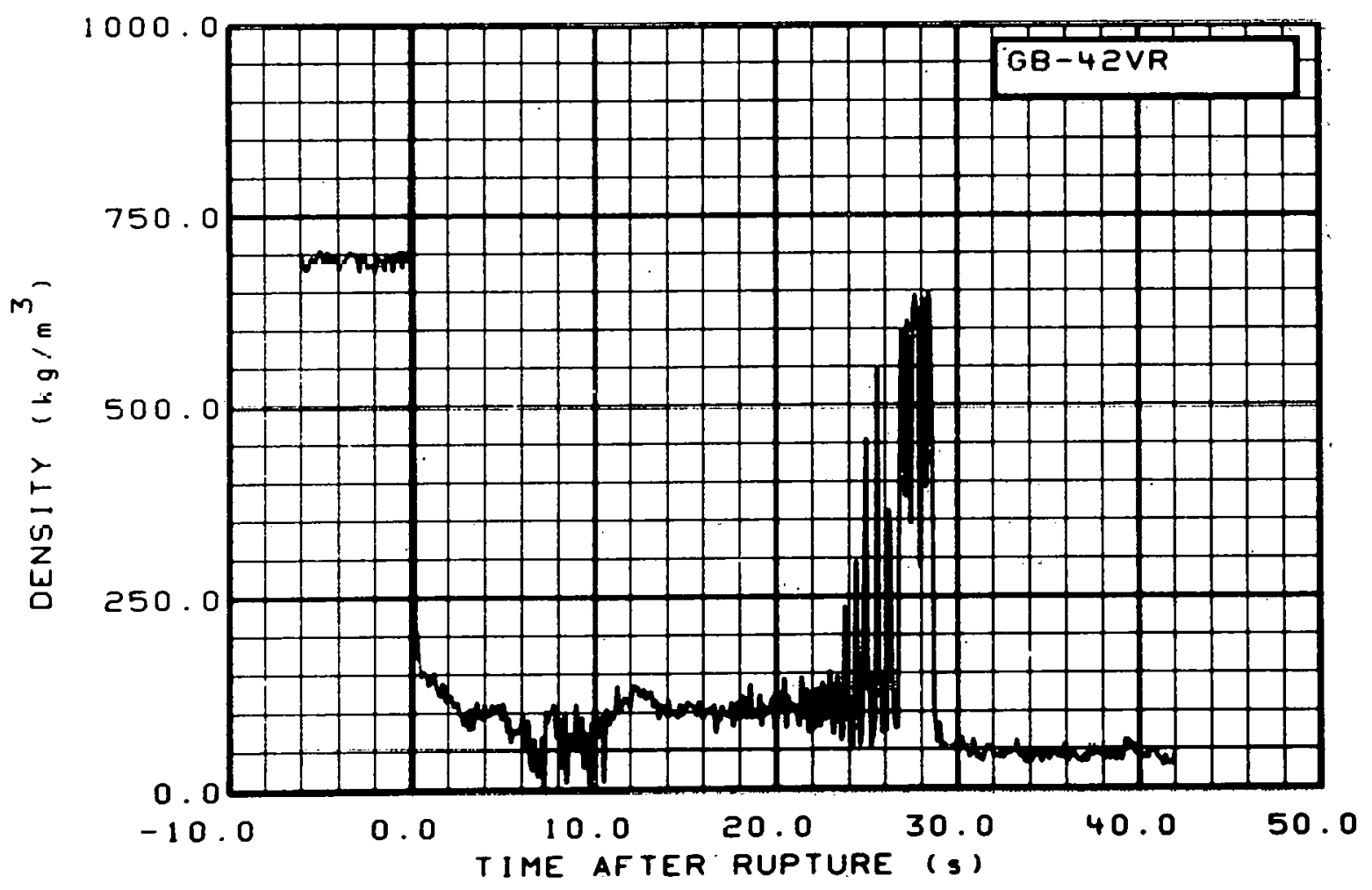

Fig. 305 Density in broken loop (GB-42VR), from -6 to $42 \mathrm{~s}$. 


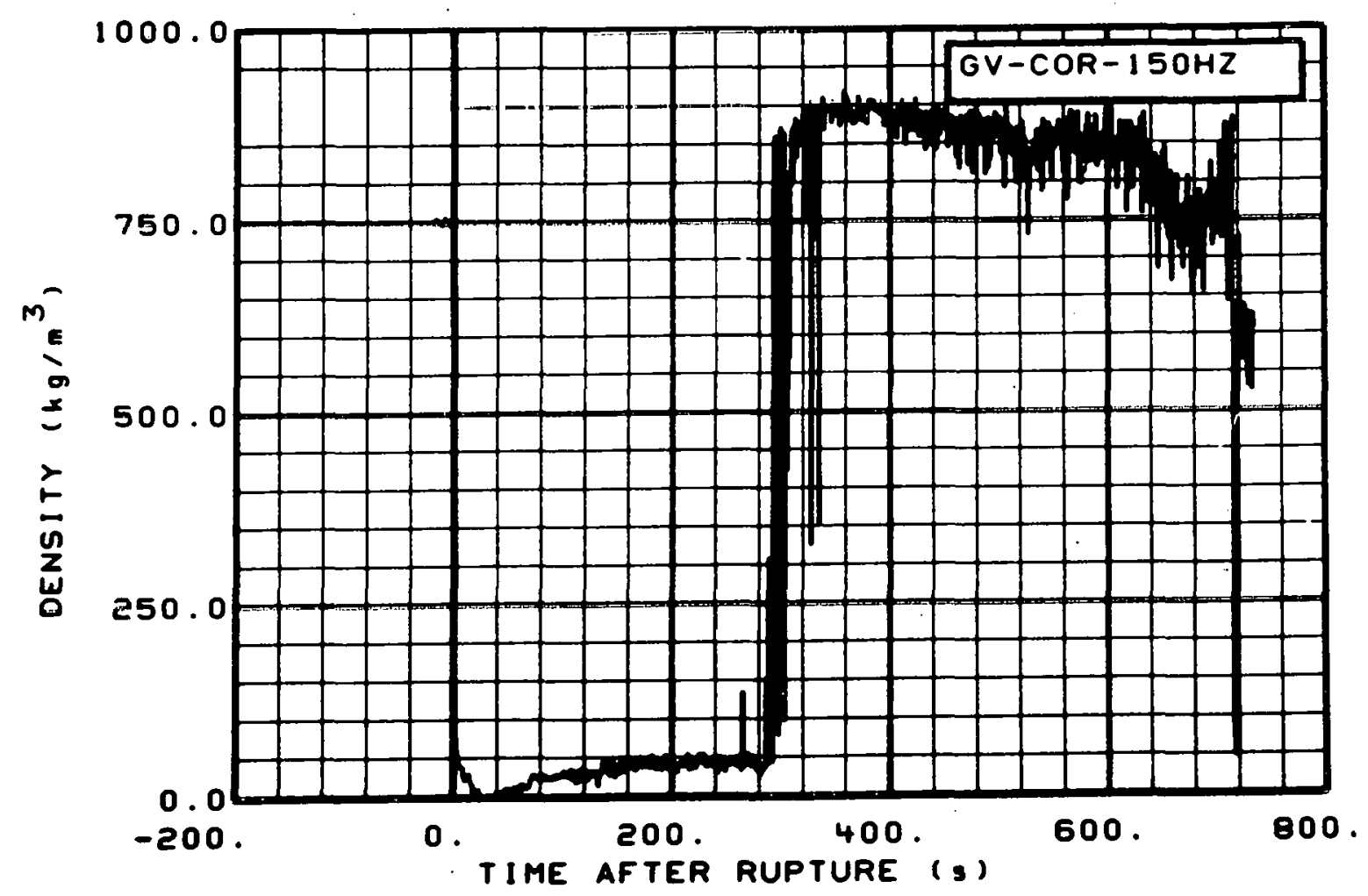

Fig. 306 Density in vessel (GV-COR-150HZ), from -20 to $736 \mathrm{~s}$.

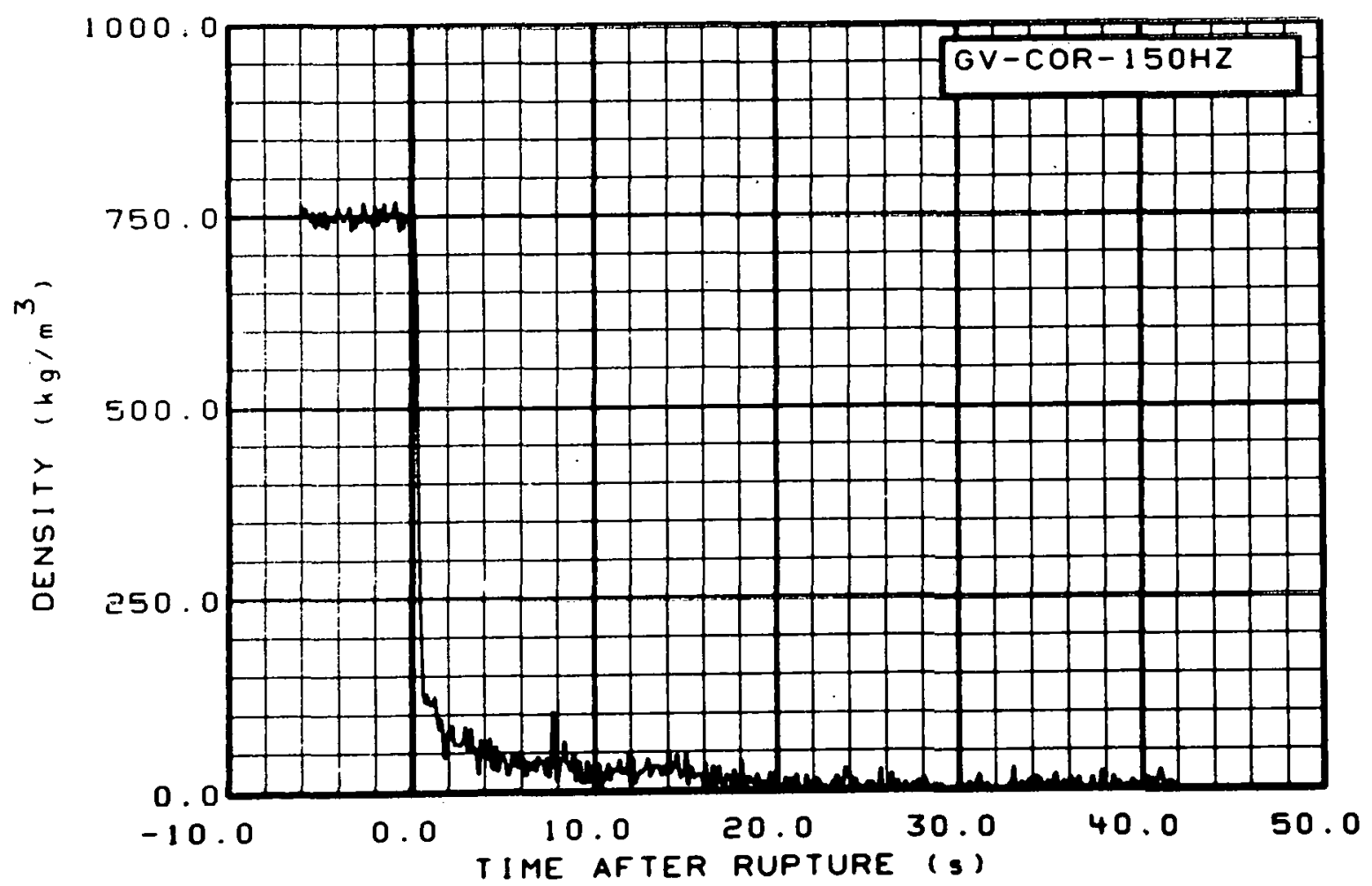

Fig. 307 Density in vessel (GV-COR-150HZ), froiil -6 to $42 \mathrm{~s}$. 


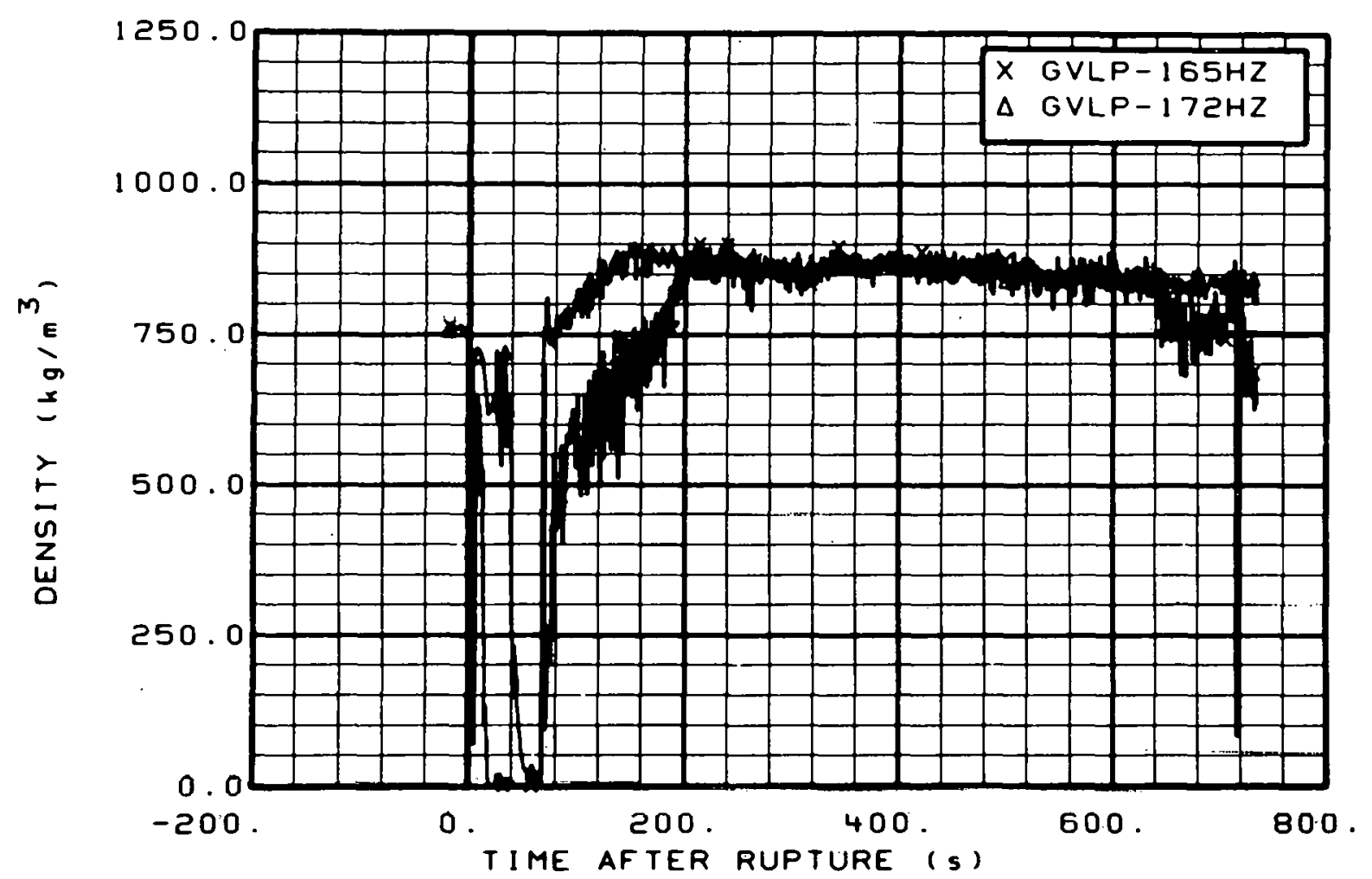

Fig. 308 Density in vessel (GVLP-165HZ and GVLP-172HZ), from -20 to $736 \mathrm{~s}$.

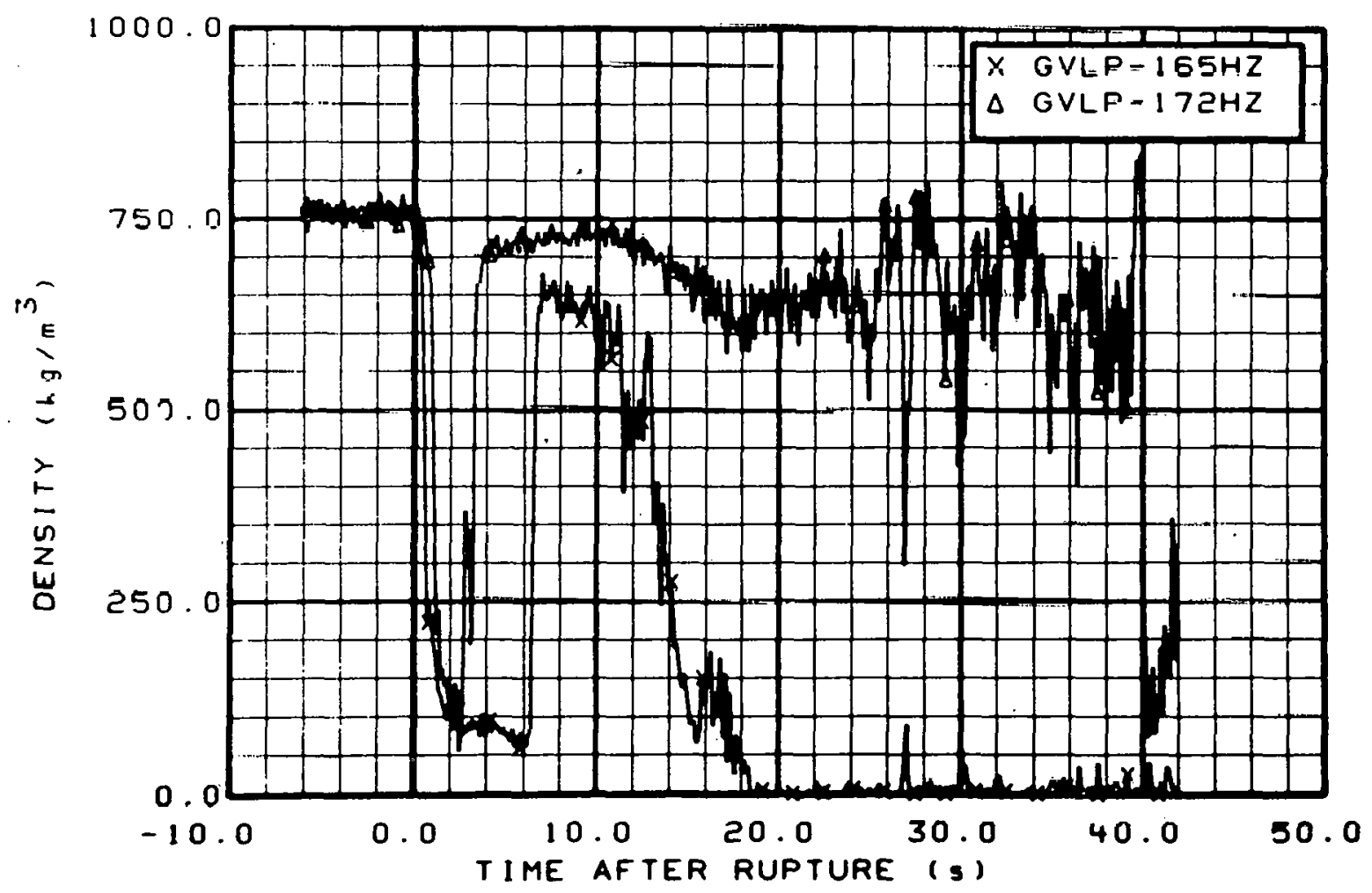

Fig. 309 Density in vessel (GVLP-165HZ and GVLP-172HZ), from -6 to $42 \mathrm{~s}$. 


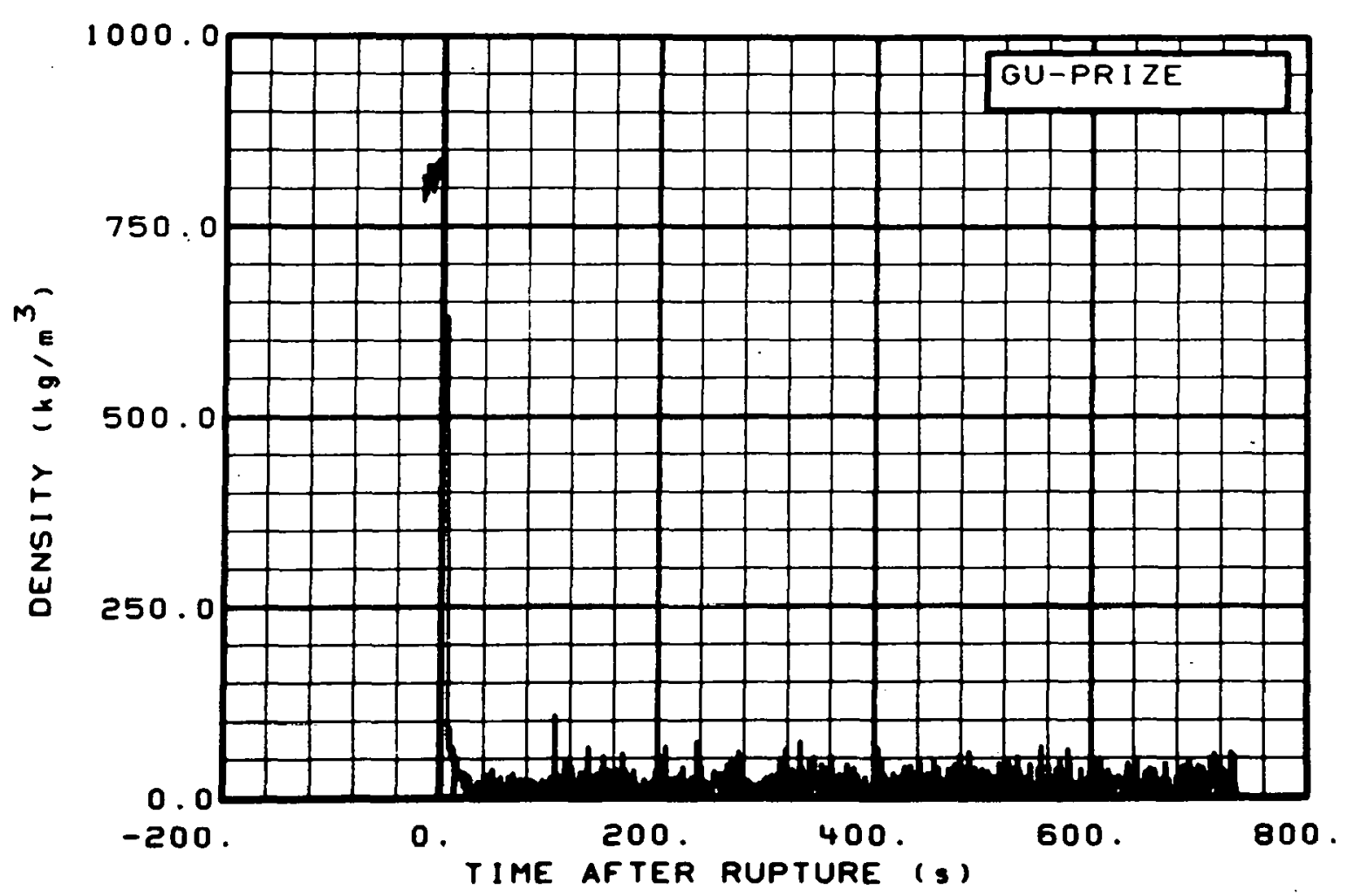

Fig. 310 Density in pressurizer (GU-PRIZE), from -20 to $736 \mathrm{~s}$.

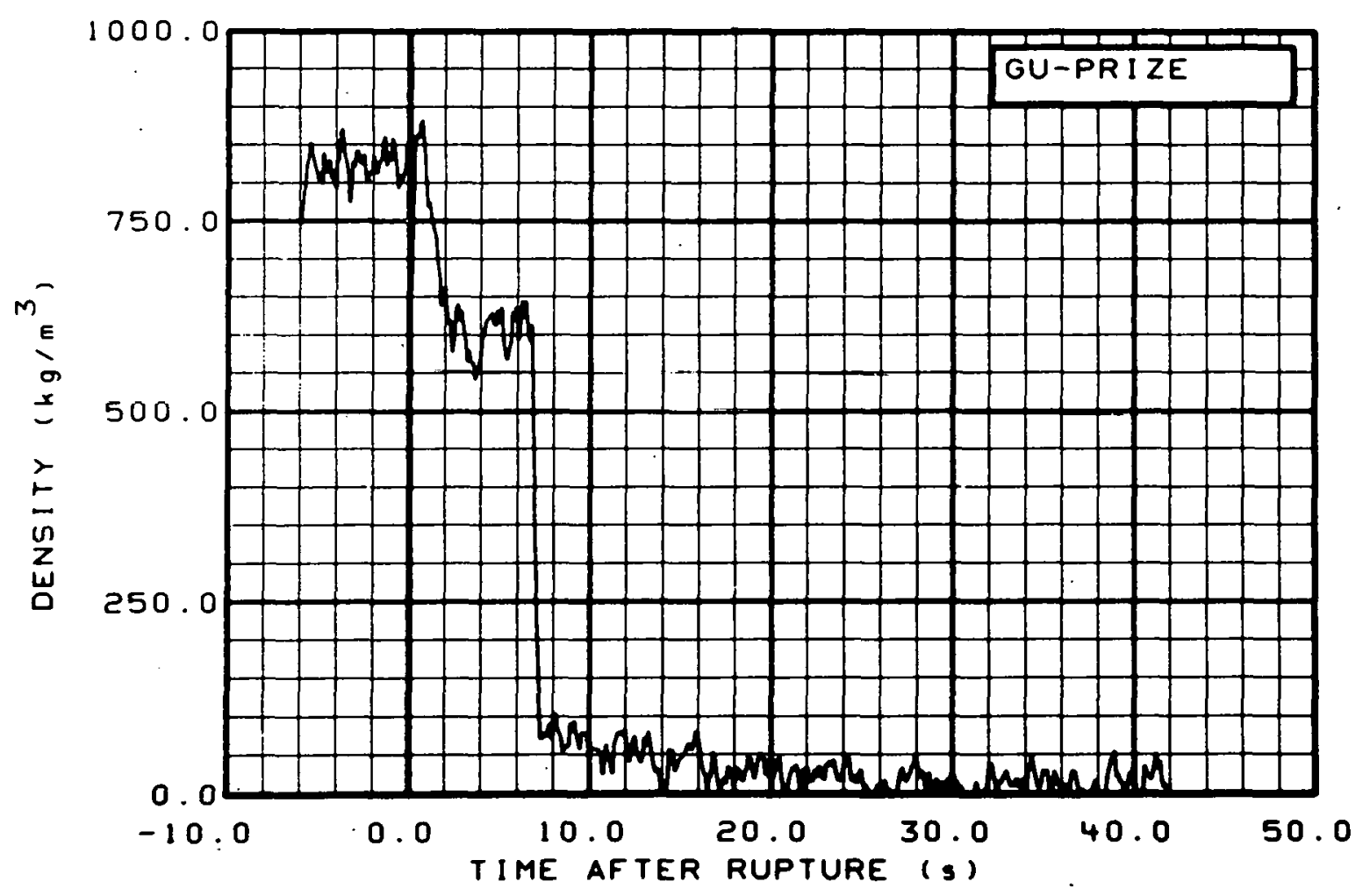

Fig. 311 Density in pressurizer (GU-PRIZE), from -6 to $42 \mathrm{~s}$. 


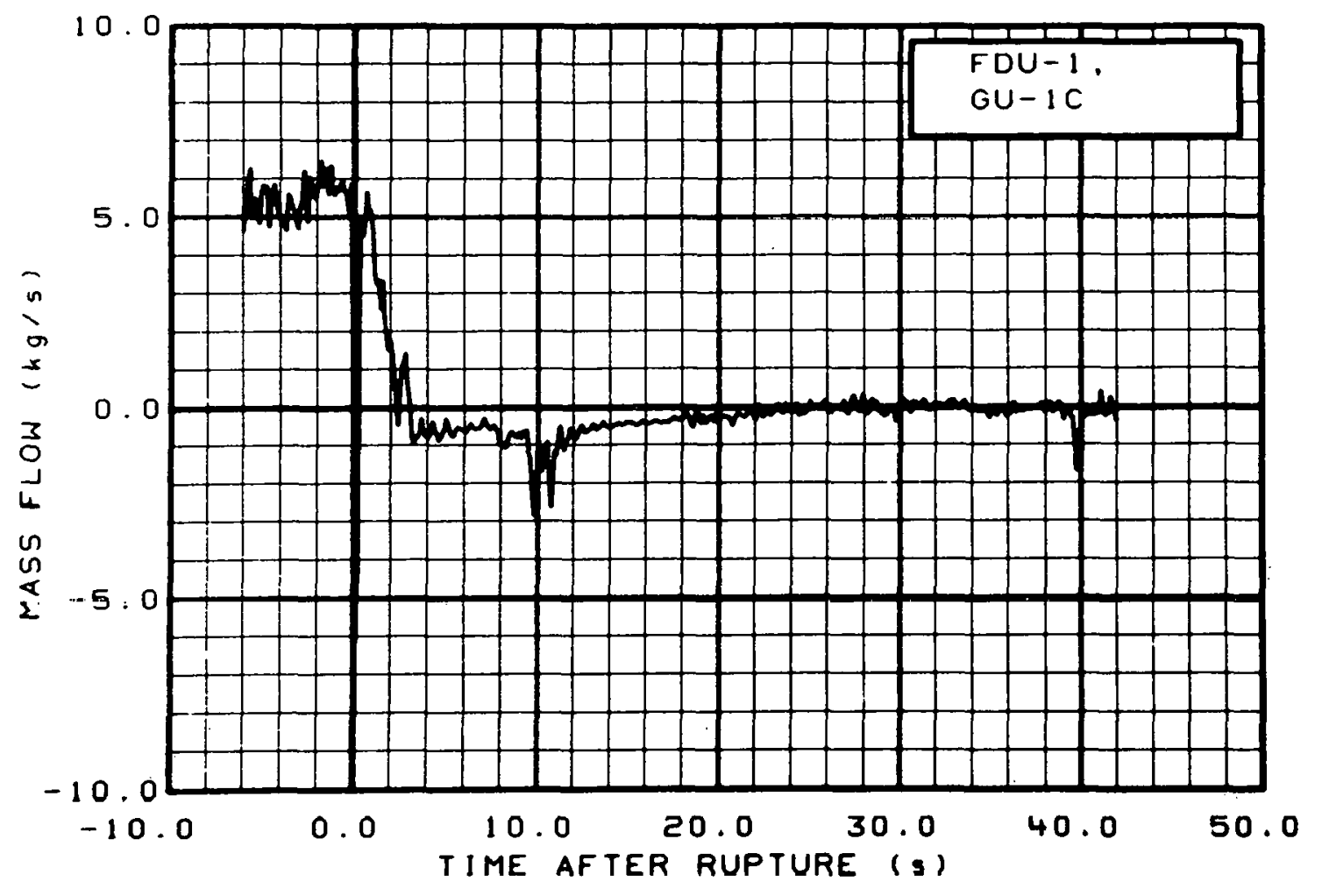

Fig. 312 Mass flow in intact loop (FDU-1, GU-1C), from -6 to $42 \mathrm{~s}$.

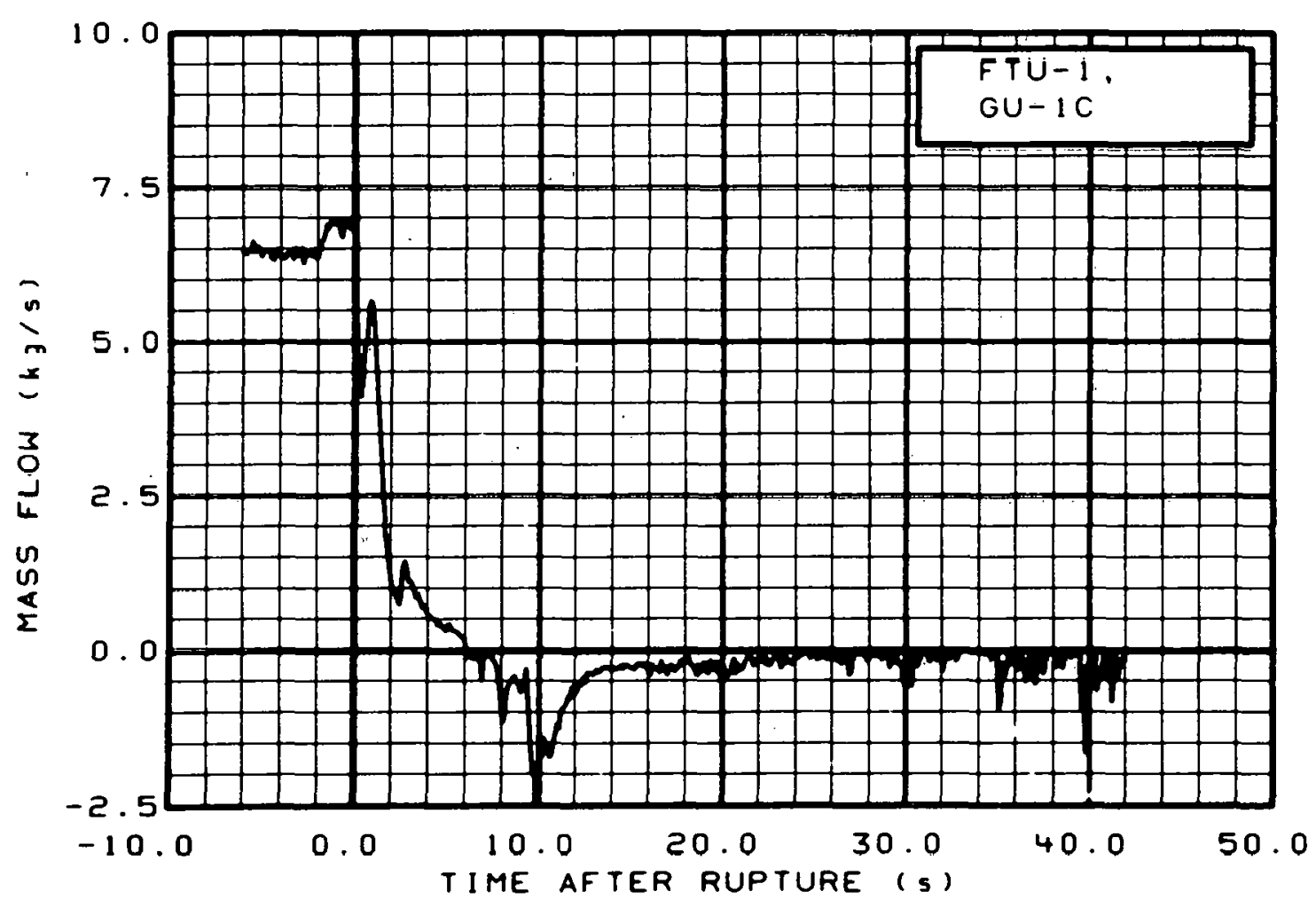

Fig. 313 Mass flow in intact loop (FTU-1, GU-1C), from -6 to $42 \mathrm{~s}$. 


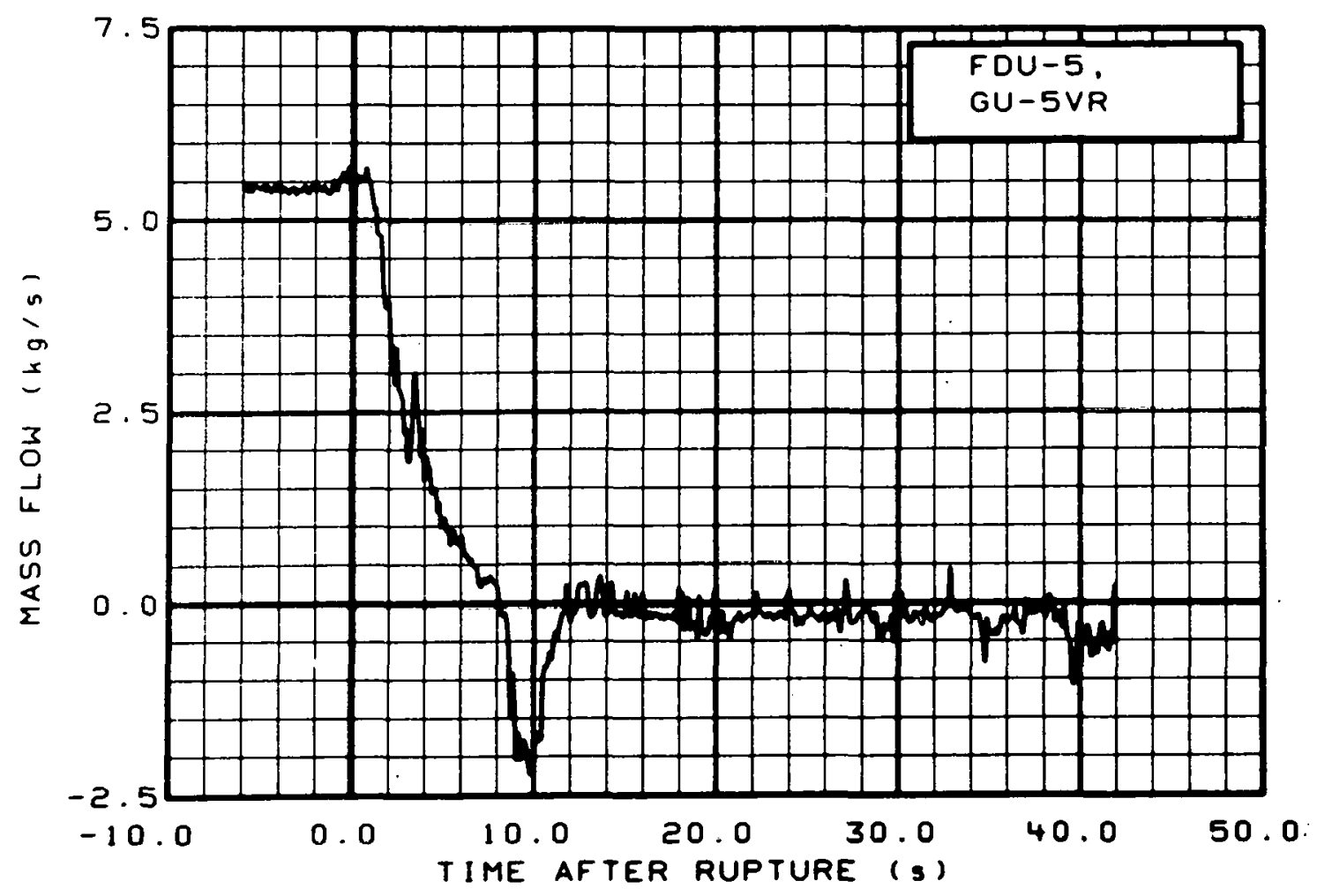

Fig. 314 Mass flow in intact loop (FDU-5, GU-5VR), from -6 to $42 \mathrm{~s}$ :

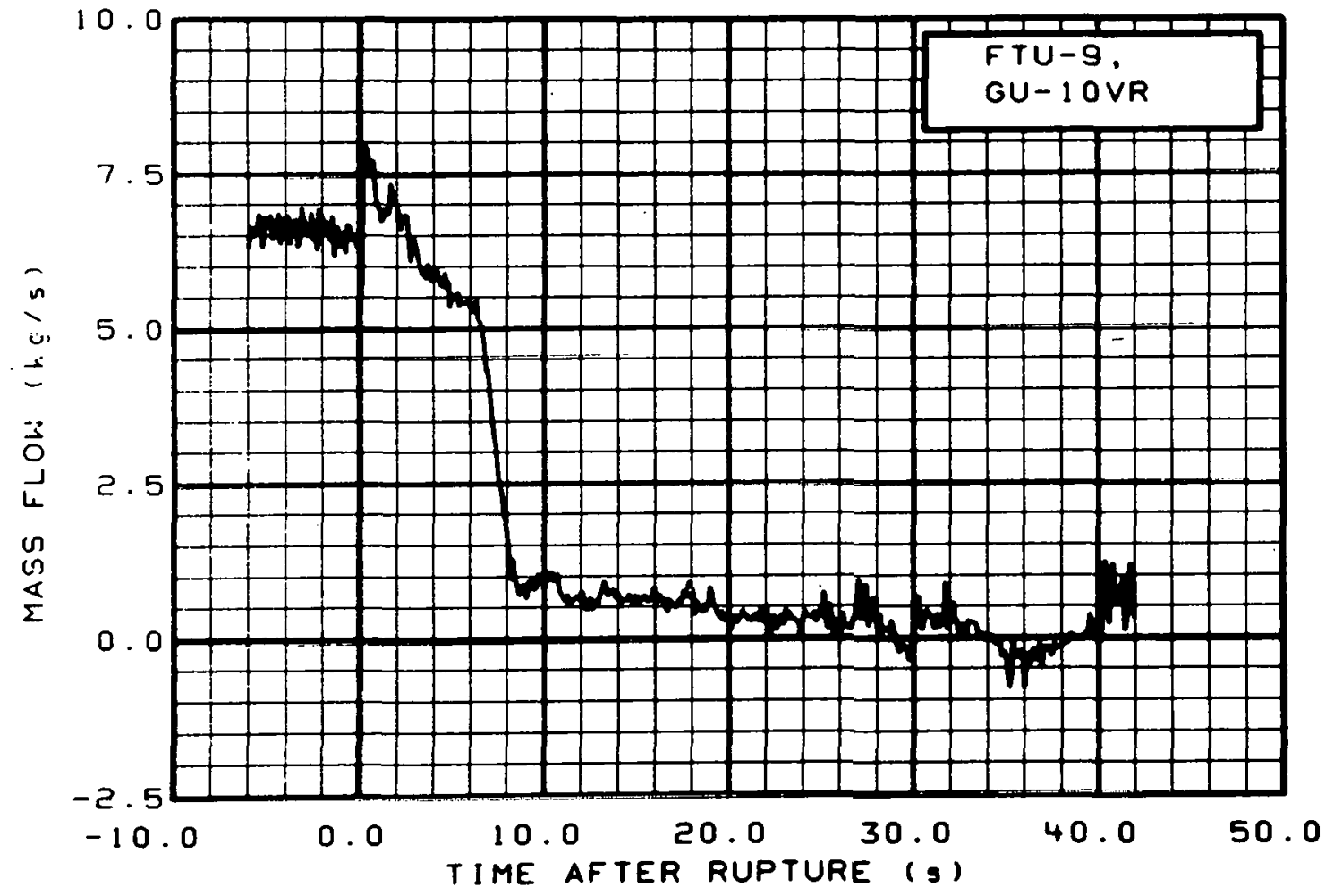

Fig. 315 Mass flow in intact loop (FTU-9, GU-IUVR), from -6 to $42 \mathrm{~s}$. 


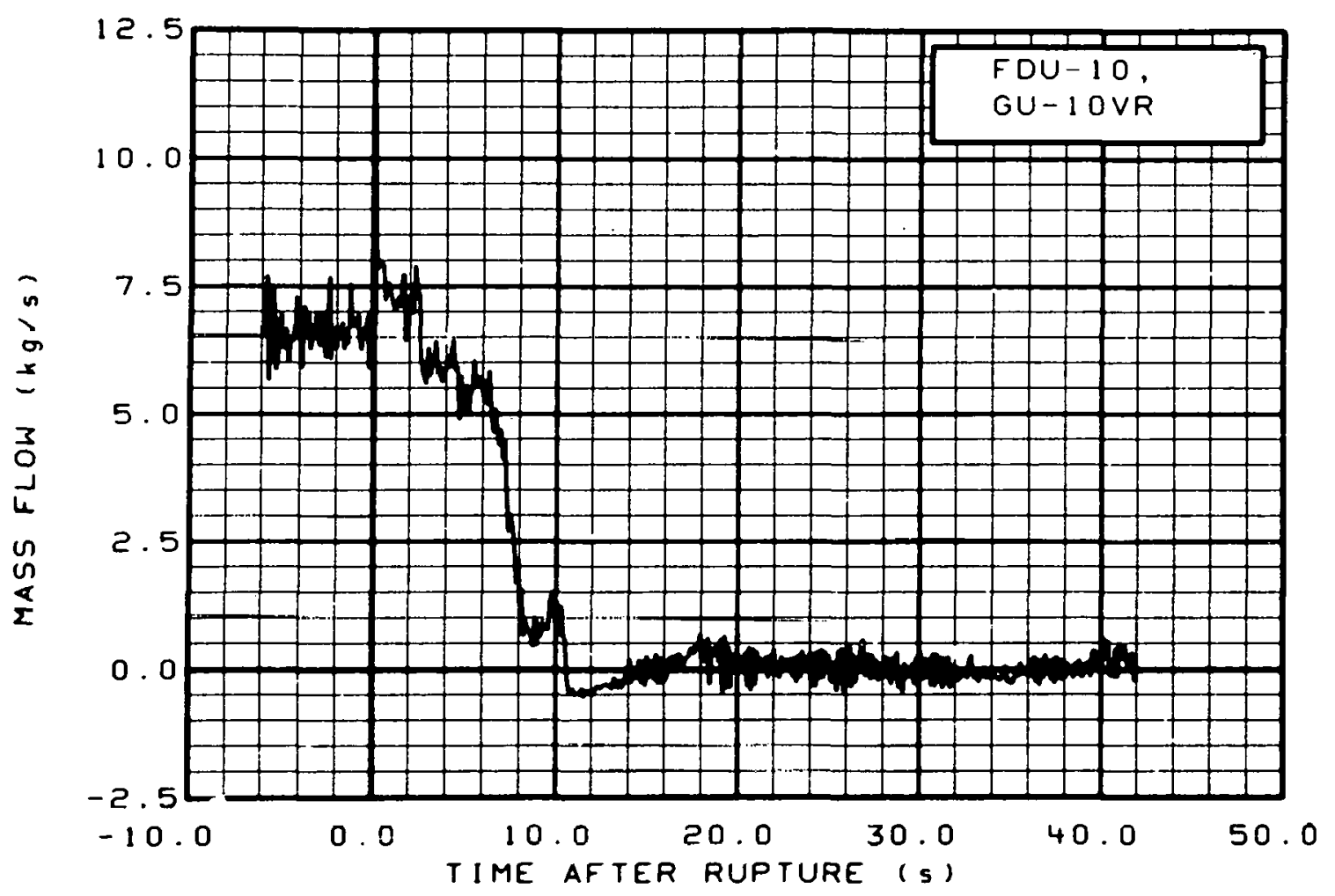

Fig. 316 Mass flow in intact loop (FDU-10, GU-10VR), from -6 to $42 \mathrm{~s}$.

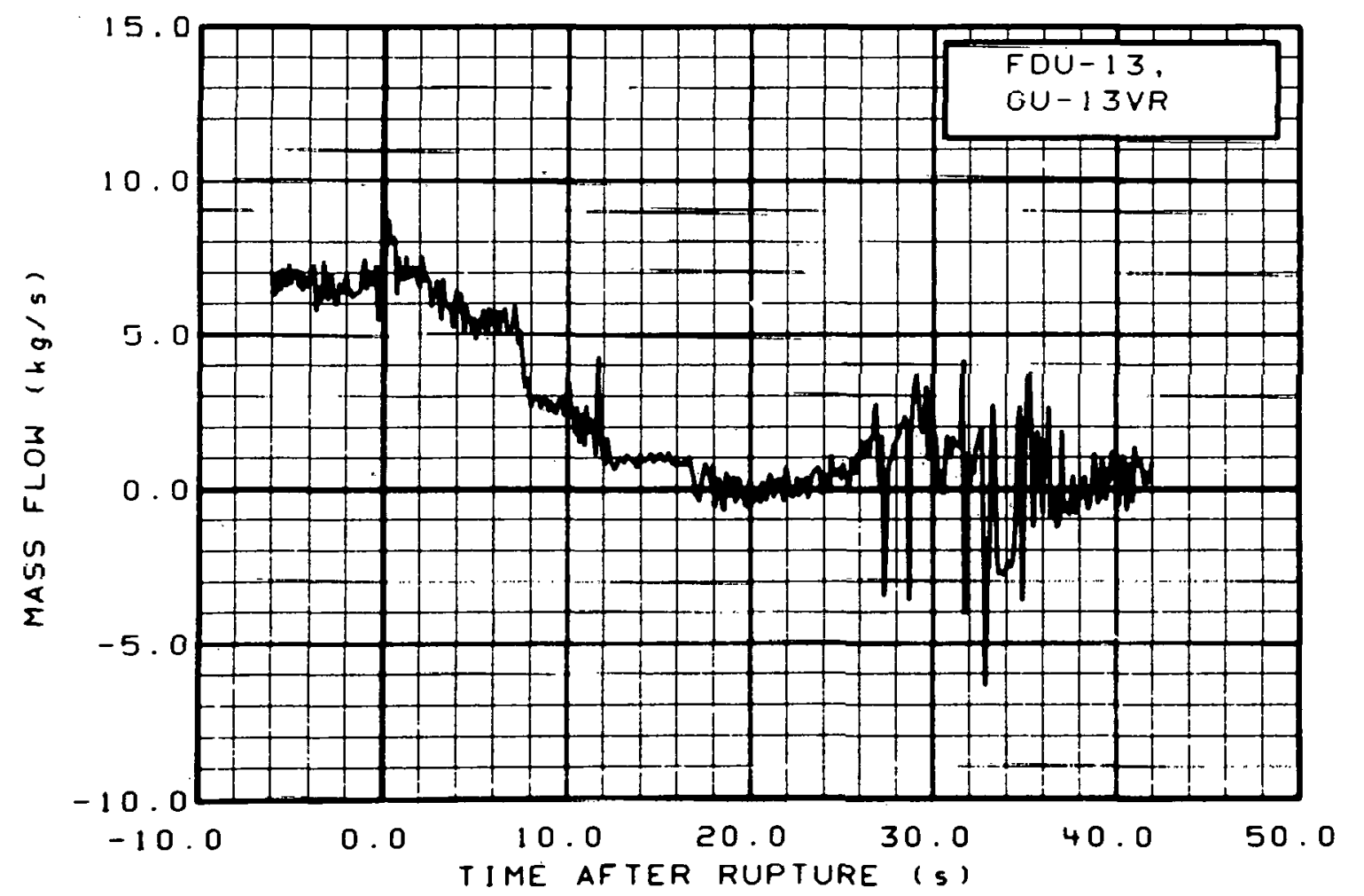

Fig. 317 Mass flow in intact loop (FDU-13, GU-13VR), from -6 to $42 \mathrm{~s}$. 


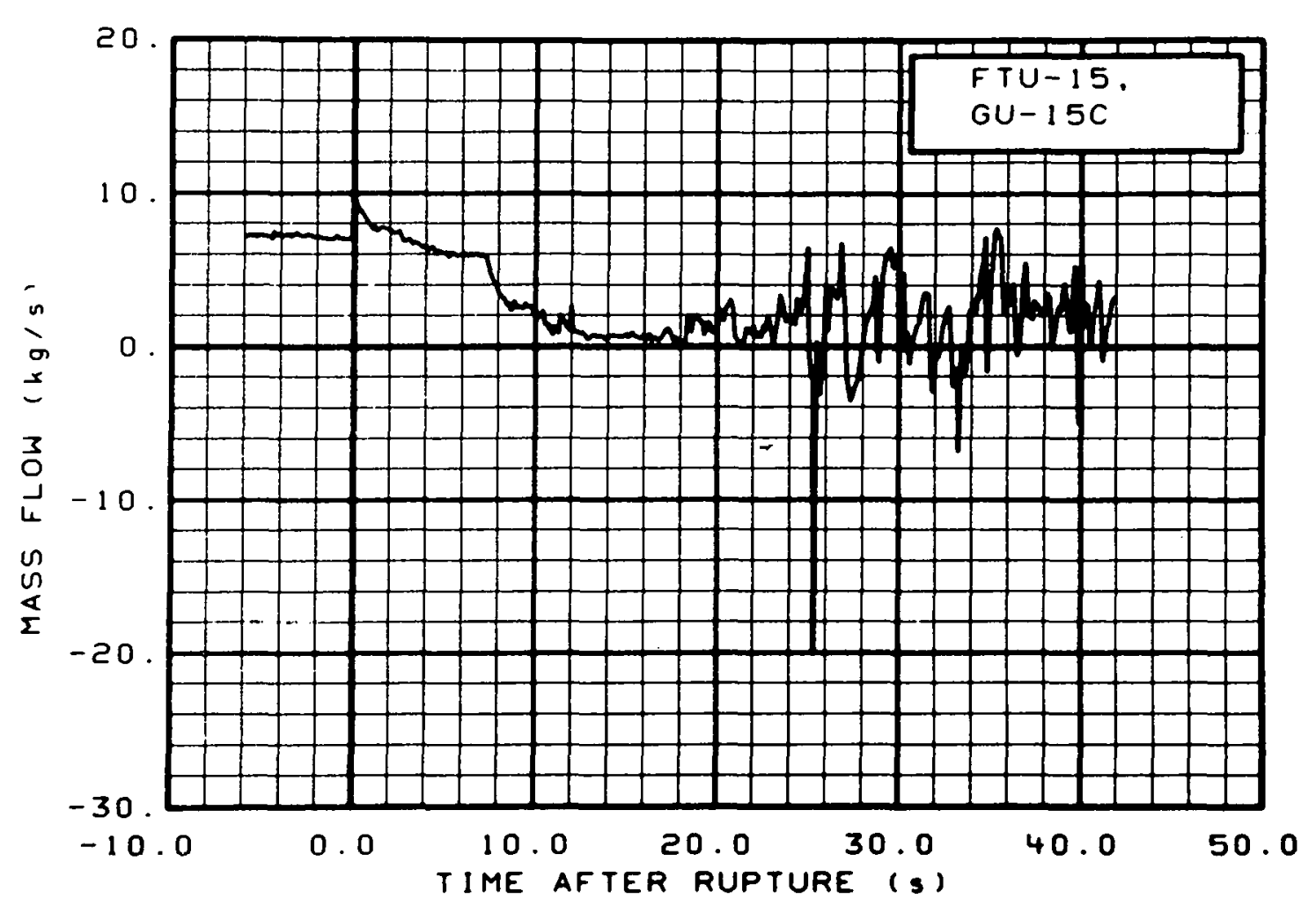

Fig. 318 Mass flow in intact 1oop (FTU-15, GU-15C), from -6 to $42 \mathrm{~s}$.

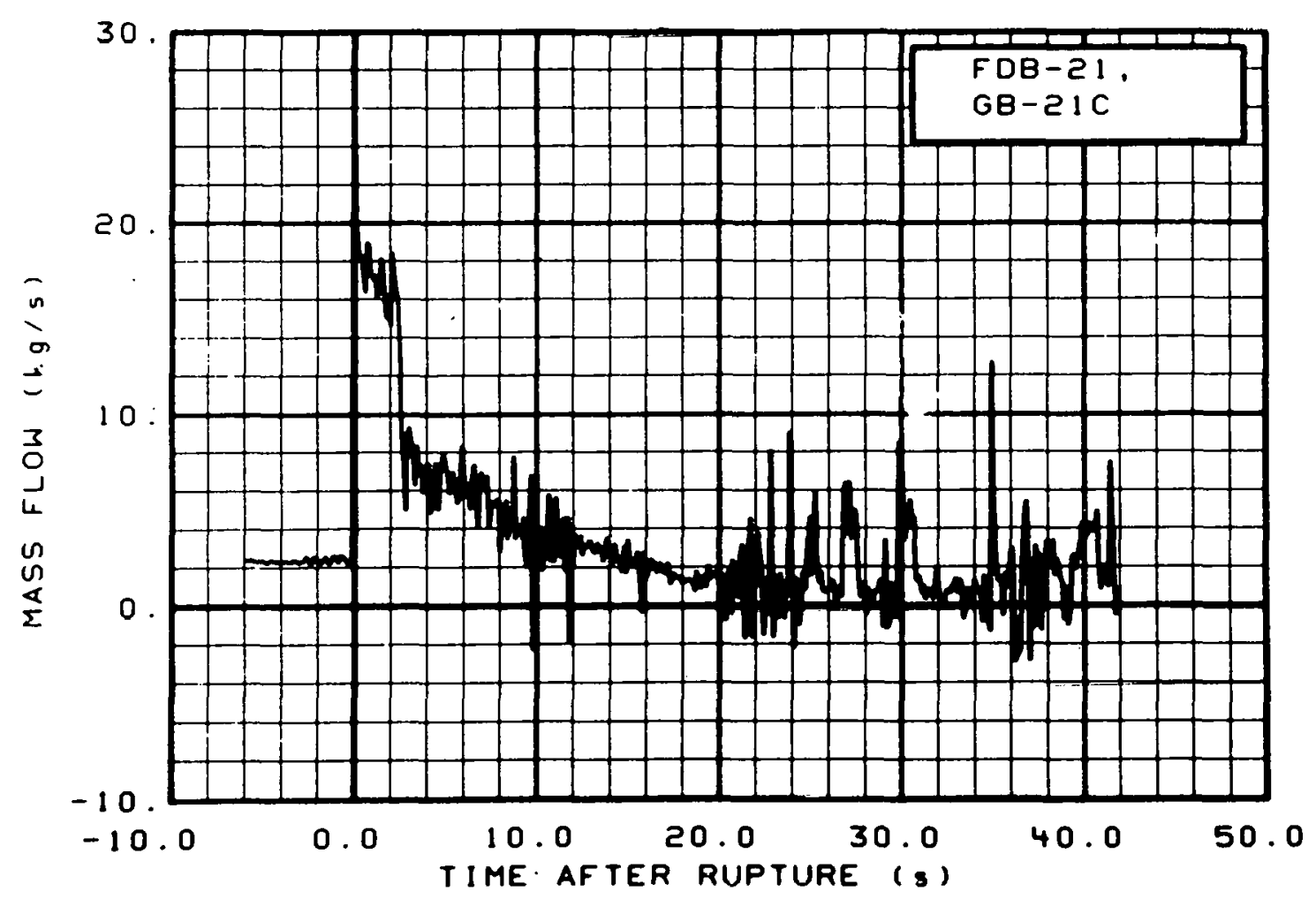

Fig. 319 Mass flow in broken loup (FDB-21, GB-21C), from -6 to $42 \mathrm{~s}$. 


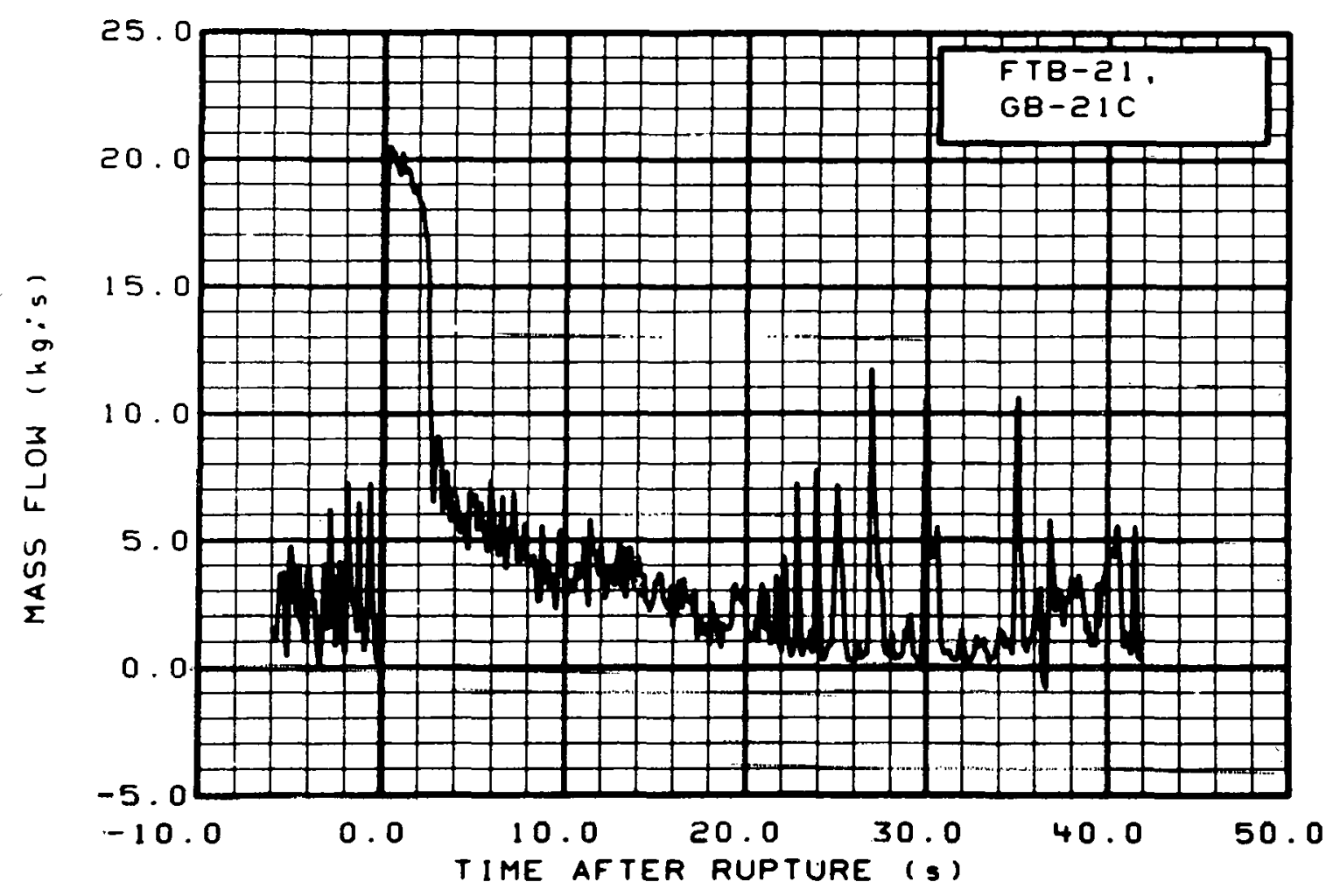

Fig. 320 Mass flow in broken loop (FTB-21, GB-21C), from -6 to $42 \mathrm{~s}$.

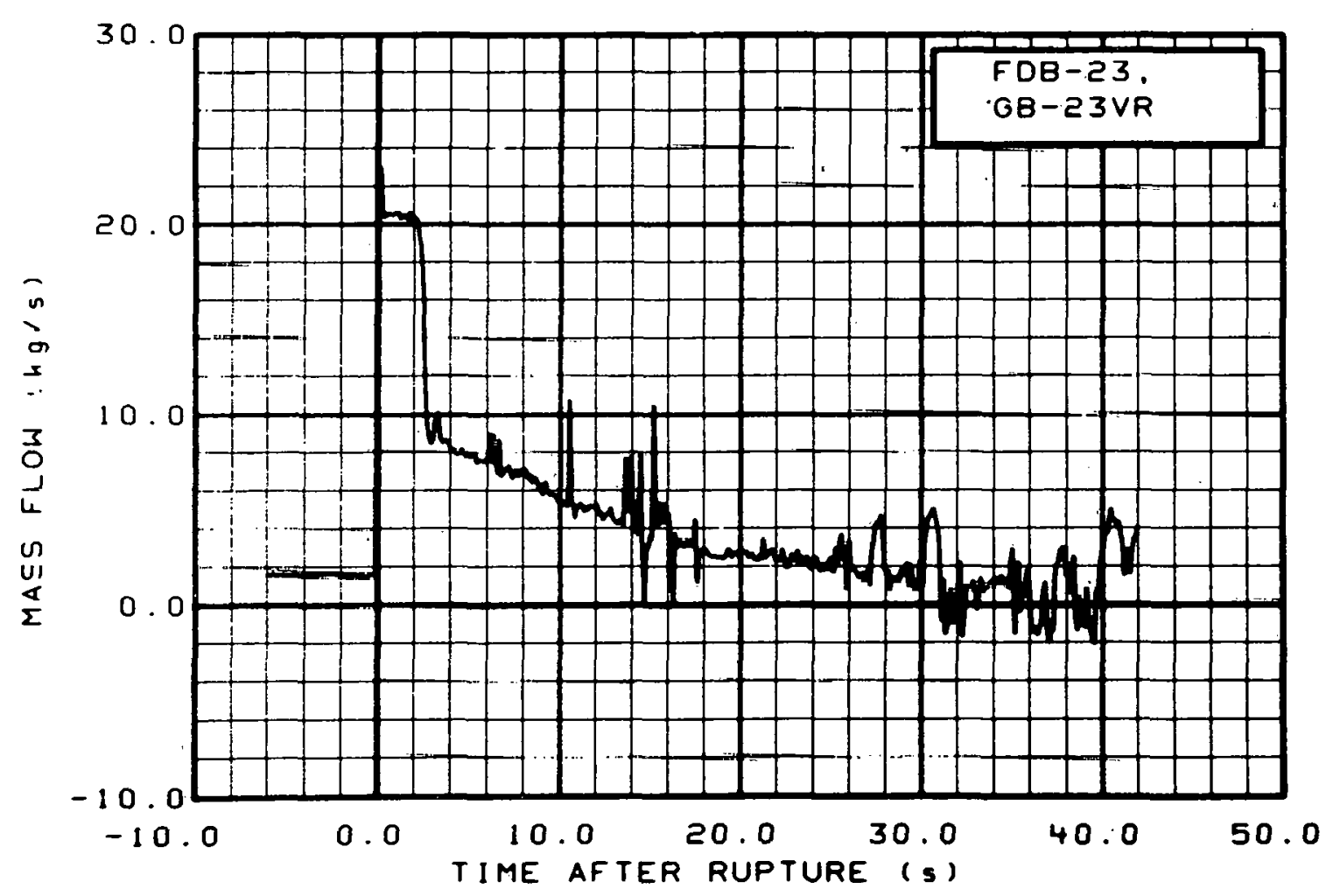

Fig. 321 Mass flow in broken loop (FDB-23, GB-23VR), from -6 to $42 \mathrm{~s}$. 


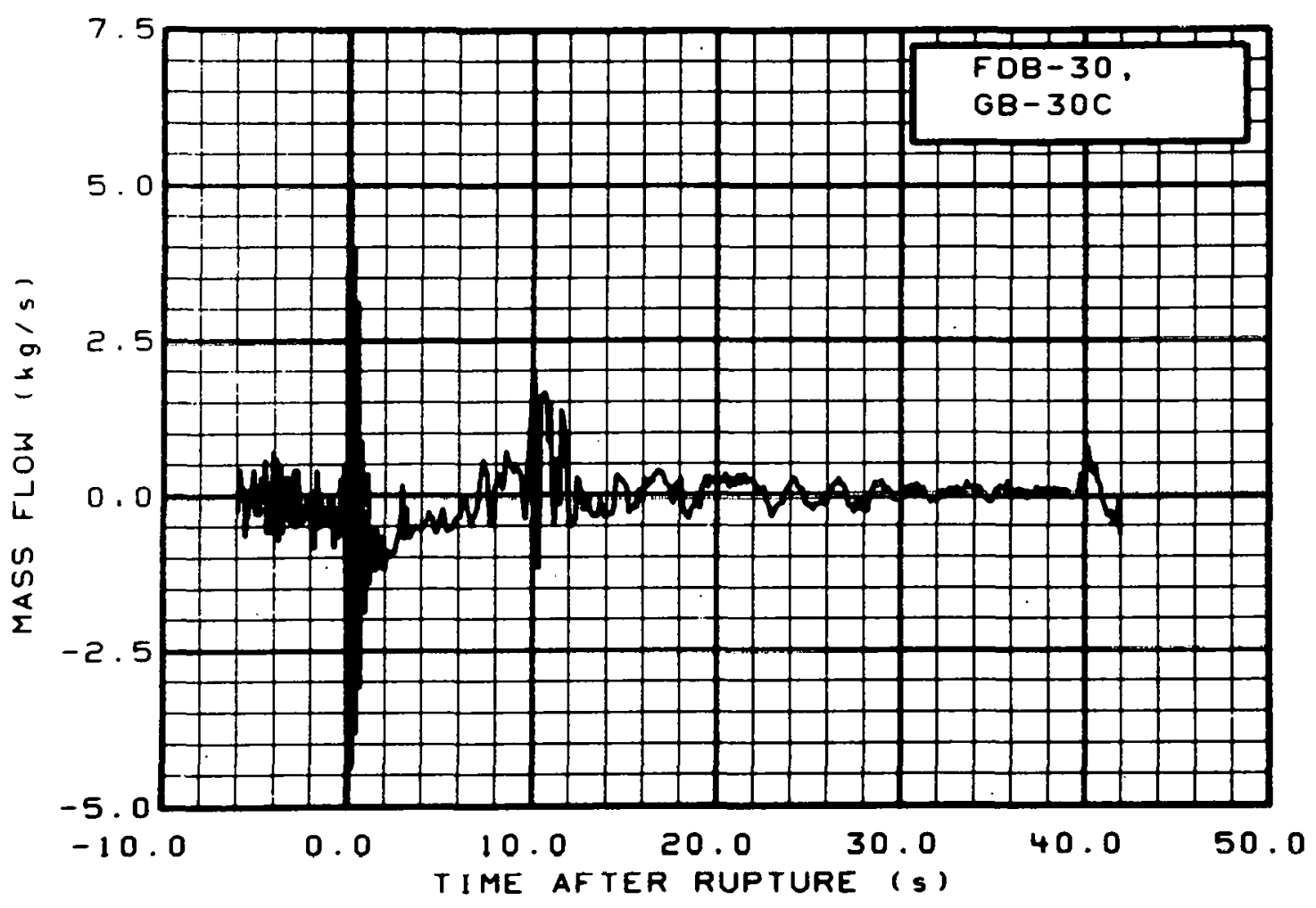

Fig. 322 Mass flow in broken loop (FDB-30, GB-30C), from -6 to $42 \mathrm{~s}$.

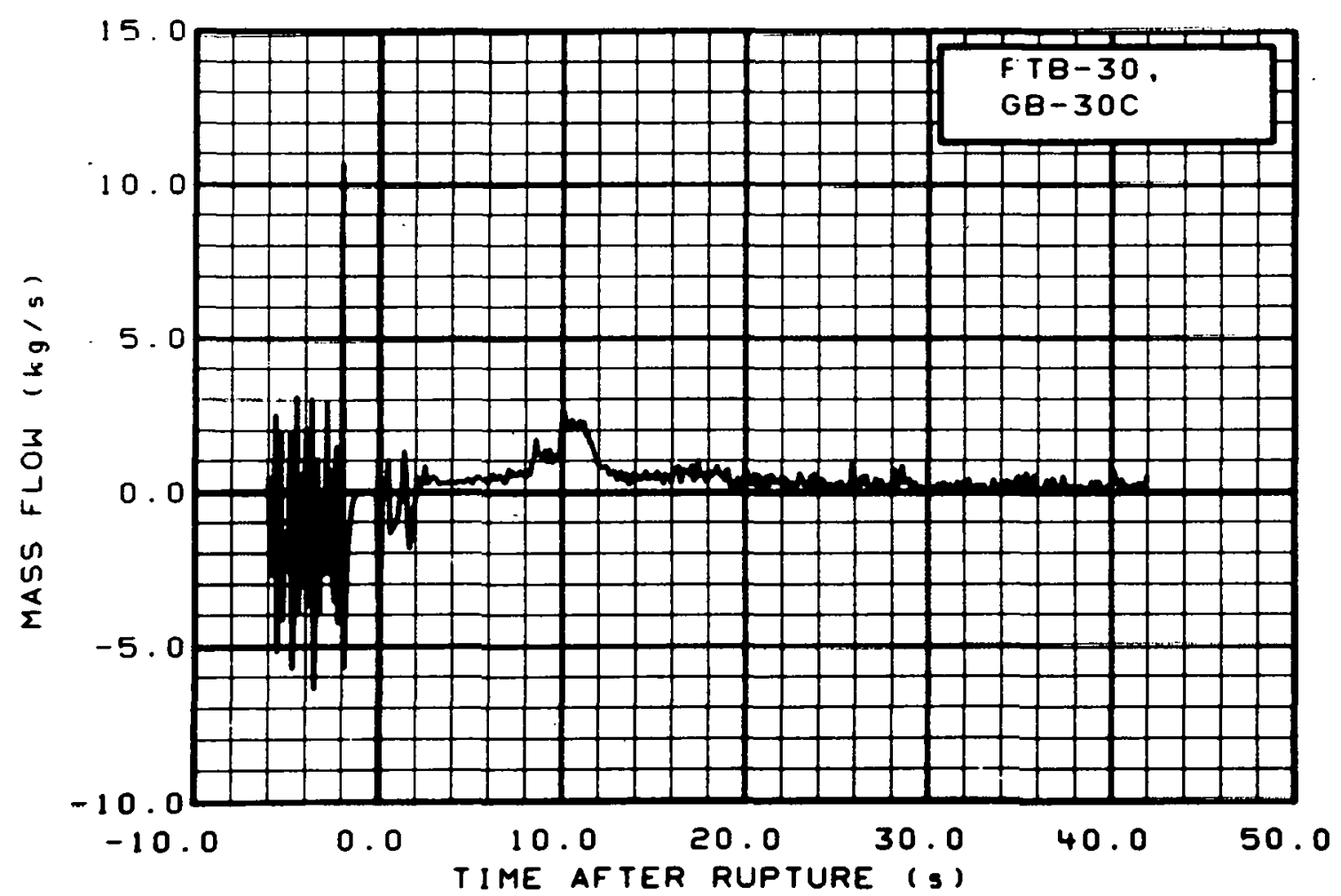

Fig. 323 Mass flow in broken loop (FTB-30, GB-30C), from -6 to $42 \mathrm{~s}$. 


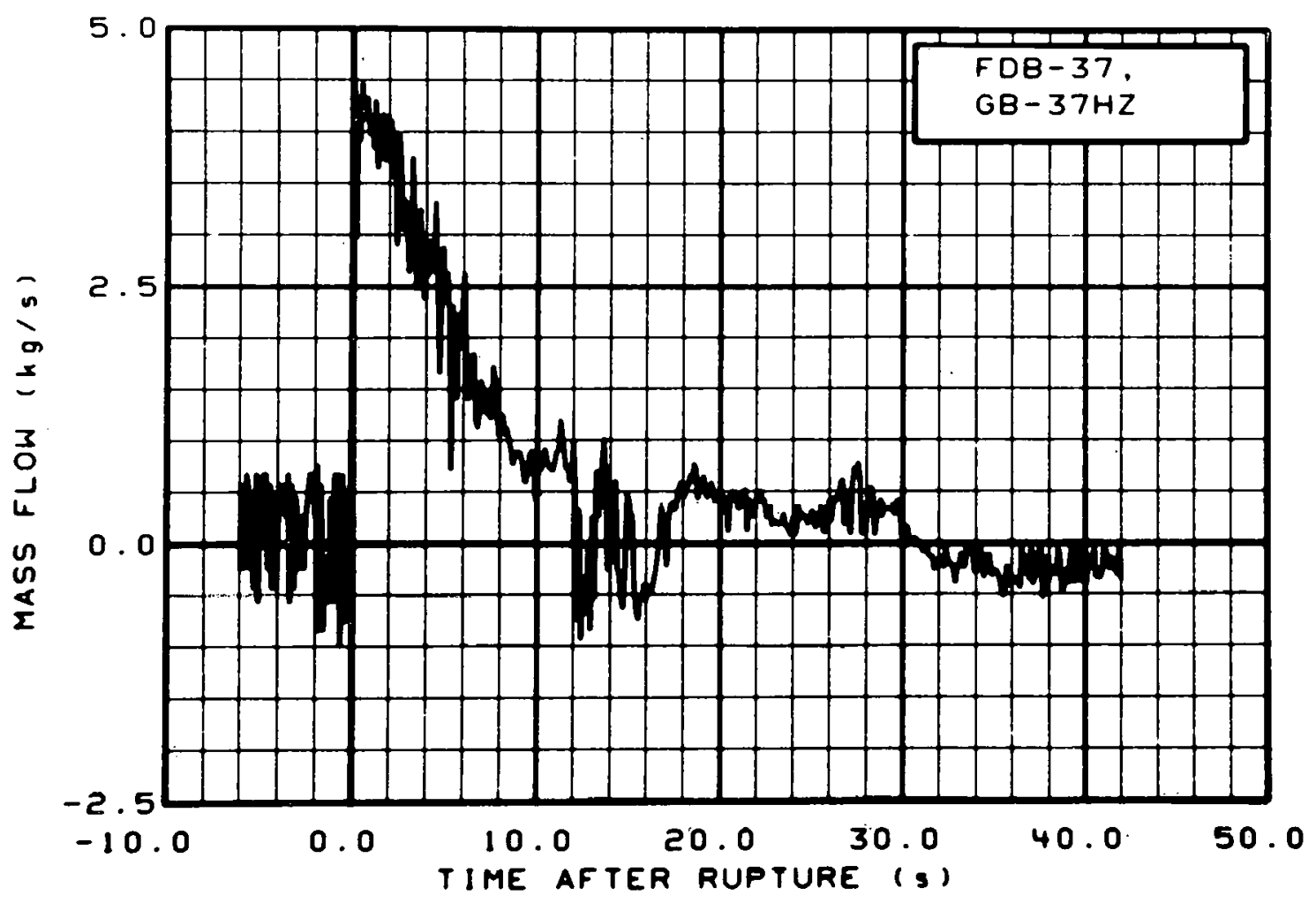

Fig. 324 Mass flow in broken loop (FDB-37, GB-37HZ), from -6 to $42 \mathrm{~s}$.

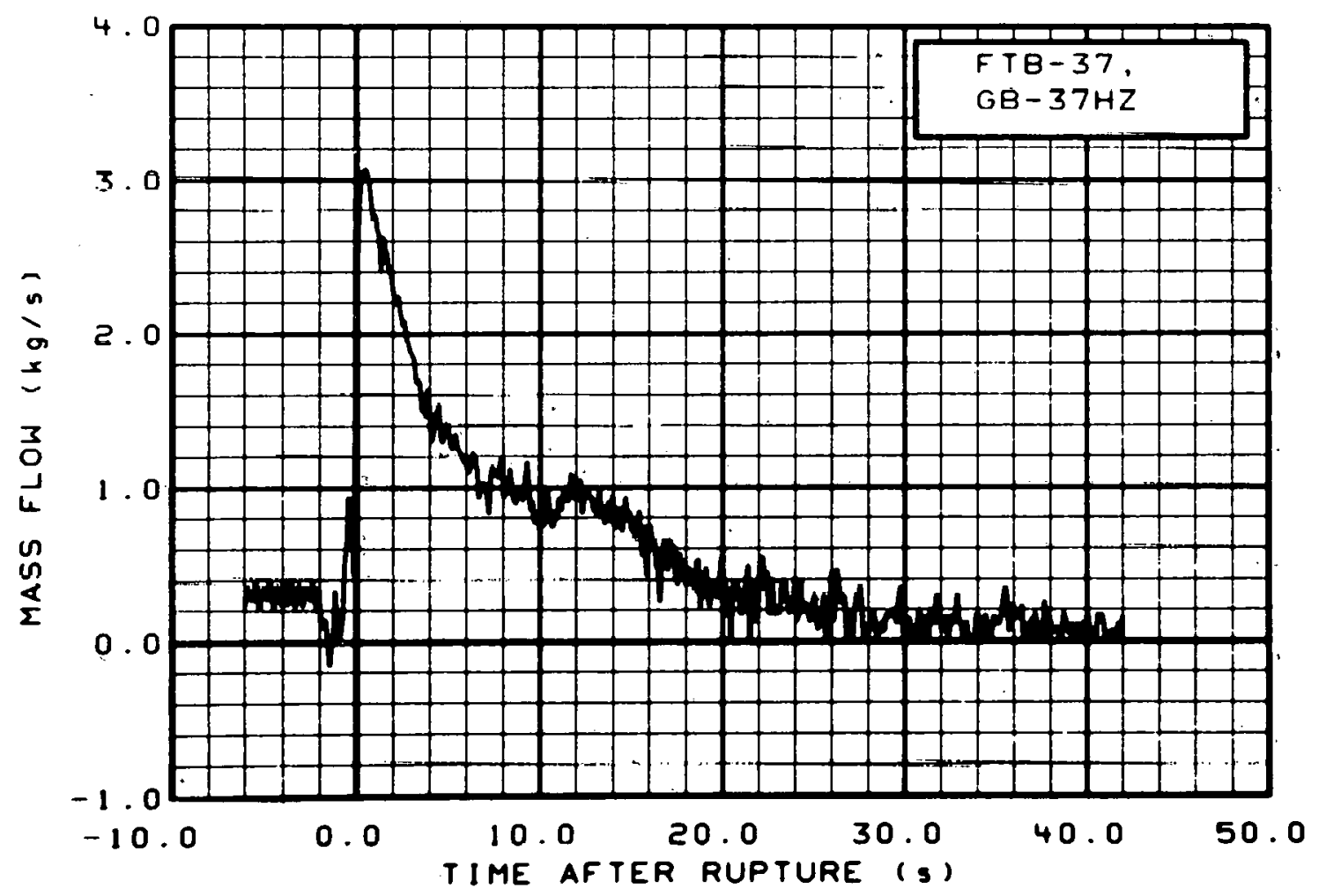

Fig. 325 Mass flow in broken loop (FTB-37, GB-37HZ), from -6 to $42 \mathrm{~s}$. 


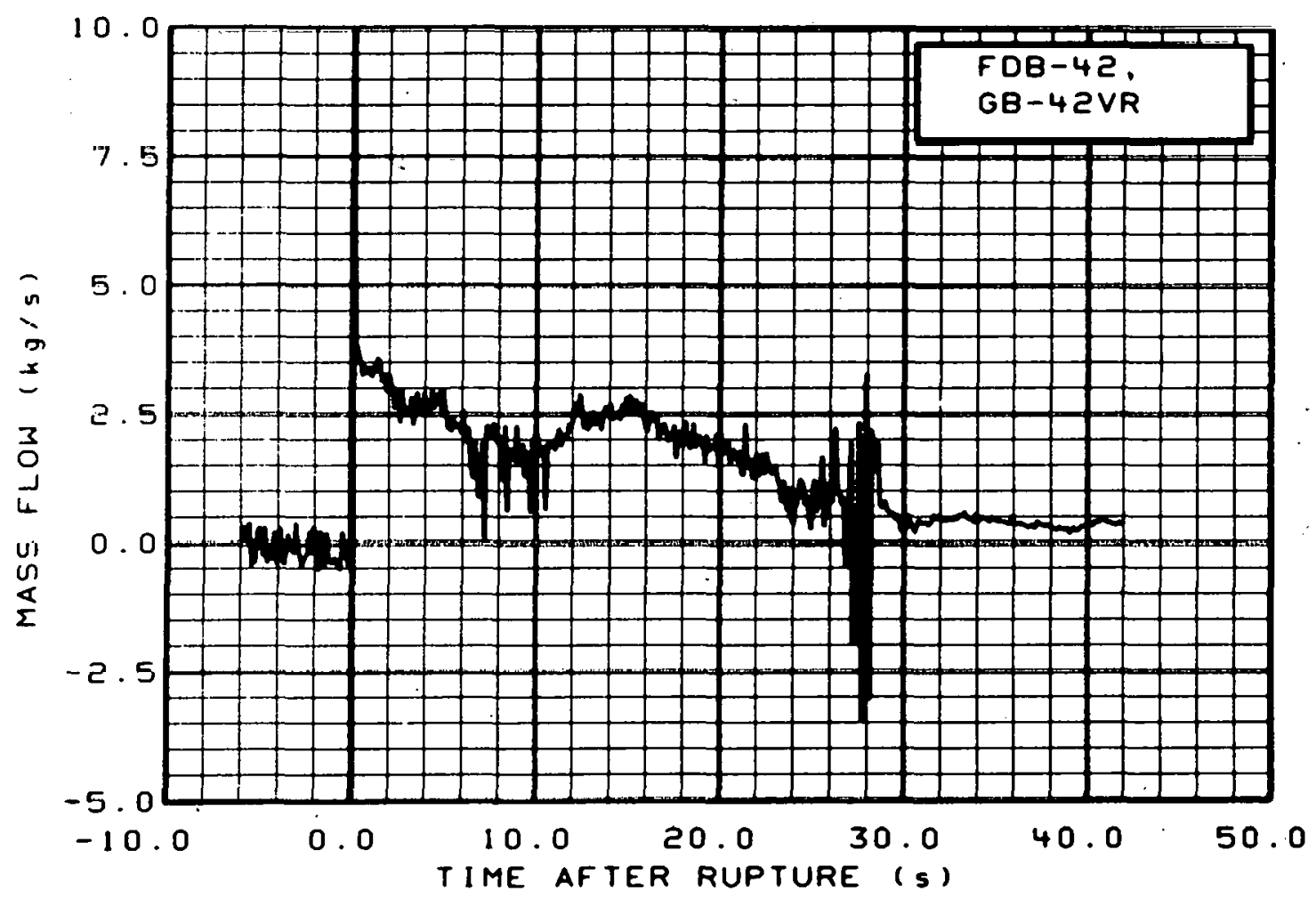

Fig. 326 Mass flow in broken loop (FDB-42, GB-42VR), from -6 to $42 \mathrm{~s}$. 


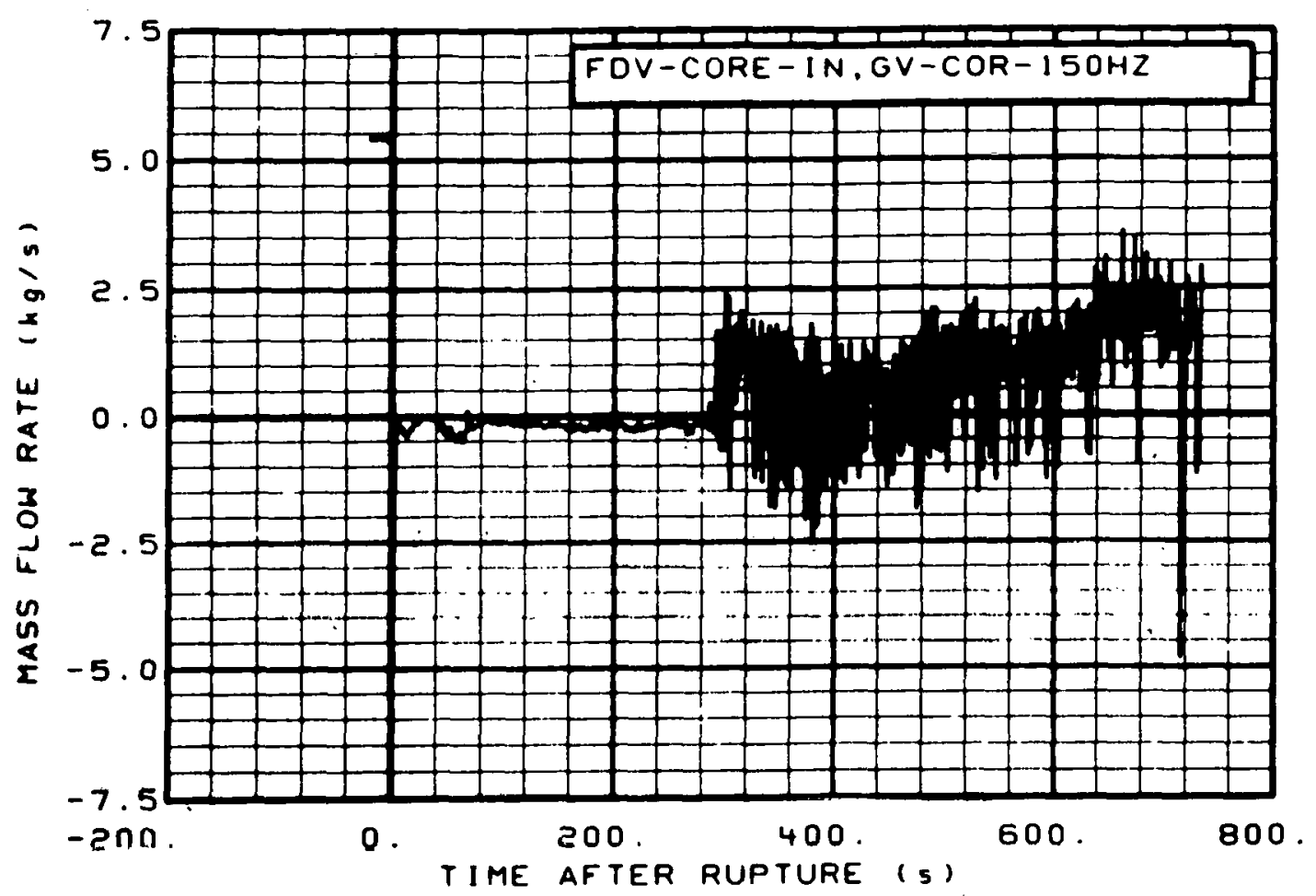

Fig. 327 Mass flow in vessel (FDV-CORE-IN, GV-COR-150HZ), from -20 to $736 \mathrm{~s}$.

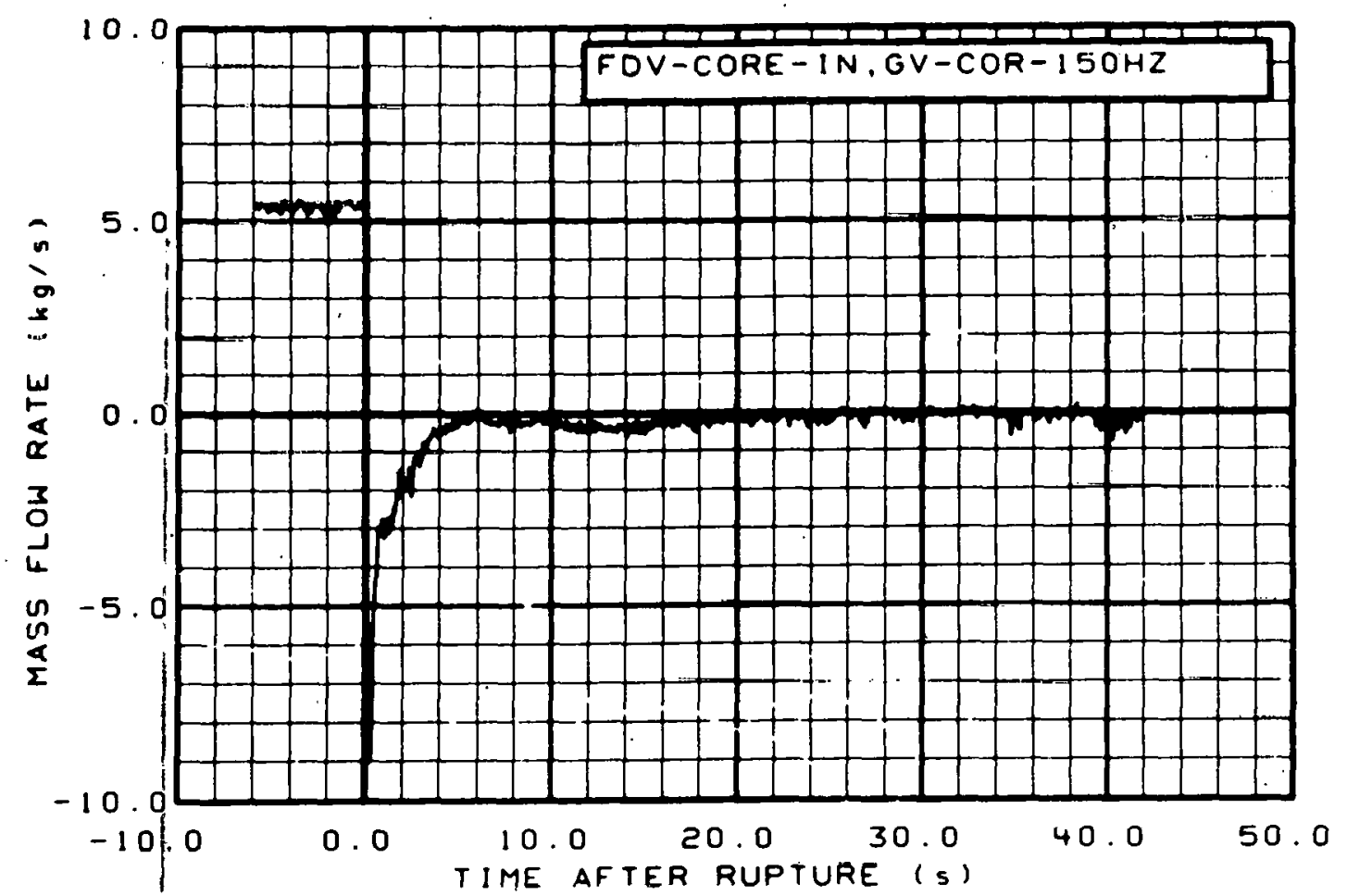

Fig. 328 Mass flow in vessel (FDV-CORE-IN, GV-COR-150HZ), from -6 to $42 \mathrm{~s}$. 


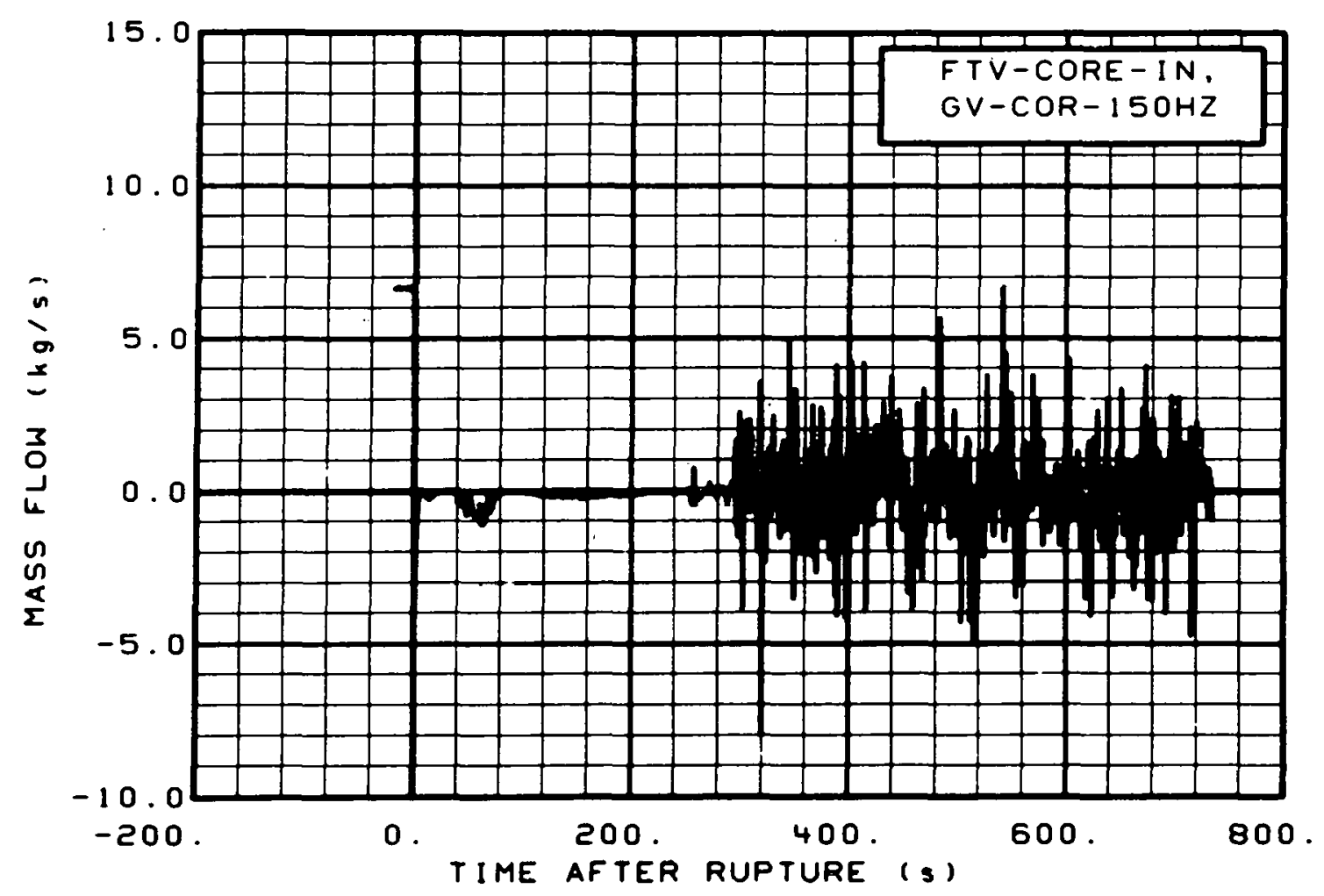

Fig. 329 Mass flow in vessel (FTV-CORE-IN, GV-COR-150HZ), from -20 to $736 \mathrm{~s}$.

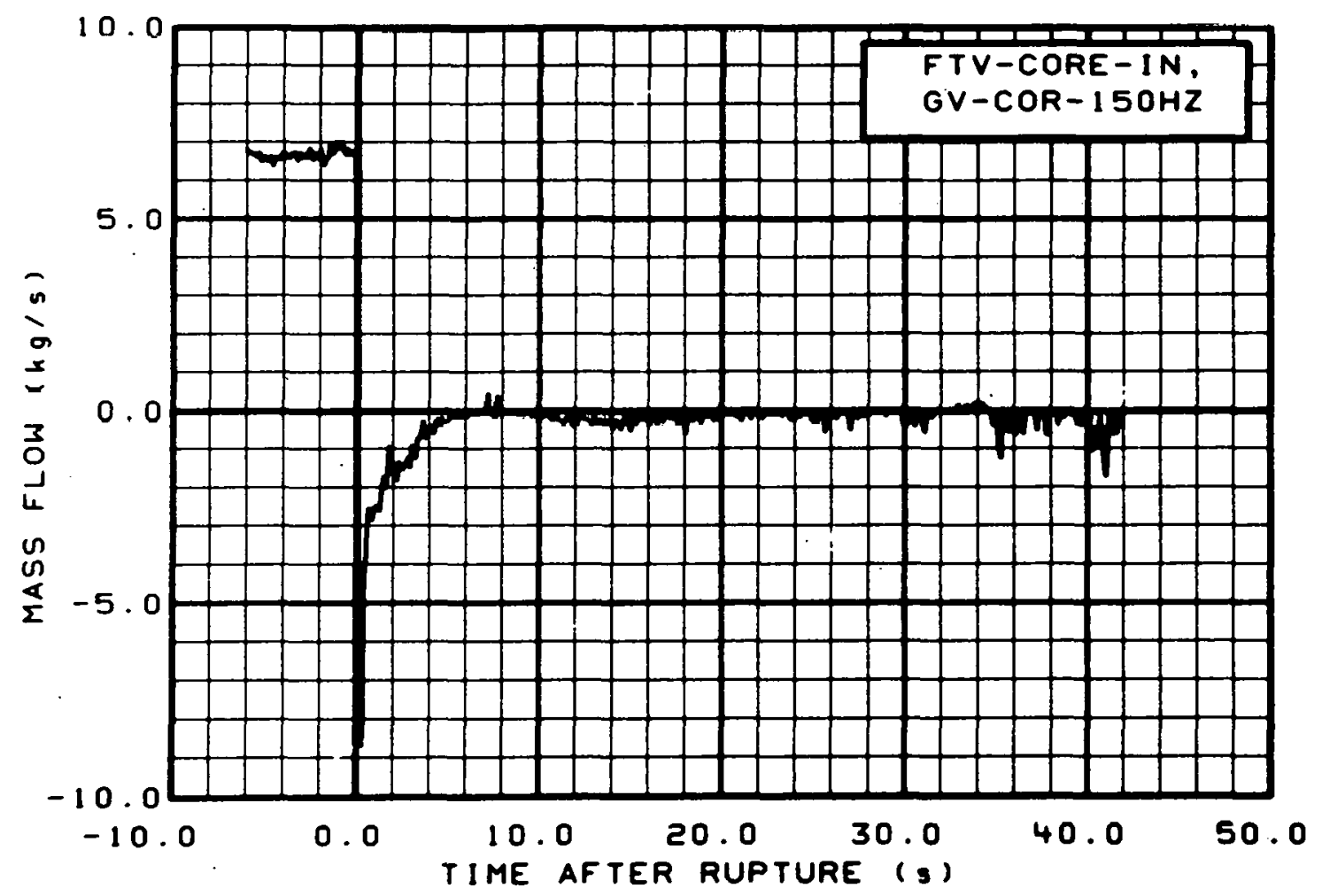

Fig. 330 Mass flow in vessel (FTV-CORE-IN, GV-COR-150HZ), from -6 to $42 \mathrm{~s}$. 


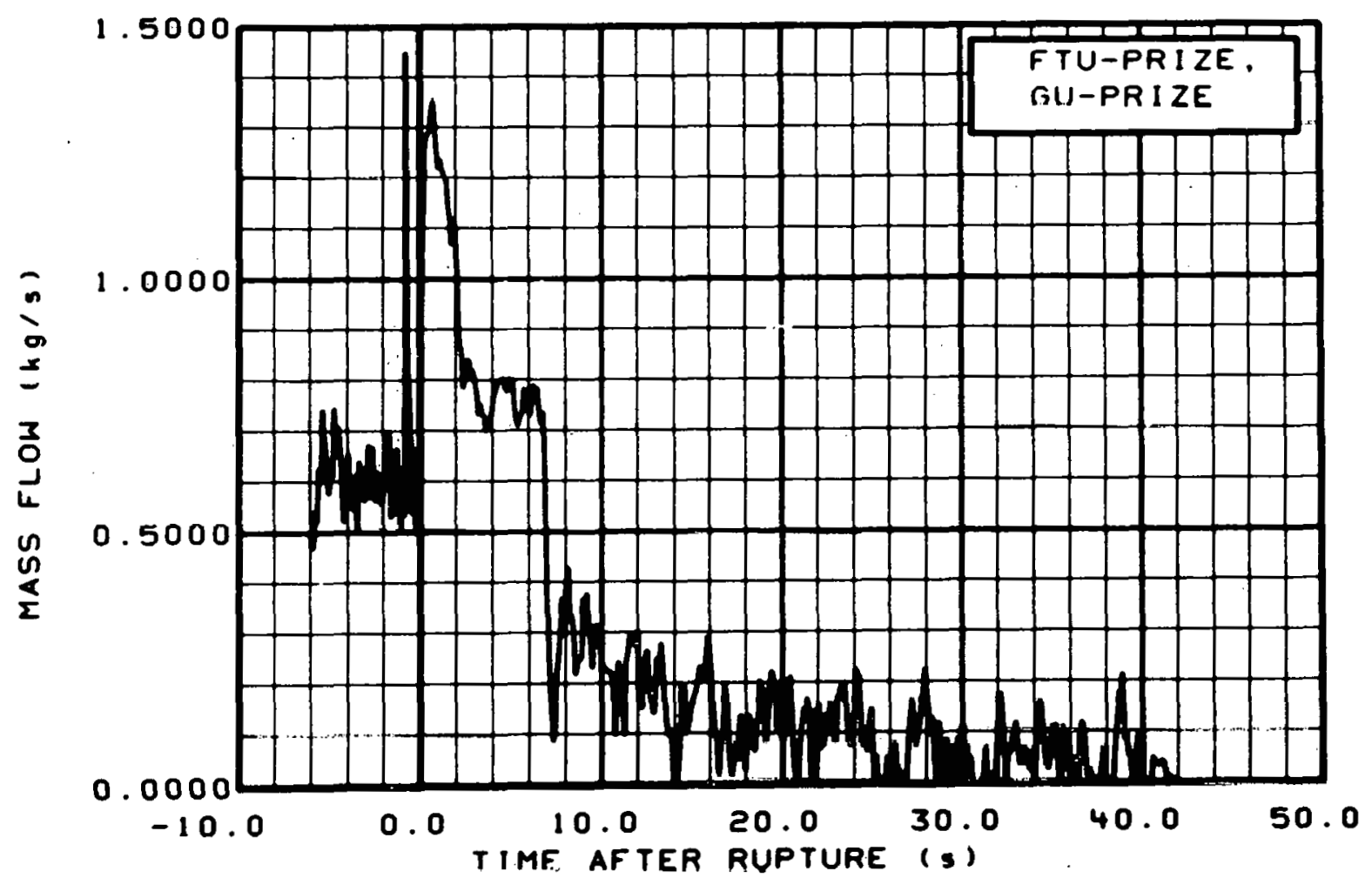

Fig. 331 Mass flow in pressurizer (FTU-PRIZE, GU-PRIZE), from -6 to $42 \mathrm{~s}$. 


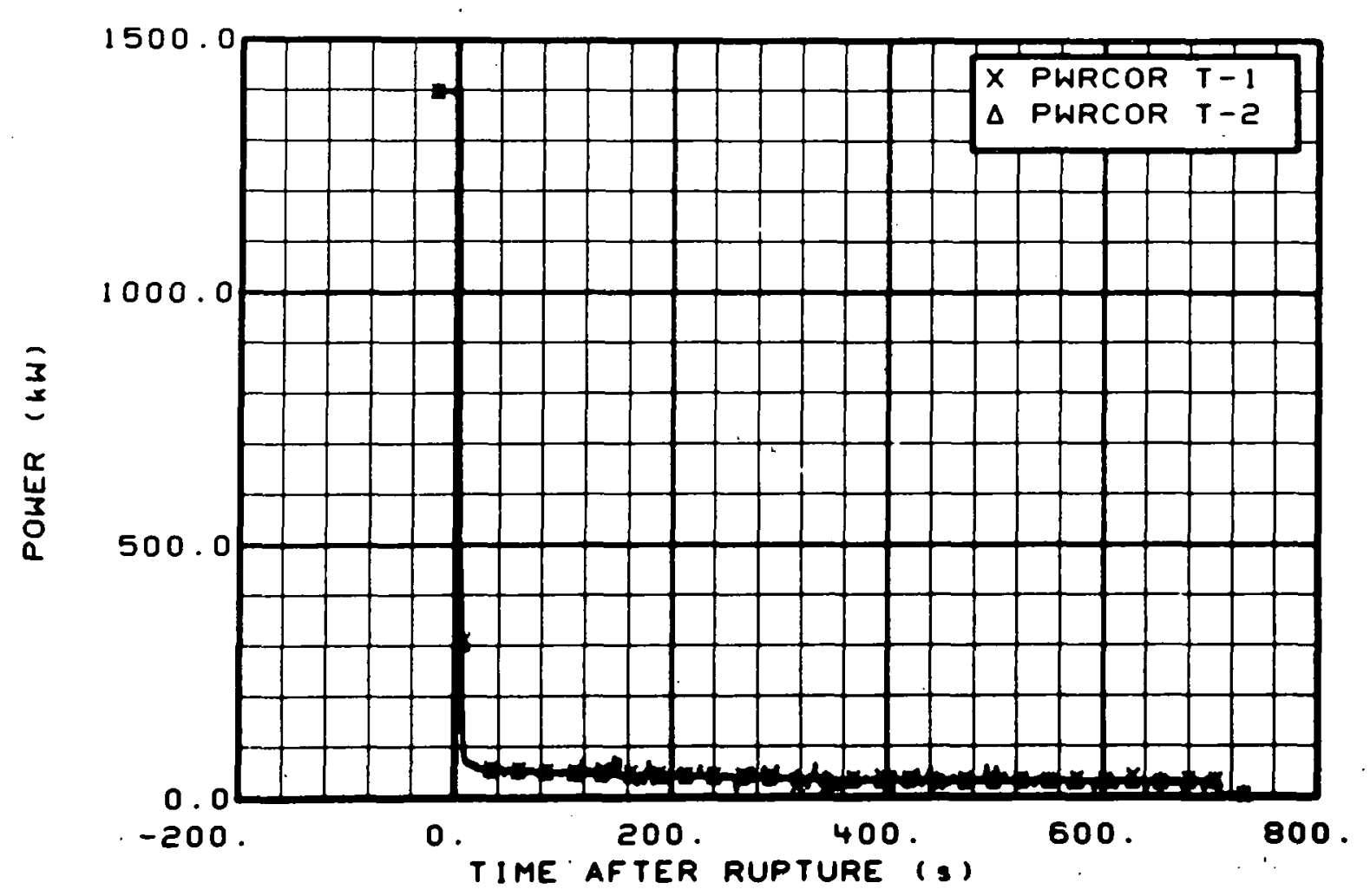

Fig. 332 Core heater rod total power (PWRCOR T-1 and PWRCOR T-2), from -20 to $736 \mathrm{~s}$.

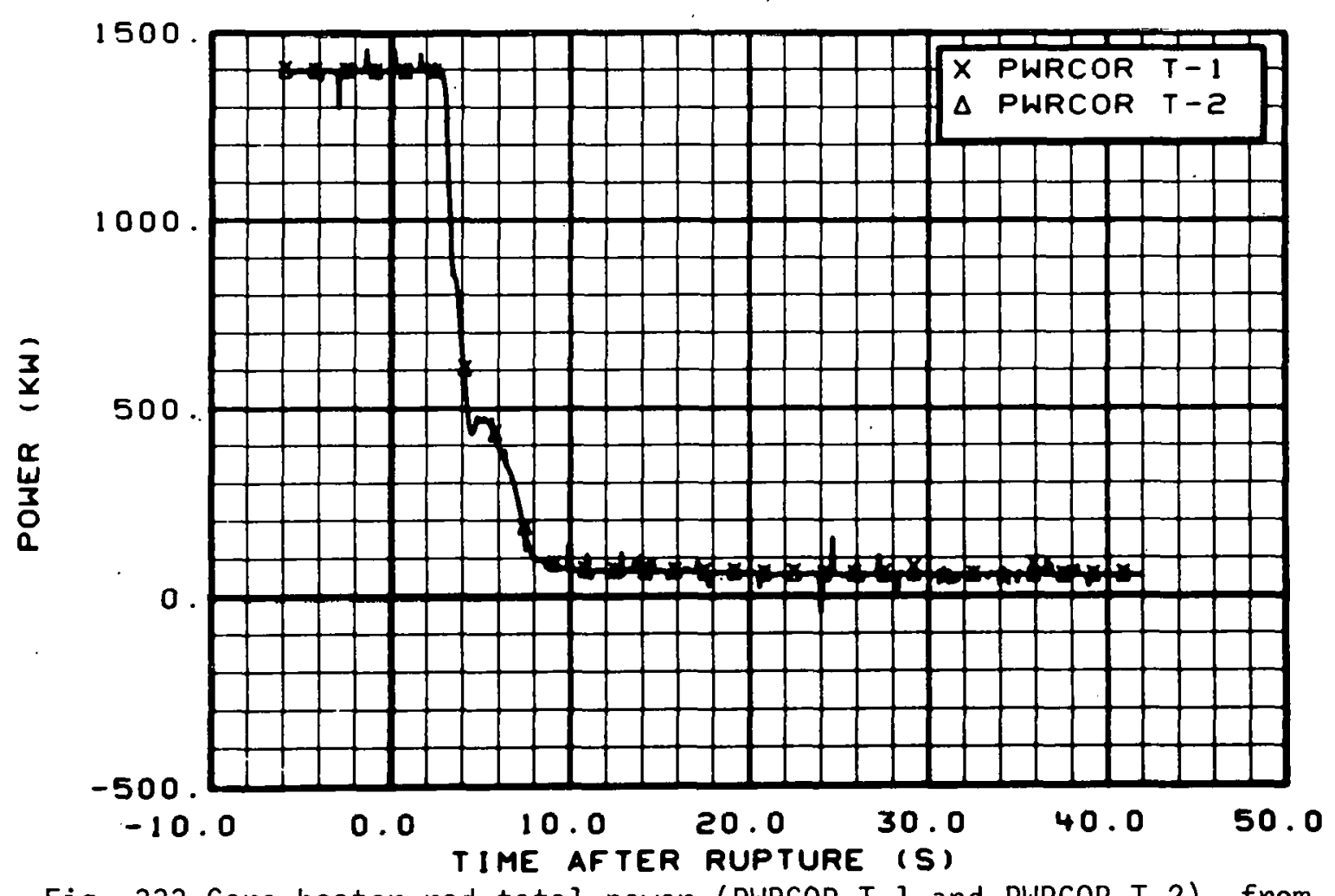

Fig. 333 Core heater rod total power (PWRCOR T-1 and PWRCOR T-2), from -6 to $42 \mathrm{~s}$. 


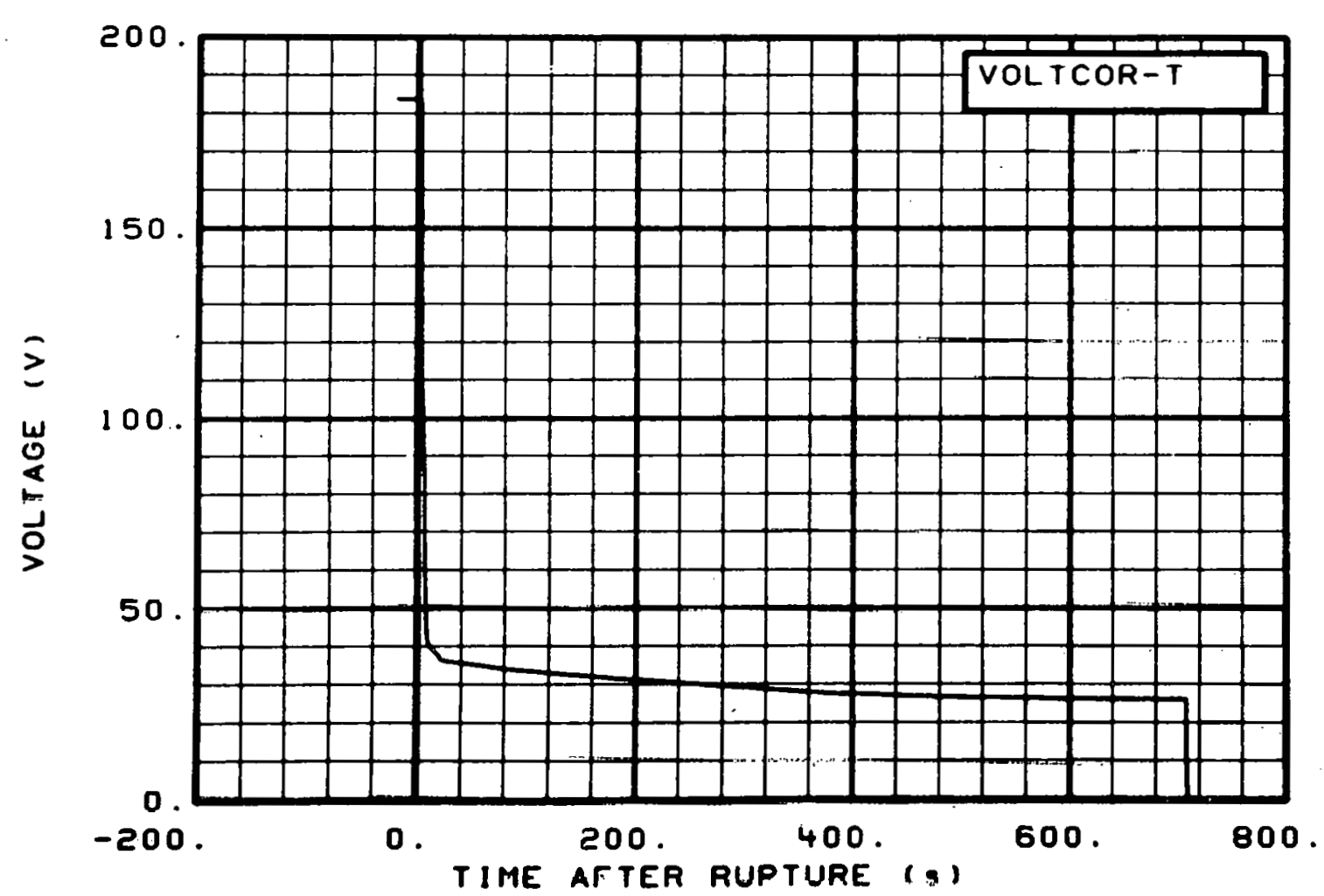

Fig. 334 Core heater voltage (VOLTCOR-T), from -20 to $736 \mathrm{~s}$.

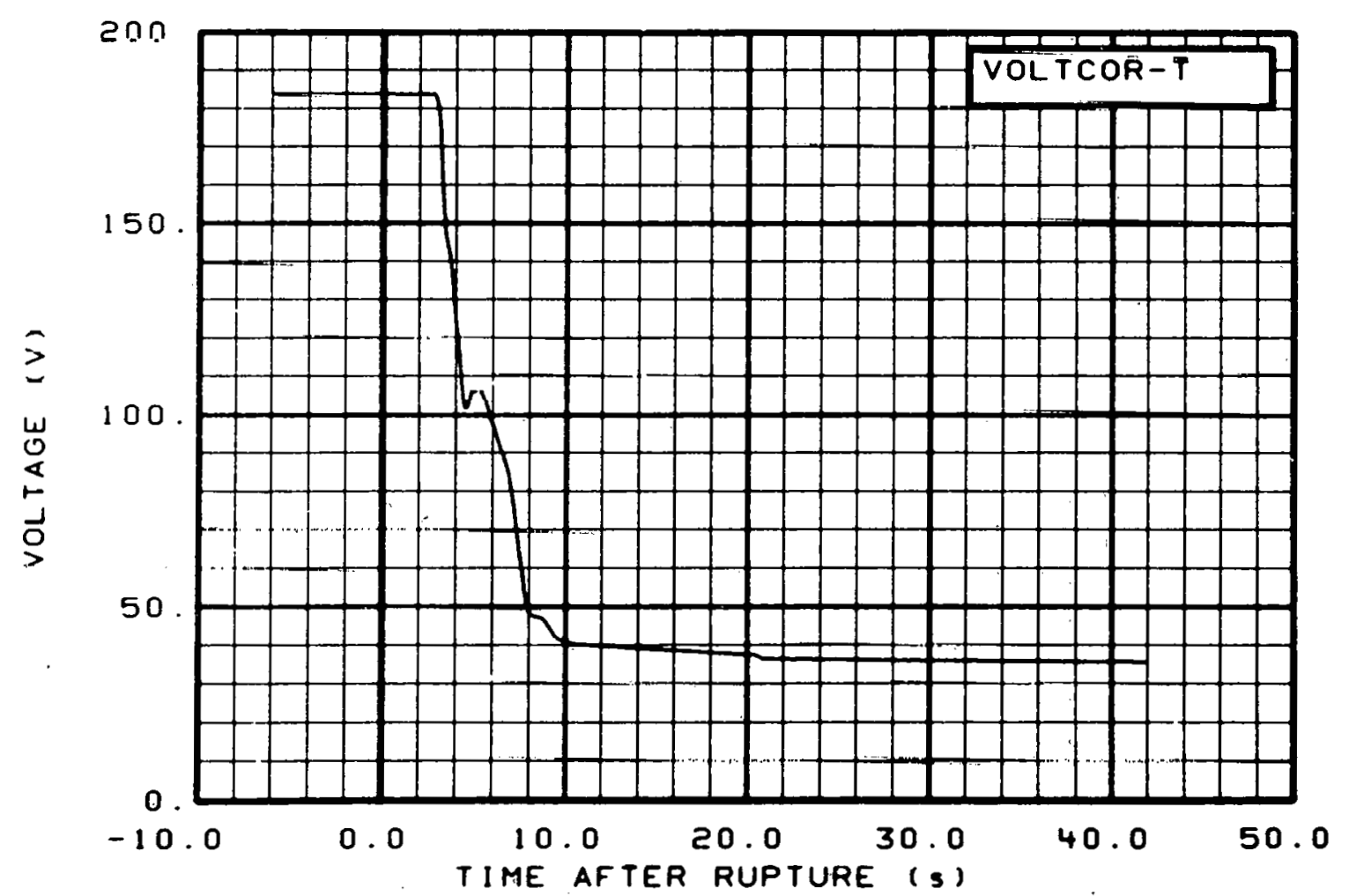

Fig. 335 Core heater voltage (VOLTCOR-T), from -6 to $42 \mathrm{~s}$. 


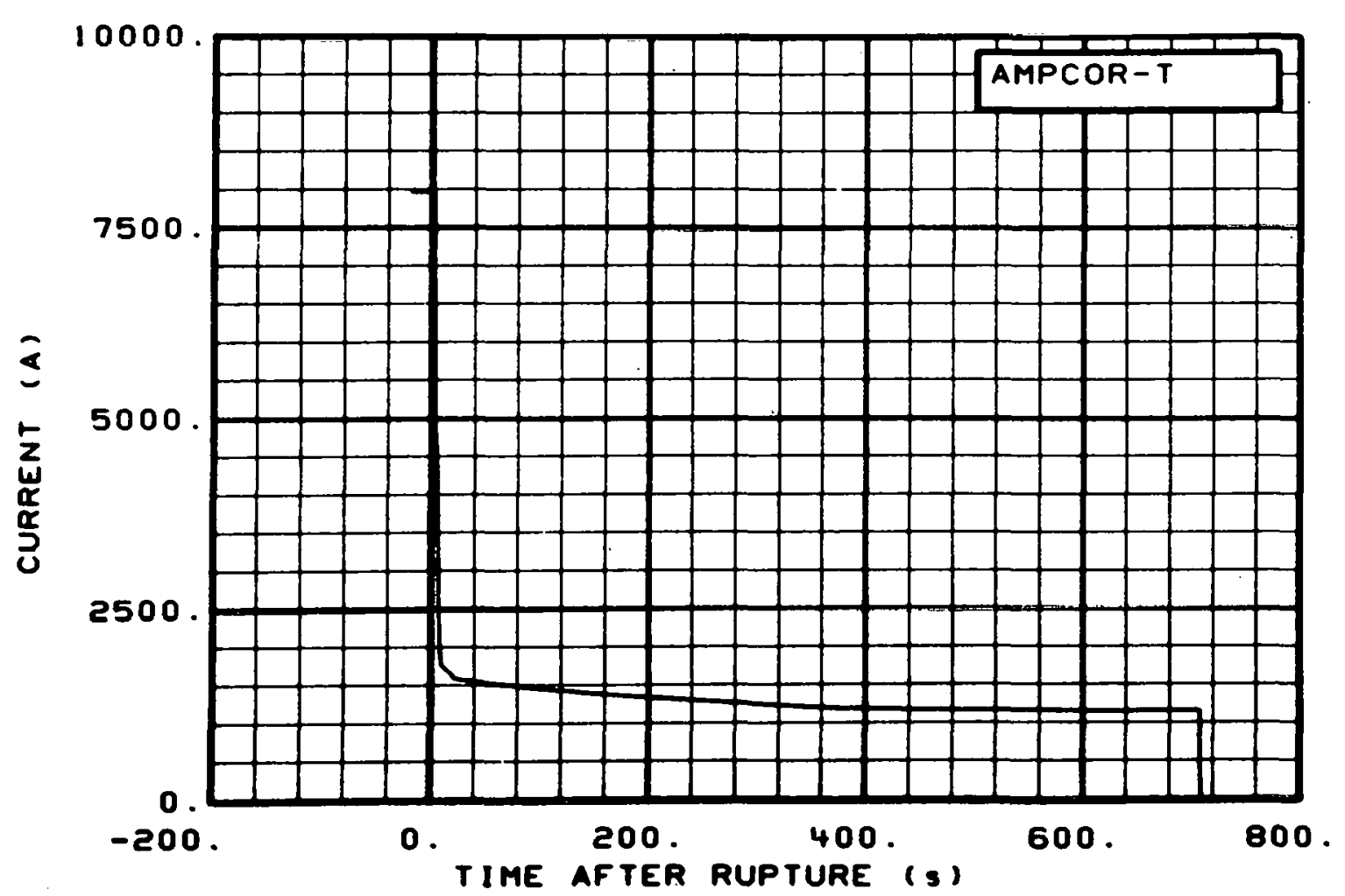

Fig. 336 Core heater total current (AMPCOR-T), from -20 to $736 \mathrm{~s}$.

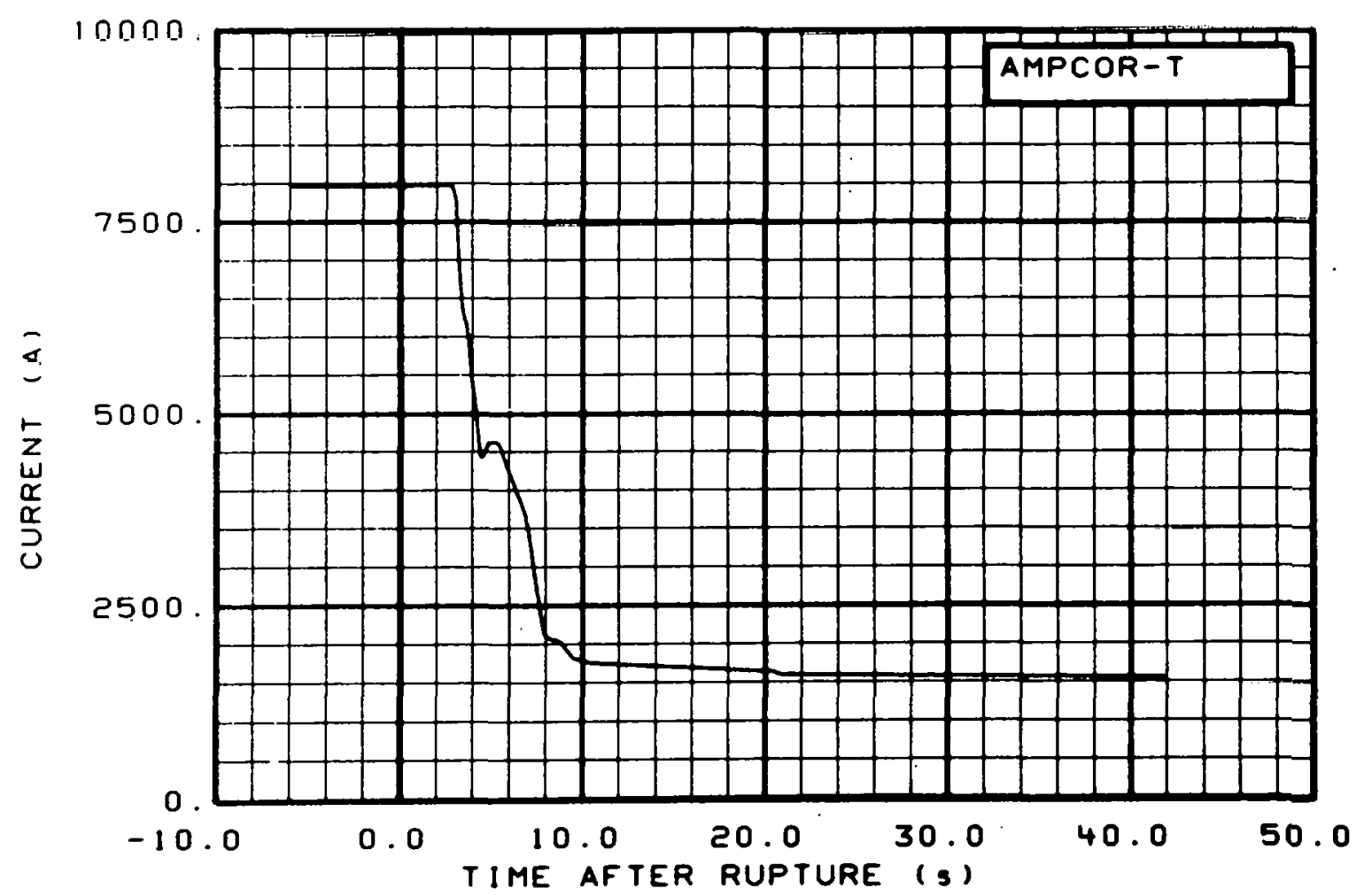

Fig. 33 l Core heater total current (AMPCOR-T), from -6 to $42 \mathrm{~s}$. 


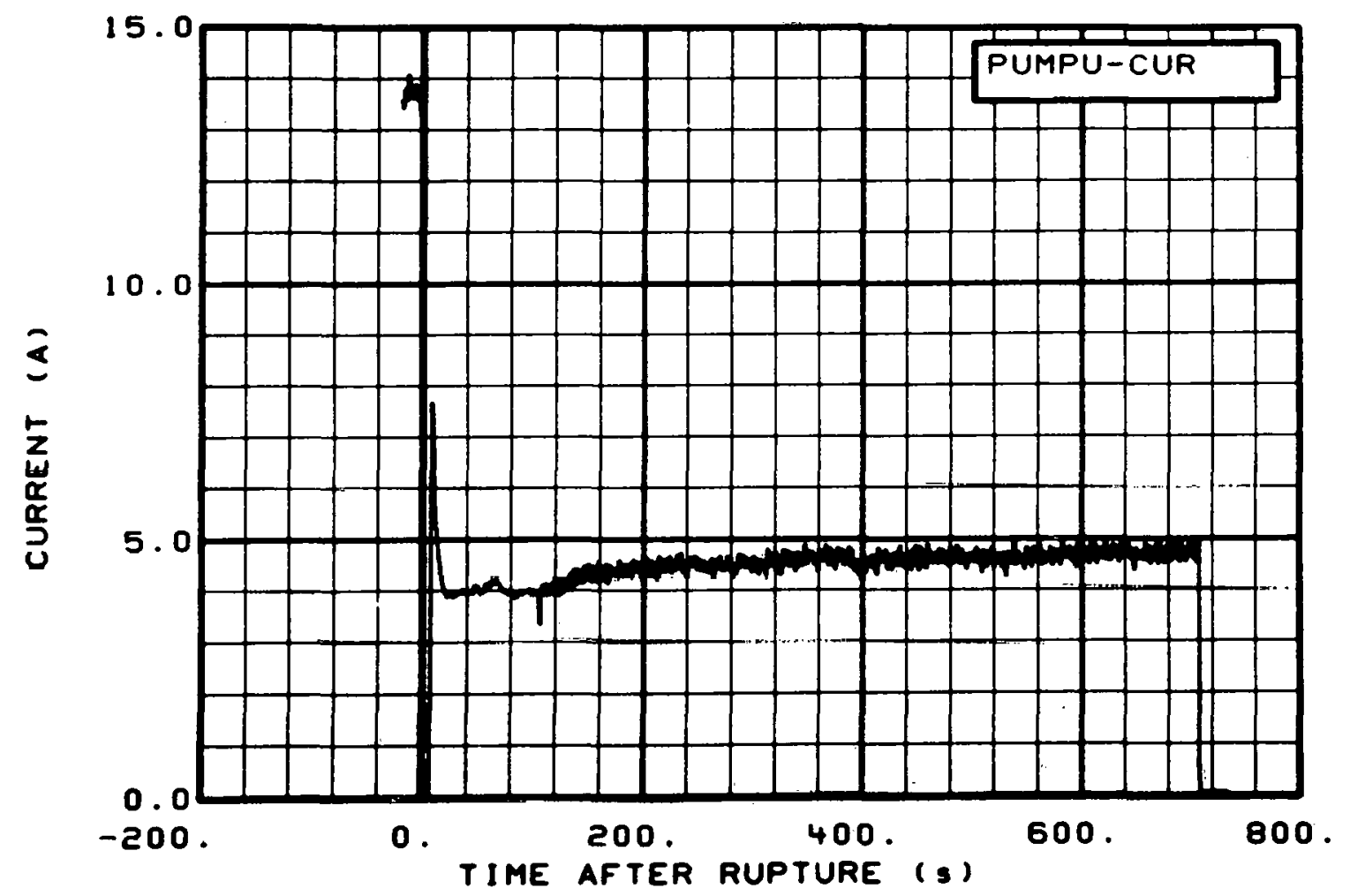

Fig. 338 Primary pump current (PUMPU-CUR), from -20 to $736 \mathrm{~s}$.

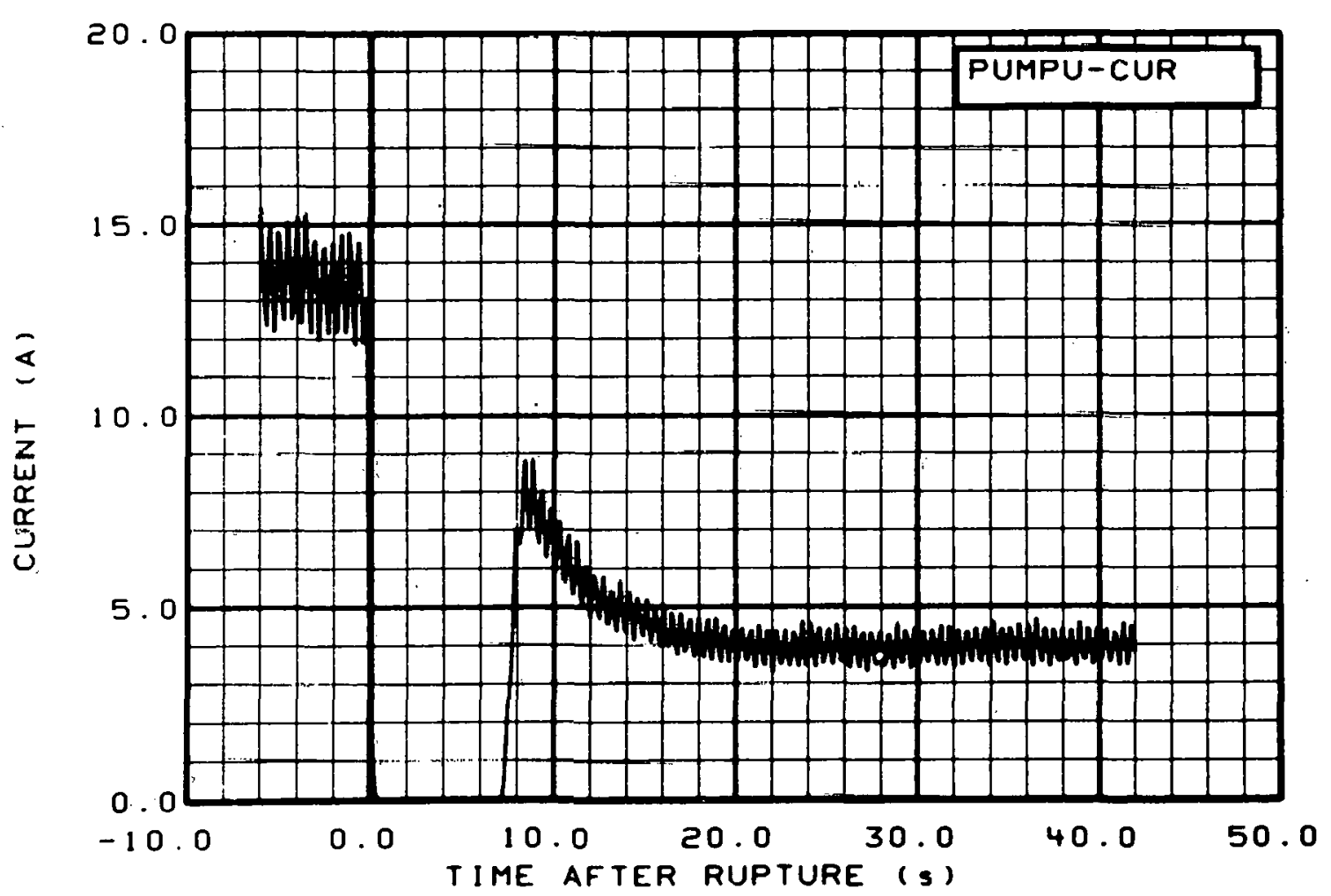

Fig. 339 Primary pump current (PUMPU-CUR), from -6 to $42 \mathrm{~s}$. 


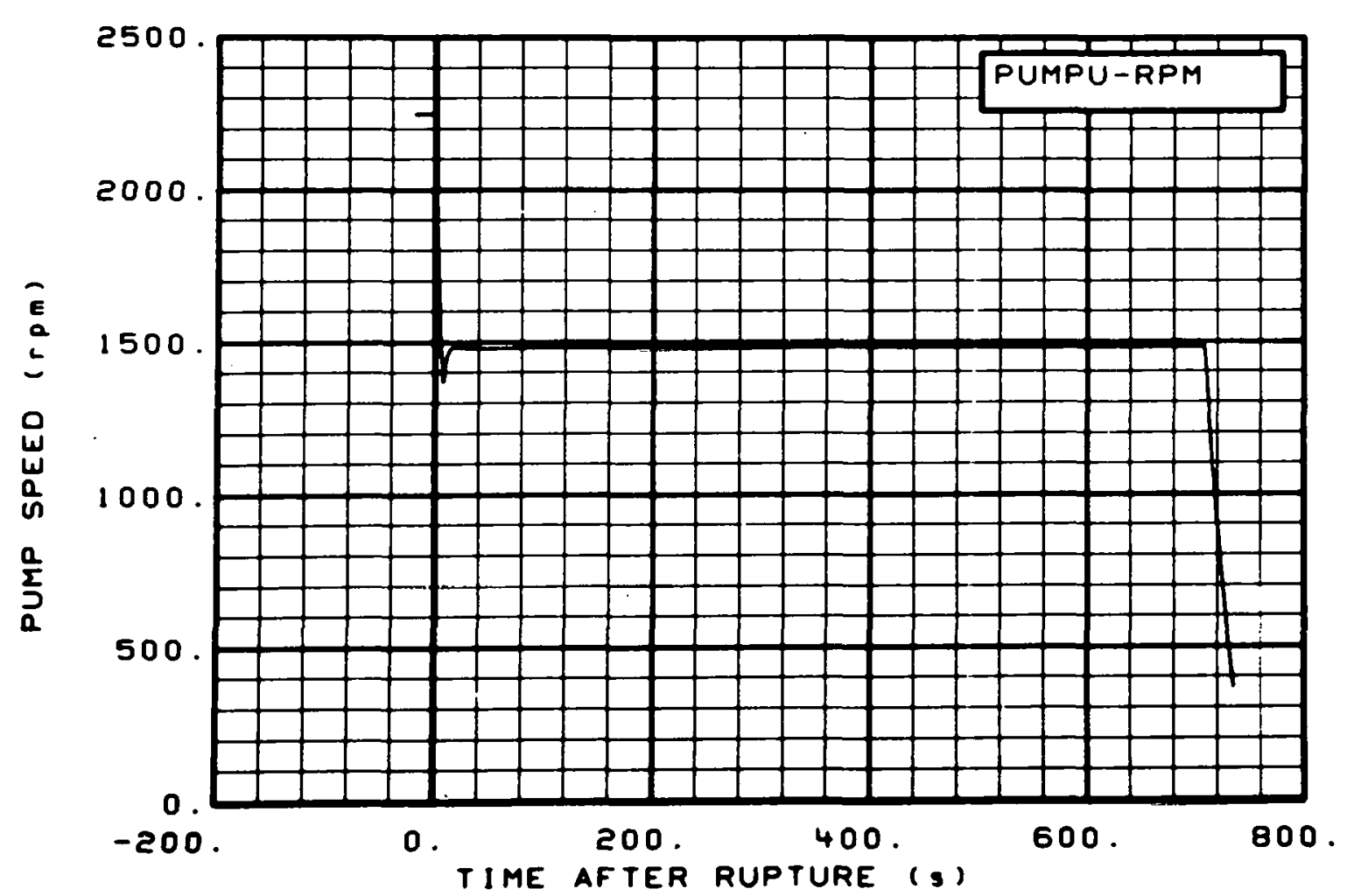

Fig. 340 Primary pump speed (PUMPU-RPM), from -20 to $736 \mathrm{~s}$.

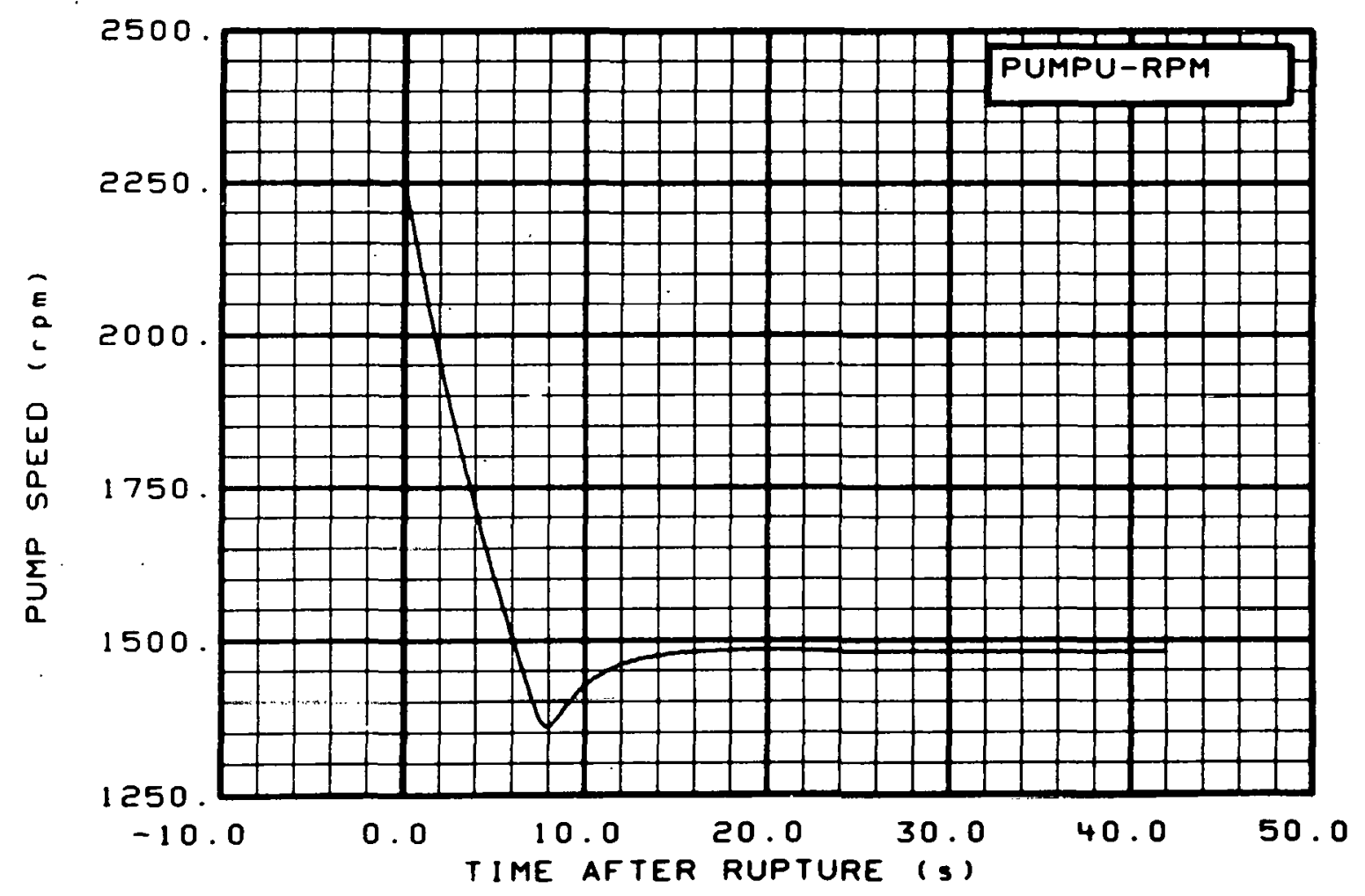

Fig. 311 Primary pump speed (PUMPU-RPM), rruill -6 to $42 \mathrm{~s}$. 


\section{REFERENCE}

1. E. M. Feldman and D. J. Olson, Semiscale Mod-1 Program and System Description for the Blowdown Heat Transfer Tests (Test Series 2), ANCR-1 230 (August 1975). 
APPENDIX A

DATA ACQUISITION SYSTTEM CAPABILITIES 
THIS PAGE

WAS INTENTIONALLY

LEFT BLANK 


\section{APPENDIX A \\ DATA ACQUISITION SYSTEM CAPABILITIES}

The Semiscale Mod-1 system provides for the acquisition, processing, and presentation of test data. Detectors, signal conditioners, signal processors, and recording and display equipment comprise the test data system. The data obtained are principally recorded on an on-line digital system. Selected data channels are also recorded on an analog system.

The on-line digital.system is called the digital data acquisition and processing system (DDAPS). The DDAPS has dual and single speed capabilities with identical storage and data output limitations. The dual speed mode is used to extend the recording time when obtaining high frequency data.

From each of up to 240 data channels, the test data system stores 20 blocks of data. Each block of data contains 920 words (each word is the abscissa and ordinate of a data point) of digital information. These 920 words represent a fixed storage display.

The maximum measured throughput rate for the system is 24000 words per second. The throughput rate can be reduced in increments of 100 words per second. The throughput rate, the number of data channels recorded, and the fixed display of 920 words per block determine the time base for displaying the data.

After the data have been stored, data reduction can be made for presentation and analysis purposes. Because of hardware limitations and aesthetic considerations of data presentation, only certain time bases are used when the data are reduced. For data displayed from -20 to $300 \mathrm{~s}$, the recorded data are made to occupy a $320 \mathrm{~s}$ span. This yields a time base of $16 \mathrm{~s}$, which is the $320 \mathrm{~s}$ span divided by the 20 blocks of recorded data.

Generally, 920 words from a given data channel are displayed in the nominal time base of $16 \mathrm{~s}$. Integral ( 1 to 20 ) multiples of $16 \mathrm{~s}$ may be used as variations on the nominal time base. Because the output is tixed at 920 words, data compression is made by averaging adjacent data points to give the desired compression. 


\section{THIS PAGE}

\section{WAS INTENTIONALLY LEFT BLANK}


APPENDIX B

POSTTEST ADJUSTMENTS TO DATA FROM SEMISCALE MOD-1 TEST S-28-5 


\section{THIS PAGE}

\section{WAS INTENTIONALLY \\ LEFT BLANK}




\section{APPENDIX B \\ POSTTEST ADJUSTMENTS TO DATA FROM SEMISCALE MOD-1 TEST S-28-5}

Many of the transducers used in the Semiscale Mod-1 system exhibit significant sensitivity to one or more spurious inputs. Strain gage bridge circuits used in pressure transducers, differential pressure transducers, and drag discs are sensitive to changes in ambient temperature. Differential pressure cells are also sensitive to changes in system pressure. Photomultiplier tubes used as gamma ray detectors in the density transducers are sensitive to temperature changes, as well as to random variations in the locations of the radiation sources. Core power measurements depend on a calibrated resistor, whose resistance changes in value as a function of time and power level as it heats up.

Although the errors introduced in to the data by spurious secondary inputs generally do not exceed the specified error ranges of the transducers, significant improvement in measurement accuracy can be achieved if the secondary sensitivity can be identified and removed. In the case of the drag discs, corrections are absolutely necessary because the signal due to temperature fluctuations can exceed that due to flow by several hundred percent. Since the exact values of the spurious inputs to which different transducers might be sensitive cannot often be easily predicted and are sometimes inconvenient to measure, secondary effects have been accounted for by correcting the data after the test rather than by using elaborate real time programs in the data acquisition system computer. The methods and results of the posttest data correction analysis for Test S-28-5 are presented in the following paragraphs and tables.

\section{PRESSURE MEASUREMENTS}

Corrections to pressure transducer measurements in the main system loop are based on data taken from the standard reference (Heise) gauge at Spool 4, taken $15 \mathrm{~s}$ before initiation of blowdown and at $300 \mathrm{~s}$ after initiation of blowdown. The pressure readings are adjusted to account for pressure variations around the main loop, using the readings of nearby differential pressure cells. A linear correction is then applied to the pressure data to match the data to the calculated reference data at the two specified time points.

Correction of the steam generator secondary pressure (PU-SGSD) measurement is done in the same manner as for the main loop pressures using a Heise gauge installed expressly for this purpose.

Pressure measurement corrections are performed using the data acquisition system (DAS) computer using the following equation:

$$
F^{\prime}(t)=C_{0}+C_{1}[F(t)]
$$


where

$$
\begin{aligned}
& F^{\prime}(t)=\text { corrected data } \\
& F(t)=\text { raw data } \\
& C_{Q}=\text { offset, } \mathrm{kPa} \\
& \mathrm{C}_{1}=\text { scaling factor. }
\end{aligned}
$$

The values of the offset and scaling factor are given in Table B-I.

\section{TABLE B-I}

CONSTANTS FOR PRESSURE MEASUREMENT CORRECTIONS (TFST S-TR-5)

\begin{tabular}{cccc}
\hline $\begin{array}{c}\text { Detector } \\
\text { Identification }\end{array}$ & $\frac{C_{0}}{1}$ & $\frac{C_{1}}{2}$ \\
\hline PU-SGSD & & -5.52 & 0.9757 \\
PB-42 & -53.78 & 1.0205 \\
PB-CN1 & -46.88 & 1.0125 \\
\hline
\end{tabular}

\section{DIFFERENTIAL PRE33URE MLASUREMENTS}

Pressure sensitivity in the differential pressure cells in the main system loop is determined from the pretest system pressure check. Digital data are recorded for all measurements at ambient temperature, with no system flow, at pressures of ambient, 1380, $3450,6900,10350,13800$, and $15500 \mathrm{kPa}$. The output of the differential pressure cells is plotted against system pressure, with the resulting plots used to describe the pressure response of the transducers.

The response of the differential pressure cells due to amblent temperalure is determined from a digital data scan taken at $533 \mathrm{~K}$ and $12150 \mathrm{kPa}$ with no system tlow. The measured transducer outputs are corrected for pressure and compared with the values calculated due only to the density difference between the water inside the loop $(533 \mathrm{~K})$ and outside the loop in the sense lines ( 300 to $311 \mathrm{~K}$ ).

The difference between the measured pressure corrected value and the calculated value is the thermal drift. After the data scan at $533 \mathrm{~K}$ is made, no more opportunities exist to obtain data with the pump stopped and the system full of fluid; therefore, for lack of 
later data, the thermal drift calculated from the $533 \mathrm{~K}$ data is assumed to be constant throughout the test.

For some differential pressure measurements, the data scan at $533 \mathrm{~K}$ cannot be used as a reference for thermal drift, so other references are used. For these detectors, and those having nonlinear pressure sensitivities, the corrections are performed according to the following equations:

$$
F^{\prime}(t)=K F(t)+c_{1} \text { for } t<t_{1} \text { or when no } t_{i} \text { are listed }
$$

for time points $t$, where $t_{1} \leqslant t \leqslant t_{n}$

$$
F^{\prime}(t)=K F(t)+c_{i}+\frac{t-t_{i}}{t_{i+1}-t_{i}}\left(c_{i+1}-c_{i}\right) \text { for } t_{i} \leq t \leq t_{i+1}
$$

where $\mathrm{i}$ takes on values 1 to $\mathrm{n}-1$

$$
F^{\prime}(t)=K F(t)+C_{n} \text { for } t>t_{n}
$$

where

$$
\begin{array}{lll}
\mathrm{t} & = & \text { time } \\
\mathrm{F}^{\prime}(\mathrm{t}) & = & \text { corrected data } \\
\mathrm{F}(\mathrm{t}) & = & \text { raw data } \\
\mathrm{K} & = & \text { scaling factor } \\
\mathrm{C}_{\mathbf{i}} \text { and } \mathrm{t}_{\mathrm{i}} & = & \text { corrections and time points. }
\end{array}
$$

\begin{tabular}{|c|c|c|}
\hline $\begin{array}{c}\text { Detector } \\
\text { Identification }\end{array}$ & K & $\mathrm{C}_{1}$ \\
\hline DPU-SGS-6 & -1 & 0 \\
\hline DPR-42-HN1 & -1 & 0 \\
\hline
\end{tabular}

The values of the constants are given in Table B-II.

TABLE B-I I

CONSTANTS FOR DIFFERENTIAL PRESSURE

MEASUREMLNT CORRECTIONS (TEST S-28-5) 


\section{MOMENTUM FLUX MEASUREMENTS}

The temperature sensitivity of drag discs is determined from pretest warmup data taken at 366 and $533 \mathrm{~K}$ with no system flow. The temperature sensitivity is removed before the data are converted to momentum flux. The temperature of each transducer is taken from the signal of a nearby fluid or metal temperature thermocouple. Slight corrections for errors in setting the transducer output to zero at ambient conditions are also made at this time. Corrections are made using the following equation:

$$
F^{\prime}(t)=F(t)+C_{0}-T_{1} T(t)-P_{1} P(t)
$$

where

$$
\begin{aligned}
& F^{\prime}(t)=\text { corrected data } \\
& F(t)=\text { raw data } \\
& T_{1}=\text { temperature sensitivity } \\
& T(t)=\text { temperature data from the transducer used for temperature correction } \\
& C_{0}=\text { ansitivity } \\
& P_{1}=\text { pressure sensitivity } \\
& P(t)=\text { pressure: data from the indicated. transducer used for pressure correction }
\end{aligned}
$$

Values of the constants are given in Table B-III. 
TABLE B-III

CONSTANTS FOR MOMENTUM FLUX

MEASUREMENT CORRECTIONS (TEST S-28-5)

\begin{tabular}{|c|c|c|c|c|c|c|c|}
\hline $\begin{array}{c}\text { Detector } \\
\text { Identification } \\
\end{array}$ & $\mathrm{C}_{0}$ & $\mathrm{~T}_{1}$ & & $T(t)^{[a]}$ & $P_{1}$ & & $P(t)^{[b]}$ \\
\hline FDU-1 & 0.467 & 0.000 & 338 & RBU-2 & -0.000 & 0400 & $P V-U P+10$ \\
\hline FDU-5 & 0 & -0.000 & 119 & TFU -6 & 0.000 & 0724 & $P V-U P+10$ \\
\hline FDU-10 & 0 & 0.000 & 102 & TFU-10 & & & \\
\hline FDU-13 & 0 & 0.000 & 483 & RBU-14A & & & \\
\hline FDB-21 & -0.025 & -0.000 & 438 & TFB-20 & -0.000 & 2255 & $P B-21$ \\
\hline FDB-23 & 0 & -0.000 & 477 & TFB -23 & -0.000 & 0648 & PB -23 \\
\hline $\mathrm{FDB}-30^{[\mathrm{c}]}$ & -0.174 & -0.000 & 488 & TFB -30 & & & \\
\hline $\mathrm{FDB}-37^{[\mathrm{c}]}$ & -0.015 & 0.000 & 277 & TFB -37 & -0.000 & 0062 & PB -37 \\
\hline FDB -42 & 0.167 & 0.000 & 364 & $T F B-42$ & 0.000 & 4682 & $P B-42$ \\
\hline FDV-CORE-IN & 0 & -0.000 & 027 & TFV-CORE-IN & & & \\
\hline
\end{tabular}

[a] $T(t)$ is the temperature data used for temperature sensitivity correction. The symbols listed identify the thermocouples from which the data are obtained.

[b] $P(t)$ is the pressure data from the indicated transducer used for pressure sensitivity correction. The symbols listed identify the pressure transducers from which the data are obtained.

[c] Temperature sensitivity corrections were applied as usual; however, because FDB-30 and FDB-37 are mounted horizontally, during blowdown they are partially filled with subcooled water which affected the temperature sensitivity. Therefore, the temperature sensitivity correction is more uncertain than that applied to other temperature sensitivity corrections. 


\section{DENSITY MEASUREMENTS}

Density calculations are based on the voltage output of the photomultiplier tubes in the gamma-attenuation densitometer assemblies. The equation used for converting voltage to density is as follows:

$$
\rho=(I / C) \ln \{D /[A F(t)+B]\}
$$

where
$\rho=$ the density in $\mathrm{kg} / \mathrm{m}^{3}$
C. = a constant based on the length of the gamma bcam path
$\mathrm{D}=\mathrm{a}$ theoretical voltage for zero altenualiun inside the vesscl
A $\equiv$ an amplification factor
B. $\quad=$ a biasing factor
$F(t)=$ the transducer voltage output.

Constants $\mathrm{A}$ and $\mathrm{B}$ are adjusted to match the find dala lo denisity values calculated from measured pressure and temperature values at the prebluwduwin and postdrain conditions, effectively giving the data an in-placc calibration. The values of the constants for various transducers are given in Table B-IV.

The density measurements GVLP-172HZ and GV-COR-150HZ use amplifiers which. precalculate the logarithm function, and hence have a simpler conversion formula:

$$
\begin{array}{ll}
\text { GVLP-172HZ } & \rho=-27.743 \mathrm{H}(\mathrm{t})-1084.4 \\
\text { GV-COR-150HZ } & \rho=-49.640 \mathrm{~F}(\mathrm{t}) .-1925.4 .
\end{array}
$$

Some density measurements are obtained using a two-beam gamma densitometer which operates. on the same basic principle of gamma attenuation as does the single-beam. gamma densitometer: Each beam originates from the same gamma source and is allowed to pass through separate portions of the piping cross-sectional flow area to obtain an average density measurement in that particular region. The geometrical relationship of the gammit heam path through the piping and geometrically related variables used for processing of data from a two-beam gamma densitometer are shown in Figure B-1.

The average density measured by each individual gamma beam is obtained using the same equation as is used for the single-beam gamma densitometers. Values for the constants 
TABLE B-IV

CONSTANTS FOR DENSITY MEASUREMENT

CONVERSIONS TO ENGINEERING UNITS (TEST S-28-5)

\begin{tabular}{|c|c|c|c|c|}
\hline $\begin{array}{c}\text { Detector } \\
\text { Identification } \\
\end{array}$ & A & $B$ & $C$ & D \\
\hline GU-1T & 1.076 & -0.242 & 0.000356 & 6.80 \\
\hline GU-1B & 1.006 & 0.200 & 0.000499 & 7.33 \\
\hline GU-5VR & 1.091 & -0.261 & 0.000593 & 4.70 \\
\hline GU-10VR & 1.092 & -0.393 & 0.000593 & 6.76 \\
\hline GU-13VR & 0.810 & 0.402 & 0.000593 & 1.92 \\
\hline GU-15T & 1.169 & -0.818 & 0.000 .356 & 6.55 \\
\hline GU-15B & 1.003 & 0.216 & 0.000499 & 7.47 \\
\hline GB-21T & 1.061 & -0.157 & 0.000356 & 6.81 \\
\hline$G B-21 B$ & 1.081 & -0.357 & 0.000499 & 7.94 \\
\hline$G B-23 V R$ & 1.023 & 0.085 & 0.000375 & 7.01 \\
\hline GB-30T & 1.139 & -0.603 & 0.000356 & 6.26 \\
\hline$G B-30 B$ & 1.035 & -0.001 & 0.000499 & 8.13 \\
\hline $\mathrm{GB}-37 \mathrm{HZ}$ & 1.670 & -2.518 & 0.000593 & 4.15 \\
\hline$G B-42 V R$ & 0.726 & 2.366 & 0.000375 & 7.96 \\
\hline GVLP- $165 \mathrm{HZ}$ & 1.018 & -0.033 & 0.001498 & 7.15 \\
\hline GU-PRIZE & 1.275 & -0.218 & 0.000593 & 0.93 \\
\hline
\end{tabular}

for the single-beam density measurements obtained with the two-beam gamma densitometers are presented in Table B-IV along with the constants for single-beam gamma densitometers.

In the Semiscale Mod-1 system, two-beam gamma densitometers provide added information which allows the calculation of a better average density than that obtained from a single beam. A mathematical model is used for processing the two-beam data to obtain the improved average density information. The processing method used is based on a froth-water model coupled with information from the two individual gamma beams and 


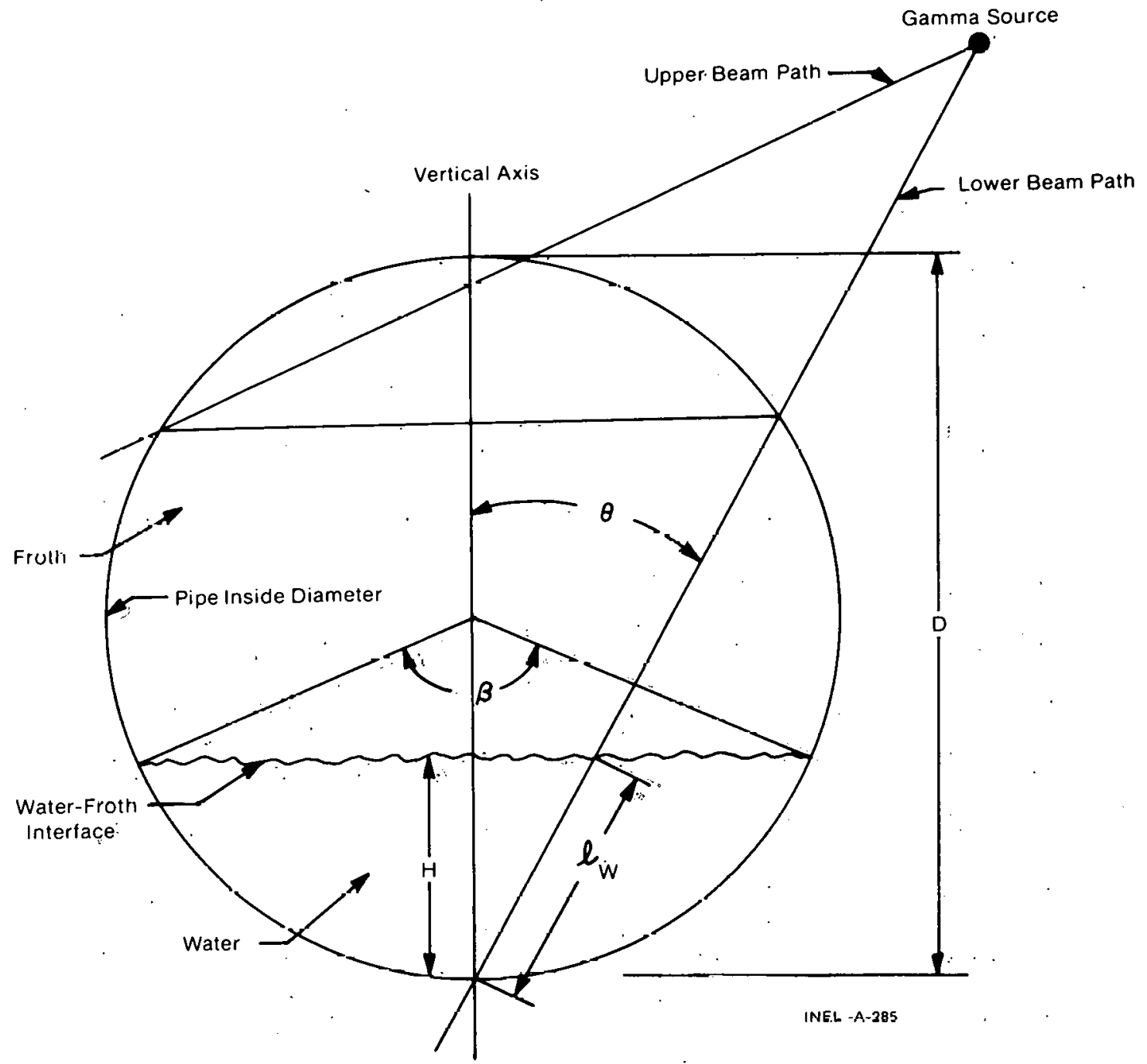

Fig. B-1. Geometry used for processing of density data obtained from two-beam gamma densitometers.

related beam path and piping cross-sectional geometry. The rcsulting information is reçorded and reported under the density measurement identification ending with a " $\mathrm{C}$.", for example, GB-21.C.

The use of the froth-water model: for obtaining average density from a two-beam gamma densitometer is based on observations indicating that flow regimes in the Semiscale Mod-1 systcm can be modeled by a layer of water on the bottom of the pipe with a degree of froth on the surface. For homogeneous flow conditions such as all froth or all liquid the model remains valid. At any point in time slug flow is also modeled. The froth-water model does not model annular or inverted annular flows very well: However, these flows are not expected to exist : for significant portions of a Semiscale Mod-1 system blowdown in horizontal piping. Density gradients from the top to the bottom of the pipe may exist showing no. distinct location change from water to froth. This flow is neither totally homogeneous nor stratified, but the froth-water model does provide an adequate approximation of the average density characteristic of this flow pattern. 
The average density obtained by using the gamma beam geometry shown in Figure B-1 and by applying the froth-water model is given by:

$$
\bar{\rho}=\alpha_{f} \rho_{1}+\left(1-\alpha_{f}\right) \rho_{w} \mathrm{~kg} / \mathrm{m}^{3}
$$

where

$$
\begin{aligned}
& \bar{\rho}=\text { average cross-sectional density } \\
& \rho_{1}=\begin{array}{l}
\text { average density measured by the upper gamma beam (measures the froth } \\
\text { density) }
\end{array} \\
& \rho_{\mathrm{W}}=\text { density of liquid water (at local system conditions) } \\
& \alpha_{\mathrm{f}}=1+(1 / 2 \pi)(\sin \beta-\beta)=\text { froth fraction. }
\end{aligned}
$$

The angle which $\beta$ represents is shown in Figure B-1. Values for $\beta$ are obtained as follows:

$$
\beta=2 \cos ^{-1}(1-2 h)
$$

where

$$
\mathrm{h}=\frac{\mathrm{H}}{\mathrm{D}}=\cos ^{2} \theta \frac{\rho_{2}-\rho_{1}}{\rho_{\mathrm{w}}-\rho_{1}}
$$

where

$\mathrm{H}=\ell_{\mathrm{W}} \cos \theta\left(\ell_{\mathrm{W}}\right.$ and $\theta$ are defined in Figure B-1 $)$

$\mathrm{D}=$ piping inside diameter

$\rho_{2}=$ the average density measured by the lower gamma beam.

Average density is not calculated using the two-beam froth-water model when the angle $\theta$ is not favorable due to system hardware restrictions in positioning the source. The froth-water model requires separate density sampling in both the upper portions of the piping cross section.

\section{CORE POWER MEASUREMENTS}

Corrections to core power readings are determined from the core voltage and core current readings, with a slight adjustment for the power lust in setting the core radial peaking factor. The adjustments are as follows: 


$$
\begin{array}{ll}
\text { PWRCOR T-1: } & F^{\prime}(t)=1.0137 F(. t)+2.07^{\circ}=\text { (voltage) }(\text { current })(0.954) \\
\text { PWRCOR T-2: } & F^{\prime}(t)=1.0168 F(t)+4.78=(\text { voltage) (current) }(0.954)
\end{array}
$$

where

$$
\begin{aligned}
& F^{\prime}(t)=\text { core power in kilnwatts } \\
& F(t)=\text { the raw core power reading. }
\end{aligned}
$$




\section{APPENDIX C}

SELECTED DATA WITH ESTIMATED TOTAL ERROR BANDS FROM SEMISCALE MOD-1 TEST S-28-5 


\section{THIS PAGE WAS INTENTIONALLY LEFT BLANK}




\section{APPENDIX C \\ SELECTED DATA WITH ESTIMATED TOTAL ERROR BANDS FROM SEMISCALE MOD-1 TEST S-28-5}

Analysis has been performed on selected data from Test S-28-5 to provide a guide to the uncertainty associated with data measurements in the Semiscale Mod-1 system. The end result of the analysis is presented as error bands about the measured data which represent a $95 \%$ confidence level.

The error bands are obtained by combining uncertainties obtained from analysis of the data itself (random error) and engineering analysis of the measurement system (engineering error). The procedure by which error bands were established for the data presented in this appendix is described in the following paragraphs.

The data trace under analysis was empirically fitted with a linear difference equation, which was subject to a white noise input at each sampling time point. The objective of the empirical fitting procedure was to characterize the white noise, which was taken to represent the random error. The procedures for fitting the difference equation are discussed in depth in Reference C-1. A data trace was often segmented and different equations were fitted to each segment with statistical correlations between successive observations accounted for by the fitting procedure. The white noise input was assumed to arise from a normally distributed population. The standard deviation of the white noise, as found during the fitting procedures, was taken as an estimate of the random error standard deviation and is shown in Table C-I. The data traces of the error band analysis are shown in Figures C-1 through $\mathrm{C}-44$.

TABLE C-I

RANDOM ERROR VARIANCE (TEST S-28-5)

\begin{tabular}{|c|c|c|c|c|}
\hline Measurement & $\begin{array}{c}\text { Random Error } \\
\text { Variance } \\
\sigma_{\mathrm{R}} \\
\end{array}$ & $\begin{array}{c}\text { Period of } \\
\text { Application } \\
\text { (s) } \\
\end{array}$ & Figure & Comments \\
\hline TFB-23 & $\begin{array}{r}12.559 \\
j .105\end{array}$ & $\begin{aligned} 0 & \text { to } \\
68 & \text { to } 736\end{aligned}$ & $c-1$ & \\
\hline TFV-ANN-35A & $\begin{array}{r}18.543 \\
0.959\end{array}$ & 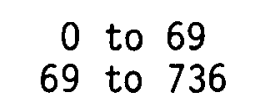 & $C-2$ & \\
\hline$T F V-L P-2$ & $\begin{array}{c}37.374 \\
0.53\end{array}$ & $\begin{aligned} 0 & \text { to } \\
69 & \text { to } 736\end{aligned}$ & $C-3$ & \\
\hline
\end{tabular}


TABLE C-I" (continued)

\begin{tabular}{|c|c|c|c|c|}
\hline Measurement & $\begin{array}{c}\text { Random Error } \\
\text { Variance } \\
\sigma_{R} \\
\end{array}$ & $\begin{array}{c}\text { Period of } \\
\text { Application } \\
\text { (s) }\end{array}$ & Figure & Comments \\
\hline$T F V-1, P-4$ & $\begin{array}{r}18.857 \\
34.073 \\
69.639 \\
66.968 \\
0.504\end{array}$ & $\begin{array}{l}n \text { to } 45 \\
45 \text { to } 56 \\
56 \text { to } 64 \\
64 \text { to } 73 \\
73 \text { to } 736\end{array}$ & r. -4 & \\
\hline TFV-LP-7 & $\begin{array}{r}36.806 \\
63.122 \\
38.240 \\
53.532 \\
0.752\end{array}$ & $\begin{array}{l}0 \text { to } 31 \\
31 \text { to } 41 \\
47 \text { tu } 60 \\
60 \text { to } 70 \\
70 \text { to } 736\end{array}$ & $C-5$ & \\
\hline$T F G-5 C D-45$ & $\begin{array}{r}12.647 \\
3.563\end{array}$ & $\begin{array}{r}0 \text { to } 745 \\
145 \text { to } 736\end{array}$ & C. -6 . & \\
\hline TFU-SG3 & 0.367 & 0. to 736 & $C-7$ & \\
\hline TFU-PRIZE. & $\begin{array}{l}5.732 \\
.1 .133\end{array}$ & $\begin{array}{r}0 \text { to } 40 \\
40 \text { to } 736\end{array}$ & $c-8$ & \\
\hline TMU- 1 TI6 & 0.331 & 0 to 736 & C.9. & \\
\hline TMV-CI-70A & $\begin{array}{l}3.655 \\
2.492 \\
0.486 \\
7.927 \\
0.470\end{array}$ & 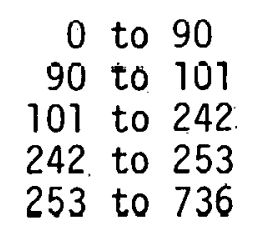 & $c-10$ & \\
\hline TH-E4-09 & $\begin{array}{r}2.329 \\
39.692 \\
0.616\end{array}$ & $\begin{array}{r}0 \text { to } 402 \\
402 \text { to } 415 \\
411 \text { to } 736\end{array}$ & $c-11$ & \\
\hline TH-E4-27 & $\begin{array}{r}2.931 \\
29.939 \\
8.807\end{array}$ & $\begin{array}{r}0 \text { to } 504 \\
504 \text { to } 521 \\
521 \text { to } 736\end{array}$ & $C-12$ & . \\
\hline TH-E4-55 & 1.254 & 0 to 736 & $c-13$ & \\
\hline PU- 13 & $\begin{array}{r}11.409 \\
1.860\end{array}$ & $\begin{aligned} 0 & \text { to } 29 \\
29 & \text { to } 736\end{aligned}$ & $C-14$ & \\
\hline PB-23 & $\begin{array}{r}12.015 \\
1.406\end{array}$ & $\begin{array}{c}0 \text { to } 34 \\
34 \text { to } 736\end{array}$ & $C-15$ & \\
\hline
\end{tabular}


TABLE C-I (continued)

\begin{tabular}{|c|c|c|c|c|}
\hline Measurement & $\begin{array}{c}\text { Ranidom Error } \\
\text { Variance } \\
\sigma_{R} \\
\end{array}$ & $\begin{array}{l}\text { Period of } \\
\text { Application } \\
\text { (s) } \\
\end{array}$ & Figure & Comments \\
\hline DPU-6-SGIP & $\begin{array}{l}0.162 \\
2.127 \\
0.234 \\
0.082 \\
0.408 \\
0.280 \\
0.939 \\
0.072\end{array}$ & $\begin{array}{r}0 \text { to } 31 \\
31 \text { to } 41 \\
41 \text { to } 78 \\
78 \text { to } 632 \\
632 \text { to } 640 \\
640 \text { to } 707 \\
707 \text { to } 718 \\
718 \text { to } 736\end{array}$ & $C-16$ & \\
\hline DPU-SGOP- 7 & $\begin{array}{l}1.415 \\
0.231\end{array}$ & $\begin{array}{r}0 \text { to } 79 \\
79 \text { to } 736\end{array}$ & $C-17$ & \\
\hline DPU-7-10 & $\begin{array}{l}0.156 \\
0.060\end{array}$ & 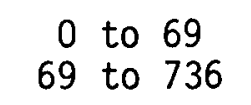 & $C-18$ & \\
\hline DPU- $12-10$ & $\begin{array}{l}0.725 \\
0.158\end{array}$ & $\begin{aligned} & 0 \text { to } \\
& 43 \\
& 43 \text { to } 736\end{aligned}$ & $C-19$ & \\
\hline DPU- $12-15$ & $\begin{array}{l}0.306 \\
0.059\end{array}$ & $\begin{array}{r}0 \text { to } 71 \\
71 \text { to } 736\end{array}$ & $C-20$ & \\
\hline FTU-1 & $\begin{array}{r}109.613 \\
12.290 \\
29.436\end{array}$ & $\begin{aligned} 0 & \text { to } 68 \\
68 & \text { to } 637 \\
637 & \text { to } 736\end{aligned}$ & $C-21$ & , \\
\hline FTU- 15 & $\begin{array}{l}23.953 \\
49.420 \\
13.326 \\
81.134\end{array}$ & $\begin{aligned} & 0 \text { to } \\
& 85 \text { to } 100 \\
& 100 \text { to } 640 \\
& 640 \text { to } 736\end{aligned}$ & $C-22$ & \\
\hline FTU-HPIS & 0.051 & 0 to 736 & $C-23$ & \\
\hline FTU-LPIS & $\begin{array}{l}0.471 \\
0.056\end{array}$ & $\begin{aligned} 0 & \text { to } 67 \\
67 & \text { to } 736\end{aligned}$ & $C-24$ & \\
\hline FTU-ACCl & $\begin{array}{l}2.145 \\
2.329 \\
0.673 \\
2.906 \\
2.093\end{array}$ & $\begin{array}{c}0 \text { to } 7 \\
7 \text { to } 19 \\
19 \text { to } 59 \\
59 \text { to } 72 \\
72 \text { to } 92\end{array}$ & $C-25$ & $\begin{array}{l}\text { Error bands are not } \\
\text { presented from }[\mathrm{a}] \\
t=92 \text { to } 736 \mathrm{~s}\end{array}$ \\
\hline FTV-40A & $\begin{array}{l}7.519 \\
1.357\end{array}$ & $\begin{aligned} 0 & \text { to } 72 \\
72 & \text { to } 736\end{aligned}$ & $C-26$ & \\
\hline FTV-40M & $\begin{array}{l}8.104 \\
0.935\end{array}$ & 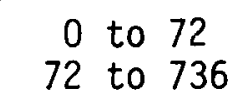 & $C-27$ & \\
\hline
\end{tabular}


TABLE C-I (continued)

\begin{tabular}{|c|c|c|c|c|}
\hline Measurement & $\begin{array}{c}\text { Random Error } \\
\text { Variance } \\
\sigma_{R} \\
\end{array}$ & $\begin{array}{c}\text { Period of } \\
\text { Application } \\
\text { (s) }\end{array}$ & Figure & Comments \\
\hline GU-1T & $\begin{array}{l}1.180 \\
0.387\end{array}$ & 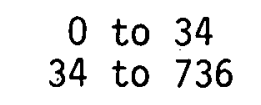 & $C-28$ & \\
\hline GU- IB & $\begin{array}{l}2.862 \\
0.821 \\
1.110 \\
1.327\end{array}$ & $\begin{aligned} & 0 \text { to } 15 \\
& 15 \text { to } 59 \\
& 59 \text { to } 503 \\
& 503 \text { to } 736\end{aligned}$ & $C-29$ & \\
\hline GU- IC & $0 . / 9 /$ & 0 to 736 & $C-30$ & \\
\hline GU- 10VR & $\begin{array}{l}2.317 \\
0.361\end{array}$ & $\begin{array}{c}0 \text { to } 34 \\
34 \text { to } 736\end{array}$ & $C-31$ & \\
\hline GU- $15 T$ & $\begin{array}{r}1.227 \\
5.494 \\
8.302 \\
0.621 \\
7.576\end{array}$ & $\begin{array}{r}0 \text { to } 21 \\
21 \text { to } 58 \\
58 \text { to } 68 \\
68 \text { to } 640 \\
640 \text { to } 736\end{array}$ & $C-32$ & \\
\hline GU-15B & $\begin{array}{r}8.070 \\
6.978 \\
11.118 \\
1.982 \\
1.248 \\
6.293\end{array}$ & $\begin{array}{r}0 \text { to } 21 \\
21 \text { to } 58 \\
58 \text { to } 68 \\
68 \text { to } 98 \\
98 \text { to } 610 \\
640 \text { to } 736\end{array}$ & $c-33$ & \\
\hline fill- 15 C. & $\begin{array}{l}8.464 \\
8.592 \\
1.160 \\
6.925\end{array}$ & $\begin{array}{c}0 \text { to } 58 \\
50 \text { to } 71 \\
71 \text { to } 640 \\
640 \text { to } 136\end{array}$ & $C-31$ & \\
\hline$G B=23 V R$ & $\begin{array}{l}8.495 \\
7.359 \\
2.022\end{array}$ & $\begin{array}{l}: 0 \text { to } 60 \\
60 \text { to } 71 \\
71 \text { to } 736\end{array}$ & $C-35$ & \\
\hline GV-COR-15OHZ & $\begin{array}{r}0.559 \\
12.859 \\
3.646\end{array}$ & $\begin{array}{r}0 \text { to } 279 \\
279 \text { to } 336 \\
336 \text { to } 736\end{array}$ & $c-36$. & \\
\hline GVI.P- $165 \mathrm{HZ}$ & $\begin{array}{l}6.270 \\
0.285 \\
9.733 \\
4.017 \\
2.730\end{array}$ & $\begin{array}{r}0 \text { to } 18 \\
18 \text { to } 59 \\
59 \text { to } 72 \\
72 \text { to } 164 \\
164 \text { to } 736\end{array}$ & $C=37$ & \\
\hline
\end{tabular}


TABLE C-I (continued)

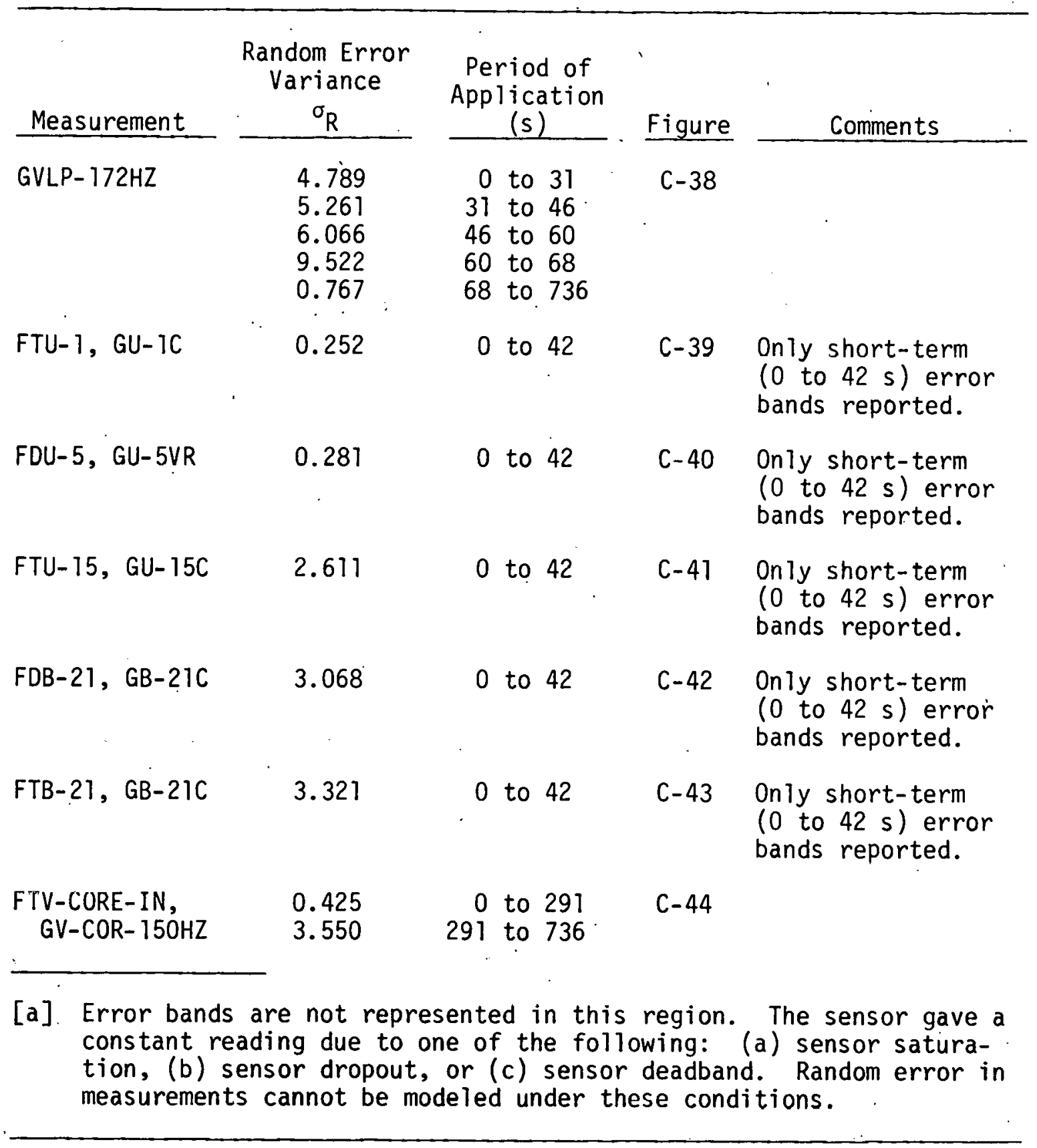

Other errors in the data exist because of such factors as variability in installation procedures and techniques, calibration errors, variability in materials, and temperature and pressure sensitivities. These errors and the procedures for estimating them are discussed in Reference C-2. They are referred to as engineering errors and the estimates are largely subjective. Because of the continuing effort to improve the accuracy of the measured data, such as through the use of better transducers, better signal conditioning and processing equipment, and better calibration and installation techniques, the engineering errors for data from most of the transducer systems have changed from those published in Reference C- 2 . 


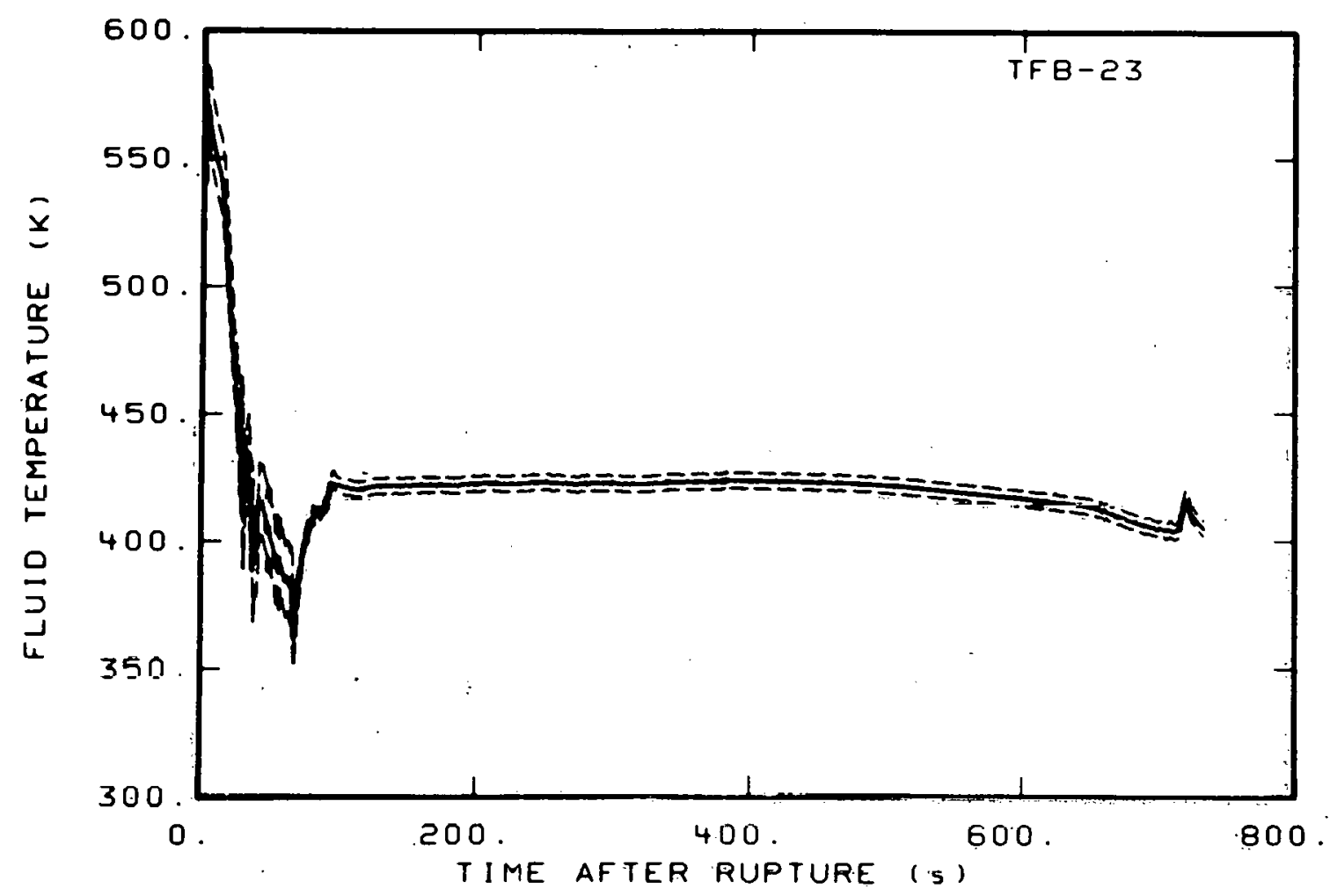

Fig. C-1 Fluid temperature in broken loop (TFB-23).

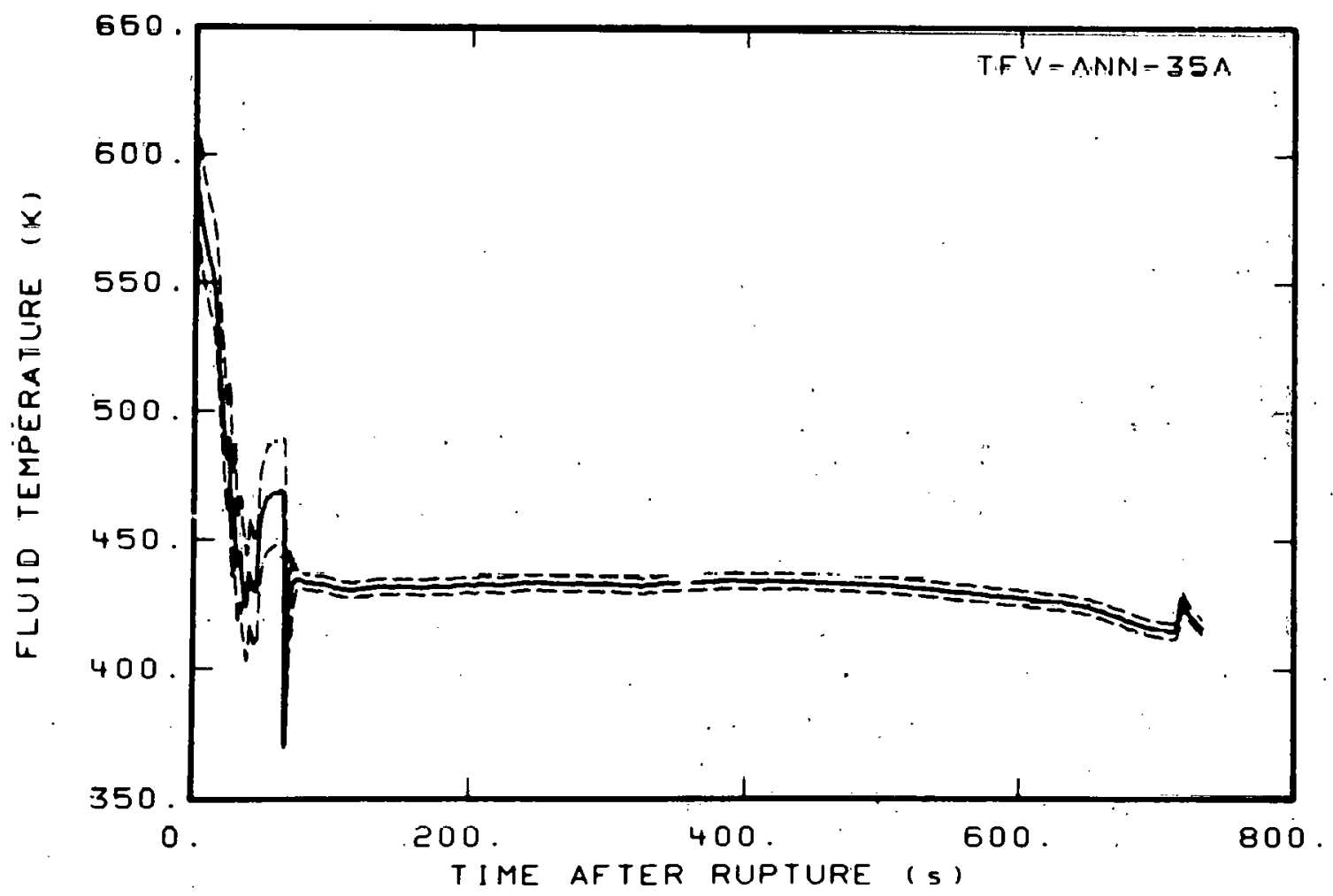

Fig. C-2 Fluid temperature in downcomer annulus (TFV-ANN-35A). 


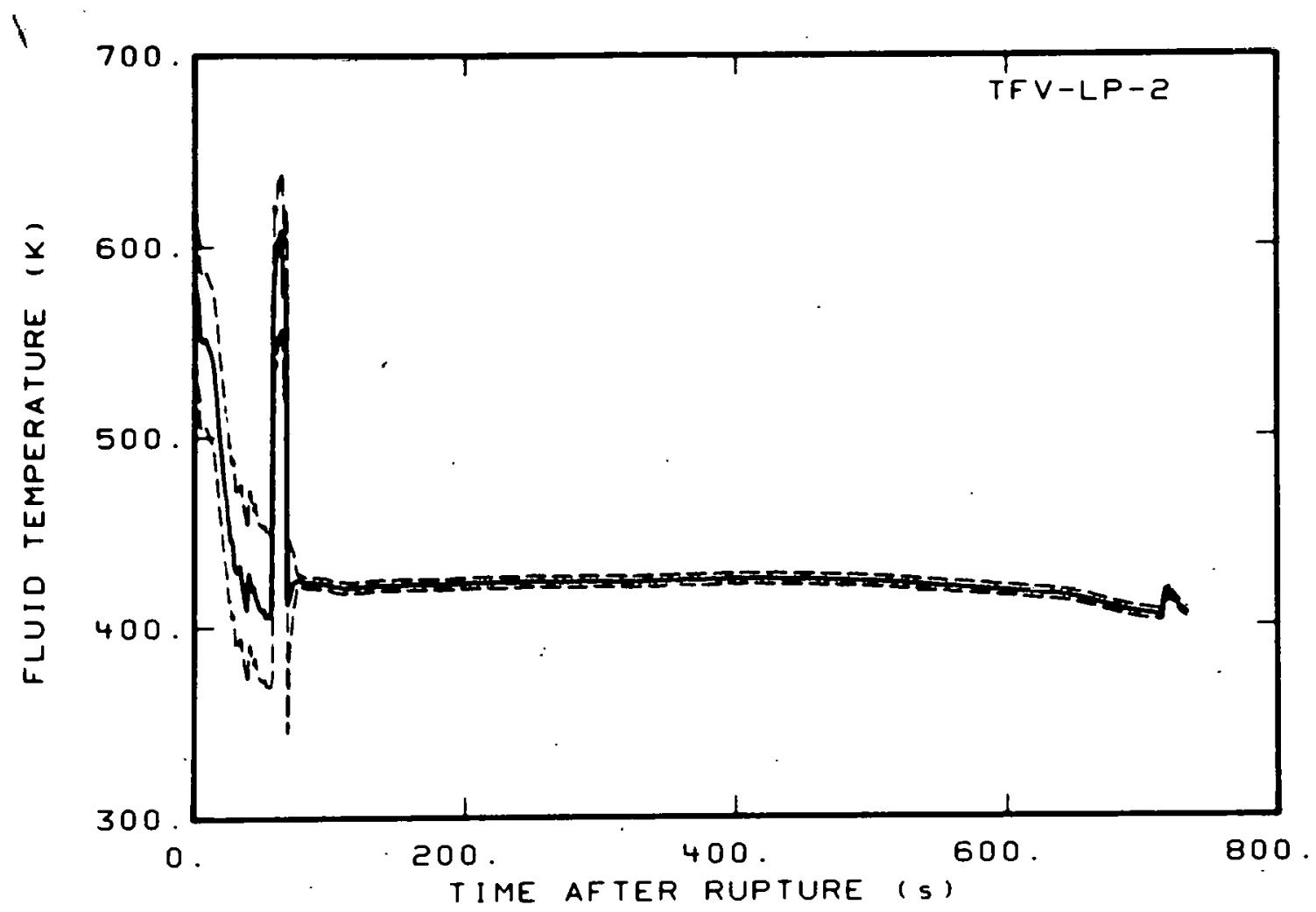

Fig. C-3 Fluid temperature in lower plenum (TFV-LP-2).

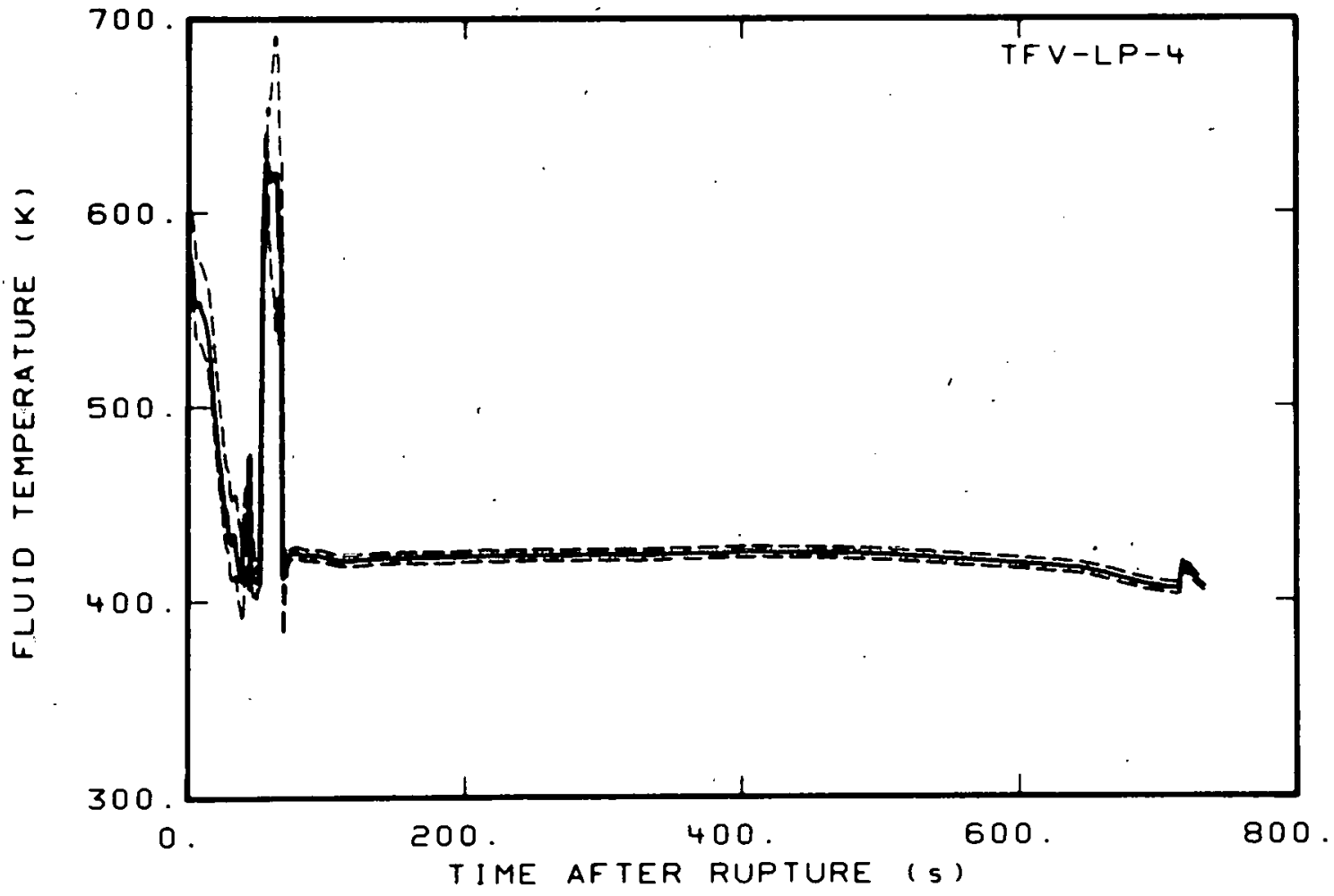

Fig. C-4 Fluid temperature in lower plenum (TFV-LP-4). 


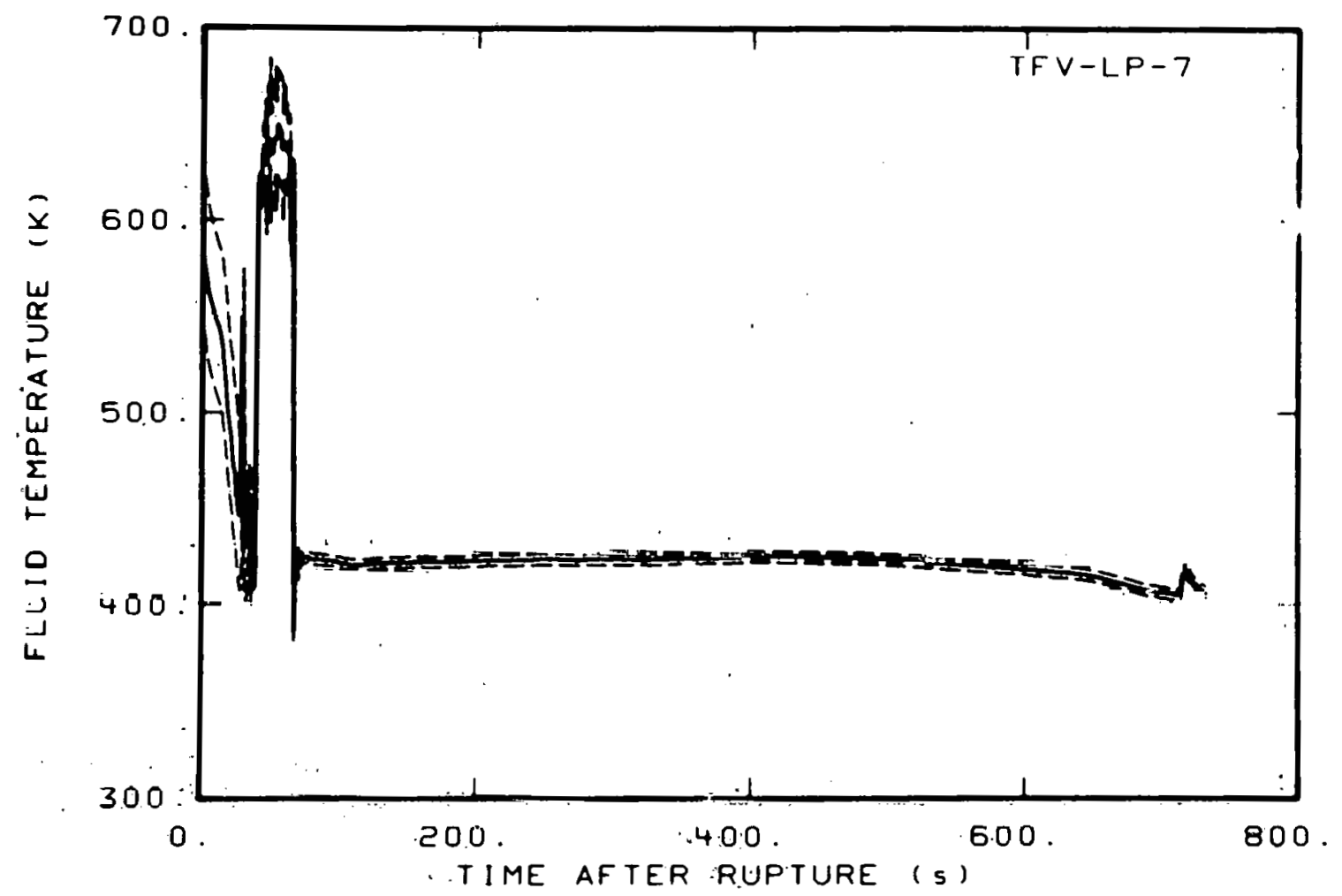

Fig. C-5 Fluid temperature in lower plenum (TFV-LP-7).

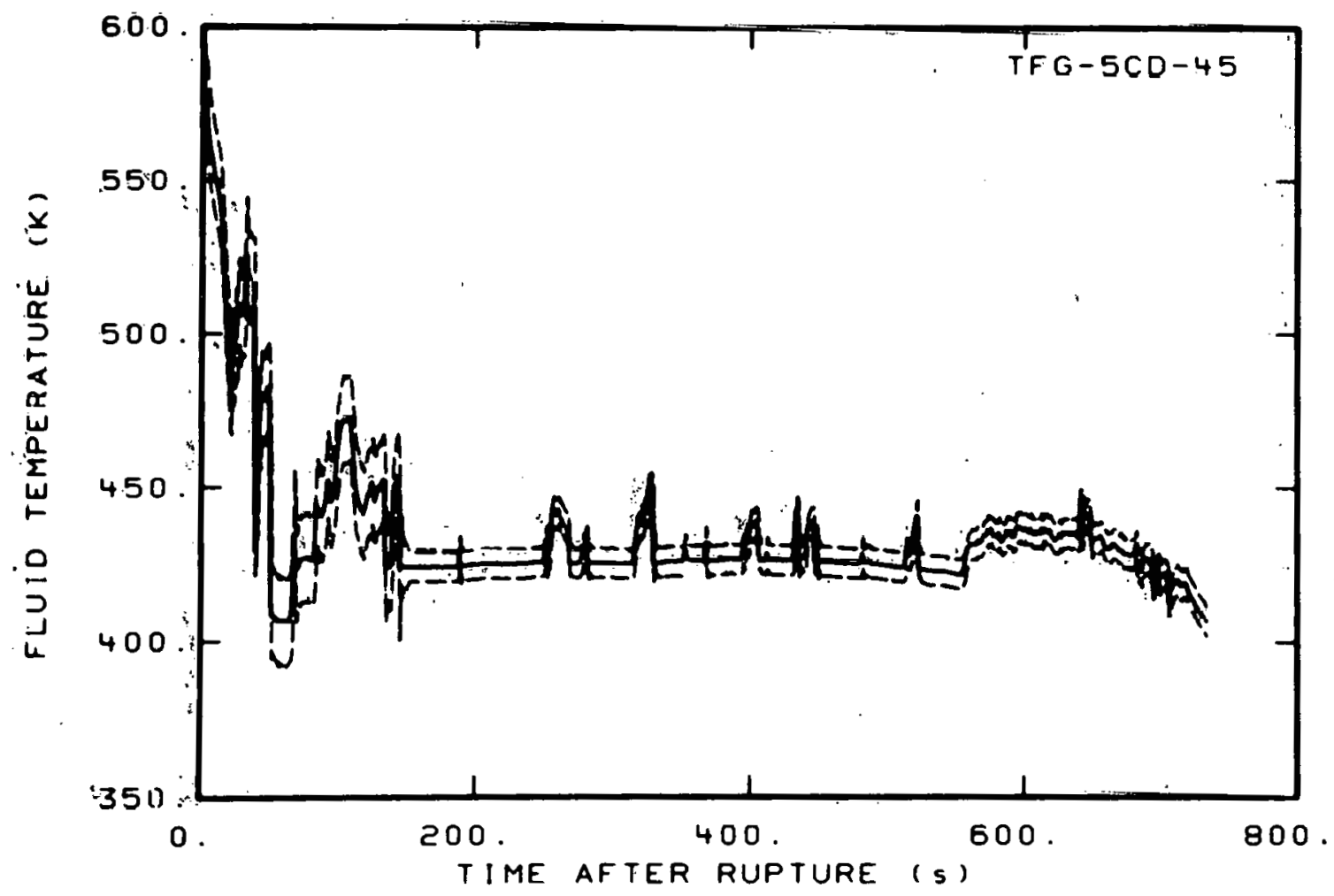

Fig. C-6 Fluid temperature in core, Grid Spacer 5 (TFG-5CD-45). 


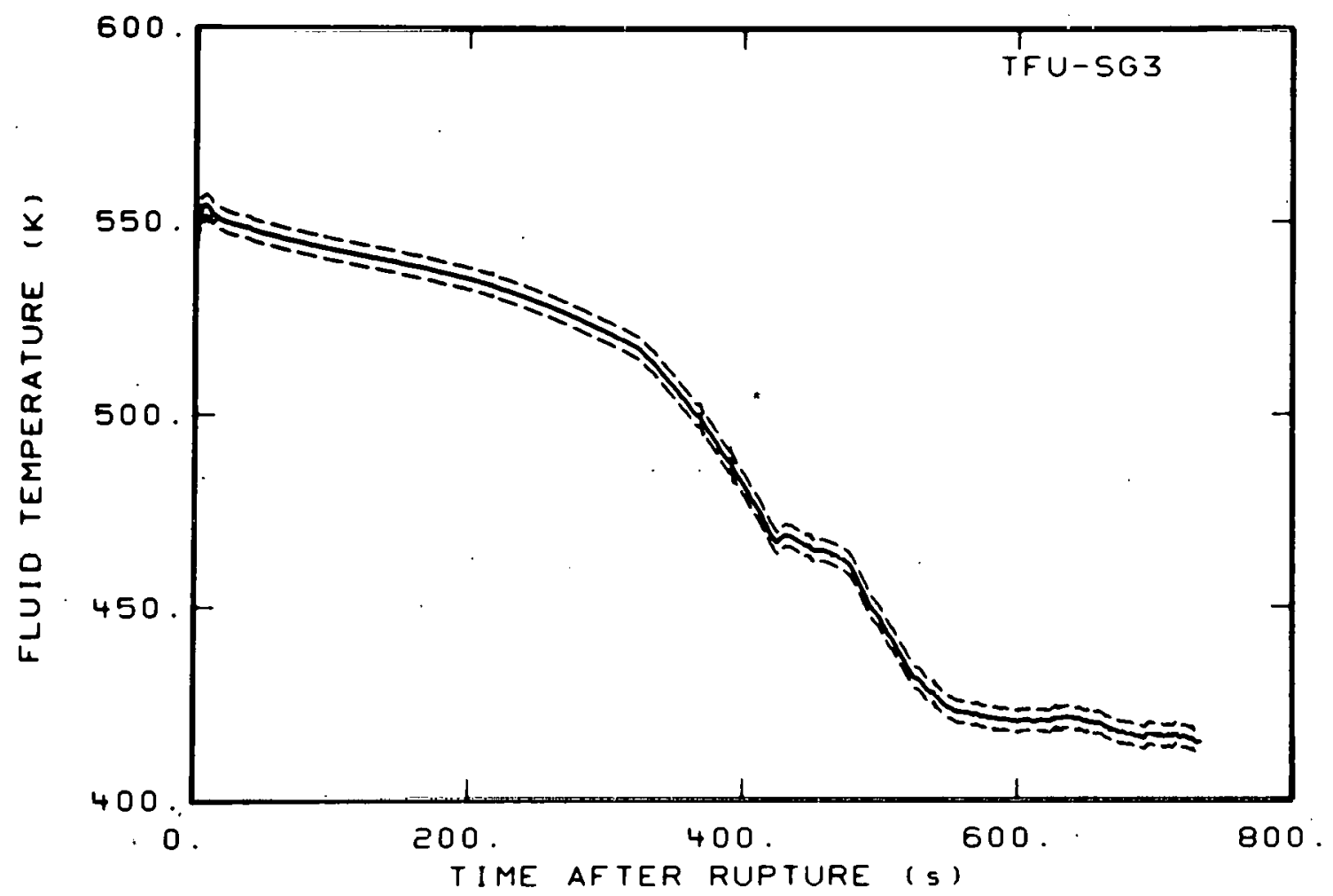

Fig. C-7 Fluid temperature in steam generator, secondary side (TFU-SG3):

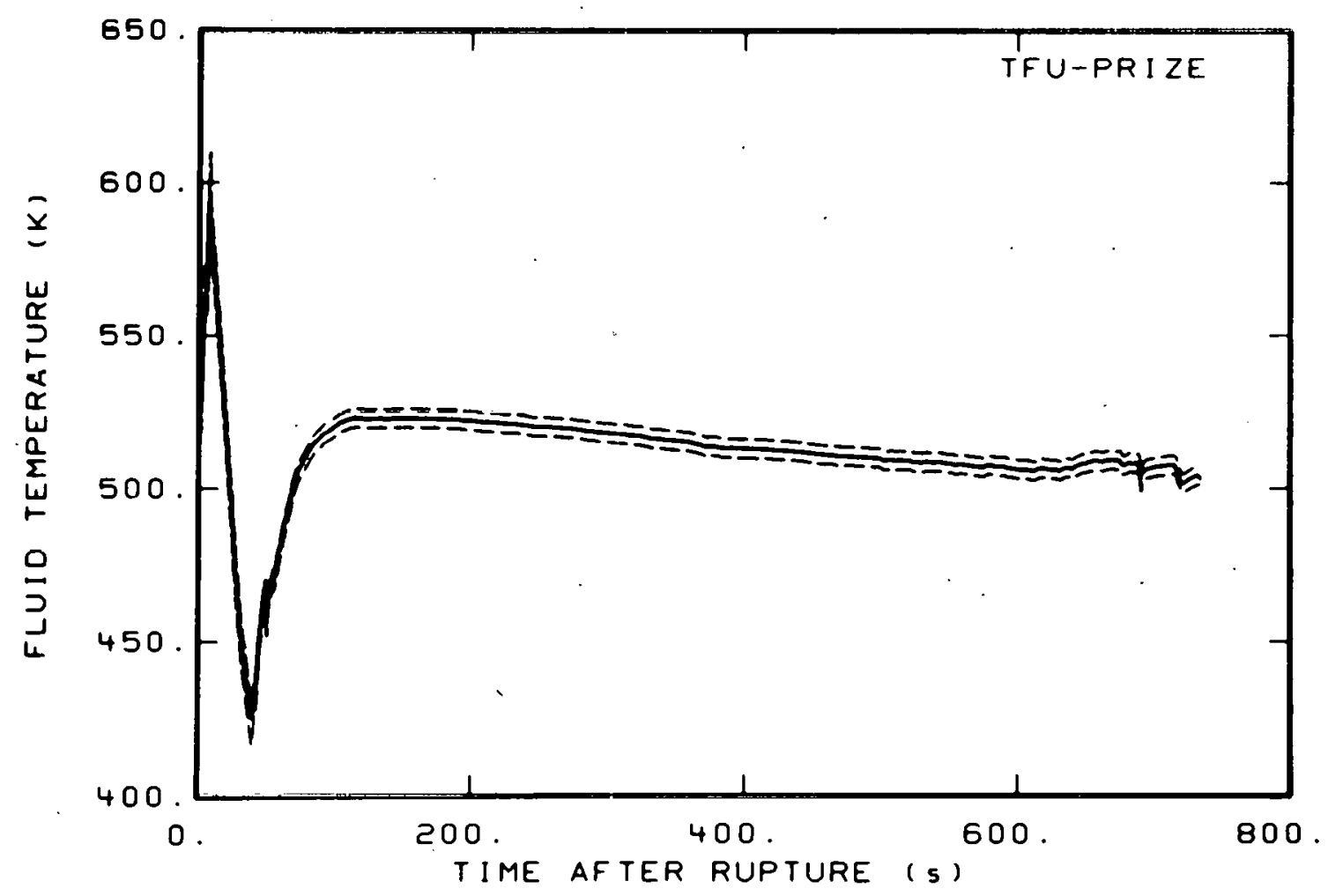

Fig. C-8 Fluid temperature in pressurizer surge line (TFU-PRIZE). 


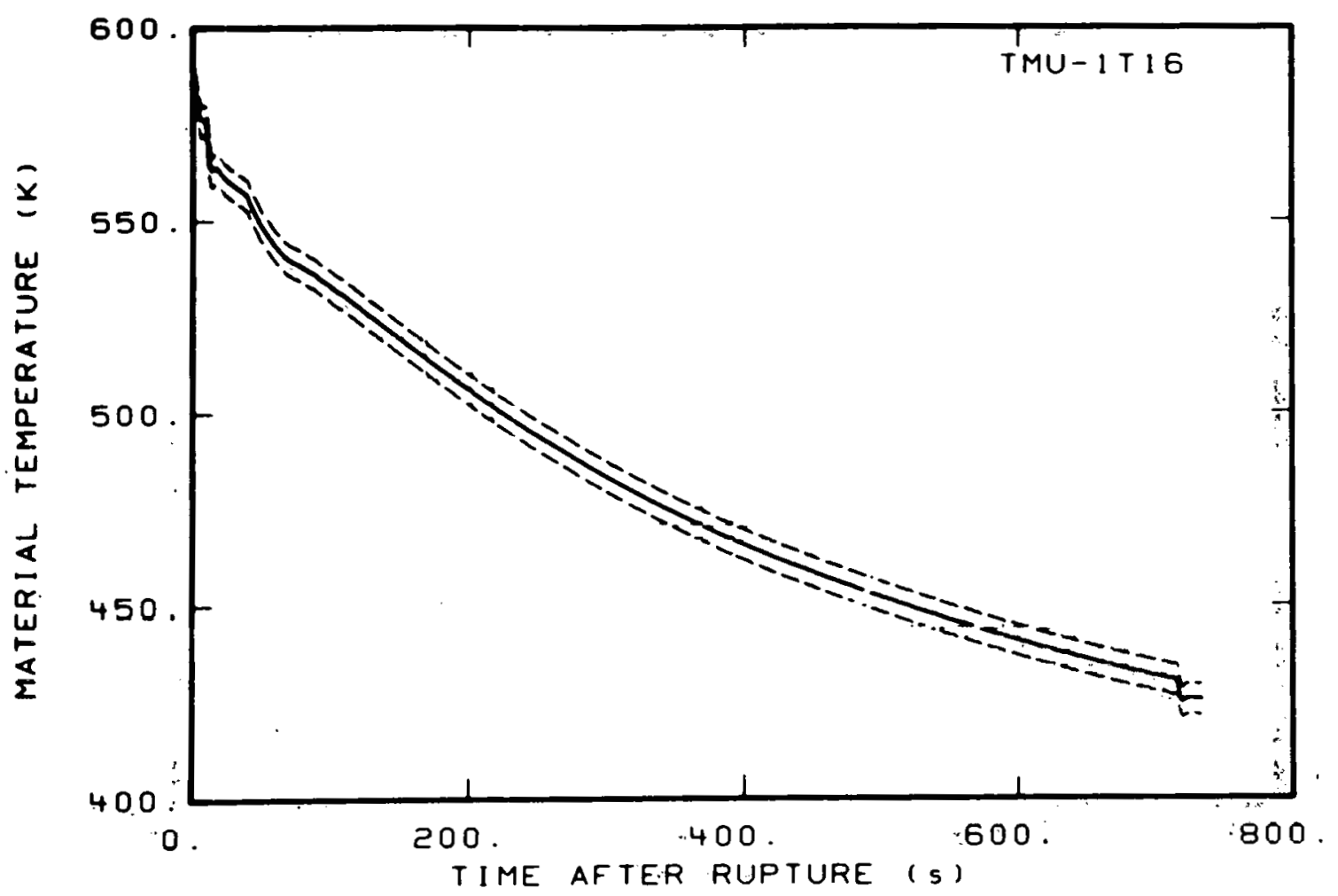

Fig. C-9 Material temperature in intact loop (TMU-1T16).

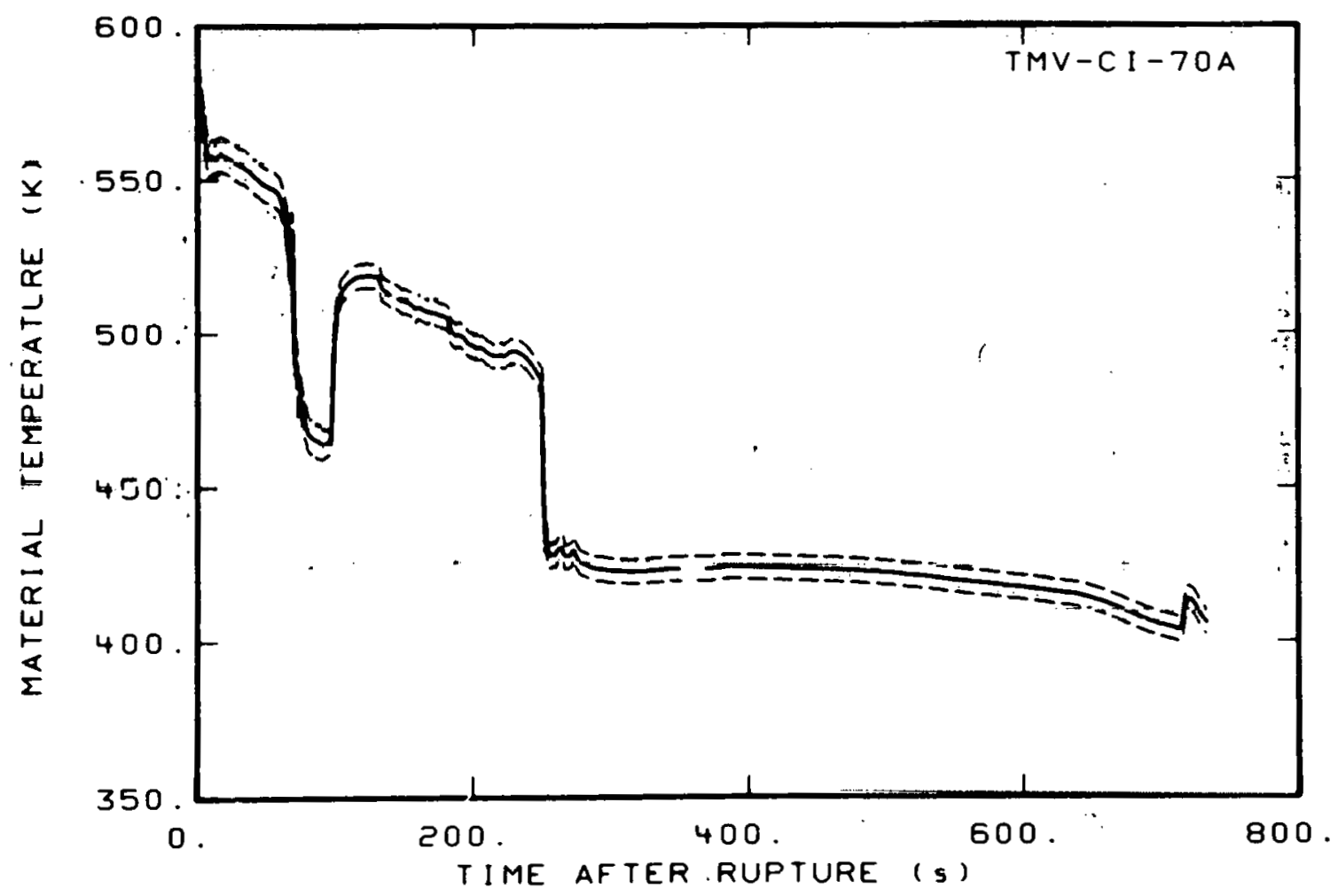

Fig. C-10 Material temperature in vessel filler (TMV-CI-70A). 


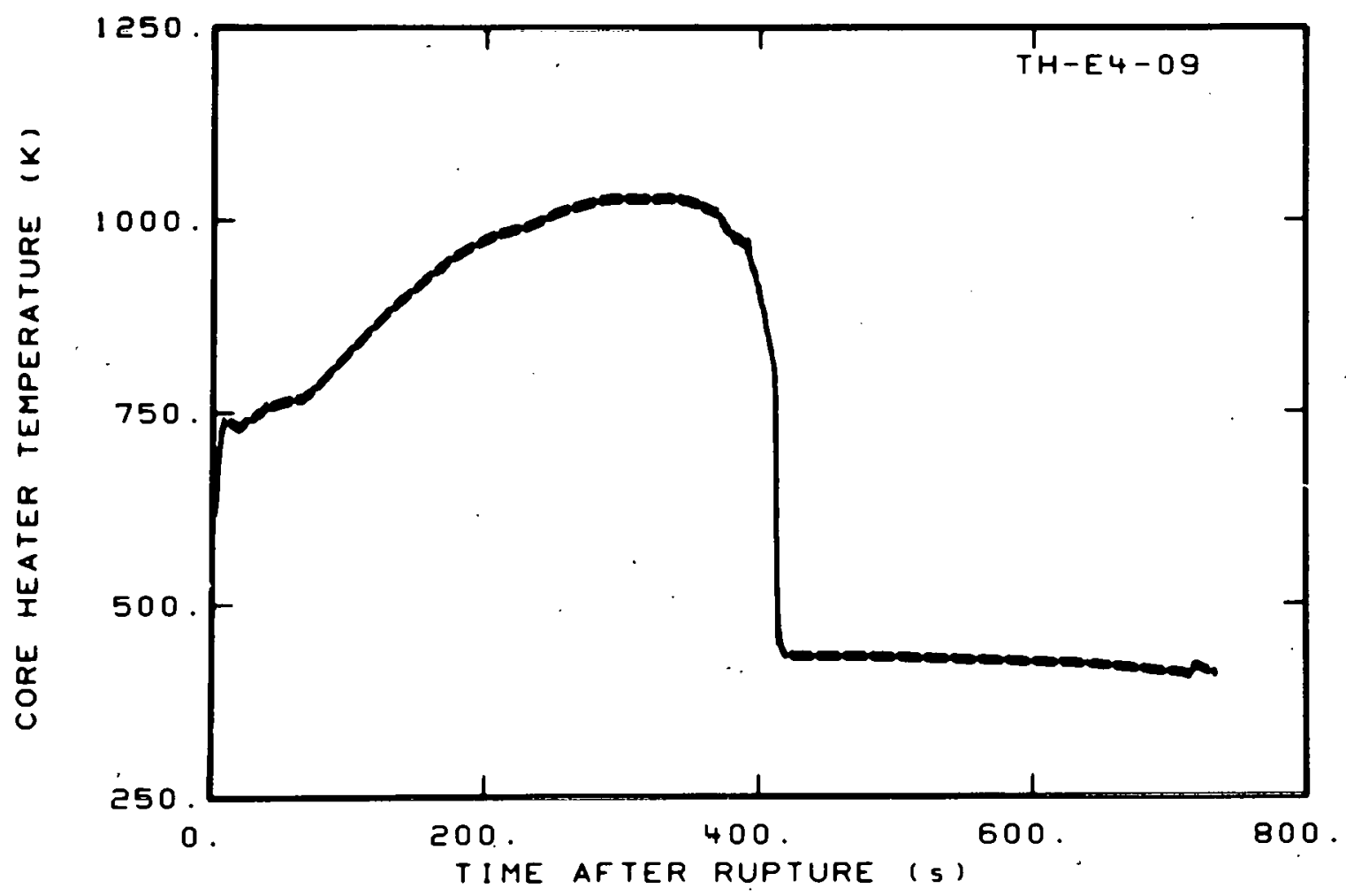

Fig. C-11 Core heater temperature, Rod E-4 (TH-E4-09).

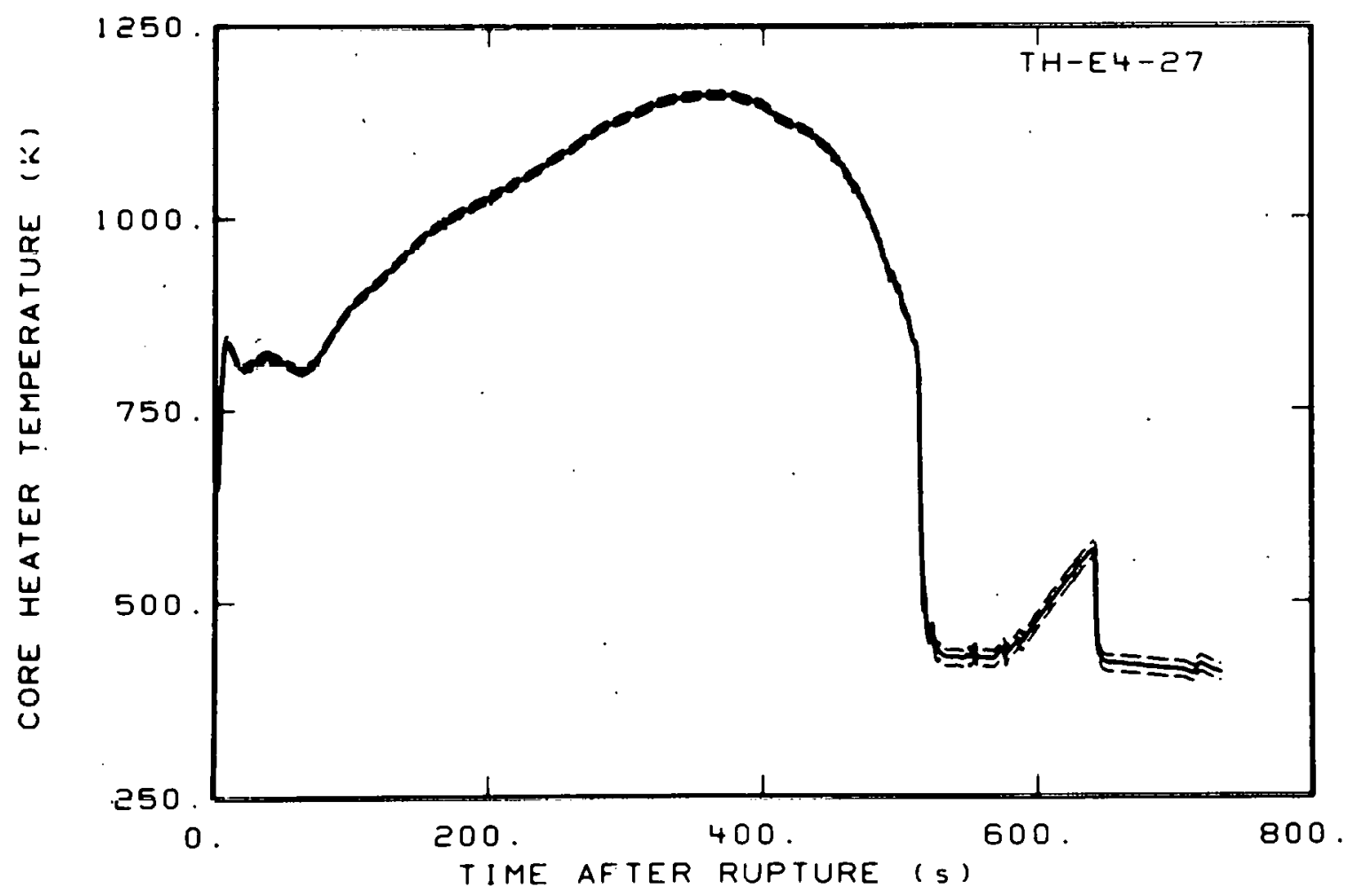

Fig. C-12 Core heater temperature, Rod E-4 (TII-E4-27). 


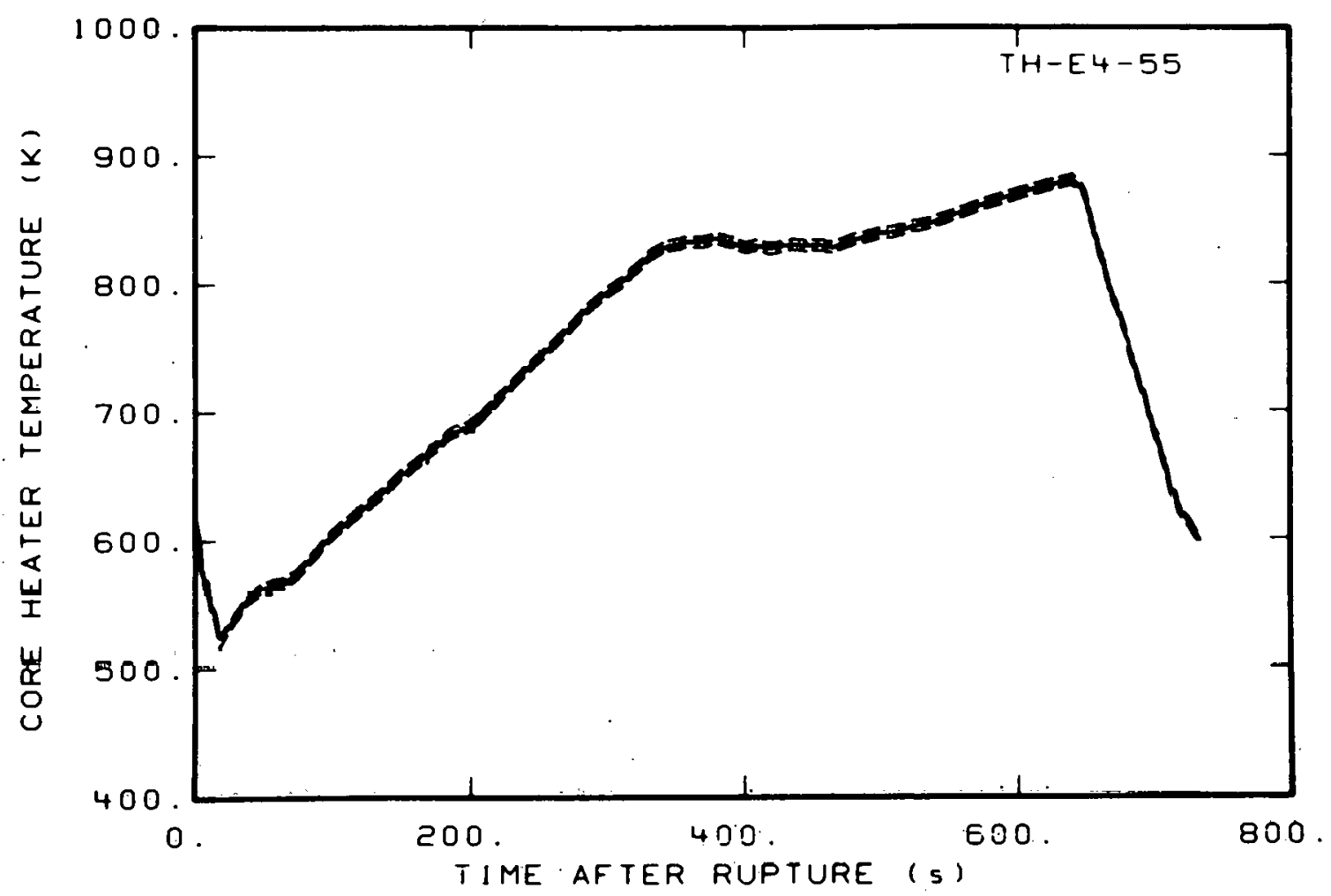

Fig. C-13 Core heater temperature, Rod E-4 (TH-E4-55).

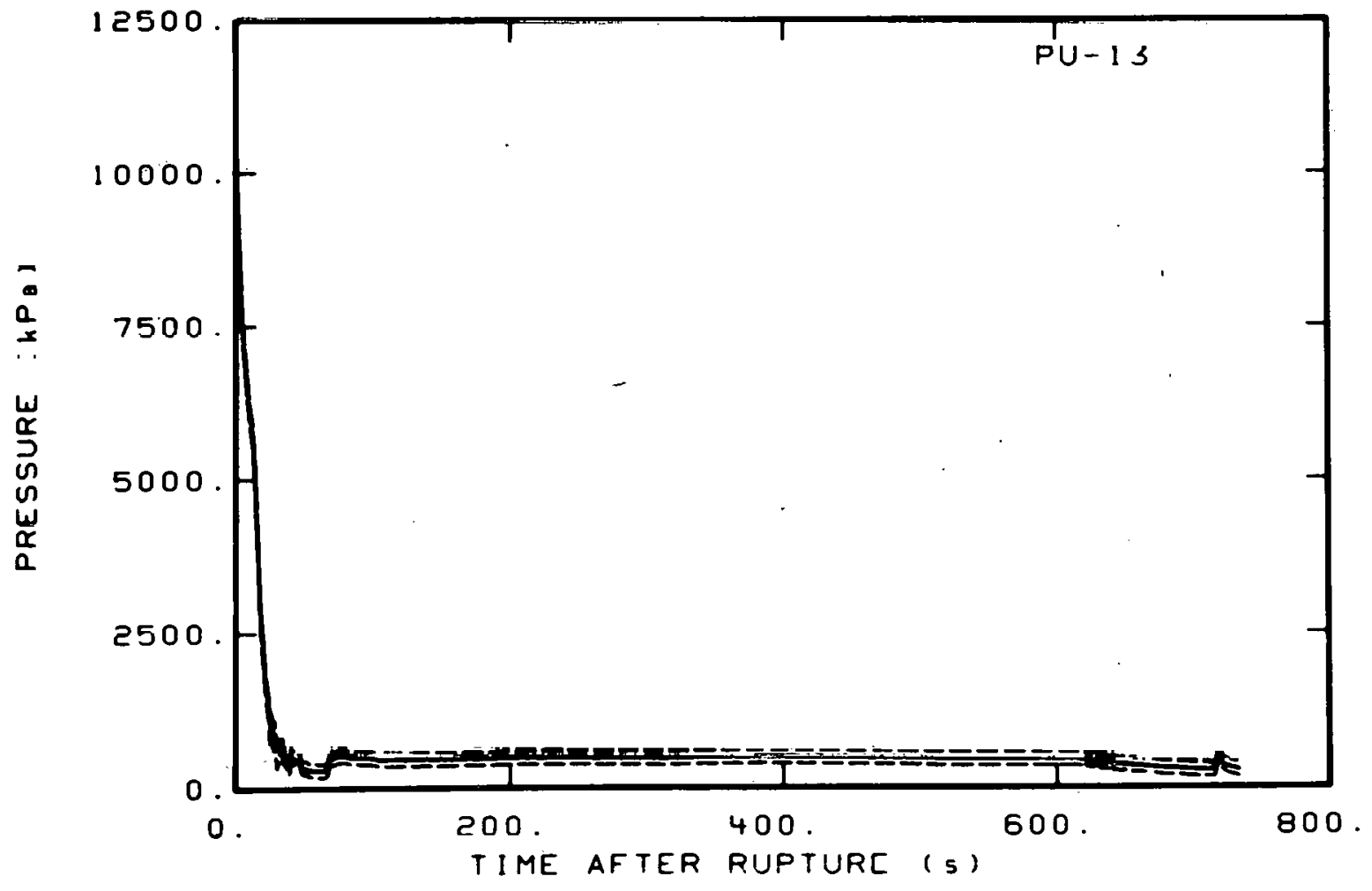

Fig. C-14 Pressure in intact 10op, Spool 13 (PU-13). 


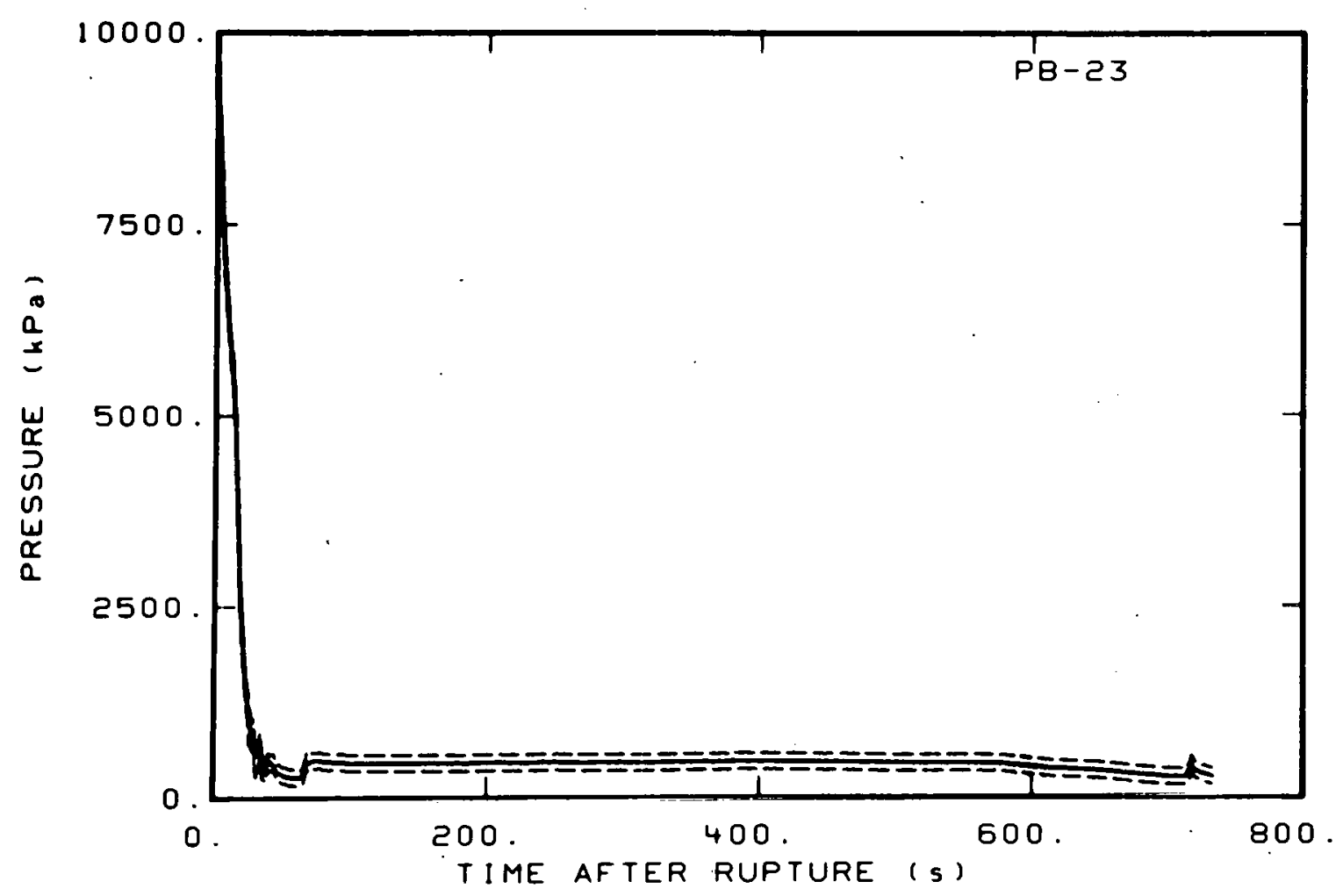

Fig. C-15 Pressure in broken 100p, Spool 23 (PB-23).

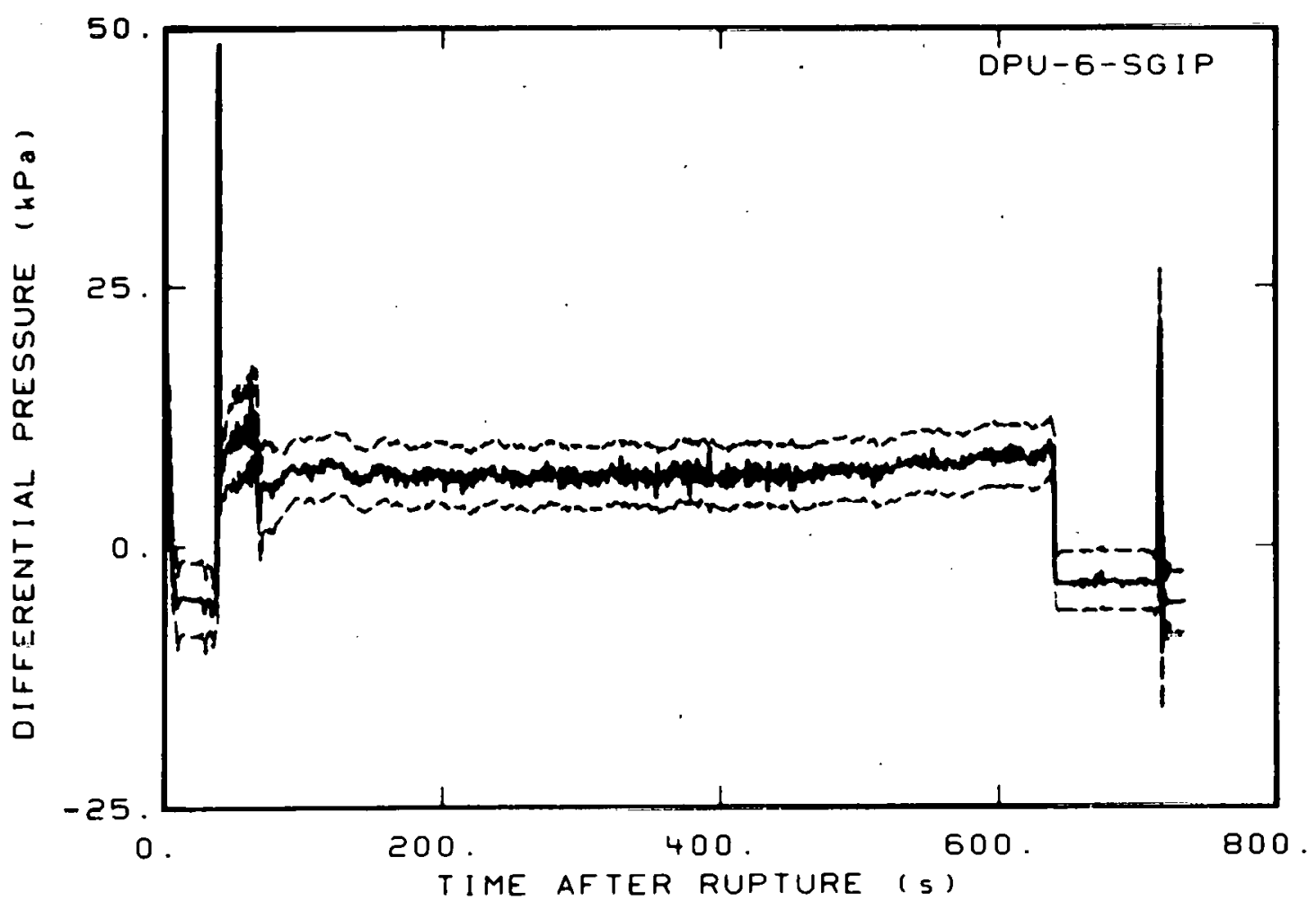

Fig. C.16 Differential pressure in intact loop (DPU=6-SGIP). 


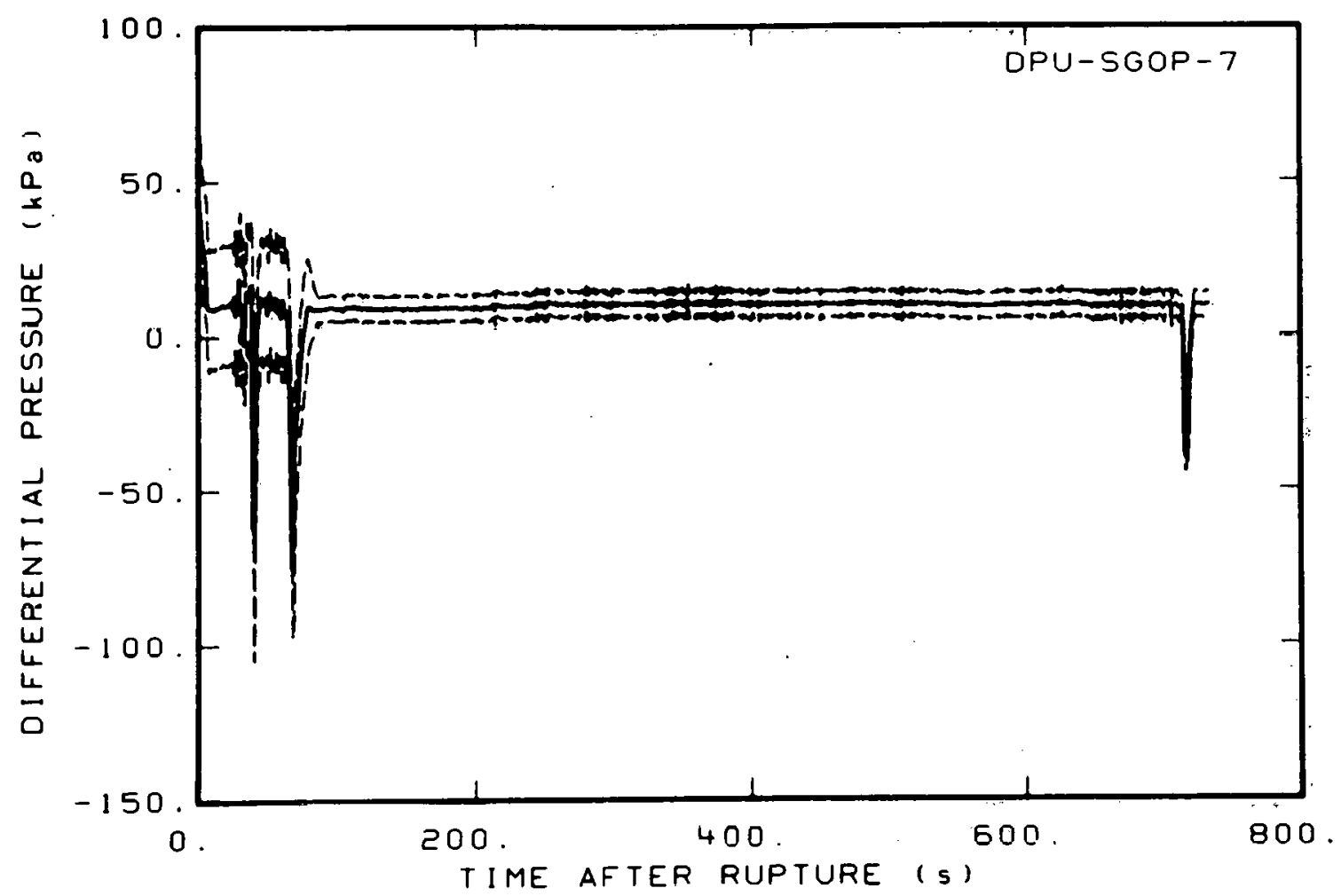

Fig. C-17 Differential pressure in intact loop (DPU-SGOP-7).

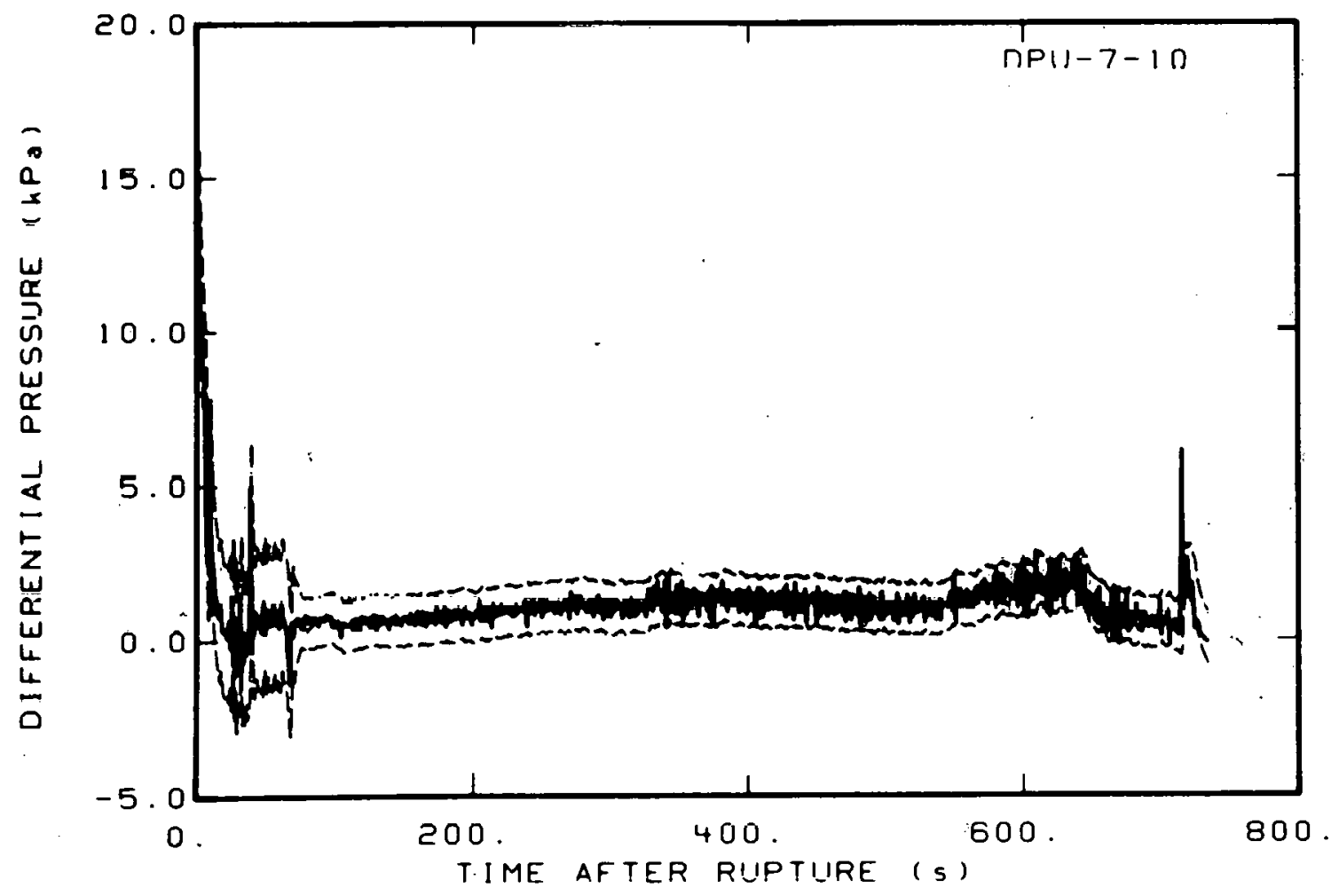

Fig. C-18 Differential pressure in intact loop (DPU-7-10). 


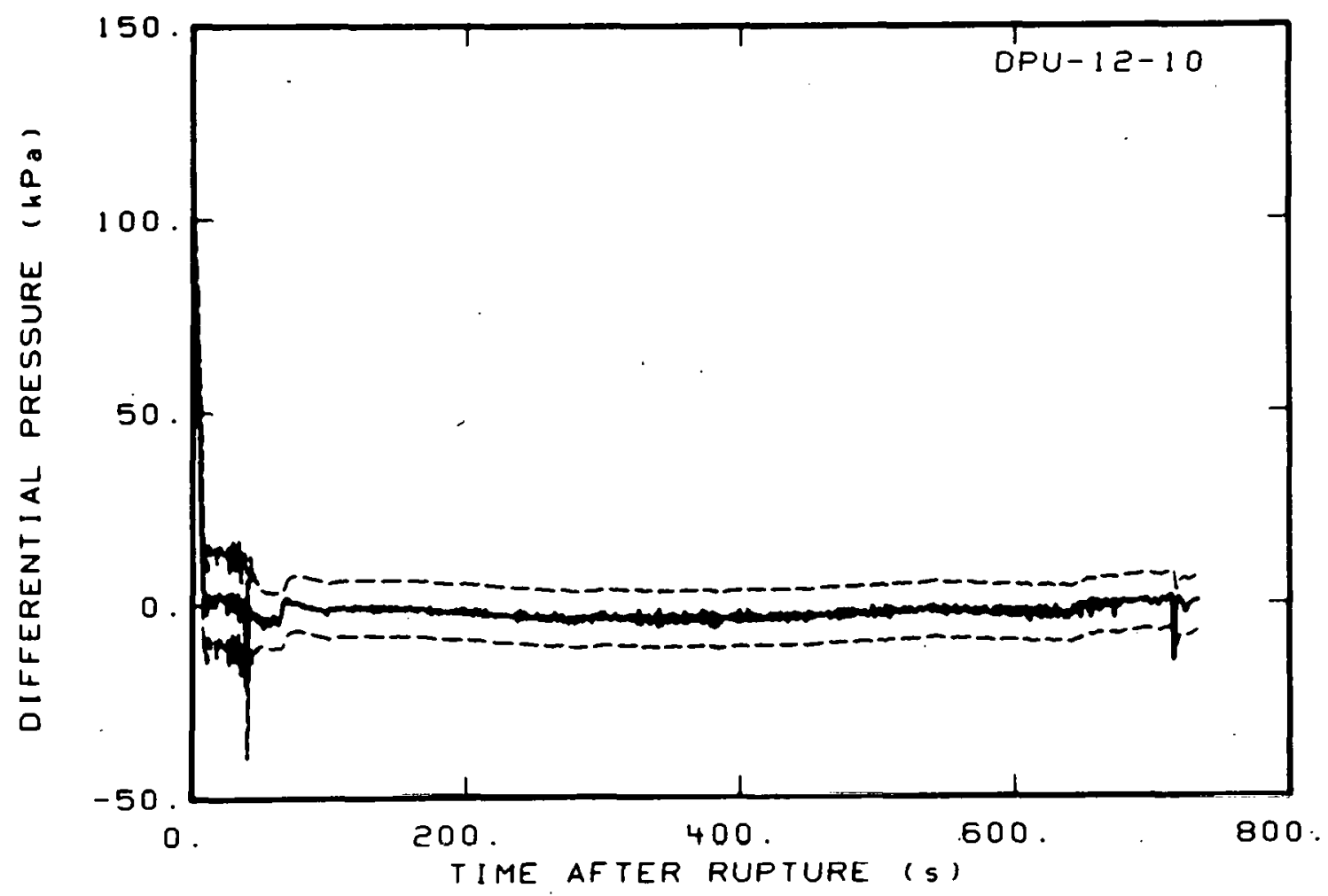

Fig. C-19 Differential pressure in intact loop (DPU-12-10).

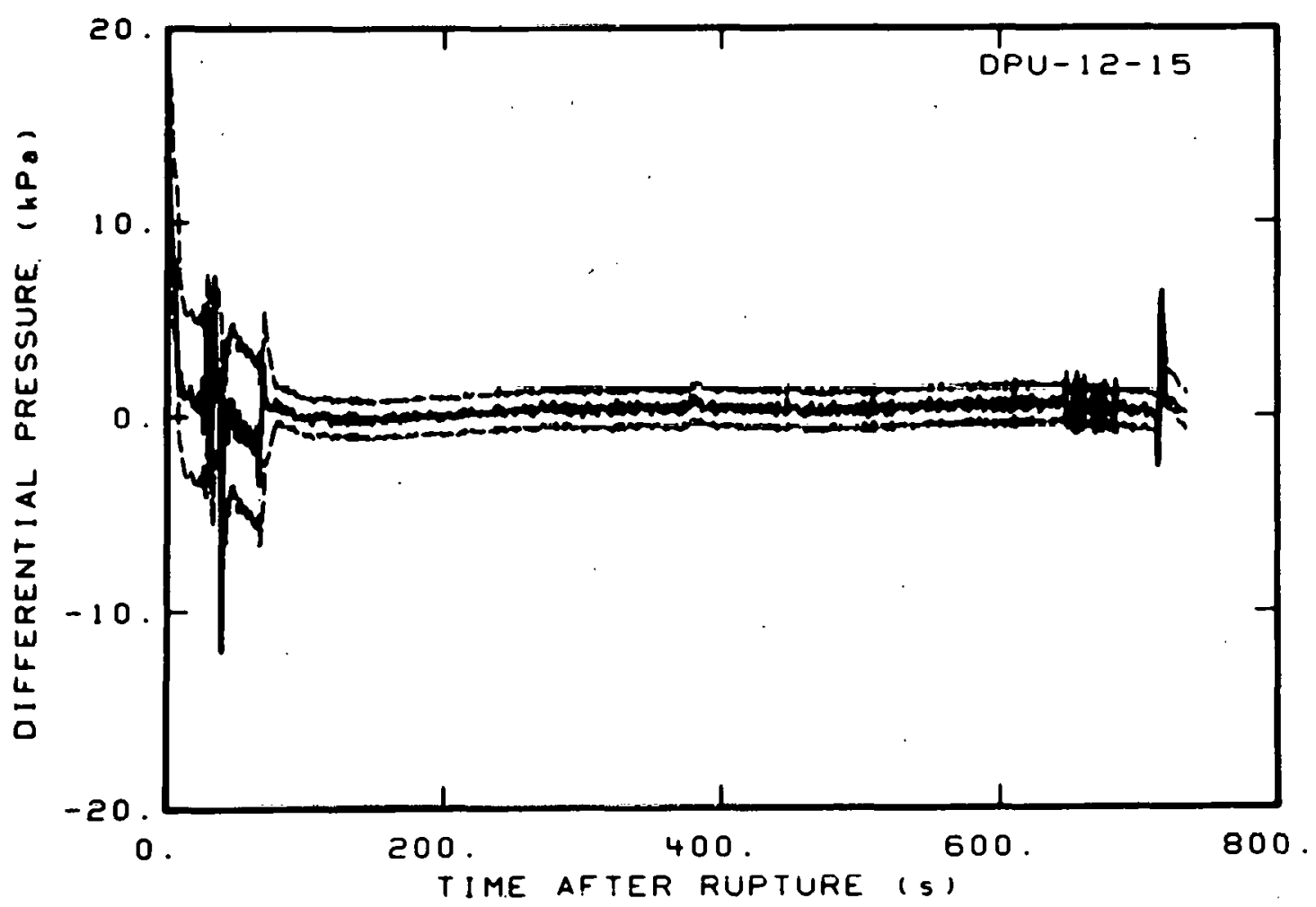

Fig. C-20 Differential pressure in intact loop (DPU-12-15). 


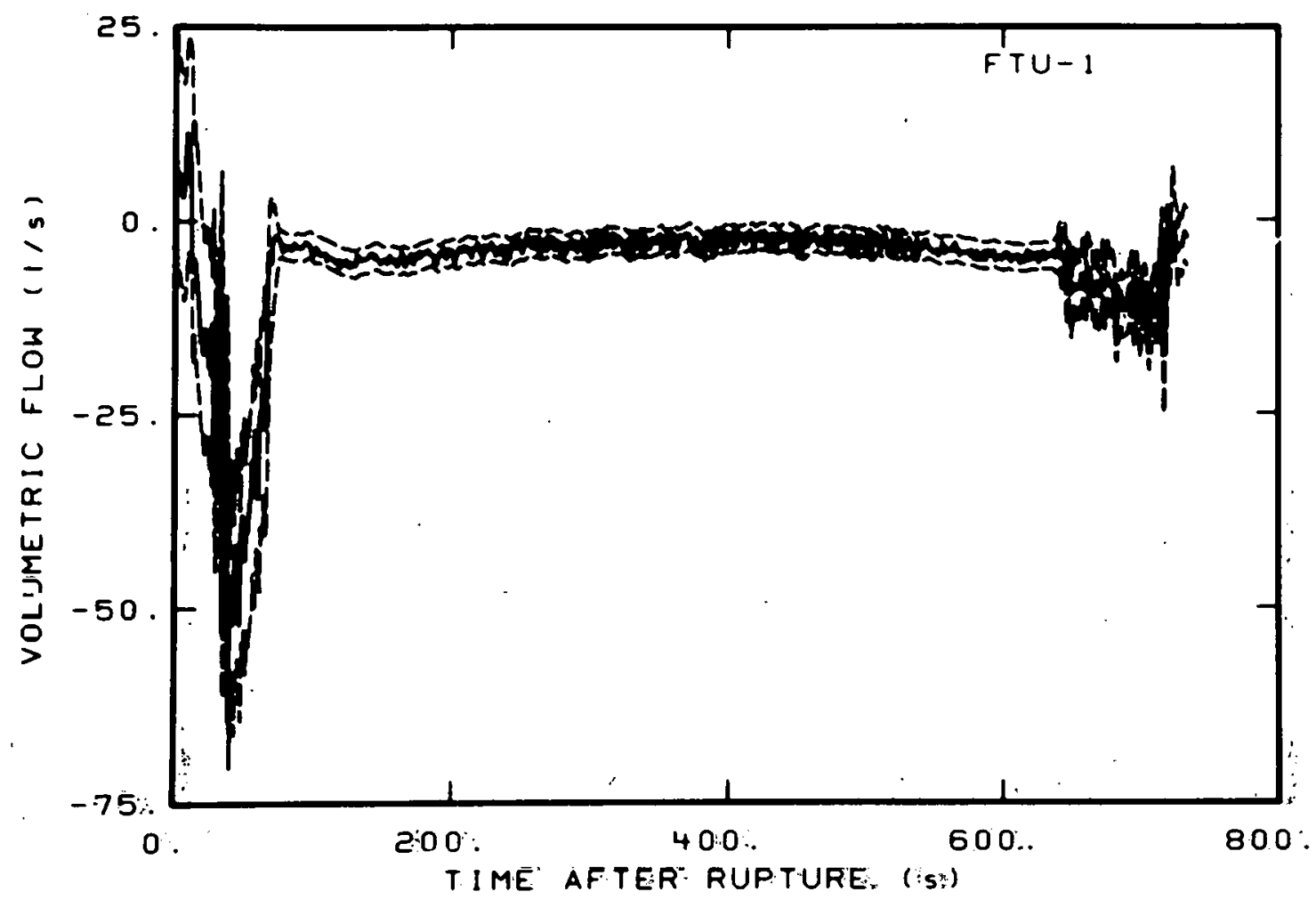

Fig. C-21 Volumetric flow in intact loop (FTU-1).

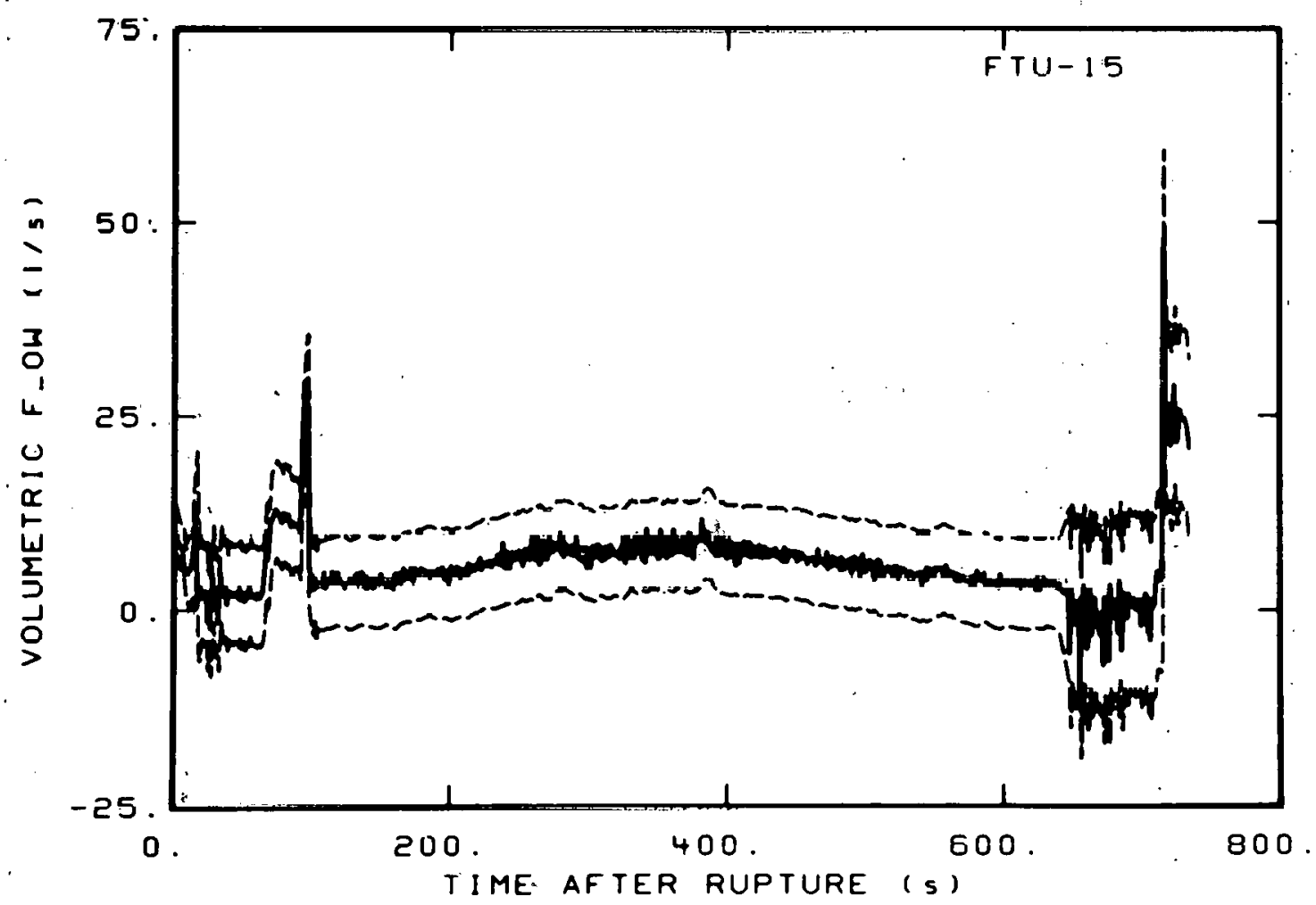

Fig. C-22 Volumetric flow in intact loop (FTU-15). 


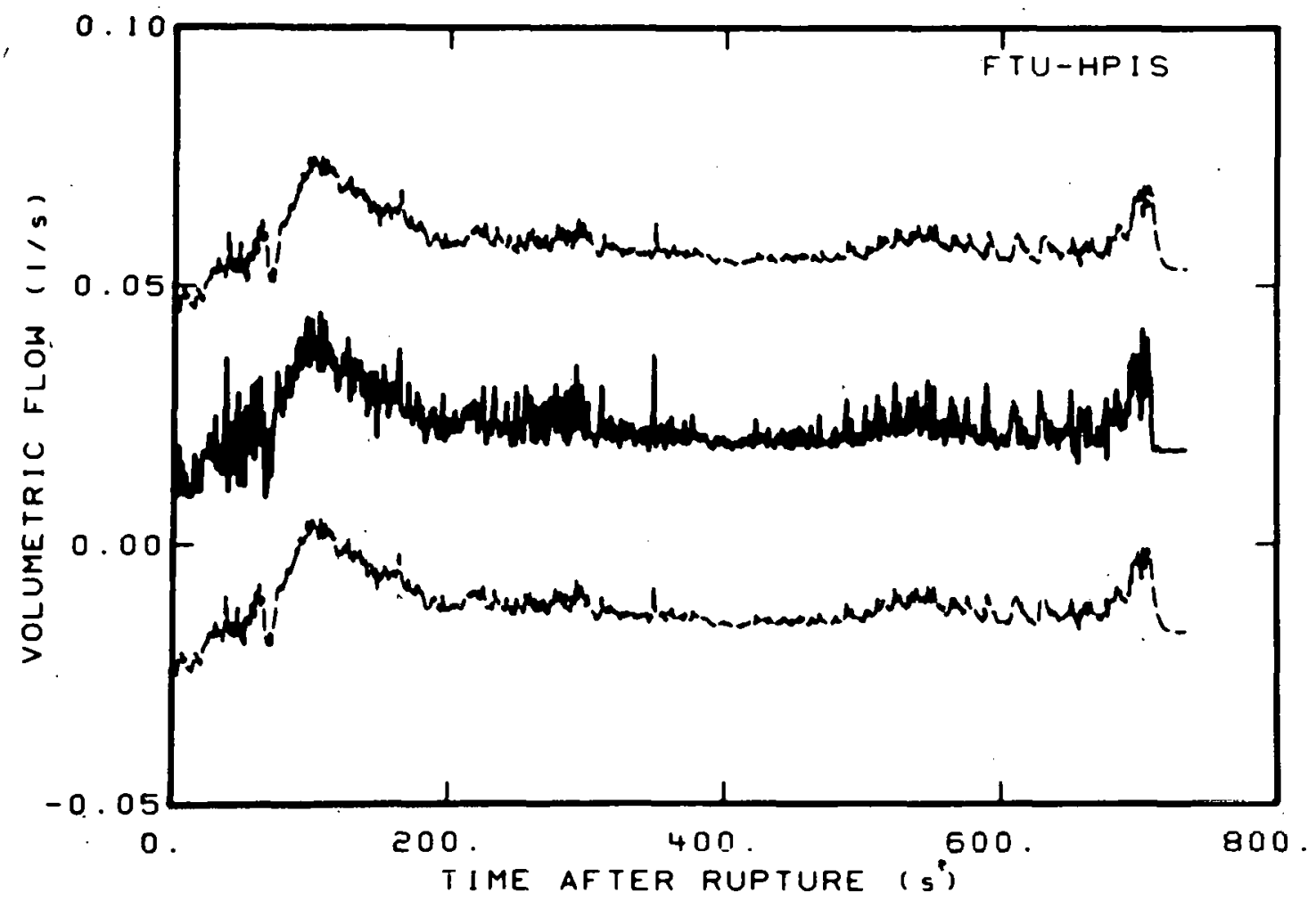

Fig. C-23 Volumetric flow in intact loop high pressure injection line (FTU-HPIS).

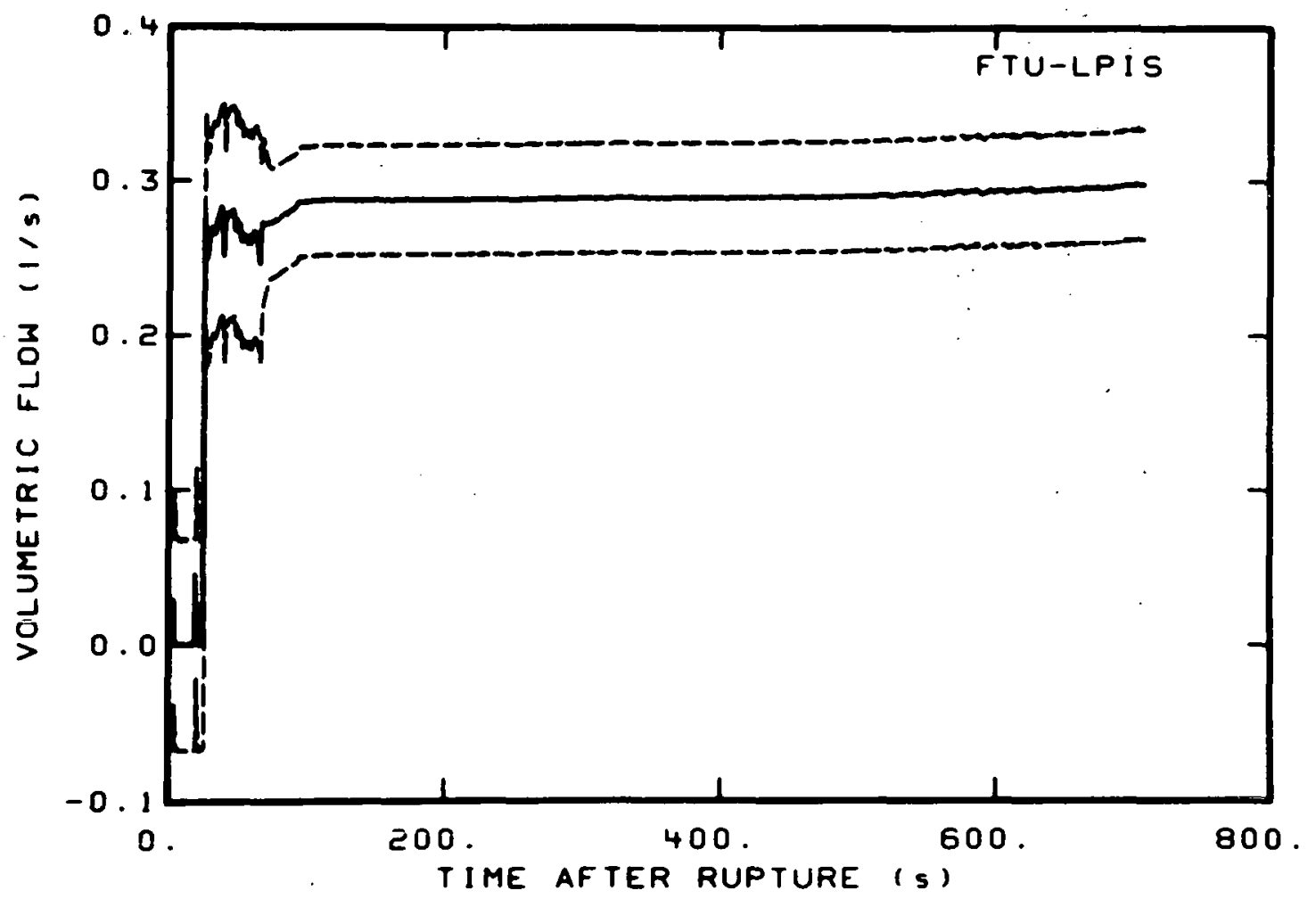

Fig. C-24 Volumetric flow in intact loop low pressure injection line (FTU-LPIS). 


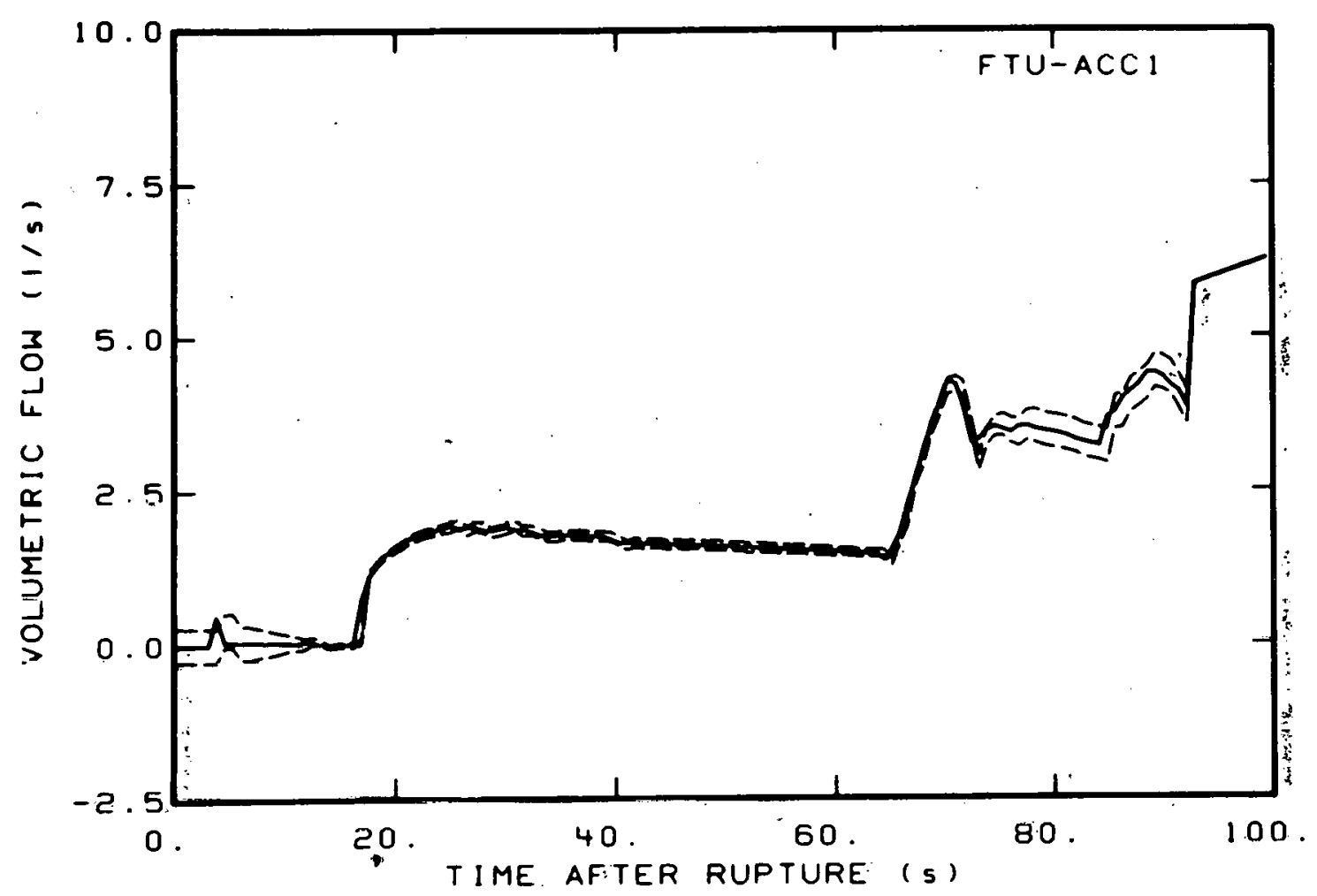

Fig. C-25 Volumetric flow in intact loop accumulator discharge line (FTU-ACC1).

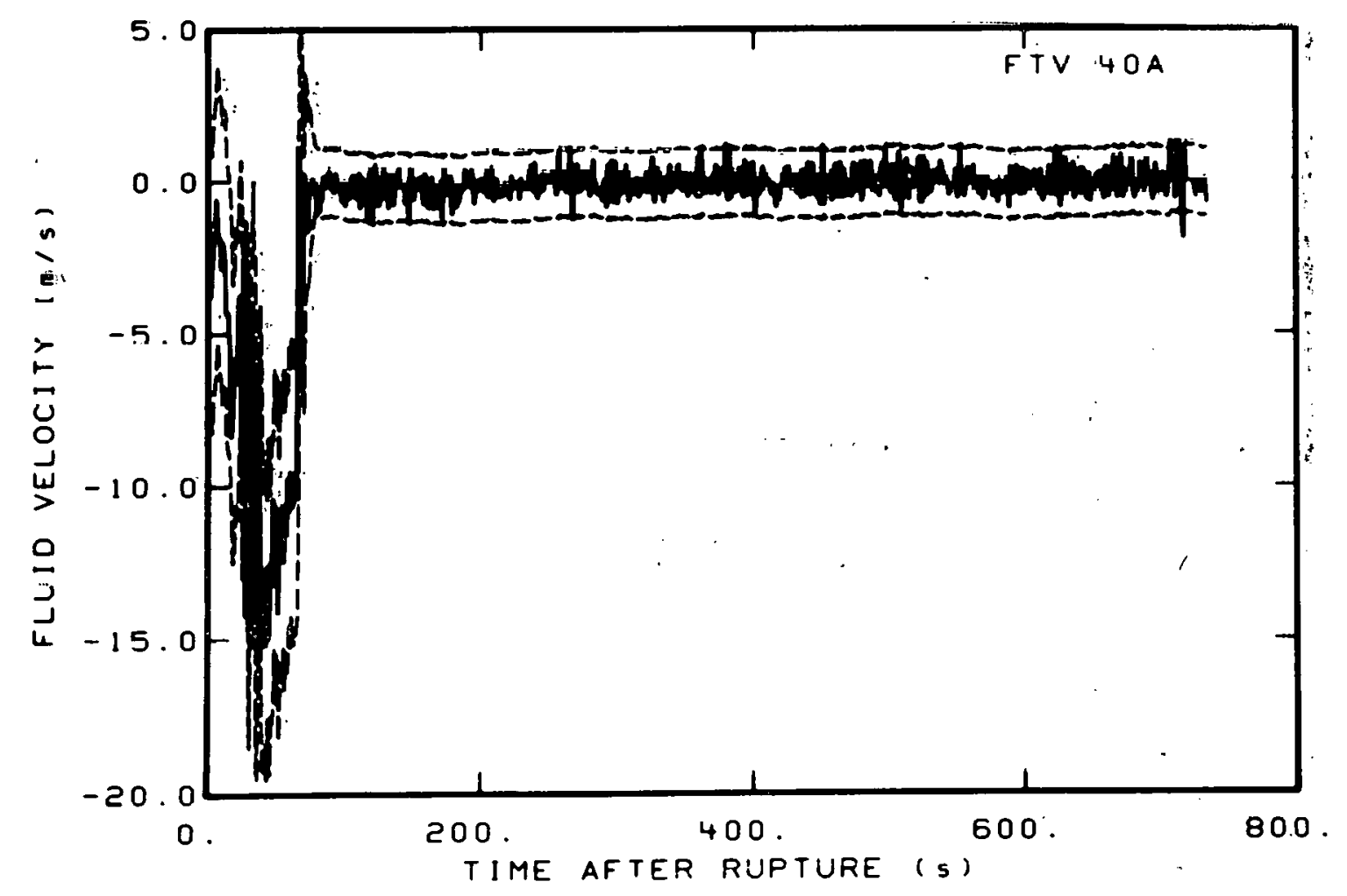

Fig. C-26 Fluid velocity in vessel' (FTV-40A)? 


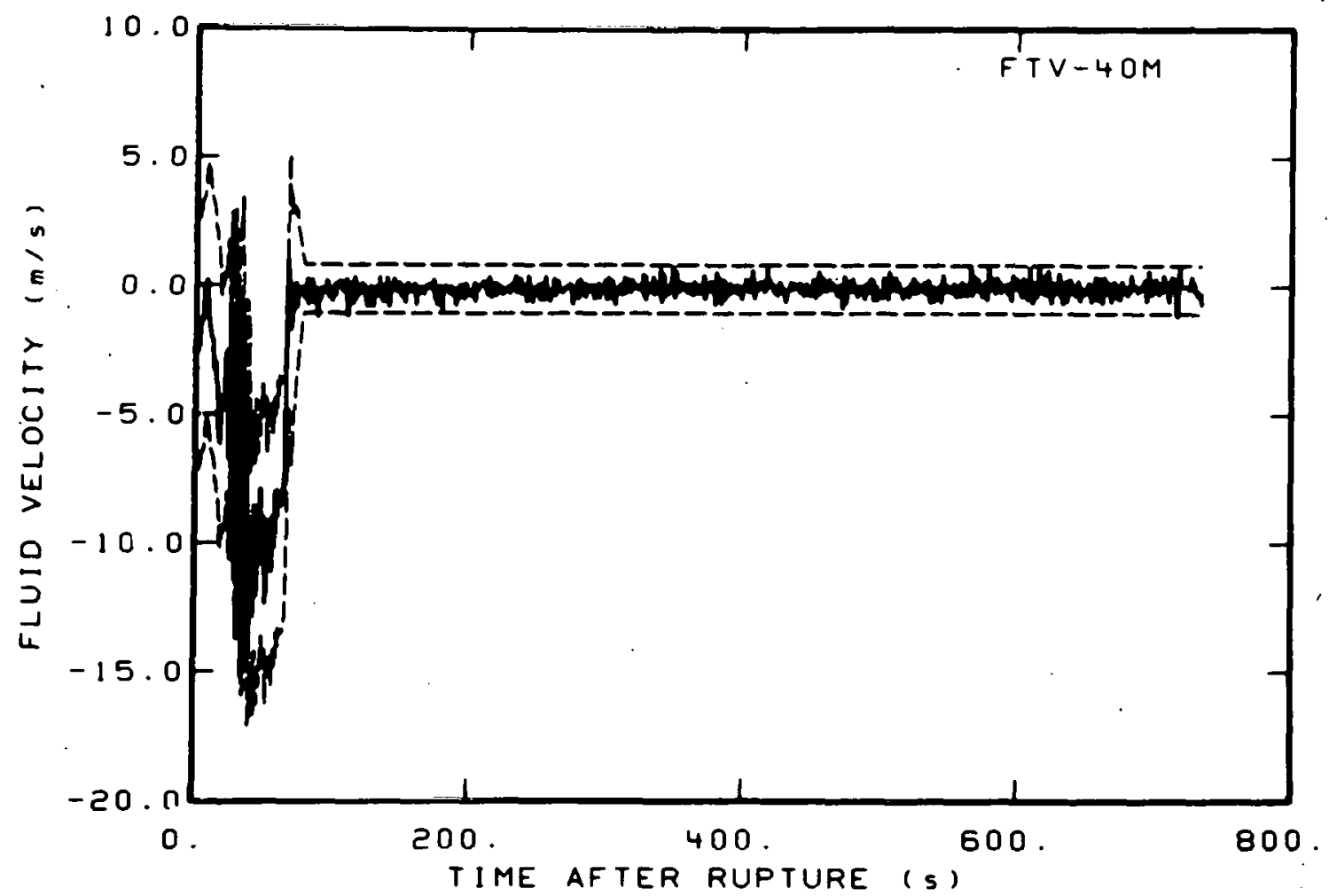

Fig. C-27 Fluid velocity in vessel (FTV-40M).

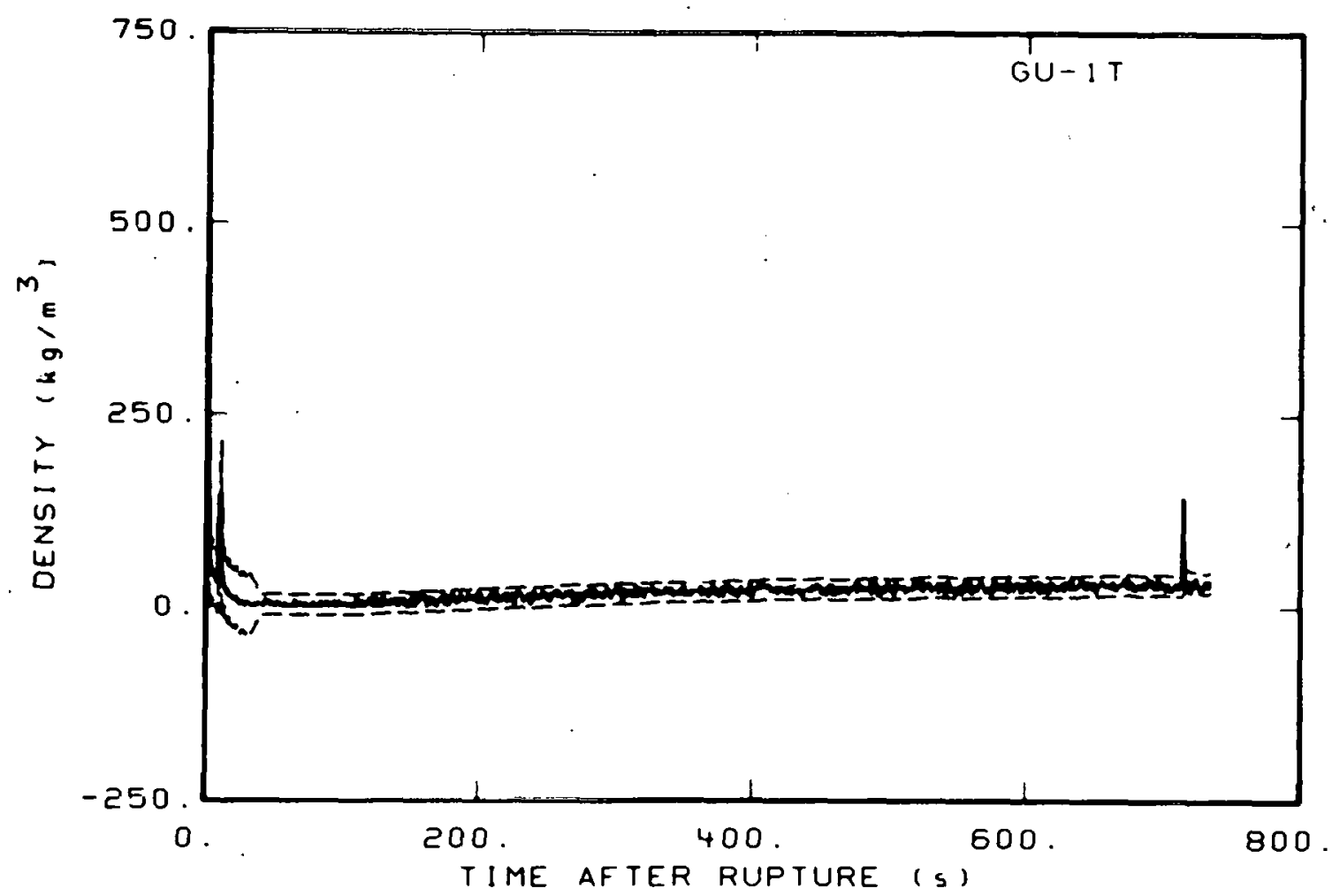

Fig. $C=28$ Density in intact loop (GU-1T). 


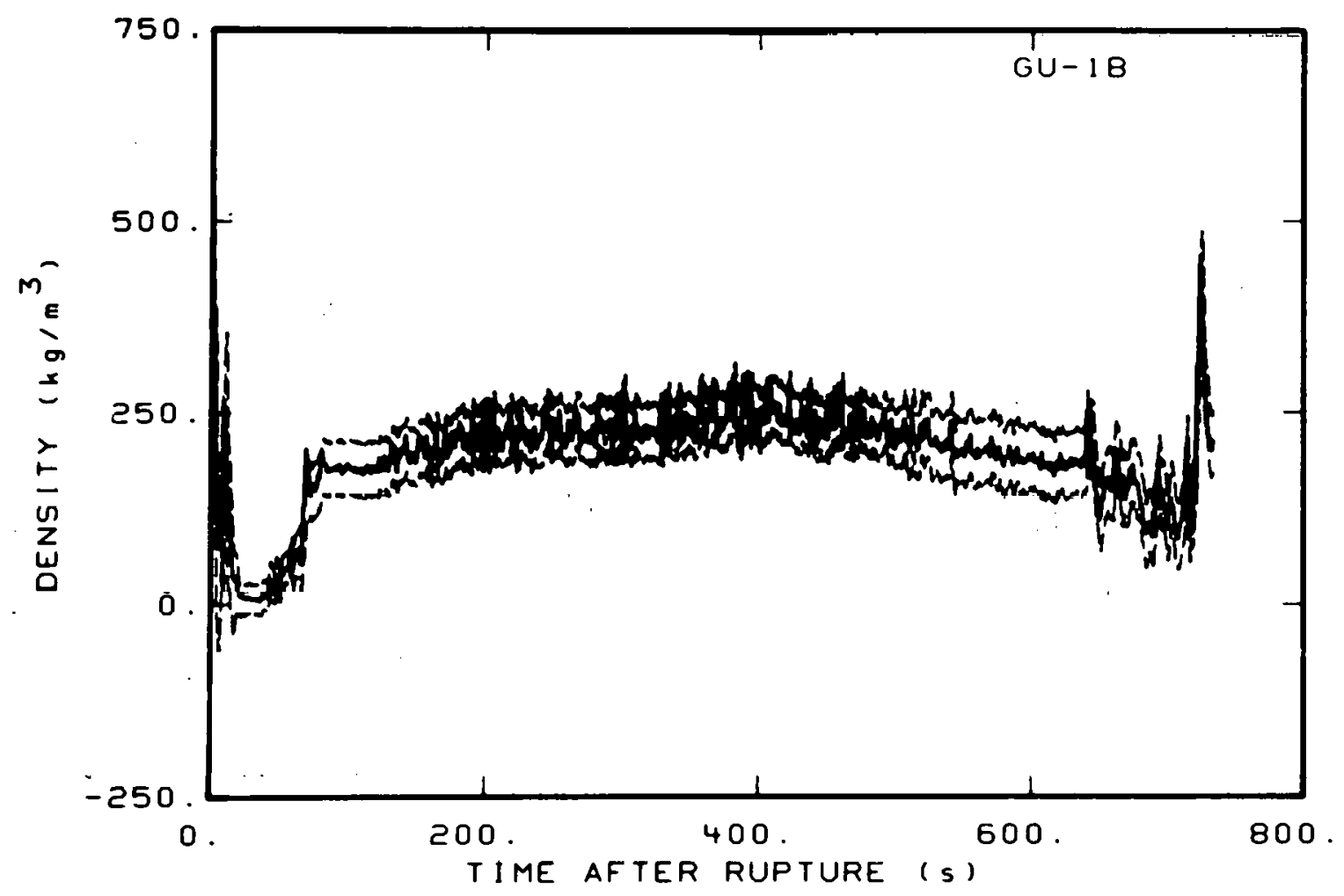

Fig. C-29 Density in intact loop (GU-1B).

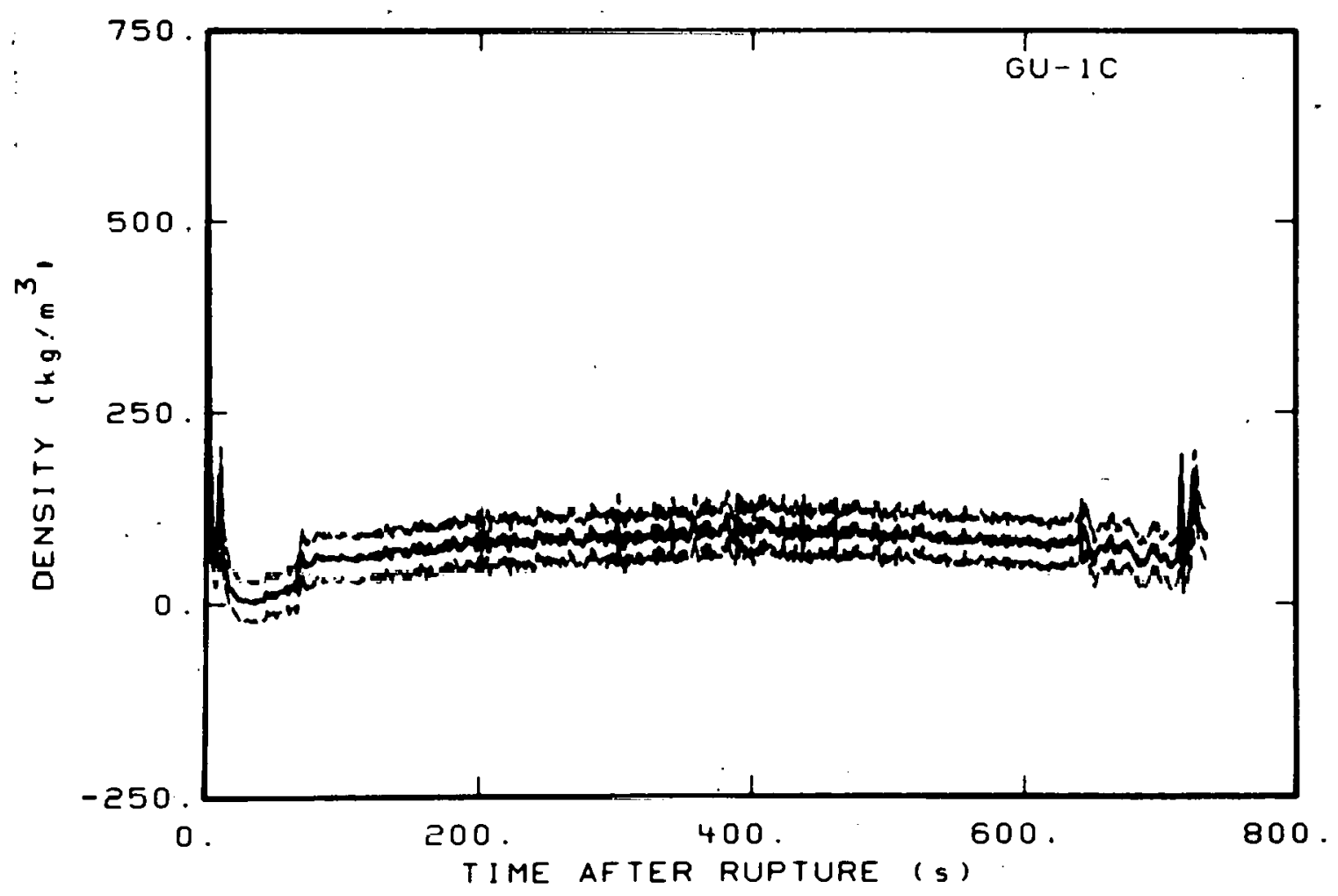

Fig. C-30 Density in intact loop (GU-1C). 


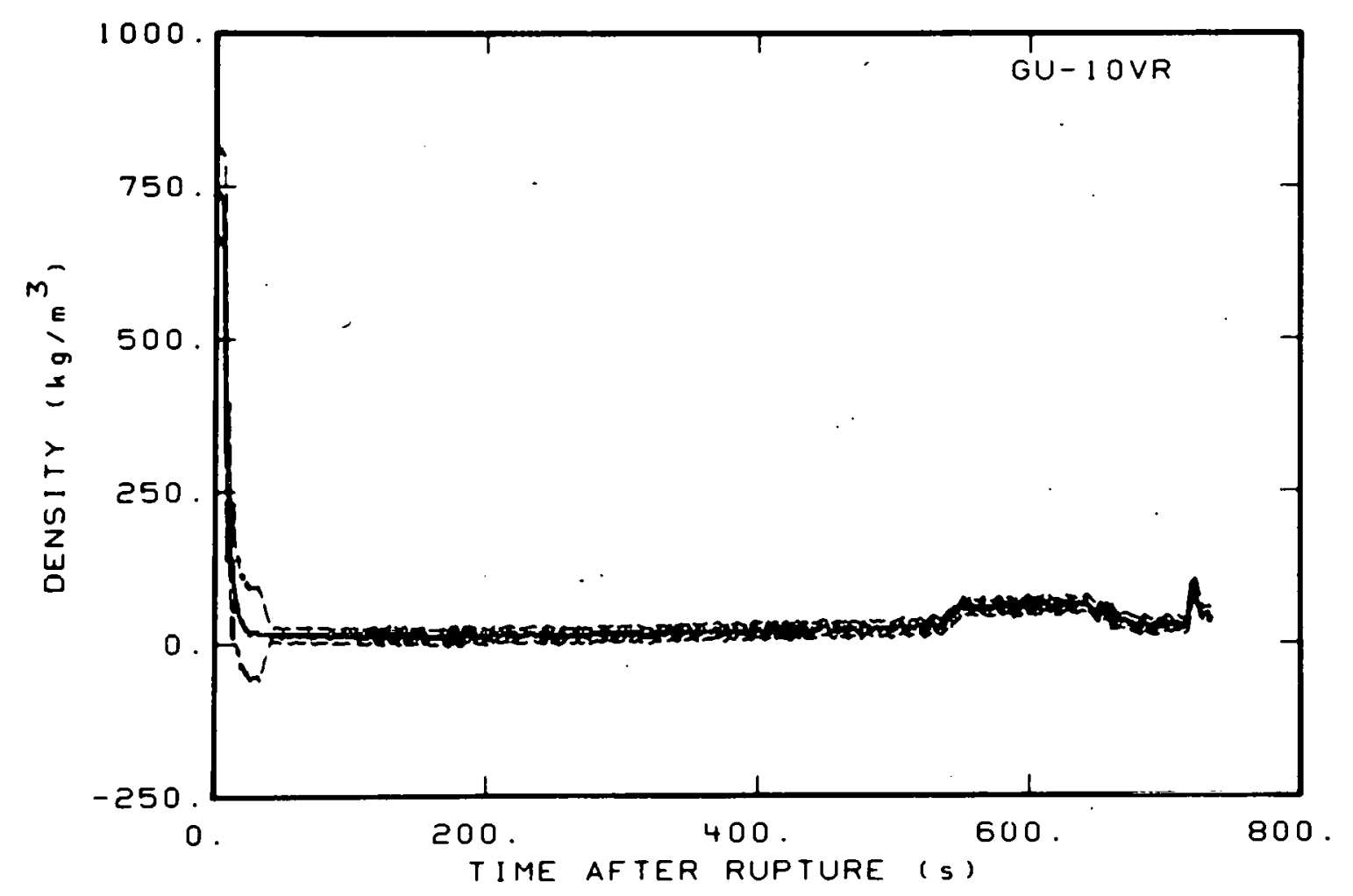

Fig. C-31 Density in intact loop (GU-10VR).

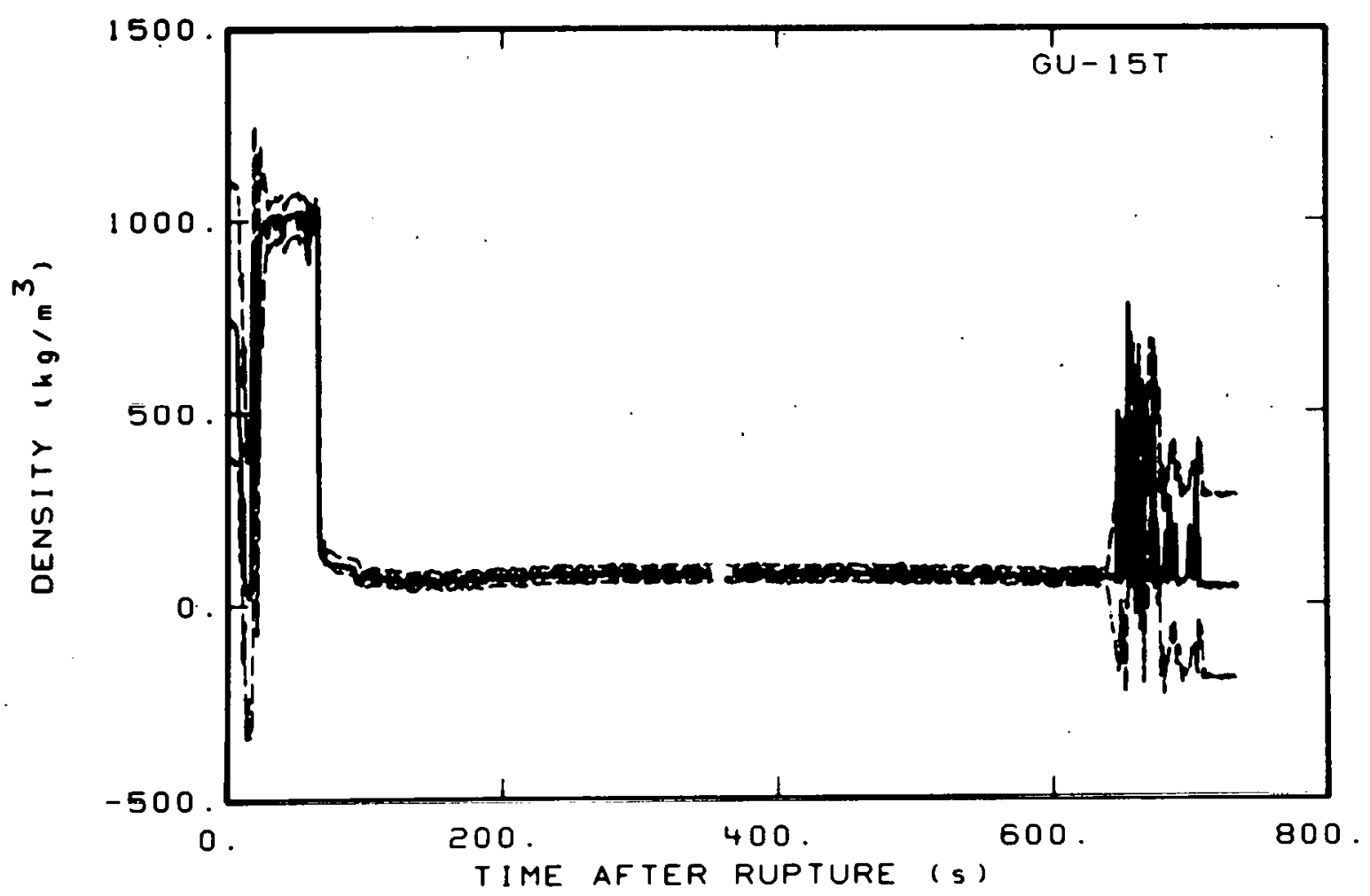

Fig. C-32 Density in intact loop (GU-15T). 


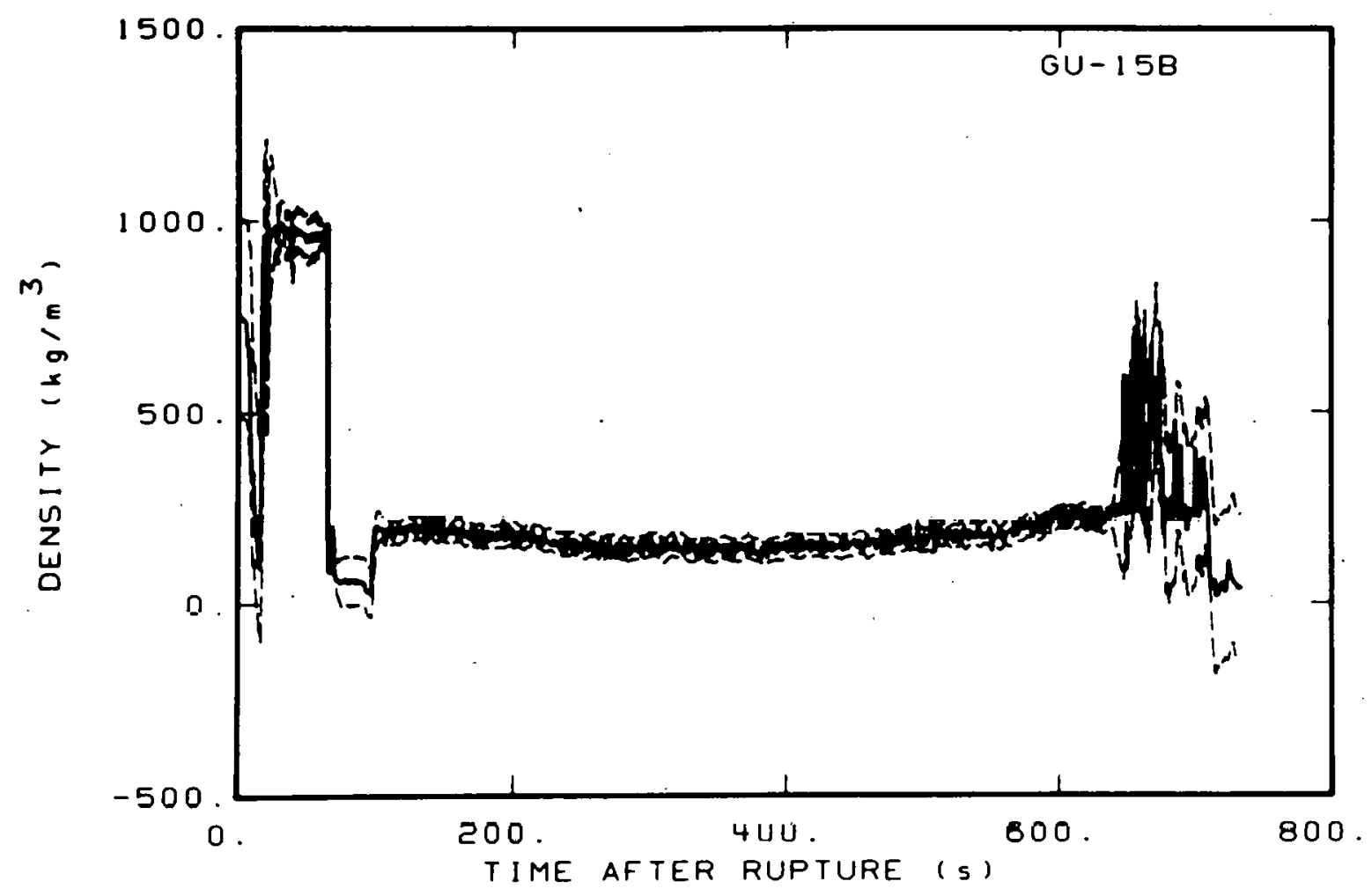

Fig. C-33 Density in intact loop (GU-15B).

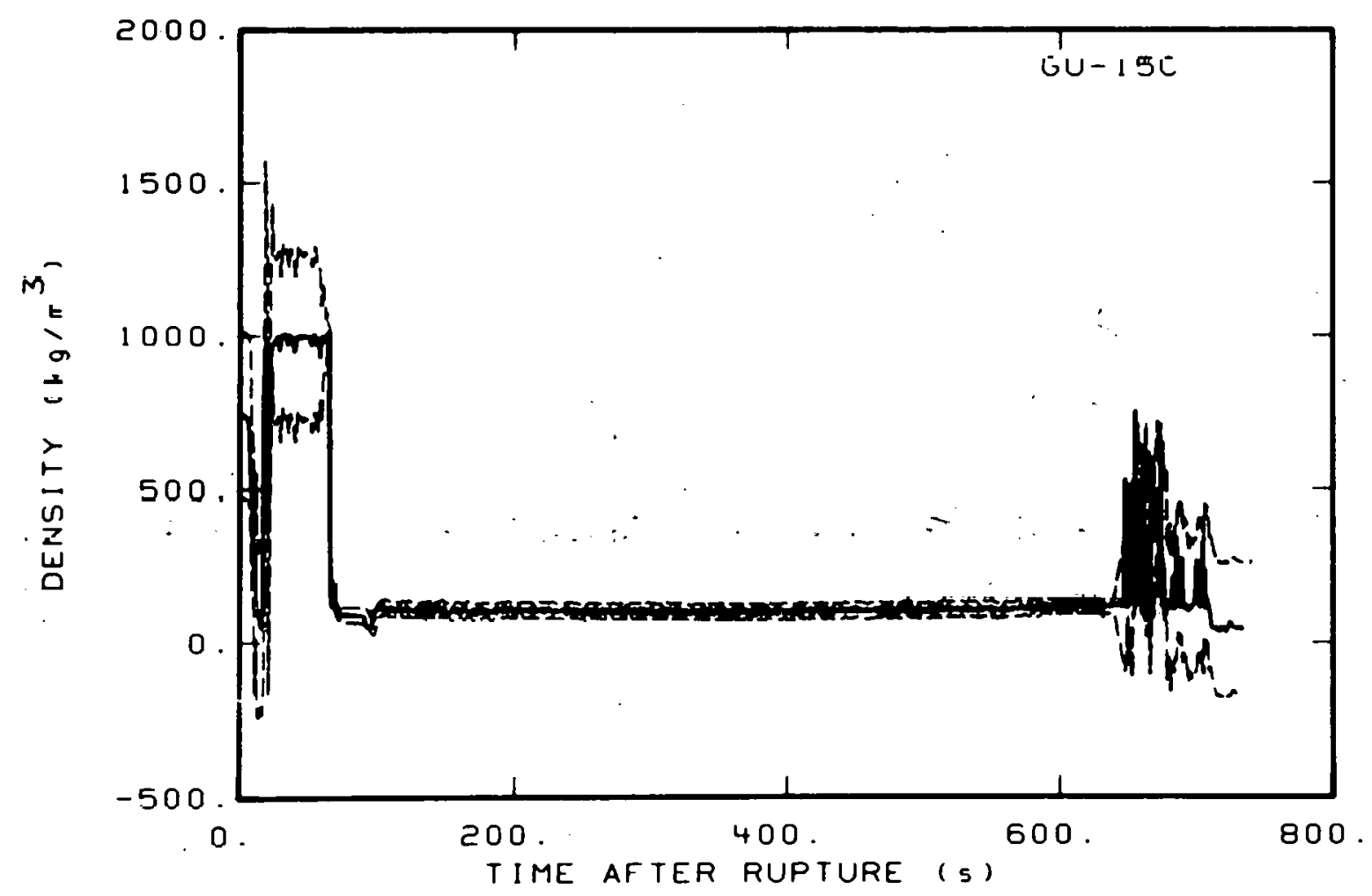

Fig. C-34 Density in intact loop (GU-15C). 


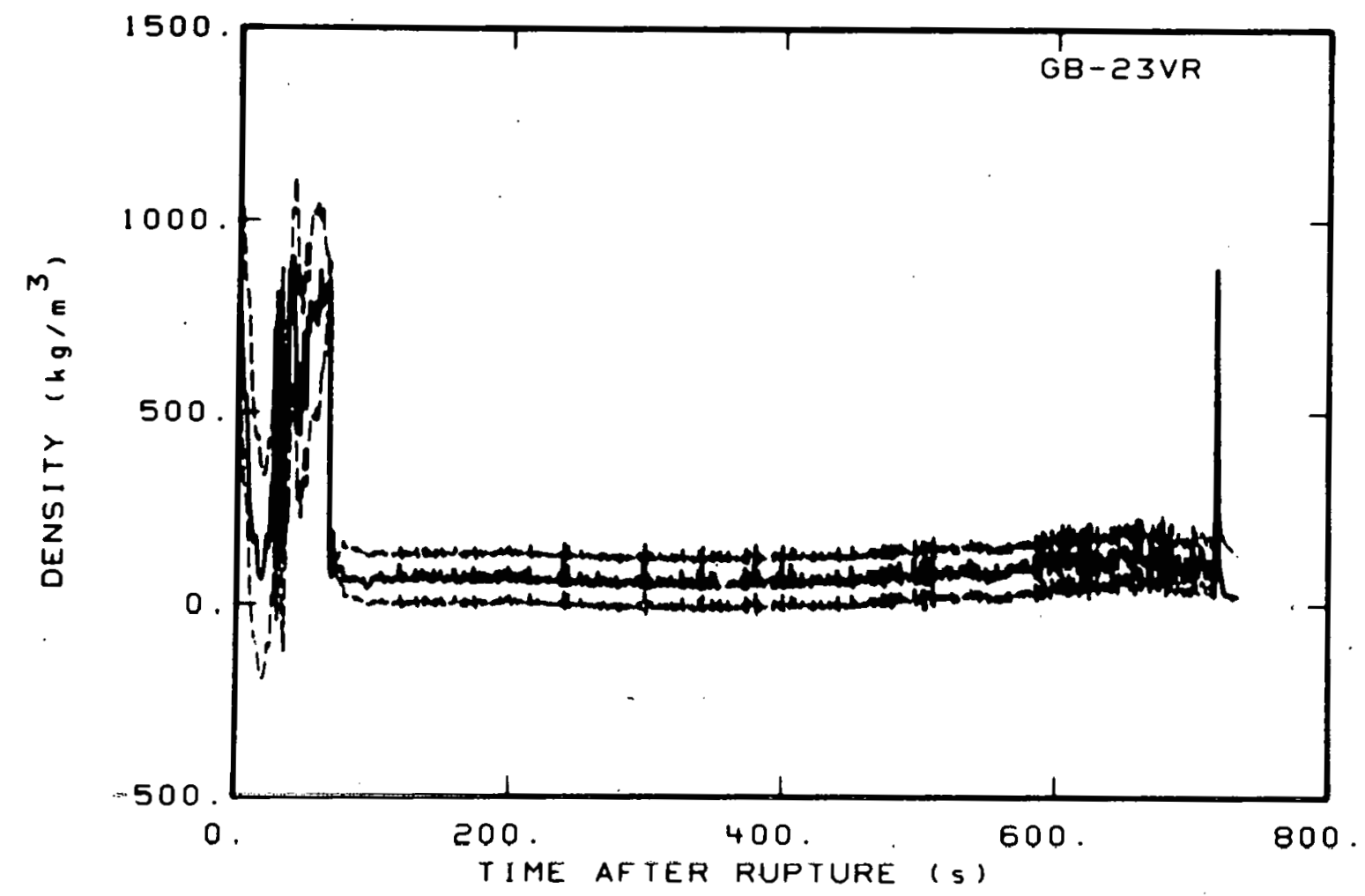

Fig. C-35 Density in broken loop (GB-23VR).

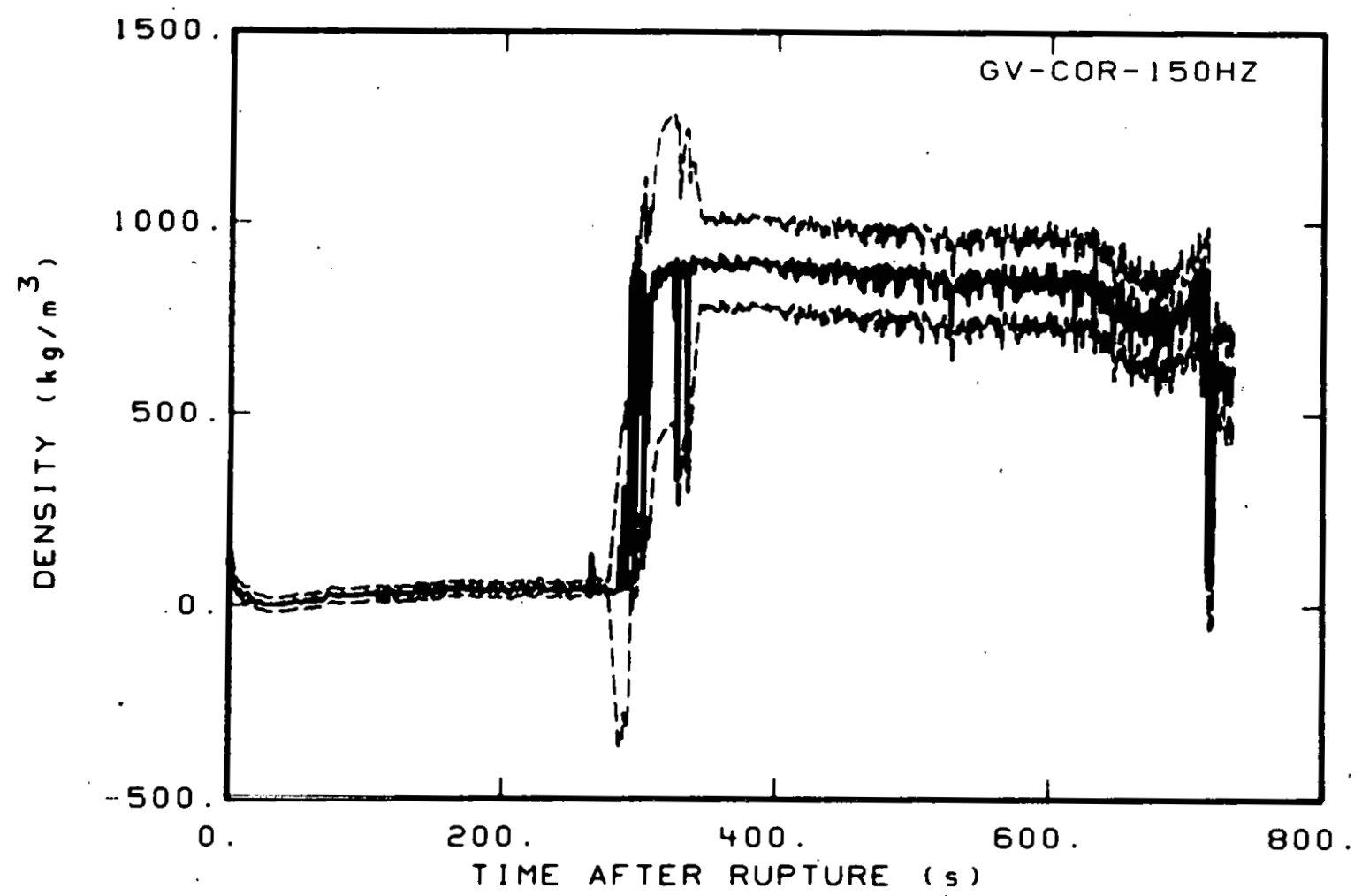

Fig. C-36 Density in vessel (GV-COR-150HZ). 


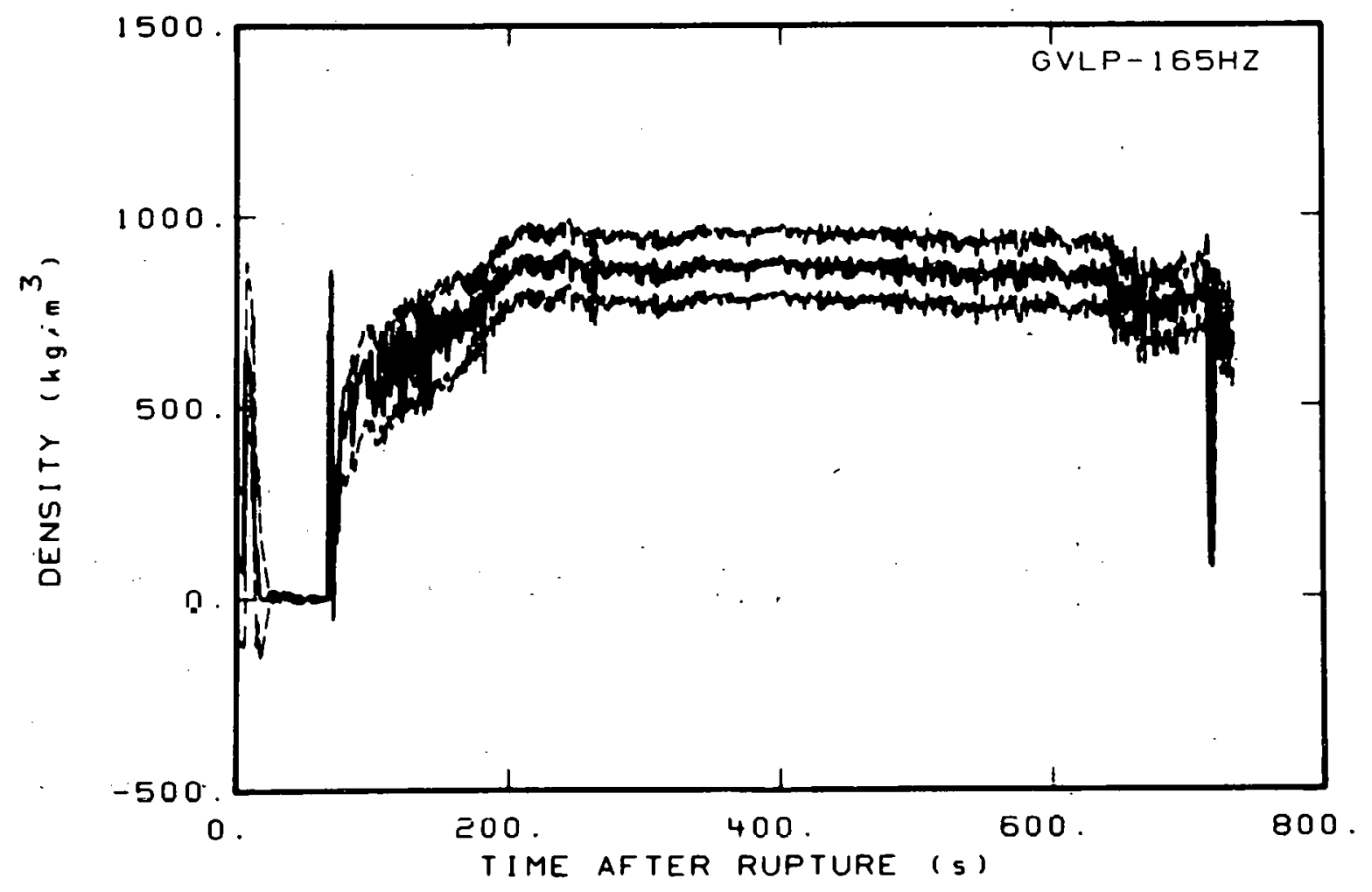

Fig. C-37 Density in vessel (GVLP-165HZ).

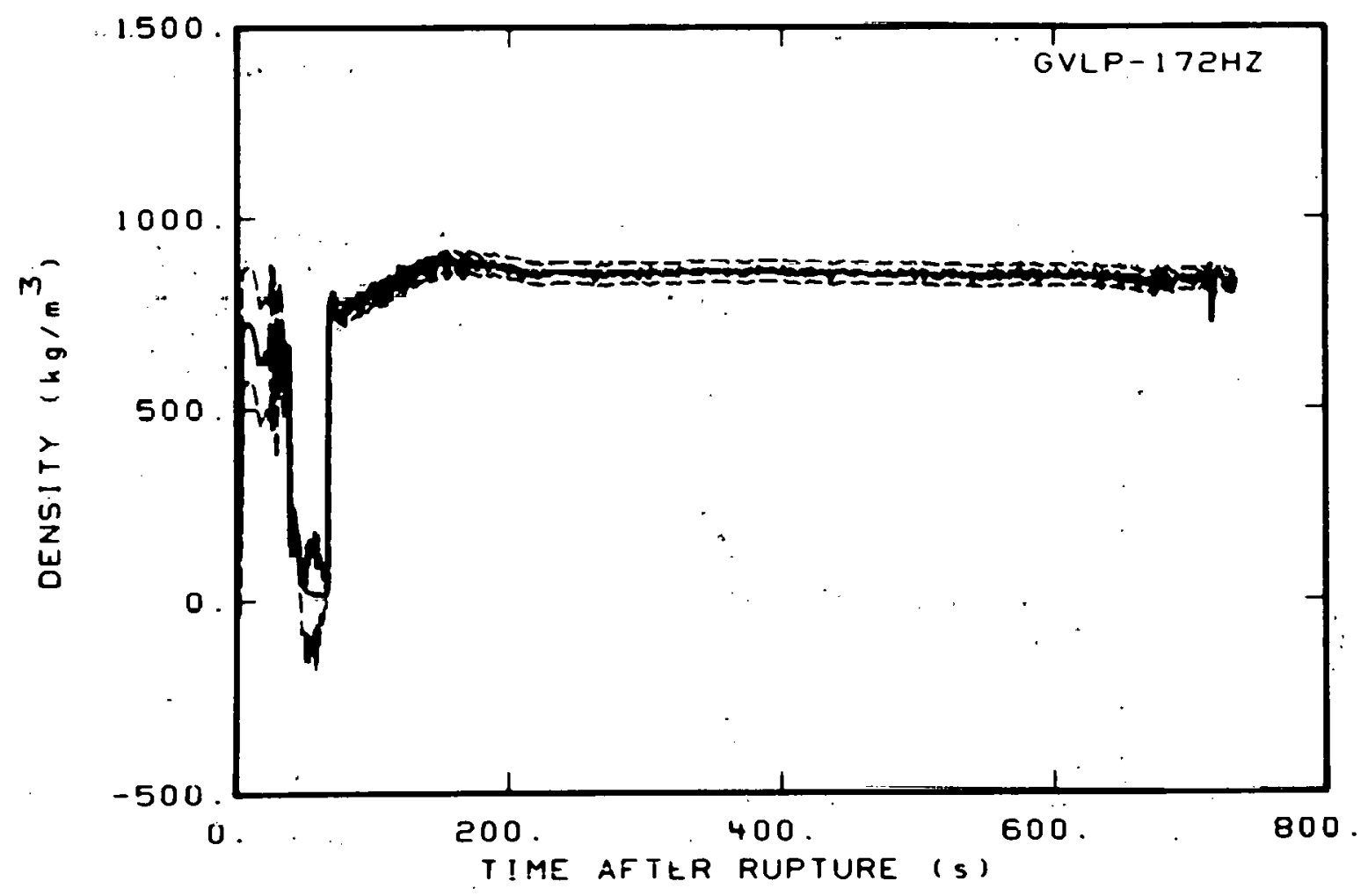

Fig. C-38 Density in vessel (GVLP-172HZ). 


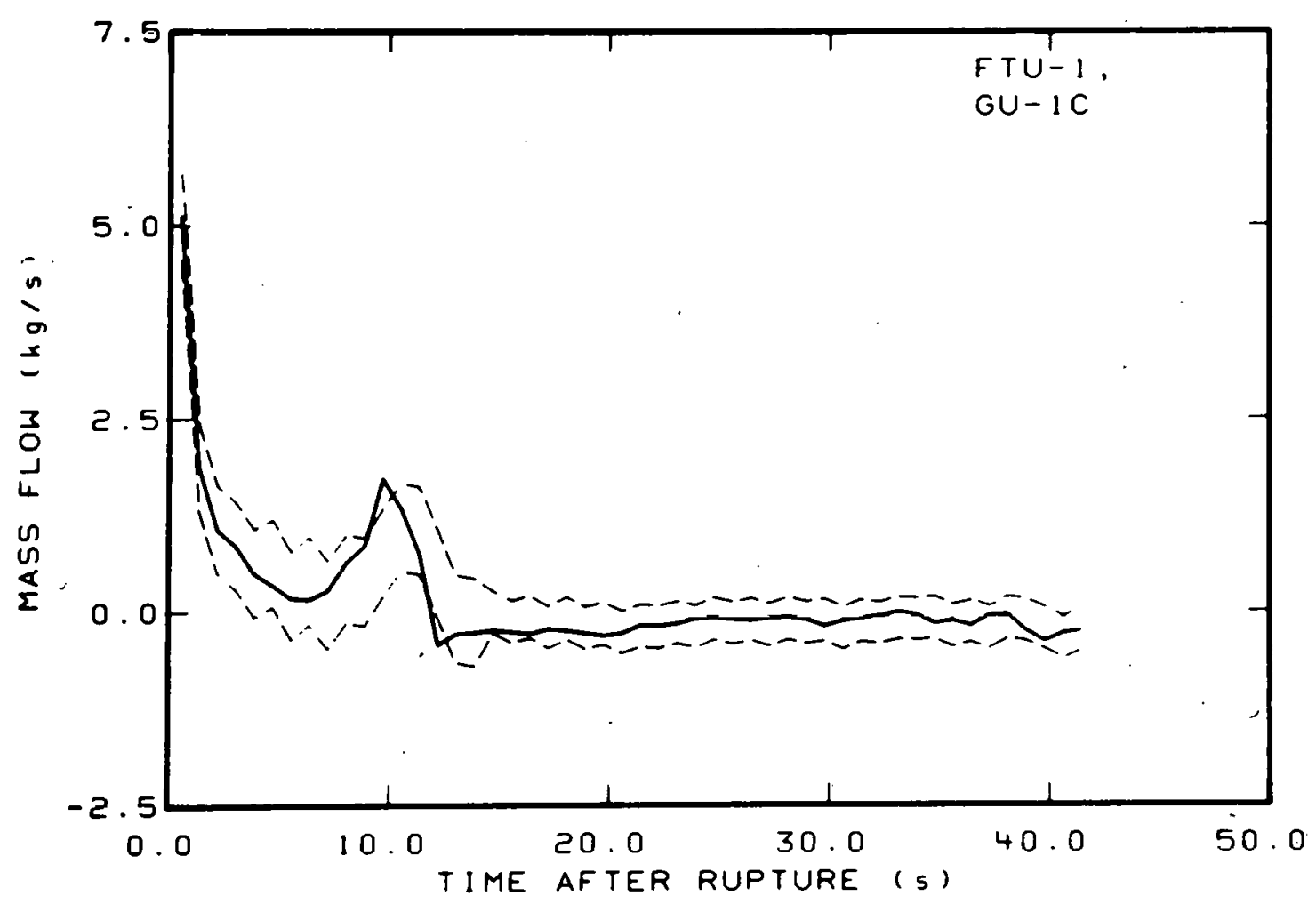

Fig. C-39 Mass flow in intact loop (FTU-1, GU-1C).

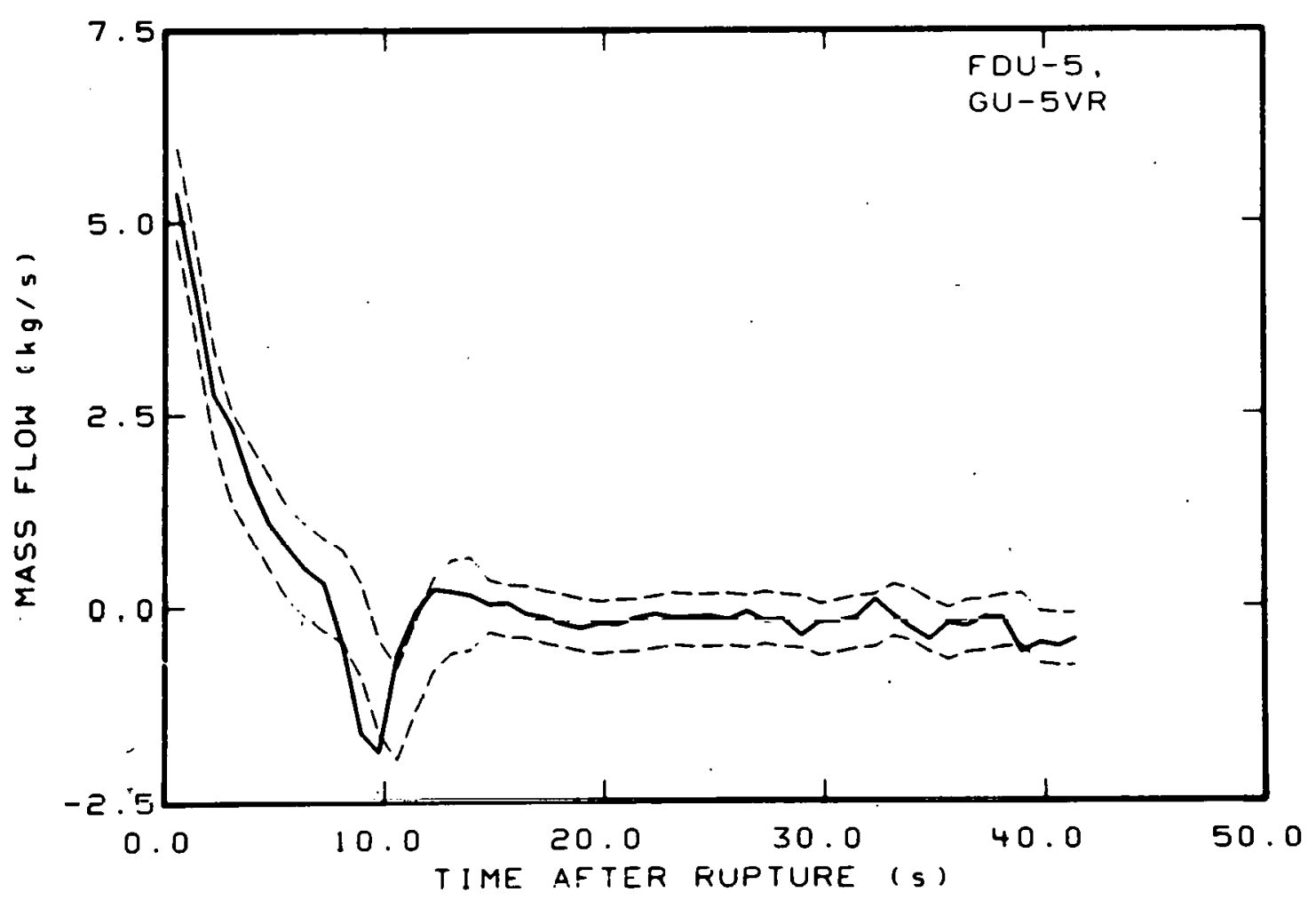

Fig. C-40 Mass flow in intact loop (FDU-5, GU-5VR). 


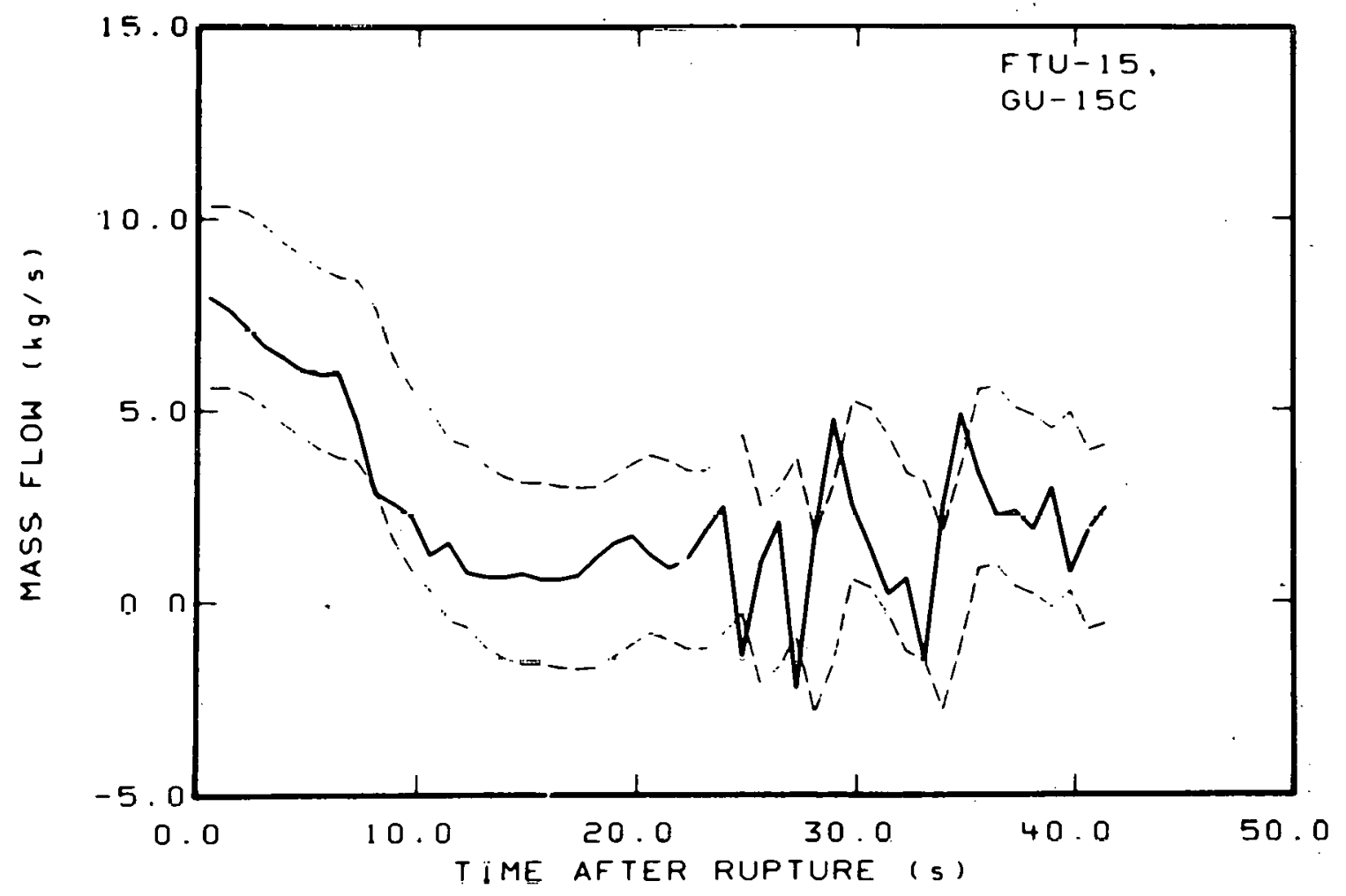

Fig. C-41 Mass flow in intact loop (FTU-15, GU-15C).

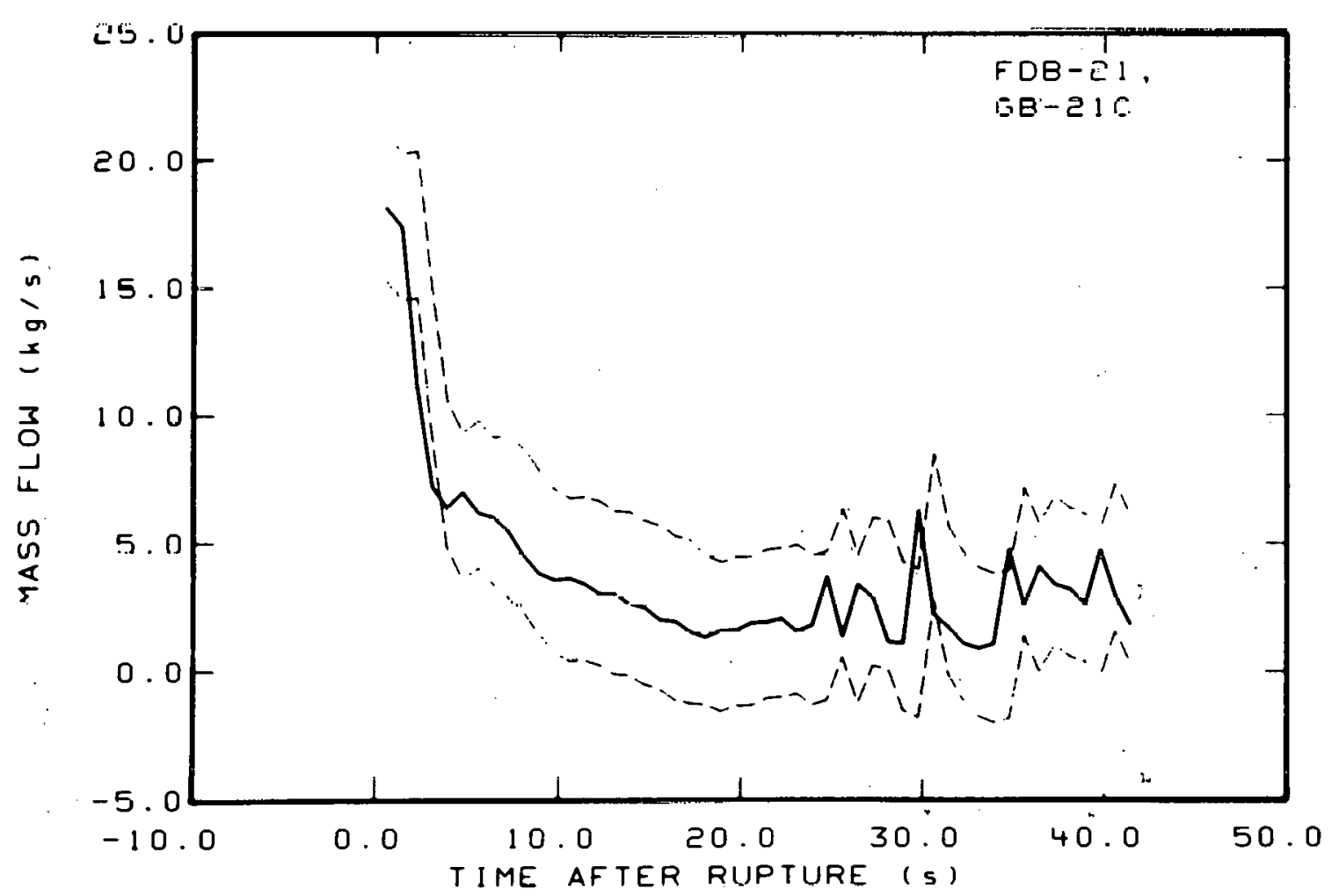

Fig. C-42 Mass flow in broken loop (FDB-21, GB-21C). 


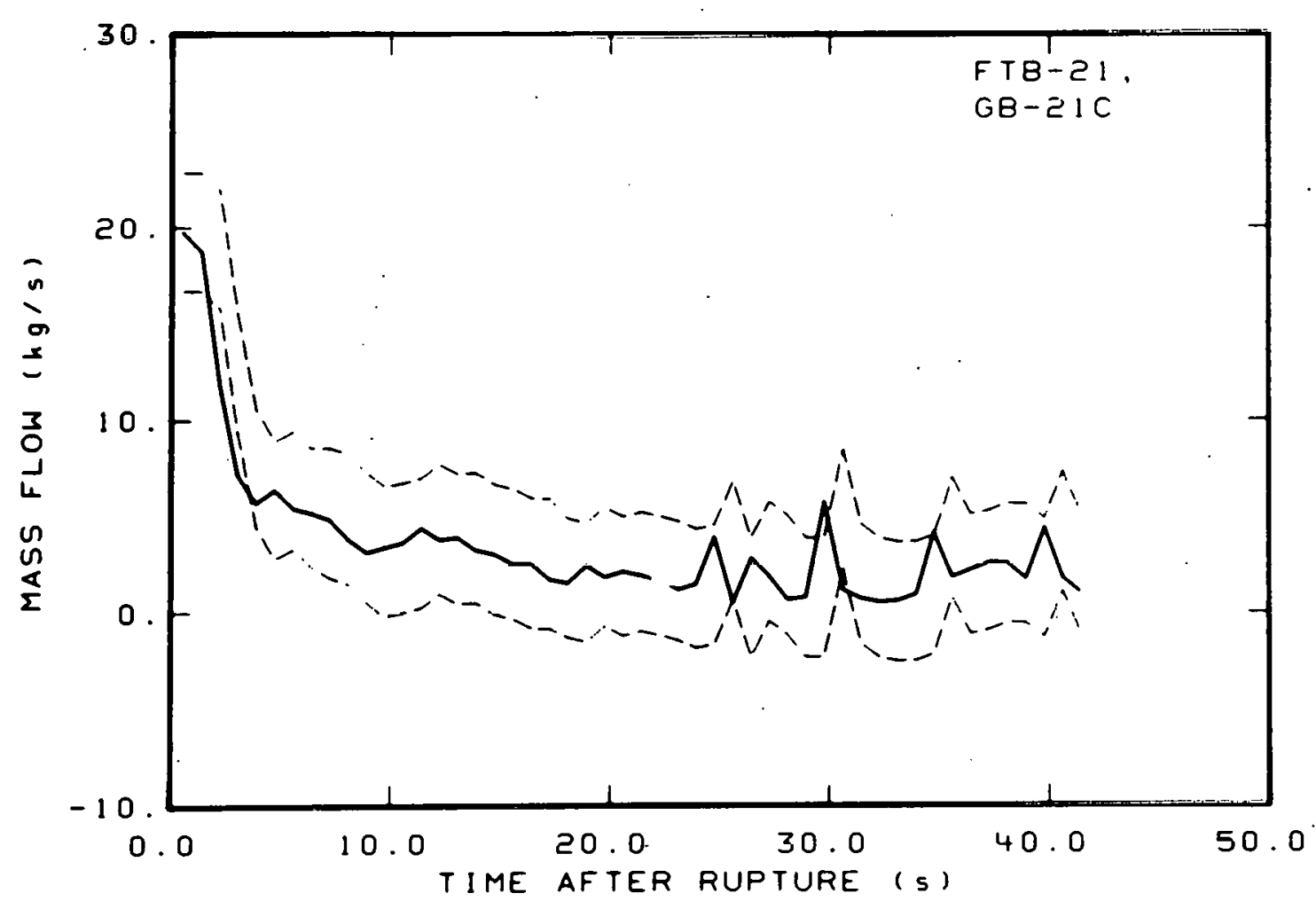

Fig. C-43 Mass flow in broken loop (FTB-21, GB-21C).

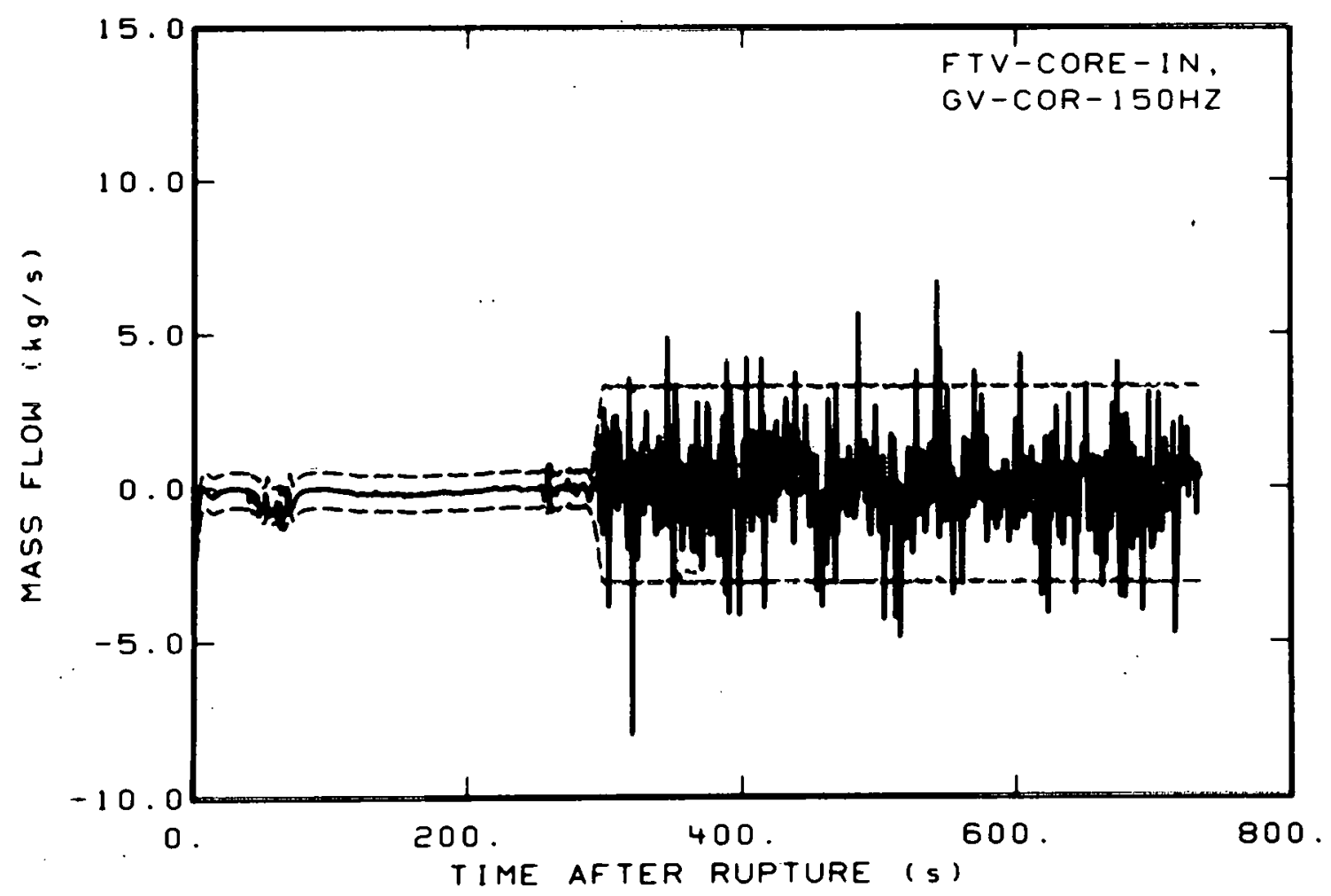

Fig. C-44 Mass flow in vessel (FTV-CORE-IN, GV-COR-150HZ). 
Table C-II provides a summary of engineering error values obtained from current analysis techniques as applied to the data presented herein.

In addition to the normal hardware and installation related sources of engineering error, a significant measurement uncertainty results when the current transducer systems are subjected to separated two-phase flow regimes during the course of the blowdown transient. Accordingly, for those data affected (fluid density, momentum flux, volumetric flow, and mass flow), which are presented in this appendix, a more extensive assessment was conducted for additional engineering error due to flow regime effects. Table C-III identifies the data analyzed and the period in the blowdown process for which flow regime errors were included as a part of the total engineering error. The time of occurrence of separated two-phase flow and the resulting efrecl un the uilcertainty of the data wcrc cvaluatcd by considering, on an individual basis, each delectur untput with reference to indications by other auxiliary measurements.

The gamma densitometer density measurement data are affected by two-phase separated flow regimes. The resulting transducer output is a measurement of the average attenuation of the gamma beam through the measured medium. The beam attenuation, in turn, is interpreted through physical relationship to be a measure of the average density along the beam path. When stratified type flow was considered present, the gam ma beam attenuation was considered to be a result of a liquid layer and steam at system conditions. With this assumption and the system geometry, a void fraction was calculated and a new "effective" average density was calculated. The difference between the average density based on the assumption of homogeneous conditions and the average density for stratified conditions was considered to be the error.

Momentum flux measurement uncertainties for two-phase flow regimes present the most difficult engineering evaluation problems. The drag target and arm location, degree of flow stratification, transducer temperature sensitivity, and slip ratios all combine to produce possible flow regime errors ranging from a small fraction of the transducer output value to multiples of it. Therefore, the error values were obtained, where possible, through use of the observed discrepancies between the momentum flux and lurbine flownieter data in combination with system pressure measurements and the analysis of system fluid density measurements.

The flow regime errors of the turbine flowmeter were estimated by calculating a void fraction and the cross-sectional liquid and steam flow areas for stratified flow. This calculation was accomplished using methods similar to those used to calculate the average density for stratified tlows. A simple model was used to equate the forces on the turbine with the assumption of a known void fraction, stratified flow, known component densities, and slip ratio greater than unity. This process provided phase velocities. With the phase densities, velocities, and void fraction, a volumetric flow rate could be calculated. The difference between this value and the measured value was considered to be the error. 


\section{TABLE C-II}

GENERAL MEASUREMENT ENGINEERING ERROR SOURCES AND ERROR VALUES (TEST S-28-5)

\begin{tabular}{|c|c|c|c|c|}
\hline $\begin{array}{c}\text { Measurement } \\
\text { Category }\end{array}$ & Error Sources & & Error Value & Expected Error Value \\
\hline \multirow[t]{4}{*}{$\begin{array}{l}\text { Fluid } \\
\text { Temperature }\end{array}$} & $\begin{array}{l}\text { Changes in homogeneity of the } \\
\text { thermocouple wire due to cold } \\
\text { working }\end{array}$ & \pm 7.11 & K & \\
\hline & $\begin{array}{l}\text { Data interpretation from } \\
\text { standard reference tables }\end{array}$ & \pm 1.11 & $k$ & $\pm 2.8 K^{[a]}$ \\
\hline & $\begin{array}{l}\text { General data acquisition } \\
\text { processing }\end{array}$ & +2.50 & K & \\
\hline & Thermal aging of the thermocouples & \pm 0.28 & K & \\
\hline \multirow[t]{4}{*}{$\begin{array}{l}\text { Material } \\
\text { Temperature }\end{array}$} & $\begin{array}{l}\text { Changes in homogeneity of the } \\
\text { thermocouple wire due to cold } \\
\text { working }\end{array}$ & \pm 1.111 & K & \\
\hline & Thermocouple radial position & \pm 2.78 & $k$ & \\
\hline & $\begin{array}{l}\text { Data interpretation from standard } \\
\text { reference tables }\end{array}$ & \pm 1.11 & $k$ & $\pm 3.9 k$ \\
\hline & $\begin{array}{l}\text { General data acquisition and } \\
\text { processing }\end{array}$ & +2.50 & K & \\
\hline
\end{tabular}


TAELE C-II (continued)

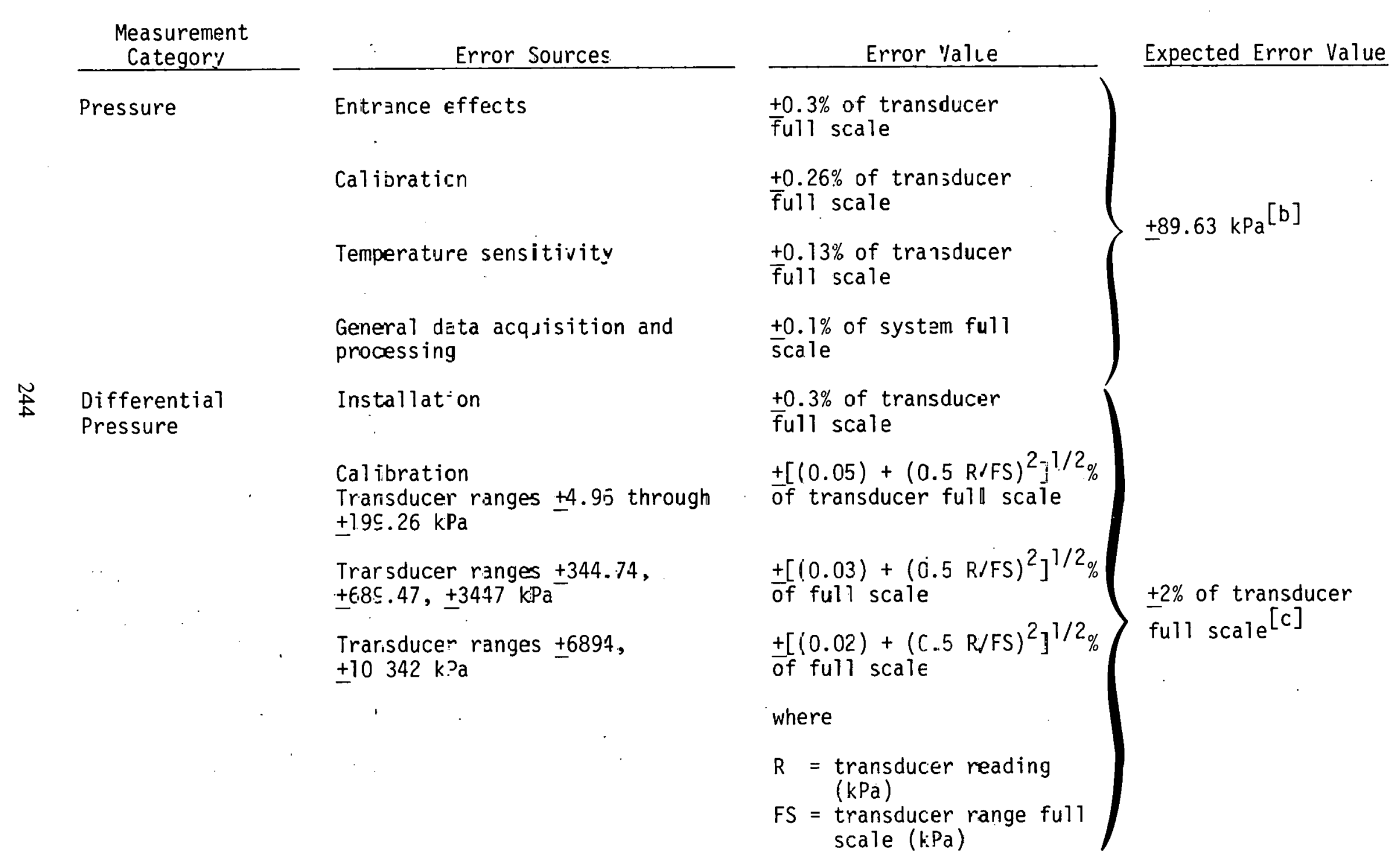


TABLE C-II (continued)

\begin{tabular}{|c|c|c|c|}
\hline $\begin{array}{c}\text { Measurement } \\
\text { Category }\end{array}$ & Error Sources & Error Value & Expected Error Value \\
\hline \multirow{3}{*}{$\begin{array}{l}\text { Differential } \\
\text { Pressure } \\
\text { (continued) }\end{array}$} & Temperature sensitivity & $\begin{array}{l}+0.5 \% \text { of transducer } \\
\text { fuli scale }\end{array}$ & \multirow{3}{*}{$\begin{array}{l} \pm 2 \% \text { of transducer } \\
\text { full scal } e^{[\mathrm{c}]}\end{array}$} \\
\hline & $\begin{array}{l}\text { General data acquisition and } \\
\text { processing }\end{array}$ & $\begin{array}{l}+0.1 \% \text { of system full } \\
\text { scale }\end{array}$ & \\
\hline & Air entrapment & $\pm 0.069 \mathrm{kPa}$ & \\
\hline \multirow{4}{*}{$\begin{array}{l}\text { Fluid velocity } \\
\text { (point velocities } \\
\text { measured with } \\
\text { turboprobes) }\end{array}$} & Installation & $\begin{array}{l}+0.8 \% \text { of transducer } \\
\text { full scale }\end{array}$ & \\
\hline & Calibration & $\begin{array}{l}+5 \% \text { of transducer } \\
\overline{f u l 1} \text { scale }\end{array}$ & $\begin{array}{l} \pm[0.5825+ \\
\left.(0.008 \mathrm{R})^{2}\right]^{1 / 2} \mathrm{~m} / \mathrm{s}\end{array}$ \\
\hline & $\begin{array}{l}\text { Data acquisition and processing } \\
\text { frequency conversion }\end{array}$ & $\begin{array}{l}+0.25 \% \text { of transducer } \\
\text { fuil scale }\end{array}$ & \\
\hline & General & $\begin{array}{l}+0.1 \% \text { of system full } \\
\text { scale }\end{array}$ & $\begin{aligned} R= & \text { transducer } \\
& \text { reading }(\mathrm{m} / \mathrm{s})\end{aligned}$ \\
\hline \multirow[t]{3}{*}{ Density } & Calibration & $\pm 1.0 \%$ of reading $\left(\mathrm{kg} / \mathrm{m}^{3}\right)$ & \multirow{3}{*}[d]{} \\
\hline & Detector system error & $\pm 2.1 \mathrm{~kg} / \mathrm{m}^{3}$ & \\
\hline & $\begin{array}{l}\text { General data acquisition and } \\
\text { processing }\end{array}$ & $\pm 1.6 \mathrm{~kg} / \mathrm{m}^{3}$ & \\
\hline
\end{tabular}




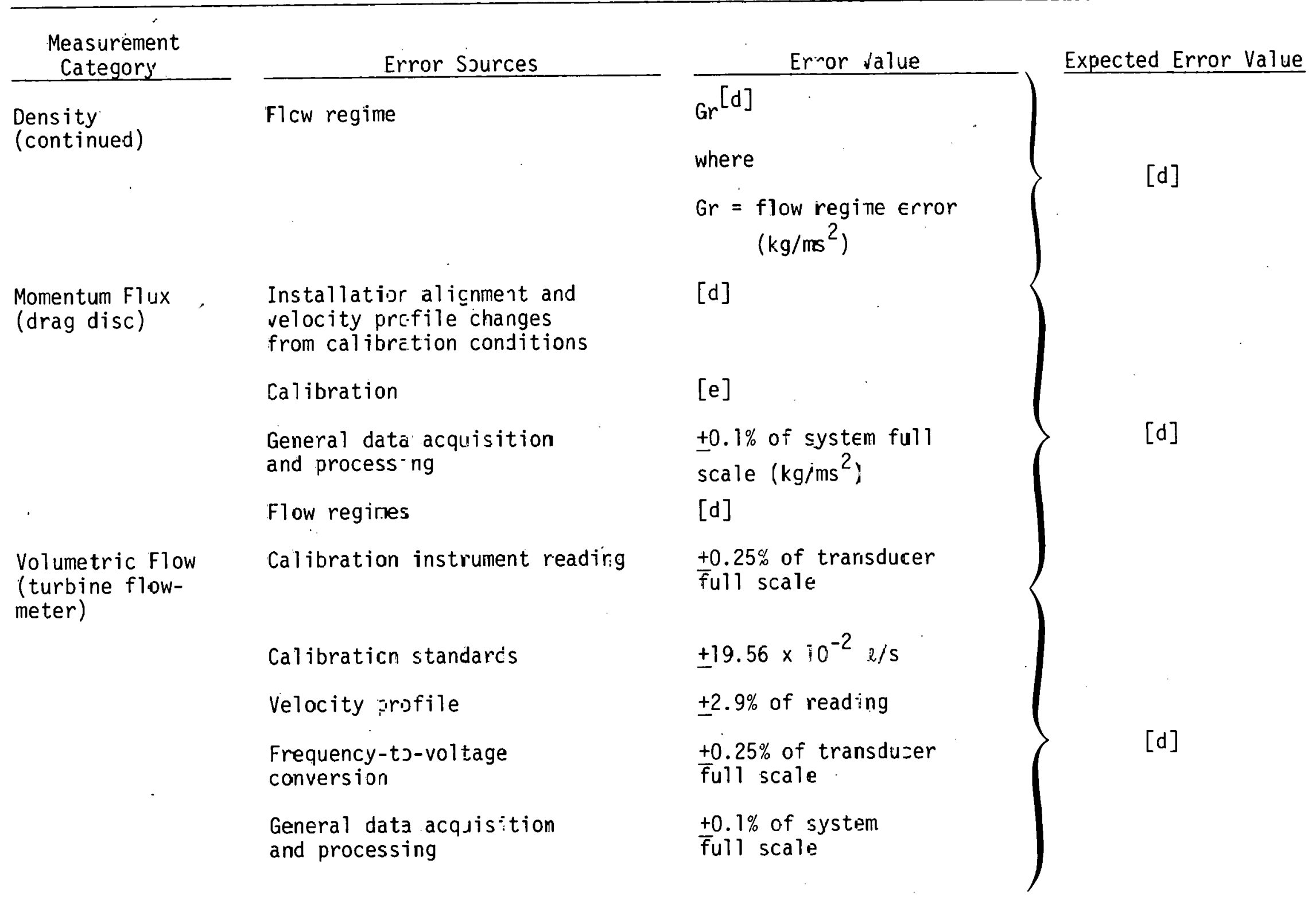


TABLE C-II (continued)

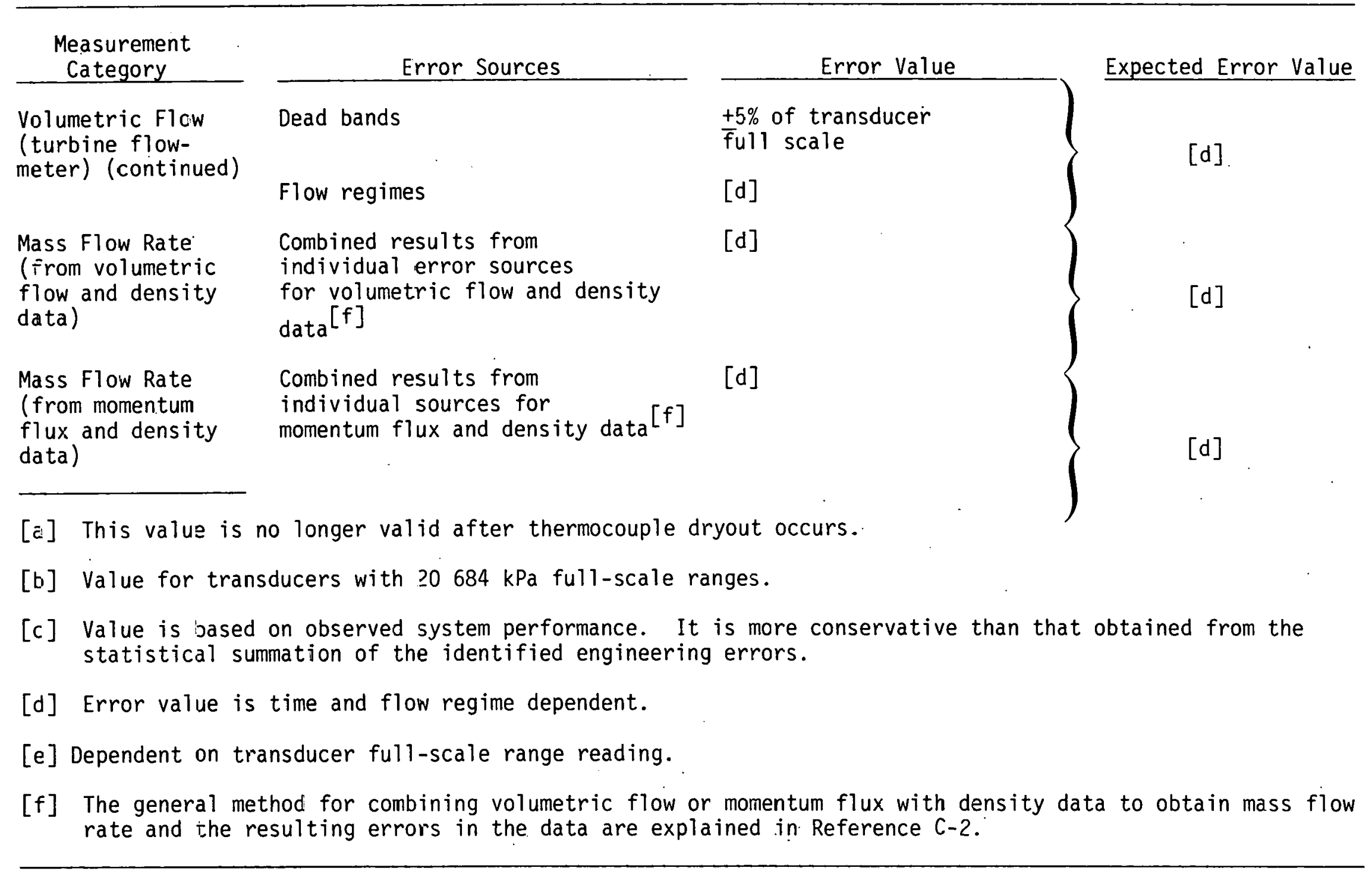




\section{TABLE C-III}

TIME PERIODS WHEN FLOW REGIME ERRORS WERE APPLIED (TEST S-28-5)

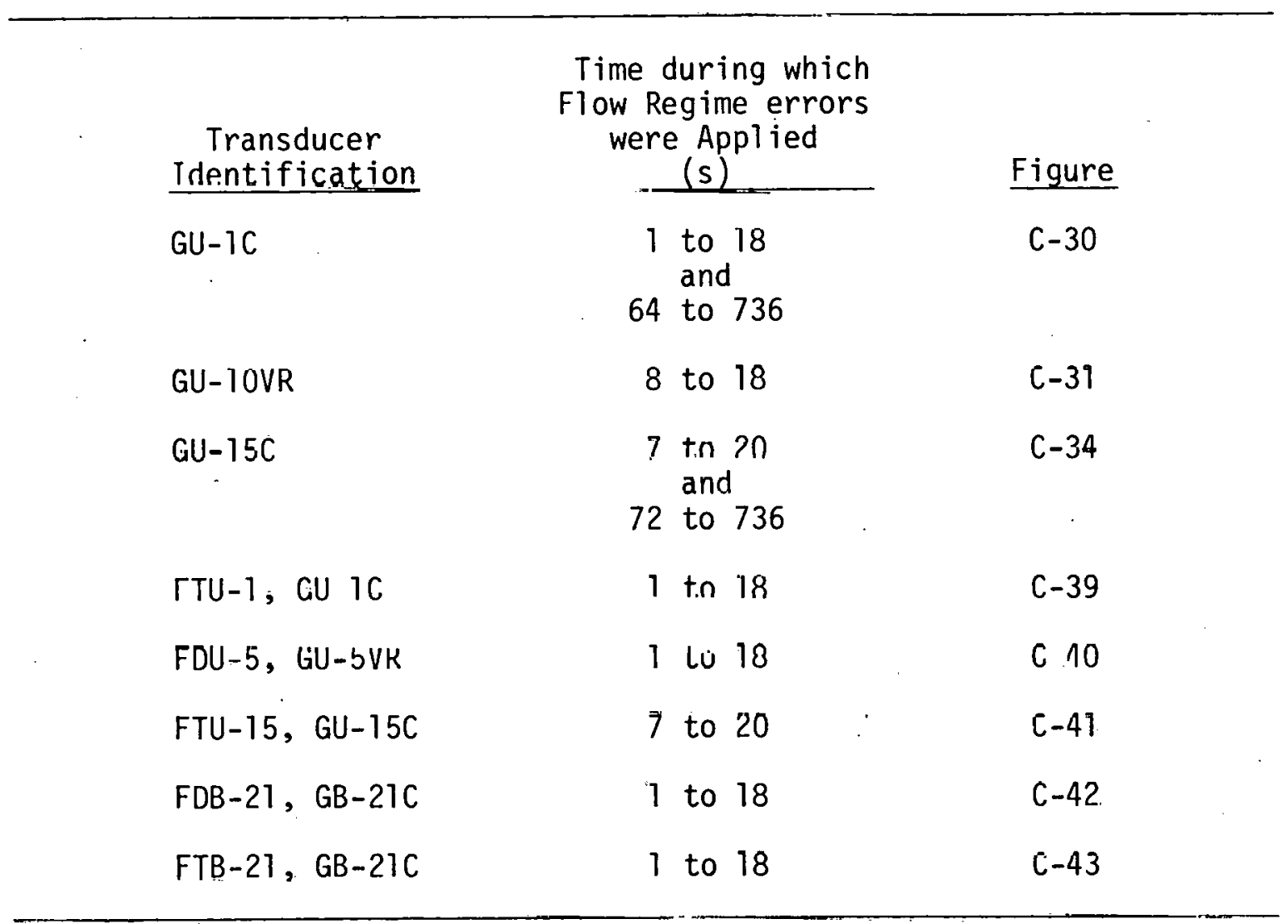

The overall standard deviation of a data point is taken as the roul nuean of the sum of the random error variation and the total engineering error variance; that is,

$$
\sigma_{0}=\sqrt{\sigma_{R}^{2}+u_{E}^{2}}
$$

where

$$
\begin{array}{ll}
\sigma_{0}= & \text { overall standard deviation of a data point } \\
\sigma_{\mathrm{R}} & =\text { random error standard deviation } \\
\sigma_{\mathrm{E}} & =\text { engineering error standard deviation. }
\end{array}
$$

The error bands for the data are computed about the value given by the fitted difference equation $y_{i}$ al line point, 1 ; thal is,

$$
\text { error band }=y_{i} \pm 1.96 \sigma_{0}
$$


With due regard to the fact that $\sigma_{\mathrm{E}}$ has been estimated subjectively, the error band may be interpreted as an approximate $95 \%$ confidence interval within which any true value of the measured variable is consistent with the data.

On certain occasions, the symmetrical error band given by Equation (C-2) is not appropriate. On those occasions, asymmetrical error bands were computed. (That is, with the width being greater on one side of $y_{i}$ than on the other.)

Finally, the original data trace, along with its error band from Equation (C-2), was input to a computer plot package. The resulting plot contained the actual data trace surrounded by an error band derived both from random error and engineering error considerations. The indicated error bands after thermocouple dryout occurred for the fluid temperature measurements should be ignored. Error bands indicated during periods when detector or data acquisition system saturation occurred should also be ignored. Error bands for these segments of the data were not obtained and bands only appear because of limitations in the plotting package.

\section{REFERENCES}

C-1. G. E. P. Box and B. M. Jenkins, Time Series Analysis - Forecasting and Control, San Francisco: Holden-Day, 1970.

C-2. E. M. Feldman and S. A. Naff, Error Analysis for 1-1/2-Loop Semiscale System Isothermal Test Data, ANCR-1188 (May 1975). 
DISTRIBUTION RECORD FOR TREE-NUREG- 1152

\author{
Internal Distribution \\ 1 - Chicago Patent Group-DOE \\ 9800 South Cass Avenue \\ Argonne, Illinois 60439 \\ 2 - C. A. Benson \\ Idaho Operations Office-DOE \\ Idaho Falls, Idaho 83401 \\ 3 - R. J. Beers, ID \\ 4 - P. E. Letteneker, ID \\ 5 - R. E. Tiller, ID \\ 6 - R. E. Wood, ID \\ 7 - H. P. Pearson, Supervisor \\ Technical Information \\ 8-17 - INEL Technical Library \\ 18-37 - Authors \\ 38-90 - Special Internal
}

External Distribution

91-92 - Saul Levine, Director Office of Nuclear Regulatory Research, NRC Washingtür, DC 20555

93-397 - Distribution under NRC-2, Water Reactor Safety Research Systems Engineering 